\author{
UNIVERSIDADE DE SÃO PAULO \\ MUSEU DE ARQUEOLOGIA E ETNOLOGIA \\ PROGRAMA DE PÓS-GRADUAÇÃO EM ARQUEOLOGIA
}

\title{
História das Caretas: \\ A Tradição Borda Incisa na Amazônia \\ Central
}

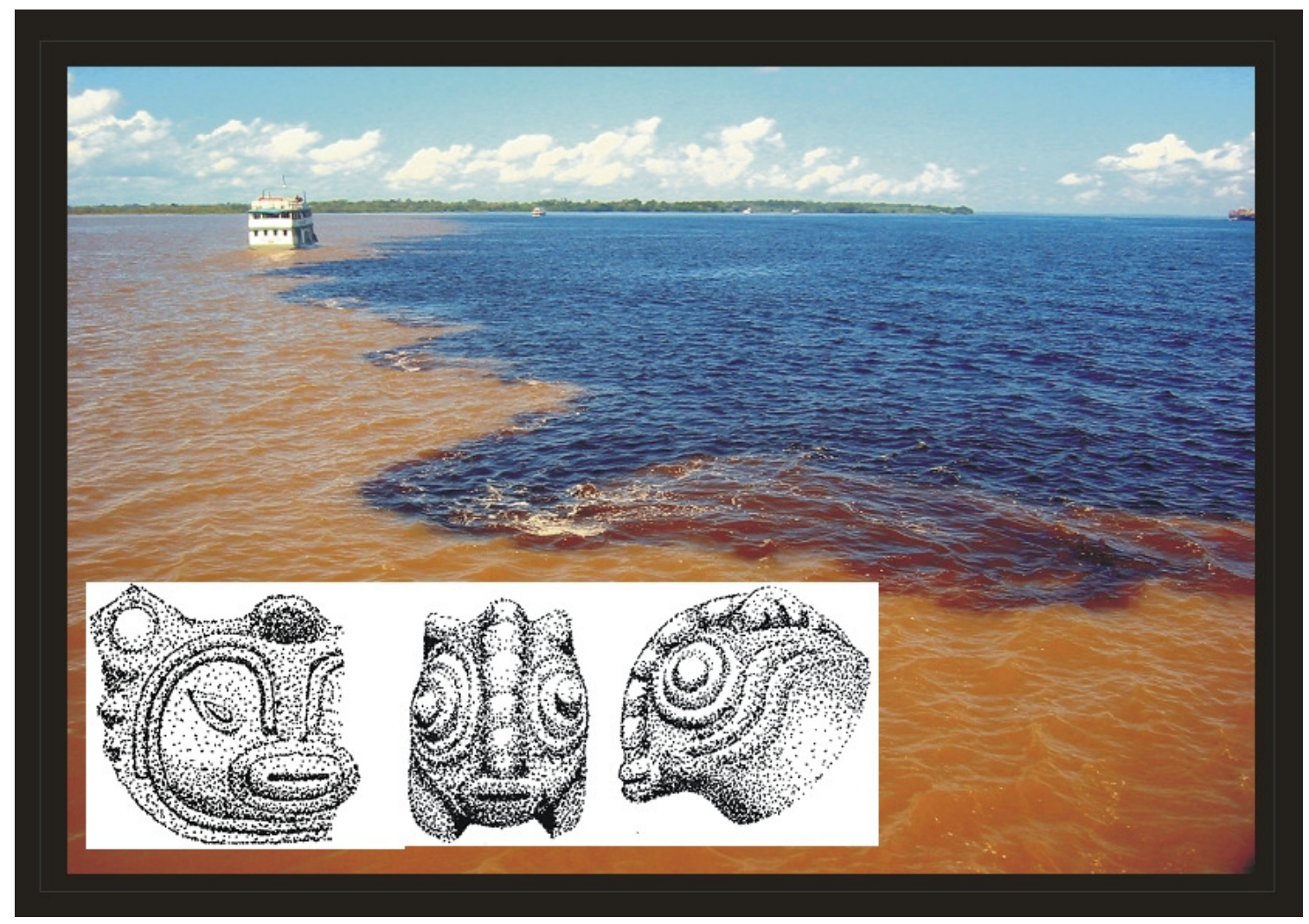

Volume 1

Helena Pinto Lima 
UNIVERSIDADE DE SÃO PAULO

Museu de Arqueologia e Etnologia

PROGRAMA DE PÓS-GRADUAÇÃO EM ARQUEOLOGIA

\section{História das Caretas: A Tradição Borda Incisa na Amazônia Central}

Helena Pinto Lima

Tese apresentada ao Programa de Pós-Graduação em Arqueologia, do Museu de Arqueologia e Etnologia da Universidade de São Paulo, para obtenção do título de Doutor em Arqueologia.

Volume 1

Orientador: Prof. Dr. Eduardo Góes Neves

Linha de pesquisa: processos de formação e transformação social 


\section{À minha família}

De onde sempre tive apoio incondicional

Ao Bruno e à Flora

Meu novo núcleo familiar 
"The question is not so much about the extent of our current knowledge, but about the limits to knowledge and the ways by which we can assess what is in principle knowable, given favorable conditions of research, and what is in principle unknowable, been beyond the reach of human investigation"

Colin Renfrew, 2000 


\section{AGRADECIMENTOS}

A perspectiva de longa duração adotada nessa pesquisa foi mais do que uma orientação teórico-metodológica, uma vez que seu próprio tempo de elaboração, amadurecimento e execução foram tão aprazados quanto seu próprio objeto. Assim, neste período que somou alguns bons anos, muitas foram as pessoas que contribuíram para que ela existisse. Talvez eu não me lembre agora de todos os nomes, pois a lista é grande, mas essas pessoas, integrantes ou não do Projeto Amazônia Central (PAC), estão presentes nas idéias e nas linhas desta tese.

Começo pela nossa "equipe cabocla", onde fiz além de companheiros de trabalho, verdadeiros amigos. Lei, Cláudio, Pupunha, Tijolo, seu Nego, Bené, são apenas alguns destes amigos de Manaus, Iranduba e Lago do Limão, com quem me sinto honrada de poder compartilhar tantos trabalhos de campo, laboratório, e momentos de descontração. Também ao pessoal da casa em Manaus, que deu duro no laboratório entre milhares e milhares de fragmentos, amostras de solo, e afins. Anne, Márjorie, Elaine, Merrinha, Miguel, Rodrigo, e também ao Claide, que ajudou na implantação e desenvolvimento da rotina de laboratório e com quem troquei várias idéias importantes sobre a metodologia de análise.

Em especial, gostaria de agradecer aos amigos da "velha guarda", a começar pelo Edu e Caminhão, e também ao Marquito, Bob e Manolo, pelas tantas conversas sobre arqueologia e assuntos relacionados, que renderam importantes reflexões presentes nessa tese. Ao Marquito, agradeço também pelas topografias, mapas e desenhos de perfis e peças que com certeza elevaram a qualidade visual do trabalho. Do mesmo modo, as fotos e desenhos da Val, junto à especial formatação dada pela Adri na parte das tipologias, deram a esta tese um apreço estético que, devo dizer, muito me agradou.

Não poderia deixar de mencionar o auxílio do Kazuo com os gráficos e tabelas de datas: eu o amolei dia e noite! A Bruna, que passou horas revisando a extensa bibliografia; a Jaque, que se dispôs, por duas vezes, a sair de sua casa em Pelotas para me ajudar em temporadas de análises na PUC-RS, em Porto Alegre. Também o trabalho da Silvia, Luis e Regivaldo, na parte de conservação e restauro, foi importante para que as análises cerâmicas alcançassem melhores resultados. 
Enfim, agradeço a toda a equipe do PAC, agora em ordem cronológica (não de idade, mas de tempo de Projeto): Patrícia, Emília, Jú, Adolfinho, Ricardo, Sarah, Anderson, Raoni, Fabio, Carol, Ceará, Pitoco, Marcinho, Adriana, Natália. Não poderia deixar de mencionar a Dona Dina, que cuida do bem-estar de todos no laboratório em Manaus. Também o Bernardo, Girino, Baiano, e outros que ajudaram nos trabalhos de campo ou laboratório.

Vale dizer ainda que o sucesso que o PAC como um todo tem tido em seu desenvolvimento se deve aos trabalhos de Educação Patrimonial que a Carlinha, Tereza e Fábio vêm desenvolvendo em Manaus e Iranduba, o que facilitou sobremaneira esta pesquisa, além de garantir integridade e preservação aos sítios arqueológicos da região.

Agradecimento especial, in memoriam, ofereço ao Prof. James Petersen. Pessoa muito simples, sempre presente e disposto a ajudar e ensinar estudantes no árduo e fascinante ofício de ser arqueólogo na Amazônia. Jim faleceu durante nossas pesquisas de campo em Iranduba, mas sua simplicidade e seus ensinamentos permanecem na memória de todos nós.

Agradeço também à todas aquelas instituições que tornaram possível esta pesquisa, ou auxiliaram, de alguma maneira, em sua realização. Em primeiro lugar à FAPESP (Fundação de Amparo à Pesquisa do Estado de São Paulo), que financiou o trabalho desde o seu embrião até sua conclusão. Também ao IPEN (Instituto de Pesquisas Energéticas e Nucleares) e IME-USP (Instituto de Matemática e Estatística), pelo auxílio com as análises arqueométricas e estatísticas. Ao IF-USP (Instituto de física), na pessoa de Adriana Delgado, por facilitar o acesso à aparelhagem de microscopia ótica, para leitura das lâminas. Do mesmo modo, devo mencionar o amplo apoio que recebi das instituições amazonenses. O Museu Amazônico, da UFAM (Universidade Federal do Amazonas), $1^{\underline{a}}$ SR do IPHAN (Instituto do Patrimônio Histórico e Artístico Nacional), e o CCPA (Centro Cultural dos Povos Amazônicos). Também ao Projeto PIATAM, vinculado ao CCA-UFAM (Centro de Ciências Ambientais) e à PETROBRAS, que deram condições logísticas para as prospecções e escavações em sítios na calha do Solimões, muitos deles de difícil acesso. Finalmente, à PUC-RS, na pessoa do Prof. Dr. Klaus Hilbert, pelo acesso às coleções, reserva técnica e laboratório da instituição, além das verdadeiras aulas sobre cerâmica amazônica que ali recebi, ao olhar e dialogar sobre o material. 
Finalmente, não poderia deixar de dizer que tudo isso somente foi possível através do apoio incondicional que recebi de minha família, desde o princípio de tudo. Pai, mãe, irmãs e irmão, além dos amigos, ficam lembrados aqui, com muito carinho, por terem tornado esta jornada mais feliz. Por último, e mais importante, é o especial agradecimento que tenho pelo Bruno, meu esposo, que deixou tudo nesses últimos meses para trabalhar, junto comigo, na redação. Posso dizer que esta tese foi, literalmente, uma tese escrita a quatro mãos. Também devo mencionar a paciência que ele teve durante este período, abrindo mão, inclusive, de nossa lua-de-mel para ficar frente ao computador. E também à pequena Flora, minha filha, que está esperando pacientemente a conclusão do trabalho para sair da barriga. 


\section{SUMÁRIO}

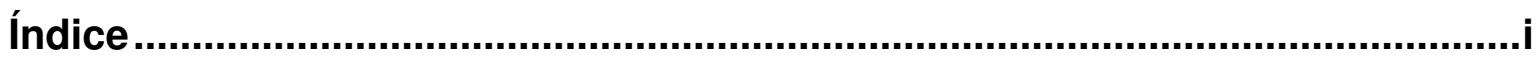

Índice de Figuras.............................................................................................

Índice de Gráficos ................................................................................vi

Índice de Tabelas ......................................................................................viii

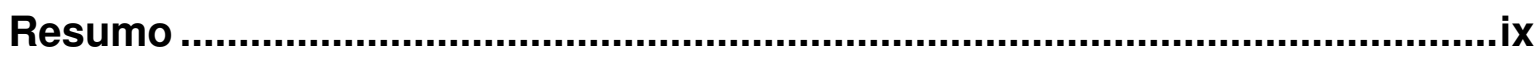

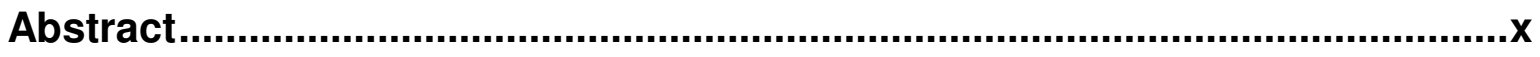

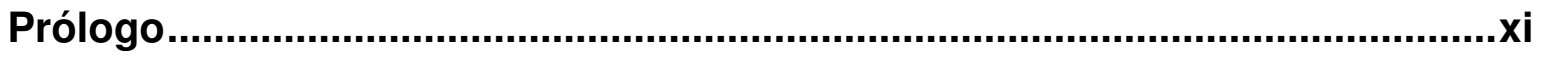

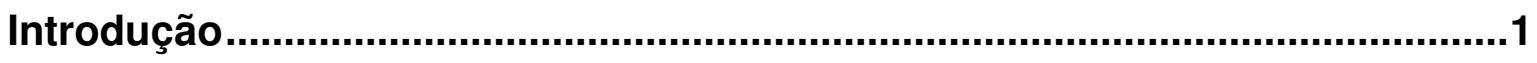

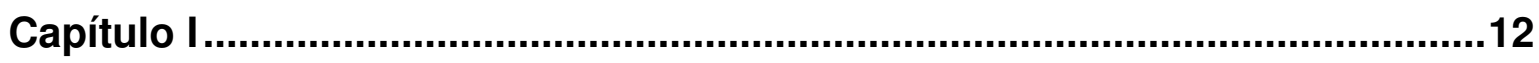

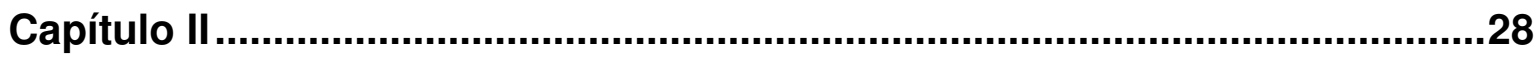

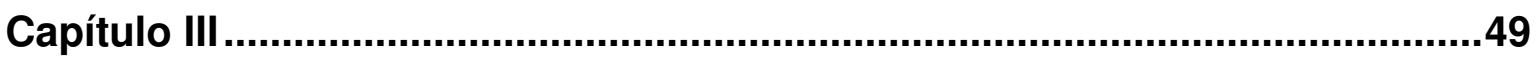

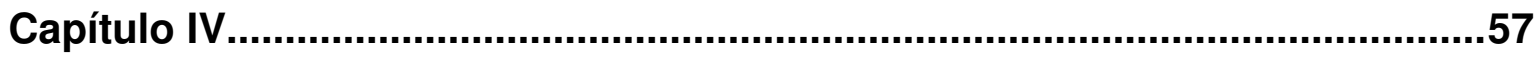

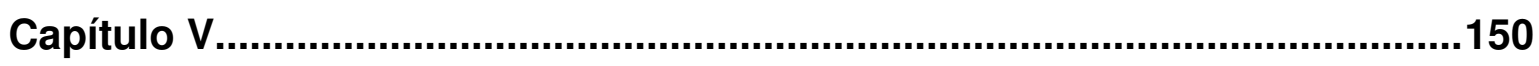

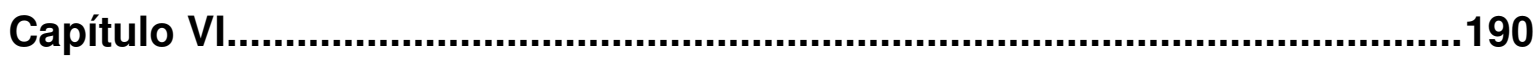

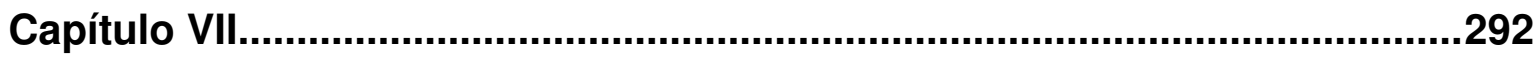

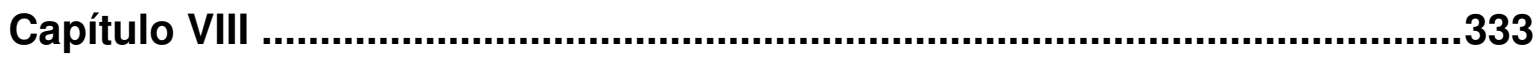

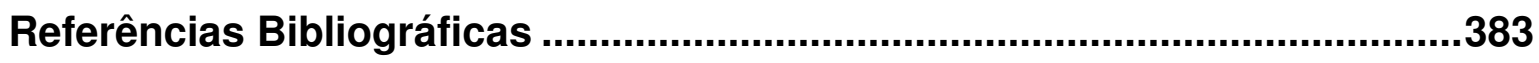

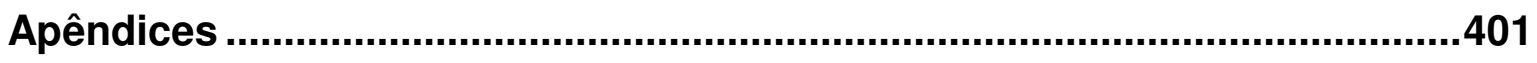




\section{ÍNDICE}

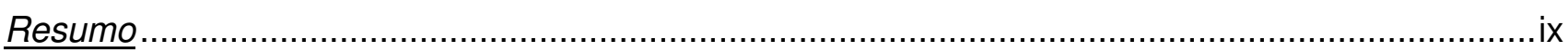

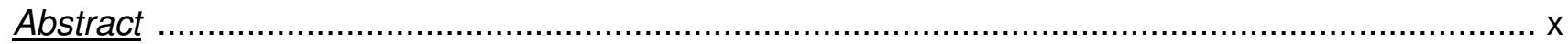

\section{Prólogo}

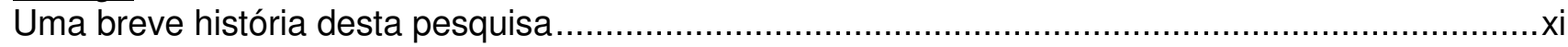

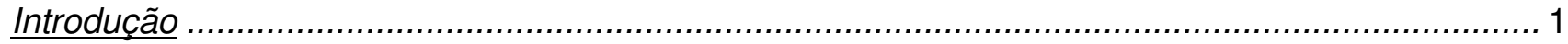

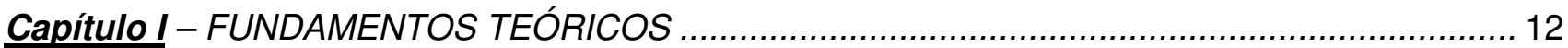

I. I. História da arqueologia na Amazônia, dualismos e paradigmas .......................................... 12

I. II. Arcabouço teórico, bases conceituais e pressupostos metodológicos da pesquisa ............... 20

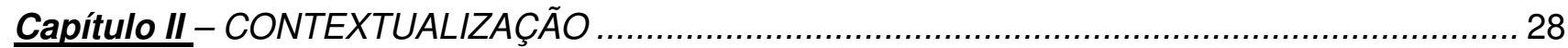

II. I. A seqüência cronológica da Amazônia central............................................................ 28

II. II. Repensando as tipologias: um estudo de caso ............................................................ 43

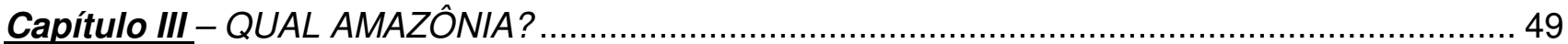

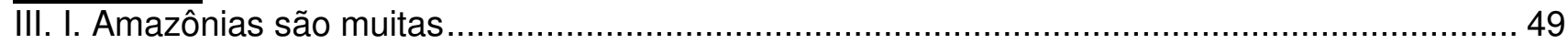

Capítulo IV - SÍTIOS ARQUEOLÓGICOS DA AMAZÔNIA CENTRAL ..................................... 57

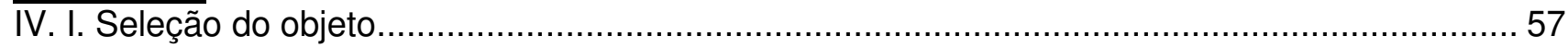

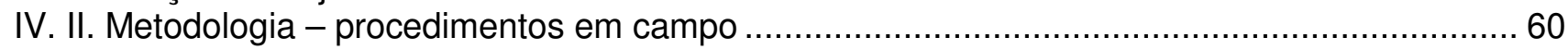

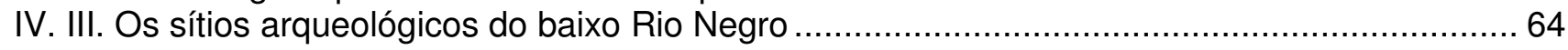

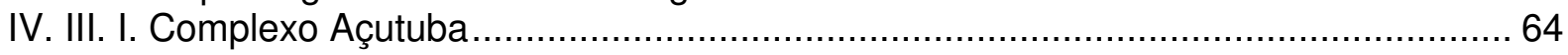

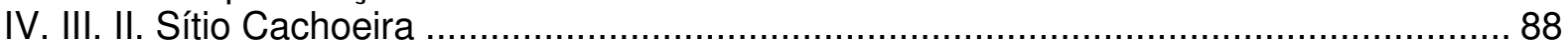

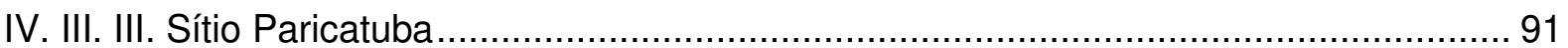

IV. IV. Os sítios arqueológicos do baixo Solimões ............................................................... 96

IV. IV. I. Sítio Nossa Senhora do Perpétuo Socorro, no rio Manacapuru ............................. 96

IV. IV. II. Sítio Hatahara, na barranca do Solimões...................................................... 111

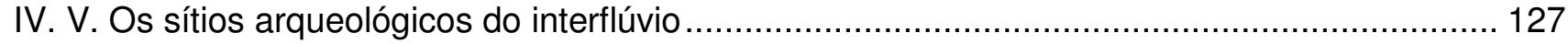

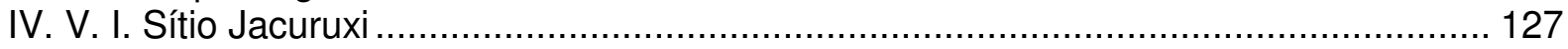

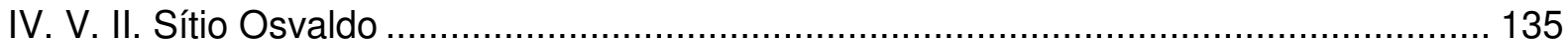

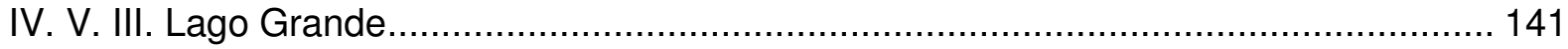

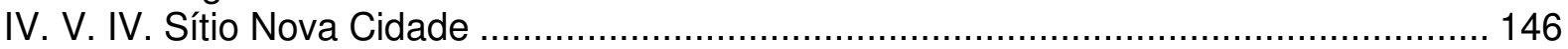

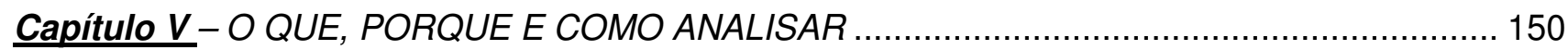

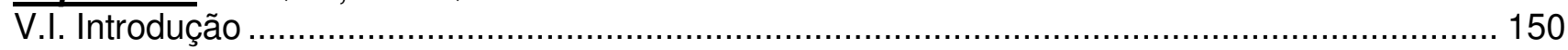

V.II. Análises cerâmicas na Amazônia: antecedentes históricos .............................................. 153

V.III. Sobre a interpretação dos sistemas tecnológicos e mudança cultural ........................................ 157

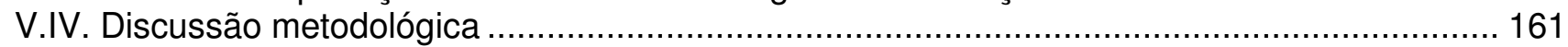

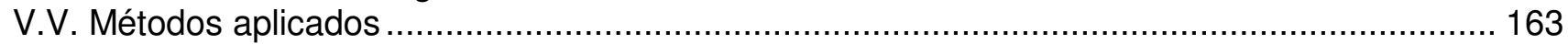

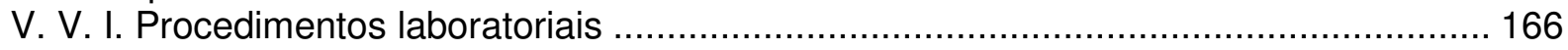

V. V. II. A ficha de análise e seus parâmetros metodológicos ........................................ 172

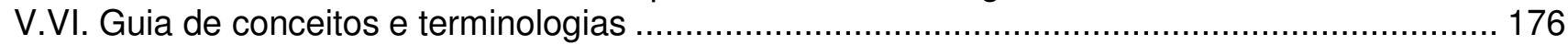

Capítulo VI - ATRADIÇÃO BORDA INCISA NA AMAZÔNIA CENTRAL ................................... 190

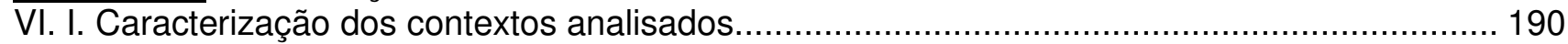

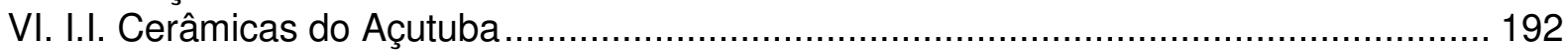

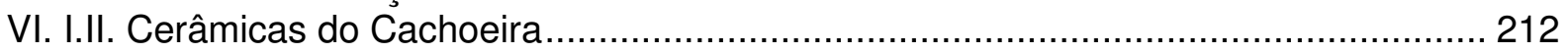




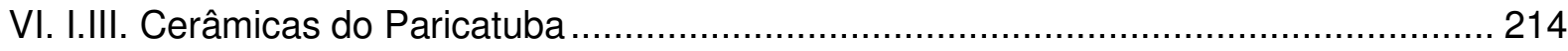

VI. I.IV. Cerâmicas do Nossa Senhora do Perpétuo Socorro.......................................... 215

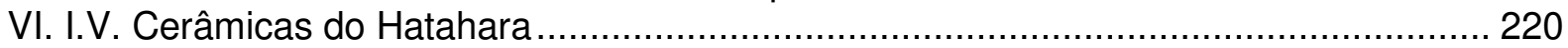

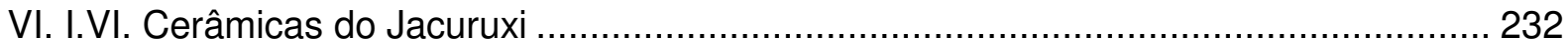

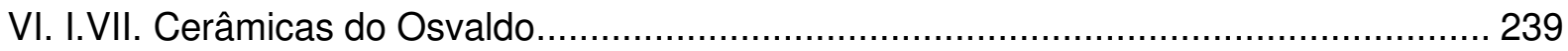

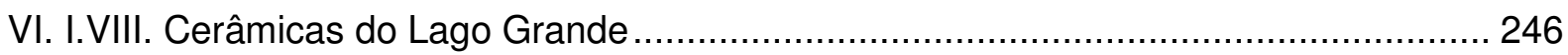

VI. I.IX. Cerâmicas do Nova Cidade ........................................................................ 250

VI. II. O estabelecimento das tipologias e a vinculação às fases cerâmicas .............................. 256

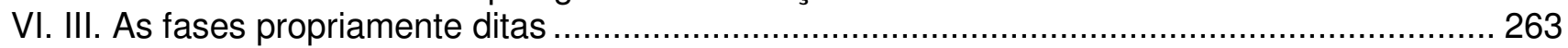

VI.III.I. Cerâmicas da fase Açutuba ......................................................................... 263

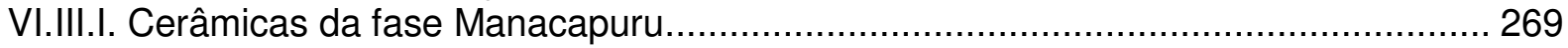

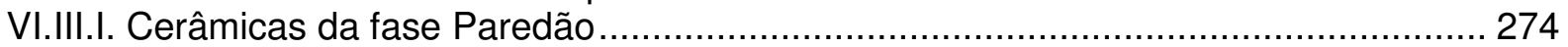

VI. IV. A Tradição Borda Incisa, finalmente .......................................................................... 279

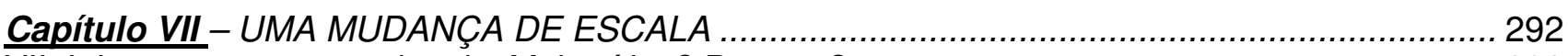

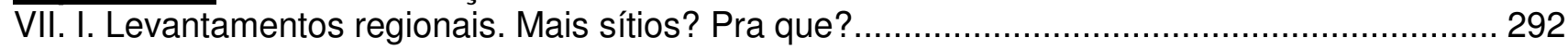

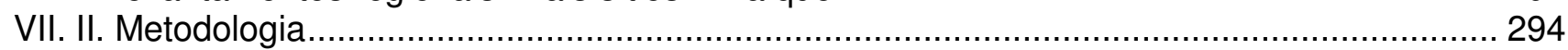

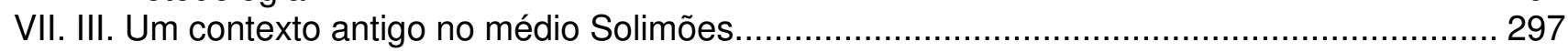

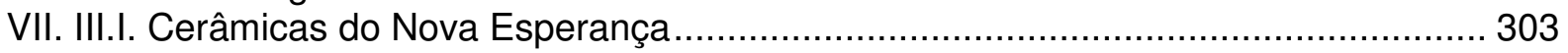

VII. IV. O Baixo Amazonas e o contexto Pocó .................................................................. 312

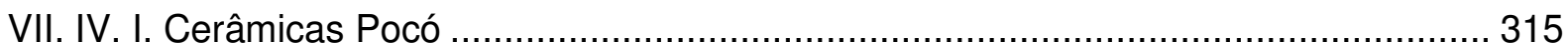

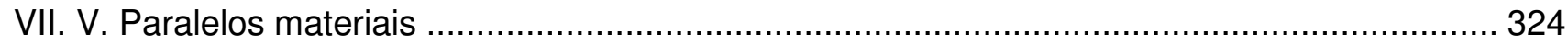

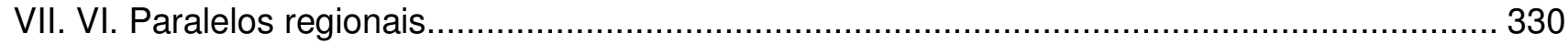

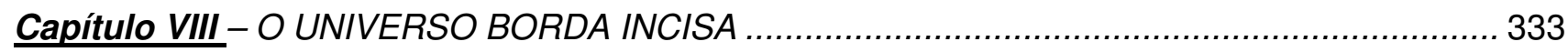

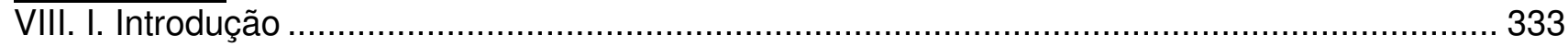

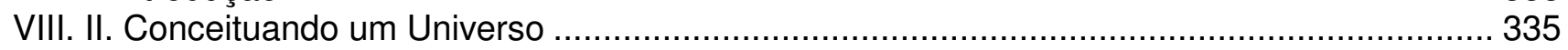

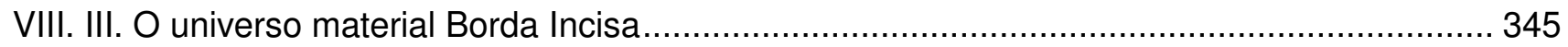

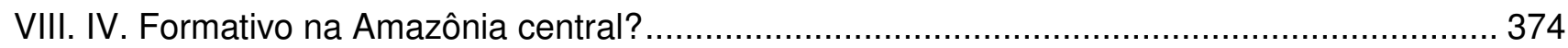

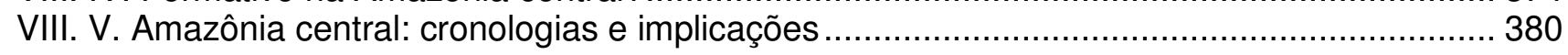

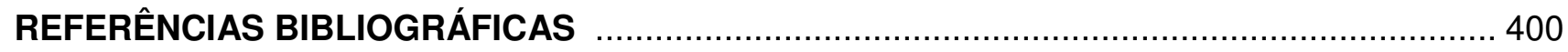

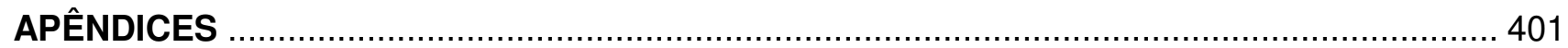

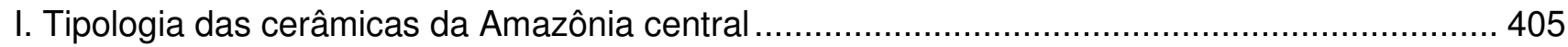

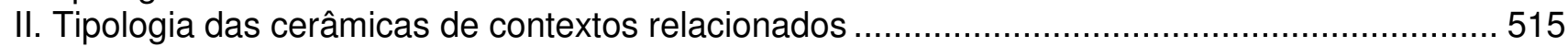

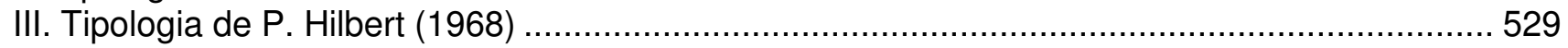




\section{ÍNDICE DE FIGURAS}

\section{Introdução}

Figura 1 - Mapa de Localização da área de estudos.

\section{Capítulo I}

Figura 2 - Vasos cerâmicos da fase Guarita da comunidade Lauro Sodré em Coari/AM ............................. 12

Figura 3 - Mapa das diferentes hipóteses de dispersões populacionais no norte da América do Sul ............. 17

\section{Capítulo II}

Figura 4. Quadro cronológico dos Horizontes Estilísticos propostos por Meggers e Evans (1961) ................ 29

Figura 5. Hipotéticas levas de dispersão dos horizontes estilísticos de Meggers e Evans (1961) .................. 30

Figura 6. Fragmentos cerâmicos e cachimbo tubular da fase Jauarí, tradição Hachurada Zonada................. 31

Figura 7. Exemplos de cerâmicas da fase Manacapuru segundo Hilbert (1968) ......................................... 32

Figura 8. Apliques antropomorfos da fase Paredão, tradição Borda Incisa, segundo Hilbert (1968) ............... 33

Figura 9. Carimbos plano e cilíndrico da fase Guarita, tradição Policroma, segundo Hilbert (1968) ................ 34

Figura 10. Apliques da fase Itacoatiara, tradição Incisa e Ponteada, segundo Hilbert (1968)........................ 35

Figura 11. Apliques cerâmicos da fase Açutuba ................................................................................ 44

\section{Capítulo III}

Figura 12. A confluência dos rios Negro e Solimões (fonte: Google Earth) ................................................. 51

Figura 13. Camada de terra preta soterrada por sedimentação do rio Solimões.......................................... 53

\section{Capítulo IV}

Figura 14. Sítios arqueológicos estudados na área de confluência dos rios Negro e Solimões.......................59

Figura 15. Procedimentos de registro em campo: preenchimento de fichas e desenho de croquis................ 63

Figura 16. Vista aérea do sítio Açutuba, no período da cheia do rio Negro ................................................ 64

Figura 17. Hipótese sobre a configuração da estrutura e feição interceptadas por T9 e T10 ....................... 68

Figura 18. Reservatório perfil Sul, unidades 9 a 11. Nível de ocupação da fase Açutuba ............................. 71

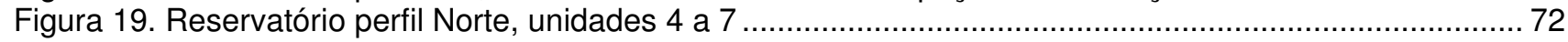

Figura 20. Reservatório perfil Norte, Feições do tipo 1 .......................................................................... 74

Figura 21. Reservatório perfil Norte, unidades 4 a 8. Escavação das feições do tipo 3 .................................... 75

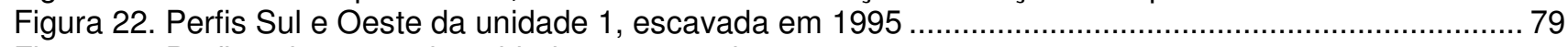

Figura 23. Perfis sul e oeste da unidade 2, escavada em 1995 ............................................................... 80

Figura 24. Planta topográfica, densidades de fragmentos e datações radiocarbônicas do sitio Açutuba ......... 85

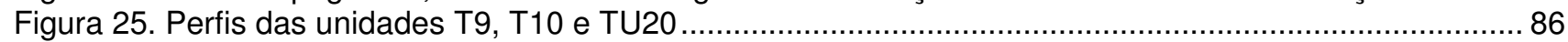

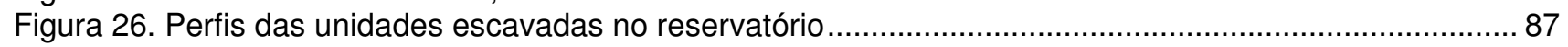

Figura 27. Perfil e planta baixa da sondagem 1 escavada no sítio Cachoeira.............................................. 90

Figura 28. Unidades de escavação com contextos Manacapuru preservados ........................................... 92

Figura 29. Planta topográfica do sitio Paricatuba, e intervenções realizadas no sítio em 2005 ........................ 94

Figura 30. Perfis estratigráficos de intervenções realizadas no sítio Paricatuba em 2005 ................................. 95

Figura 31. Estruturas cerâmicas enterradas na unidade N1076 E1151; densidade de fragmentos por nível.. 97

Figura 32. Feição com estrutura de combustão na unidade N1125 E1076 ................................................. 98

Figura 33. Feições sinalizadas na rampa de acesso à clareira 28............................................................... 100

Figura 34. Feições sinalizadas expostas à forte erosão pluvial .................................................................... 100

Figura 35. Escavação de uma superfície ampla abrangendo as feições 26 a 32 ....................................... 101

Figura 36. Diferentes etapas da escavação de F26 …................................................................... 102

Figura 37. Perfil Leste da unidade N1068 E1169 e perfil Norte da unidade N1081 E1182 (F. 82 e 94) ....... 105

Figura 38. Unidade na rampa de acesso evidenciando vasilha Manacapuru exposta pela erosão pluvial .... 105

Figura 39. Vista geral das valas Norte e Leste, e feições na vala Leste ...................................................... 106

Figura 40. Planta topográfica do sítio NSP Socorro, com intervenções arqueológicas, densidades de

vestígios e datações radiocarbônicas ................................................................................................ 109

Figura 41. Perfis das unidades escavadas no sítio N S P Socorro ........................................................... 110

Figura 42. Trincheira escavada no montículo 1 com feições anteriores ao montículo ................................... 1112

Figura 43. Unidade com vasos Manacapuru em pedestais e nas paredes Norte e Leste.............................114

Figura 44. Secção delgada mostrando laminação interpretada como piso de ocupação .............................. 115

Figura 45. Área de ocorrência de vasos inteiros, vaso $\mathrm{n}^{\circ} 7$ evidenciado no perfil entre camadas I e II ........ 117

Figura 46. Área com ocorrência de vasos inteiros da fase Manacapuru com feições no latossolo amarelo.. 117

Figura 47. Escavação em Hatahara com vasilhas inteiras Manacapuru e Açutuba e feições das fases

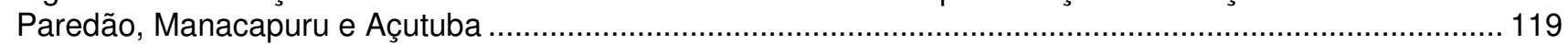


Figura 48. Planta topográfica do sítio Hatahara com intervenções arqueológicas, densidades de vestígios e datações radiocarbônicas.

Figura 49. Planta baixa das feições e recipientes escavados no sítio Hatahara ....................................... 125

Figura 50. Perfil da unidade N1209/10/11 W1421 do sítio Hatahara ...................................................... 126

Figura 51. Feições e Perfil da trincheira escavada no sítio Jacuruxi ......................................................... 128

Figura 52. Perfil Sul da unidade N1000 E1024-25 e perfil Oeste da unidade N1002 E1126..................... 130

Figura 53. Planta topográfica do sítio Jacuruxi, com densidades de vestígios e datações radiocarbônicas.. 132

Figura 54. Perfis das unidades escavadas no sítio Jacuruxi................................................................ 133

Figura 55. Perfis das unidades escavadas no sítio Jacuruxi..................................................................... 134

Figura 56. Vista do sítio Osvaldo, a partir do Lago do Limão............................................................ 135

Figura 57. Planta topográfica do sítio Osvaldo, com densidades de vestígios e datações radiocarbônicas.. 139

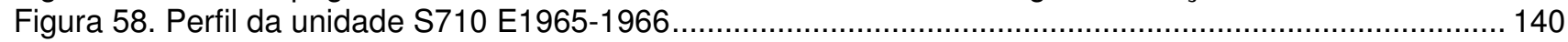

Figura 59. Planta topográfica do sítio Lago Grande, com concentrações de vestígios e datações

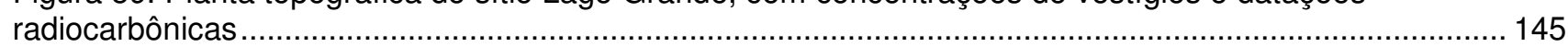

Figura 60. Vista aérea do sítio arqueológico Nova Cidade, na zona urbana de Manaus ............................ 146

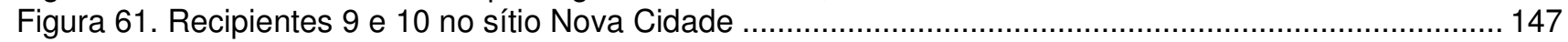

Figura 62. Planta topográfica do sítio Nova Cidade............................................................................. 149

\section{Capítulo V}

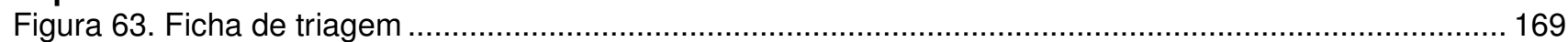

Figura 64. Gabarito e Ficha de Análise ................................................................................... 173

Figura 65. Organograma de relacionamento entre as variáveis da ficha de análise ...................................174

Figura 66. Organograma de relacionamento entre as variáveis da ficha de análise ................................... 176

Figura 67. Natureza da peça: informações estruturais das partes constituintes do vasilhame ...................... 179

Figura 68. Aspecto dos temperos mais comumente encontrados na Amazônia (lupa binocular 50x)............ 182

Figura 69. Diferentes tipos de queima observáveis na fratura dos fragmentos .......................................... 183

Figura 70. Análise estrutural da morfologia do vasilhame. Relação entre forma e contorno ........................... 185

Figura 71. Análise morfológica do vasilhame. Classificação das bordas e lábios ......................................... 186

\section{Capítulo VI}

Figura de Rosto: Decoração incisa do Recipiente 1, sítio Hatahara (desenho: Claide Moraes) ................... 190

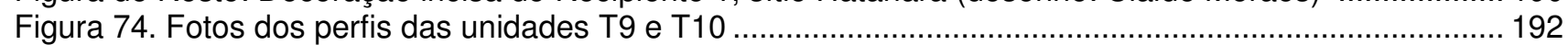

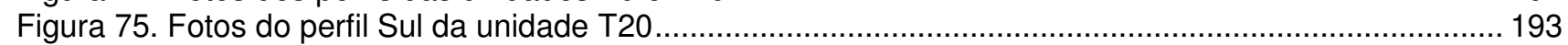

Figura 76. Legendas das siglas utilizadas nos gráficos de freqüências das variáveis ................................ 196

Figura 77. Variabilidade formal das cerâmicas do sítio Açutuba a partir de T9-T10 e de TU20...................... 199

Figure 78. Flange labiais das fases Açutuba e Manacapuru ..................................................................... 201

Figura 79. Apêndice modelados das fases Açutuba e Manacapuru ............................................................ 202

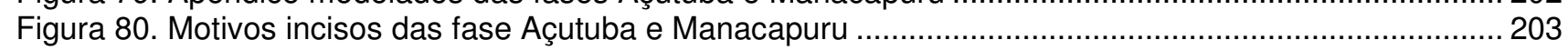

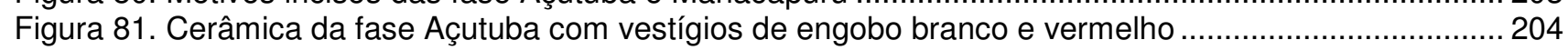

Figura 82. Fragmentos cerâmicos da fase Açutuba com vestígios de pintura policroma ............................. 205

Figura 83. Fragmentos cerâmicos da unidade 2, fases Açutuba e Manacapuru ........................................... 206

Figura 84. Etapa de campo, tradagens, reservatório, e escavações no reservatório, sítio Açutuba ............... 207

Figura 85. Fragmentos cerâmicos coletados na unidade 5-6, parede norte do Reservatório ........................... 211

Figura 86. Vasos coletados na sondagem 1, escavada no sítio Cachoeira.................................................213

Figura 87. Forma reconstituída do recipiente 1 do sítio Paricatuba ........................................................ 214

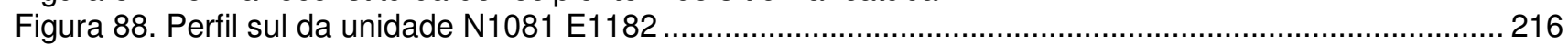

Figura 89. Cerâmicas do NSP Socorro: aspectos gerais ................................................................. 218

Figura 90. Vaso coletado na feição 83, escavada no sítio NSP Socorro ................................................ 219

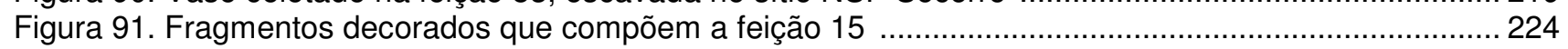

Figura 92. Formas reconstituídas das cerâmicas do Hatahara, das duas áreas analisadas .......................... 225

Figura 93. Exemplo de imagem do interior de um recipiente, reproduzida pelo Raio X ...............................227

Figura 94. Densidade total de fragmentos cerâmicos do sítio Jacuruxi ...................................................... 232

Figura 95. Cerâmicas do Jacuruxi: aspectos gerais ............................................................................... 234

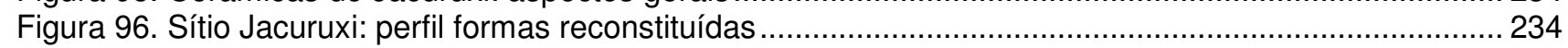

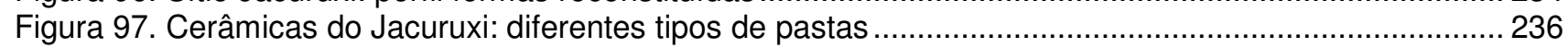

Figura 98. Sítio Jacuruxi: perfil oeste da unidade N1002 E1126........................................................... 237

Figura 99. Fragmento de gargalo e de base em pedestal .................................................................... 238

Figura 100. Unidade S710W1966 do sítio Osvaldo: densidade de fragmentos por nível............................ 239

Figura 101- Fragmento de lâmina de machado da unidade S710 W1966 ......................................................243

Figura 102. Variabilidade formal identificada nas cerâmicas da unidade S710 W1966, sítio Osvaldo .............244 
Figura 103. Cerâmica Manacapuru do sítio Osvaldo

Figura 104. Cuia pintada e cesta com alça da fase Paredão encontrados no sítio Lago Grande ....................2 246

Figura 105. Variabilidade formal identificada nas unidades 1 , 3 e 4 do sítio Lago Grande ..........................248

Figura 106. Fragmentos cerâmicos e recipientes parcialmente remontados ............................................. 251

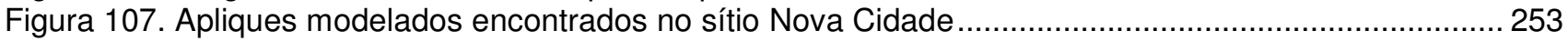

Figura 108. Formas reconstituídas do sítio Nova Cidade................................................................... 254

Figura 109. Decoração plástica: fragmentos cerâmicos incisos do sítio Nova Cidade .................................. 254

Figura 110. Fragmento de lâmina polida encontrada no sítio Nova Cidade ..............................................25

Figura 111. Apliques modelados e fragmentos decorados Açutuba, dos sítios Açutuba e Hatahara ........... 267

Figura 112. Variabilidade formal Açutuba ....................................................................................... 268

Figura 113. Fragmentos decorados Manacapuru, dos sítios Osvaldo e Jacuruxi....................................... 272

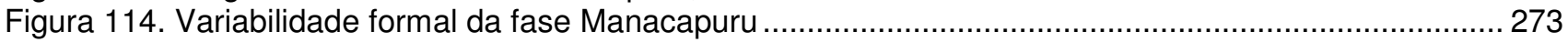

Figura 115. Apliques modelados Paredão do sítio Nova Cidade ........................................................... 277

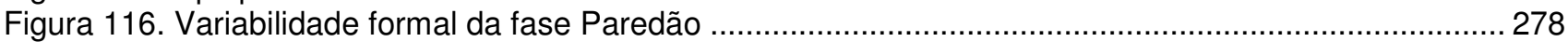

Figura 117. Espículas silicosas do cauixi presentes na pasta cerâmica (lupa binocular) ..............................281

Figura 118. Secções delgada das pastas cerâmicas de diferentes fases e sítios arqueológicos.................... 283

\section{Capítulo VII}

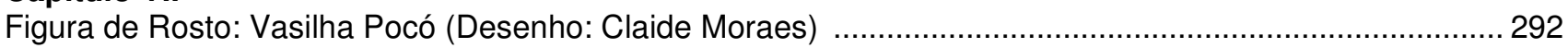

Figura 199. Localização do sítio arqueológico Nova Esperança............................................................... 298

Figura 200. Vista do sítio Nova Esperança a partir do rio Urucu............................................................. 299

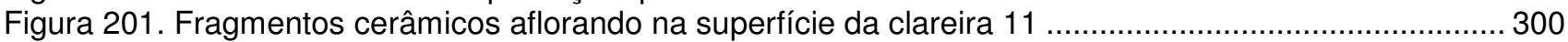

Figura 202. Perfil Norte da unidade N994 E1070, densidade de fragmentos por nível .............................. 301

Figura 203. Perfil Norte da unidade N1037E1051, recipiente cerâmico na base do nível $70 \mathrm{~cm} . . . \ldots \ldots \ldots \ldots \ldots . . . . . . . .301$

Figura 204. Perfil Norte da unidade N1000 E801, densidade de fragmentos por nível ................................ 303

Figura 205. Aspectos gerais das cerâmicas do sítio Nova Esperança ..................................................... 304

Figura 206. Cerâmicas antigas do Nova Esperança .......................................................................... 301

Figura 207. Mapa topográfico do sítio Nova Esperança, com densidades de vestígios ................................. 310

Figura 208. Perfis estratigráficos das unidades escavadas no sítio Nova Esperança ................................... 311

Figura 209. Sítios arqueológicos da região do baixo Trombetas-Nhamindá com cerâmicas Pocó ................. 314

Figura 210. Reconstituição morfológica a partir de fragmentos Pocó da Sondagem 1-92 .......................... 321

Figura 211. Cerâmica Pocó: vasilhas com flanges labiais, decoração incisa, e motivo zoomorfo ................... 321

Figura 212. Cerâmica Pocó: vaso com borda incisa e flange labial com impressão de corda ........................ 322

Figura 213. Cerâmicas Pocó: pintura policroma.................................................................................... 322

\section{Capítulo VIII}

Figura de Rosto: Vasilha da "Tradição Barrancas" (Sanoja, 1979, figura 93) ............................................. 333

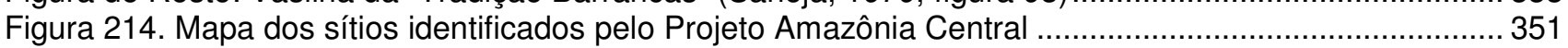

Figura 215. Cerâmicas associadas à fase Itacoatiara recolhidas por moradores de Itacoatiara.....................366

Figura 216. Cerâmicas associadas à fase Itacoatiara coletadas por P. Hilbert ........................................... 367

Figura 217. Cerâmicas Manacapuru, Paredão e Guarita coletadas por P. Hilbert no sítio Paredão ............... 369

Figura 218. Fragmento cerâmico do sítio Açutuba .................................................................................... 379 


\section{ÍNDICE DE GRÁFICOS}

\section{Capítulo IV}

Gráfico 1. Densidade de fragmentos cerâmicos por nível na unidade TU20

Gráfico 2. Densidade de fragmentos cerâmicos e quantidade de líticos nas unidades T9 e/ou T10 ...............67 67

Gráfico 3. Quantificação do material coletado no reservatório, perfil S ….................................................. 70

Gráfico 4. Densidade de fragmentos cerâmicos por nível nas unidades do perfil Norte ............................... 72

Gráfico 5. Densidade de fragmentos cerâmicos por nível nas unidades dos perfis Leste e Oeste .................. 73

Gráfico 6. Variação cronológica das fases cerâmicas encontradas no sítio Açutuba ........................................ 83

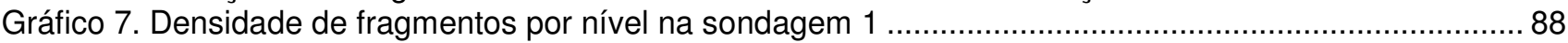

Gráfico 8. Datações obtidas para o sítio Hatahara .................................................................................... 121

Gráfico 9. Freqüência por nível de fragmentos relacionados às fases Guarita e Paredão no montículo 1 .... 122

Gráfico 11. Cronologia dos montículos M1 e M2 ................................................................................. 123

Gráfico 12. Datações radiocarbônicas obtidas para a unidade S710 E1966 do sítio Osvaldo ...................... 137

Gráfico 13. Cronologia das ocupações no sítio Osvaldo........................................................................ 138

Gráfico 14. Datações radiocarbônicas calibradas obtidas para o sítio Lago Grande ................................. 142

Gráfico 15. Cronologia de ocupação do sítio Lago Grande..................................................................... 144

\section{Capítulo VI}

Gráfico 16. Resultado da triagem do material cerâmico proveniente das escavações T9 e T10 ................... 193

Gráfico 17. Resultado da triagem do material cerâmico proveniente da unidade TU20 ............................... 194

Gráfico 18. Quantidade de fragmentos por unidade de escavação e por nível ............................................ 195

Gráfico 19. Variação do antiplástico nos fragmentos de T9-T10 e de TU20.............................................. 197

Gráfico 20. Variação de técnicas de manufatura e queima nos fragmentos de T9-T10 e TU20 .................... 198

Gráfico 21. Variação dos tratamentos de superfície dos fragmentos de T9-T10 e de TU20 …..................... 198

Gráfico 22. Variáveis de posicionamento e forma das bordas de T9-T10 e de TU20 ................................ 200

Gráfico 23. Boxplots do diâmetro da borda, espessura da peça, e espessura do lábio (T9-T10, TU20) ....... 200

Gráfico 24. Técnicas de decoração plásticas e tipos de acabamento dos lábios (T9-T10 e TU20) ................ 202

Gráfico 25. Técnicas de decoração plástica e tipos de acabamento dos lábios (T9-T10 e de TU20) ............. 203

Gráfico 26. Técnicas de decoração plástica e tipos de acabamento dos lábios (T9-T10 e de TU20) ............ 204

Gráfico 27. Densidade de fragmentos cerâmicos por nível na unidade 2 ................................................ 206

Gráfico 28. Quantidade de fragmentos por nível coletados na unidade 5-6, parede norte............................ 208

Gráfico 29. Resultado da triagem dos fragmentos coletados na unidade 5-6, parede norte ......................... 209

Gráfico 30. Freqüência de temperos por nível na unidade 5-6, parede norte ............................................ 210

Gráfico 31. Freqüência relativa de cauixi e cariapé na unidade 5-6, parede norte .................................... 210

Gráfico 32. Freqüência relativa dos tipos de queima, por nível, na unidade 5-6, parede norte..................... 210

Gráfico 33. Freqüência relativa da forma do vaso, por nível, na unidade 5-6, parede norte ......................... 210

Gráfico 34. Sítio Cachoeira. Resultado da triagem do material cerâmico ............................................... 212

Gráfico 35. Sítio Cachoeira. Tipos de queima e acabamentos de superfície to material cerâmico ................ 213

Gráfico 36. Resultados da triagem dos fragmentos de N S P Socorro ................................................... 217

Gráfico 37. Freqüência das cores da superfície , por nível, nas cerâmicas do NSP Socorro........................ 217

Gráfico 38. Freqüência dos tipos de queimas, por nível, nas cerâmicas do NSP Socorro........................... 217

Gráfico 39. Freqüência dos temperos preponderantes, por nível, nas cerâmicas do NSP Socorro............... 217

Gráfico 40. Freqüência de tipos de decoração no nível 10-20, na unidade N1081 E1183 ...........................218

Gráfico 41. Índice de fragmentação das cerâmicas que compõem o montículo 1 ......................................... 221

Gráfico 42. Freqüência dos tipos de antiplástico, por nível, nas cerâmicas do Hatahara................................ 222

Gráfico 43. Freqüência dos tipos de tratamento de superfície, por nível, nas cerâmicas do Hatahara........... 222

Gráfico 44. Freqüência de decoração, por nível, nas cerâmicas do Hatahara ........................................... 222

Gráfico 45. Freqüência de decoração, geral, nas cerâmicas do Hatahara ................................................ 225

Gráfico 46. Resultado da triagem das cerâmicas de F3, Hatahara............................................................... 226

Gráfico 47. Freqüência relativa das técnicas decorativas nos lábios por nível no sítio Jacuruxi....................235

Gráfico 48. Freqüência relativa de temperos preponderante por nível no sítio Jacuruxi .............................. 235

Gráfico 49. Freqüência das cores da argila observadas nas cerâmicas do Jacuruxi ................................... 235

Gráfico 50. Freqüência dos tipos de queima observados nas cerâmicas do Jacuruxi ................................. 235

Gráfico 51. Triagem dos fragmentos coletados na unidade S710 W1966 ........................................... 241

Gráfico 52. Tipos de anti-plásticos observados por nível nos fragmentos da unidade S710 W1966 242

Gráfico 53. Tipos de acabamentos de superfície por nível nos fragmentos da unidade S710 W1966 ......... 242

Gráfico 54. Tipos de decoração plástica observados por nível nos fragmentos da unidade S710 W1966 ... 242

Gráfico 55. Tipos de decoração plástica observados por nível nos fragmentos da unidade S710 W1966 ... 242 


\section{Capítulo VII}

Gráfico 56. Sítio Nova Esperança, densidade de vestígios arqueológicos por nível .................................. 302

Gráfico 57. Temperos preponderantes nos fragmentos da unidade N1000 E801, sítio Nova Esperança ..... 305

Gráfico 58. Resultado da triagem dos fragmentos do sítio Nova Esperança ............................................... 306

Gráfico 59. Tratamentos de superfície observados nos fragmentos do sítio Nova Esperança ......................306

Gráfico 60. Técnicas de manufatura dos fragmentos do sítio Nova Esperança .......................................... 306

Gráfico 61. Temperos preponderantes dos fragmentos do sítio Nova Esperança ...................................... 306

Gráfico 62. Decorações plásticas dos fragmentos do sítio Nova Esperança ................................................ 307

Gráfico 63. Decorações crômicas dos fragmentos do sítio Nova Esperança .............................................. 308

Gráfico 64. Freqüência de fragmentos Pocó por nível na sondagem 1-92 ............................................. 317

Gráfico 65. Coloração da superfície da cerâmica nos fragmentos da Sondagem 1-92 .............................. 318

Gráfico 66. Freqüência relativa do tempero preponderante nos fragmentos da Sondagem 1-92 ................. 318

Gráfico 67. Freqüência relativa dos tipos de queima observados nos fragmentos da Sondagem 1-92 ......... 318

Gráfico 68. Temperos observados nos fragmentos Pocó da Sondagem 1-92......................................... 318

Gráfico 69. Freqüência dos tipos de decoração dos fragmentos Pocó da Sondagem 1-92 …..................... 319

Gráfico 70. Freqüência relativa de tratamentos de superfície nos fragmentos da Sondagem 1-92 ...............320

Gráfico 71. Resultado da triagem dos fragmentos Pocó da Sondagem 1-92 ............................................ 320

Gráfico 72. Quantidade de vestígios analisados em cada sítio arqueológico ............................................. 325

Gráfico 73. Proporção das cores das argilas observadas nos fragmentos analisados................................. 327

Gráfico 74. Proporção dos temperos majoritários observados nos fragmentos analisados .......................... 327

Gráfico 75. Proporção das técnicas de manufatura observadas nos fragmentos analisados ....................... 328

Gráfico 76. Proporção dos tipos de queima observados nos fragmentos analisados .................................328

Gráfico 77. Proporção dos tratamentos de superfície observados nos fragmentos analisados ..................... 328

Gráfico 78. Proporção das marcas de uso observadas nos fragmentos analisados ................................... 328

Gráfico 79. Freqüência de marcas de uso observadas nos fragmentos da Sondagem 1-92 ....................... 329

Gráfico 80. Intervalos cronológicos das fases arqueológicas da Amazônia central .............................360

Gráfico 81. Quadro cronológico contendo datações de $\mathrm{C}_{14}$ dos sítios Hatahara, Açutuba, Lago Grande e área

do Lago do Limão, na Amazônia central ................................................................................................ 370 


\section{ÍNDICE DE TABELAS}

\section{Capítulo II}

Tabela 1. Quadro cronológico da Amazônia central proposto por Hilbert (1968) ......................................... 35

Tabela 2. Variabilidade cronológica das fases Açutuba e Manacapuru na Amazônia central........................... 43

\section{Capítulo IV}

Tabela 3. Sítios cerâmicos estudados e fases da Tradição Borda Incisa a eles correlacionadas .................... 58

Tabela 4. Quantidade de fragmentos cerâmicos por nível recolhidos nas tradagens ....................................69

Tabela 5. Datas calibradas obtidas para o sítio Açutuba...........................................................................77

Tabela 6. Descrição dos vestígios líticos coletados na unidade S710 E1966 ............................................. 89

Tabela 7. Datas calibradas obtidas para o sítio Nossa Senhora do Perpétuo Socorro ................................ 107

Tabela 8. Datações obtidas para o sítio Hatahara ……........................................................................... 120

Tabela 9. Feições escavadas no sítio Jacuruxi ............................................................................... 129

Tabela 10. Datas calibradas obtidas para o sítio Jacuruxi .......................................................................... 130

Tabela 11. Datas calibradas obtidas para o sítio Osvaldo ................................................................. 137

Tabela 12. Datações radiocarbônicas obtidas para o sítio Lago Grande ..................................................... 143

\section{Capítulo VI}

Tabela 13. Datações radiocarbônicas obtidas para a unidade S710 W1966 no sítio Osvaldo.......................240

Tabela 14. Descrição dos vestígios líticos coletados na unidade S710 E1966 .........................................243

Tabela 15. Relação dos recipientes cerâmicos coletados no sítio Nova Cidade ....................................... 252

Tabela 16. Quantidade de fragmentos ou vasos inteiros analisados em cada coleção arqueológica............ 258

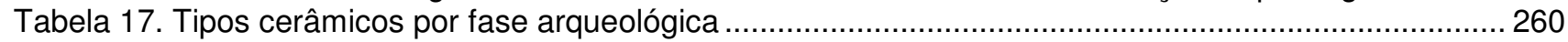

Tabela 18. Freqüências de tipos coleções mais representativas ...............................................................2262

Tabela 19. Fragmentos cerâmicos selecionados para realização das secções delgadas.............................. 284

Tabela 20. Comparação dos atributos entre as diferentes fases cerâmicas.................................................. 289

\section{Capítulo VII}

Tabela 21. Datações radiocarbônicas do sítio Nova Esperança (Clareira 11) ............................................. 308

Tabela 22. Datas calibradas do sítio Nova Esperança ......................................................................... 309

Tabela 23. Informações estratigráficas da sondagem 1 - 1992 ........................................................... 316

Tabela 24. Quantidade de vestígios analisados em cada sítio arqueológico............................................... 325

\section{Capítulo VIII}

Tabela 25. Relação entre os ambientes, tamanhos e cronologia dos sítios arqueológicos pesquisados ....... 354

Tabela 26. Datações radiocarbônicas antigas para os sítios Itacoatiara e Paredão

Apêndice

Tabela 27. Sítios Analisados de acordo com tipos encontrados e suas fases relacionadas. 


\section{RESUMO}

Esta pesquisa expõe contraposições teóricas e empíricas aos clássicos modelos de ocupação da Amazônia. Através de uma fusão entre base empírica e o corpus de conhecimento atualmente disponível, propõe uma história de ocupação da Amazônia central agenciada por grupos culturais integrados através de um complexo sistema sócio-político, que extrapolou fronteiras étnicas, lingüísticas e ambientais. Este sistema estaria materializado na tradição Borda Incisa e teria se desenrolado ao longo de muitos séculos, com início em torno do anno domini e se estendendo até os séculos XI e XII d.C. A esta intrincada rede macro-regional, que aqui denomino Esfera de Interações, estão ligados elementos como a padronização de um sistema de comunicação, expresso através da cultura material e das formas de usar e organizar o espaço. A cronologia apresentada neste doutoramento também oferece parâmetros para uma reavaliação do uso de conceitos arqueológicos tradicionais, como as fases e tradições. Logra-se maior flexibilização de tais categorias, uma vez que a fluidez de limites é inerente aos conjuntos artefatuais estudados. $\mathrm{Na}$ área de confluência dos rios Negro e Solimões, esta história é contada através do entendimento das relações entre as fases Açutuba, Manacapuru e Paredão.

\section{PALAVRAS-CHAVE}

Arqueologia amazônica; Cronologia; Amazônia central; Tradição Borda Incisa; Esfera de Interações 


\begin{abstract}
This dissertation offers new theoretical insights and empirical data that supplements some of the classic models of occupation of Amazonia. Through a combination between empirical data and current knowledge, the dissertation proposes a history of occupation of the Central Amazon region that places cultural groups integrated in a complex socio-political system extending beyond ethnic, linguistic and environmental boundaries as its main agents. The material correlates of this system, which developed from around the beginning of the Christian era and reached until the eleventh or twelve century $A D$, would be pottery and associated contexts of the Incised Rim tradition. This intricate macroregional network, in effect an Interaction Sphere, includes such features as a standardisation of communication systems expressed in material culture and in forms of using and organizing space. The chronology presented in this dissertation also provides pointers to reassess the use of traditional archaeological concepts such as phases and traditions. It employs these categories with some flexibility inasmuch as the sets of artefacts that have been studied show inherent fluidity in their definitions. In the confluence area of the Negro and Solimões rivers, this permits unravelling a history that is based on an understanding of the relationships between the Açutuba, Manacapuru and Paredão phases.
\end{abstract}

\title{
KEY WORDS
}

Amazonian archaeology; Chronology; Central Amazon; Incised Rim Tradition; Interaction Sphere 


\section{PRÓLOGO}

\section{Uma breve história desta pesquisa}

Vale a pena começar contando um pouquinho da história da pesquisa cujos resultados apresento agora, na forma de uma tese de doutorado.

Tudo começou em 1998, quando entrei no curso de História da USP e uma amiga indicou um estágio num tal de Museu de Arqueologia. Eu nem sabia que tinha isso na universidade. Fui! Caí lá meio de pára-quedas, mas fui. Era um estágio voluntário em arqueologia amazônica, e logo comecei a lavar caquinhos de cerâmica. Lembro do primeiro texto que tive que ler: De Onde Surgem os modelos? Considerações sobre a origem e expansão dos Tupi (Heckenberger, Neves \& Petersen, 1998) indicado pelo meu orientador. Passei bons anos lavando, contando e pesando os - agora chamados - fragmentos cerâmicos.

Em 1999 fui pela primeira vez a campo na Amazônia, escavar na llha de Marajó (no Pará) e depois no famigerado sítio Açutuba (Estado do Amazonas) vou falar bastante dele ao longo do trabalho! Daí surgiu a idéia para minha iniciação científica, intitulada "Análise dos vestígios cerâmicos do sítio arqueológico Açutuba" financiada pela FAPESP (Processo n01/10934-3, 2003). Dois objetivos principais, relacionados entre si, orientaram os trabalhos. O primeiro era o teste e aplicação de um novo método de análise cerâmica que vínhamos desenvolvendo no laboratório. A idéia principal era amenizar os aspectos subjetivos das seriações tradicionalmente feitas na Amazônia (Hilbert, 1968; Meggers, 1970). Pretendia fazer isso através de uma ficha com mais de cem variáveis que contemplasse, sem hierarquias, os diversos atributos dos fragmentos. Os dados então passariam por análises estatísticas multivariadas.

Levei mais de um ano para analisar os fragmentos de duas unidades de $1 \mathrm{~m}^{2}$. Dessa maneira, quantas gerações não seriam necessárias para avançar em questões de arqueologia amazônica? Aprendi que, às vezes, não vale a pena reinventar a roda! Acabei por desenvolver outro método, utilizado neste trabalho, que é uma combinação de aspectos do método de tipo-variedade de Meggers (1970) e da análise modal utilizada por Lathrap e seus seguidores em outras partes da Amazônia e América do Sul (por exemplo, Raymond, 1996). 
O segundo objetivo da iniciação era entender a variabilidade interna de cerâmicas supostamente associadas à fase Manacapuru, uma fase cerâmica filiada a Tradição Borda Incisa (Hilbert, 1968; Meggers \& Evans, 1961). Os resultados me levaram a formular as questões que seriam posteriormente desenvolvidas no mestrado.

Acabei terminando o projeto de iniciação quase ao mesmo tempo em que me formei na graduação. Logo no ano seguinte, em 2003, ingressei no mestrado, e contei novamente com o apoio da FAPESP (processo $n^{\circ} 03 / 03434-0,2004$ ). $O$ título do projeto é elucidativo: "Cronologia da Amazônia Central: o significado da variabilidade da fase Manacapuru". Naquele momento os problemas de pesquisa já eram mais sólidos e genuinamente arqueológicos. Estava trabalhando com cerâmicas Manacapuru, oriundas de dois contextos bem diferentes, e com características também bastante díspares. Parte delas vinha dos ricos solos de origem antrópica, as Terras Pretas de Índio (TPI), e outras eram provenientes das matrizes naturais da área, não modificadas por ação humana. E as características destes conjuntos eram também diferentes.

As hipóteses que orientaram o mestrado visavam explicar este padrão. Consideravam que a origem de tal variação poderia ser de ordem diacrônica, sincrônica, ou mesmo as duas. $O$ andamento da pesquisa forneceu uma bateria de datações radiocarbônicas, que indicaram uma lacuna temporal entre os dois contextos. Confirmada a hipótese de variação cronológica, desmembrei a fase Manacapuru, sugerindo a ocorrência de um conjunto distinto, mais antigo, que batizei de fase Açutuba - nome do sítio arqueológico onde foi encontrada. Propus ainda que as duas correspondessem a dois períodos de uma manifestação na Amazônia central da tradição Barrancóide.

Tudo isso foi apresentado em minha qualificação do mestrado, que ocorreu em julho de 2005. Compuseram a banca os Professores Fabíola Silva e Levi Figuti, ambos do MAE-USP e, cada um à sua maneira, muito contribuíram para um bom encaminhamento da pesquisa. Decidiu-se naquele momento pela mudança para o doutorado direto.

Com a mudança para o doutorado e o fim da bolsa de mestrado, tive a oportunidade de trabalhar em diversos projetos na Amazônia. Passei quase dois anos morando em Manaus e bem perto (ou dentro) da minha área de pesquisa. Desenvolvi, pelo IPHAN (Instituto do Patrimônio Histórico e Artístico Nacional), o 
projeto "Levantamento Arqueológico do Médio Amazonas", através do qual tive a chance de percorrer um longo trecho, de quase $400 \mathrm{~km}$, do rio Amazonas, passando por doze municípios entre Manaus e Nhamundá, na fronteira com o Pará (Lima \& Silva, 2005). Pelo Gasoduto Coari-Manaus da PETROBRAS, coordenado por E. Neves, trabalhei em levantamentos e resgates de sítios arqueológicos ao longo do médio-baixo Solimões. Alguns destes sítios estão diretamente relacionados com meus problemas de investigação e se tornaram objetos da pesquisa. Esses trabalhos me deram oportunidade de conhecer - e fazer - a arqueologia de extensas regiões amazônicas. Um acúmulo tão grande de dados, e ainda uma intensa vivência na Amazônia, inevitavelmente tornaram a abrangência do projeto e dos problemas da pesquisa, muito maior.

Durante o doutorado pude contar, mais uma vez, com o auxílio da FAPESP (processo $n{ }^{\circ} 06 / 50287-0$ ). O novo exame de qualificação, dessa vez do doutorado, ocorreu em 10 de julho de 2007. Compuseram a banca examinadora o Prof. Dr. Klaus Hilbert (Pontífica Universidade Católica - RS) e o Prof. Dr. Michael Heckenberger (University of Florida). As sugestões por eles dadas para encaminhamento e conclusão da pesquisa foram cuidadosamente trabalhadas. Parte delas, como uma maior atenção às discussões sobre fases e tradições arqueológicas, bem como uma maior atenção aos próprios resultados das análises cerâmicas, foram incorporadas às discussões apresentadas no corpo da tese. De fato, o aprimoramento teórico cobrado pela banca teve em sua essência uma mudança de perspectiva do trabalho como um todo. Tal mudança residiu mais em como o tema foi abordado do que no substrato teórico geral da pesquisa.

Se o caso estudado, da Amazônia central, era inicialmente um proposto fim da pesquisa, ele passou a ser encarado, além de fim, quase como um ponto de partida. Explico: os dados gerados e interpretações alvitradas para a compreensão do registro arqueológico local subsidiaram discussões mais amplas, que dizem respeito aos próprios aspectos decodificáveis de categorias arqueológicas, que nos aproximam dos aspectos êmicos, ou sócio-etno-políticos e históricos procurados.

Considerada como um longo processo (10 anos!), a pesquisa teve seus esforços divididos em diversas etapas, todas interligadas e de igual importância. Todas as atividades acadêmicas desenvolvidas durante o período, muitas e bastante diversificadas, tiveram, sempre, o intuito de acrescentar conhecimentos 
à minha formação científica. Tanto as disciplinas como as pesquisas bibliográficas tiveram fundamental relevância para um amadurecimento intelectual, tanto em relação aos problemas arqueológicos específicos à pesquisa como ao conhecimento de diferentes posturas teóricas e abordagens disciplinares. Para cursar as disciplinas, procurei diferentes departamentos e áreas, entendendo que uma abordagem interdisciplinar é fundamental para o desenvolvimento de uma sólida pesquisa arqueológica.

Durante o primeiro ano do mestrado, dei maior ênfase às atividades de análise cerâmica, realizadas no laboratório do MAE/USP. Os fragmentos provenientes de sítios arqueológicos escavados nos anos de 1999 e 2002 foram lavados, numerados, triados e analisados. Em 2005-6 as análises foram retomadas, e levadas a cabo até 2008. Os trabalhos de laboratório ocorreram em Manaus, São Paulo (MAE-USP) e em Porto Alegre (PUC-RS). As análises laboratoriais foram de suma importância e se deram num longo processo de erros e acertos, mas creio que o saldo foi positivo: chegamos a uma metodologia coerente com os problemas de pesquisa e com os materiais disponíveis.

Ainda assim, confesso que a grande parte do meu tempo foi investida em trabalhos de campo: levantamentos e escavações, que são uma parte da pesquisa pela qual sou verdadeiramente apaixonada! Incontáveis etapas de campo ocorreram ao longo do trabalho. Dentro do âmbito dos problemas de pesquisa, a área geográfica foi consideravelmente ampliada com a mudança do mestrado para o doutorado. Além da confluência dos rios Negro e Solimões, que era 0 foco inicial, foram inseridos o médio-baixo Solimões e baixo Amazonas. Nestas três regiões foram realizados levantamentos, escavações, delimitações e mapeamentos de sítios arqueológicos.

Também Investi muito tempo na participação e apresentação de trabalhos em simpósios nacionais e internacionais, o que resultou num crescente amadurecimento profissional. Além de somar conhecimentos em minha formação científica, outros eventos como palestras, oficinas e mini-cursos que ministrei me deram a chance de compartilhar aqueles saberes adquiridos ao longo dos anos de pesquisa com estudantes e jovens arqueólogos. Entendo que a difusão dos dados, dos métodos, técnicas e questões da arqueologia são de suma importância para o desenvolvimento pleno da profissão do arqueólogo. 
A pesquisa integra um projeto de arqueologia mais amplo denominado Projeto Amazônia Central (PAC), que é vinculado ao Museu de Arqueologia e Etnologia da Universidade de São Paulo, MAE-USP, e coordenado pelo Prof. Dr. Eduardo Góes Neves, docente desta instituição. Este projeto vem atuando nos municípios de Manaus e Iranduba, estado do Amazonas, desde 1995. Durante este período, foi identificada mais de uma centena de sítios arqueológicos, sendo que dez deles já foram sistematicamente pesquisados através de trabalhos de mapeamento, delimitação, escavação e análises. Grande parte dos dados gerados pelo PAC compõe este Doutorado, que teve seu embrião formado já em 1998, quando me integrei ao Projeto.

Se os objetivos iniciais do PAC eram: "o estabelecimento de tamanho e forma dos assentamentos, a reconstrução da densidade e duração das ocupações e o refinamento da cronologia da área de confluência dos rios Negro e Solimões" (Neves, 1999), pode-se dizer que hoje o PAC caminha rumo ao entendimento de tais questões. Uma série de pesquisas vinculadas ao projeto tem fornecido subsídios para uma completa revisão dos modelos de ocupação da Amazônia. Dentre iniciações científicas, mestrados e doutorados, o PAC tem contribuído tanto para reescrever a história do Amazonas como para formar novos pesquisadores (Abreu, 2000; Costa, 2003; Donatti, 2002, 2003; Gibertoni, 2004; Heckenberger et al. 1998, 1999; Lima \& Machado 2005; L. Lima, 2003; Lima et al., 2006; Machado, 2005; Moraes, 2007; Neves, 2000, 2001, 2002, 2003, 2005; Neves \& Petersen 2005; Neves et al., 2003, 2004; Portocarrero, 2006; Petersen et al. 2001; Rebellato, 2007).

Outro aspecto digno de menção é a atuação que o PAC tem tido na formação de novos arqueólogos na - e da - Amazônia. Através de ações sistemáticas de educação patrimonial e principalmente da incorporação de pessoas locais à equipe, existem hoje em Manaus e Iranduba colaboradores do projeto de volta às salas de aulas, muitos deles depois de vários anos de interrupção dos estudos, com o intuito de receberem uma formação que os permita atuar como arqueólogos na região.

De fato hoje se pode dizer que, além das questões científicas inerentes à pesquisa arqueológica, é também objetivo do PAC formar e incorporar novos arqueólogos amazonenses. Tão grandes foram as dimensões tomadas pelo Projeto, que deram origem ao "CABA" - Centro de Arqueologia da Biota 
Amazônica. Este centro, que será sediado no município de Iranduba, virá a incorporar institucionalmente estes novos cientistas da Amazônia, promovendo a continuidade das pesquisas acadêmicas, bem como o desenvolvimento de uma série de pesquisas de contrato, que tem ganhado cada vez mais espaço no quadro de pesquisas da região. Pode-se atribuir a este crescimento duas razões principais. Em primeiro lugar, o acelerado desenvolvimento econômico que Manaus e outros municípios amazônicos de médio porte têm vivenciado. Em adição a isso, foi apenas nos últimos anos que a Lei do Patrimônio de $1961^{1}$, que trata da proteção do patrimônio arqueológico, se fez cumprir com maior rigor no Estado do Amazonas.

Com este trabalho, procuro responder a recentes questionamentos que colocam a Amazônia num contra-fluxo das atuais correntes teóricas do Brasil, que comungam numa mesma tendência de reavaliação de conceitos arqueológicos tradicionais. Encorajo-me a dizer que esta pesquisa, junto com outras tantas vinculadas ou não ao PAC, representa um avanço no que tange o desenvolvimento do pensamento arqueológico voltado à resolução de problemas específicos, e de questões de maior envergadura, que dizem respeito ao potencial interpretativo dos registros, independente da nomenclatura que se dê aos conceitos utilizados: afinal, vale o conteúdo. Estas pesquisas, como um todo, fornecem os parâmetros de qualidade e de ética da arqueologia tropical sulamericanista atualmente em voga.

\footnotetext{
${ }^{1}$ Lei federal 3924, promulgada em 1961, que determina os parâmetros de proteção das jazidas arqueológicas brasileiras.
} 


\section{Introducão}

"Ao eliminar a história de uma situação cultural suprimimos a sua componente ou dimensão maior."

(Kroeber, 1952)

A reconstrução da história da ocupação pré-colonial da Amazônia é feita, basicamente, através da análise e interpretação dos registros materiais deixados pelos povos que habitaram essas áreas no passado. Embora o ambiente tropical úmido, característico desse tipo de formação morfo-climática, tenha sido avaliado por muitos pesquisadores como um intenso agente que atuaria sobre a rápida destruição desses registros (Hilbert, 1968, p. 272; Meggers et al., 1988, p. 275), sabe-se, desde o século XIX, que diversas categorias de vestígios podem se preservar. Além de artefatos cerâmicos e líticos, os restos faunísticos, botânicos, sepultamentos humanos e uma infinidade de vestígios macro e microscópicos encontrados na região são passiveis de utilização como fonte potencial de informação histórica e cultural. A associação entre as diferentes categorias de vestígios arqueológicos é, portanto, o meio mais efetivo de reconstrução dos modos de vida das sociedades pretéritas.

No entanto, a escassez de dados controlados disponíveis para a maior parte da região amazônica, aliada às diferentes linhas de pesquisa adotadas por estudiosos, acabou por resultar em hipóteses contraditórias sobre a ocupação humana; modelos estes que marcaram profundamente a história da arqueologia da Amazônia. Assim, as ricas várzeas amazônicas dos tempos pré-coloniais podiam ser interpretadas tanto como um "habitat infinitamente mais atraente para o homem" (Lathrap, 1970a, p. 28), ou como a verdadeira "ilusão de um paraíso" (Meggers, 1971), local onde a imprevisibilidade dos recursos de subsistência teria limitado o desenvolvimento de uma série de traços culturais, que, à época, eram índices de complexidade social. 
Se, por um lado, tal escassez apresentou-se como um problema, por outro pode-se dizer que, graças a ela, desde muito cedo a arqueologia amazônica se destacou no quadro brasileiro, dado seu caráter de cunho antropológico, calcado na compreensão das relações entre o homem, enquanto ser social, e seu habitat. Temas historicamente debatidos foram, por exemplo, a influência do ambiente tropical úmido sobre o desenvolvimento cultural e o impacto da conquista européia sobre os modos de vida das populações indígenas (Neves, 2000; Roosevelt, 1992, p. 53). Nos últimos anos, tais discussões têm se aprofundado, voltando-se a uma crescente base empírica gerada e explorada por novas abordagens, que levam em conta uma série de aspectos sócio-culturais marcados nos vestígios arqueológicos, outrora esquecidos.

Assim, o reconhecimento de complexos sistemas regionais de assentamento, ou de profundas transformações na paisagem, tem sido interpretado à luz de novos olhares (Heckenberger, 2005; Neves et al, 2004; Schaan, 2004). As chamadas Terras Pretas de Índio (TPI), por exemplo, que são solos ricos em matéria orgânica e, portanto, muito férteis, têm uma origem antrópica, sugerindo que técnicas de manejo ambiental eram praticadas em diversas partes da Amazônia há pelo menos dois mil anos (Denevan, 1996, p. 666; Lima et al., 2006; Neves et al. 2003, 2004; Petersen et al., 2001; Woods \& McCann, 1999, p. 14).

É neste sentido que o trabalho ora apresentado vem expor novas contraposições teóricas e empíricas aos clássicos modelos de ocupação da Amazônia. Através de uma fusão entre base empírica e corpus de conhecimento disponível, propõe-se uma história de ocupação da Amazônia central agenciada por grupos culturais integrados através de um complexo sistema sócio-político, que extrapolou fronteiras étnicas, lingüísticas e ambientais. Este sistema teria se desenvolvido ao longo de muitos séculos, tendo início em torno de 2.000 atrás e se estendendo, em algumas regiões, até a época da conquista.

$\mathrm{Na}$ Amazônia central, sua duração é observada até, pelo menos, os séculos XI e XII da era Cristã, quando então é substituído por um novo modo de interação social com o meio, que também foi, por sua vez, profundamente impactado pela conquista européia. A materialidade deste sistema social, na região pesquisada, está impressa na forma de diversas feições paisagísticas, tais como as mencionadas terras pretas, os montículos artificiais e a circularidade dos 
assentamentos. A essas feições estão conjugados outros vestígios, tais como a própria indústria cerâmica que, quando analisada comparativamente em perspectivas cronológica, local e regional, traz importantes informações sobre elementos envolvidos no que, por hipótese, é tratado enquanto uma esfera de interações, tal como descrito por Boomert (2000) para a região caribenha de Trinidad e Tobago e o baixo Orinoco. Juntos, estes elementos lançaram luz a um entendimento mais holístico da história dos modos de vida da Amazônia central.

Os principais focos desta pesquisa são: 1) o processo de ocupação da Amazônia central nos períodos imediatamente anteriores ao início da era Cristã; 2) as relações históricas entre estas e outras ocupações de regiões contíguas a ela, tradicionalmente enquadradas no chamado Período Formativo do norte da América do Sul; 3) as relações entre tais ocupações e aquelas que as precederam e as sucederam, constituindo um quadro de suposta continuidade dentro do nosso hipotético sistema regional de interações, visando também entender hiatos temporais existentes na cronologia de algumas regiões, incluindo a Amazônia central, no âmbito de tal sistema e, por fim, sua desestruturação na Amazônia central.

Lacunas, continuidades e rupturas co-ocorreram de maneira homóloga em diferentes regiões da Amazônia continental. Os dados analisados nos levaram a propor um novo componente na cronologia cerâmica da Amazônia central, e a propor uma hipótese para interpretar sua relação com outros complexos a ele contemporâneos, de modo a inseri-la num quadro regional mais amplo. Uma abordagem regional torna-se, neste contexto, um meio efetivo para a conexão e contraposição entre as generalizantes hipóteses de ocupação da Amazônia e as seqüências cronológicas locais, onde a mudança possa ser compreendida na escala temporal de gerações (Neves, 2006). Entende-se como intrinsecamente ligadas questões relativas ao início da produção de cerâmica, da formação das Terras Pretas de Índio e da origem e adoção da agricultura na floresta tropical; fenômenos estes que marcam o início do chamado Período Formativo do norte da América do Sul. Neste mesmo contexto verifica-se a formação de complexos sistemas de interações macro-regionais, com a abrangência já mencionada. Assim, a pergunta chave da pesquisa é: como se insere a Amazônia central nesses processos que perpassaram tantas centenas de anos? Mais do que isso, creio que este estudo de caso pode trazer à luz dados, informações e reflexões 
que virão a elucidar meandros da história pré-colonial amazônica, e das terras baixas do norte da América do Sul em geral.

Para atingir tais objetivos, uma série de trabalhos de campo e laboratório foi realizada em diferentes partes da Amazônia, incluindo: mapeamento e escavação de sítios arqueológicos situados na área de confluência dos rios Negro e Solimões, nos municípios de Manaus, Iranduba e Manacapuru/AM; o levantamento extensivo em diversas áreas dos rios Negro, Solimões e Amazonas; e também análises tecnológicas das coleções resultantes das escavações, realizadas em Manaus e no laboratório do MAE-USP, bem como de coleções oriundas do baixo Amazonas (Hilbert, P. \& Hilbert, K., 1980), hoje sob a guarda da PUC-RS, em Porto Alegre. Estas análises sempre incorporaram uma gama muito variada de dados hoje disponíveis, quais sejam, estudos de composição e processos formativos de terra preta, análises paleobotânicas, zooarqueológicas, micromorfológicas, etc.

O substrato teórico do trabalho advém de uma revisão de perspectivas culturalistas e históricas bastante difundidas na arqueologia e antropologia brasileira da primeira metade do século passado, que trataram de entender as sociedades desde um ponto de vista de uma história cultural de longa duração (Galvão, 1960; Renfrew, 2000; Rouse, 1996). A revisão epistemológica e a abordagem propostas utilizaram aspectos da ecologia e antropologia cultural, bem como da geografia humana. Tal proposta se justifica pela validade, para a utilização na Amazônia, de conceitos disciplinares tais como esfera de interação, paisagem, território, e as tão criticadas áreas culturais.

A pesquisa propôs uma cronologia de ocupação da região, reformulando o quadro pioneiro proposto por Hilbert na década de sessenta (Hilbert, 1968), em particular no que se refere às ocupações associadas à tradição Borda Incisa; Incisa e Modelada ou Barrancóide (Heckenberger, 2002; Hilbert, 1968; Lathrap 1970a, 1970b; Meggers e Evans 1961, 1983) e indicando a ocorrência de uma nova fase cerâmica, com datações de até 300 anos a.C. (Lima et al., 2006). As correlações crono-espaciais propostas tangem diversos aspectos culturais, como certo grau de desenvolvimento agrícola e densidade populacional, que deram origem, há aproximadamente dois mil anos, às Terras Pretas de Índio na Amazônia central. Propõe-se que o período pré-colonial amazônico circunscrito a essa esfera cultural, social, política e simbólica seja marcado por processos de 
intensificação, refletidos na consolidação das terras pretas como característica dos assentamentos humanos, que se tornam maiores e com maior densidade de ocupação, tendo seu apogeu populacional nos séculos XII e XIII d.C.

São apontados também alguns dados que tratam de outro ponto latente das discussões sobre a ocupação tardia da Amazônia central, neste mesmo período, relativos aos processos que levaram à substituição da Tradição Borda Incisa pela Tradição Policroma da Amazônia (Heckenberger et al., 1999; Hilbert, 1968; Lathrap, 1970b; Meggers e Evans, 1961, 1983). Estão aqui envolvidas mudanças sociais e econômicas consideráveis. Tais mudanças incluiriam também modificações nos padrões de organização, e nas próprias indústrias cerâmicas, que se diversificam e dividem a região geograficamente.

Neste sentido, é sugerido ainda que as áreas de dispersão da Tradição Policroma da Amazônia e da Tradição Incisa e Ponteada (Hilbert, 1968; Hilbert, P. \& Hilbert, K., 1980; Meggers e Evans, 1961, 1983) indicam que o baixo Amazonas, na região do entorno da atual divisa entre os estados do Amazonas e Pará, marcou uma fronteira cultural, com data provável a partir de 1.000-1.200 d.C. Estas, porém, são hipóteses cuja validade ainda queda por ser testada com trabalhos futuros. 


\section{MAPA DE LOCALIZAÇÃO DA ÁREA DE ESTUDOS}

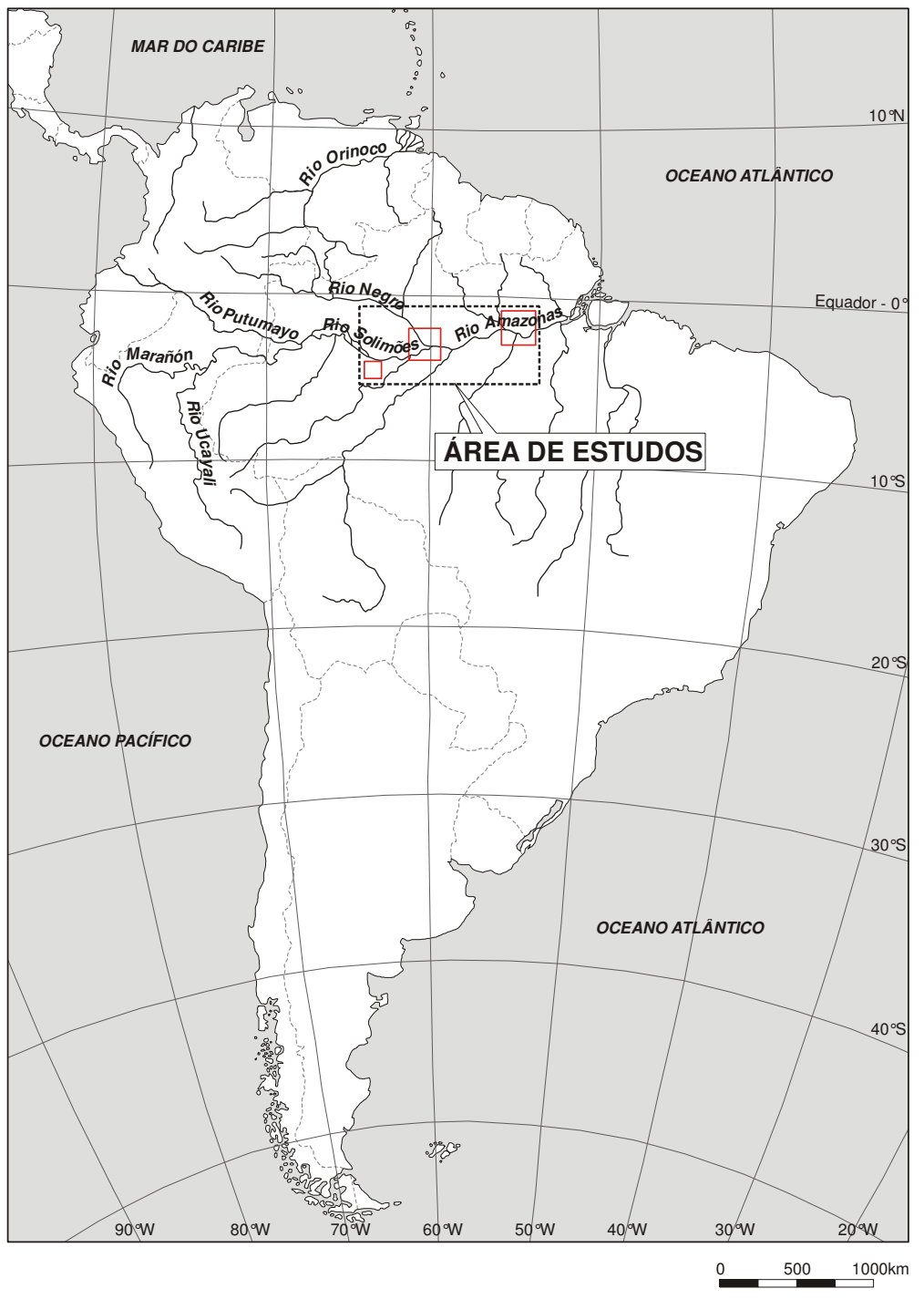

Figura 1 - Mapa de Localização da área de estudos (Mapa: Marcos Brito). 


\section{A estrutura geral da tese}

A prática da arqueologia tem como alicerce três elementos principais: coleta, análise e interpretação de dados, e foi deste modo que procurei estruturar a presente tese. Calcados nesses três componentes principais, encontram-se distribuídos seus oito capítulos.

Os tão necessários esclarecimentos teóricos têm início com um primeiro capítulo que trata dos princípios abrangentes que permeiam a história da arqueologia amazônica, da arqueologia brasileira e da própria antropologia cultural. Tais questões são tratadas em duas esferas distintas. Uma delas, denominada "História da arqueologia na Amazônia, dualismos e paradigmas", coloca num quadro histórico os clássicos problemas da arqueologia amazônica, enquanto campo disciplinar. A segunda, "Arcabouço teórico e pressupostos metodológicos", busca esclarecer qual é a posição adotada na pesquisa.

Ainda dentro de uma perspectiva de discussão dos modelos e esclarecimentos no âmbito teórico-metodológico, o capítulo dois apresenta o escopo espaço-temporal da pesquisa, bem como o dos problemas gerais e específicos. Procura-se demonstrar, a partir de uma revisão dos conjuntos artefatuais historicamente definidos para a Amazônia central, que serão tratados direta ou indiretamente na pesquisa, a pertinência de uma abordagem histórica de longa duração, que permeará as interpretações propostas ao longo de todo o texto. Ainda neste capítulo, as clássicas hipóteses de ocupação da Amazônia são re-visitadas à luz de suas expectativas arqueológicas específicas à área de estudo, ou seja, a Amazônia central. Nesta ocasião apresento também o Projeto Amazônia Central (o PAC), do qual este trabalho é parte.

No terceiro capítulo, "Qual Amazônia" (já que Amazônias são muitas, de acordo com Ab'Saber) destacam-se as características físicas das áreas tratadas, a começar pela área de pesquisa do PAC, a confluência dos rios Negro e Solimões. Esta é uma região chave dentro das discussões dos modelos de ocupação, não só da Amazônia, mas de todo o norte do continente sul-americano, e abrindo para uma escala em que serão abrangidas também outras duas áreas de relevância para os problemas de pesquisa tratados, o médio Solimões e parte do baixo Amazonas. Se, como se diz, "os olhos do mundo estão voltados para a 
Amazônia", a quantidade de estudos de seu meio físico é incontável. Não sendo este o foco direto da pesquisa, não me ative delongadamente a dados físicos que não tivessem estrita relevância aos objetivos deste doutoramento.

O capítulo seguinte, denominado "Sítios Arqueológicos da Amazônia Central", apresenta os trabalhos de campo na Amazônia central realizados durante a pesquisa. No início, tratei de esclarecer os parâmetros de seleção dos sítios trabalhados e de detalhar a metodologia de abordagem, que seguiu os procedimentos básicos adotados pelo PAC. Posteriormente, passo para a apresentação dos sítios arqueológicos, incluindo os dados e interpretações inerentes a cada um deles. Não se trata apenas de uma descrição de sítios, nem tampouco das atividades desenvolvidas em cada um deles, mas sim da discussão de dados em vias de interpretação, sempre visando os problemas que são tratados ao longo de toda a pesquisa. É por isso que, ao final da apresentação de cada sítio arqueológico, são colocados, de uma maneira breve, elementos que dizem respeito à sua cronologia e espacialidade. Portanto, mais do que descrições, o capítulo apresenta, de fato, a arqueologia feita em cada sítio arqueológico, através de um esboço interpretativo que vincula datas, dados laboratoriais e contextuais dos sítios descritos. Isto se pode ver, inclusive, nos próprios mapas dos sítios, que congregam uma série de informações arqueológicas tais como densidades de vestígios, datações etc.

O próximo capítulo, "O que, porque e como analisar", dá início ao tratamento laboratorial dos dados coletados em campo. Falando de forma específica em cerâmica, um assunto tão polemicamente debatido em arqueologia amazônica, os pressupostos metodológicos, e a teoria subjacente às interpretações que partem de tais análises, mereceram um capítulo à parte. Apresento uma discussão (e também uma autocrítica) sobre a metodologia de análise do material cerâmico, que se traduziu numa tentativa de rever os conceitos básicos presentes nas classificações realizadas anteriormente, e numa busca por uma metodologia aplicável aos problemas de pesquisa em questão e à grande quantidade de materiais disponíveis. Neste momento, se discute a potencialidade do próprio vestígio cerâmico enquanto fonte de informações históricas e culturais, assim como a necessidade de se conjugar elementos contextuais dentro destas análises. O método analítico, desenvolvido a princípio para o tratamento de tais coleções, foi esmiuçado no formato de um "Guia de 
conceitos e terminologias", de modo a fornecer bases referenciais para novos trabalhos vinculados ao PAC, de natureza semelhante, a serem desenvolvidos no futuro.

A complexidade e abrangência dos resultados de tais análises fizeram com que seus resultados fossem apresentados de diferentes maneiras, ao longo dos capítulos seguintes. Esta sexta seção, intitulada "A Tradição Borda Incisa na Amazônia Central', destacará algumas delas, a começar pelas características das coleções presentes nos sítios arqueológicos, mostrando a amplitude da variabilidade do material trabalhado. Mais uma vez, não me restringi a uma simples descrição de dados. Os resultados das análises de atributos foram, dessa forma, exaustivamente discutidos a fim de se inferir certos elementos cronológicos e outras possíveis associações dentro do contexto de cada sítio apresentado. Por serem bastante extensas, as tipologias cerâmicas foram compiladas em uma seção anexa a esta tese, apresentada como apêndice ao final desta. Ainda neste capítulo, foram tecidas considerações sobre as tipologias resultantes e a vinculação destas às fases cerâmicas, seguidas por uma pormenorização dos contextos em que elas se inserem. Ao final, aspectos de cada uma destas fases foram elencados em uma consideração mais ampla sobre esta tradição tecnológica.

Daqui em diante, ocorre uma importante mudança de escala dentro do objeto tratado. O sétimo capítulo trata em especial de duas regiões adjacentes à confluência dos rios Negro e Solimões, cujos dados arqueológicos se mostraram de extrema relevância para o viés interpretativo adotado até então. Da região conhecida como baixo Amazonas, a leste da área central da pesquisa, os contextos Pocó do baixo Trombetas-Nhamundá mostraram afinidades em vários aspectos com os materiais trabalhados na Amazônia central, principalmente aqueles mais antigos. Já na outra área, a oeste, um dos sítios resultantes de levantamentos regionais realizados nos rios Urucu e Solimões sugeriu uma possível semelhança com os conjuntos Borda Incisa, foco da pesquisa. Assim, pode parecer estranho, mas um capítulo que trata de dados provenientes de levantamentos regionais está intencionalmente colocado após as discussões anteriores.

Se por um lado vinha apresentando dados com alto grau de detalhamento, como a grande quantidade de sítios, alguns deles muito trabalhados, ao partir 
para uma perspectiva geográfica maior, tendo em vista que a magnitude de minha amostragem dentro das diferentes áreas apresentadas diminui (apenas um sítio em cada uma destas regiões), é natural que o nível de detalhes também diminua. Para essas regiões, a quantidade de dados apresentados é bem menor do que aqueles que possuo na Amazônia central. Esta mudança de ponto de vista se faz importante para auxiliar na interpretação dos próprios dados da Amazônia central, além de cumprir o papel de inseri-la, com maior consistência, em um quadro regional mais amplo. Assim, o capítulo se organizou da seguinte maneira: os métodos de levantamento e os projetos paralelos aos quais eles se vincularam foram explicitados rapidamente, e cada uma dessas regiões arqueológicas foi caracterizada, incluindo os dados de campo e as análises laboratoriais realizadas, para, ao final, estabelecer uma comparação em bases quantitativas das informações angariadas para as três regiões estudadas.

E é com base nestes dados todos que arrisco a propor, ao final do trabalho, uma tentativa de síntese intitulada "O Universo Borda Incisa", na qual apresento três faces de uma mesma moeda. O corpo interpretativo que permeou toda a pesquisa, e que tem como objetivo sair do 'material' para se aproximar do histórico e do cultural, será delineado então neste último e mais denso capítulo da tese. Neste momento teoria e prática são mescladas, tendo sido o meu universo empírico tomado para que conceitos interpretativos fossem então cunhados.

Através de "Conceituando um universo", o substrato teórico de tais associações, que perpassou todas as discussões, procurou amarrar as informações obtidas em todos os sítios e análises, levantando uma discussão sobre o significado da Tradição Borda Incisa na Amazônia central, do sistema regional a ela relacionado, em seus mais diversos aspectos: social, econômico, político e simbólico. Em "O universo material Borda Incisa", foi feita uma caracterização geral deste amplo conjunto, levando-se em conta as particularidades das fases arqueológicas em questão: Açutuba, Manacapuru e Paredão. Posteriormente, aponta-se alguns elementos que podem indicar continuidades e mudanças culturais dentro desses contextos ao longo do tempo. Num esforço interpretativo, e dentro do corpus da pesquisa, esboço o que, afinal, significa uma tradição tecnológica e suas fases arqueológicas. Assim, parte-se dos conjuntos materiais, e tenta-se acessar os conjuntos sociais - históricos e culturais - a eles relacionados. 
Como resultado da pesquisa, propõe-se um quadro histórico hipotético da Amazônia em níveis local e regional. Parte-se da escala local (micro), mais rica em detalhes e na profundidade do conhecimento específico, e a confrontamos com dados em escalas mais abrangentes geográfica e cronologicamente (macro), mesmo que não tão detalhados. Para tanto, aspectos geográficos e arqueológicos de outras áreas são explorados: o Médio e Baixo Solimões, o Baixo Amazonas, e - Baixo Orinoco. De tal modo, história e cultura da Amazônia central são colocadas frente a um amplo contexto. Analisam-se agora semelhanças e diferenças entre conjuntos amazônicos contemporâneos.

Os resultados apresentados, ainda que preliminares, refletem um avanço das questões científicas sobre o tema tratado. O quadro cronológico hipotético proposto tem como conseqüência a necessidade de reformulação das hipóteses de ocupação da Amazônia no período pré-colonial. As indagações que motivaram a pesquisa, utilizadas como um estudo de caso, com foco na Amazônia central, poderão ser usadas também para discutir questões mais amplas, que dizem respeito a entidades sócio e etno-políticas na Amazônia. 


\title{
Capítulo I \\ FUNDAMENTOS TEÓRICOS
}

\section{I. História da arqueologia na Amazônia, dualismos e paradigmas}

\author{
"A linguagem disciplinar é uma barreira \\ aparentemente intransponível para um neófito. \\ E todos somos neófitos uns dos outros.
}

Seria a Torre de Babel inevitável?"

(Nicolescu, 2005, p. 51)

Na Amazônia, uma quantidade imensa de vestígios arqueológicos, tais como grandes urnas e potes cerâmicos finamente decorados, eram e são ainda hoje encontrados por viajantes, curiosos e arqueólogos, despertando um legítimo interesse na reconstrução da história e dos modos de vida das populações que habitaram nessas áreas no passado. Neste capítulo, então, será feito um breve retrospecto de como a Amazônia vem sendo pensada desde então, destacando, sempre, o meu posicionamento frente às questões colocadas. Os reflexos desta discussão, e a forma como foi absorvida pela arqueologia, bem como os problemas específicos da presente pesquisa, estarão em destaque no capítulo seguinte.

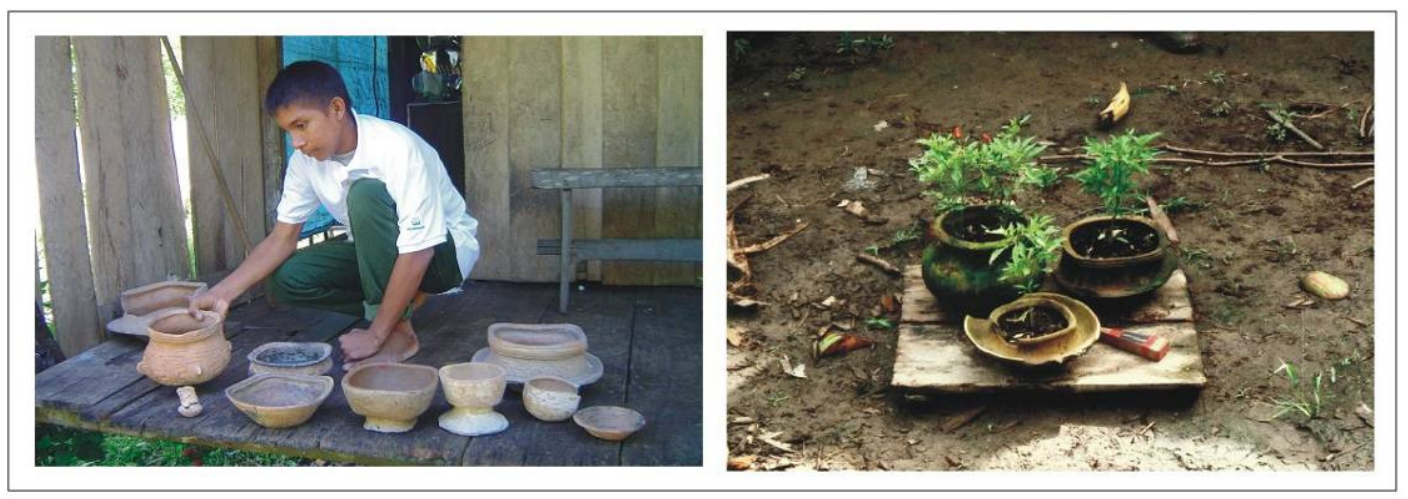

Figura 2 - Vasos cerâmicos da fase Guarita são encontrados pela população da comunidade Lauro Sodré em Coari/AM; muitos deles são utilizados (Fotos: J. Caldas e C. A. da Silva). 
Sendo assim, os primeiros esforços nesse sentido remontam a fins do século XIX e início do séc. XX, com os estudos de F. Hartt, Ladislau Netto, Barbosa Rodrigues, Bernardo Ramos, Curt Nimuendaju, entre outros, que trouxeram valiosas contribuições para a constituição da história pré-colonial da região (Barreto, 2000, p. 35; Roosevelt, 1995, p. 115). Este foi o chamado primeiro período da história da disciplina no Brasil, quando certa ausência de especialização disciplinar levou a uma visão integradora dos povos então ditos primitivos, abordando numa perspectiva holística seus aspectos culturais e materiais, além do ambiente no qual estavam inseridos.

A arqueologia amazônica teve, a partir de meados do século $X X$, um caráter diferenciado em relação às demais regiões do Brasil. Isso se deveu, em parte, à herança deixada pela escola norte-americana, que tinha uma orientação a partir de questões antropológicas gerais, que por sua vez demandavam tratamentos essencialmente arqueológicos e etnográficos (Neves, 2000, p. 87). E neste sentido, a publicação, em 1948, do terceiro volume do Handbook of South American Indians, editado por Julian Steward, deu um grande impulso às pesquisas arqueológicas e antropológicas nas terras baixas da América do Sul, marcando assim um segundo período da história da disciplina no Brasil.

Foi através do Handbook que primeiramente se lançou o modelo de Cultura da Floresta tropical (TFC), definida por Lowie pelos seguintes traços: o uso de redes de dormir, da navegação fluvial, e da cerâmica; uma agricultura incipiente, com predominância do cultivo de tubérculos, e a ausência de elementos arquitetônicos ou metalúrgicos (Lowie, 1948).

Este modelo preconizava que as limitações ecológicas inerentes aos ambientes tropicais teriam impossibilitado o desenvolvimento de sociedades hierarquizadas do tipo cacicado na Amazônia. Nessa perspectiva, os povos que viveram na Amazônia no passado seriam oriundos de levas migratórias de populações sub-andinas, com um nível cultural considerado mais avançado, denominado Cultura Circum-Caribe. Este movimento populacional teria partido do noroeste da América do Sul em direção ao litoral Atlântico. Ao atingir a foz do rio Orinoco, esses povos teriam se separado em dois grupos. Um teria se dirigido às Antilhas, mantendo seu padrão cultural tradicional, e o outro grupo teria chegado à foz do rio Amazonas, subindo o rio continente adentro. O ambiente tropical teria impossibilitado estes grupos humanos de manterem seus padrões culturais, 
forçando-os a abandonar certas características mais complexas, e se estabilizando na condição de Cultura de Floresta Tropical (Steward, 1948). Este modelo degeneracionista e adaptacionista de ocupação da Amazônia é referido como Standard Model (Balée \& Erickson 2006; Viveiros de Castro, 1996), e sua versão simplificada ainda povoa o senso comum até os dias atuais.

Como se pode ver, tanto o modelo de Steward como os que o sucederam estavam calcados num exacerbado determinismo ecológico: "se a subsistência depende das características ambientais e parece ser amplamente pelo nível de desenvolvimento atingido pela cultura que ela suporta, alguma relação de causa e efeito entre ambiente e cultura está implicada" (Meggers, 1954, p. 822).

Entretanto, a maior contribuição de Steward e Lowie para a arqueologia das terras baixas tropicais da América do Sul foi, sem dúvida, a criação de modelos preditivos testáveis, que impulsionaram uma série de pesquisas arqueológicas na região que, por sua vez, geraram hipóteses e debates sobre a cronologia de ocupação da Amazônia e o processo de formação dos sítios arqueológicos.

Com o objetivo de testar as proposições do Handbook, os arqueólogos norte-americanos B. Meggers e C. Evans realizaram uma série de pesquisas em várias regiões da Amazônia, a partir de 1949-1950, data de seus primeiros trabalhos no Brasil. Sua passagem marcaria um capítulo importante na história da arqueologia amazônica. Estes dois arqueólogos tiveram um papel central no desenvolvimento da arqueologia brasileira desde então, ao imprimir uma forte influência teórico-metodológica da escola americana no Brasil.

O grande alcance de tais influências pode ser explicado, em parte, pelo contexto da época, ligado a uma forte demanda gerada pela necessidade da preservação dos sítios arqueológicos brasileiros, em especial após a promulgação da lei federal 3924, em 1961. Aliado a isso, a falta de profissionais no Brasil foi o motor de um processo que trouxe para cá, principalmente através de cursos ministrados em universidades, importantes arqueólogos estrangeiros, como ocorreu com o casal Emperaire, que também realizou suas pesquisas em território nacional (Dias, 2003, p. 8).

Assim, no ano de 1965, teve início o Programa Nacional de Pesquisas Arqueológicas (PRONAPA), que se estendeu até o início da década seguinte, promovendo levantamentos por todo o país através de metodologias 
padronizadas de campo e laboratório, com o intuito de proceder a um quadro geral da pré-história do país, com ênfase nas populações agricultoras e ceramistas (Barreto, 2000, p. 60). Desenvolvido como uma parceria entre a então Secretaria do Patrimônio Artístico e Histórico Nacional e o Smithsonian Institute, o PRONAPA foi, inclusive, coordenado por Meggers e Evans.

Este programa gerou pesquisas com metodologias padronizadas, de campo e laboratório, destinadas também a treinar jovens pesquisadores brasileiros. As pesquisas realizadas a partir desse período forneceram um reconhecimento da variabilidade artefatual, com base em uma metodologia de seriação cerâmica, o método Ford, que permitia comparações em escalas regionais e continentais. Mais tarde, em 1977, já em associação com alguns pesquisadores brasileiros, deram origem ao PRONAPABA (Programa Nacional de Pesquisa Arqueológica na Bacia Amazônica), que por sua vez gerou uma proposta de cronologia de ocupação da Amazônia.

Também levando em conta a adequação da cultura ao meio ambiente em termos de subsistência, Meggers e seus colaboradores concluíram que a Amazônia teria ocupado uma posição periférica na pré-história sul-americana, sendo um receptáculo de populações oriundas do norte e noroeste do continente (Meggers, 1948, Meggers et al, 1988). Essa leitura divergia dos relatos, ditos fantasiosos, dos cronistas à época da conquista, que falavam em grandes aldeias encontradas às margens dos rios. Dentro desta perspectiva, os grandes sítios localizados no registro arqueológico, em especial nas proximidades das várzeas, seriam resultado de múltiplas reocupações (1990, p. 22). Além disso, o padrão que se acreditava mais desenvolvido encontrado na várzea resultaria tanto de fatores ambientais favoráveis, porém específicos das restritas áreas de várzea, quanto das influências externas de sociedades mais avançadas, supostamente andinas. De fato, o estudo de grupos indígenas atuais de terra firme, como os Kayapó, Jívaro e Camayurá, forneceu subsídios para analogias etnográficas que mais uma vez reforçavam o padrão defendido, de sociedades simples, cujas culturas eram semelhantes aos grupos da várzea, mas num ambiente ainda inferior em produtividade primária.

Dentro da mesma linha teórica, Eurico Miller, trabalhando no sudoeste amazônico, concluiu que "o aumento do tamanho e concentração da população foi limitado e inibido pelas flutuações sazonais dos recursos de subsistência e 
inaptidão para estocar alimentos para o consumo durante os períodos de baixa predabilidade e produtividade" (Miller, 1992, p. 331).

D. Lathrap (1970a) apropriou-se do mesmo conceito de Cultura da Floresta Tropical de maneira muito diversa de Meggers e seus associados, e apresentou um quadro alternativo para a pré-história da região. A constituição do chamado Modelo Cardíaco (Brochado, 1984, 1989; Brochado \& Lathrap, 1982; Lathrap 1970a; Lathrap \& Oliver 1987) colocou a Amazônia central como uma região chave para a compreensão da história pré-colonial das terras baixas da América do Sul, sugerindo ser ali um centro onde se desenvolveram inicialmente processos como adensamento demográfico, resultante de adaptações agrícolas e ribeirinhas bem sucedidas, e a emergência de complexidade sócio-política, em conseqüência de uma duradoura ocupação humana. Segundo a hipótese de Lathrap, a Amazônia central seria um dos prováveis pontos de origem e expansão da Cultura da Floresta Tropical e da agricultura no continente, assim como também o centro de dispersão inicial das populações ancestrais àquelas que hoje se comunicam através de línguas dos troncos Arawak e Tupi (Lathrap 1970a, p. 72; Lathrap, 1977). Essa expansão seria decorrência de adensamentos populacionais nas áreas ribeirinhas da Amazônia central (Heckenberger, Neves \& Petersen, 1998, p. 70; Lathrap, 1970a, p. 138). O período inicial desse processo seria datado em cerca de 4.000 anos antes de Cristo (Lathrap, 1970a; Lathrap \& Oliver, 1987; Brochado \& Lathrap, 1982).

Apesar dos modelos interpretativos de Meggers e Lathrap apresentarem-se um tanto contraditórios, ambas as vertentes estão inseridas dentro de um mesmo paradigma: os dois modelos consideram a contraposição entre os ambientes de várzea e de terra firme como determinantes dos padrões de assentamento e desenvolvimento cultural. 


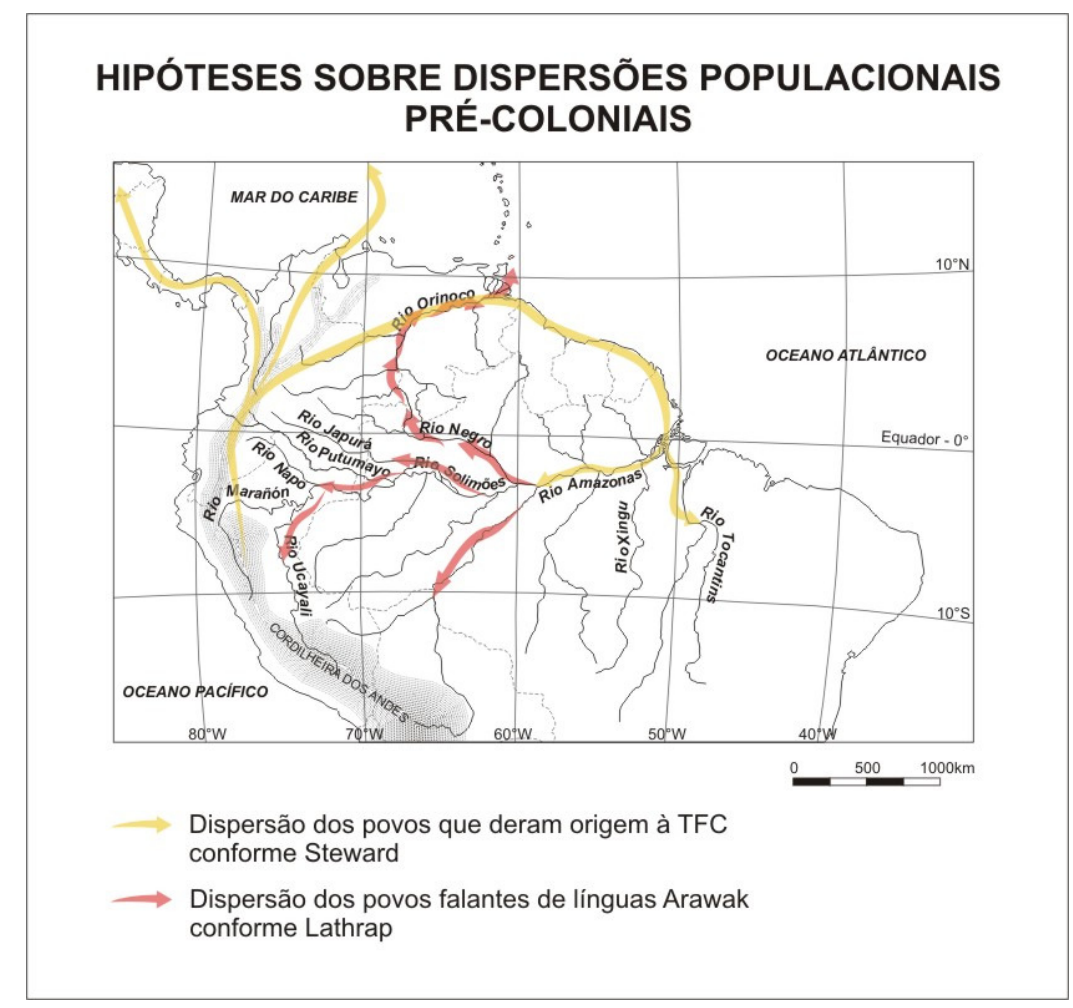

Figura 3 - Mapa indicando as diferentes hipóteses de dispersões populacionais pré-coloniais, em distintos períodos, no norte da América do Sul (Mapa adaptado de Steward [1948] e Lathrap [1970a, p. 76-77]).

Consagravam-se neste momento mais duas dicotomias fortes em arqueologia amazônica: várzea versus terra firme e continuidade versus ruptura. As ocupações da terra firme obedeceriam ao padrão de cultura de floresta tropical, com assentamentos de tamanho reduzido e alta mobilidade, assemelhando-se em grande parte aos grupos indígenas atuais. Os grandes sítios encontrados na várzea foram interpretados por Lathrap, dentre outros autores, como o correlato arqueológico de aldeias maiores, onde teriam vivido populações com padrão de organização social mais hierarquizado. Meggers, no entanto, julgou tratar-se da ocorrência de episódios de sucessivas reocupações por grupos que viviam em pequenas aldeias, com baixa densidade demográfica, o que eventualmente levaria à formação de sítios profundos e de grandes dimensões (1990). De acordo com ela, tal configuração sócio-cultural se manteria semelhante até os dias de hoje entre as sociedades indígenas que povoam a Amazônia (1970). 
A dicotomia várzea-terra firme foi reavaliada, já na década de noventa, por W. Denevan (1996), que propôs a existência de uma relação suplementar entre estes dois ambientes. O chamado Bluff Model consagrou uma nova abordagem sobre os padrões espaciais dos assentamentos pré-coloniais de densidade demográfica na Amazônia. Os assentamentos (as antigas aldeias) não estariam implantados nos aluviões das várzeas, e sim nos topos dos altos terraços terciários, feição geomorfológica tão comum à Amazônia. Situados bem perto dos terraços (bluffs), os férteis aluviões sazonais e os chamados lagos de várzea seriam explorados na medida em que seu ciclo anual permitia. Suprimentos energéticos eram obtidos também através da caça, realizada nas terras firmes. Desta maneira, os mesmos riscos de que Meggers falava, decorrentes da imprevisibilidade do regime de cheias da várzea (1971), teriam sido sobrepujados pelas populações do passado através da exploração integrada dos recursos da várzea e da terra firme (Denevan, 1996, p. 655). Evidências arqueológicas que vêm reforçar este modelo são as terras pretas, reportadas em locais tão diversos quanto as bacias do Amazonas, Orinoco, Negro, Guaporé, Tocantins, Tapajós, Xingu, Napo, Ucayali, Caquetá, Guianas, Ilha de Marajó etc., que sempre ocorrem às margens destes terraços (Bluffs) e podem se estender por quilômetros (Idem, p. 664).

Trabalhando com foco na identificação de técnicas agrícolas pré-européias, Denevan propôs uma divisão dos tipos de cultivo em três, com base no habitat. $\mathrm{O}$ primeiro é o cultivo calcado na complementaridade dos ambientes de várzea e terra firme (os bluffs); o segundo se dá nos campos elevados, como é o caso da Amazônia boliviana e de algumas regiões do Acre; e o terceiro tipo é o cultivo da terra firme, semi-permanente que, por sua vez, seria complementar aos cultivos de quintal (gardens) permanentes e às agroflorestas planejadas (Denevan, 1998).

Ainda dentro de certo paradigma ambiental, mas com forte viés tecnodeterminista, os trabalhos de A. Roosevelt $(1980,1991,1992,1997)$ apresentaram vários dados contrários às proposições de Steward e Meggers. Ela demonstrou, por exemplo, que a introdução do cultivo de milho no médio Orinoco, Venezuela, teria proporcionado o desenvolvimento de sociedades complexas, com organização social hierarquizada (1997, p. 162). Ali, assim como no estuário amazônico, os chamados cacicados teriam se desenvolvido de forma autóctone, 
sem nenhuma influência dos Andes, tal qual anteriormente proposto (Steward, 1948; Meggers, 1970).

Também contrárias aos trabalhos de Meggers, as interpretações de Roosevelt sobre a organização social pré-colonial não se calcam em comparações etnográficas. Com o assentimento de outros autores, ela alega que a conquista européia teria transformado profundamente as sociedades amazônicas, refutando o uso indiscriminado de projeções etnográficas para a explicação do registro arqueológico (Heckenberger, 1996, 2002; Neves, 1998; Roosevelt, 1989). A verdade é que "a questão empírica permanece: até que ponto as formações sociais indígenas da Amazônia contemporânea (...) representam adequadamente uma condição aborígine ou típica das sociedades amazônicas anteriores a 1492?' (Heckenberger, 2002, p. 27).

Roosevelt, assim como outros antropólogos e arqueólogos que vêm trabalhando na Amazônia, introduziram novas perspectivas de análise no que se refere aos modos de ocupação da região amazônica. Embora seus trabalhos sejam interessantes em diversos pontos, acabam sendo também calcados, em certo grau, no determinismo ecológico tradicional, pois insistem na velha dicotomia entre a várzea e a terra firme, como determinante do desenvolvimento cultural (Denevan, 1996, p. 654).

As inferências de Roosevelt a respeito dos modos de organização social são baseadas na complexidade das construções monumentais da llha de Marajó, por exemplo, no tratamento diferenciado dos mortos, e na diferenciação espacial marcada entre diferentes tipos de vestígios (1991). Não obstante, mais uma dicotomia era consagrada na arqueologia amazônica: as formações socioculturais simples versus aquelas ditas complexas, como é o caso dos cacicados.

Os trabalhos de M. Heckenberger no Alto Xingu, por exemplo, apresentam uma nova postura teórica em relação ao tema. Passa-se a colocar uma perspectiva simbólica para o entendimento da emergência de hierarquias. Os padrões etnográficos e arqueológicos apresentados pelo autor sugerem que aquela sociedade, considerada numa cronologia longa, apresentaria características consideradas como indicadoras de complexidade sócio-política, tais como: grandes assentamentos sedentários, uma "ideologia de elite", uma política econômica desenvolvida e uma integração regional (Heckenberger, 2002, p. 28). Assim, hierarquia, no caso apresentado, é essencialmente simbólica. E a 
acumulação de excedentes, mais do que econômica, ocorre no campo do capital simbólico, ritual (Idem).

Observa-se, na história recente da arqueologia amazônica, como consagrados paradigmas vêm sendo reavaliados, com freqüência, à luz de novas posturas teóricas (Gomes, 2001, 2002; Guapindaia, 2001; Heckenberger, 2002, 2003; 2006; Moraes, 2007; Neves, 2005, 2006; Pereira, 2001; Petersen et al., 2001, 2003, 2004; Schaan, 2004, 2007; Silva, 2000, entre outros tantos). Além dos dados hoje disponíveis estarem muito à frente do que poderia ser imaginado nos anos 60-70, as discussões teórico-metodológicas têm presenciado certo avanço, o que só pode vir a enriquecer, no futuro, o diálogo sobre quem eram e como viviam esses povos amazônicos do passado.

\section{I.II. Arcabouço teórico, bases conceituais e pressupostos metodológicos da pesquisa}

A história da arqueologia na Amazônia e no Brasil é marcada por ambigüidades epistemológicas e conceituais, mas não se trata de uma idiossincrasia da arqueologia. Pesquisas em outros campos disciplinares humanísticos, como em geografia, por exemplo, foram e vêm ainda sendo sistematicamente criticadas pela falta de definição teórico-metodológica, tanto pela "importação acrítica de teorias, e sua difusão num tom doutrinário" (Moraes, A. 2005, p. 39), como pela escassez de conceituação dentro do discurso disciplinar (Escolar, 1996, p. 11).

Há algum tempo, tal quadro vem se modificando graças a autores preocupados em re-pensar conceitos, já não os aceitando apenas. (Escolar, 1996). Felizmente, tal "movimento renovador", observado em outros campos disciplinares (Moraes, A., 1986, p. 34), tem paralelos na arqueologia, em especial a partir da década de 90. Era uma área de estudos que também procurava entender-se enquanto campo disciplinar, buscando "sair do suposto lugar de auxílio para com a História e a Antropologia" para se pensar enquanto ciência, com suas próprias construções teóricas (Reis, 2003, p. 53). Entretanto, este movimento de tendências pós-modernas que tinham como intuito revisar a história da arqueologia no Brasil, e posicioná-la teoricamente (ver, por exemplo, Barreto, 2000), levou também a uma exacerbada proliferação de críticas às tradicionais escolas arqueológicas atuantes no Brasil, tanto a francesa como em especial a 
norte-americana. Vale lembrar que ambas foram responsáveis pela confecção de uma enorme base de dados, que inclui milhares de sítios em todo o território nacional, e que pode, por exemplo, ser alvo de outras análises, sejam quais forem as novas abordagens.

É dentro de um movimento de natureza revisionista, mas não criticista, que procuro posicionar o presente trabalho. Ora, mesmo que antigas hipóteses, que em muitos casos incluíram grandes modelos de ocupação do continente, tenham sido duramente criticadas e ditas obsoletas no campo da teoria antropológica, acredito que estes mesmos preceitos teóricos e metodológicos possam sim ser repensados, a fim de se tratar os dados hoje disponíveis. Se os problemas de pesquisa hoje colocados frente à arqueologia da Amazônia revisitam, de certa forma, aqueles mesmos problemas com os quais os antigos pesquisadores se depararam, quais sejam, origens e dispersões de traços culturais como língua, cerâmica e agricultura, por exemplo, é natural que aquelas conclusões devam ser também revisitadas. É bom lembrar, ainda, que não há teoria sem práxis, assim como pode haver apenas descrição de dados empíricos sem uma acuidade teórica e, portanto, metodológica. Pleiteia-se aqui um mínimo de coerência teórico-metodológica, entendendo que tal coerência é dada pelo "grau de representatividade dos elementos analíticos ante o objeto estudado" (Santos, 2002, p. 22).

Se tais elementos analíticos devem se constituir como portas de acesso ao objeto, dentro deste estudo, a amplitude e a natureza dos dados que disponho direciona o esforço interpretativo em alguns sentidos. O caso amazônico em questão é bastante significativo quando se pensa nesta "representatividade ante o objeto", pois a própria natureza dos dados, essencialmente empírica, restringe o nível de detalhamento analítico a que posso chegar.

A base empírica a que me refiro, objeto próprio da arqueologia, é calcada nos vestígios de todo um universo simbólico de uma cultura em sua expressão material, ou seja, apenas parte dela. Soma-se a este fato uma área de dimensões vastas e praticamente desconhecida em termos arqueológicos, porque, apesar do crescente volume de pesquisas desenvolvidas em nossos dias, que têm contribuído para uma ampliação dos dados disponíveis, eles ainda são parcos frente a um universo de proporções amazônicas. Mais ainda, o período cronológico abordado nessa pesquisa, com abrangência além de mil anos, 
contribui para que seja extremamente difícil, quiçá impossível, situar no tempo e no espaço um nível de detalhamento em que se acesse uma perspectiva do indivíduo ou de suas relações sociais a que outras disciplinas, como a etnologia, podem obter em seus estudos.

Esta peculiaridade do objeto de minha pesquisa, em conjunto com seus objetivos que são, em última instância, históricos e culturais, não me deixou melhor alternativa que, por um lado, rever aqueles dados coletados e, por vezes, interpretados, pelos pesquisadores que me precederam e, por outro, reinterpretálos à luz tanto de novas posturas teórico-metodológicas quanto de novos dados, ao adotar uma perspectiva histórica. A história de longa duração, no contexto estudado, me permite tentar juntar fragmentos de conhecimentos dispersos, dando a eles um sentido cultural, ainda que de modo abrangente. Desse ponto de vista, trata-se de entender períodos temporais distintos da história pré-colonial amazônica, "cada qual marcado por descontinuidades culturais significantes (transformações)" assim como suas continuidades, que "se definem e se colocam no contexto de uma trajetória de maior alcance" (Heckenberger, 2001 p.54).

Influenciada pela retomada do particularismo histórico (Boas, 1940), a perspectiva histórico-culturalista - que ora estamos revendo e assumindo enquanto instrumento analítico válido - rompeu com as leis gerais de comportamento, procurando estabelecer e descrever as formas de interação entre sociedade e meio ambiente, através de métodos indutivos de descrição e interpretação da cultura material. Estabeleciam-se, assim, as noções de área cultural, sequêencia cultural e cronologia, tão caras à arqueologia até os dias de hoje (Trigger, 1989). Em contraste, porém, com a orientação teórica da antropologia da época, voltada aos estudos individualizados de tribos indígenas e completamente avessos às generalizações, o conceito de área cultural surgia da necessidade de classificações em perspectivas mais amplas, para dar conta de problemas de ordem comparativa, bem como de mudanças culturais (Galvão, 1960, p. 1).

No contexto amazônico, Eduardo Galvão (1960) propôs novas divisões das áreas pensadas por Steward na definição de seu modelo, historicizando e contextualizando-as. Os critérios de identificação de áreas culturais foram a princípio propostos por Murdock, e consistiam em: filiação lingüística, técnicas de subsistência, animais domésticos e plantas cultivadas, cerâmica, tecelagem e 
trançado, tipo de habitação, classes sociais, instituições políticas, casamento e parentesco (Galvão, 1960, p. 10). Este, contudo, assim como outros esquemas de classificação cultural, apresentava problemas. A diferença em quantidade e qualidade das informações disponíveis sobre as diferentes regiões, e a utilização indiscriminada de dados históricos em conjunto com dados atuais, sem levar em conta aspectos de mudança cultural, resultaram em certa confusão em termos de distribuição geográfica e caracterização etnográfica, comprometendo quaisquer tipos de comparações.

Para evitar tais tipos de ambigüidades e fornecer bases mais sólidas para as reconstituições culturais, Galvão pleiteou a delimitação de épocas históricas, o que concorreria para a uniformização e seleção das fontes de informação (1960, p. 12). Dessa maneira, suas então recém-criadas áreas culturais levavam em conta particularidades regionais numa escala temporal muito menor do que a anteriormente utilizada. Tais contextualizações, regionais e temporais, se fazem mister para comparações culturais de qualquer natureza. A base temporal para definição das áreas culturais de Galvão se restringe ao período histórico entre 1900 e 1950. Pode ser algo parecido o que pretendo, experimentalmente, propor para a Amazônia central do primeiro milênio d.C. Apesar da prerrogativa de compreensão dos processos históricos envolvidos no desenvolvimento das formações sociais indígenas, agrupadas em diferentes áreas culturais, Galvão contava com uma quantidade modesta de dados para explicar tais processos, mas os via como basal para posterior estabelecimento de "conexões e interferências históricas para aprofundar as perspectivas temporal e espacial" (Galvão, 1979, p. 205; Neves, 2006).

De fato, "a façanha mais significativa da antropologia, na primeira metade do século XX, foi a extensão e clarificação do conceito de cultura" (Kroeber, 1952 [1950], p. 211). Com o surgimento da arqueologia processual (ou Nova Arqueologia, como esses arqueólogos gostavam de a denominar) na década de 1960, a noção de cultura - dentro da arqueologia - passou a ser definida como um "mecanismo extra-somático de adaptação". Neste sentido, o advento das técnicas se tornava algo absolutamente pragmático e funcional: voltado para a "resolução de problemas" das necessidades básicas humanas. Esta corrente teórica absorveu idéias advindas do funcionalismo de Malinowski, assim como do 
neo-evolucionismo e da teoria de sistemas, buscando leis gerais de comportamento. E as áreas culturais eram abandonadas.

Devido à influência funcionalista, o conceito de cultura na arqueologia processual assumiu um sentido "adaptativista". Aproximando-se da ecologia cultural, passava-se a procurar "uma metodologia científica que permita a análise e compreensão de processos sociais ligados a mudanças" (Viertler, 1988, p. 9). Dentro de tal abordagem, dita sistêmica, a cultura humana, enquanto um sistema complicado e em mudança constante de componentes que interagem com o meio do qual faz parte, leva em conta, enquanto instrumentos analíticos, fatores ambientais tais como "carrying capacity" e fatores limitantes.

É aí que se encontra um importante princípio da ecologia cultural: o conceito de adaptação, que foi duramente criticado pelos representantes de uma outra perspectiva de pesquisa, a ecologia histórica. Dentro desta vertente, o entendimento da complexa relação histórica entre seres humanos e a biosfera tem nos primeiros o principal mecanismo de mudança do meio ambiente. (Balée \& Erickson, 2006, p. 4).

Com data mais recente, a partir dos anos 70 e 80 , a arqueologia incorporou perspectivas menos "tradicionais" do conceito de cultura. Procurava-se entender diversidades culturais através de uma ciência interpretativa. As explicações dadas à variabilidade formal se tornavam a maior prioridade, abandonando qualquer tipo de determinismo enquanto paradigma explanatório. Neste sentido, de um lado a agência humana, refletida nas escolhas técnicas, assim como a subjetividade das categorias analíticas de outro, ambas inerentes às pesquisas desta natureza, passaram a ser incorporadas.

Em oposição aos paradigmas e dicotomias um tanto simplistas do determinismo ecológico e cultural do "standard model", propõe-se aqui a exploração de conceitos que podem sim ter grande validade para dar conta de explicar histórica e culturalmente a distribuição dos vestígios arqueológicos em amplas áreas de floresta tropical. Os ditos conceitos são a base interpretativa da presente pesquisa, e terão sua devida apreciação mais adiante, no momento em que se discutirá a base interpretativa dos dados. Trata-se, entretanto, em última instância, de uma reinterpretação do conceito antropológico de área cultural já discutido, desde uma perspectiva arqueológica, através da qual procuro entender relações sincrônicas dentro de seqüências diacrônicas. 
Como se vê, a arqueologia tem uma longa tradição em absorver conceitos advindos de outros campos disciplinares, em especial da antropologia cultural. Falar em seqüências diacrônicas, porém, leva a outro ponto de igual importância do corpo teórico e interpretativo, não apenas desta pesquisa, que tenta dar conta de um período de pelo menos mil anos de sociabilidade humana no contexto amazônico, mas da arqueologia enquanto ciência humana. Trata-se dos problemas referentes à cronologia. É de longa data sabido que, para que sejam úteis em interpretações culturais, as cronologias arqueológicas são construídas através da identificação de sucessões culturais, estabelecidas em bases tipológicas (Thomas \& Ehrich, 1969, p. 144). E esta não é uma tarefa nada simples. Se a estrutura da interpretação arqueológica se alicerça na classificação de dados, e a própria classificação não deixa de ser um processo subjetivo que envolve a seleção de critérios considerados importantes, então especial atenção deve ser dada à explicitação da construção de seqüências culturais. Assim, a validade de relações culturais e históricas hipotéticas, deduzidas das similaridades dos dados analisados, vai depender da complexidade, também hipotética, das ligações propostas.

É particular da arqueologia o modo como busca entender esses processos sociais do passado. Seu estudo se calca na combinação de três aspectos essenciais: forma, espaço e tempo. No espaço, o objeto é global (abstrato), mas o espaço é um conjunto de territórios onde esse mesmo objeto assume sentidos particulares. Estes, por sua vez, só assumem uma realidade objetiva dentro de temporalidades definidas. Ocorre aqui um processo intelectual de concreção, através do qual se contextualizam objetos, conjuntos ou redes de objetos em termos de espaço e tempo (Santos, 2002).

Questões relativas ao contexto são aplicáveis a quaisquer vestígios arqueológicos encontrados em matrizes naturais. Tratam da disposição espacial dos vestígios nessa matriz. É através dessas relações sincrônicas e diacrônicas (horizontais e verticais) que se pode entender o uso diferenciado dos espaços, sua inserção e modificação da paisagem. E é a partir daí que se pode apreender processos de continuidades e mudanças culturais.

$\mathrm{Na}$ arqueologia brasileira, e em especial da Amazônia, classificação é um tema não consensual, e promove debates acirrados quanto à validade ou não de determinados métodos classificatórios. Tais discussões vêm gerando uma série 
de ambigüidades que não permitem que dados advindos de diferentes linhas de pesquisa sejam comparáveis. Hoje, esta ausência de diálogo sobrepuja o real objetivo da pesquisa arqueológica. Exemplos de tais ambigüidades podem ser encontrados na interpretação dada por diferentes escolas aos polêmicos conceitos de fase e tradição arqueológica, que foram historicamente utilizados na arqueologia brasileira desde os seus primórdios.

Fase arqueológica foi, no início, definida como "unidade arqueológica que possui traços suficientemente característicos para distingui-la de outras unidades (...) de uma localidade ou região cronologicamente limitadas a intervalos de tempo relativamente breves" (Willey \& Phillips, 1958). De maneira ampliada, a tradição representa a "persistência em tempo e espaço(amplos) de um conjunto de traços que caracterizam a tecnologia cerâmica" (Angulo Valdés, 1981). (Para um aprofundamento sobre este tema, e exemplos dessa ausência de diálogo, ver, por exemplo, Dias, 2003; Hilbert, 1968; Rouse, 1960; Schaan, 2007; Silva, 2000).

As atuais críticas ao uso de tais categorias classificatórias não consideram a importância que estas tiveram - e têm - ao construir um mapeamento arqueológico de grande parte do território brasileiro, permitindo em muitos casos comparações inter-regionais. Não vejo nesta posição "criticista" propostas alternativas, e a crítica só pela crítica de nada vale! Quando concebidas, essas categorias analíticas tiveram uma preocupação em termos culturais. É verdade que sua aplicação, por demais normativa, ao longo do tempo fez com que, de certa forma, se tornassem vazias de significado.

Cabe agora aprofundar questionamentos a respeito de suas significações culturais e também históricas. Fase e tradição são utilizadas na presente pesquisa dentro de uma perspectiva abrangente e profunda, com conotações contextuais. Vale mais procurar tal significação nas categorias existentes, reformulando-as quando necessário, do que a simples rejeição de seu uso em detrimento de novas denominações, muitas vezes vazias também. Se minha tese de doutorado propõe uma nova fase cerâmica na Amazônia, é porque eu sim aceito este conceito como valiosa ferramenta analítica, como um conceito a ser explorado para promover o entendimento dos modos de vida dos povos amazônicos do passado. "E, se alguém levantar objeções à terminologia (...) terei o prazer em adotar o novo termo mais apropriado, que seja cunhado ou proposto" (Kroeber, 1952 [1948], p. 173). 
Tais ferramentas permitem o estabelecimento de padrões, e padrões de similaridade arqueológica serão válidos tão somente quando interpretados enquanto tradições comuns, que definem grupos humanos que compartilhem elementos culturais, sejam origens comuns ou contatos entre comunidades ou regiões (Thomas \& Ehrich, 1969, p. 150).

A esta altura parece claro que o objetivo aqui não é promover um método interpretativo único, tampouco uma metodologia única de análise, pois jamais se encontrará uma fórmula, já que classificações e interpretações irão sempre variar de acordo com os problemas de pesquisa específicos, bem como com o próprio conjunto artefatual que se tem disponível. Foi assim, a partir do ora exposto e das ferramentas analíticas discutidas, que procurei desenvolver todo o corpo teórico e principalmente interpretativo dessa tese. Ao reavaliar antigos dados e proposições, e ao introduzir novos dados junto a um viés que esteja de fato desvinculado do contexto no qual aqueles dados foram originalmente interpretados, acredito avançar no sentido de construir interpretações mais sólidas para uma pequena história da Amazônia. 


\section{Capítulo II \\ CONTEXTUALIZAÇÃO}

"Não temos, por exemplo, a liberdade de sairmos por aí nomeando as coisas 'simplesmente pelo modo como elas são', como fez Adão, 'parecia-se com um leão, e rugia como um leão, portanto o chamei de leão".

(Sahlins, 2003, p. 11)

\section{II.I. Modelos, perguntas e o Projeto Amazônia Central}

Ficaram explícitas, no capítulo anterior, as clássicas dicotomias que permeiam a história da arqueologia amazônica. Cabe agora contextualizar a presente pesquisa dentro de tal quadro. O estudo de caso se deu na Amazônia central, que pode ser considerada como região-chave para o teste das hipóteses de ocupação da Amazônia como um todo.

Temas como densidade demográfica, duração de ocupações, padrões de mobilidade e formas de organização social foram debatidos em larga escala. A base para tais discussões estava no estabelecimento do tamanho e duração de ocupação dos sítios arqueológicos, e também na filiação cultural e posicionamento crono-estilístico dos conjuntos artefatuais ali encontrados. Embora parcamente conhecido, o registro arqueológico desta imensa região foi interpretado de maneiras muito diversas. Trata-se do debate cuja origem está na contraposição das vertentes interpretativas anteriormente mencionadas. Elas tratam, especificamente, da origem, desenvolvimento e dispersão dos conjuntos arqueológicos da Amazônia central, em termos de continuidade ou ruptura.

Neste longo histórico de debates ficaram marcadas duas posturas antagônicas. Por um lado, o viés interpretativo que se difundiu amplamente, não apenas no meio científico, mas também no senso comum, colocava a Amazônia 
como área periférica no quadro da história de ocupação do continente (Meggers, 1954, 1990; Meggers \& Evans, 1983). Em oposição a essa idéia, o já mencionado modelo cardíaco colocava a região como antigo centro dispersor de levas populacionais e de inovações culturais no continente (Brochado \& Lathrap, 1982; Lathrap \& Oliver, 1987; Lathrap, 1970a). No entanto, essas questões antropológicas gerais acabaram por ficar à revelia, dando lugar a debates essencialmente classificatórios, ou seja, toda a discussão estava calcada em princípios tipológicos que ficaram aquém de uma discussão mais aprofundada, deixando um hiato teórico-metodológico entre os modelos preditivos e o registro arqueológico em si que, à época, também era pouco conhecido.

De acordo com a hipótese ortodoxa, o registro arqueológico encontrado na Amazônia evidenciaria diferentes episódios de ocupação. Numa tentativa de correlacionar os dados arqueológicos então disponíveis para essa ampla área de floresta tropical, bem como seus possíveis locais de origem e direções de dispersão, Meggers e Evans estabeleceram, de forma hipotética, quatro horizontes estilísticos. Para tanto, tiveram como base a presença ou ausência de um determinado número de traços em vinte e dois conjuntos cerâmicos, sendo que a diagnose de cada horizonte era dada predominantemente no âmbito das técnicas decorativas (Meggers \& Evans, 1961).

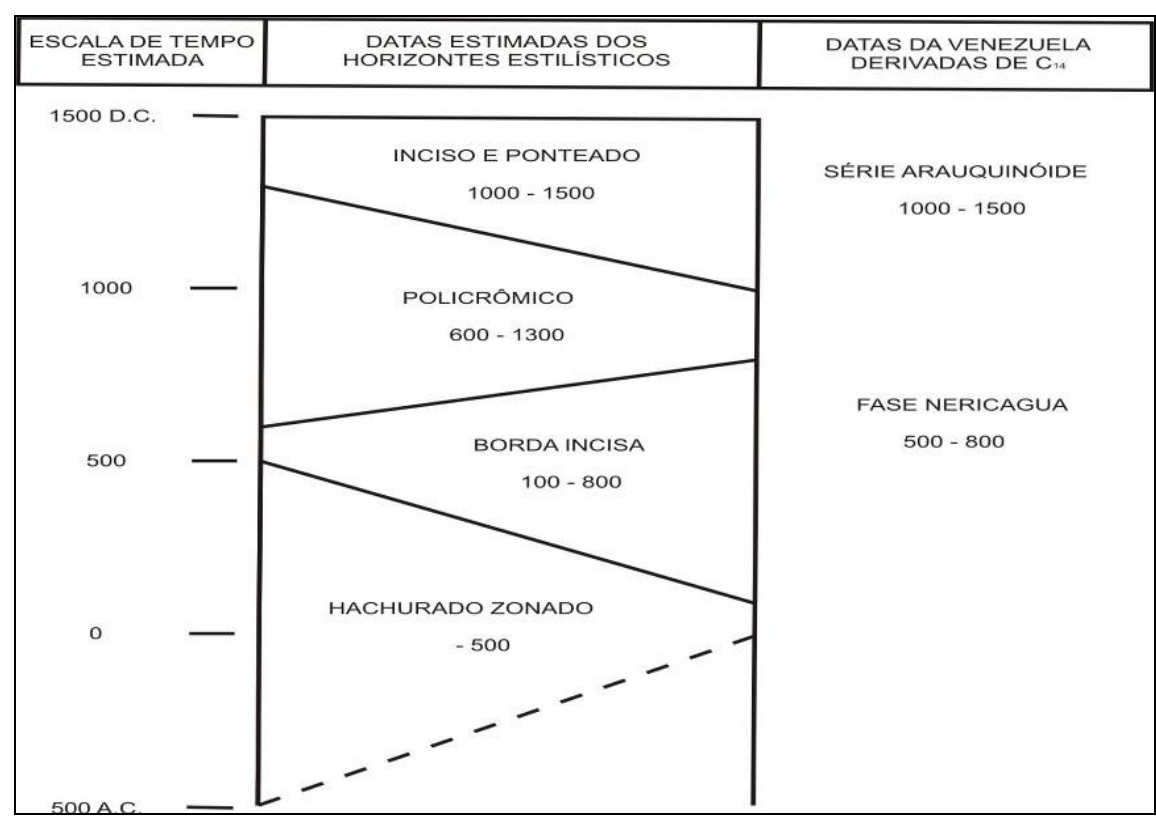

Figura 4 - Quadro cronológico dos Horizontes Estilísticos propostos por Meggers e Evans (1961). 
Os horizontes hipoteticamente definidos por Meggers e Evans indicariam quatro distintas e sucessivas levas de influências em direção à floresta tropical. Hachurado Zonado e Policrômico teriam sido introduzidos a partir do oeste, e sua ocorrência se limitaria à bacia Amazônica. Os outros dois, que teriam uma distribuição ao longo da drenagem do Orinoco e baixo Amazonas, sugeririam, por sua vez, uma direção de dispersão do primeiro para o último. Sendo assim, o baixo Amazonas seria a única região onde se encontrariam, estratigraficamente, os quatro horizontes (fig 5).

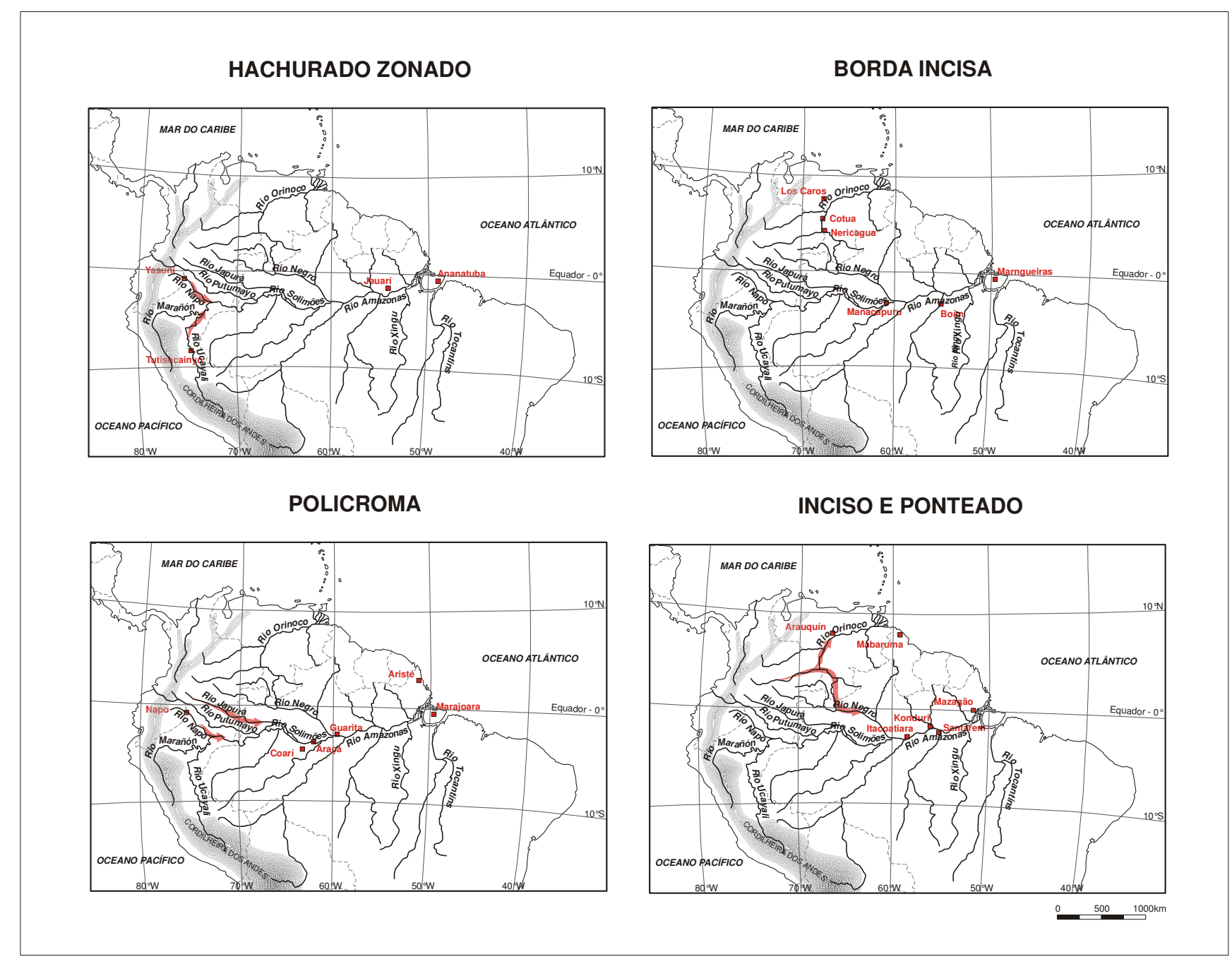

Figura 5 - Hipotéticas levas de dispersão dos Horizontes estilísticos propostos por Meggers e Evans (1961).

No médio Amazonas, na região hoje compreendida entre Tefé e Itacoatiara (que engloba, portanto, a área de pesquisa do projeto), foi o arqueólogo alemão Peter Hilbert o responsável pela identificação e caracterização do registro 
arqueológico ali encontrado (1968). Através do estabelecimento de seqüências seriadas, nas quais se observavam mudanças graduais na cerâmica, Hilbert observou que a cronologia regional seria caracterizada por rupturas entre os conjuntos cerâmicos. Estes conjuntos estariam associados a uma seqüência crono-estratigráfica, de acordo com aquela previamente proposta através dos horizontes (posteriormente chamados de tradições), de Meggers \& Evans (1961).

A fase Jauarí, filiada a então tradição Hachurada Zonada, foi identificada nas proximidades dos municípios de Oriximiná e Alemquer, e seria a mais antiga ocupação da região. Essa tradição representaria, a tais autores, a introdução da tecnologia cerâmica na floresta tropical, e teria uma suposta origem na área andina, especificamente na cultura Chavìn. As características distintivas dessas cerâmicas seriam a ênfase na decoração zonada, expressas principalmente na decoração incisa, mas evidentes também na pintura. É diagnóstico também o uso de incisões em linhas largas para definir áreas que são preenchidas com traços finos paralelos ou hachurados. Nos complexos mais a oeste, nas fases Tutishcainyo, no Peru, e Yasuní, no Equador, o tempero utilizado era areia, enquanto que nas fases Jauarí e Ananatuba, descrita por Simões (1969) na llha de Marajó, identificou-se o uso do cariapé.
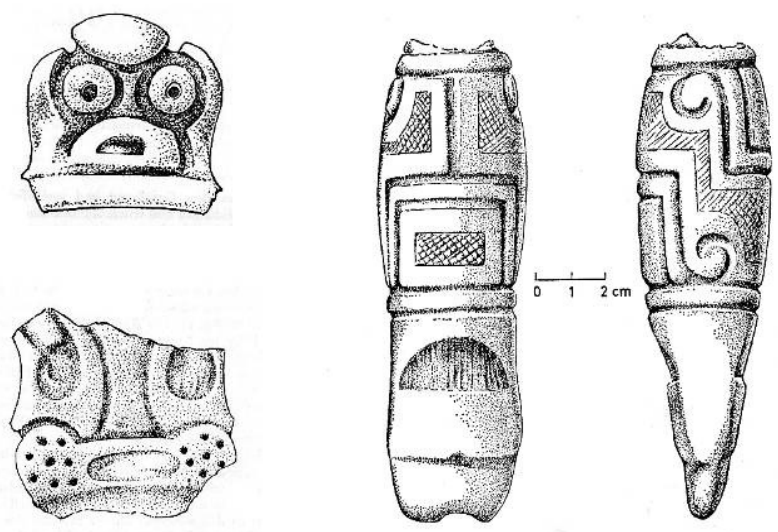

Figura. 6 - Fragmentos cerâmicos e cachimbo tubular da fase Jauarí, tradição Hachurada Zonada (Hilbert, 1968, p. 76, 77 e 83).

Dentro dos conjuntos subseqüentes identificados por Hilbert (1968), as fases Manacapuru, Paredão e Caiambé forneceram seis datações radiocarbônicas que, em conjunto com suas características decorativas, as situaram na tradição Borda Incisa, o segundo horizonte estilístico definido por 
Meggers e Evans, datado entre 100 e 800 d.C. (1961). Estes dados eram inéditos à época, uma vez que materiais associados a essa tradição eram conhecidos apenas no Orinoco e baixo Amazonas. Hilbert associou à tradição Borda Incisa o aparecimento das primeiras urnas para enterramento secundário, e os primeiros assadores de mandioca (1968, p. 273).

As características distintivas destas cerâmicas seriam bordas largas, com o topo achatado, produzidas a partir de um aumento da espessura do centro do vaso, resultando em uma silhueta seccional triangular. A superfície destas bordas seria geralmente decorada com incisões. Há, em alguns casos, pintura ou engobo vermelho decorando o interior ou o exterior de alguns vasos. Além das fases definidas por Hilbert, a tradição Borda Incisa englobaria outras fases cerâmicas nas bacias do Amazonas e Orinoco, na Venezuela. Dentre aquelas representadas na Amazônia, estão Boím (médio Amazonas) e Mangueiras (na llha de Marajó). $\mathrm{Na}$ Bacia do Orinoco, a tradição Borda Incisa se manifesta através das fases Nericagua, Cotua e Los Caros. Cotua e Los Caros foram incluídas no período III da cronologia proposta por Rouse e Cruxent para a Venezuela, que corresponderia ao intervalo entre 350 e 1150 d.C (1963).

$\mathrm{Na}$ Amazônia central, a tradição Borda Incisa seria representada pelas fases Manacapuru e Paredão. A primeira, caracterizada por grande variabilidade formal, mas sempre com as bordas expandidas características à tradição. $O$ vasilhame é temperado com o cauixi, uma esponja de água doce comumente encontrada em rios de águas pretas. A decoração, um tanto rebuscada, consistiria essencialmente na modelagem de figuras abstratas, zoomorfas e antropomorfas, em incisões de todos os tipos e também no engobo.
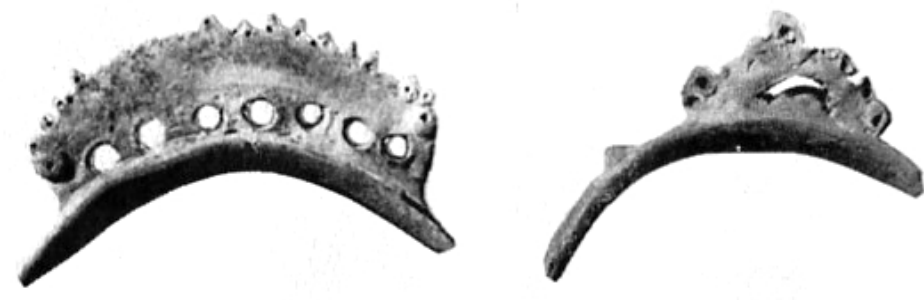

Figura 7 - Exemplos de cerâmicas da fase Manacapuru, de acordo com Hilbert (1968, p. 304).

Já a fase Paredão teria uma variabilidade formal pequena, principalmente quando comparada com outras fases cerâmicas da Amazônia. As formas mais 
comuns seriam os vasos com alça (fruteiras), cuias, grandes urnas funerárias e panelas sem decoração. A decoração, mais rara, era feita através de pintura vermelha com motivos geométricos em espiral e em gregas, e apêndices antropomorfos (sempre aplicados nas urnas). O tempero mais utilizado seria também o cauixí.
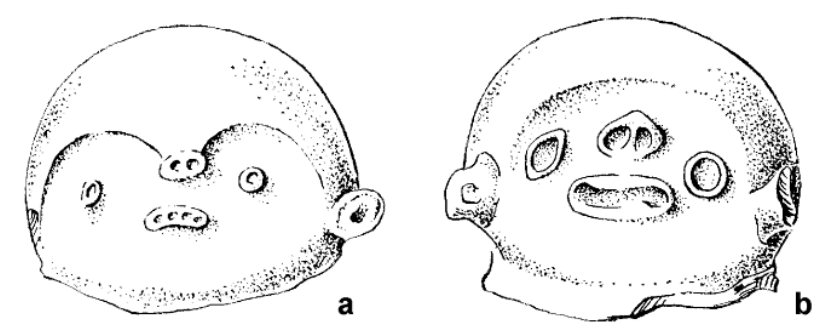

Figura 8 - apliques antropomorfos da fase Paredão, tradição Borda Incisa (Hilbert, 1968, p. 119).

Meggers não ousou precisar a fonte ou direção de sua difusão dos complexos relacionados a esta tradição, e reconheceu tratar-se de um conjunto ainda pouco conhecido, já que "a ocorrência dos traços diagnósticos nessas seis fases é menos consistente e menos proeminente do que em qualquer dos outros horizontes propostos, conseqüentemente o horizonte Borda Incisa é o mais hipotético dos quatro" (Meggers \& Evans, 1983, p. 378). De fato, a filiação cultural e o posicionamento crono-estilístico de tais conjuntos geraram debates, que serão abordados posteriormente.

A maior parte dos sítios estudados por Hilbert, no entanto, situou-se cronologicamente na tradição Policroma, mais recente, e que teria uma ampla dispersão geográfica, através de sítios que vão desde o rio Napo, distribuindo-se ao longo do rio Amazonas até Marajó. As coleções por ele descritas foram classificadas nas fases Guarita, Tefé, São Joaquim e Pirapitinga. Hilbert atribui estes complexos policromos a grupos populacionais com um substrato cultural de cunho norte-andino. A estes grupos associaram-se características culturais ditas mais avançadas, tais como métodos mais intensivos de agricultura, aldeias maiores e mais duradouras, hierarquização social e divisão do trabalho, elementos típicos do então definido estágio cultural Circum-Caribe ou Sub-andino (1968, p. 273-274).

$\mathrm{Na}$ seqüência da Amazônia central, a tradição Policroma seria representada apenas pela fase Guarita, que teria como características principais o engobo branco associado ou não à pintura policroma (vermelha e preta sobre o 
branco), a decoração acanalada e a presença de flanges mesiais. O vasilhame conta com uma variedade de formas e é geralmente temperado com uma fibra vegetal de nome cariapé. Com datas entre os séculos IX e XVI d.C. (Hilbert, 1968; Heckenberger et al, 1998) esses grupos ceramistas persistiram em alguns locais até o momento do contato com os europeus. Carvajal descreveu a cerâmica encontrada na aldeia da louça, abaixo da foz do rio Coari (aprox. $400 \mathrm{~km}$ de Manaus, a montante do rio Solimões):

A melhor que já se viu no mundo, porque a ela nem as de Málaga se iguala. É toda vidrada e esmaltada de todas as cores, tão vivas que espantam, e alem disso os desenhos e pinturas que fazem nela são tão compassados que com naturalidade eles trabalham e desenham tudo com o romano (Carvajal, 1941, p. 47, apud. Porro, 1995, p. 32)
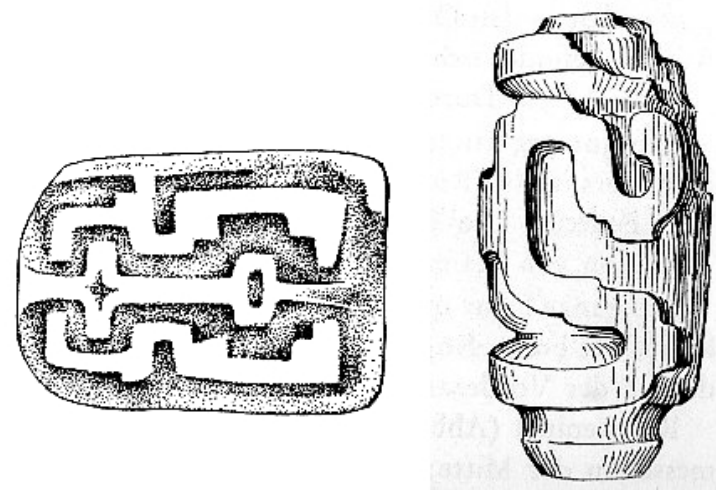

Figura 9 - Carimbos plano e cilíndrico da fase Guarita, tradição Policroma (Hilbert, 1968, p. 164 e 165).

Já para a fase Itacoatiara, Hilbert não publicou datações radiocarbônicas. Não obstante, as características gerais das cerâmicas e sua posição estratigráfica o levaram a incluí-la na tradição Incisa e Ponteada, datada entre 1000 e 1500 d.C., ou seja, seria este o conjunto supostamente mais recente encontrado na região. Outros complexos identificados com esta tradição aparecem distribuídos nas bacias do Orinoco e Amazonas, passando também pela antiga Guiana Inglesa. Sua caracterização se deu pelo uso de incisões e ponteados, combinando e alternando-se como elementos decorativos que ocupam bordas ou pescoços de vasos, em conjunção com modelados de várias formas. Outra característica diagnóstica seria o preenchimento de áreas com incisões em linhas 
finas, paralelas e com pouco espaçamento entre elas. Adornos modelados são muito comuns e incluem formas antropomórficas, zoomórficas e geométricas. $\mathrm{O}$ uso de engobo vermelho seria também característico desta tradição.
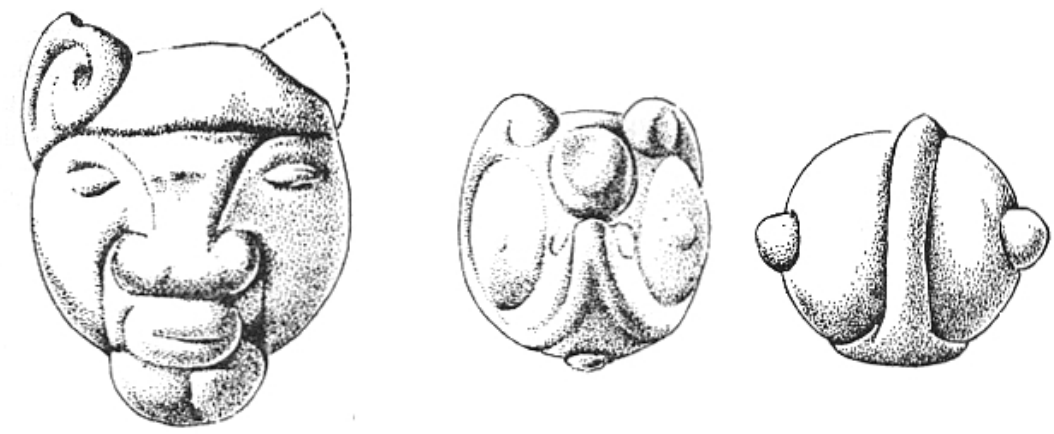

Figura 10: Apliques da fase Itacoatiara, tradição Incisa e Ponteada, segundo Hilbert (1968, p. 219).

A construção de uma seqüência cronológica foi a grande contribuição de Hilbert para a arqueologia do médio Amazonas. Na Amazônia central, a cronologia ficou representada pelas fases Manacapuru, Paredão, Guarita e Itacoatiara, relacionadas às tradições Borda Incisa, Policroma e Incisa e Ponteada, todas mais recentes do que as expectativas do modelo de ocupação da Amazônia proposto por Lathrap (1970a, 1970b). A tabela abaixo compila as datações publicadas (Hilbert, 1968).

\begin{tabular}{|c|c|c|}
\hline Fase & Tradição & Datas 14C \\
\hline Itacoatiara & Incisa e Ponteada & Sem datas \\
\hline Guarita & Policroma da Amazônia & $1150 \pm 57$ DC \\
\hline Paredão & Borda Incisa & $880 \pm 70 ; 870 \pm 70$ DC \\
\hline Manacapuru & Borda Incisa & $425 \pm 58$ DC \\
\hline
\end{tabular}

Tabela 1 - Quadro cronológico da Amazônia central, tal como proposto por Hilbert (1968).

As cronologias relativas construídas através de seqüências seriadas indicariam, para este grupo de autores, claras evidências de rupturas na seqüência de ocupação dos sítios, confirmando os padrões arqueológicos enunciados pelas hipóteses em questão, cujas prerrogativas, anteriormente mencionadas, colocavam a Amazônia e a cultura da floresta tropical como 
receptáculos de inovações culturais e de levas populacionais circum-caribenhas ou andinas. Essas cronologias confirmariam, por exemplo, o padrão etnográfico de aldeias de dimensões reduzidas com episódios de sucessivas reocupações (Hilbert, 1968; Meggers, 1970, 1971, 1990; Meggers \& Evans, 1961).

Em contraponto a esta interpretação, Donald Lathrap apresentou, em 1970, uma hipótese de ocupação da Amazônia bem diversa do que esses autores haviam sugerido até então. Antigo núcleo de inovações culturais e centro de dispersão das culturas ceramistas arqueologicamente encontradas por amplas regiões da Bacia Amazônica, do Orinoco e partes do Caribe, a Amazônia central teria como correlato arqueológico a ausência de rupturas entre os complexos cerâmicos em sua seqüência estratigráfica local. A expectativa cronológica para a região também diferia muito dos dados apresentados por Hilbert, e recuava a presença de sociedades vivendo ali a até pelo menos 4.000 anos a.C. (Idem; Lathrap \& Oliver, 1987).

Nas expectativas do modelo de D. Lathrap (1970a), haveria uma indicação de continuidade entre os conjuntos anteriormente discutidos, no âmbito da Amazônia central. Assim, segundo o autor, a tradição Barrancóide, encontrada na Venezuela e Caribe, teria se desenvolvido inicialmente na Amazônia central e, mais tarde, migrado para o norte da América do Sul (Lathrap, 1970a, p. 130-132). Para ele, estava claro que as cerâmicas da fase Manacapuru eram um correlato material dos povos falantes de línguas do tronco Arawak, que teriam partido da Amazônia central (seu locus de origem) e colonizado, em diferentes levas migratórias, a Bacia do Orinoco e o Caribe. Junto com a tecnologia cerâmica, classificada por Lathrap como Barrancóide e não Borda Incisa, esses povos teriam levado a esta porção setentrional do continente outros elementos, tais como as técnicas agrícolas do cultivo de mandioca e a própria língua.

No que se refere à seqüência local, propôs que a fase Guarita teria surgido como um desenvolvimento antigo da fase Manacapuru; um claro exemplo de idéias diametralmente opostas para a interpretação da relação entre estes complexos. Assim, onde Meggers via ruptura, Lathrap acreditava haver indícios de continuidade. Para ele, as cerâmicas da fase Manacapuru e da fase Guarita deveriam apresentar influências mútuas. Os flanges labiais da fase Manacapuru teriam migrado até o bojo dos vasos, transformando-se nos flanges mesiais 
característicos das cerâmicas Guarita; as incisões teriam se transformado nos acanalados, e os motivos incisos seriam similares aos motivos pintados.

Ainda dentro da perspectiva do autor, que atribui a ocorrência de complexos com características Barrancóides, na periferia noroeste da Amazônia, às dispersões provenientes da Amazônia central (Lathrap, 1970a, p. 132; 1970b, p. 500), a fase Itacoatiara, também encontrada nesta região, originaria as cerâmicas Barrancóides. Portanto, ela não poderia constar na cronologia relativa tal como identificada por Hilbert. Como vimos, a fase Itacoatiara foi filiada por Hilbert (1968) à tradição Incisa e Ponteada (Meggers \& Evans, 1961), cujas datas são posteriores à tradição Policroma da Amazônia, ou seja, supostamente muito mais recentes do que a tradição Borda Incisa ou Barrancóide. As premissas de Hilbert foram o tempero e a posição estratigráfica: a cerâmica Itacoatiara é temperada com cauixí e está sobreposta a materiais Guarita. Esta proposta foi contestada por Donald Lathrap (1970b, p. 500-501), que alegou a ocorrência de mistura mecânica entre os dois componentes, e defendeu que também a fase Itacoatiara seria associada às cerâmicas Barrancóides.

Como se pode ver, a cronologia de Hilbert para a Amazônia central, composta por quatro conjuntos cerâmicos, difere bastante da hipótese de Lathrap, uma vez que indica datas muito mais recentes para as cerâmicas da área. Como conseqüência, foi duramente criticada (Lathrap, 1970b). Trata-se ainda daquele velho embate teórico-metodológico que diz respeito à origem, desenvolvimento e dispersão dos conjuntos arqueológicos da Amazônia central, em termos de continuidade ou ruptura. As implicações de um ou de outro quadro têm enorme relevância para a construção da história cultural da Amazônia, configurando um quadro ambíguo frente à arqueologia da Amazônia central, uma vez que os modelos propunham diferentes expectativas para o registro arqueológico dessa área específica da Amazônia.

À época, contava-se apenas com tipologias cerâmicas e poucas datações radiocarbônicas. A própria estratigrafia dos sítios, sendo muitos deles multicomponenciais, dificulta também sua interpretação (Simões, 1974). Havia ainda muitos fatores agravantes. Em primeiro lugar, a própria composição da maioria dos sítios arqueológicos, que tinham como matrizes de solo as Terras Pretas, mascarava a percepção das camadas estratigráficas na leitura dos perfis. Aliado a isso, foi somente em tempos recentes que os arqueólogos passaram a 
atentar para as mudanças antrópicas na paisagem, como os montículos artificiais e outras feições, que alteram a configuração original do registro arqueológico. Os montículos, por exemplo, são acúmulos que têm como material construtivo o próprio sedimento e as cerâmicas que se encontram em seu entorno. Como conseqüência desta atividade humana do passado, em que aterrava-se uma superfície com os materiais de entorno originalmente mais antigos, obtém-se uma estratigrafia invertida, que não condiz com ocupações seqüenciais ao longo do tempo.

Por estas razões, a afiliação cultural e a posição crono-estilística de tais fases arqueológicas foram tão debatidas na arqueologia amazônica. Dois dos componentes crono-estratigráficos apresentados até o momento, Manacapuru e Paredão, compõem, na área de confluência dos rios Solimões e Negro, na Amazônia central, a chamada tradição "Borda Incisa, Incisa e Modelada ou Barrancóide" (Heckenberger et al., 1999; Hilbert, 1968; Lathrap, 1970b; Lima, 2003; Meggers \& Evans, 1961; Meggers, 1983; Neves, 2000), foco direto deste trabalho. A própria multiplicidade de nomenclaturas dadas a esta tradição demonstra a quantidade de questões não consensuais acerca de sua validade epistemológica e de suas implicações culturais.

Durante muito tempo, as discussões se desenrolaram num âmbito puramente tipológico, deixando à margem das interpretações os elementos contextuais inerentes aos conjuntos. De certa forma, esta perspectiva tipológica encarava o material, submetido a exaustivas análises, como um fim em si próprio, dando uma importância exagerada a discussões de nomenclatura. Eram justamente estas discussões que embasavam as hipóteses gerais para a ocupação da Amazônia, e que se propunham a ter uma abrangência muito maior do que os dados, da forma como foram trabalhados, permitiam. Foi por conta dessa restrição empírica, que limitava um quadro interpretativo mais apurado, que se recorreu às analogias etnográficas. Essas analogias viriam a preencher tais lacunas, tornando estes modelos antropológicos gerais aplicáveis tanto ao registro arqueológico quanto à realidade etnográfica em si. Como se pode ver, embora contrastantes, estas hipóteses foram construídas a partir de bases teóricas parecidas, desconsiderando as restrições impostas tanto pela pequena quantidade de dados, quanto pela forma como foram interpretados (Roosevelt, 1989). 
Este mesmo hiato, existente entre a base empírica e as hipóteses gerais, pode ser preenchido a partir de outras bases, ou seja, é possível sair do plano tipológico-classificatório e adentrar uma esfera contextual deste material, que acredito abranger aquela percepção mais apurada de uma história cultural de longa duração, dentro dos parâmetros e limites impostos pela própria natureza dos dados. Lidando com uma escala temporal de mais de um milênio, e uma dispersão geográfica de dimensões amazônicas, minhas inferências ficam cingidas à representatividade da variabilidade e dos padrões identificados, e das relações entre eles. Assim sendo, dentro do viés aqui empreendido, não me caberiam nem interpretações de caráter tão generalizante quanto a ocupação da Amazônia como um todo, nem tampouco atingir um nível de detalhamento que me permitisse aludir à análise etnográfica.

Como diferencial às abordagens anteriores na perspectiva adotada, procurou-se observar, no registro arqueológico da Amazônia central, elementos de diferentes naturezas que parecem se associar especificamente a essa tradição, a "Borda Incisa, Incisa e Modelada ou Barrancóide". São estes os elementos a serem explorados na presente pesquisa, que compõem, em conjunto, uma análise alternativa àquelas anteriormente propostas, dos significados dessa tradição. De fato, na arqueologia da Amazônia central, quanto mais se amplia a base empírica, mais evidente fica a interpolação cronológica entre as diferentes fases cerâmicas ali encontradas, o que nos leva para além de uma abordagem puramente tipológica. Começou-se a questionar os mecanismos estabelecidos para gerir as relações que se dão em diferentes esferas da vida social, entre grupos culturais distintos ou não.

As questões que hoje se colocam, que têm cunho essencialmente cronológico e, ressalto, tratam de uma história cultural de longa duração, demandam tratamentos que permitam uma completa revisão das fases e tradições estabelecidas para a região, com foco na identificação das relações entre elas e, principalmente, da identificação dos elementos contextuais inerentes a cada uma delas. Foram estas as necessidades que impulsionaram a presente pesquisa.

Longe de ser incipiente, esta linha interpretativa tem uma tradição centenária na arqueologia (Childe, 1946; Willey \& Phillips,1958) e, ao mesmo tempo, tem se mostrado extremamente atual e efetiva em pesquisas recentes que 
tratam de problemas amplos como, por exemplo, as origens e a dispersão da agricultura (Bellwood, 2005). Esta abordagem se mostrou útil também para o problema da pesquisa ora estudado, na composição de um quadro mais abrangente e preciso da história cultural regional. O escopo temporal da proposta analítica é tão abrangente quanto a temporalidade inerente à tradição Borda Incisa na Amazônia central, que dá conta de uma história cultural de mais de um milênio. $O$ que pretendo aqui é tentar conjugar os diferentes aspectos hipoteticamente associados à tradição Borda Incisa, a fim de propor um quadro de relações sociais, políticas, econômicas e simbólicas levadas a cabo entre diferentes grupos culturais numa Amazônia central pretérita, que são por nós acessadas através de certas padronizações observáveis no registro arqueológico.

Os hipotéticos padrões associados, neste caso, são: 1) a tecnologia cerâmica; 2) a forma das aldeias; 3) o uso do espaço; 4) a filiação lingüística. A validade, em termos históricos e culturais, de tais associações é, portanto, a esfera de objetivos gerais da pesquisa. Trata-se de uma tarefa um tanto complicada, uma vez que a arqueologia lida, pela própria natureza de seu objeto de estudo, com padrões de cultura material e suas interpretações, que estão longe de ser direta ou explicitamente ligados ao complexo contexto sistêmico que os originou. Ainda assim, acredito que vale o esforço de tentar, mesmo que num plano hipotético, integrá-los.

Neste sentido, hoje é possível avançar. Em primeiro lugar, a gama de dados disponíveis na atualidade é infinitamente maior do que aquela com a qual autores como Lathrap e Hilbert puderam contar. Foi, portanto, a necessidade de ampliar a base empírica para o esclarecimento de problemas antropológicos que deu origem, em 1995, ao chamado Projeto Amazônia Central (PAC), do qual este doutorado é parte. O PAC teve sua origem a partir da colaboração entre arqueólogos brasileiros e norte-americanos, o que veio a aumentar consideravelmente a quantidade e o ritmo de pesquisas arqueológicas na região. Hoje o projeto tem atuado em diversos municípios do Estado do Amazonas, entre eles Iranduba, Manaus e Manacapuru.

Seus principais objetivos são: o estabelecimento de tamanho e forma dos assentamentos, a reconstrução da densidade e duração das ocupações, e o refinamento da cronologia da área de confluência dos rios Negro e Solimões. Até o momento, mais de uma centena de sítios arqueológicos foi identificada, dos 
quais alguns foram intensamente trabalhados através de sua delimitação e escavações sistemáticas, e da criação de mapas topográficos detalhados. O projeto já gerou uma bateria de quase cem datações radiocarbônicas, que vêm possibilitando um refinamento da cronologia de ocupação dos sítios da região. Com efeito, pode-se dizer que hoje a Amazônia central, embora tão vasta, é uma das regiões mais bem conhecidas arqueologicamente do Brasil, tanto em termos de dados como de problemas de pesquisa sólidos e bem definidos. De fato, consideráveis avanços foram obtidos nesse sentido, sendo que antigos debates podem ser reconsiderados à luz de novos dados, que são o foco desta pesquisa e serão apresentados nos próximos capítulos.

O Projeto Amazônia Central tem permitido também o treinamento especializado de arqueólogos e técnicos baseados em Manaus, e qualificados a atuar em outros projetos na região. Como conseqüência, participantes do PAC têm atuado em outras intervenções de proteção e salvamento do patrimônio arqueológico na região, realizadas através de parcerias com o IPHAN $^{2}$ (Instituto do Patrimônio Histórico e Artístico Nacional), a PETROBRAS ${ }^{3}$, e diversas ONG's que atuam na Amazônia. Tais projetos têm tido papel importante na ampliação de conhecimento da arqueologia da região e em sua divulgação.

O PAC vem estimulando, também, uma série de pesquisas pontuais e publicações realizadas por pesquisadores e estudantes de graduação e pósgraduação (Abreu, 2000; Costa, 2003; Donatti, 2002; Gibertoni, 2004; Heckenberger et al. 1998, 1999; Lima \& Machado, 2005; Lima, L. 2003; Lima, 2003, 2004; Lima, et al., 2006; Machado, 2005; Moraes, 2007; Neves 2000 2003, Neves \& Petersen 2005; Neves et al., 2003, 2004; Petersen et al., 2001; Portocarrero, 2006; Rebellato, 2007).

Além de uma considerável ampliação da base empírica geral, essas pesquisas pontuais têm explorado problemas arqueológicos através de diferentes perspectivas. Por exemplo, a micromorfologia de solos tem sido utilizada na

\footnotetext{
2 Exemplos de parcerias com o IPHAN são o "Levantamento Arqueológico do Médio Amazonas" (Lima e Silva, 2005), realizado em 2004 e o "Levantamento Arqueológico do Município de Manaus", ocorrido em 2006 (Costa e Lima, 2006). Os resultados de ambos foram incorporados à presente pesquisa.

${ }^{3}$ Trata-se do "Levantamento e Resgate Arqueológico do Gasoduto Coari-Manaus", e do projeto PIATAM, ambos em andamento, coordenados por E. Neves.
} 
identificação de pisos de ocupação em sítios multicomponenciais, cuja interpretação estratigráfica é complicada (Arroyo-Kalin, 2006). Também, em adição aos dados da distribuição espacial dos vestígios, a identificação dos elementos físico-químicos do solo pode auxiliar na identificação de formas de aldeias (Rebellato, 2007). O que pretendi fazer nesta pesquisa foi interpretar essa nova e ampla base empírica, no que se refere às ocupações da Amazônia central do primeiro milênio d.C., sob o foco de um novo olhar, neste caso, mais relacional e contextual.

Um exemplo da aplicação, em minha pesquisa, deste tipo de abordagem, foi a problematização dos contextos Manacapuru encontrados em diversos sítios arqueológicos na Amazônia central. Em si mesma, a fase Manacapuru suscitou dúvidas e sua própria identificação, caracterização e filiação cultural, como vimos, não eram claras. Na Amazônia central, a fase Manacapuru está presente em sítios unicomponenciais e multicomponenciais, com matrizes sedimentares compostas por solos orgânicos de coloração escura. São as chamadas Terras Pretas de Índio (TPI), descritas já no século XIX por O. Derby (apud. Faria, 1946, p. 14):

"Em diferentes pontos, encontram-se manchas de terra preta muito abundante, e em todos os casos, tanto quanto consegui informar-me, elas estão cheias de antiguidades dos índios, utensílios de pedra e fragmentos de louça"

O surgimento das TPI tem sido interpretado como um marcador cronológico e cultural que envolve o aumento da densidade populacional, a intensificação do uso do solo, e a emergência de formações sócio-políticas mais complexas (Neves et al., 2003, 2004; Petersen et al., 2001; Roosevelt, 1999). A presente pesquisa está demonstrando que, na Amazônia central, esse fenômeno parece estar relacionado cronologicamente ao surgimento de ocupações associadas às cerâmicas da fase Manacapuru. As evidências de aumento da densidade demográfica na região são mais visíveis a partir do século $V$ d.C. (Heckenberger et al., 1999; Hilbert, 1968; Neves, 2000), atestadas pela formação de depósitos profundos de terras pretas, e pelo aumento da densidade de depósitos cerâmicos nos sítios. 


\section{II. Repensando as Tipologias: um estudo de caso}

Em 2003, lancei algumas hipóteses para explicar a presença de sensíveis variações dentro de diferentes contextos relativos à mesma fase Manacapuru, tradição Borda Incisa (ou Barrancóide?) (Meggers \& Evans, 1961; 1983; Hilbert, 1968; Lathrap, 1970a, 1970b; Lima, 2003). Nos casos analisados, provenientes de uma série de sítios arqueológicos da região, o padrão de variabilidade da indústria cerâmica estava positivamente correlacionado ao contexto de deposição. "As cerâmicas da fase Manacapuru localizadas nos ricos solos de origem antrópica, as Terras Pretas de Índio (TPI), são sempre distintas daquelas provenientes das matrizes naturais da área, os latossolos e espodossolos não modificados intensamente por ação humana" (Lima, 2003). No entanto, estes dois conjuntos cerâmicos foram, a princípio, classificados numa mesma categoria. As hipóteses propostas para explicar tal padrão consideravam que a origem de tal variação poderia ser diacrônica ou sincrônica, ou ambas. No primeiro caso, de variação cronológica, a TPI é tomada como um marcador cronológico e cultural, implicando na premissa de que materiais a ela associados são mais recentes. No segundo caso, de variação funcional, assume-se que as diferenças entre as matrizes, bem como entre as formas e a decoração da cerâmica, estão associadas a diferentes funções dentro de um mesmo sitio, e entre os sítios (Idem).

O andamento da pesquisa forneceu uma série de datações radiocarbônicas, que indicou uma grande lacuna temporal entre os dois contextos anteriormente considerados como pertencentes à fase Manacapuru. (tabela 2). Assim, os dados contextuais, cronológicos e de variabilidade cerâmica examinados levaram à subdivisão da fase Manacapuru em duas fases cerâmicas distintas, denominadas Açutuba e Manacapuru. Os dados foram publicados (Lima, et al, 2006). 


\begin{tabular}{|c|c|}
\hline Fase & Variação cronológica aproximada \\
\hline Manacapuru & $600-1000 \mathrm{DC}$ \\
\hline Açutuba & $300 \mathrm{AC}-360 \mathrm{DC}$ \\
\hline
\end{tabular}

Tabela 2 - Variabilidade cronológica das ocupações das fases Açutuba e Manacapuru na Amazônia central.

As datações radiocarbônicas obtidas naquele momento indicaram para a fase Açutuba uma durabilidade de cinco séculos, entre 300 a.C. e 200 d.C. As cerâmicas são caracterizadas por uma ampla variabilidade formal, e decoradas através de técnicas diversas, como modelagem, incisões, excisões, o engobo vermelho e pintura policrômica (várias tonalidades de vermelho e/ou preto), aplicada sobre camada de engobo branco ou diretamente sobre a superfície. $\mathrm{O}$ estabelecimento e caracterização deste conjunto cerâmico indicaram, também, haver claras características Saladóides e Barrancóides, bem como fortes semelhanças com contextos Pocó encontrados no baixo Amazonas (Lima, et al, 2006).

$\mathrm{Na}$ região do município de Iranduba, os contextos Açutuba ocupam os estratos mais antigos dos sítios escavados, sempre multicomponenciais, o que dificultou o estabelecimento dos padrões relacionados a esses conjuntos. Observou-se apenas que se tratavam de depósitos de proporções reduzidas, com densidades diferenciadas de vestígios, em matrizes de latossolos e espodossolos, mas sem as terras pretas.
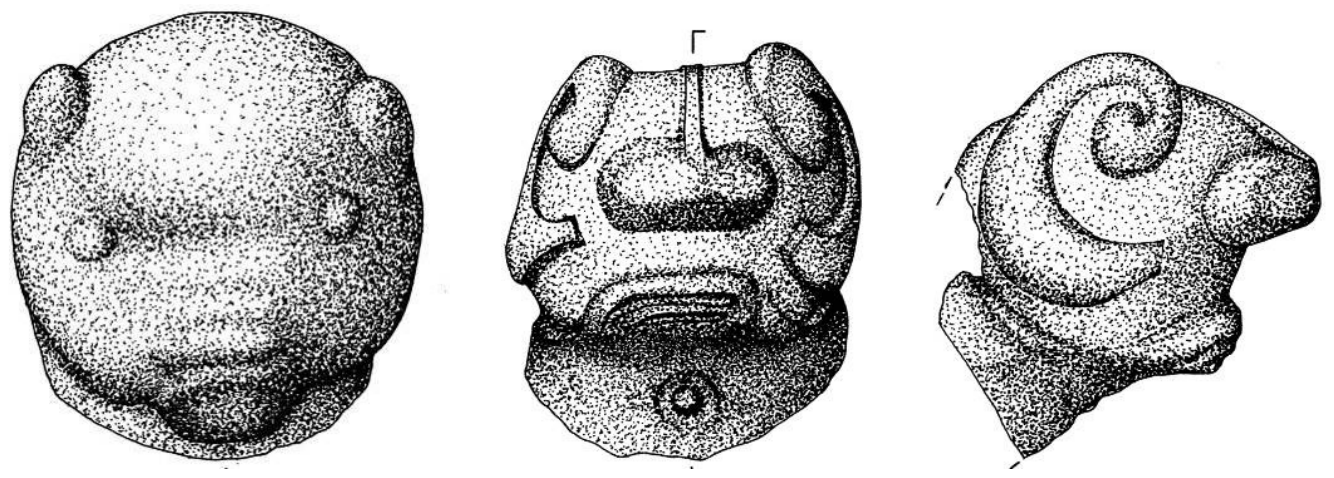

Figura 11 - Apliques cerâmicos da fase Açutuba 
Como se pode ver, uma abordagem que vai além das discussões tipológicas, e insere num mesmo quadro interpretativo elementos contextuais inerentes aos conjuntos analisados, tende a refinar o quadro empírico, ao mesmo tempo em que amplia a quantidade de questões colocadas frente a este quadro.

Assim, o problema apresentado para a fase Manacapuru, que levou à definição de mais uma fase cerâmica na Amazônia central, se ampliou: do mesmo modo que para os contextos Manacapuru, a filiação cultural da recém-definida fase Açutuba permaneceu incógnita. Como interpretar as semelhanças existentes entre estas cerâmicas com os materiais das tradições Saladóide e Barrancóide que abrangem uma área ampla em todo o norte da América do Sul, incluindo a Colômbia, Venezuela e Caribe Insular (Boomert, 2000; Gasson, 2002; Roosevelt, 1997; Rouse \& Cruxent, 1963)? E, destas, com os contextos tais como Pocó, do baixo Amazonas?

E relacionado a este, um segundo questionamento não poderia deixar de surgir. Passei assim para uma busca das origens dessa sociedade ceramista. Sedentarismo, agricultura, surgimento e adoção da tecnologia cerâmica, foram temas que não poderiam deixar de ser explorados, e remontam a outro debate que versa sobre um período da história pré-colonial sul-americana, denominado "Formativo".

Também sobre o surgimento e adoção dessa nova tecnologia, os arqueólogos se colocam em posições contrastantes. $O$ debate reflete pressupostos diferentes sobre os mecanismos de mudança cultural e os padrões que eles deixam no registro arqueológico. Teria o início da produção cerâmica ocorrido de forma independente em diferentes locais (Hoopes, 1994; Raymond et al, 1994), ou haveria um único centro de produção antiga, a partir do qual as idéias e técnicas relativas à produção cerâmica teriam se difundido (Meggers, 1997; Williams, 1997)?

O problema que então se coloca trata, por um lado, de entender a origem de um modo de vida ao qual se associa a fase Açutuba e, por outro, de compreender quais seriam as relações entre Açutuba e Manacapuru na Amazônia central. E as questões referentes à cronologia da Amazônia central prosseguem e se ampliam, do mesmo modo que a própria cronologia avança no tempo. Trata-se do entendimento da natureza das relações entre as diferentes fases cerâmicas, 
não apenas em termos de continuidade ou ruptura, mas em termos históricos e culturais. Observa-se no registro arqueológico da Amazônia central uma constante correlação estratigráfica de contextos Manacapuru a contextos associados à fase Paredão, posterior a ela na cronologia de Hilbert.

Há discussões sobre a continuidade ou não na tecnologia cerâmica em relação às fases Manacapuru e Paredão, mas, de todo modo, a associação entre estes dois conjuntos é uma constante na Amazônia central, sendo que alguns trabalhos realizados no âmbito do PAC têm demonstrado que tal associação vai muito além dos dados estratigráficos (Donatti 2003; Moraes 2007; Portocarrero, 2006). Estas questões se colocam como um problema de ordem cronológica, bem como de natureza geopolítica. Juntas, as fases Açutuba, Manacapuru e Paredão compõem a chamada tradição Borda Incisa na Amazônia central e representam, em termos analíticos e interpretativos, um foco maior da presente pesquisa, como o próprio título da tese pressupõe.

Para o presente estudo, contextos unicomponenciais associados às fases Manacapuru e Paredão, recentemente trabalhados pelo PAC, foram selecionados como base analítica (Abreu, 2000; Donatti, 2005; Moraes, 2007; Portocarrero, 2006). A conjugação dos dados e interpretações obtidas destes trabalhos rendeu uma hipótese, a ser testada, sobre o significado da própria tradição Borda Incisa.

A princípio, a configuração espacial destes sítios, tanto daqueles relacionados à fase Manacapuru quanto os da fase Paredão, é sempre semelhante, com um diferencial apenas, que é a presença de montículos nos sítios mais recentes. A composição e disposição espacial destes montículos artificialmente construídos sugerem tratar-se de unidades habitacionais (Moraes, 2007). Em conjunto com aquelas identificadas em contextos Manacapuru (Portocarrero, 2006), ambas podem ser interpretadas como evidências de aldeias circulares, associadas às fases Manacapuru e Paredão (idem). Aliam-se a isso outros fatores. Em primeiro lugar, coloca-se a co-ocorrência, sempre em proporções reduzidas, de materiais de uma fase em sítios da outra, e vice-versa, ou seja, materiais Manacapuru aparecendo, em pequenas proporções, nos contextos Paredão, e cerâmicas Paredão presentes nos sítios Manacapuru. Estes locais foram ocupados por períodos de algumas gerações. Mesmo sendo as 
ocupações Paredão, pela própria cronologia, mais recentes, os sítios compartilham de alguma contemporaneidade.

A identificação de padrões circulares de assentamento na região, relacionados a uma cronologia bem estabelecida, que demonstra certas mudanças, intensificação de alguns fatores, mas sempre dentro de uma mesma configuração espacial, revelada pelas aldeias circulares, dirigem a discussão para um interessante caminho: apesar das relações tecno-estilísticas entre as cerâmicas das fases Manacapuru e Paredão não serem consensuais em meio aos pesquisadores do PAC, alguns deles (e eu me incluo nesta lista) consideram a fase Paredão como uma manifestação local de mudanças dentro da fase Manacapuru (Moraes, 2007). Indo além, esta correlação pode ser utilizada para definir os produtores dessas cerâmicas "Borda Incisa" como possíveis falantes de línguas Arawak, de acordo com o modelo de dispersão lingüística proposto por Lathrap (1970a) e revisto por Heckenberger, que o chamou de Diáspora Arawak (2002). É claro que tais associações serão exploradas com cautela, mas a linha interpretativa parece bastante frutífera (Schmidt, 1917).

Mas, os problemas cronológicos não se findam aí. Em verdade, a questão mais debatida entre Meggers e Lathrap está, justamente, nos processos que levaram à substituição, na Amazônia central, da tradição Borda Incisa pela tradição Policroma da Amazônia (Heckenberger et al, 1999; Hilbert, 1968; Lathrap, 1970a, 1970b; Meggers \& Evans, 1961, 1983). São discutidas, em termos de continuidade ou ruptura, as relações entre os contextos Manacapuru e Guarita. Assim sendo, se conforme a proposição de Lathrap, a tradição Barrancóide se desenvolveu inicialmente na Amazônia central para, em fase posterior, migrar para o norte da América do Sul, e a fase Guarita surgiu como um desenvolvimento antigo da fase Manacapuru, então as cerâmicas das duas fases deveriam apresentar influências mútuas. Para ele, flanges labiais Manacapuru teriam migrado até o bojo dos vasos; as incisões teriam se transformado nos acanalados Guarita e os motivos incisos seriam similares aos motivos pintados (1970a, p. 130-132; 1970b, p. 500). Não é isso, no entanto, o que se observa no registro arqueológico, como demonstrarei adiante. Estão envolvidas nessa discussão mudanças sociais e econômicas consideráveis, que incluiriam também modificações nos padrões de organização social. 
Os contextos associados à fase Itacoatiara também foram controvertidos: esta fase foi incorporada na cronologia de Hilbert (1968) na tradição Incisa e Ponteada (Meggers \& Evans, 1961), e ao mesmo tempo foi considerada por Lathrap como Barrancóide (Lathrap 1970b). Em verdade, Lathrap escreveu todo um artigo que refuta essa proposta cronológica de Hilbert para a fase Itacoatiara, alegando, como vimos, a ocorrência de mistura mecânica entre os contextos no sítio arqueológico (idem). As análises realizadas no âmbito deste projeto, embora não tivessem na fase Itacoatiara um foco analítico prioritário, puderam elucidar esta questão. Uma cautelosa observação da cerâmica e dos contextos de alguns dos sítios onde fora identificada por Hilbert, em associação com algumas datações radiocarbônicas obtidas pelo autor, embora ainda inéditas, situaram esta controversa, porém consistente, fase cerâmica junto à tradição Borda Incisa, completando seu quadro cronológico e regional.

Como pretendo demonstrar ao longo do trabalho, o velho problema da filiação cultural e posição crono-estilística das fases cerâmicas encontradas na Amazônia central pode, hoje, ser interpretado à luz de novos dados e novas perspectivas. Um dos objetivos da presente pesquisa visou, portanto, elucidar tais questões através de um estudo detalhado de contextos associados a essas fases, provenientes de uma série de sítios arqueológicos da Amazônia central para, a partir daí, interpretá-los desde uma perspectiva comparativa, em níveis local, regional e continental. O esforço interpretativo se deu através de um escopo teórico-metodológico próprio, desenvolvido especificamente para trabalhar com tais questões.

O problema desta pesquisa trata, em primeira instância, do entendimento e interpretação da seqüência estratigráfica da Amazônia central. E em adição a isso, busco caracterizar os conjuntos em diversos aspectos, como tamanho e forma dos assentamentos, relações cronológicas entre eles, e analisá-los dentro de um corpo teórico específico. A partir daí, busca-se compreender os significados dessa região em escala mais ampla, abrangendo o norte da América do Sul. 


\section{Capítulo III \\ QUAL AMAZÔNIA?}

\section{III.I. Amazônias são muitas}

"the Amazon forest was not pristine in 1942 , nor is it today"

(Denevan, 1998, p. 57)

"The neotropical lowlands exhibit

classic anthropogenic or cultural

landscapes formed over thousands of years"

(Balée \& Erickson, 2006, p.1)

Neste capítulo as principais características da área de foco da pesquisa serão apresentadas dentro de suas singularidades e uniformidades. Como as duas epígrafes demonstram, nossa perspectiva é que "as Amazônias" que hoje vemos são fruto da agência integrada da natureza e das sociedades humanas. Cai por terra o antigo mito da floresta virgem. As diferentes regiões serão geograficamente determinadas desde o ponto de vista da ocupação humana atual e do que se conhece em termos arqueológicos.

Trata-se de uma ampla porção setentrional da América do Sul, cujas terras baixas são caracterizadas pelo clima tropical úmido, em geral muito florestadas, e situadas em altitudes abaixo de aproximadamente 500 metros (Balée \& Erickson, 2006, p. 1). E nessas mesmas áreas, as populações indígenas têm significativa e permanentemente transformado, construído e mantido ambientes em tal escala que se influenciou não só a diversidade de espécies locais e regionais, como a riqueza ambiental em geral, a qualidade do solo e outras características naturais que freqüentemente são atuais objetos de um esforço de conservação. (Idem, 2006, p. 10). 
De fato, a ocupação humana na Amazônia desenvolveu-se a partir de contextos naturais marcados pela diversidade ecológica e paisagística. E as evidências arqueológicas e etnográficas disponíveis parecem indicar que a ação humana contribuiu para tornar ainda mais complexa tal diversidade, criando novos micro-ambientes que aumentaram ainda mais a diversidade do mosaico (Balée, 2003). É claro, "a semantização do território pode explicar-se parcialmente a partir do meio, mas a investigação do meio físico nunca nos permitirá concluir que deve dar-se um tipo determinado de semantização” (Haesbaert, 2004, p. 70).

Considerada como um verdadeiro "mosaico paisagístico" (Neves, 2003), a área de pesquisa do Projeto Amazônia Central, em sua configuração inicial, era delimitada a leste pelo rio Negro, a oeste pelo Solimões e a norte pelo rio Ariaú, no município de Iranduba, estado do Amazonas, formando um triângulo com aproximadamente $900 \mathrm{Km}^{2}$. Hoje o PAC vem aos poucos ampliando sua área de pesquisa, na medida em que novos projetos e questões científicas são incorporados ao seu escopo arqueológico. Os municípios de Manaus e Manacapuru, fronteiriços com Iranduba, foram incorporados, aumentando consideravelmente a área de pesquisa, bem como a variabilidade de microregiões estudadas.

A chamada área de confluência dos rios Negro e Solimões (fig 12) possui um relevo de planície bem suave, com terraços escarpados, quase sempre com mais de 15 metros, acima dos quais na maioria das vezes estão implantados sítios arqueológicos (Neves, 2000, p. 11).

O habitat amazônico é caracterizado por uma imensa rede hidrográfica composta por rios, igarapés e lagos, que há tempos foram explorados pelas sociedades humanas. Seus principais ecossistemas, associados a rios de águas pretas e rios de águas brancas, estão presentes na área pesquisada pelo PAC, tornando-a um microcosmo do verdadeiro mosaico das paisagens presentes na bacia amazônica (Neves, 2000). É nesta área que acontece o famoso "encontro das águas" que sempre impressionou nossos olhos e sentidos. 


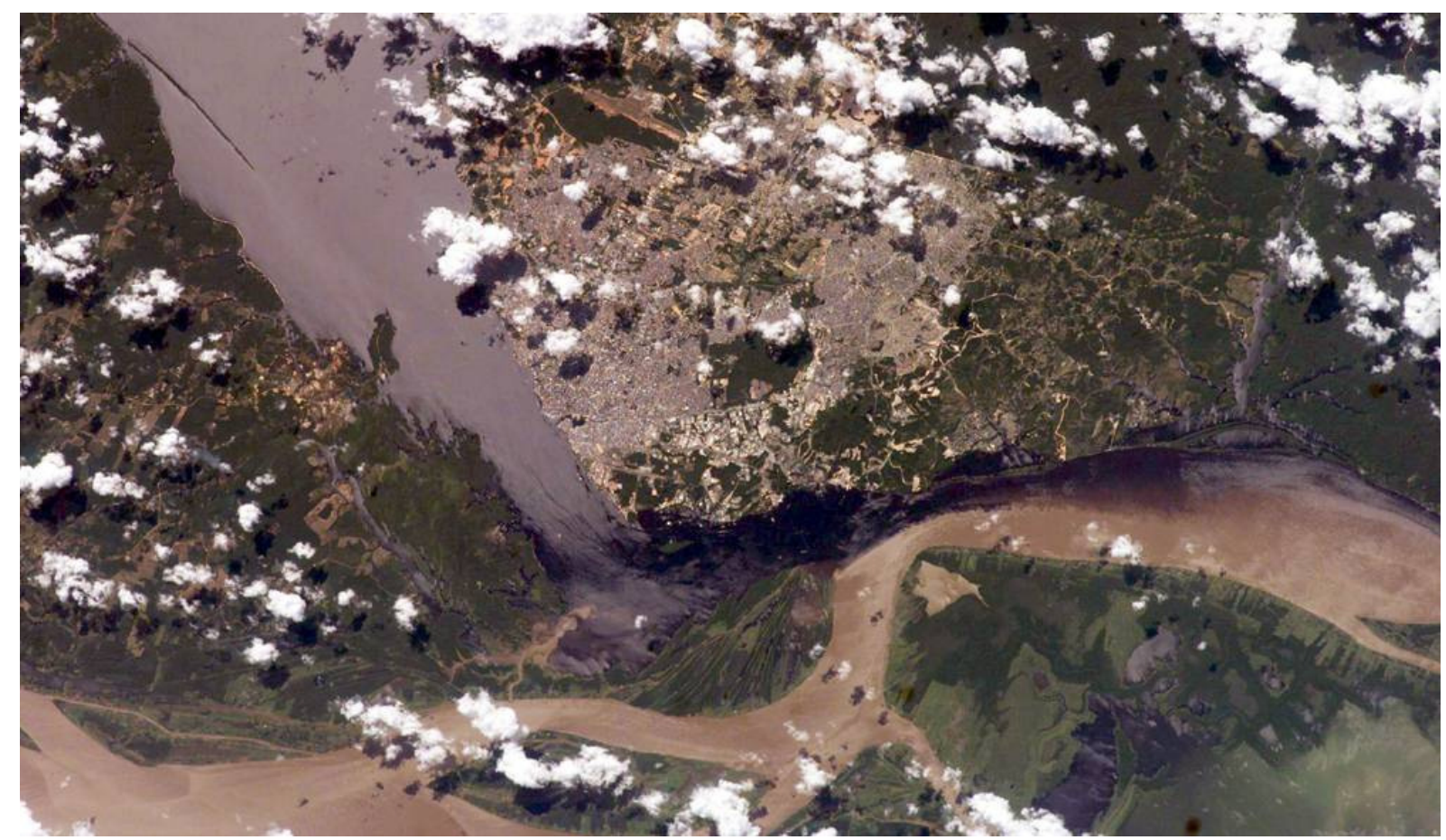

Figura 12 - A confluência dos rios Negro e Solimões (fonte: Google Earth).

O rio Negro, assim como outros rios de águas pretas, com suas águas de aspecto transparente e escuro, tem suas nascentes nas areias brancas do escudo das Guianas. Esses rios não formam várzeas e são caracterizados pelo baixo teor de oxigênio e alta acidez de suas águas, resultando numa baixa produtividade primária. Segundo Meggers, os solos por eles irrigados têm, do ponto de vista do aproveitamento humano, "tão baixo potencial na produção de meios de subsistência que são conhecidos como rios da fome" (1971, p. 36).

Embora válida para o alto curso deste rio, na área pesquisada tal afirmação parece não se sustentar por diversos fatores. Em primeiro lugar, a existência de variados pontos com grande extensão de terra preta, ao longo das margens do rio e de seus afluentes, demonstra que seu baixo potencial produtivo vem sendo historicamente sobrepujado pelas sociedades humanas, desde pelo menos dois mil anos atrás. Além disso, a grande quantidade e diversidade de espécies de peixes descritas por Alfred Russel Wallace, entre os anos de 1850-1852 (2002), nos rios Negro e Uaupés, apontam para uma fonte adequada de recursos protéicos, que é contrabalançada com a coleta de frutos silvestres e com o amido proveniente dos subprodutos da mandioca (Manihot esculenta), cujo cultivo é importante na vida dessas populações, e cresce muito bem em solos arenosos, pouco férteis. 
Às margens do rio Negro, é comum a ocorrência do arenito-silicificado da unidade Manaus, que com freqüência aflora na superfície nas épocas de vazante de suas águas. Este é um dos inúmeros tipos litológicos da formação Altér do Chão (Costa, 2003; Léxico Estratigráfico do Brasil, 1984). Além das margens do rio Negro nos arredores de Manaus, podem ser encontrados também em todo o médio Amazonas e seus afluentes do baixo curso. Igualmente ocorrem argilitossilicificados de fina granulação e cor vermelha, sempre pertencentes à variedade Manaus. (Costa, 2003).

Estes arenitos e argilitos apresentam características propícias ao lascamento, e esta tecnologia foi explorada pelos antigos habitantes da região, o que é atestado pela presença, em quantidade, de artefatos líticos lascados e refugos de lascamento encontrados nos sítios arqueológicos da localidade, em associação com vestígios de ocupações datadas de diferentes momentos (Costa, 2003; Neves et al., 2004). É interessante notar, porém, que essa ocorrência é restrita aos sítios localizados às margens do rio Negro, onde a oferta de matéria prima é abundante.

Já os rios de águas brancas, como o Solimões, têm seu aspecto barrento causado pela grande quantidade de partículas inorgânicas que carregam. Nessas imensas faixas de planície, próximo de onde se situa a maioria dos sítios arqueológicos estudados, encontram-se principalmente aluviões fluviais holocênicos, extremamente férteis. Nos trechos de interflúvio tabular ocorrem sedimentos da formação Solimões (também Alter do Chão) sob a forma de espessas camadas de latossolo amarelo. Não se verificam nessas áreas afloramentos rochosos passíveis de exploração de matérias primas para o lascamento. E nesses sítios não ocorre uma indústria lítica lascada tal como se verifica em sítios próximos do rio Negro. A nomenclatura dada ao alto curso do Amazonas, ou seja, do rio Solimões, é confusa. Segundo uma primeira vertente, o rio Amazonas começa no Peru, onde se juntam os rios Marañon e Ucayali (citado no trabalho de Lathrap 1970, por exemplo). Outra vertente o denomina como Solimões, sendo que o Amazonas propriamente dito só nasce na sua confluência com o Negro. A denominação Solimões dada ao rio é uma corruptela criada pelos portugueses ao nome indígena Sorimã, que correspondia ao nome de uma tribo local. Seus habitantes eram os sorimões que, com o tempo, se transformaram em solimões. (Silveira Bueno, 1998, p. 319). 
"a causa de chamar-se Solimões foi por habitar naquelas alturas a nação chamada Solimões, que parece era a mais numerosa daquele distrito"

(Daniel, Pe. João, [1722-1776] 2004, p. 49)

O Solimões é um rio de águas brancas, caracterizado pelo forte carreamento de sedimento proveniente dos contrafortes orientais dos Andes, que são geologicamente muito recentes e pouco consolidados. Há quem o chame de rio "adolescente" que, devido à força de sua correnteza, muda rapidamente seus meandros e as paisagens do entorno. Ilhas podem surgir ou desaparecer em poucos séculos ou mesmo em décadas. Assim, o processo de formação dos sítios arqueológicos na região apresenta constantes mudanças naturais (ou não culturais, $n$-transforms, no conceito de Schiffer, 1987). Ocorrem dois tipos de mudanças, seja pela erosão dos barrancos do rio, seja pelo depósito de grande volume de sedimento sobre os sítios.

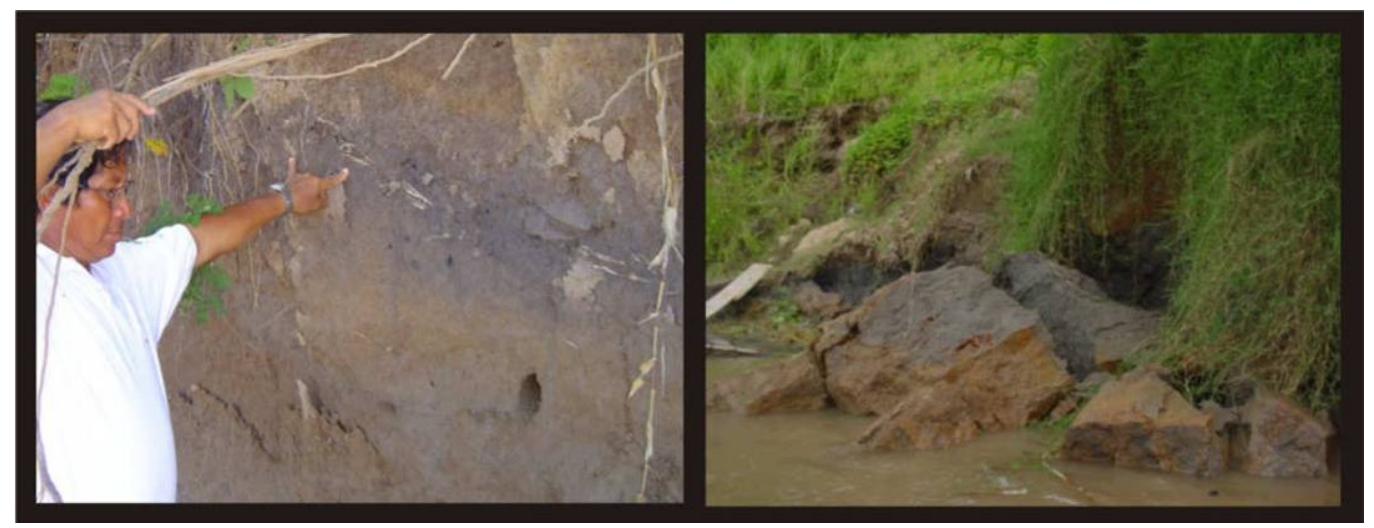

Figura 13 - Camada de terra preta soterrada por sedimentação do rio Solimões; desmoronamento do barranco (fotos: Helena Lima).

Diferente do rio Negro, no ecossistema do Solimões a distinção entre várzea e terra firme é latente. As chamadas várzeas amazônicas têm extensões extremamente variáveis, podendo ter alguns metros ou dezenas de quilômetros. Os levantamentos arqueológicos foram realizados em diferentes etapas de campo, em diferentes períodos do ano, o que permitiu que tivéssemos acesso ao rio e seus ambientes em momentos variados de seu ciclo anual, onde as alterações climáticas configuram paisagens bastante diversificadas. Em junho- 
julho, os rios estão no ápice de sua cheia, período em que as várzeas estão submersas. A partir daí inicia-se sua vazante e, em dezembro, essas áreas de menor altitude são ocupadas pelo plantio e criação de gado. Na cheia, esses locais ficam novamente submersos e são abandonados. A distribuição dos vestígios arqueológicos indica que, no passado, essas áreas foram também ocupadas pelos grupos indígenas, no mesmo ritmo.

A cobertura vegetal da região pesquisada também apresenta variações de acordo com os diferentes ecossistemas nela manifestados. Em áreas com solos arenosos, que dão condições para a formação dos rios de água preta, cresce uma vegetação arbustiva, denominada campinarana. Nesses locais, têm-se identificado afloramentos rochosos associados a sítios arqueológicos précerâmicos, característicos das ocupações humanas mais antigas da região, que remontam até 8000 anos A.P. (Costa, 2003). Tais áreas contrastam com a vegetação típica da terra firme amazônica, composta por árvores de grande porte, com copas altas, como as castanheiras (Bertholetia excelsa) e seringueiras (Hevea brasiliensis). Já os sítios arqueológicos do período pré-colonial tardio, compostos pelas terras pretas antrópicas, quando não cultivadas são rapidamente recobertas pelas capoeiras, vegetações densas, de médio porte. Nessas áreas, é comum a concentração de palmeiras com frutos comestíveis como açaís (Euterpe oleracea), pupunhas (Bactris gasipaes) e bacabas (Oenocarpus patua). Essas concentrações em áreas habitadas no passado sugerem certo grau de manejo da floresta, que foi chamada por alguns autores de floresta antrópica (Denevan, 1996; Balée, 1994).

O clima tropical chuvoso e úmido da região caracteriza-se por elevadas temperaturas durante $\mathrm{O}$ ano todo (média anual de $27,1^{\circ} \mathrm{C}$ ). Já o regime das águas se divide em duas estações: o inverno, que tem início no mês de dezembro, caracterizado por um alto índice pluviométrico, e o verão, quando as chuvas escasseiam e o nível dos rios, que atinge seu ápice em junho, começa a diminuir. As atividades das populações ribeirinhas atuais acompanham esse regime climático. Pode-se inferir que este ritmo determinava também os modos de vida das populações que habitaram essas áreas no passado. De fato, uma alta porcentagem de sítios arqueológicos está situada em áreas habitadas. São locais em geral compostos pelas Terras Pretas de Índio, conhecidos pela sua alta fertilidade. Assim, longe de constituir um vasto espaço inabitado, a Amazônia foi 
alvo de intensa ocupação ao longo de muitos séculos. Do mesmo modo, os registros dessas ocupações, aparentemente imperceptíveis, fazem parte ativa da vida das populações que agora ocupam a região, como no caso das TPI.

Hoje, ao longo do Amazonas, as áreas de menor altitude são ocupadas periodicamente durante as épocas de vazante, seja pelo plantio de sementes com crescimento rápido, como o milho, feijão e amendoim, seja pela criação de gado. $\mathrm{Na}$ cheia, esses locais ficam submersos e são abandonados (Sternberg, 1998). A distribuição dos vestígios arqueológicos indica que, no passado, essas mesmas áreas foram também ocupadas por grupos indígenas. A reutilização dos mesmos locais ao longo do tempo sugere que os critérios de assentamento não mudaram de forma drástica a partir do período pré-colonial. Estes se situam, na maior parte das vezes, em locais não inundáveis, mas próximos aos cursos d’água, e corroboram o modelo de uso do espaço proposto por Denevan, o bluff model, que pressupõe interações sociais e ecológicas entre ambientes de várzea e de terra firme (1996, p. 661).

O potencial arqueológico da região, atestado pelos mais de cem sítios arqueológicos identificados pela equipe do PAC, pode ser atribuído à confluência de dois grandes rios, como são o Negro e o Solimões. Com efeito, na região pesquisada a ocorrência de sítios grandes e com alta densidade de vestígios está limitada às confluências dos grandes rios com o Amazonas, assim como, por exemplo, o Madeira e o Tapajós. Os levantamentos arqueológicos realizados nos altos cursos do Solimões, bem como do Negro (Neves, 1998; Valle \& Costa, 2008) vêm reforçar este argumento.

Também a região denominada por baixo (ou médio) Amazonas, que tem seu início após a confluência do Negro e do Solimões, engloba ecossistemas diferenciados. Os quase novecentos quilômetros percorridos ao longo do rio Amazonas, seus afluentes e meandros, revelam uma enorme variabilidade de ambientes. Quanto ao relevo, além do já discutido contraste entre a várzea e terra firme, esta região do baixo Amazonas se divide em duas principais áreas. Nas proximidades de Manaus e Itacoatiara, o relevo de planície é plano ou levemente ondulado. Já nas proximidades de Parintins e da desembocadura do rio Nhamundá, ele se torna mais escarpado, com altas terras firmes.

Além disso, os afluentes das duas margens do Amazonas apresentam sensíveis diferenças. Aqueles da margem esquerda, como o Urubu, Jatapu, 
Uatumã e Nhamundá, são originários do escudo das Guianas e apresentam as características dos chamados rios de águas claras: águas cristalinas e solos arenosos. Já os afluentes da margem direita como são, o Madeira, o Paraná do Ramos e o rio Andirá, apresentam as características de rios de águas brancas, com as extensas várzeas características da planície amazônica, periodicamente inundadas (Beltrão, s/d, p. 241-242). 


\section{Capítulo IV \\ SÍTIOS ARQUEOLÓGICOS DA AMAZÔNIA CENTRAL}

"O que o campo uniu, os livros não separam"

(Juan Luis Arsuaga, 2005, p. 24)

\section{I. Seleção do objeto}

A partir dos problemas de pesquisa anteriormente explicitados, foram selecionados dez sítios arqueológicos para estudo. Os critérios foram os seguintes:

1) distribuição regional - os sítios arqueológicos estudados representam uma boa amostra regional, abrangendo tanto as margens dos rios Negro e Solimões, como a área de interflúvio. Desta forma, objetivou-se detectar os padrões de variabilidade em sítios pertencentes a diferentes nichos geográficos, dando luz às interpretações sobre seus usos e funções. Além disso, a partir do trabalho em tais sítios, pôde-se ter uma idéia da variabilidade regional da Tradição Borda Incisa dentro de uma ampla área da Amazônia.

2) crono-estratigráfico - os sítios arqueológicos apresentam níveis de ocupação supostamente relacionados às fases Açutuba, Manacapuru e Paredão na Amazônia central. Foram abordados contextos uni e multicomponenciais, associados ou não com as Terras Pretas. Esses diferentes contextos permitiram o estabelecimento de comparações intra-sítio e regionais. Vale lembrar que as associações dos contextos estudados às fases cerâmicas não são dadas a priori: elas são hipotéticas. O objetivo da pesquisa foi justamente melhor defini-las e relacioná-las dentro dos diferentes contextos estratigráficos e espaciais. 
Parte dos sítios abordados neste trabalho já foi alvo de pesquisas sistemáticas pelo PAC, com trabalhos de campo e de laboratório, e já produziram cronologias de ocupação (Abreu, 2000; Donnati, 2003; Machado, 2005; Moraes, 2007; Portocarrero, 2006; Rebellato, 2007). Nestes casos, utilizei-me dos dados secundários como complemento das análises e como base para inferências visando a generalizações. Outros sítios arqueológicos foram analisados unicamente no âmbito deste doutorado, sendo sua cronologia ainda inédita. Espera-se que, com o andamento das pesquisas relacionadas ao PAC, novos dados e contribuições sejam agregadas às informações ora em exposição.

Ao apresentar os diferentes sítios arqueológicos, e as atividades desenvolvidas em cada um deles, procurei também lançar mão das interpretações acerca dos mesmos, seja no âmbito cronológico, seja em relação a outros aspectos relacionais, na medida em que os dados foram permitindo ou sendo delineados. A tabela abaixo apresenta as ocupações hipoteticamente representadas nos sítios estudados, que foram abordados com maior ou menor intensidade, e o mapa a seguir indica a localização dos mesmos.

\begin{tabular}{|l|l|l|l|}
\hline \begin{tabular}{|l|l|} 
Sítios/ \\
Ocupações hipotéticas
\end{tabular} & $\begin{array}{c}\text { Fase } \\
\text { Açutuba }\end{array}$ & $\begin{array}{c}\text { Fase } \\
\text { Manacapuru }\end{array}$ & $\begin{array}{c}\text { Fase } \\
\text { Paredão }\end{array}$ \\
\hline Açutuba & & & \\
\hline Cachoeira & & & \\
\hline Paricatuba & & \\
\hline NSP Socorro & & \\
\hline Hatahara & & \\
\hline Jacuruxi & & \\
\hline Lago Grande & \\
\hline Osvaldo & \\
\hline Nova Cidade & \\
\hline
\end{tabular}

Tabela 3 - Sítios cerâmicos estudados e as fases a eles correlacionadas, da Tradição Borda Incisa. 


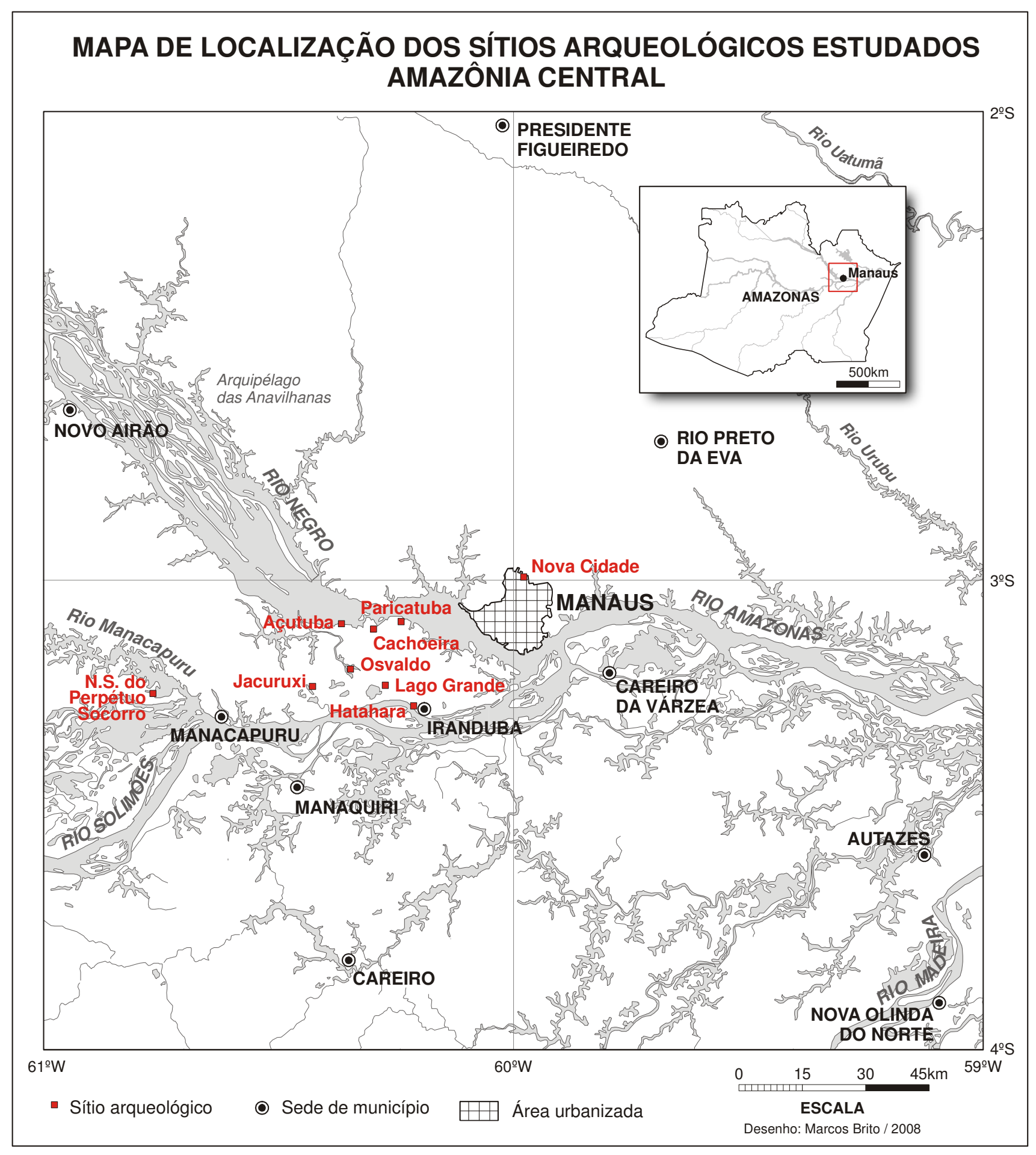

Figura 14 - Sítios arqueológicos estudados, situados na área de confluência dos rios Negro e Solimões. 


\section{II. Metodologia - procedimentos em campo}

Os sítios pesquisados resultam de levantamentos realizados no âmbito do Projeto Amazônia Central, bem como de outros projetos de resgate arqueológico 4 . Como se poderá ver, nesta pesquisa, as prospecções tiveram um papel diferenciado. Ao invés de ter a função de identificar os sítios que seriam mais tarde pesquisados, como em geral acontece, elas vieram a complementar os estudos nos sítios arqueológicos previamente conhecidos da Amazônia central. Sítios-chave como Açutuba e Hatahara, por exemplo, são conhecidos e vêm sendo pesquisados há mais de dez anos. Por esta razão, deixo os levantamentos para o próximo capítulo, que trata de sua relevante contribuição para a asserção de vários aspectos interpretativos.

Os trabalhos de campo desenvolvidos nos sítios arqueológicos pesquisados tiveram diferentes níveis de abordagem, variando de acordo com os problemas e perguntas, gerais ou pontuais, colocadas frente ao registro, mas seguiram, sempre, a mesma orientação metodológica empregada na área do PAC. Trata-se de uma metodologia adequada tanto a sítios com grandes dimensões quanto a sítios em áreas de floresta, típicos da Amazônia. Através dos trabalhos de campo, objetivou-se estabelecer o tamanho, densidade e duração de ocupação dos sítios arqueológicos na região. Portanto, a delimitação e escavação dos sítios arqueológicos identificados são atividades necessárias para que se compreenda, por exemplo, a seqüência e cronologia de ocupação da região, problemas básicos desta pesquisa. As intervenções são orientadas a partir de algumas etapas básicas: 1) estabelecimento do grid; 2) topografia; 3) verificação de vestígios em superfície; 4) delimitação do sítio através de linhas de tradagens e 5) escavações.

A malha, ou grid, irá nortear todas as demais intervenções realizadas no sítio arqueológico. Trata-se de um sistema cartesiano de coordenadas (eixos $\mathrm{X} e$ $\mathrm{Y}$ num plano bidimensional, e $\mathrm{Z}$ representando a profundidade), georreferenciado através de uma amarração entre determinados pontos desta malha a suas coordenadas geográficas (leste e norte). Inicia-se com o arbítrio de um ponto nomeado N1000E1000, ou seja, mil metros a norte e mil metros a leste de um

\footnotetext{
${ }^{4}$ Os resgates cujos sítios arqueológicos foram diretamente incorporados à pesquisa foram o já mencionado Gasoduto Coari-Manaus, e o "Resgate emergencial do sítio Nova Cidade" (Neves e Costa, 2001; Neves et al., 2004a).
} 
ponto zero, também arbitrário. Desta forma, para qualquer direção em que se estenda a área do sítio arqueológico, as chances de cair em coordenadas negativas (crescendo na direção sul ou oeste) serão pequenas. Uma vez determinado este ponto, cada metro quadrado do sítio terá um "nome", ou seja, uma coordenada $\mathrm{N}$ e $\mathrm{E}^{5}$, e, a partir daí, podem ser estabelecidas linhas em todas as direções. Geralmente elas formam dois eixos ortogonais, norte-sul e lesteoeste, levando sempre em consideração o relevo local. Essas linhas podem ser marcadas apenas com trena e bússola, ou com o auxílio de uma estação total. Concomitantemente a esta etapa e à delimitação são realizados mapas topográficos digitais, como aqueles apresentados. Estes mapas são de enorme importância quando se está estudando a configuração espacial de um sítio arqueológico.

Para a delimitação dos sítios arqueológicos que, em muitos casos, apresentam materiais em superfície, leva-se em conta também a presença de vestígios e de terra preta em sub-superfície. Esta etapa é feita geralmente através de tradagens, realizadas com instrumentos do tipo boca de lobo ou trado manual, com copo de $20 \mathrm{~cm}$ de diâmetro, e atingem uma profundidade máxima de $1 \mathrm{~m}$. São alocadas nas linhas do grid e recebem sua denominação a partir do mesmo, ou seja, com coordenadas $\mathrm{N}$ e E, de acordo com sua localização. Em geral as tradagens têm espaçamento regular de $25 \mathrm{~m}$, mas podem variar de acordo com as condições contextuais do local. Cada perfuração é fotografada, e as informações, como a quantidade de fragmentos cerâmicos e a coloração e textura do solo a cada $20 \mathrm{~cm}$ de profundidade, são registrados em fichas. Todo o material arqueológico e de amostras de sedimento são coletados.

Este procedimento garante uma intervenção rápida e de baixo impacto, e é extremamente útil na avaliação da profundidade, variabilidade e densidade dos vestígios enterrados (Neves, 2000). A partir dos dados gerados pelas tradagens, definem-se as intervenções subseqüentes no sítio arqueológico, como as escavações de unidades de um ou mais metros quadrados.

Essas unidades consistem em áreas de $1 \mathrm{~m}^{2}$ com registro autônomo, que podem ser escavadas sozinhas ou em conjunto com outras unidades contíguas,

\footnotetext{
${ }^{5}$ Em alguns sítios arqueológicos, como Hatahara e Osvaldo, o sistema de coordenadas foi orientado a partir de outras direções, por exemplo, S (sul) e W (oeste), mas seguindo o mesmo princípio cartesiano, tal como descrito.
} 
formando trincheiras ou áreas amplas. Assim como com as tradagens, elas são nomeadas de acordo com o grid do sítio, tendo como referência seu vértice N/E. Do mesmo modo, todo o controle da escavação no interior da unidade também é feito de acordo com um plano cartesiano tridimensional (eixos $X, Y$ e Z ), para que se tenha uma referência espacial apropriada do material em sub-superfície.

As informações são controladas e registradas a partir de níveis artificiais de $10 \mathrm{~cm}$, que são escavados com o auxílio de colheres de pedreiro, nos níveis antrópicos, e ferramentas do tipo "ferro de cova", nos substratos arqueologicamente estéreis. O solo escavado é peneirado por completo. $\mathrm{Na}$ maioria das vezes, essas profundidades referem-se a um ponto "zero" marcado junto à superfície da unidade e são medidas com um nível de bolha. Este ponto zero é depois adicionado à malha e à topografia do sítio, através de instrumentos de leitura topográfica, como uma estação total ou um nível.

Os materiais evidenciados durante a escavação - cerâmicas, líticos, carvões, vestígios ósseos, amostras de solo - são todos recolhidos. A coleta pode ser feita de acordo com dois procedimentos básicos: num primeiro caso, o conjunto de materiais escavados dentro de um mesmo nível de $10 \mathrm{~cm}$, seja na escavação ou na peneira, recebem uma mesma identificação. Em outros casos, a localização e profundidade exatas de um vestígio específico são registradas, sendo este coletado separadamente com um registro próprio, que inclui sua plotagem numa ficha. Cabe ao arqueólogo, em campo, a decisão de selecionar ou não um determinado vestígio para coletas individuais.

Todos os vestígios, de qualquer natureza, retirados do sítio arqueológico, recebem um número de proveniência $(\mathrm{PN})$, e é através deste número que se controla, com exatidão, sua procedência. Um PN pode ser atribuído a uma peça individual ou a um conjunto de peças, dentro, por exemplo, de um nível artificial numa unidade de escavação. Cada PN atribuído é discriminado em uma ficha. Também se registra, em fichas específicas, as informações referentes a um nível de $10 \mathrm{~cm}$, tais como cor e textura do solo, observadas através da tabela de solos MUNSELL, presença de raízes ou perturbações, assim como a quantidade e características dos vestígios encontrados. Durante o preenchimento das fichas, especial atenção é dada aos elementos contextuais e interpretativos, observados durante a escavação. 
São realizadas também coletas de materiais apropriados para determinados tipos de análises. Por exemplo, em cada nível artificial de $10 \mathrm{~cm}$ dentro de uma unidade de $1 \mathrm{~m}^{2}$, uma amostra de $10 \mathrm{~cm}^{3}$ é coletada separadamente. É o que chamamos de AVC: Amostra de Volume Constante. É deste local que se seleciona solo para análises paleobotânicas, por exemplo. Já para as análises micromorfológicas, o procedimento de coleta é outro. Nestes casos, as amostras de solo são coletadas diretamente dos perfis estratigráficos, e toda atenção é prestada para que se mantenha a estrutura original do solo. Através dos dados fornecidos por tais análises, pode-se obter um quadro muito mais preciso dos processos de formação dos sítios arqueológicos.

Os procedimentos básicos podem ser modificados na medida em que os contextos trabalhados indiquem tal necessidade. Isto ocorre, às vezes, quando se está operando com feições ou estruturas arqueológicas específicas, como, por exemplo, fogueiras, buracos de esteio, silos, ou lixeiras. Nestes casos, onde os vestígios encontram-se estruturados de modo a sugerir funcionalidades, elas passam a ser tratadas - escavadas e registradas - enquanto um conjunto. Assim, materiais coletados do interior ou entorno recebem PNs e registros específicos. Nestes casos, em geral, o cuidado com desenhos, croquis e fotografias, é reforçado.

A flexibilidade das orientações metodológicas do PAC permitiu, sempre, uma melhor adequação dos procedimentos adotados em campo dentro de um escopo prévio que vem, basicamente, responder questões concernentes ao estabelecimento do tamanho, forma e duração de ocupação nos sítios arqueológicos (Neves, 2000).

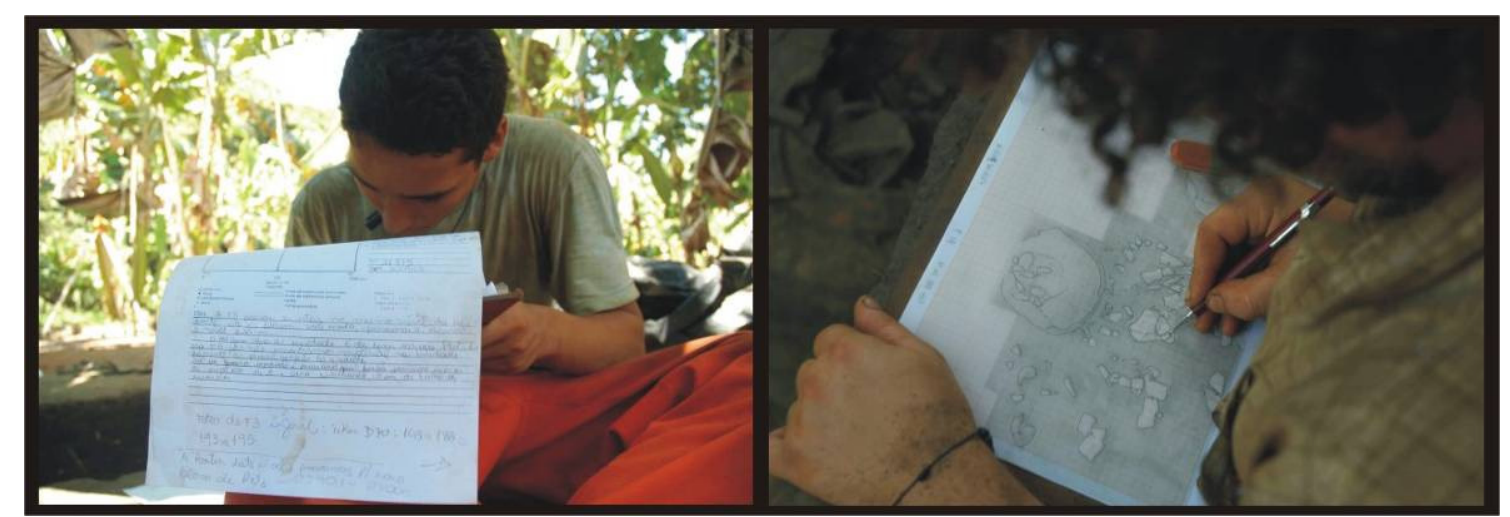

Figura 15 - Procedimentos de registro em campo: preenchimento de fichas e desenho de croquis (fotos: Val Moraes). 


\section{III. Sítios Arqueológicos do Baixo Rio Negro \\ IV. III. I. Complexo Açutuba (Am-Ir-02)}

O chamado complexo Açutuba é um sítio arqueológico que se estende por aproximadamente $3 \mathrm{~km}$ ao longo da margem direta do baixo rio Negro, cerca de $40 \mathrm{~km}$ a montante de sua foz, ocupando o topo e a vertente de um terraço não muito elevado (fig 16). Suas dimensões estimadas são $3000 \times 400 \mathrm{~m}$ e sua profundidade chega a mais de $250 \mathrm{~cm}$. O sítio foi dividido em três setores denominados I, II e III, de acordo com suas características geomorfológicas. Identificado em 1994, este é um dos sítios mais intensamente trabalhados pelo PAC, com etapas de escavações em 1995, 1997, 1999, 2002 e 2004. As escavações permitiram a identificação de contextos arqueológicos intactos, bem como o estabelecimento de uma hipótese sobre sua cronologia de ocupação (Heckenberger et al., 1999; Lima et al., 2006).

Açutuba é um sítio chave em toda a área de pesquisa do PAC devido, em parte, às suas grandes dimensões (cerca de 90 hectares de área), e por ser multicomponencial, com uma seqüência de depósitos que indica a ocorrência de pelo menos quatro ocupações distintas. De fato, a seqüência crono-estratigráfica do sitio Açutuba fornece o parâmetro para a cronologia regional.

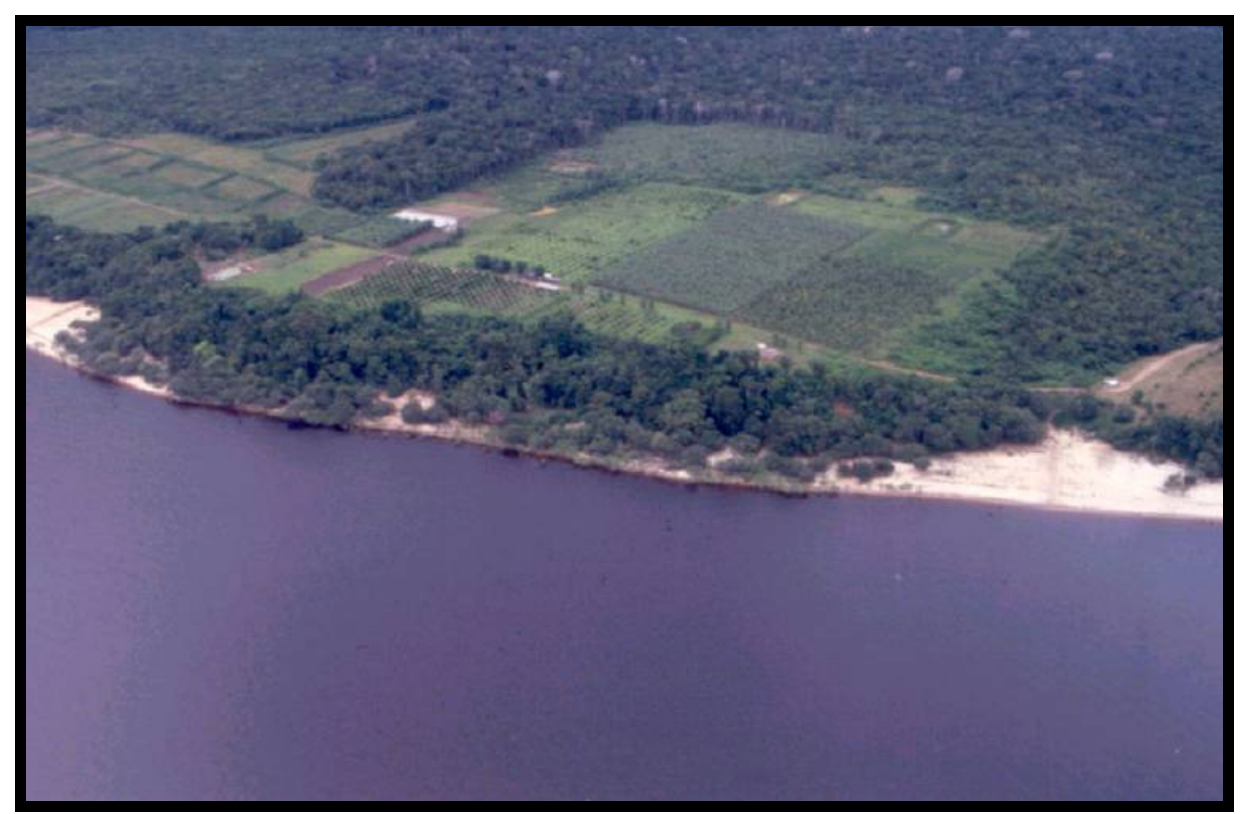

Figura 16 - Vista aérea do sítio Açutuba, no período da cheia do rio Negro. (Foto: Eduardo Neves, 1999). 
As evidências seguras da ocupação mais antiga do sítio, recentemente identificadas, apresentam contextos associados à fase Açutuba, datados em torno de 300 a.C. até o século IV d.C (Lima et al., 2006). Também relacionadas à Tradição Borda Incisa, as cerâmicas da fase Manacapuru se encontram dispersas pelos setores I e II do sítio, e estão datadas entre os séc.VI e IX d.C. No setor I, detectou-se a presença de um complexo funerário associado à fase Paredão e, em 2002, uma série de urnas funerárias foi exposta pelo corte do barranco da estrada que atravessa a parte leste do sítio, indicando tratar-se, possivelmente, de um cemitério. A ocupação mais recente do sítio tem datas entre os séc. IX e XVI d.C, com fragmentos cerâmicos dispersos por uma ampla área, associados à fase Guarita da Tradição Policroma Amazônica. A essa ocupação se associam depósitos sedimentares de TPI, com espessuras que superam $1 \mathrm{~m}$, indicando intensas atividades antrópicas. As datações e a análise dos vestígios em superfície indicam que neste período o sitio foi densamente povoado (Heckenberger et al., 1999).

A distribuição horizontal e vertical de vestígios arqueológicos, associados a diferentes ocupações, indica tratar-se de uma sobreposição de componentes arqueológicos de tamanhos e densidades bem distintos. Isso se dá quando um mesmo local é reocupado diversas vezes, com lacunas temporais entre cada ocupação. Tal processo resultou numa "sobreposição de sítios arqueológicos". Esta observação foi feita por Meggers em outros sítios arqueológicos da Amazônia (Meggers, 1971). Sua argumentação é que tais sobreposições causaram uma falsa percepção, por parte dos arqueólogos, sobre o tamanho dos sítios. Embora correta para as ocupações mais antigas do sítio, a ocupação mais recente, da fase Guarita, se espalha por quase toda a superfície do sítio e parece tratar-se de um único evento. A presença de montículos e valas correlaciona Açutuba a outros sítios das fases Guarita e Paredão, confirmando o padrão de grandes aldeias dispostas ao longo das margens dos rios, conforme proposto no modelo de Lathrap (1970a).

O interesse específico no estudo neste sítio arqueológico visou compreender melhor a ancestralidade e o contexto de deposição das ocupações mais antigas do sítio, associadas às fases Açutuba e Manacapuru, cujas coleções cerâmicas e dados contextuais relacionados foram utilizados como parâmetro comparativo para os demais sítios, e para o estabelecimento das tipologias. Este 
material resultou de diferentes tipos de intervenções arqueológicas, realizadas em diversas áreas do sítio. Foram elas: quatro unidades de $1 \mathrm{~m}^{2}$ denominadas TU20 e T9 (escavadas em 1999), T10 (escavada em 2002), sondagem 2 (escavada em 1995); os materiais provenientes das limpezas de perfil numa área específica de Açutuba II, denominada Reservatório; além dos materiais provenientes das tradagens.

A unidade TU20, escavada em 1999, se localiza na área central do sítio, no setor II, e apresentou cerâmicas associadas à ocupação Manacapuru, entre 35 e $50 \mathrm{~cm}$ de profundidade, depositadas num espesso estrato de Terra Preta (gráfico 1). A este nível se sobrepõem materiais correspondentes à ocupação mais recente do sítio, com cerâmicas Guarita, que sofreram perturbações recentes. Embora as perturbações tenham afetado em parte o componente de nosso interesse, com maiores evidências na parte oeste da unidade, o material cerâmico proveniente dos níveis mais profundos apresentou um contexto relativamente bem preservado, com fragmentos grandes e remontáveis. Isso pode ser observado tanto no perfil quanto na análise das cerâmicas. A análise dos vestígios da unidade TU20 indicou a ocorrência, nos mesmos níveis, de grande quantidade de cerâmicas da fase Manacapuru, alguns fragmentos da fase Guarita e fragmentos associados à fase Paredão, também em pequena quantidade.

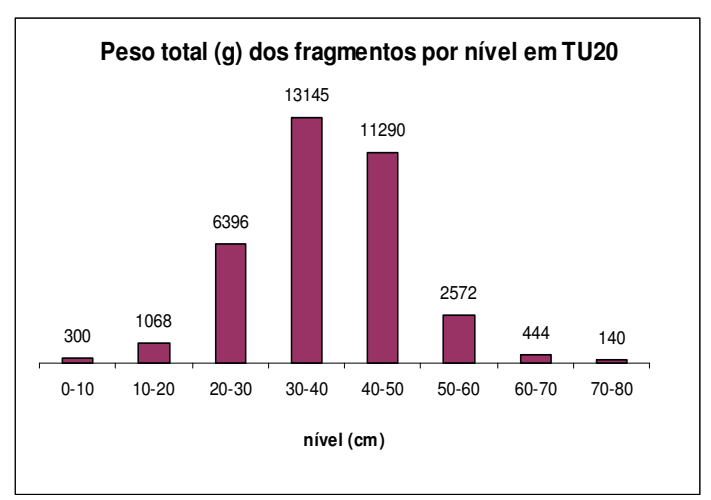

Gráfico 1 - Densidade de fragmentos cerâmicos por nível na unidade TU20 (g).

Já a área onde se localizam as unidades T9 e T10 se apresenta de maneira bastante distinta de TU20. É uma área periférica do sítio, no limite sul de Açutuba II, sem associação com as TPI em nenhum dos níveis. A escavação de T9, realizada em 1999, detectou um nível de ocupação supostamente Manacapuru num contexto bem preservado, bastante profundo, entre 70 e $110 \mathrm{~cm}$ de profundidade, selado por uma espessa camada de solo arenoso estéril. Tratase de um local onde foram abertas covas para o plantio de bananas, e os materiais arqueológicos só eram visíveis na superfície nos pontos onde as covas foram abertas. O objetivo da abertura de T10, realizada em 2002, foi o teste de hipóteses anteriormente apresentadas (Lima, 2003), que se referem à associação entre materiais cerâmicos em diferentes contextos de deposição, procurando 
amostras de carvão que possibilitassem a datação deste contexto específico, bem como aumentar a amostragem de material cerâmico para análise, uma vez que T9 apresentou densidade inferior às outras escavações no sítio.
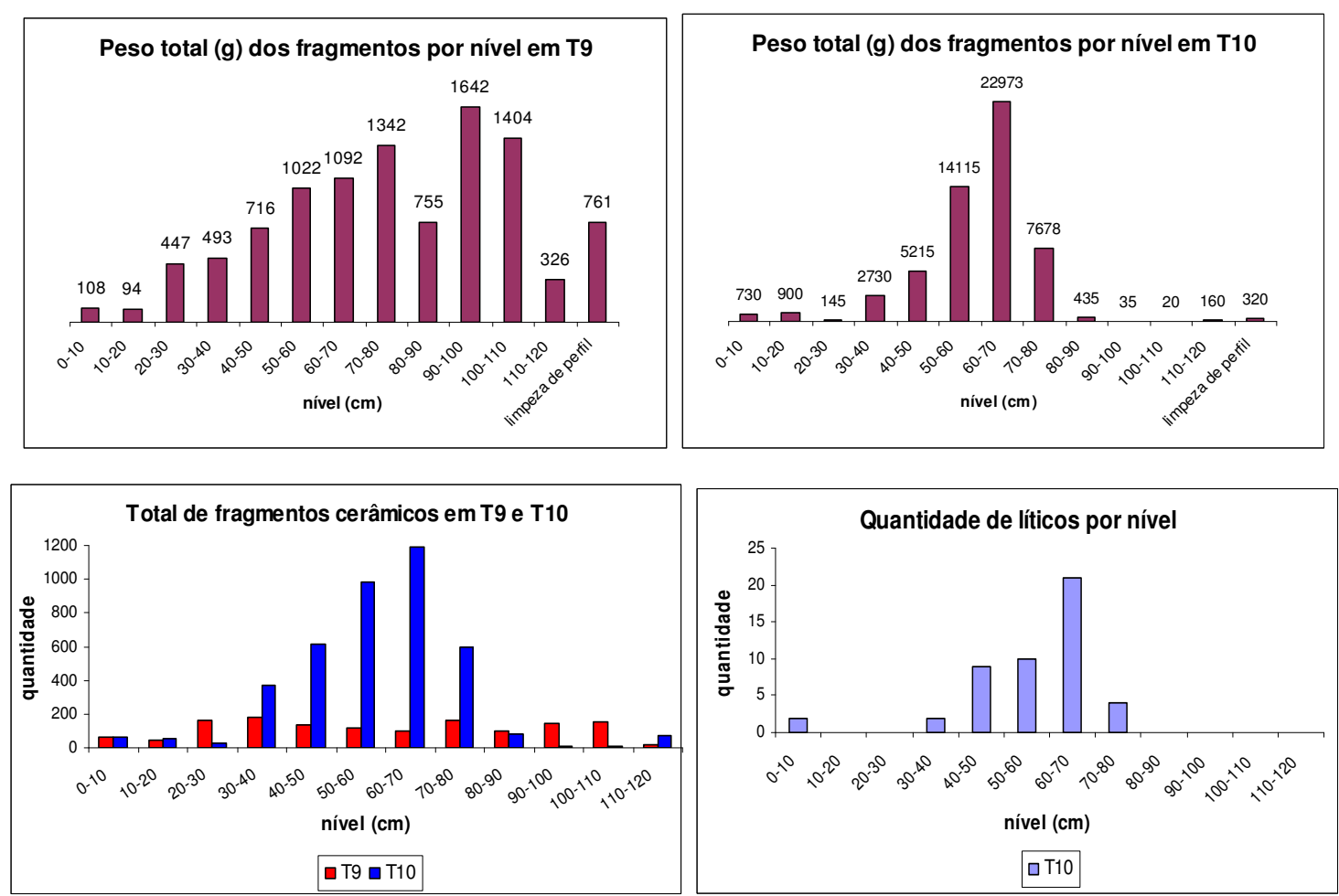

Gráfico 2 - Densidade de fragmentos cerâmicos por nível nas unidades T9 e T10 (g); total comparativo de fragmentos em T9 e T10 (quant.); quantidade de líticos por nível em T10.

Os perfis estratigráficos e as freqüências relativas das cerâmicas demonstraram que as unidades T9 e T10 cortaram partes de uma mesma estrutura, caracterizada por um denso agrupamento de cerâmicas, líticos queimados e lateritas. A unidade T9 interceptou uma de suas margens, enquanto que a escavação de T10 atingiu sua região central. Essa estrutura foi interpretada como uma área de descarte, semelhante àquelas etnograficamente registradas, sempre nas proximidades de unidades domésticas (Silva, 2000) (fig. 17). Suporta esta interpretação a alta densidade de matéria orgânica carbonizada, de cerâmicas, e o baixo índice de remontagens, tanto horizontal como verticalmente, entre materiais dos diferentes níveis estratigráficos. Em sua região central, a estrutura é interceptada por uma feição circular com $30 \mathrm{~cm}$ de diâmetro, composta por sedimento acinzentado pouco compacto, circundado por um anel com $2 \mathrm{~cm}$ de espessura de raízes em decomposição. 
A associação espacial entre a estrutura e a feição é corroborada pela disposição do material arqueológico e pela estratigrafia: ocorrem na mesma profundidade, entre 40 e $70 \mathrm{~cm}$. Já a associação cronológica é incerta. De todo modo, pode tratar-se de um buraco de esteio que, após sua decomposição, concentrou matéria orgânica reocupada por raízes provavelmente de palmeira (observar também as plantas baixas das escavações, na pág. 406, no apêndice desta tese).

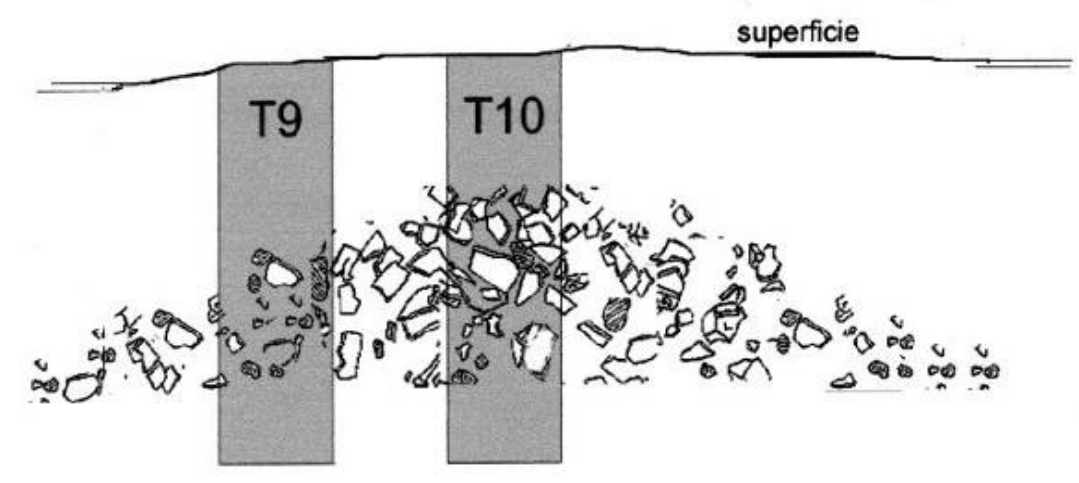

Figura 17 - Hipótese sobre a configuração da estrutura e feição interceptadas por T9 e T10.

Conforme já mencionado, na etapa de campo de 2004 foi estabelecida uma malha de tradagens, sobre a qual se realizou um total de 17 intervenções, com 25 $\mathrm{m}$ de espaçamento entre elas. As linhas de tradagem foram traçadas com a estação total em quatro direções a partir de T9 e T10, nos sentidos norte-sul e leste-oeste. A partir dessas séries principais, outras linhas perpendiculares a elas foram traçadas (ver mapa). As tradagens indicaram a continuidade da ocupação relacionada à fase Açutuba, ao longo de uma área de pelo menos $300 \mathrm{~m}$ a partir do local onde foram inicialmente identificadas.

Os resultados em termos de densidade e profundidade do depósito não foram muito satisfatórios, por tratar-se de um componente arqueológico pouco denso e profundo, em alguns pontos com profundidade maior do que o alcance máximo do trado, que é de um metro. Esta área do sítio apresenta solo arenoso com grande ocorrência de concreções lateríticas (piçarras), o que também dificultou a realização das tradagens. 
A tabela ao lado indica aquelas que forneceram fragmentos cerâmicos, e suas respectivas profundidades. Notar que a maior parte dos vestígios arqueológicos ocorre entre 40 e $60 \mathrm{~cm}$, mas podem alcançar até um metro de profundidade.

Já os trabalhos de escavação e limpeza dos perfis realizados no Reservatório, em Açutuba IIB, forneceram uma grande quantidade de dados para a caracterização estratigráfica e espacial da fase Açutuba, incluindo algumas de suas estruturas e feições. Um total de onze unidades de $1 \mathrm{~m}^{2}$ foi escavado junto aos quatro

\begin{tabular}{|l|l|l||}
\hline TRADAGEM & NÍVEL & \# FRAGS. \\
\hline T10-1 & $0-20 \mathrm{~cm}$ & 1 \\
\hline T10-3 & $40-60 \mathrm{~cm}$ & 6 \\
\hline T10-4 & $40-60 \mathrm{~cm}$ & 3 \\
\hline T11-3 & $40-60 \mathrm{~cm}$ & 2 \\
\hline T11-3 & $60-80 \mathrm{~cm}$ & 2 \\
\hline T11-4 & $40-60 \mathrm{~cm}$ & 1 \\
\hline T11-5 & $0-20 \mathrm{~cm}$ & 13 \\
\hline T12-3 & $80-100 \mathrm{~cm}$ & 5 \\
\hline T12-5 & $0-20 \mathrm{~cm}$ & 2 \\
\hline T12-5 & $20-40 \mathrm{~cm}$ & 1 \\
\hline
\end{tabular}

Tabela 4 - Quantidade de fragmentos cerâmicos por nível recolhidos nas tradagens. perfis, sendo quatro metros no perfil Norte, três no perfil Sul e dois metros nos perfis Leste e Oeste. Os perfis $\mathrm{N}$ e $\mathrm{S}$ foram os mais informativos, por isso maiores esforços foram concentrados nessas áreas.

O Reservatório tem dimensões de 22 × 16 metros, e $2 \mathrm{~m}$ de profundidade. A distância das unidades T9-T10 é de aproximadamente $300 \mathrm{~m}$, no sentido noroeste. A proximidade e eqüidade dos vestígios arqueológicos demonstraram tratar-se de uma continuação da mesma ocupação, o que foi corroborado também pelas tradagens. Contudo, a interpretação da estratigrafia dos perfis do Reservatório é mais complexa, pois tivemos acesso a áreas que aparentavam possuir diferentes funções dentro de um mesmo nível de ocupação, e por ocorrer também outros conjuntos sobrepostos de artefatos.

Pelas razões supracitadas, estudos sobre forma e padrão de assentamentos relacionados ao componente Açutuba, neste sítio, ficaram comprometidos. Ainda assim, identificou-se, por hipótese, duas unidades habitacionais (através de suas áreas de descarte), uma delas em T9 e T10 e a segunda na parede sul do Reservatório. Entre elas, interceptou-se uma área com baixa densidade ou ausência de refugos (linhas T11 e T12). Inferências a partir destes dados seriam precipitadas, mas eles podem servir como ponto de partida para estudos futuros, com foco na organização espacial Açutuba neste sítio.

A metodologia de abordagem sobre os perfis foi anteriormente detalhada. Vale lembrar que um mesmo datum foi considerado para todas as unidades de escavação. Foi alocado, no início, no canto NE, mais alto, acima da camada VI, 
composta por um aterro recente feito quando da construção do reservatório, em 2003. Assim, as profundidades indicadas nas descrições dos perfis deverão ser tomadas a partir dos croquis. A interpretação dos perfis considerou as correlações internas entre as camadas, e também entre camadas de outras áreas escavadas do sítio. Definimos seis camadas, sendo que algumas delas não ocorrem em todas as faces. Apresento a seguir a descrição das camadas e as interpretações dos perfis e feições.

\section{Interpretação da Seqüência Estratigráfica dos Perfis}

Perfil Sul (unidades 8 a $11 \mathrm{~m}$ )

Dentre os quatro perfis escavados, a configuração do Perfil Sul se apresentou mais semelhante às unidades T9 e T10. Esta é também a área mais próxima. As três unidades (8 a $11 \mathrm{~m}$ ) escavadas no Perfil Sul evidenciaram um piso de ocupação da fase Açutuba na camada III, composto por grande concentração de cerâmicas, lateritas e líticos. A espessura do nível de ocupação é de $40 \mathrm{~cm}$, e ocorre entre 150 e $190 \mathrm{~cm}$ de profundidade. A partir deste nível, a quantidade de fragmentos diminui bastante, com apenas dois ou três fragmentos por nível. A partir de aproximadamente $210 \mathrm{~cm}$, a densidade de fragmentos cerâmicos aumenta um pouco, e estes seguem aparecendo até $240 \mathrm{~cm}$, quando o solo se torna estéril (gráfico 3). Estes materiais mais profundos apresentaram características um tanto distintas daqueles da fase Açutuba. Seria um mesmo contexto? A matriz arenosa do sítio arqueológico, associada à alta incidência de bioturbações, gerou certa dificuldade de associação destes materiais mais profundos a um contexto seguro, passível de uma caracterização mais precisa. Um conjunto similar, proveniente de outra área do sítio, forneceu uma data antiga, maior do que até então obtida para Açutuba ou para a área de

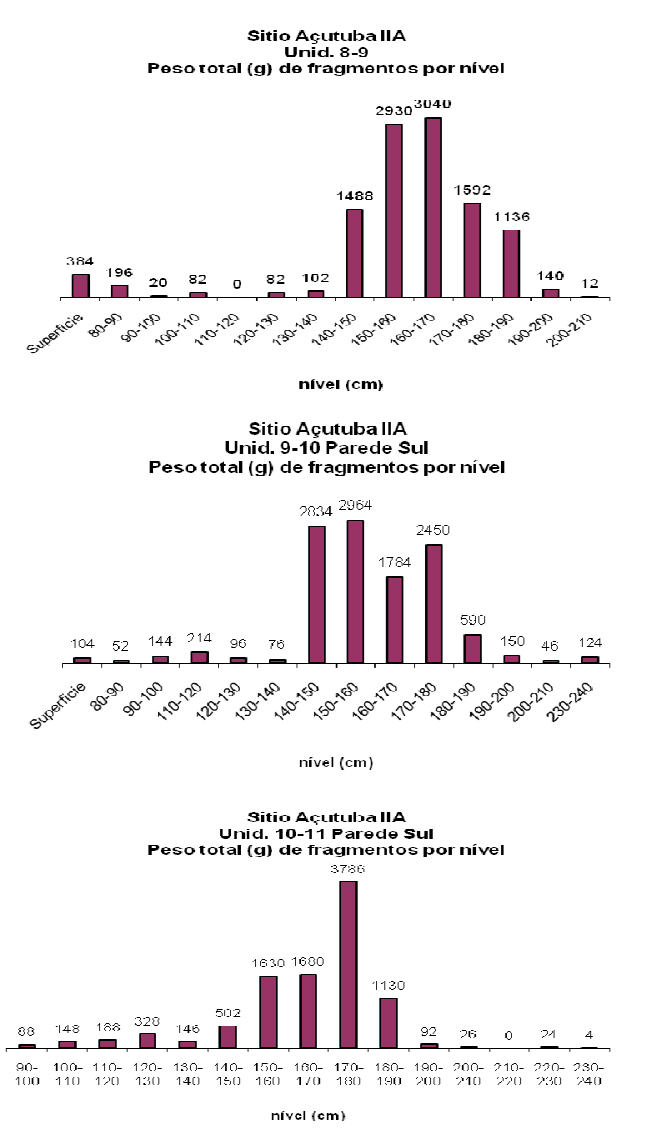

Gráfico 3 - Quantificação do material coletado no reservatório, perfil S. 
pesquisa, que levantou interessantes questões cronológicas, que serão abordadas adiante.

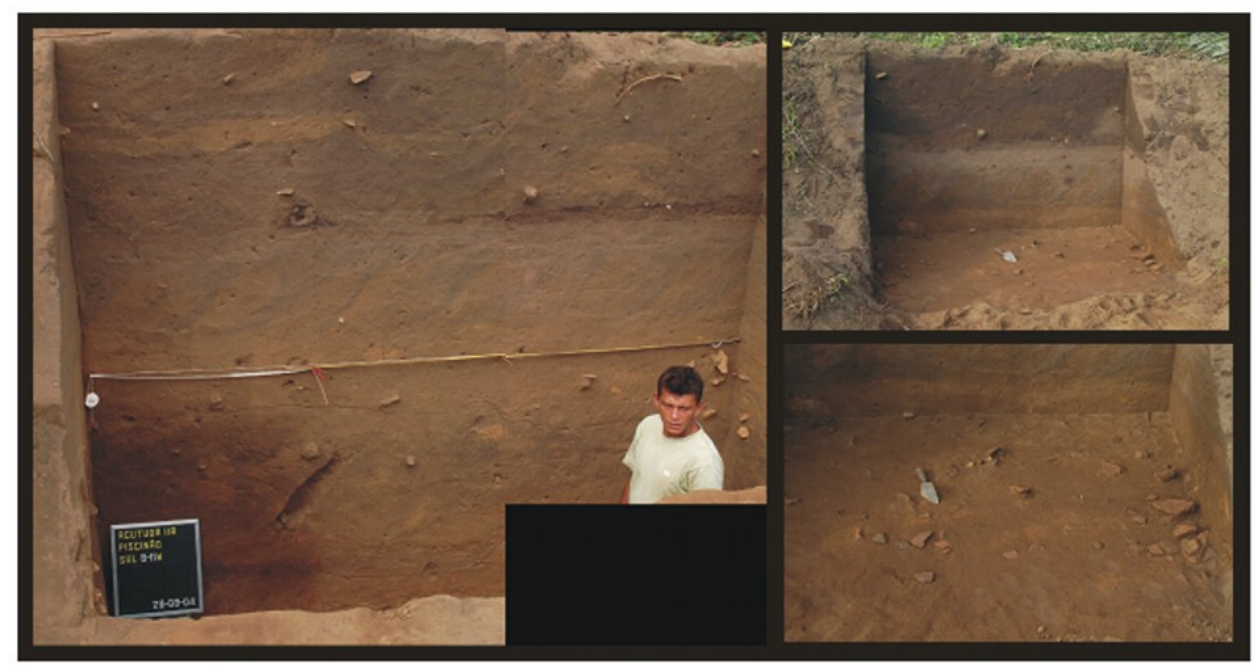

Figura 18 - Reservatório perfil Sul, unidades 9 a 11. Final da escavação, exposição do nível de ocupação associado à fase Açutuba (fotos: Helena Lima).

\section{Perfil Norte (unidades 4 a $8 \mathrm{~m}$ )}

Este foi o único perfil que apresentou uma camada de terra preta (cam. IV), e alguns fragmentos cerâmicos da fase Guarita. É a área mais próxima da margem do rio, e também da ocupação Guarita que ocorre na superfície em parte do setor II do sítio. Conforme foi mencionado, este perfil não apresenta uma estratigrafia completa, pois parte da camada IV (Guarita) foi removida e recoberta pelo aterro que cobre as margens do Reservatório. A camada logo abaixo da terra preta (cam. III) apresentou uma elevada concentração de feições circulares, algumas delas interpretadas como silos e, outras, como buracos de esteio. Sua disposição sugere associação com a ocupação da terra preta, não identificada. Pensamos tratar-se de uma unidade habitacional com maior concentração de matéria orgânica e ação de fogo, que levaria a formação das TPI em áreas restritas. Esta questão será melhor enunciada na interpretação das feições, apresentada a seguir. 

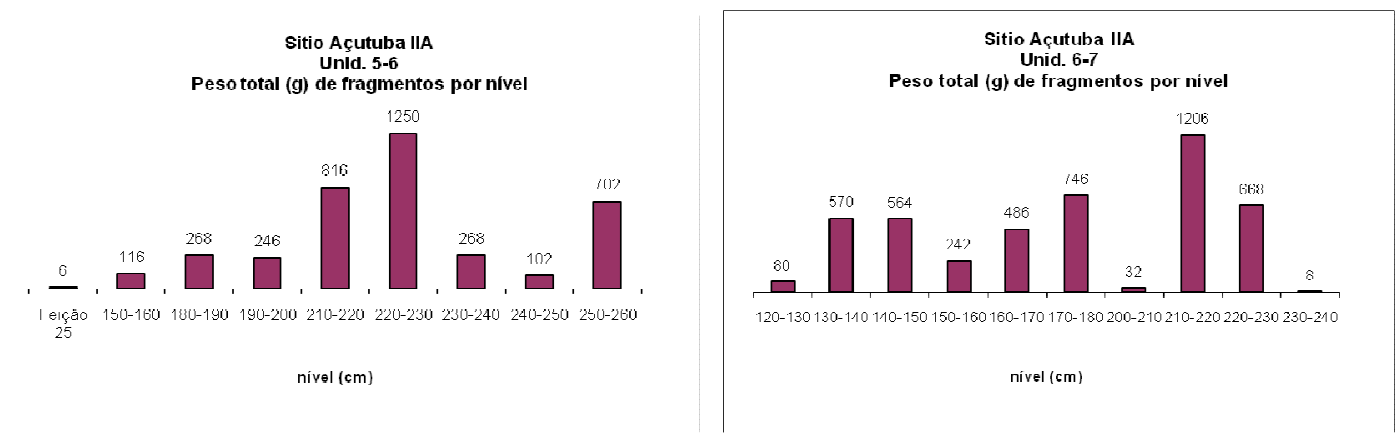

Gráfico 4 - Densidade de fragmentos cerâmicos por nível nas unidades do perfil Norte (g).

Também no perfil Norte, ocorreram vestígios arqueológicos numa profundidade maior do que a associada à fase Açutuba. Neste caso, eles estão associados a um tipo característico de feições (tipo 4, descrito a seguir), que formam uma espécie de bolsões repletos de cerâmicas. Um fragmento proveniente de uma dessas feições, F36, foi datada a partir de seu tempero vegetal. A datação radiocarbônica obtida, 780-410 a. C., condiz com a expectativa para o grupo anteriormente descrito, identificado no perfil Sul, bem como de outra área do sítio arqueológico, esticando ainda mais cronologia de ocupação de Açutuba, levando-a mais alguns séculos para trás.

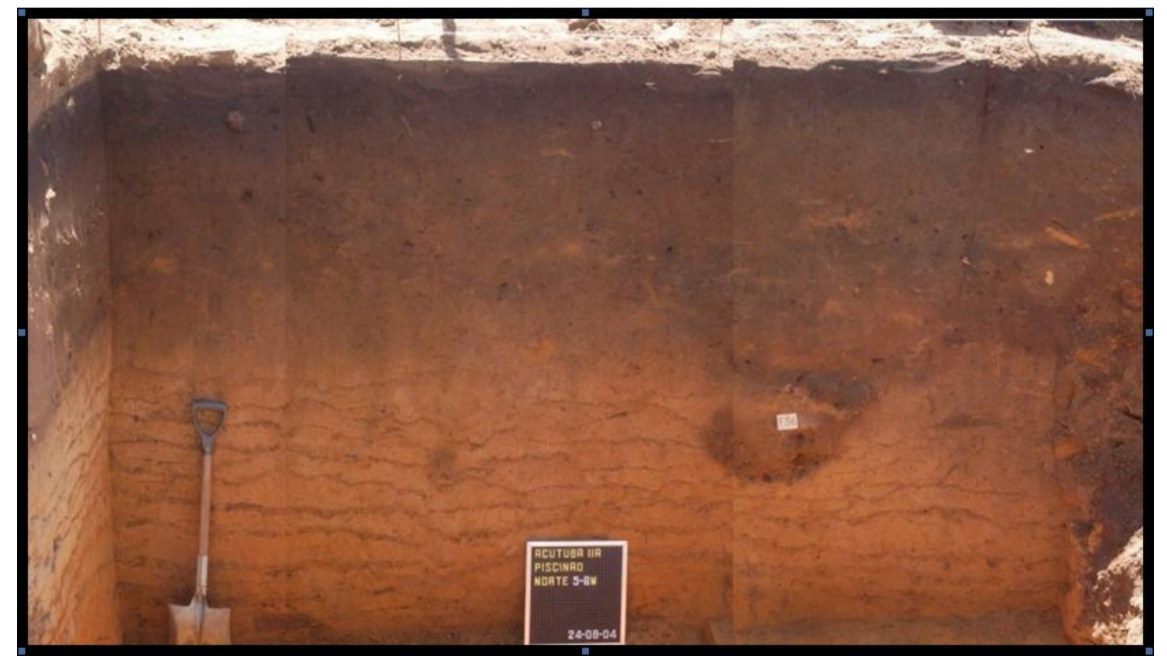

Figura 19 - Reservatório perfil Norte, unidades 4 a 7. Notar a composição da camada 1 e a feição 32 (tipo 4).

\section{Perfis Leste e Oeste (unidades 9 a 11)}

A estratigrafia dos perfis Leste e Oeste é relativamente semelhante. Como se pode ver na representação dos perfis estratigráficos (fig 26), ambos tiveram difícil visualização das camadas, que estavam muito misturadas e perturbadas. 
Em nenhum deles as escavações atingiram a camada I (embasamento). No perfil Leste, a presença de um pacote cultural relacionado às cerâmicas da fase Açutuba foi mais evidente, assim como nos perfis Sul e Norte. Já o perfil Oeste apresentou uma estratigrafia muito perturbada, com densidade de fragmentos menor do que os demais, o que dificultou ainda mais sua interpretação.
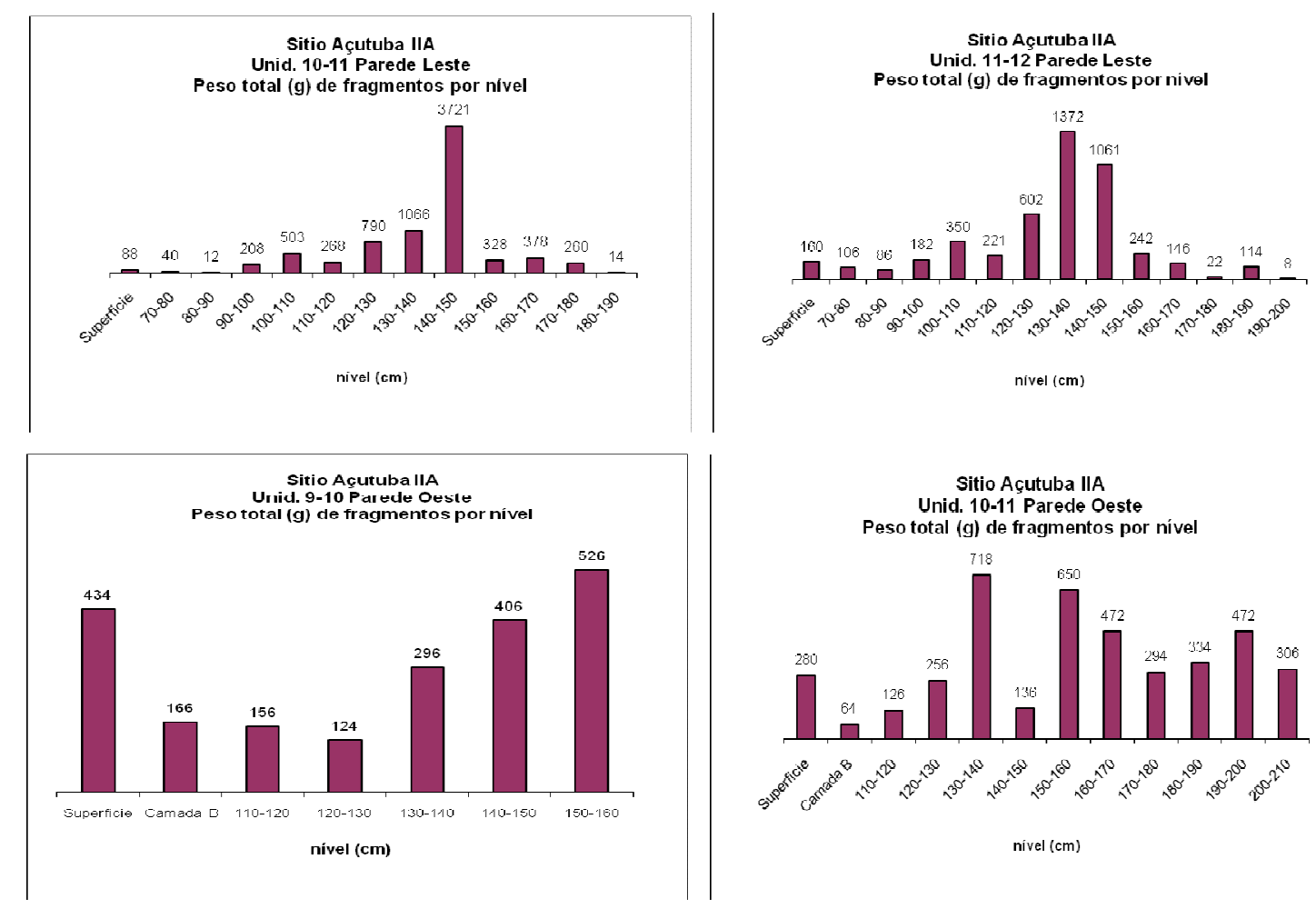

Gráfico 5 - Densidade de fragmentos cerâmicos por nível nas unidades dos perfis Leste e Oeste (g).

\section{As Feições}

A oportunidade de observar perfis com grandes dimensões permitiram a identificação de 20 feições com diferentes composições ao longo das camadas arqueológicas. A tipologia das feições indicou quatro categorias, definidas a partir de suas características e da associação com as camadas de ocupação, permitindo a inferência de diferentes áreas de atividades dentro do sítio. 
Tipo 1

São nove feições caracterizadas por manchas com formato circular, com solos de coloração geralmente mais escura do que a camada na qual se inserem, pouco compactos, com grande quantidade de carvões, raízes, em alguns casos sementes carbonizadas em seu interior. Ocorrem nas camadas III e IV dos perfis Norte, Sul e Leste (fig 26). Elas são geralmente mais

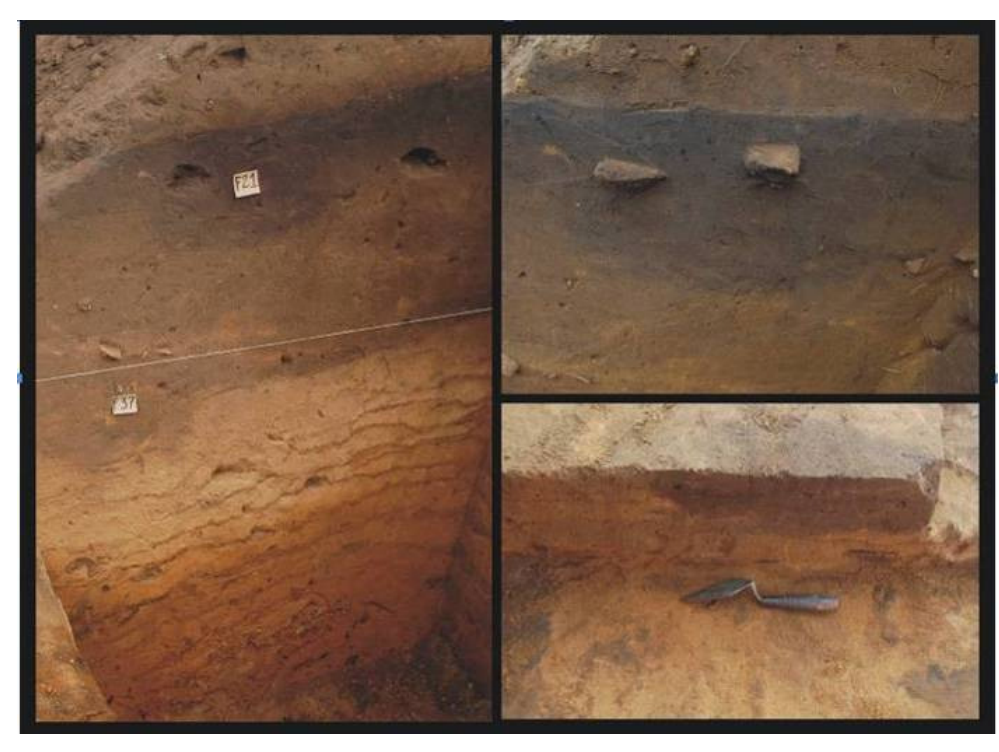

Fig 20 - Reservatório perfil Norte, Feições do tipo 1 (fotos: Holona I ima 2nก⿻1

largas do que profundas, com uma média de $40 \mathrm{~cm}$ de diâmetro por 20 de profundidade. Sua composição e formato sugerem tratar-se de silos para armazenagem de alimentos. Silos como estes, utilizados para armazenamento de farinha de mandioca, foram reportados etnograficamente entre grupos do Alto Xingu, por exemplo (Heckenberger, 2002, p. 37). Essa hipótese poderá ser corroborada ou não pelas análises micromorfológicas e paleobotânicas das amostras de solo coletadas.

\section{Tipo 2}

Trata-se de 4 buracos de esteio, com média de $15 \mathrm{~cm}$ de diâmetro por $30 \mathrm{a}$ $50 \mathrm{~cm}$ de profundidade, dispostos linearmente e eqüidistantes (1,1 m entre eles). Podem estar relacionados a uma unidade habitacional, por suposição localizada na camada IV do perfil Norte, já que ocorrem imediatamente abaixo, na estratigrafia, da camada de terra preta (cam. V). Dois outros fatores que reforçam a hipótese de associação com uma habitação são: o fato de ser esta a única área escavada que apresentou terra preta e a localização próxima dos supostos silos de armazenagem de alimentos. Ainda não é possível assegurar a qual ocupação do sítio esta estrutura se relaciona, mas pode-se afirmar que seja mais recente do que as ocupações Açutuba da área. 


\section{Tipo 3}

O tipo 3, presente apenas na camada III do perfil Sul, apresenta as mesmas características já descritas para as unidades T9 e T10: trata-se de um piso composto por cerâmicas, líticos e lateritas, similar em todos os aspectos à estrutura escavada nas unidades T9 e T10. As semelhanças abarcam os aspectos tecnológicos e tipológicos das cerâmicas, com todas as características da fase Açutuba, e a associação então notada entre cerâmica, lítico queimado e laterita, e também a feição circular (tipo 1, feição 38), que intercepta 0 agrupamento.

Desse modo, parece haver uma associação entre a ocupação da fase Açutuba e esse tipo de estruturas no sítio. As datações, bem como a análise tecnológica das cerâmicas indicam tratar-se de um mesmo evento de ocupação. Aventa-se aqui a hipótese de tais estruturas serem áreas de descarte próximas de unidades habitacionais. As tradagens indicaram uma escassez de vestígios entre as duas áreas, que poderia ser uma espécie de área pública no centro da aldeia.

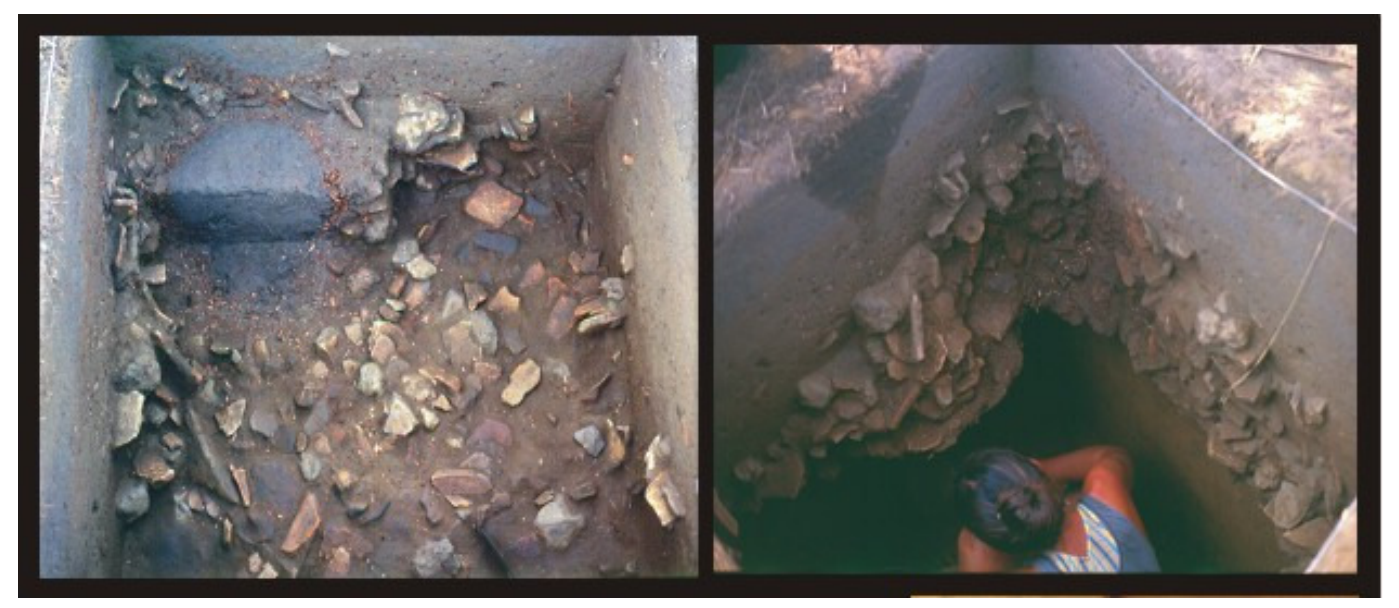

Figura 21 - Reservatório perfil Norte, unidades 4 a 8 . Escavação das feições do tipo 3 (fotos: Eduardo Neves, 2002).

\section{Tipo 4}

As quatro feições deste tipo estão concentradas no perfil Norte, e são bem diferentes das anteriores. Trata-se também de manchas de solo com concentrações cerâmicas, mas com matrizes e preenchimentos característicos. $O$ sedimento do interior das feições tem uma coloração alaranjada e aspecto de cascalho, com pequenos grãos de seixo. Ocorrem nos níveis mais profundos da escavação, mergulhando em alguns casos no estrato estéril (cam. II). As feições 
não apresentaram um formato definido, mas existe uma clara distinção entre elas e a matriz arenosa original.

Embora pouco representadas (foram poucos fragmentos coletados), as cerâmicas provenientes das feições do tipo 4 são diferenciadas. Suas características e a posição estratigráfica levam a inferir uma antigüidade maior desses materiais em relação à própria ocupação Açutuba no sítio.

\section{As lateritas: gênese e uso}

A laterita, ou plintita ${ }^{6}$, é a denominação geral dada aos latossolos ricos em ferro e óxido de alumínio que, quando expostos ao ar, tornam-se endurecidos e impermeáveis, de forma irreversível (Moran, 1994, p. 397, Bigarella, 1996, p. 547). Na Indonésia, este recurso foi utilizado no passado para a construção de templos (Moran, 1994, p. 309). A plintita consiste em um material rico em óxidos, pobre em húmus, com uma mistura de argila alterada, quartzo e outros minerais que se distribuem em manchas vermelhas num conjunto reticulado ou poligonal. Tais concreções estão presentes em grandes áreas das regiões tropicais e subtropicais, sendo favorecidas pelo clima sazonal e pela decomposição de matéria orgânica produzida em grande quantidade, e rapidamente destruída (Bigarella, 1996, p. 547).

As evidências presentes no sítio Açutuba sugerem que as lateritas foram utilizadas como material construtivo: as estruturas associadas à fase Açutuba, descritas acima (feições do tipo 3), são exemplos disso. Estruturas similares, descritas como montículos lateríticos, foram registrados no município de Manacapuru, na década de 1970, e recentemente na região do Lago do Limão, Iranduba, AM (Moraes, 2007).

\footnotetext{
${ }^{6} \mathrm{O}$ termo Laterita vem sendo substituído por Plintita pelos pedólogos, devido à falta de clareza de sua definição (Moran, 1994, p. 309).
} 


\section{Cronologia de ocupação e uso do espaço}

A partir das diversas etapas de campo realizadas no sítio Açutuba, foi possível obter vinte e cinco datações radiocarbônicas provenientes de diferentes áreas, profundidades e contextos, que permitiram a formulação de uma hipótese mais consistente sobre a história de sua ocupação. Como a tabela abaixo e o mapa topográfico do sítio demonstram, Açutuba tem uma longa seqüência cronológica, tendo sido ocupado, com intervalos, desde 1100 a.C. ${ }^{7}$ até 1380 d.C., ou seja, a extensa área de três quilômetros da margem do rio Negro, onde se localiza Açutuba, foi ocupada em tempos pré-coloniais durante mais de dois mil anos.

\begin{tabular}{|c|c|c|c|}
\hline $\begin{array}{l}\text { Número do } \\
\text { Laboratório }\end{array}$ & Proveniência & \begin{tabular}{|c} 
Profundidade \\
$\mathbf{c m}$.
\end{tabular} & $\begin{array}{l}\text { Idade calibrada } \\
(66.8 \%)^{8}\end{array}$ \\
\hline BETA 97527 & IA-Unit 2 & $30-40$ & 890 d.C. -1160 d.C. \\
\hline BETA 90724 & IA-Unit 2 & $70-80$ & 120 d.C. -340 d.C. \\
\hline BETA 178910 & IIB - T09 & & 410 a.C. -170 a.C. \\
\hline BETA 178908 & IIB - T10 & 65 & 430 d.C. -550 d.C. \\
\hline BETA 178909 & IIB - T10 & 77 & 410 d.C. -600 d.C. \\
\hline BETA 202677 & IIB-Reservatorio-Unit $\mathrm{x}-\mathrm{x} \mathrm{S}$ & 132 & 350 a.C. -40 a.C. \\
\hline BETA 202676 & IIB-Reservatorio-Unit 10-11 S, F. 33 & $160-170$ & 870 d.C. -1030 d.C. \\
\hline BETA 202675 & IIB-Reservatorio-Unit 4-5 N, F. 29 & $200-210$ & 50 a.C.-60 d.C. \\
\hline BETA 242432 & IIV-Reservatório Unit 5-6 N & $250-260$ & 1310 d.C. -1450 d.C. \\
\hline BETA 109183 & IIB-S0230W0889 & $40-45$ & 1220 d.C. -1390 d.C. \\
\hline BETA 109180 & IIB-S0231W0859 & $40-50$ & 1300 d.C. -1450 d.C. \\
\hline BETA 109181 & IIB-S0231W0859 & $70-80$ & 880 d.C. -1020 d.C. \\
\hline BETA 109182 & IIB-S0231W0859 & $130-140$ & 1290 d.C. -1410 d.C. \\
\hline BETA 109178 & IIB-S0250W0500 & $40-50$ & 70 d.C. -320 d.C. \\
\hline BETA 109179 & IIB-S0250W0500 & $130-140$ & 1270 d.C. -1400 d.C. \\
\hline BETA 109184 & IIB-S0350W0970 & $60-70$ & 990 d.C. -1160 d.C. \\
\hline BETA 90009 & IIB & sup. & 1210 d.C. -1270 d.C. \\
\hline BETA 97529 & IIB & sup. & 1270 d.C. -1390 d.C. \\
\hline BETA 97530 & IIB & sup. & 660 d.C. -810 d.C. \\
\hline BETA 90723 & IIB-Unit 1 & $30-40$ & 690 d.C. -880 d.C. \\
\hline BETA 106437 & IIB-Unit 1 & $40-50$ & 1220 a.C. -1000 a.C. \\
\hline BETA 90722 & IIB-Unit 1 & $50-60$ & 410 d.C. -550 d.C. \\
\hline BETA 106438 & IIB-Unit 1 & $50-60$ & 750 a.C. -150 a.C. \\
\hline BETA 97528 & IIB-Unit 1 & $60-70$ & 5840 a.C. -5640 a.C. \\
\hline BETA 90721 & IIB-Unit 1 & $90-100$ & 780a.C.-410a.C. \\
\hline
\end{tabular}

Tabela 5 - datas calibradas obtidas para o sítio Açutuba.

\footnotetext{
${ }^{7}$ As datas apresentadas na tese são todas calibradas. Por conveniência, as menções a elas ao longo do texto referem-se ao ponto médio da variação do erro padrão da data calibrada.
} 
A questão que guiou a abordagem desta pesquisa sobre o sítio, no entanto, focou-se em seus estratos mais antigos, que refletem o estabelecimento de aldeias, provavelmente com tamanho reduzido e que não tiveram como efeito alterações permanentes perceptíveis na paisagem. Há, em Açutuba, pelo menos duas áreas que sugerem tratar-se de ocupações distintas, tão antigas quanto a cronologia estabelecida para a fase de mesmo nome, ou seja, em torno do anno domini.

Vale lembrar que, neste sítio, tais ocupações possuem depósitos sedimentares profundos, por vezes enterrados a mais de um metro e meio de profundidade. Por esta razão, embora exploradas de forma intensa, essas áreas não puderam ser delimitadas com precisão, e inferências sobre padrões de assentamento, por exemplo, ficaram comprometidas. Apesar disso, procurou-se deduzir supostas áreas de habitação ou circulação, dentro de uma aldeia também supostamente inferida.

A primeira delas englobaria as unidades T9 e T10, o Reservatório, e parte das tradagens (ver mapa). Foi, inclusive, a partir dos dados obtidos para esta área do sítio, trabalhada em maior detalhe, que se definiu a dita fase Açutuba, contemplando as características tecnológicas das cerâmicas, sua configuração espacial e os elementos contextuais a elas relacionados (Lima et al., 2006). Também a partir desta área estabeleceu-se seu alcance cronológico e sua duração, de 290 a.C., chegando até 505 d.C., numa seqüência aparentemente ininterrupta. Há também para esta área do sítio uma datação mais recente, obtida para o perfil Sul do Reservatório, de aproximadamente 950 d.C. (BETA 202676). Esta data é mais tardia do que as expectativas para a fase Açutuba, assim como não corresponde à hipótese de tratar-se, neste contexto específico, de uma mesma ocupação contínua. Ela foi obtida através de uma amostra de carvão coletada no interior de uma feição (F33, do tipo 3) e, como já foi exposto, trata-se de uma matriz sedimentar bastante perturbada, de modo que o carvão datado pode ter percolado de níveis mais superficiais.

Por se tratar de uma área do sítio de difícil associação cultural dos carvões datados, selecionou-se, também para a datação, um fragmento de cerâmica com alta incidência de tempero orgânico em sua pasta (cariapé). A antiguidade da data obtida não surpreendeu. Mais antiga do que as datações radiocarbônicas até 
então obtidas para Açutuba, a data de 590 a. C. (BETA 242432) situaria um parco conjunto, composto por cerâmicas com uma decoração peculiar, temperadas não apenas com cauixi, mas também com cariapé, na tradição Hachurada Zonada da cronologia de Meggers e Evans (1961). Estas representariam as ocupações mais antigas de toda a área de pesquisa do PAC. No entanto, a já citada ausência de informações contextuais, nos levam a adotar uma postura ainda conservadora, ao aguardar dados mais precisos para uma caracterização segura do conjunto em questão. A associação de tais materiais a um conjunto bem definido da fase Açutuba também não é clara, e demandará trabalhos posteriores. Tem-se, por hora, a existência de tais conjuntos nas paredes norte (na feição 29) e sul do Reservatório, abaixo de um claro piso de ocupação Açutuba.

O Reservatório dista poucos metros da unidade 1, escavada em 1995 (ver mapa). Essa sondagem apresentou uma seqüência de seis datações radiocarbônicas, com uma variação cronológica entre 1.110 a.C. e 785 d.C. (Heckenberger et al., 1998, p. 361). Uma dessas datas (BETA 90721), que forneceu uma antigüidade de 5.740 a.C., foi descartada por não representar uma ocupação ceramista compatível ao contexto datado. Ainda assim, a data de 1.110 a.C., obtida para o nível 60-70 cm, corresponderia às ocupações mais antigas e profundas identificadas na área do Reservatório. O restante da seqüência foi vinculado às ocupações da fase Manacapuru, que trazem em si elementos que evidenciam um uso mais intensivo dos recursos, resultando, por exemplo, na formação das Terras Pretas de Índio.

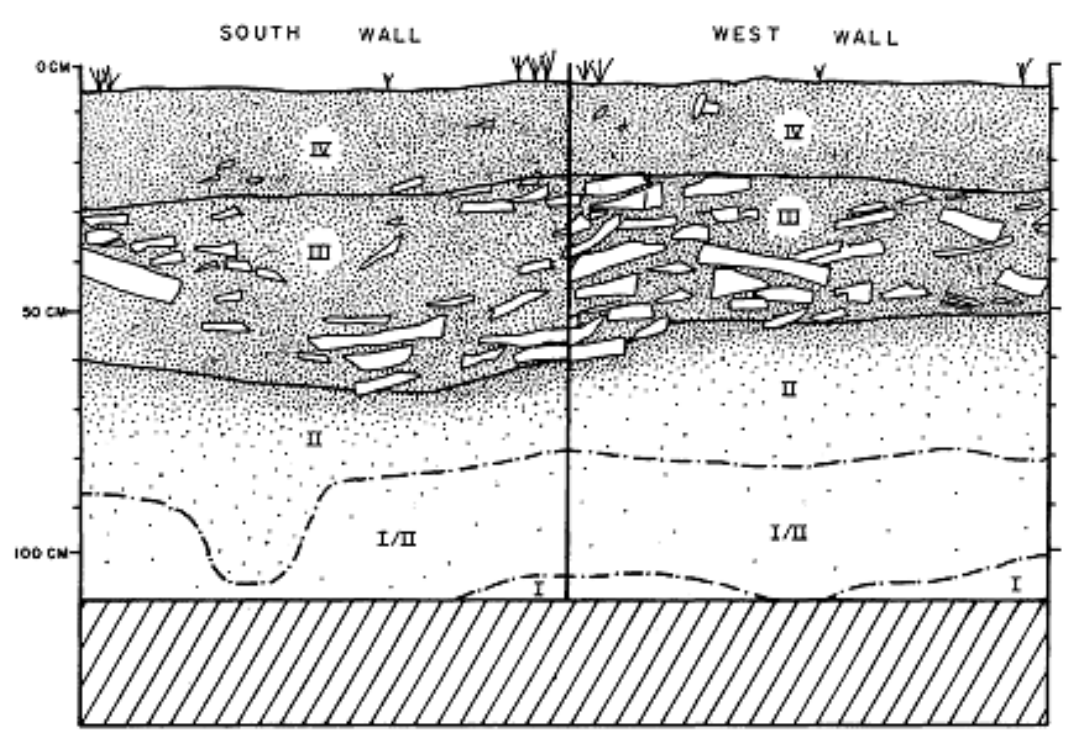


Figura 22 - Perfis Sul e Oeste da unidade 1, escavada em 1995 (Heckenberger et al., 1999, p. 360).

Pode-se deduzir que o final da ocupação de uma hipotética aldeia associada à fase Açutuba, ocorrido por volta de 200 d.C., foi seguido por um período de abandono. O depósito cultural é profundo e coberto por uma espessa camada arqueologicamente estéril, com uma profundidade superior a $1 \mathrm{~m}$ em alguns locais. O processo de deposição desta camada, que sugere ser eólico, indica ainda que, durante o período de abandono, a cobertura vegetal também não era densa. O sítio só volta a ser habitado de maneira intensa quase quinhentos anos mais tarde, quando já se verifica a constituição das TPI, associada às ocupações da fase Manacapuru. É interessante notar também que, neste local, as ocupações mais recentes não se sobrepõem à ocupação Açutuba, como ocorre, por exemplo, na área das unidades 1 e 2, de 1995.

Também escavada em 1995, a unidade 2, localizada no setor I do sítio, forneceu duas datações, de 230 d.C. no nível mais profundo $(70-80 \mathrm{~cm})$ e 1025 d.C no nível 30-40 cm, ambas associadas a um material cerâmico descrito como pertencentes à tradição Borda Incisa / Incisa e Modelada (Heckenberger et al., 1998, p. 262). Essas datas correspondem, segundo a hipótese ora proposta, às fases Açutuba e Manacapuru. O perfil da sondagem 2 apresenta um nível de ocupação bastante profundo, assim como no setor II do sítio anteriormente apresentado. O material cerâmico coletado naquela ocasião, que se encontra na reserva técnica do MAE-USP, foi mais uma vez analisado. As análises demonstraram tratar-se, de fato, da sobreposição da fase Manacapuru pela fase Açutuba.

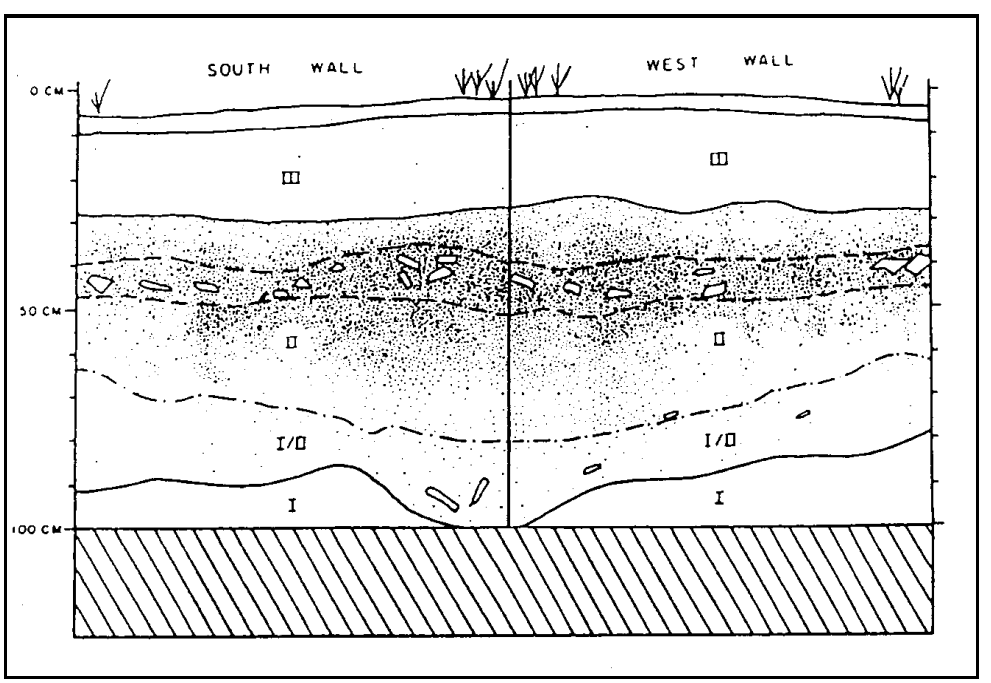

Figura 23 - Perfis sul e oeste da unidade 2, escavada em 1995 (Heckenberger et al., 1999, p. $360)$. 
Como se pode ver, a ocorrência de cerâmicas da fase Manacapuru, sempre em sub-superfície e associadas às TPl's, aparecem espalhadas numa área muito mais ampla do sítio arqueológico do que as restritas áreas de ocupação Açutuba. A associação cronológica entre as diferentes áreas (unidades 1 e 2 de 1995, unidade Tu20) parece comprovar a hipótese de tratar-se de assentamentos maiores, e as próprias TPl's indicam serem estes mais estáveis.

Além das já mencionadas cerâmicas Manacapuru identificou-se, em 2002, uma série de urnas funerárias, no setor I do sítio, nas proximidades de onde se escavou a unidade 2. Essas urnas, relacionadas à fase Paredão, foram expostas pelo corte do barranco de uma estrada que atravessa a parte leste do sítio, e indicam tratar-se, possivelmente, de um cemitério relacionado a eventos mais recentes de ocupação do sítio. Contextos semelhantes a esses, com grande concentração de materiais funerários, são muito comuns na região de Manaus e adjacências, bem como no Baixo Amazonas, e são sempre relacionados às ocupações Paredão, quase sempre datadas a partir do século IX d.C. Em Açutuba, as datações obtidas para materiais Paredão são provenientes de outra área. Isso porque, também relacionados às ocupações Paredão no sítio, encontram-se os montículos artificiais. Um deles foi escavado (sondagem S231 W839) e forneceu uma seqüência de datações entre 950 e 1375 d.C. As datas mais recentes, no entanto, parecem relacionadas a um evento de re-ocupação do montículo.

Assim, embora as urnas do setor I não tenham sido datadas através do carbono 14, pode-se atribuir uma contemporaneidade entre elas e as ocupações que construíram os montículos do setor II. Como se pode ver, já é possível esboçar o uso de dados espaciais para deduções acerca da própria organização social desses primeiros grupos construtores de montículos e de cemitérios. Temse que uma extensa área do sítio arqueológico deu lugar a uma ocupação Paredão, mais ampla, cujos espaços tinham usos específicos.

Estes espaços parecem ter sido re-ocupados, com outras significações e funcionalidades, ao redor dos séculos XII e XIV, por populações portadoras de uma tecnologia cerâmica bastante diferenciada, associada à fase Guarita. A nova significação dos espaços parece ocorrer ao observar-se a distribuição espacial das cerâmicas em superfície. 
Tal padrão foi interpretado por Heckenberger, Neves e Petersen (1998, p. 363-364) como evidência de uma praça central, uma espécie de espaço publico central, circundado pelos montículos "trash middens", associados a unidades habitacionais. O padrão distribucional teria um eixo maior, no sentido leste-oeste, e seria simétrico a partir da referida praça, situada com precisão em Açutuba IIB. Para chegarem a tais interpretações os autores utilizaram-se, além do padrão distribucional dos fragmentos em superfície, de datações da pasta de cerâmicas Guarita diagnósticas coletadas em superfície, datadas entre 1075 a 1330 d.C., e de escavações estratigráficas, algumas delas realizadas em montículos, com datas em torno dos séculos XIII e XIV. Usaram, ainda, outras mais antigas, como por exemplo, de uma urna funerária coletada sob um montículo, por eles também associada às ocupações Guarita no sítio, datada em 850 d.C.

A mudança do viés interpretativo que se coloca agora sobre tais dados se baseia, com maior ênfase, no aumento da base empírica comparativa hoje existente, tanto para Açutuba como para os demais sítios arqueológicos da região. A nova proposta interpretativa é de que as ocupações mais recentes, Guarita, tenham tido uma duração menor do que se pensava outrora, restrita aos séculos XII e XIV. A construção dos montículos, bem como a filiação cultural da referida urna, pensada como Guarita, seriam, na verdade, resultado de ocupações anteriores, Paredão, cujos espaços teriam sido reutilizados.

A disposição dos montículos, que pode sugerir um padrão de assentamento circular, estaria vinculada, dentro da interpretação ora proposta, às ocupações Paredão (e não Guarita). De fato, num momento posterior, as ocupações Guarita teriam se voltado para as margens do rio, estabelecendo o padrão de simetria entre os lados de um eixo leste-oeste, observado pelos autores (idem), a partir da reutilização de uma mesma área central.

Finalmente, as sucessivas habitações ocorridas neste sítio arqueológico podem sugerir, também, que o motivo pelo qual as aldeias foram abandonadas não foi a escassez de recursos, conforme apontam algumas hipóteses gerais de ocupação da Amazônia. Por outro lado, pode-se observar que Açutuba foi abandonado no século XIV, antes do contato com o europeu, e por razões ainda desconhecidas. 
Em termos de cronologia, no entanto, o quadro não é tão claro como a exposição acima deixa parecer. Em verdade, como o gráfico abaixo demonstra, há muitas interpolações cronológicas entre diferentes ocupações, o que dificulta em muito a definição de padrões espaciais em bases temporais. Devo deixar claro que a associação entre amostras datadas e filiação cultural, representadas no gráfico, são interpretações de dados, e deverão ser refinadas na medida em que novos elementos sejam acrescentados à base empírica de Açutuba, bem como ao viés interpretativo referente a ela. Deste modo, a maior duração das ocupações Açutuba representada no gráfico reflete uma maior quantidade de dados, e não uma realidade pretérita.

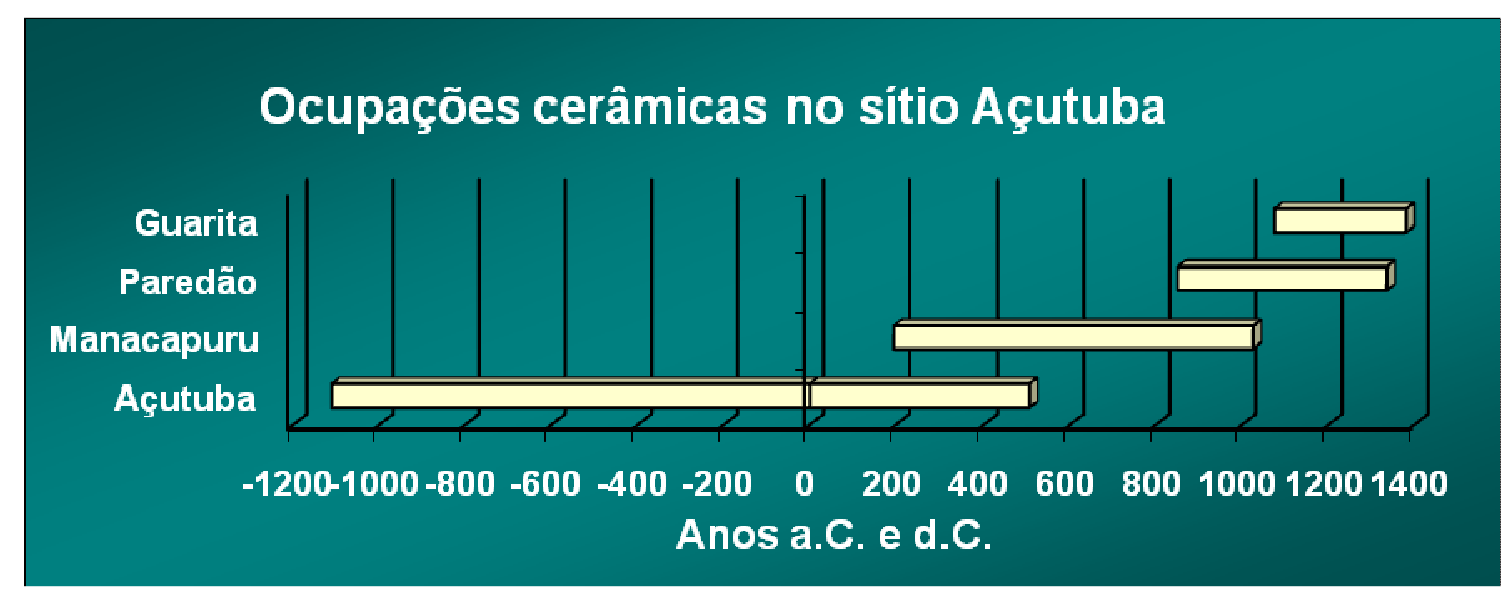

Gráfico 6 - Variação cronológica das fases cerâmicas encontradas no sítio Açutuba.

No entanto, as datações obtidas para o sítio corresponderam às nossas expectativas, aumentando ainda mais a importância de Açutuba enquanto sítioguia para a compreensão da cronologia da Amazônia Central. A correlação com datas de outros sítios arqueológicos da região indica interessantes padrões, e dão luz, de fato, ao reconhecimento da história local, regional, mesmo a outros complexos do norte da América do Sul. 
A quantidade e intensidade de intervenções arqueológicas realizadas no sitio Açutuba forneceu uma série informações inéditas. Em primeiro lugar, ficou demonstrada a maior antigüidade de ocupação do sítio, relacionada às ocupações da fase Açutuba, representando o início da ocupação de grupos ceramistas na região. Verificou-se, também, que a correlação entre cerâmicas da fase Manacapuru com a terra preta se confirmou, representando as primeiras ocupações efetivamente associadas às TPI, marco cronológico e cultural na Amazônia central. As ocupações Paredão e Guarita, por outro lado, apresentaram uma série de questões relevantes acerca de sua configuração espacial, que deverão ser tratadas com maior cautela em trabalhos futuros.

Como se pode ver, Açutuba permanece suscitando mais e mais questões, que se apresentam cada vez com maior intensidade para que pensemos a cronologia da Amazônia central. 


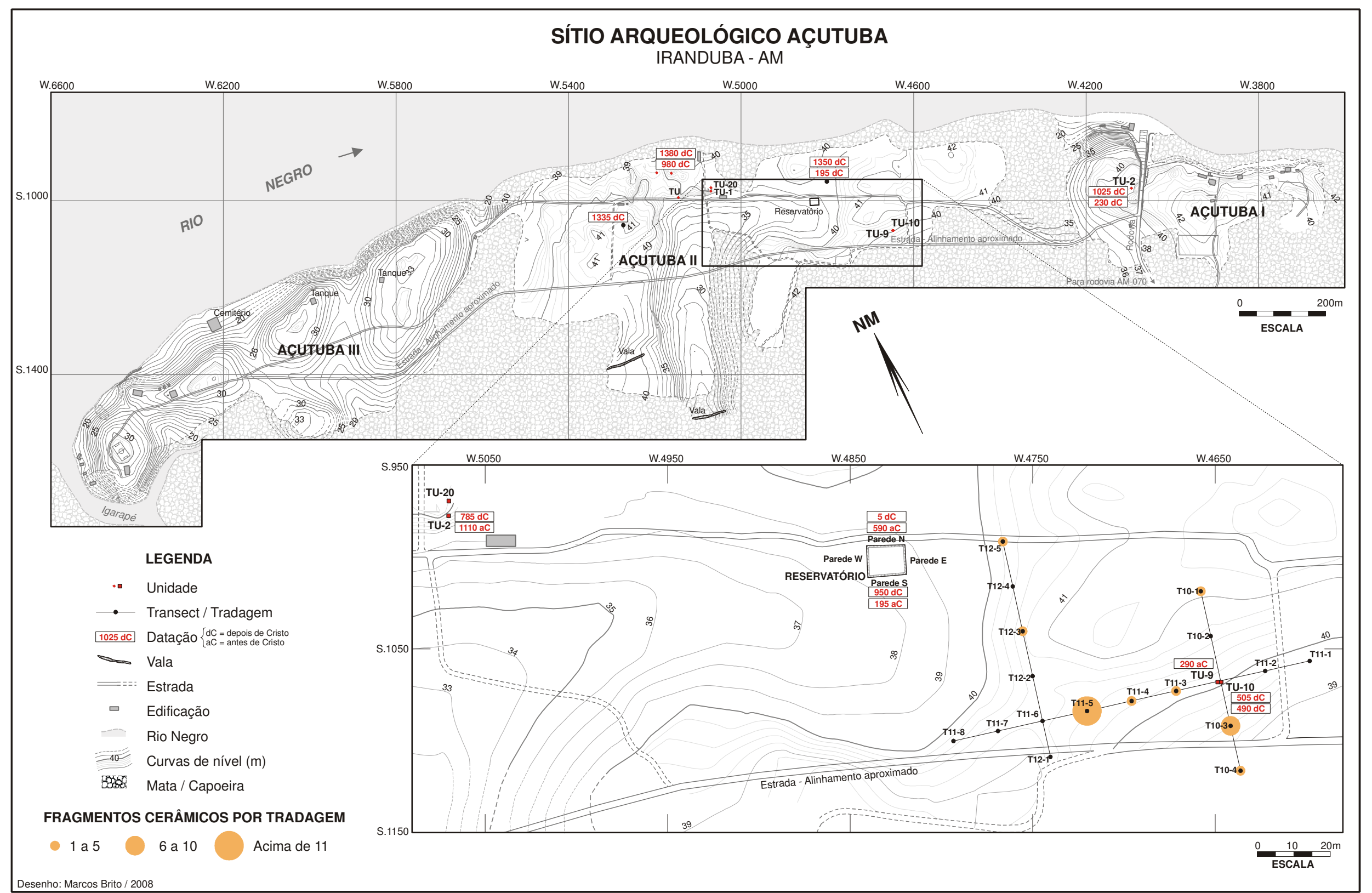

Figura 24 - Planta topográfica do sitio Açutuba, com as intervenções realizadas, densidades de fragmentos e datações radiocarbônicas. 


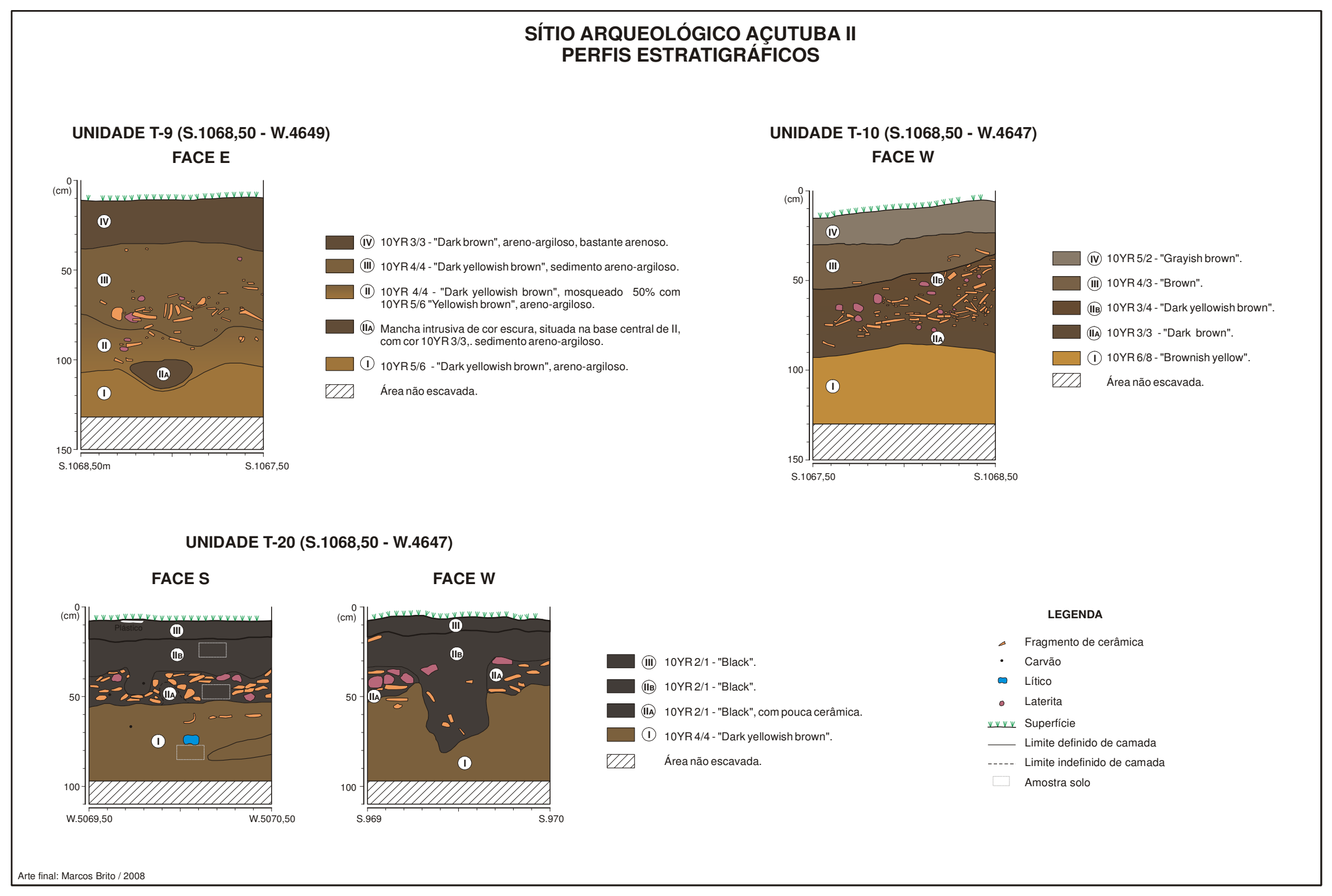

Figura 25 - Perfis das unidades T9, T10 e TU20. 
SÍTIO ARQUEOLÓGICO AÇUTUBA II

PERFIS ESTRATIGRÁFICOS - RESERVATÓRIO

FACE NORTE

Unidades $5-6,6-7$ e 7-8

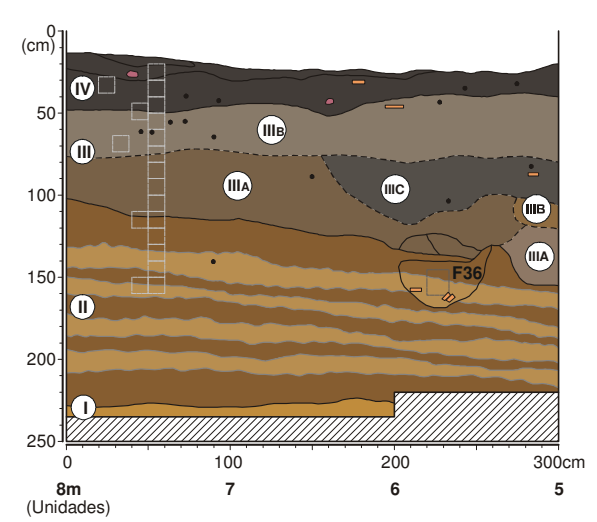

FACE LESTE

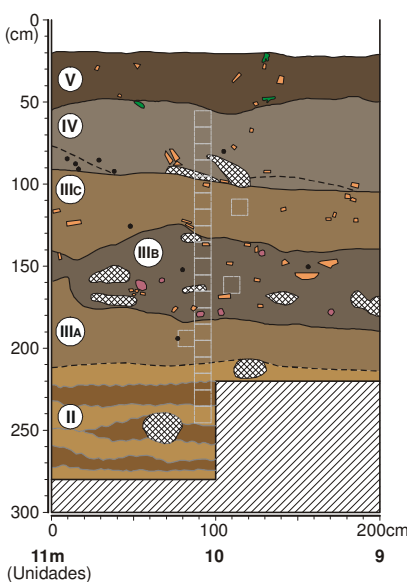

FACE SUL

Unidades 8-9, 9-10 e 10-11m

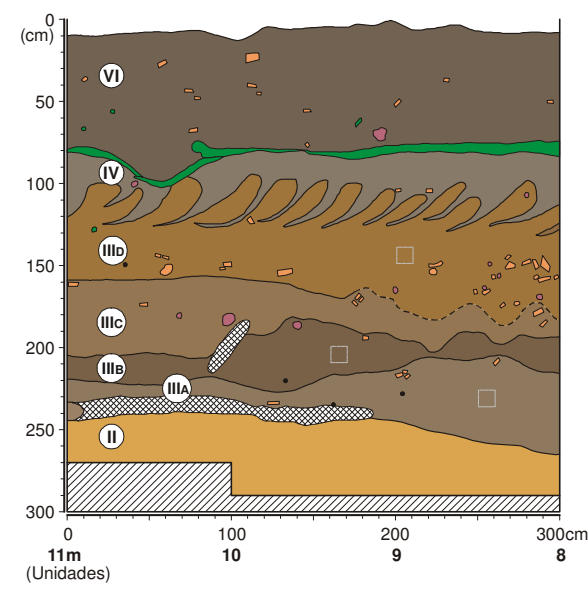

Camada V - Aterro, camada totalmente perturbada, colocada acima
de IV (superficicie original Io to terreno), na ocasiáo de abertura do

Camada IV - Zona de cultivo. Presença de materiais arqueológicos
bastante fragmentados. Cor: 10YR $5 / 2$ grayish brown.

Camada III - Nível de ocupação. Presenç̧a de material arqueológico, camada em três sub-camadas. Neste caso, porém, IIIA e IIII tềm as

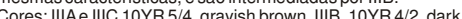
brown.

Camada ll - estéril. Camada espessa (até $70 \mathrm{~cm}$ ), composta por dois
tipos de sedimento superpostos, formando linhas horizontais

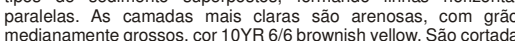
por camadas de sedimento mais escuro, compacto. Bioturbaçöes

Camada I- embasamento pela misturarade areia medianamente granulosa e blocos de
laterita. E um pacote denso e compacto, que forma o embasamento do terreno em todo o sitio. Cor: 10YR 6/8
brownishyellow MIIA Areanäo escavada

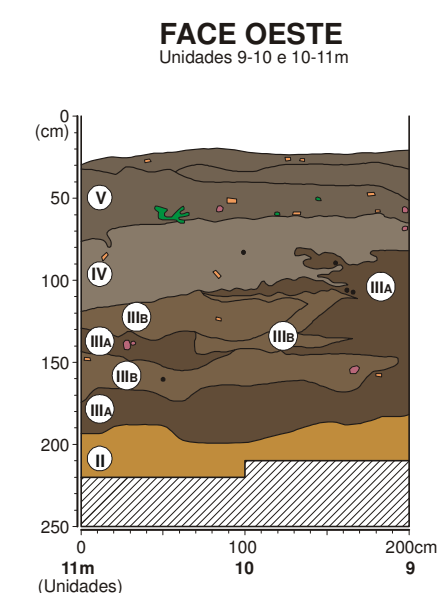

Arte final: Marcos Brito / 2008
Camada V - Aterro, camada perturbada, colocada acima de IV (superfíicie original do terreno), na ocasiáo d
abertura do reservatório. Cor: 10YR 4 (2) dark grayish brown.

Camada IV - Zona de cultivo. Superficie original do terreno, perturbada por cultivo. Presença de ráizes,
plásticos, etc. Baixa densidade de vestigios
arqueológicos.

A Camada III - Camada cultural, sedimento arenoso, com superiores e inferiores. Média densidade de vestígios arqueológicos: cerâmica, laterita e carvão. Esta camad
foi sub-dividida em duas, lliA e lliB, que se intercalam. As

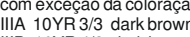

Camada II - Estéril, sedimento arenoso, com grăos grossos, pouco compacto Ausencia de vestigios
aruueologicos. Cor : 10 Y 6 6 8 brownishyellow

VIIA Área não escavada.

Figura 26 - Perfis das unidades escavadas no reservatório. 


\section{III. II. Sítio Cachoeira (Am-Ir-03)}

O sítio Cachoeira se localiza num terraço alto e plano às margens do igarapé do Castanho, que deságua no rio Negro, já perto de sua foz. Suas dimensões estimadas são de 224×70 m e a profundidade chega a pelo menos 75 $\mathrm{cm}$. O sítio foi localizado por E. Neves e R. Bartone em prospecções realizadas pelo PAC em 1997, ocasião em que escavaram uma sondagem de 0,5 m x 0,5 m. Apesar da pequena quantidade de trabalhos realizados e da reduzida área escavada no sítio, Cachoeira forneceu vasos inteiros, relacionados à fase Açutuba ou Manacapuru.

A condição favorável de preservação do material cerâmico proveniente desse sítio possibilitou que as análises laboratoriais abordassem, também, amostras de vasilhame não fragmentado, que são extremamente úteis na definição de tipologias e no reconhecimento da variabilidade das indústrias locais, tão complicadas quando se tem amostras dessa natureza.

No entanto, pouco ou quase nada se conhece sobre o contexto deposicional desse sítio arqueológico. Com apenas uma sondagem escavada, não foi possível, por exemplo, assegurar com precisão sua cronologia de ocupação. A presença de um depósito relativamente profundo de terra preta, representado no perfil (fig 27), em conjunto com a análise da cerâmica coletada na sondagem, sugere tratar-se, talvez, de uma ocupação da fase Manacapuru, depositada em terra preta, com predominância arenosa e elementos de argila. Por outro lado, as características tecno-estilísticas dos vasos inteiros coletados os relaciona ao conjunto mais antigo, vinculado à fase Açutuba. De fato, eles foram coletados na base da camada de terra preta, e podem ser anteriores à sua formação.

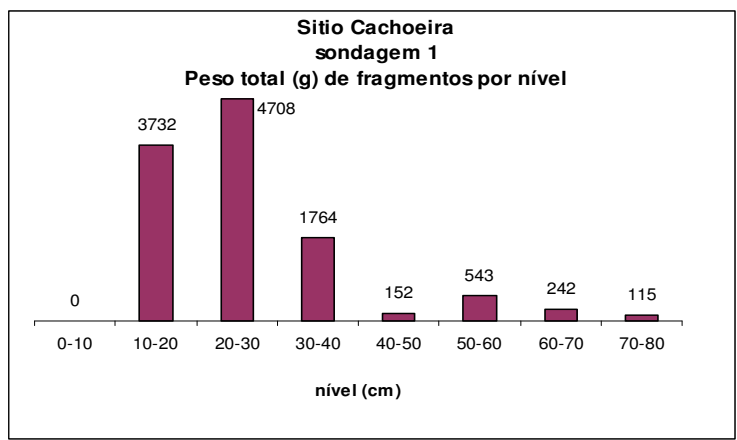

Gráfico 7 - Densidade de fragmentos por nível na sondagem 1 (peso em gramas). 
Como o gráfico de freqüência de cerâmicas por nível na sondagem 1 sugere, há mesmo um claro nível de ocupação, Manacapuru, entre 10 e $40 \mathrm{~cm}$. Este se associa à terra preta demonstrada no perfil (fig 27). Ao invés de uma redução gradual, como se esperaria num sítio unicomponencial, a densidade de cerâmicas tem um sensível aumento entre 50 e $80 \mathrm{~cm}$, local de onde foram coletados os vasos, hipoteticamente associados a um nível de ocupação mais antigo, da fase Açutuba.

Os vestígios líticos coletados na escavação da sondagem 1 estão descritos na tabela a seguir. Eles aparecem, em quantidades mínimas, apenas no conjunto mais recente.

\begin{tabular}{|l|l|}
\hline Nível & Quantidade e descrição \\
\hline $10-20 \mathrm{~cm}$ & 01 fragmento de arenito (tipo Manaus) queimado, $<2 \mathrm{~cm}$ \\
\hline $20-30 \mathrm{~cm}$ & 01 fragmento de arenito (tipo Manaus) queimado, $<2 \mathrm{~cm}$ \\
\hline $30-40 \mathrm{~cm}$ & 03 fragmentos de arenito (tipo Manaus) queimado, $<2 \mathrm{~cm}$ \\
\hline
\end{tabular}

Tabela 6 - Descrição dos vestígios líticos coletados na unidade S710 E1966.

A ausência de carvões ou restos orgânicos datáveis, resultantes da escavação de 1997, não auxiliaram na solução de tal questão. Uma nova etapa de campo neste sítio seria, portanto, fundamental para que compreendêssemos as relações em termos de continuidade e ruptura entre as ocupações dessas duas fases arqueológicas. Tal etapa foi planejada por diversas vezes mas, por razões técnicas e logísticas, não puderam acontecer até o presente momento, de modo que, apenas em trabalhos futuros, conhecer-se-ão os processos de formação de Cachoeira que poderão validar ou não os padrões identificados nos demais sítios arqueológicos trabalhados na região. 


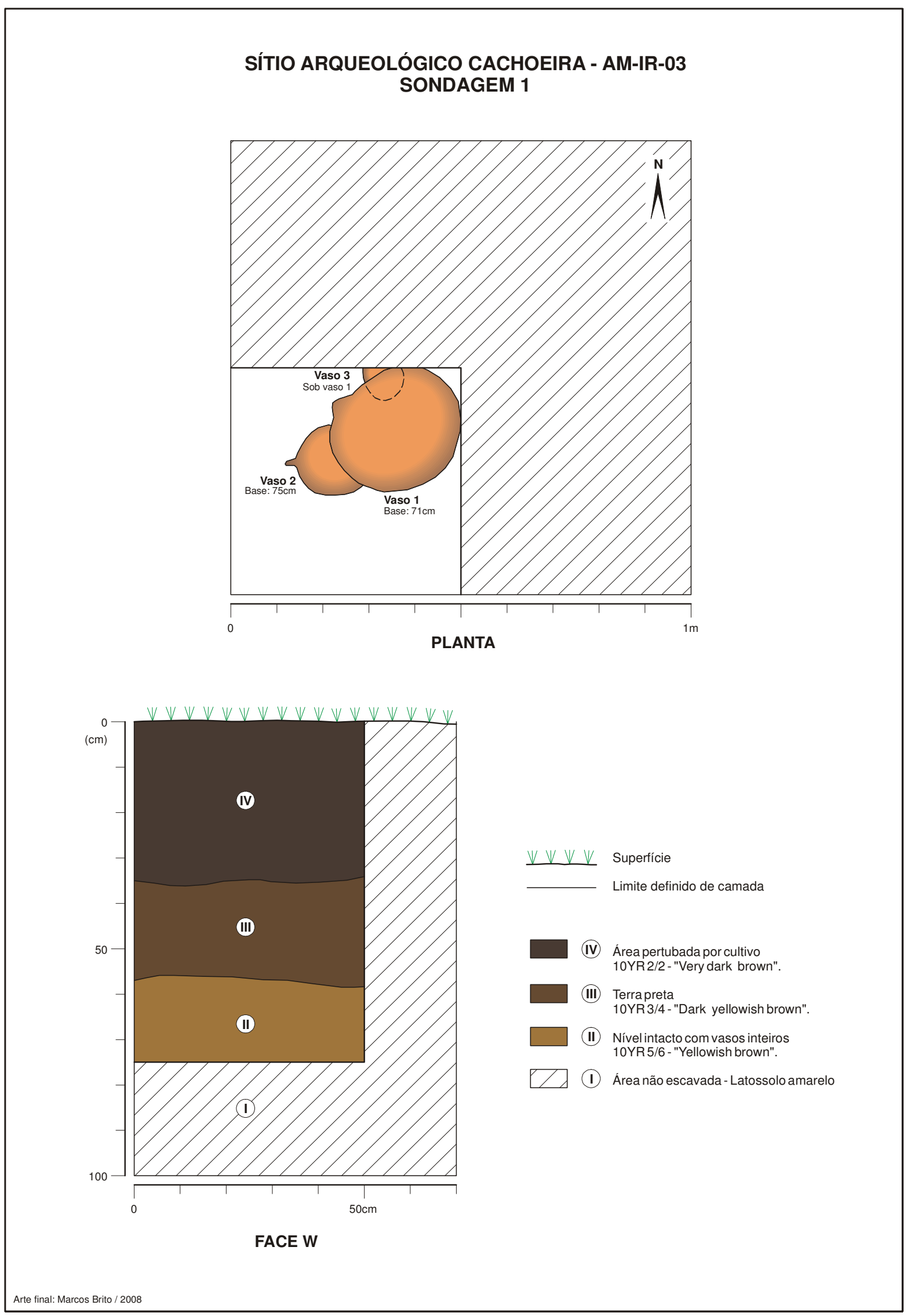

Figura 27 - Perfil e planta baixa da sondagem 1 escavada no sítio Cachoeira. 


\section{III. III. Sítio Paricatuba}

Apesar de bastante perturbado por ações antrópicas, Paricatuba apresenta características importantes para a arqueologia da região. Como o próprio nome indica, o sítio arqueológico está localizado numa enseada à margem direita do rio Negro, cerca de $20 \mathrm{~km}$ a montante de Manaus, em uma área privilegiada para a ocupação humana. Estende-se ao longo de um alto terraço de grandes proporções, sob a comunidade ora conhecida como Paricatuba.

Diferente do sítio Açutuba, que vem sendo sistematicamente explorado no âmbito acadêmico há mais de dez anos, os trabalhos em Paricatuba se deram num contexto de arqueologia de contrato, ou seja, as escavações estiveram direcionadas ao resgate dos vestígios, visando a liberação dos locais para a instalação de futuras obras de infra-estrutura. Com o desenvolvimento da vila de Paricatuba, foi iniciada a implantação de um novo sistema hidráulico, que levou à abertura de diversas valas pelas principais ruas e vielas da comunidade. Esta obra foi contemplada com os recursos do governo do Estado do Amazonas, meio pelo qual os estudos arqueológicos foram subsidiados.

A partir dos dados obtidos através das tradagens, foi possível fazer uma delimitação da área do sítio, que tem 49,4ha, e apresenta uma configuração espacial interessante. Os vestígios se apresentam em três áreas: uma grande concentração central e duas concentrações satélites (ver mapa). Nestes locais, foi adotada a metodologia de escavações por trincheiras, em unidades de $1 \mathrm{~m} \times 0,50$ $\mathrm{m}$, com a finalidade de resgatar o material que seria impactado, ao mesmo tempo em que as trincheiras já poderiam ser utilizadas como valas para a colocação dos condutos hidráulicos. Nas áreas em que não houve quantidades significativas de vestígios entre as três concentrações, as escavações foram realizadas por sondagens alternadas, até a liberação da área.

Nas áreas de concentração, algumas escavações evidenciaram uma estratigrafia um pouco mais profunda, com a ocorrência de espessas camadas de terra preta, especialmente na concentração central. Também desta área forma coletados materiais cerâmicos e líticos, relacionados às fases Açutuba, Manacapuru, Paredão e Guarita, sugerindo para Paricatuba uma longa cronologia de ocupação, tal como em Açutuba. Nessa área identificou-se, inclusive, a 
presença de estruturas semelhantes, embora mais discretas, às encontradas nos sítios com montículos.

Ocorre, no entanto, que o sítio arqueológico encontra-se numa vila com avançado processo de urbanização, de tal feita que tais estruturas se encontram bem afetadas pela construção de ruas, estradas, edificações, etc. Como os perfis estratigráficos demonstram (fig 30), a área central do sítio, que é também uma importante área da comunidade hoje, onde se encontram a escola, a igreja e o campo de futebol, teve parte de seu componente arqueológico perdido pela terraplenagem do local.

Apesar dos já mencionados impactos que sofreu o sítio arqueológico (seja por construções, terraplenagem ou aterros), seus níveis de ocupação mais antigos - focos deste estudo - apresentaram bom estado de conservação, fornecendo, inclusive, um grande recipiente parcialmente intacto, associado à fase Manacapuru. Trata-se de um vaso piriforme com gargalo carenado, coberto por uma tampa (fig 28). Tanto a forma do vaso como seu contexto associado reforçam um padrão identificado em outros sítios, de concomitância, ao menos ao longo de alguns séculos, entre materiais das fases Manacapuru e Paredão. O estrato arqueológico ainda não foi datado, mas as amostras de carvão coletadas serão, no futuro, envidadas para datação radiocarbônica a fim de esclarecer esta questão.
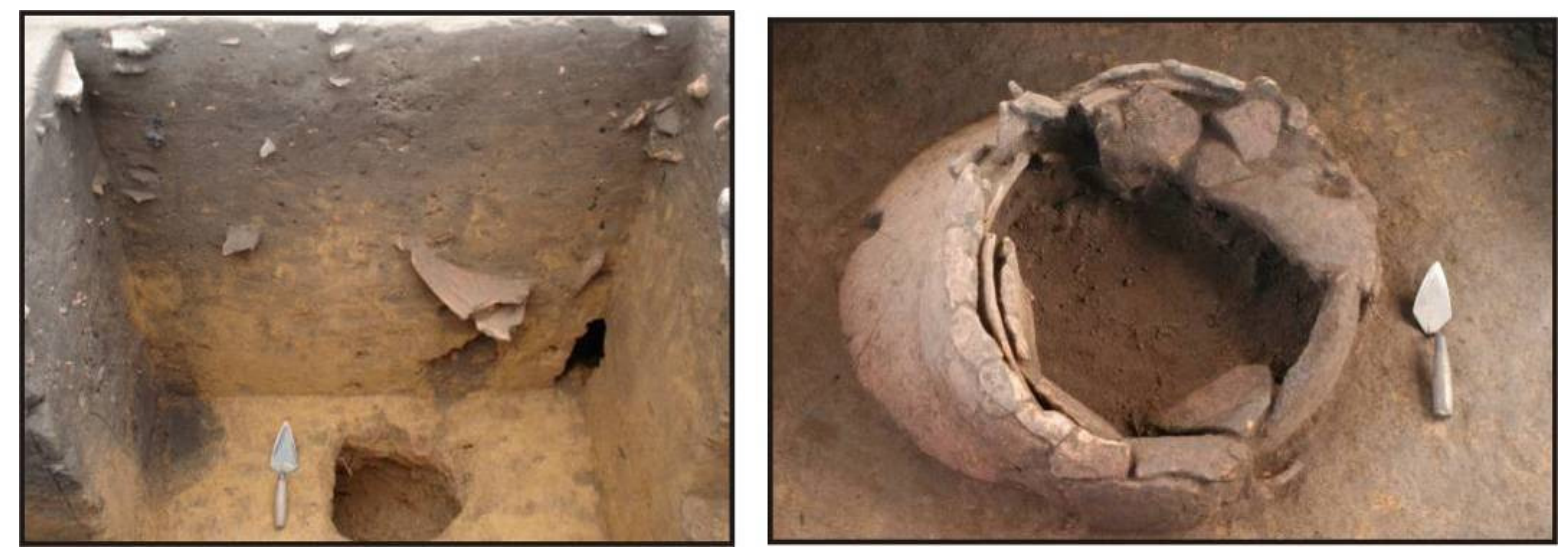

Figura 28 - Unidades de escavação com contextos Manacapuru preservados (a colher de pedreiro indica o norte magnético). (Fotos: Helena Lima). 
De modo geral, o sítio Paricatuba tem características semelhantes ao Açutuba, e provavelmente foi contemporâneo a ele em muitos momentos. Mas, diferente de Açutuba, a configuração espacial deste sítio arqueológico não demonstra trata-se de assentamentos de tão grandes proporções quanto aqueles encontrados em alguns momentos de Açutuba. Não se sabe ainda a relação - de contemporaneidade ou não - entre as três áreas de concentração do sítio, mas o exame dos perfis não sugeriu uma conexão direta entre as mesmas, tal como identificada entre os setores I, II e III de Açutuba, durante as ocupações Paredão e Guarita. Ao contrário, a própria área central se apresentou como um assentamento de aspecto independente. Tais afirmações dependem de datações e de trabalhos futuros, mas as hipóteses aqui lançadas sobre a configuração espacial de Paricatuba diz respeito, não apenas a este sítio arqueológico, mas também à sua relação com os demais sítios a ele contemporâneos, existentes nas proximidades.

Embora as deduções sobre o sítio Paricatuba sejam ainda muito preliminares, é certo que este sítio tem grande importância no contexto da arqueologia do baixo rio Negro. Os dados ora apresentados, inéditos, em conjunto com outros sítios arqueológicos, trazem contribuições sobre a cronologia de ocupação dessa área e sobre os sistemas que ali se desenvolveram. 


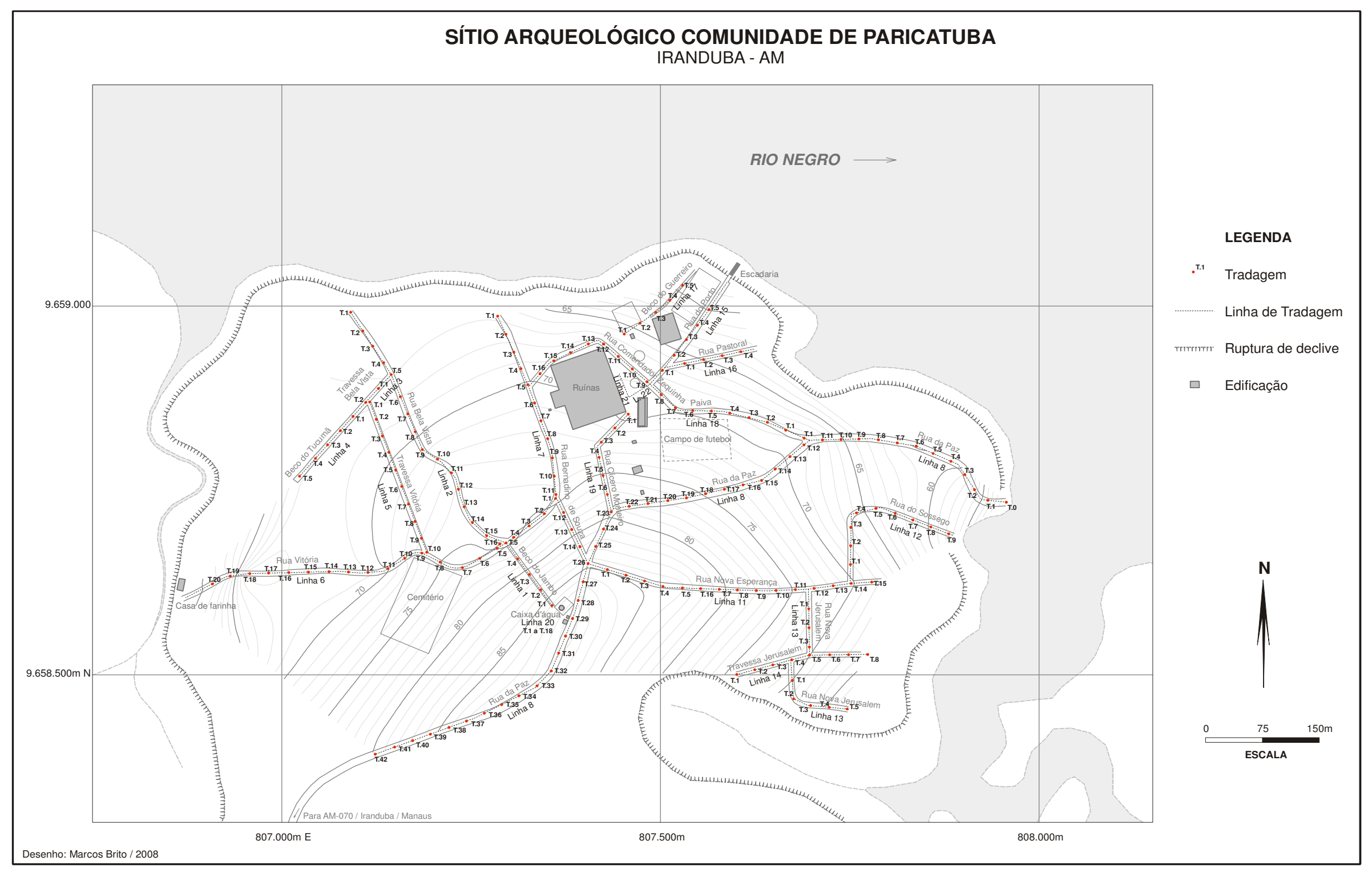

Figura 29 - Planta topográfica do sitio Paricatuba, e intervenções realizadas no sítio em 2005. 


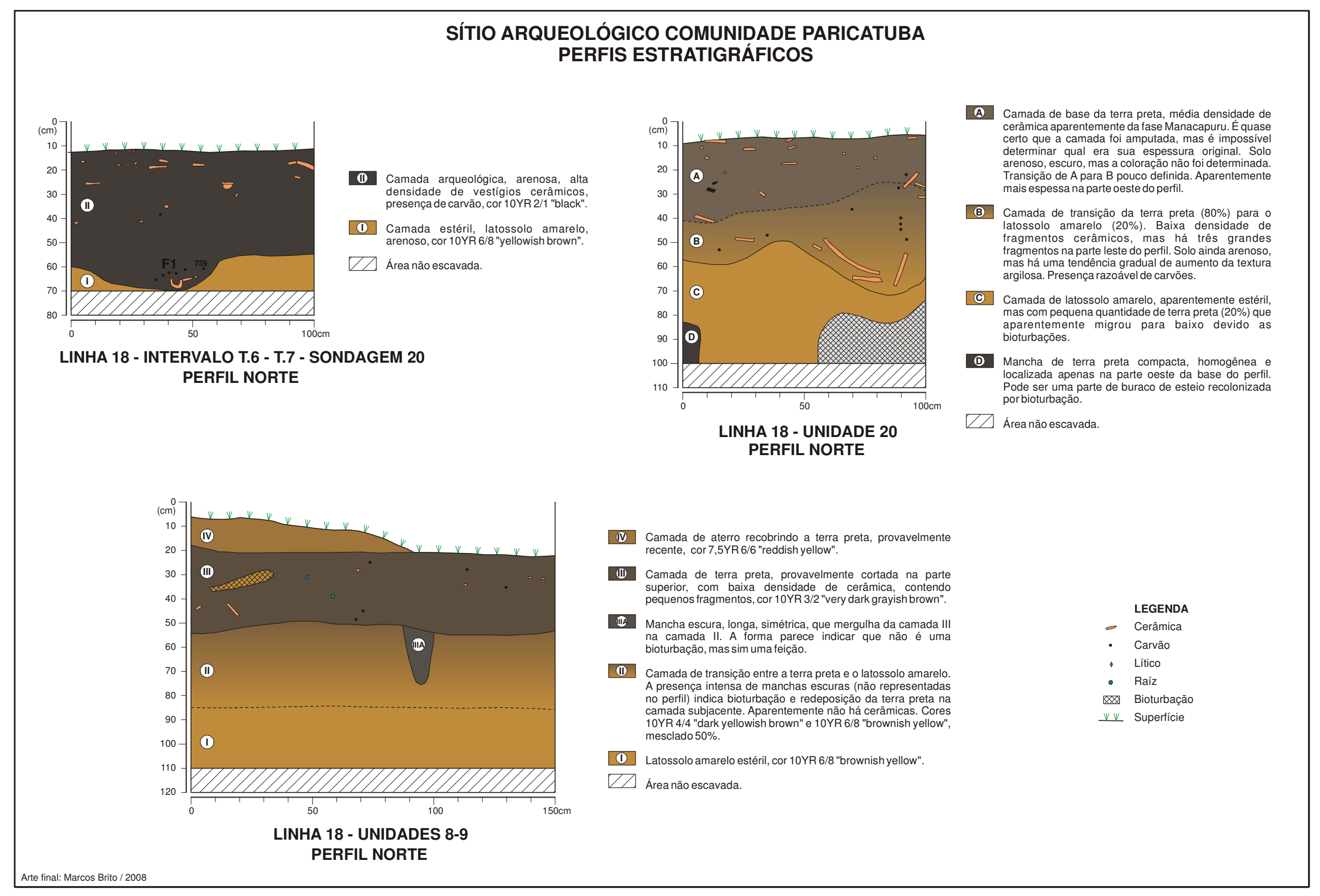

Figura 30 - Perfis estratigráficos de intervenções realizadas no sítio Paricatuba em 2005. 


\section{VI. Os sítios arqueológicos do baixo Solimões}

\section{IV. I. Sítio Nossa Senhora do Perpétuo Socorro, no rio Manacapuru}

No local onde foi construída a clareira 28 da Petrobras, em função das obras do Gasoduto Coari-Manaus, encontra-se um sítio arqueológico de grande relevância científica. Quatro etapas de campo ocorreram no sítio, com a duração de 20 dias cada uma. O sítio Nossa Senhora do Perpétuo Socorro está situado na margem direita do rio Manacapuru, na localidade denominada Cajazeiras, município de Manacapuru/AM. O acesso ao sítio, que dista 17,5 km NW da sede municipal em linha reta, é feito somente por via fluvial, levando em média 40 minutos numa lancha com motor de 60hps. A cobertura vegetal é composta por gramíneas relacionadas às atividades agropecuárias da região. Apesar de não se constituir em uma área de várzea, o sítio tem partes que são periodicamente alagadas. Há também áreas de mata secundária e primária, com a presença de castanheiras, açaí, goiabeira, entre outras. A área pesquisada se constitui em uma planície pouco elevada, com vertentes suaves em direção ao lago Manacapuru.

Além dos fragmentos cerâmicos hoje dispersos na superfície do terreno em função das obras, encontra-se também uma quantidade de instrumentos líticos de diferentes matérias primas. Trata-se de um sítio de aspecto unicomponencial, com materiais cerâmicos associados à fase Manacapuru, focos desta pesquisa. $O$ pacote arqueológico tem uma espessura média de $20 \mathrm{~cm}$, depositado numa matriz argilosa. Encontra-se selado por uma camada estéril, com cerca de $20 \mathrm{~cm}$ a partir da superfície.

A fim de se investigar a distribuição e espessura da camada arqueológica em sub-superfície, foi realizado o mapeamento do sítio a partir de um grid composto por 6 transects, nos quais foram realizadas tradagens com espaçamento regular de $25 \mathrm{~m}$. A profundidade dessas tradagens variou de $20 \mathrm{~cm}$ a $1 \mathrm{~m}$, sendo que a grande maioria delas se manteve em torno dos $60 \mathrm{~cm}$. Ao todo foram realizadas 54 tradagens e 6 unidades de escavação de $1 \mathrm{~m}^{2}$. A partir do mapeamento prévio da dispersão e densidade da camada arqueológica na área impactada, foram selecionados três setores principais para a abertura de unidades de escavação. A escolha dos locais de escavação levou em conta a implantação na paisagem (diferentes compartimentos - áreas altas e vertentes); maior densidade de vestígios arqueológicos; estruturação dos vestígios na 
camada arqueológica. Nesse sentido, foram abertas as seguintes unidades no sítio:

\section{Unidade N1076 E1151:}

Situada na área SE do sítio, está implantada na parte mais alta do terreno, próximo à margem do Lago Manacapuru. O local foi selecionado devido à grande densidade de vestígios cerâmicos articulados. Após a abertura da unidade, foi constatada a presença de vestígios cerâmicos e de alguns poucos exemplares líticos nos níveis $0-20 \mathrm{~cm}$ e $20-30 \mathrm{~cm}$. Esses vestígios apresentaram-se concentrados e articulados espacialmente, podendo indicar concentrações de 2 a 3 potes fragmentados in situ (figura 31). A unidade escavada apresentou uma feição no perfil W, caracterizada pela presença de carvão e sedimento de coloração cinza escuro; um conglomerado disposto em forma semicircular, logo abaixo da camada de ocupação. Tal estrutura destacava-se bem de seu entorno, já bastante mosqueado com o latossolo amarelo e alaranjado. A baixa quantidade de vestígios cerâmicos associada à grande quantidade de carvão, além da coloração cinza do sedimento indicou se tratar de uma estrutura de combustão muito profunda e reutlizada. A base dessa estrutura é abrupta e apresenta forma quadrada.
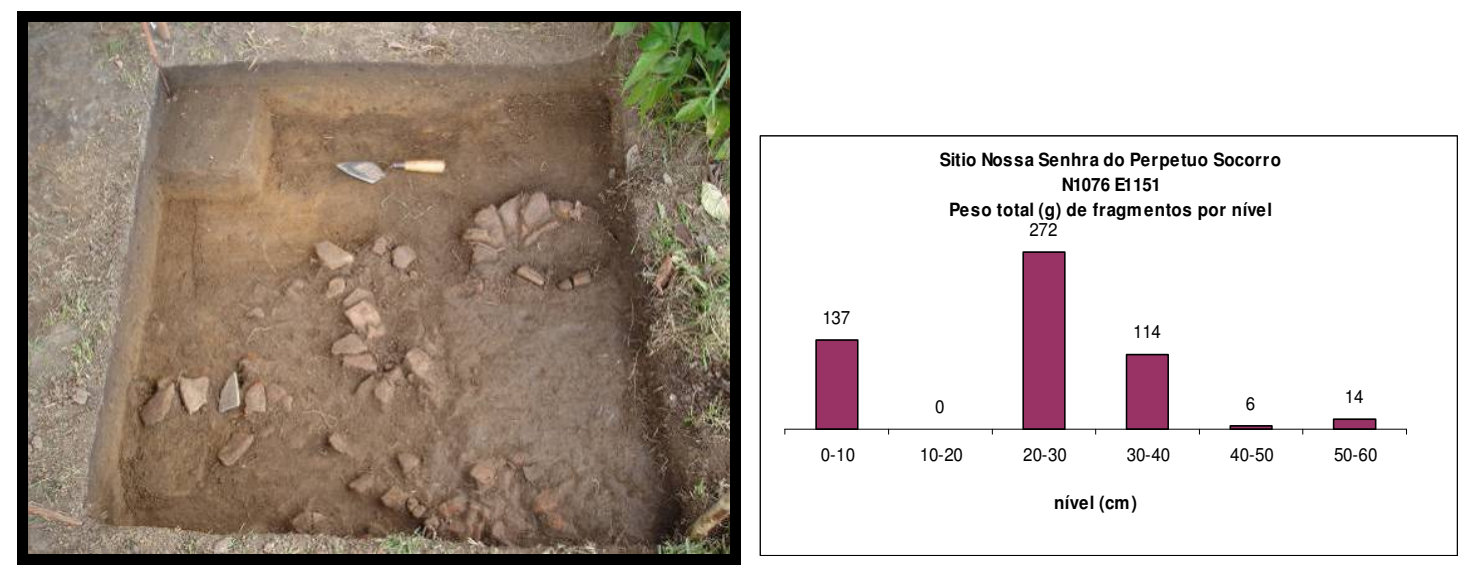

Figura 31 - Estruturas cerâmicas enterradas na unidade N1076 E1151; densidade de fragmentos por nível (foto: Juliana Machado). 
A grande densidade de fragmentos cerâmicos articulados, e a sua continuidade em direção ao perfil SE, assim como a presença de um pequeno machado polido encontrado em tradagem realizada a $1 \mathrm{~m}$ do quadrante SE da unidade escavada, levaram à abertura de uma segunda unidade de escavação, localizada a SE da primeira.

\section{Unidade N1075 E1152:}

A segunda unidade de escavação, N1075 E1152, apresentou um contexto semelhante à primeira, sendo, no entanto, as concentrações cerâmicas localizadas em um nível acima da anterior $(0-10 \mathrm{~cm}$ e 10-20 cm). Essa unidade apresentou também um pequeno machado polido, vestígio que não foi encontrado na unidade próxima. O padrão de sobreposição de fragmentos cerâmicos, altamente decorados, por fragmentos cerâmicos sem decoração, também foi observado nesse contexto. Essa unidade não apresentou feições, o que a torna importante para o entendimento da estratigrafia do sítio.

\section{Unidade N1125 E1076:}

Localizada em uma área alta à NW do sítio, a implantação dessa área de escavação está voltada para um braço interno do lago Manacapuru. A unidade apresentou uma baixa quantidade de vestígios cerâmicos, exceto em um nível (10-20 cm), no qual foi encontrada uma densidade média de vestígios, desarticulados espacialmente. No entanto, logo abaixo desse nível de ocupação, foi encontrada uma grande estrutura de combustão (feição 1) - bastante distinta daquela encontrada na face NE do sítio. Essa feição, também associada a uma estrutura de combustão, apresentou grande quantidade de carvão, baixa quantidade de vestígios cerâmicos, e pequena quantidade de vestígios faunísticos de tamanho reduzido.

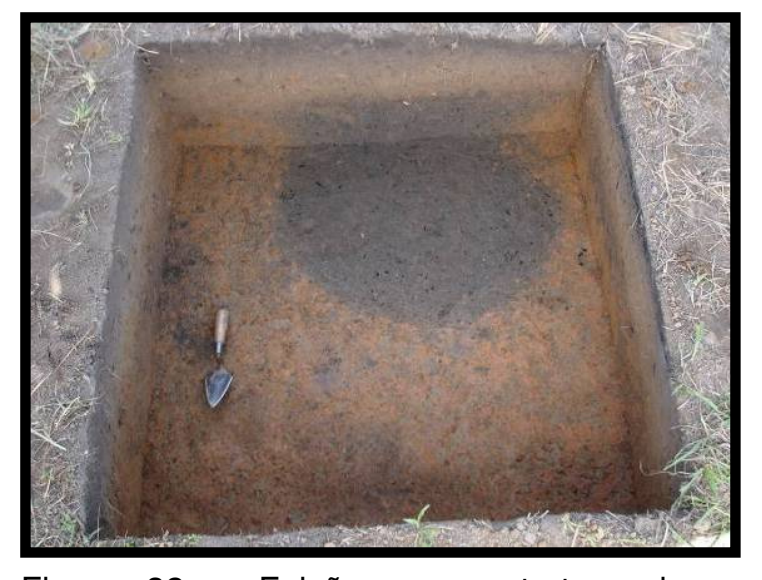

Figura 32 - Feição com estrutura de combustão na unidade N1125 E1076 (foto: Juliana Machado). 
O aspecto mais marcante deste sítio arqueológico é, de fato, a enorme concentração de estruturas de combustão com formas e diâmetros variados (ver mapa). A retirada de uma camada em torno de 20 a $30 \mathrm{~cm}$ do solo superficial em ocasião da abertura da clareira, aliada à posterior erosão pluvial, causou a destruição total do estrato arqueológico em determinadas áreas do sítio, em especial na rampa de acesso à clareira. Por outro lado, esta mesma retirada de solo possibilitou a visualização de tais estruturas de combustão, denominadas feições ( $F+$ numeração). Foram resgatadas sessenta e uma feições. Elas se distribuem em três áreas: na rampa de acesso à clareira (F 26 a 84), na vala Norte (F85a e F85) e na vala Leste (F 25 e F 86 a 91).

Em termos de visibilidade arqueológica, há uma diferença fundamental entre as feições da rampa de acesso e aquelas que foram expostas pelas valas de drenagem. As feições da rampa sofreram um processo de erosão que causou a retirada completa do pacote arqueológico, como uma espécie de "decapagem", que nos permitiu observá-las na superfície em contato com o latossolo alaranjado da formação geológica Alter do Chão (fig 33 e 34). Já as feições das valas foram expostas pelo corte, o que possibilitou a visualização de seu perfil e, como conseqüência a metodologia de intervenção sobre elas foi diferenciada. As feições visíveis na superfície da rampa de acesso foram sinalizadas com bandeirinhas para posterior mapeamento, realizado com uma estação total. $O$ objetivo do mapeamento é entender a relação espacial entre elas, a fim de identificar possíveis funcionalidades das mesmas. Também o diâmetro de cada uma foi registrado (ver mapa). Como se pode visualizar na figura 35 , a densidade de feições expostas pela erosão da rampa de acesso é surpreendente: uma média de cinco feições por $\mathrm{m}^{2}$.

Optou-se por iniciar as intervenções nas feições da rampa de acesso por serem estas mais evidentes e correrem maior risco de destruição, pois estão localizadas na área de escoamento de água e da erosão. Cada uma foi registrada com fotografias digitais, e amostras do material interno foram coletadas. As seguintes informações foram registradas: forma, diâmetro, cor e textura do sedimento interno, tipos e disposição dos materiais. Os carvões foram coletados, mas por serem superficiais, podem estar contaminados, não servindo, portanto, para datação radiocarbônica. 


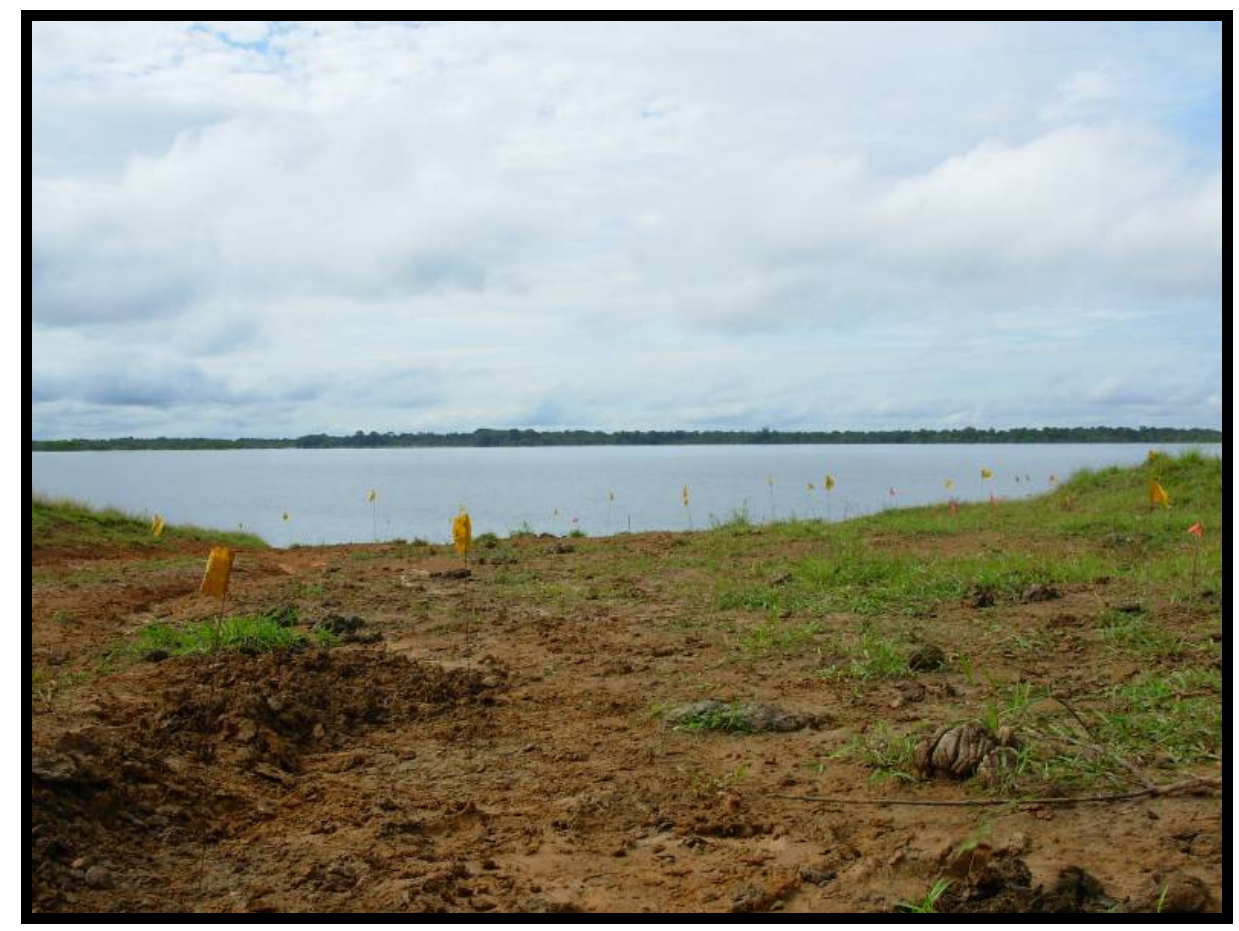

Figura 33 - Feições sinalizadas na rampa de acesso à clareira 28 com vista para o lago de Manacapuru (foto: Helena Lima).

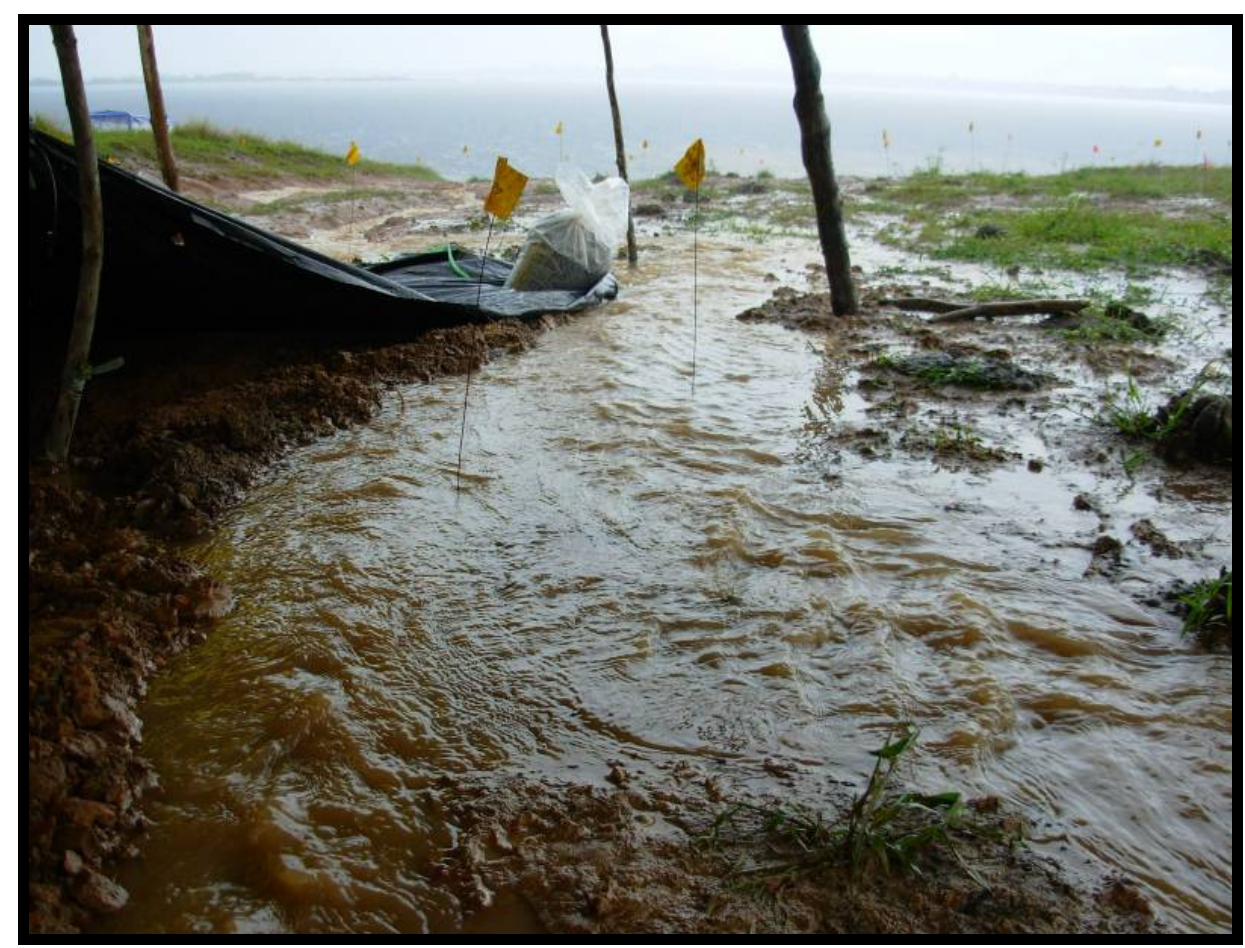

Figura 34 - Feições sinalizadas expostas à forte erosão pluvial (foto: Helena Lima). 
Após as coletas sistemáticas, uma área mais próxima do topo do terreno, e com maior densidade de feições, foi selecionada para a abertura de uma escavação de superfície ampla, com nove metros quadrados, que abrangeu as feições 26 a 32. Decidimos por uma superfície ampla para entender melhor a conexão entre as feições dentro de uma área de atividade do sítio seguramente relacionada à combustão. A figura 3 mostra o primeiro momento da decapagem, onde se escavou entre 1 e $4 \mathrm{~cm}$ para expor as feições e evidenciar seus limites.

Este procedimento possibilitou algumas observações importantes: 1) o contato das feições com o latossolo queimado indica combustão in situ; 2) sua disposição no espaço ocorre em pares, com uma feição maior relacionada com uma menor. Assim, F26 e F27 estão correlacionadas, tanto como F28 e F29, e F30 e também 31 ; 3) embora todas apresentem um mesmo padrão circular, elas diferem em profundidade, composição, e provavelmente em função. Apresentaremos a seguir as feições 26 a 32, expostas na escavação de superfície ampla.

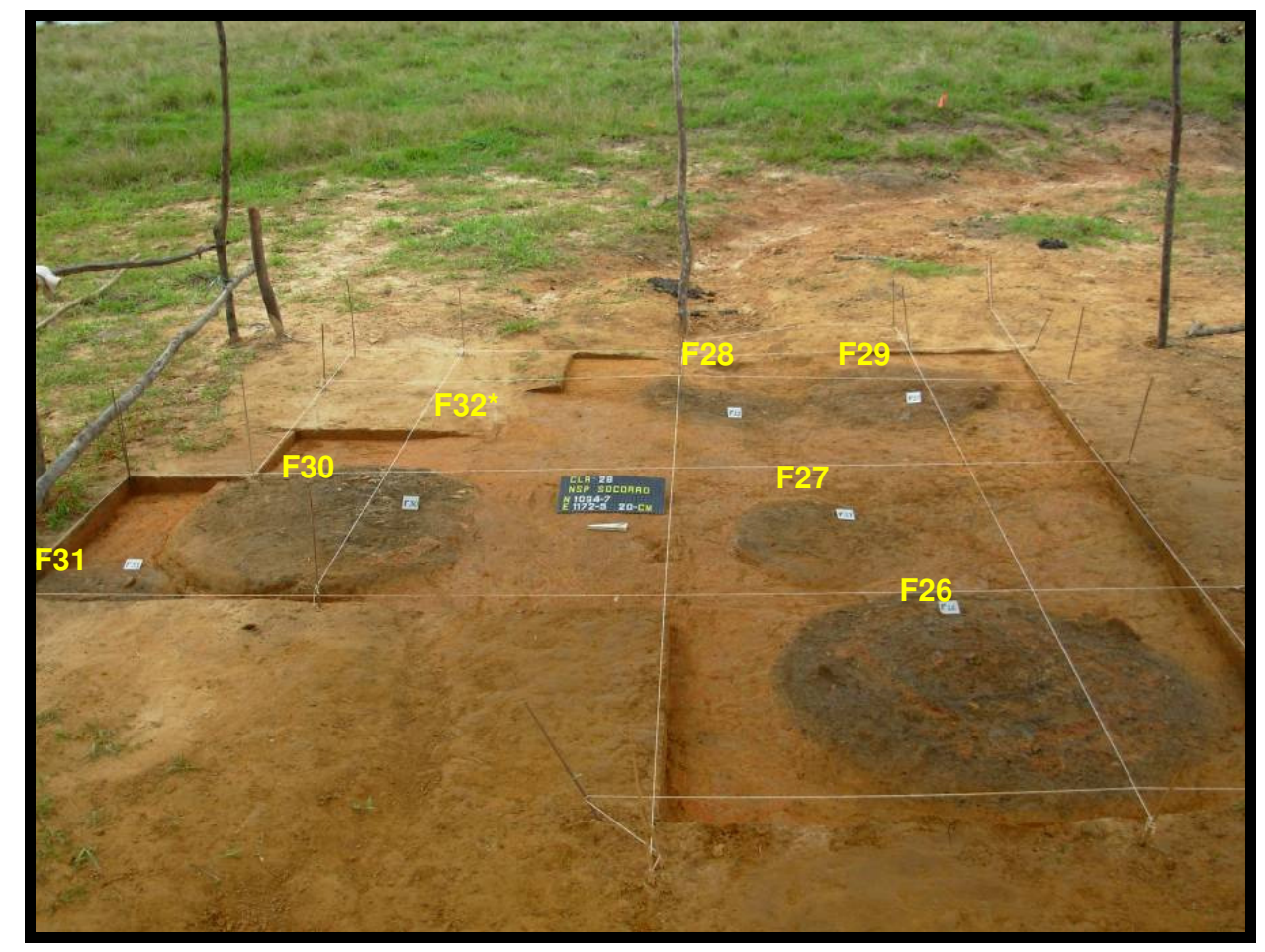

Figura 35 - Escavação de uma superfície ampla abrangendo as feições 26 a 32. Obs. F32 indicada na foto ainda não está evidenciada; a escavação foi expandida posteriormente (Foto: Helena Lima). 
A feição 26 apresentou maior diâmetro e composição mais complexa. A figura 4 mostra as diferentes etapas de sua escavação. A estrutura com forma retangular visível nas fotos (no interior do círculo de solo escuro) é composta por argila queimada de cor alaranjada a vermelha. Ela forma uma espécie de recipiente modelado e queimado in loco. $\mathrm{O}$ sedimento interno do recipiente tem coloração marrom-clara e nele há carvões centimétricos dispersos, ossos pulverizados $^{9}$, pequenos fragmentos de cerâmica, blocos de argila queimada semelhantes àquela do recipiente. Em sua base há três perfurações repletas de grandes pedaços de carvão. Os carvões ocorrem também no entorno do recipiente, junto a um solo de cor cinza-escuro que forma um círculo, e que está em contato com o latossolo.

Procedemos na escavação de F26 da seguinte maneira: retiramos, no início, o conteúdo do interior, até chegar à base de sua face interna. Posteriormente, o material externo foi escavado, deixando apenas a estrutura de argila queimada (o forno) em evidência (fig. 36-c). O recipiente de barro queimado (por nós interpretado como um forno) apresenta três perfurações em sua base; abaixo dele observou-se uma grande quantidade de fragmentos de cerâmica, muito grandes e espessos ${ }^{10}$. Eles estão posicionados horizontalmente, de modo a sustentar a referida estrutura de combustão.
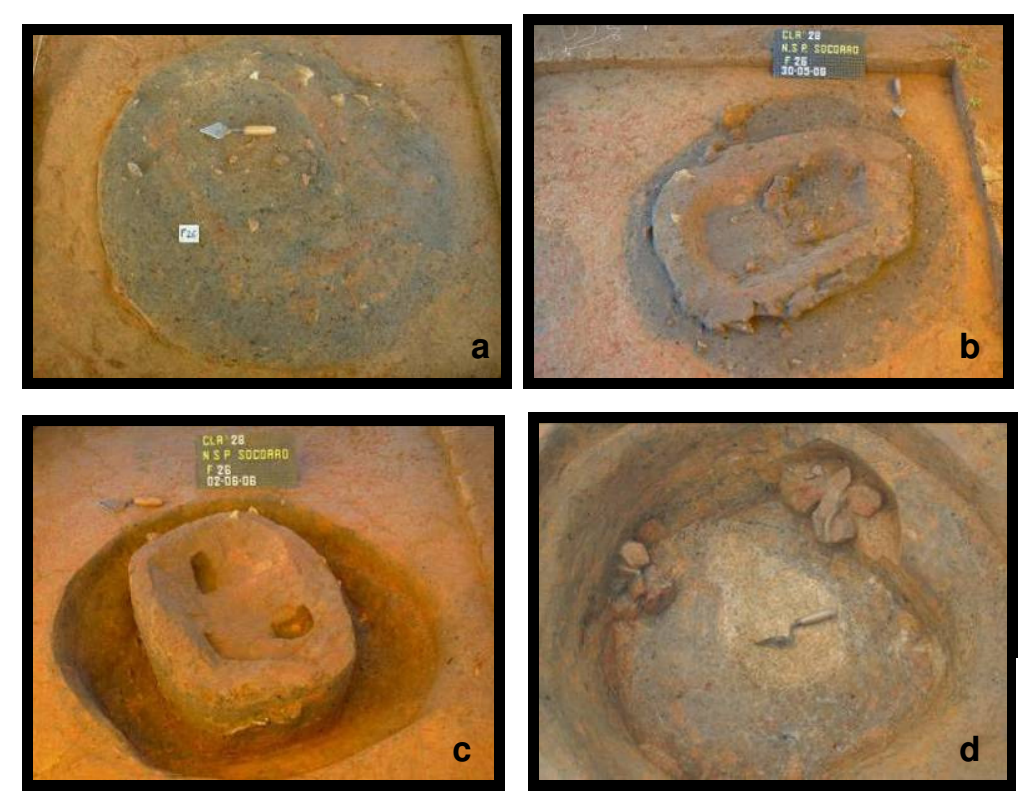

Figura 36 - Diferentes etapas da escavação de F26 (Fotos: Helena Lima).

\footnotetext{
${ }^{9}$ Não se sabe se são realmente ossos pulverizados. Pode ser amido ou mineral. Muitas amostras deste pó de cor branca foram coletadas para análise deste conteúdo interno da feição, que nos auxiliará em sua interpretação.

${ }^{10}$ São principalmente fragmentos de bases, com espessura média de $4 \mathrm{~cm}$ e tamanhos de até $30 \mathrm{~cm}$.
} 
F27 foi muito comprometida pela erosão pluvial causada por um pequeno canal de drenagem. Poucos centímetros restaram da feição, e puderam ser escavados apenas $3 \mathrm{~cm}$ de sua base. F28 e 29 são semelhantes, apresentando formato cônico com base plana. Seu preenchimento é composto por terra preta e argila compacta vermelha, carvão, e poucas cerâmicas. As feições 30 e 31 foram abordadas a partir de metodologias diferenciadas. Por ser a mais profunda, F31 foi escavada pela metade, a fim de obter-se um corte seccionado. Já para feição 30 não haveria sentido em adotar o mesmo procedimento, porque sua profundidade não ultrapassou $5 \mathrm{~cm}$. Assim, F30 foi completamente escavada, deixando seu negativo estampado no latossolo.

Por fim, a feição 32 apresentou um grande diâmetro, mas era pouco profunda. Em seu interior foram escavados ossos longos queimados e dentes. Havia também carvões e cerâmicas, mas em pequena quantidade.

A escavação de sete feições contíguas revelou formas, profundidades e preenchimentos bem diferentes, o que torna esta área do sítio de grande interesse. Tais assimetrias nos levam a inferir funcionalidades variadas para esta mesma área do sítio, mas todas relacionadas à combustão (a única constante foi a presença de carvão, em maior ou menor quantidade, em todas elas). Um importante passo para se entender esta relevante parte sítio arqueológico é a datação destes diferentes contextos, a fim de identificar se são contemporâneos ou não, ou qual foi o espaço de tempo em que foram formados.

Um segundo passo, tão importante quanto o primeiro, é a correlação entre tais estruturas (as feições), e o pacote de ocupação do sítio arqueológico, que é unicomponencial. Para tanto, selecionamos duas áreas diferentes para abertura de unidades de escavação de $1 \mathrm{~m}^{2}$ em locais próximos da rampa de acesso, mas não impactados pelas obras do gasoduto, ou seja, com uma estratigrafia completa passível de associação. Uma delas foi alocada a leste e a outra a oeste da rampa de acesso, a apenas uma pequena distância da área impactada, para assegurar a integridade estratigráfica e, ao mesmo tempo, a possibilidade de correlação espacial.

Tal objetivo foi realizado a contento, uma vez que ambas as unidades apresentaram uma estratigrafia compatível com o restante do sítio, e feições similares àquelas da rampa de acesso em suas paredes. Passaremos para a descrição das unidades escavadas. 


\section{Unidade N 1081 E1183}

Conforme anteriormente mencionado, o objetivo da escavação desta unidade era correlacionar as feições da rampa de acesso ao estrato arqueológico do sítio. Diferente daquelas feições, que se encontram bastante erodidas e com perda total do pacote arqueológico, esta unidade encontra-se numa região menos erodida, num aclive em direção ao nordeste, próximo das feições 40,41 e 76 . A foto abaixo, do perfil Norte da unidade, mostra ocorrência de uma nova feição, denominada F84. Ela se torna perceptível logo abaixo do pacote arqueológico, a partir dos $20 \mathrm{~cm}$ de profundidade, ocorrendo até aos $70 \mathrm{~cm}$. $O$ solo do interior da feição é menos compacto e apresenta uma coloração diferenciada em relação à matriz. Assim como aquelas encontradas na rampa, a feição 84 foi escavada no latossolo a partir do nível de ocupação Manacapuru; seus limites são bem marcados e o preenchimento é composto por lentes de carvão intermediadas por latossolo.

Os dados fornecidos pela escavação desta unidade nos auxiliaram na interpretação das demais feições presentes nesta área do sitio, realizando assim o objetivo desta escavação, que era relacionar as feições ao pacote arqueológico.

\section{Unidade N 1068 E1169}

Também esta unidade foi aberta com o intuito de correlacionar as feições da rampa com o estrato arqueológico do sítio. Mais uma vez, tivemos a sorte de localizar uma feição ocorrendo na parede Leste da unidade, também imediatamente abaixo do pacote cultural. Foi denominada F92, e tem forma irregular. Seus limites não são bem definidos, principalmente na extremidade sul. A figura abaixo demonstra a ocorrência de grandes fragmentos de cerâmica na base de F92, que é abaulada. Assim como nas demais feições, F92 apresenta um solo escuro, carvões e também latossolo em seu interior. 

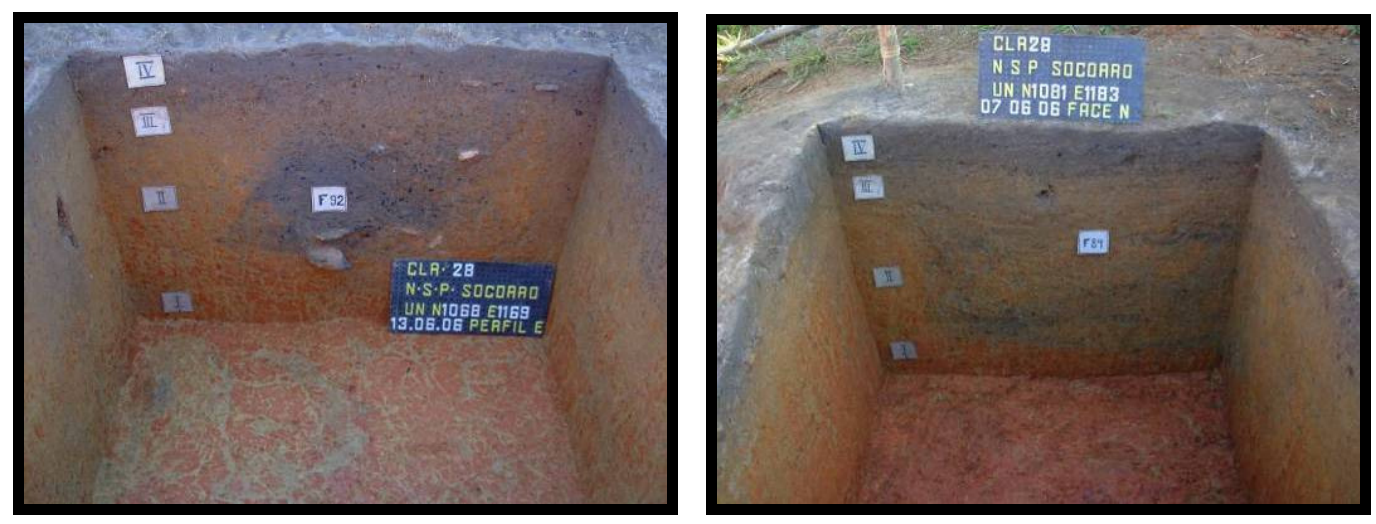

Figura 37 - Perfil Leste da unidade N1068 E1169, com a Feição 92, e perfil Norte da unidade N1081 E1182, notar a presença da Feição 84 (Fotos: Helena Lima)

A erosão pluvial que ocorre em várias áreas do sítio, com maior incidência na rampa de acesso, levou ao desenterramento parcial de um fragmento cerâmico muito característico da fase Manacapuru. Tratava-se de um belo flange labial com decoração incisa e modelada. Para que se pudesse registrar com critério o contexto de tal recipiente, que ocorria no interior de uma feição (F83), marcamos uma unidade com $0,5 \times 0,5 \mathrm{~m}^{2}$. Muitos carvões e amostras de solo foram coletados do interior de F83 para análise e datação radiocarbônica. A datação obtida confirmou o padrão esperado, situando este conjunto na Tradição Borda Incisa. O recipiente estava fragmentado, mas boa parte dele foi remontada no laboratório de restauração do MAE-USP, para onde foi encaminhado.

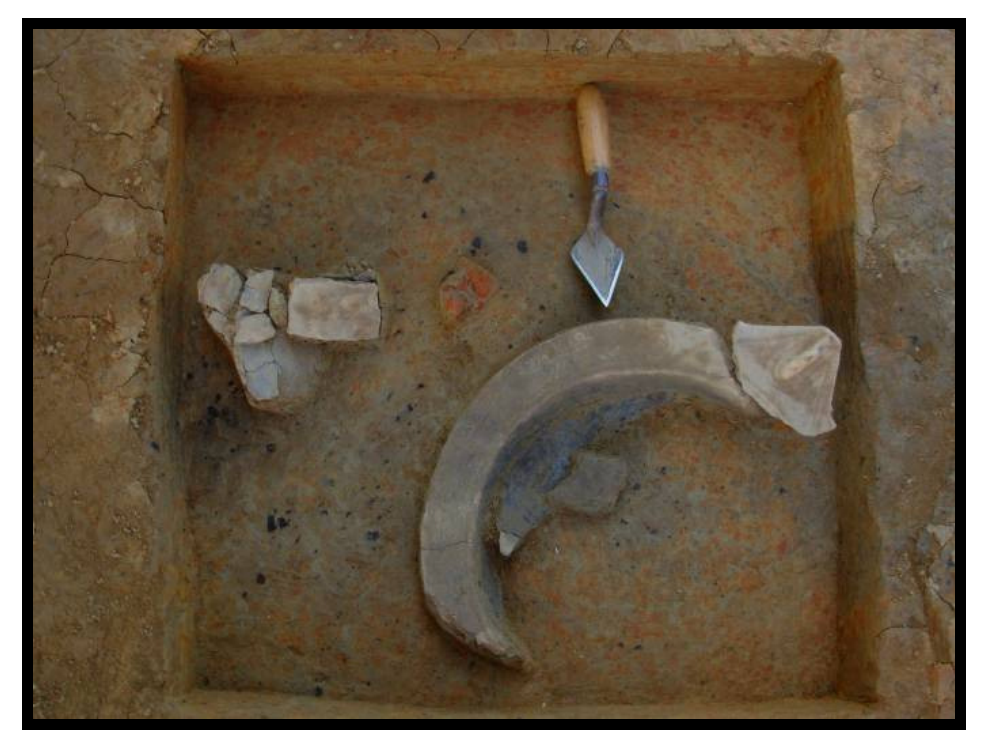

Figura 38 - Unidade com $0,5 \times 0,5 \mathrm{~m}^{2}$, também aberta na rampa de acesso, com o objetivo de evidenciar uma vasilha Manacapuru exposta pela erosão pluvial (foto: Helena Lima). 


\section{Vala Leste e Vala Norte}

Além dos trabalhos realizados na rampa de acesso e em seu entorno, as duas valas abertas para drenagem da clareira foram trabalhadas, a partir de uma metodologia diferenciada. Estas foram denominadas Vala Leste e Vala Norte, e uma série de feições apareceram no corte (ver mapa).

Fizemos, a princípio, uma limpeza com colher de pedreiro em cada uma delas, a fim de observar a estratigrafia e evidenciar os limites de cada uma das feições. Os perfis foram fotografados e desenhados (ver desenhos), e amostras de solo de cada camada estratigráfica, bem como do interior de cada feição, foram coletadas.
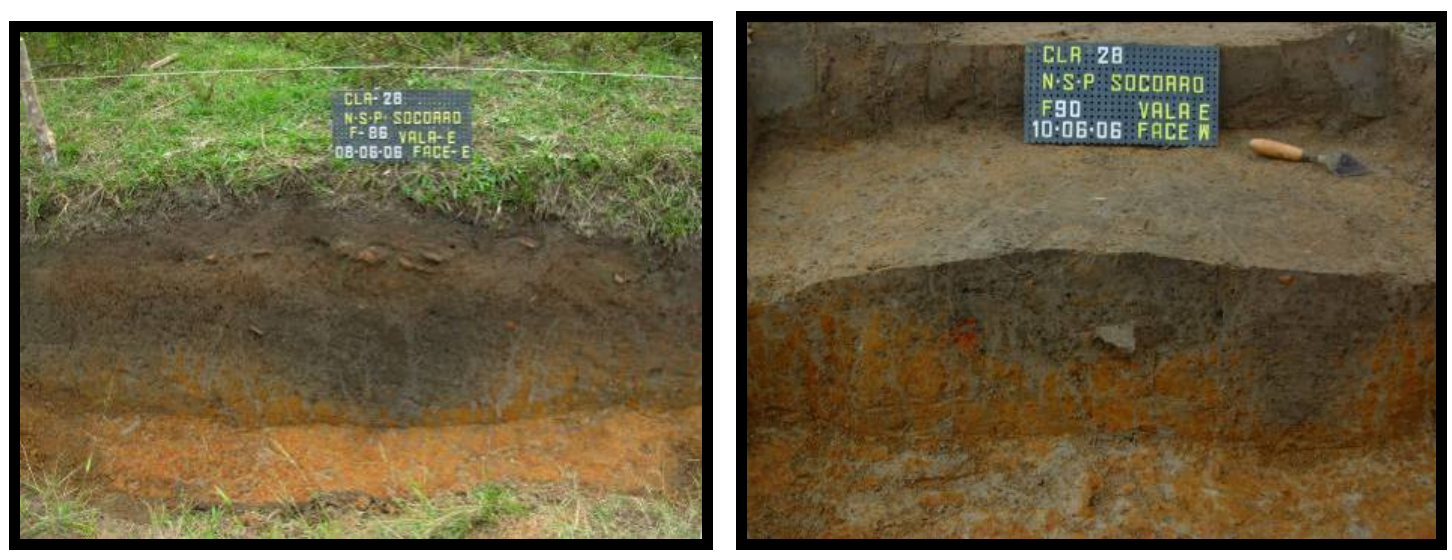

Figura 39 - Vista geral das valas Norte e Leste, e feições na vala Leste (Foto: Helena Lima).

\section{Cronologia de ocupação e uso do espaço}

De acordo com os dados discutidos, NSP Socorro se mostra um caso emblemático na interpretação dos processos de formação das Terras Pretas de Índio. A presença de nada menos que oitenta e quatro estruturas de combustão repletas de matéria orgânica parece indicar, mais do que os usos cotidianos de cozimento de alimentos, certa intencionalidade no processo de alteração das propriedades físicas deste solo; ainda mais quando se aventa certa contemporaneidade (ainda em caráter especulativo) entre elas.

As inúmeras feições agregadas em áreas contíguas, com um sedimento e a matriz deste sítio contendo uma alta densidade de matéria orgânica (em parte em função de eventos de inundação e também pelas próprias feições) são dados 
indicativos deste processo. Mais ainda, as datas obtidas corroboraram esta hipótese, ajudando na interpretação não só deste sítio, mas de vários outros.

As duas datações radiocarbônicas obtidas para o sítio arqueológico são provenientes de áreas compostas por feições. A data de 220 d.C. foi obtida do interior de F83, enquanto que a data de 20 d.C. foi obtida do sedimento imediatamente acima de uma outra feição, também caracterizada pela alta incidência de carvões e cerâmicas, indicando um espaço de tempo de duzentos anos entre uma e outra, ou seja, duas ou três gerações, mas, desde uma escala mais abrangente, pode-se inferir relativa contemporaneidade.

\begin{tabular}{|c|c|c|c|c|}
\hline $\begin{array}{c}\text { Número do } \\
\text { Laboratório }\end{array}$ & Amostra & Proveniência & Nivel & $\begin{array}{c}\text { Idade calibrada } \\
\mathbf{( 6 6 . 8 \% )}\end{array}$ \\
\hline BETA 242450 & NSPS1767 & F83 & $0-10 \mathrm{~cm}$ & 130 d.C. -240 d.C \\
\hline BETA 242449 & NSPS1672 & N1087 E1173 & $10-20 \mathrm{~cm}$ & 30 a.C.-60 d.C. \\
\hline
\end{tabular}

Tabela 7 - Datas calibradas obtidas para o sítio Nossa Senhora do Perpétuo Socorro.

A associação entre as coleções cerâmicas de NSP Socorro e seu contexto, talvez datando o início do processo de formação das terras pretas, também lançam luz a uma compreensão mais orgânica da história de ocupação deste sítio e da região. Explico: dentro de uma postura normativa, conjuntos Manacapuru deveriam ser mais recentes, pois datariam a própria terra preta na Amazônia central. Encontrar neste sítio cerâmicas Manacapuru tão antigas quanto as da fase Açutuba, relacionadas a um hipotético processo de formação de terra preta, antes de quebrar a hipótese proposta (LIMA et al., 2006) vem preencher uma lacuna no entendimento de tais questões.

Compreender este processo significa ser capaz de pensar em profundidade na relação entre aqueles por detrás das fases Manacapuru e Açutuba, o que aparenta ter um sentido de continuidade - muito mais do que de substituição ou ruptura, com a intensificação de determinados comportamentos associados ao seu modo de vida e que vão levar, dentre outras coisas, à formação das terras pretas. Caso esta interpretação esteja correta, este sítio aparenta ser uma espécie de "laboratório" de produção das TPI, o que o torna exemplar para entender a formação destes solos antrópicos. 
Através do exposto até o momento, fica clara a alta relevância científica deste sítio arqueológico e seu grande potencial de fornecer preciosas informações acerca da história pré-colonial do Baixo Solimões e da Amazônia central como um todo. Os contextos de combustão bem preservados, associados a uma ocupação Manacapuru antiga, demandam que mais esforços sejam voltados para este sitio arqueológico, que tem sua destruição iminente. Futuros trabalhos em laboratório e mais datações virão a contribuir para entendimento funcional destes contextos. Ainda assim, pode-se dizer que os trabalhos realizados no sítio NSP Socorro nos fornecem uma situação privilegiada, considerando tratar-se de um contexto de arqueologia de contrato. A quantidade de informações coletadas em diferentes etapas de campo proporcionou dados para que se fosse capaz de chegar a tais conclusões, ainda que preliminares, acerca de questões tão caras à arqueologia da Amazônia como um todo. É importante ressaltar que os trabalhos foram feitos a fim de impedir que tais informações fossem perdidas, haja vista que a destruição do sítio seria inconteste. 


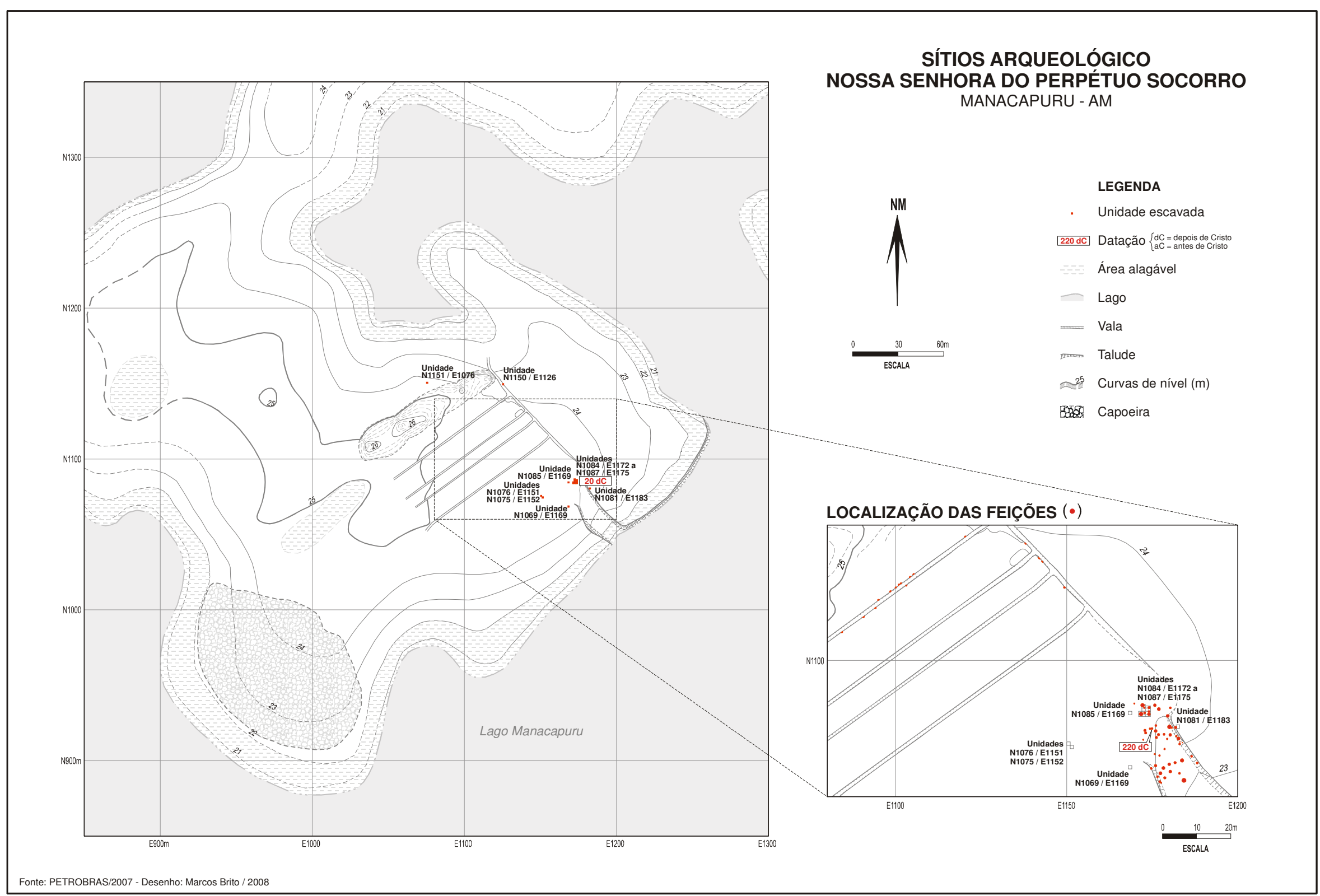

Figura 40 - Planta topográfica do sítio NSP Socorro, com intervenções arqueológicas realizadas e datações radiocarbônicas. 


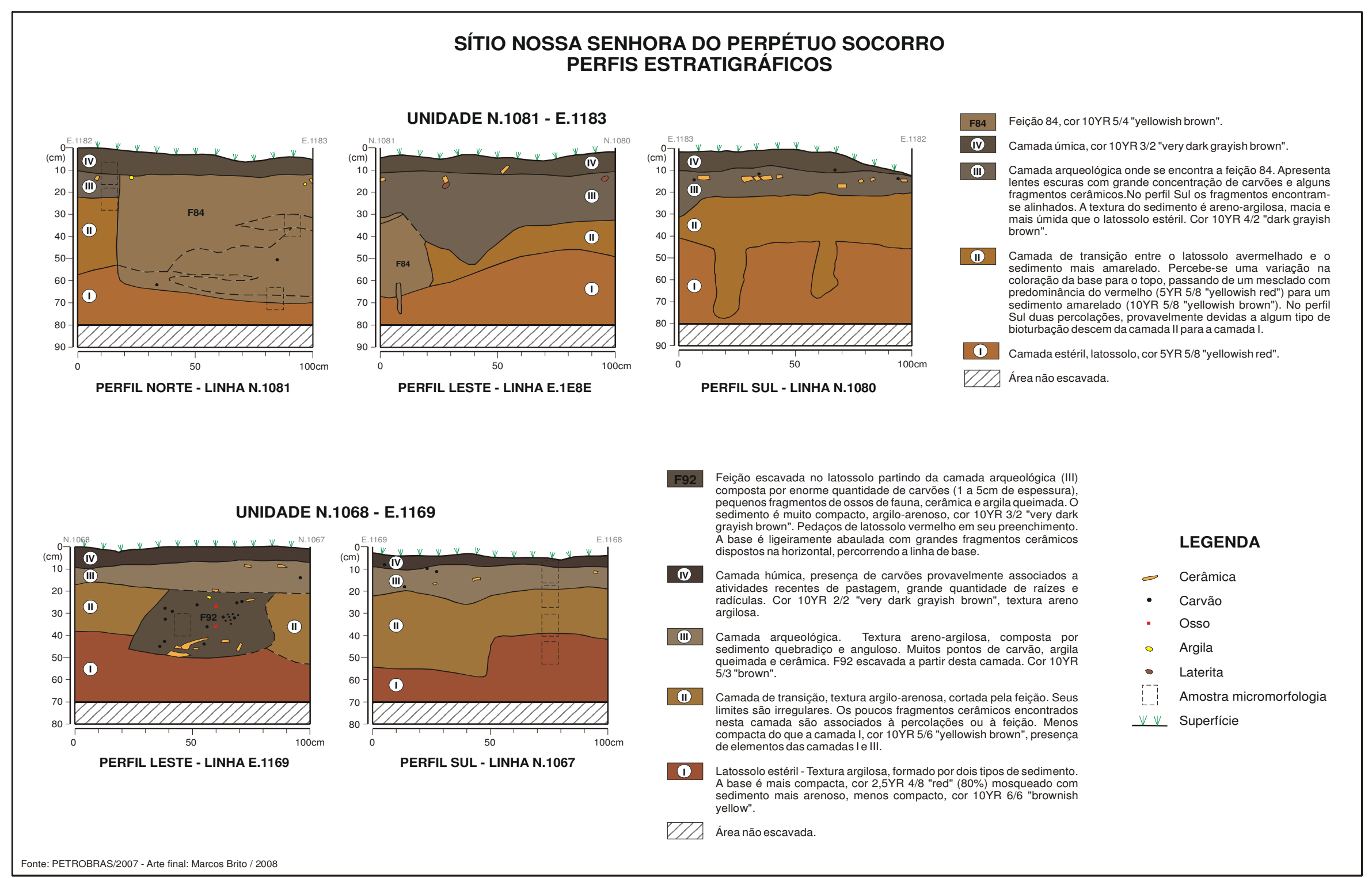

Figura 41 - Perfis das unidades escavadas no sítio N S P Socorro. 


\section{IV. II. Sítio Hatahara, na barranca do Solimões}

O sitio Hatahara (Am-Ir-13) está implantado sobre um alto terraço com vertente abrupta e topo aplainado, na margem esquerda do rio Solimões, adjacente a uma várzea pouco extensa. Localiza-se em uma área urbanizada na sede do município de Iranduba, a uma distância de $24,5 \mathrm{~km}$ de Manaus em linha reta, ou de $28 \mathrm{~km}$ pela estrada e balsa. Como se vê, o acesso a este sítio é bastante fácil, o que possibilitou trabalhos mais intensivos em Hatahara. Esta é uma situação privilegiada frente a outros contextos amazônicos.

Identificado em 1997, este sítio arqueológico vem sendo escavado com freqüência desde 1999, com um total de cinco etapas de campo, cada uma com duração variando entre um e dois meses. A última etapa, realizada no ano de 2006, contou com a presença de mais de cinqüenta pessoas entre estudantes, pesquisadores e colaboradores de diversos locais do Brasil e do exterior. Tamanha estrutura nos possibilitou concentrar muitos esforços no sítio, totalizando 41,6 $\mathrm{m}^{2}$ de intervenções no sítio, através, inclusive, de escavações em superfícies amplas, que possibilitaram um melhor entendimento da espacialidade das diferentes ocupações intra-sítio. Suas dimensões aproximadas são de 400×400 m e , assim como grande parte dos sítios arqueológicos localizados na área de confluência dos rios Negro e Solimões, Hatahara é multicomponencial e apresenta em sua seqüência estratigráfica os quatro conjuntos conhecidos na Amazônia central: Açutuba, Manacapuru, Paredão e Guarita.

A característica mais marcante deste sítio arqueológico é a presença de uma série de montículos com formas e tamanhos variados, dispostos na área do sítio de forma semicircular, com centro voltado para o rio (ver mapa). Estes montículos aparentam ter funções distintas, incluindo a habitacional e a funerária (Machado, 2005; Moraes, 2007). Assim como em diversos outros sítios da Amazônia central, a construção de montículos artificiais é um traço cultural associado às ocupações relacionadas à fase Paredão, que marca o momento em que a região foi mais densamente povoada. Já associadas à ocupação mais recente do sítio, as cerâmicas da fase Guarita afloram na superfície do terreno ou encontram-se numa profundidade de até 20 ou $30 \mathrm{~cm}$ apenas. 
O material considerado neste estudo, relacionado às ocupações Açutuba e Manacapuru, visava entender as relações contextuais entre essas duas fases cerâmicas. Para tanto, selecionou-se duas áreas diferentes dentro do sítio. Uma delas é o montículo 1, que é, de uma forma geral, bem conhecido, através, inclusive, de escavações em trincheira e superfície ampla. Um total de $25,35 \mathrm{~m}^{2}$ foi escavado neste montículo, que tem uma área de aproximadamente $1730 \mathrm{~m}^{2}$. A partir de tantos esforços, apreendeu-se a seqüência estratigráfica dessa área do sítio, que é composta por cinco camadas: 1) latossolo amarelo estéril; 2) nível de ocupação da fase Açutuba, considerado nas análises cerâmicas; 3) cerâmicas de ocupação Manacapuru, com várias intrusões, seja por feições mais recentes, ou por percolações de cerâmicas Paredão; 4) camada do montículo, com cerâmicas majoritariamente Paredão, mas com refugos secundários dos demais conjuntos; e 5) camada superficial, com cerâmicas Paredão e Guarita, perturbada por atividades agrícolas recentes.

As cerâmicas e terras pretas utilizadas como materiais construtivos para elevação do

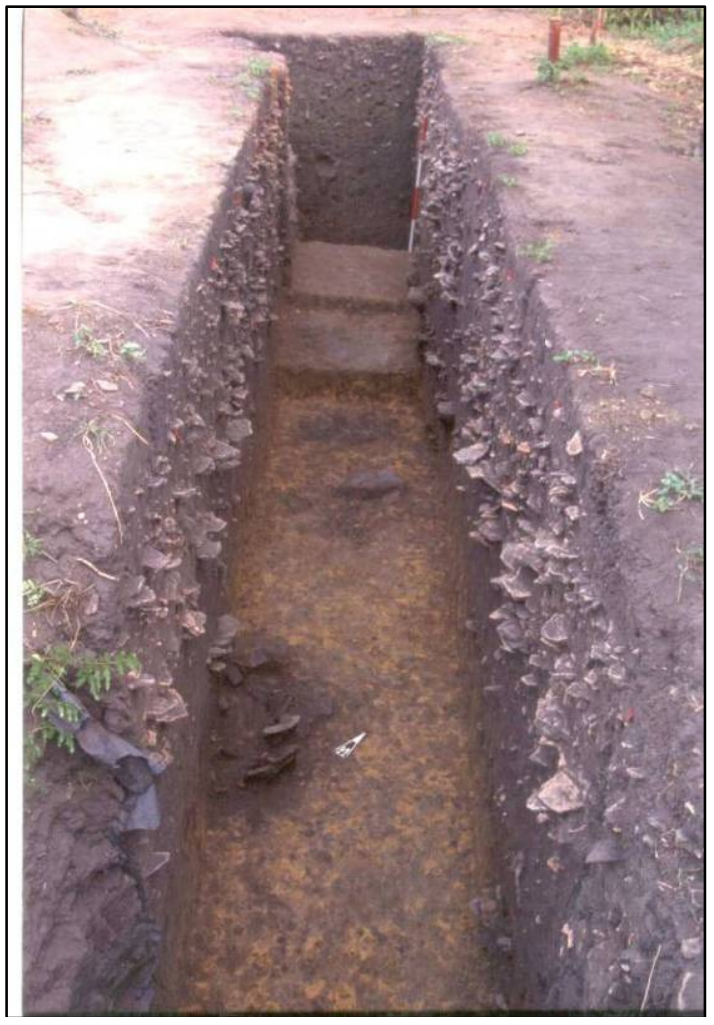

Figura 42 - Trincheira escavada no montículo 1. Em evidência estão feições anteriores ao evento do montículo (foto: E. Neves, 2001) montículo (Machado, 2005) atuam como uma verdadeira cobertura que encapsula em seu conteúdo, configurando a esta área ótima preservação, fato incomum nos solos amazônicos. Preservou-se uma série de sepultamentos humanos, diretos ou não, de onde foi possível identificar uma função funerária a este montículo (PyDaniel, 2006; Machado, 2005). Também desta região foi recolhida grande quantidade de ossos de animais em ótimas condições de preservação (Farias, 2006). Nota-se também a existência de variabilidade funcional entre os montículos dentro do sítio arqueológico. Um estudo comparativo entre os montículos 1 e 2 mostraram que, embora construídos através das mesmas técnicas, seu conteúdo difere: não se observou vestígios ósseos, de fauna ou humanos, no montículo 2, sugerindo variação funcional entre eles (Tamanaha, 2006). 
Interessam-nos, da área do montículo 1, apenas os contextos associados às camadas dois. Isto porque, além de irem de encontro com as questões colocadas frente ao registro arqueológico neste sítio, os materiais provenientes das demais camadas apresentam estratigrafias complicadas, geralmente invertidas, que impossibilitam um estudo cronológico tal como proposto, e demandam tratamentos e questões específicos. Portanto, neste projeto, que tem preocupação contextual-estratigráfica, procurei trabalhar com materiais anteriores à formação do montículo, bem como de outras áreas não monticulares. Optei por trabalhar com estes conjuntos por serem ocupações anteriores à formação da terra preta e do montículo, depositadas no latossolo amarelo. $\mathrm{O}$ resultado das análises cerâmicas indicou tratar-se, de fato, de um componente associado à fase Açutuba, colaborando para a definição e caracterização dessa fase. É interessante notar que, diferente do sítio Açutuba, a matriz do sítio Hatahara é argilosa, sendo que a ocupação da fase Açutuba está depositada no latossolo (e não no espodossolo, como em Açutuba).

A segunda área de interesse para este estudo é limítrofe do sítio arqueológico (mapa), onde ocorrem materiais associados às ocupações Açutuba, Manacapuru e Paredão. A primeira intervenção neste local ocorreu em 2002, quando foram exumados dois vasos inteiros, associados à fase Manacapuru, numa unidade de escavação com $1 \times 1,5 \mathrm{~m}$. Além destes, outros dois vasos semelhantes aos primeiros ficaram expostos nas paredes da unidade. Também muito próximo deste agrupamento de vasilhas evidenciou-se uma enorme concentração de cerâmicas, estruturadas entre si, e que pareciam estar relacionadas à fase Açutuba. Esta concentração, denominada de F3, sugeria ser anterior ao evento de deposição dos vasos, uma vez que encontrava-se cortada por um deles. Tal configuração, disposta numa área tão reduzida quanto três metros quadrados, nos levaram a retornar a esta área do sítio em 2006, para abordá-la com uma escavação em superfície ampla, com 12,5 m². 


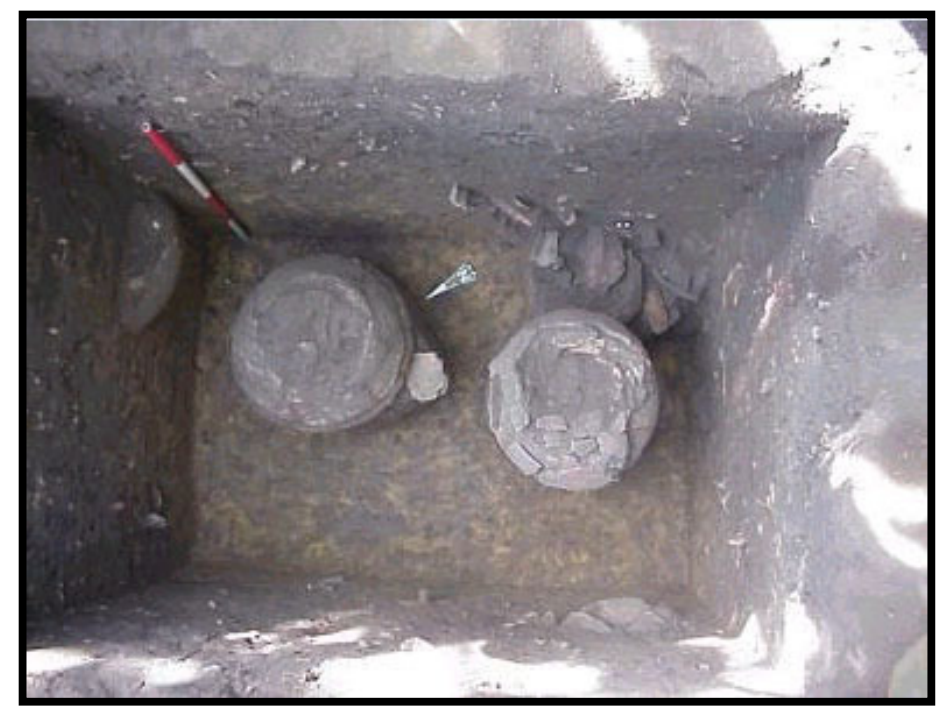

Figura 43 - Unidade com 1 x 1,5 m. escavada em 2002. Em evidência estão dois vasos Manacapuru em pedestais e outros dois nas paredes Norte e Leste (foto: E. Neves, 2001)

Como era de se esperar, a escavação desta área, desta vez em superfície ampla, rendeu belos frutos. Destacaram-se nove vasilhas inteiras, em contextos Manacapuru e Açutuba, além de uma série de estruturas e feições em contextos intactos. Também a seqüência crono-estratigráfica pôde ser entendida com maior acuidade.

Da superfície para a base, a seguinte seqüência foi observada: até os 40 cm ocorrem cerâmicas Paredão em alta densidade, numa matriz de terra preta muito escura. A partir desta profundidade, materiais Manacapuru co-ocorrem com cerâmicas Paredão, cuja proporção diminui com a profundidade, bem como a coloração da terra preta se torna mais clara com tendência a tonalidades marrons. Já em 70 cm, atinge-se um nível de ocupação Manacapuru, com solo e cerâmicas muito compactados, e começam a aparecer os recipientes inteiros. É interessante notar que, neste caso, a identificação de um piso de ocupação, ocorrida inicialmente de maneira intuitiva a partir da própria observação do registro material ainda em campo, foi , numa etapa posterior, confirmada a partir de estudos de micromorfologia de solos, como mostra a figura abaixo: 


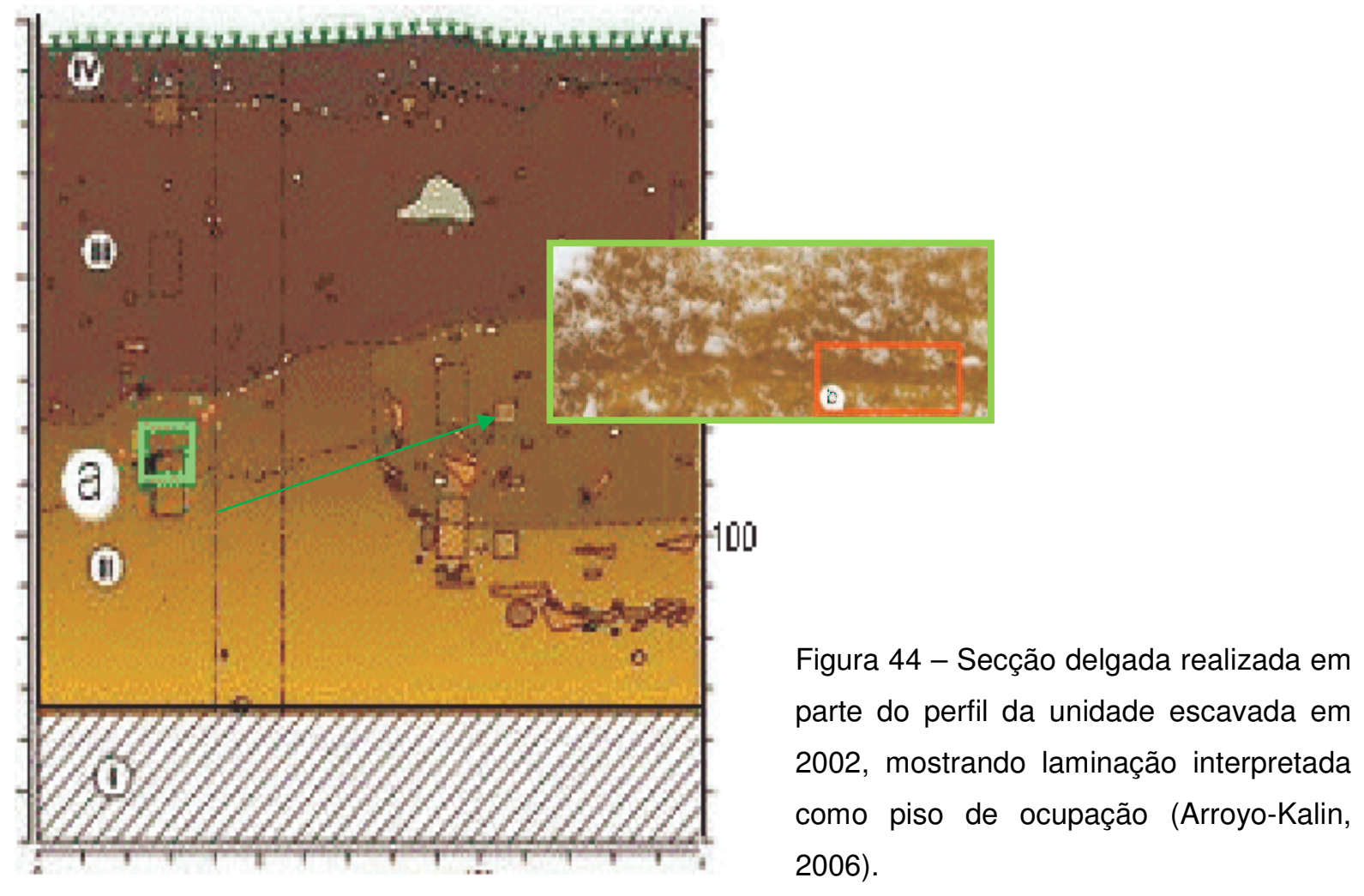

A partir desta profundidade, teve início o nível de ocupação Açutuba, que também é interceptado por uma série de feições e pela própria deposição dos vasos Manacapuru. Na base do nível de $100 \mathrm{~cm}$, bem abaixo do estrato Manacapuru, a densidade de cerâmicas e feições relacionadas à fase Açutuba aumenta de maneira expressiva. Podem indicar que foram depositadas com uma estruturação intencional ou que são, de fato, representativas da densidade e distribuição da fase Açutuba. Este estrado apresenta uma matriz com solo mesclado entre terra preta e latossolo amarelo. Nesse caso, a terra preta pode ter percolado dos níveis superiores.

Também relacionado à ocupação mais antiga do sítio, um recipiente inteiro, cujas características e contexto o vinculam à fase Açutuba, foi registrado. Ele se encontra, aparentemente, in situ. À exceção do mencionado recipiente 7 (fig 45), as demais vasilhas exumadas estão relacionadas à ocupação Manacapuru. São morfologicamente semelhantes, mesmo com tamanhos diferenciados. Segue uma breve descrição dos vasos e seus contextos: 
- Os recipientes 01 e 02, retirados na campanha de 2002, apresentavam engobo vermelho e tampa com decoração incisa em sua face externa.

- O recipiente 03 não parecia ter tampa, mas a parte superior do vaso se apresentou bastante fragmentada. Sua superfície encontra-se bem desgastada. Tem o maior diâmetro em comparação aos outros recipientes, com $50 \mathrm{~cm}$. Seu topo aparece a $80,5 \mathrm{~cm}$ de profundidade.

- O recipiente 04, um alguidar sem decoração, apresenta um bojo bem marcado, mas com contorno simples. Seu topo a aparece a $74 \mathrm{~cm}$ de profundidade. Há uma concentração de ossos de fauna queimados em seu entorno.

- O recipiente 05 estava depositado sobre o recipiente 06 , sendo menor que os outros recipientes, mas semelhante em sua morfologia.

- O recipiente 06 apresenta tampa com engobo vermelho, encontra-se parcialmente fragmentado.

- O recipiente 07 ficou evidenciado no perfil Leste da escavação. Diferentemente dos outros, sua morfologia é peculiar: com pescoço, borda extrovertida, contorno complexo e engobo branco. Sua forma parece de urnas tipicamente Guarita, mas isso é algo que ainda não conseguimos confirmar, pois ainda não foi tratado no laboratório. Essas semelhanças e os problemas trazidos por ela já foram discutidos anteriormente (Lima, 2003). Eles são não corroboram parte das expectativas arqueológicas propostas pela hipótese de ocupação da Amazônia central proposta por Lathrap (1970a). Aparentemente o recipiente não foi enterrado: encontra-se in situ. Há uma quantidade razoável de fragmentos associados a ele que, aparentemente, também pertencem à fase Açutuba. $O$ recipiente tem $23 \mathrm{~cm}$ de altura.

- O recipiente 08 também aparece coberto por uma tampa.

- O recipiente 9 tem uma forma Manacapuru clássica, com borda infletida (carenada). É muito parecido com o vaso retirado no sítio Paricatuba, também na área de pesquisa. 


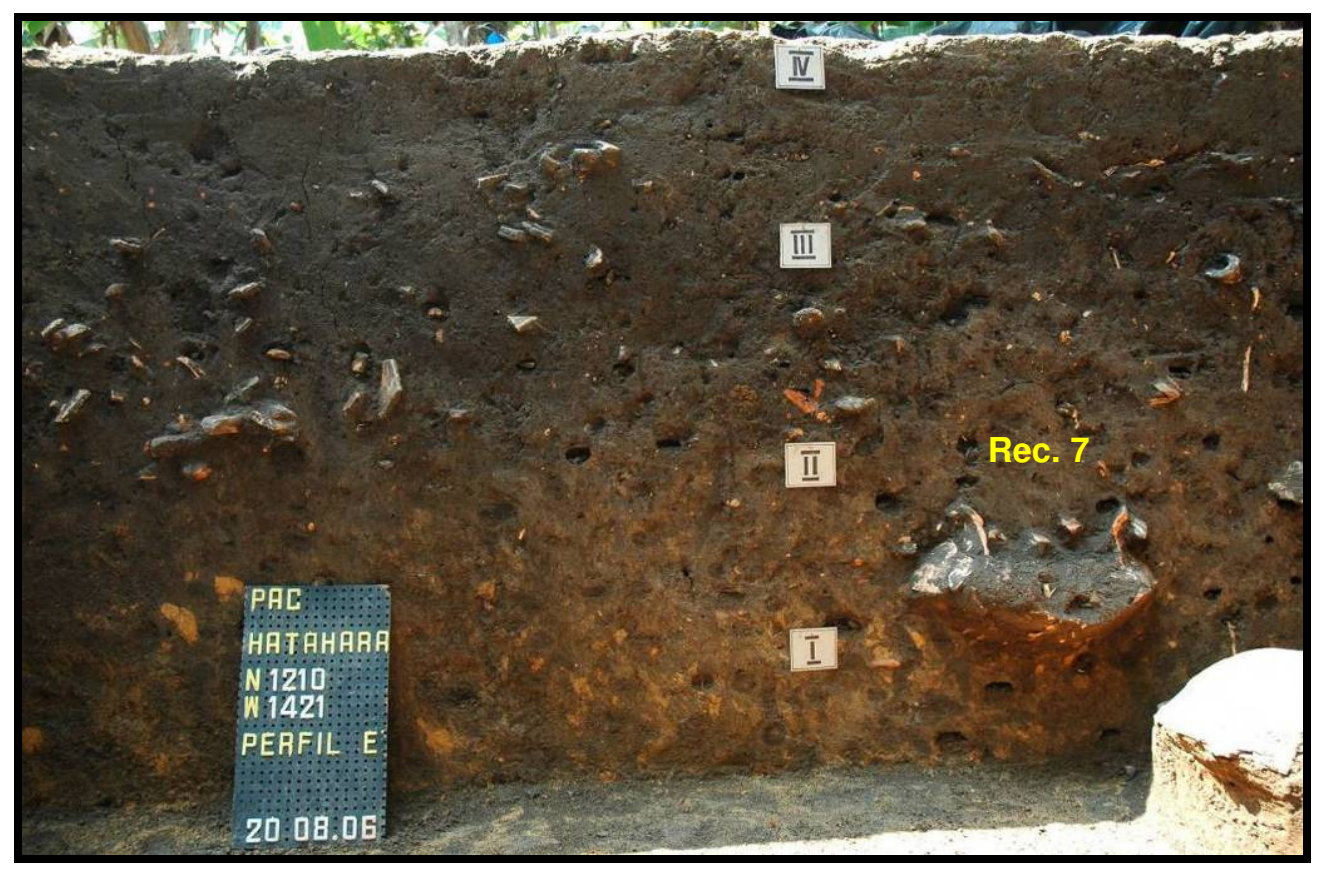

Figura 45 - Área de ocorrência de vasos inteiros, vaso $n^{0} 7$ evidenciado no perfil entre camadas I e II (foto: Val Moraes).

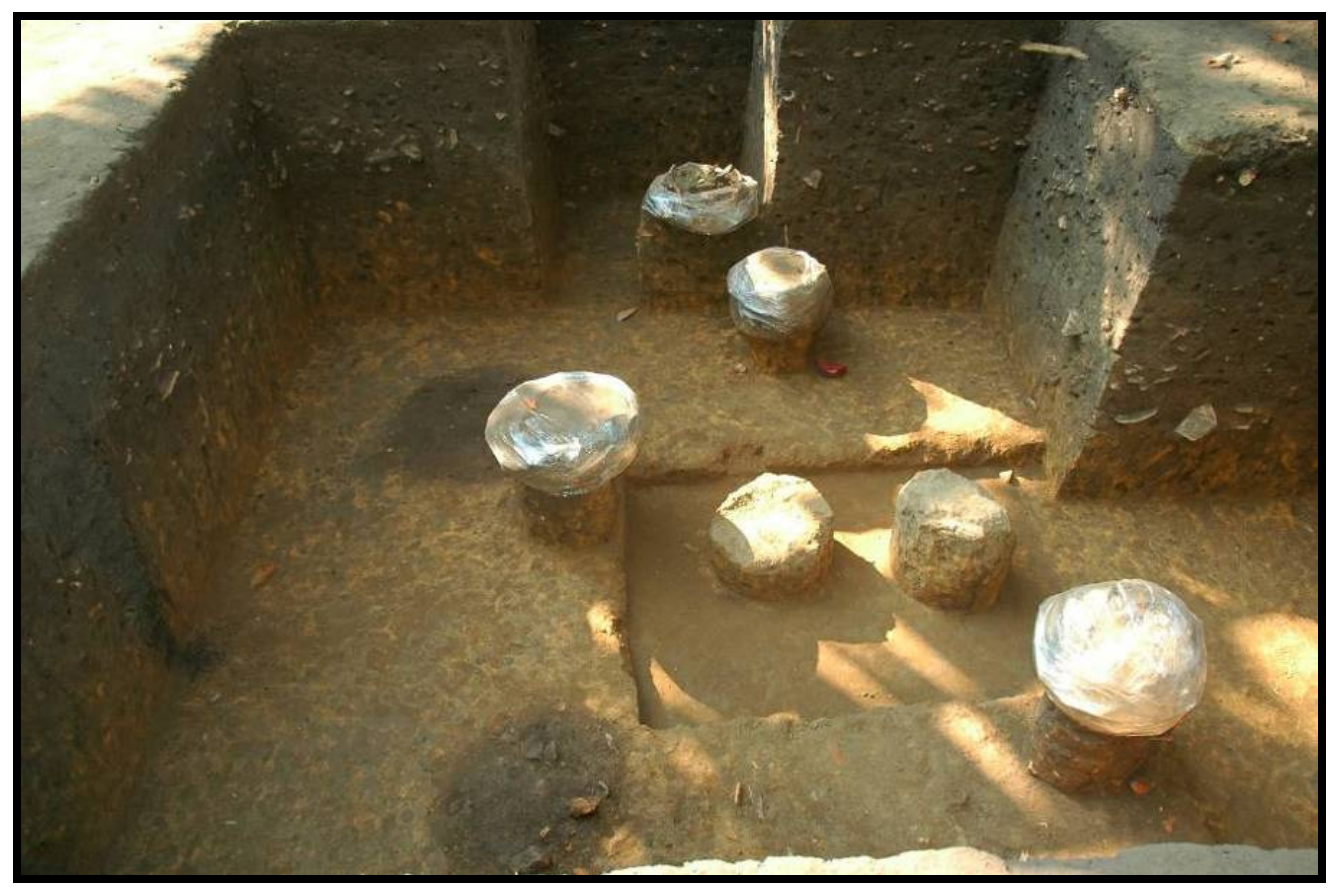

Figura 46 - Área com ocorrência de vasos inteiros da fase Manacapuru: vista das feições arredondadas e escuras cavadas no latossolo amarelo (foto: Val Moraes). 
Além do vasilhame exumado, foram registradas também oito feições nesta área do sítio. Nem sempre os limites entre uma feição, ou seja, um agrupamento de vestígios estruturados, e uma concentração ou piso de ocupação são muito claros. Das feições identificadas com precisão, aquelas com características Paredão são visíveis a partir de aproximadamente $40 \mathrm{~cm}$. F12 mostrou-se densa, com as cerâmicas depositadas, em sua maioria, na vertical. Também F13, F14 e F20, todas marcadas nos perfis, parecem estar relacionadas a esta ocupação mais recente da área. Presume-se que sejam marcas de buracos de esteio, que se projetam em grande profundidade sobre os estratos mais antigos. A própria deposição das vasilhas Manacapuru, que também interceptam um nível de ocupação anterior, constituem-se em feições e foram tratadas como tal. Por fim, das feições vinculadas à fase Açutuba, F3, F15, F19 e F27, apenas as duas primeiras eram agrupamentos claramente estruturados. $\mathrm{F} 3$, inclusive, mostrou-se composta por camadas intercaladas de cerâmica, dispostas num arranjo de forma circular e concêntricas, sugerindo eventos de deposição distintos, cujo espaço de tempo entre elas ainda não são conhecidos. Já F19 e F27, mesmo depois das análises, deixaram dúvidas se eram de fato feições ou uma concentração característica de um piso de ocupação perturbado, com certeza, pelas ocupações posteriores no sítio arqueológico.

Como se pode ver na planta baixa da escavação, (fig 46), a disposição espacial das vasilhas sugere um padrão linear: elas parecem ter sido depositadas em duas linhas, no sentido leste-oeste. Outro aspecto importante desta área do sítio é mostrado na figura 47, uma fotografia da escavação tirada em aproximadamente um metro de profundidade, onde se tem um interessante padrão de distribuição dos materiais. Observa-se, a uma mesma profundidade, um piso de ocupação Açutuba interceptado pela deposição de recipientes Manacapuru e pelas feições Paredão. Ou seja, ocorrem, num mesmo plano horizontal, pelo menos três componentes cronologicamente distintos, o que vem a dificultar as interpretações com base em dados apenas estratigráficos. 


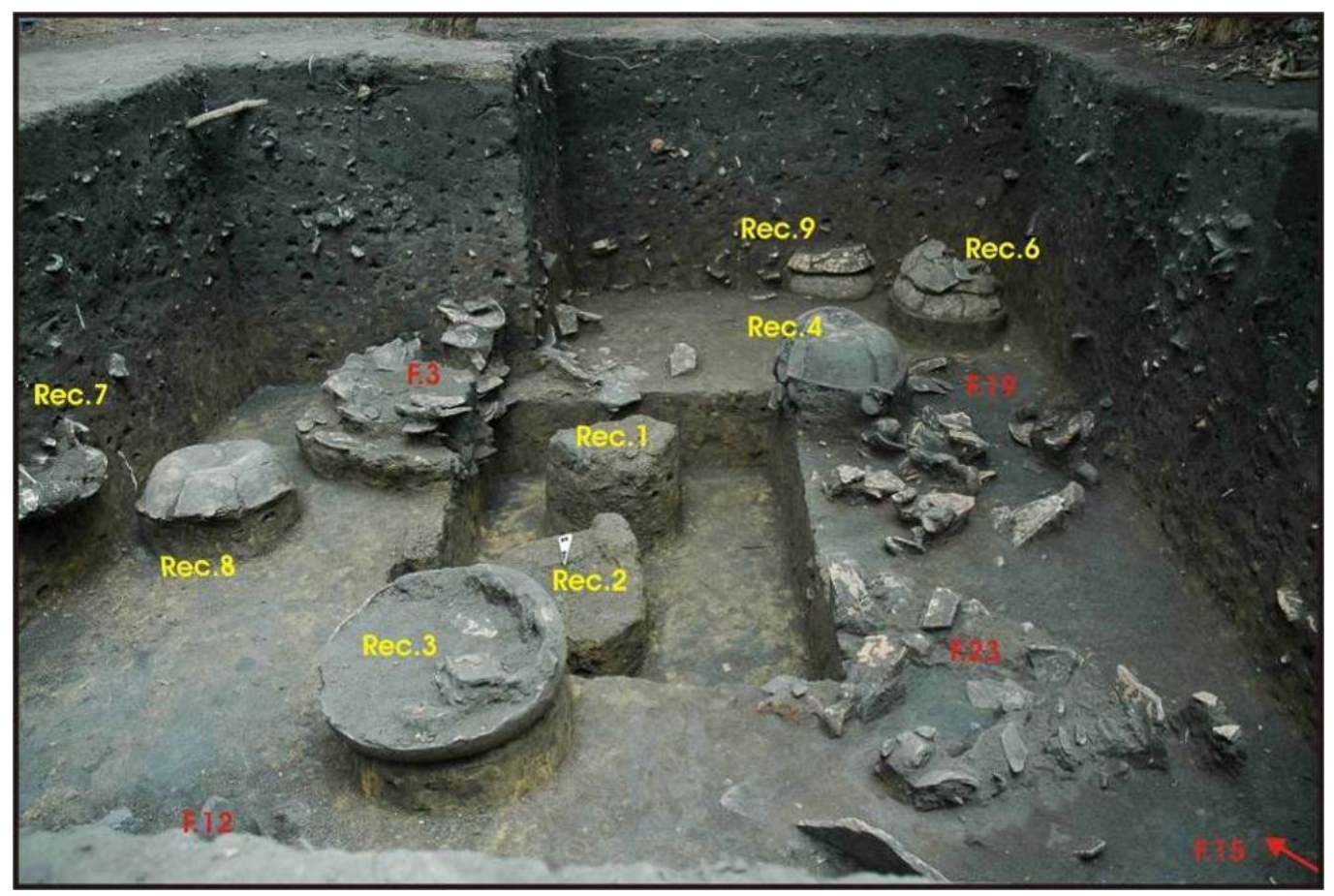

Figura 47 - Escavação em superfície ampla realizada em Hatahara, onde se evidenciaram uma série de vasilhas inteiras relacionadas às fases Manacapuru e Açutuba, além de feições com forma e tamanho variáveis, das fases Paredão, Manacapuru e Açutuba. (Foto: Val Moraes, 2006).

O que quero mostrar aqui é que interpretações dessa natureza são mais produtivas quando se tem toda uma gama de dados contextuais que podem ser relacionados. Por exemplo, a presença e as características da terra preta, a tipologia e a dispersão espacial da cerâmica, as análises paleobotânicas etc. Neste sentido, o sítio Hatahara pode ser considerado exemplar. Os trabalhos arqueológicos ali desenvolvidos envolveram uma série de disciplinas que agregaram informações referentes a diferentes contextos, ampliando a base de dados disponíveis e facilitando, assim, uma maior compreensão do sítio como um todo. Dessa forma uma gama de pesquisadores se dedicou ao estudo deste sítio: Machado (2005) trabalhou os processos formativos do montículo 1, enquanto Tamanaha (2006) fez um estudo semelhante com o montículo 2; Farias (2006) trabalhou com os vestígios faunísticos e Py-Daniel (2006) vêm estudando os sepultamentos relacionados a este sítio; Rebellato (2007) também desenvolveu seu mestrado neste sítio, onde estudou as assinaturas químicas do solo e, finalmente, Arroyo-Kalin (2008) desenvolveu seus trabalhos com a micromorfologia do solo. 


\section{Cronologia de ocupação e uso do espaço}

Com um total de trinta e uma amostras datadas, Hatahara mostrou ter uma seqüência cronológica tão longa quanto Açutuba, embora mais recente em poucos séculos, tanto em seu início quanto no fim de sua ocupação. Tamanha quantidade de datações radiocarbônicas realizadas torna este sítio o mais bem datado do Projeto Amazônia Central. No entanto, a interpretação das relações entre datas e filiação cultural, neste caso, se coloca como um desafio ainda maior, por ter sido predominantemente datado através de montículos, onde a própria configuração inverte a estratigrafia, alterando eventuais registros anteriores à sua formação. Uma correlação hipotética foi tentada, mas, esta deverá ser alterada na medida em que se angariem novos dados para este sítio arqueológico.

\begin{tabular}{|c|c|c|c|c|}
\hline $\begin{array}{l}\text { Número de } \\
\text { laboratório }\end{array}$ & Proveniência & Amostra & Profundidade & $\begin{array}{c}\text { Idade calibrada } \\
(66.8 \%)\end{array}$ \\
\hline BETA 143582 & N1152W1360 & Carvão & $29 \mathrm{~cm}$ & 1470 d.C. -1640 d.C. \\
\hline BETA 143585 & N1152W1360 & Carvão & $58 \mathrm{~cm}$ & 1010 d.C.-1160 d.C. \\
\hline BETA 143586 & N1152W1360 & Carvão & $60 \mathrm{~cm}$ & 1020 d.C. -1160 d.C. \\
\hline BETA 143587 & N1152W1360 & Carvão & $65 \mathrm{~cm}$ & 1310 d.C. -1420 d.C. \\
\hline BETA 145485 & N1152W1360 & Sep. 2 & $70 \mathrm{~cm}$ & 850 a.C.-790 a.C. \\
\hline BETA 145486 & N1152W1360 & Sep. 2 & $70 \mathrm{~cm}$ & 880 d.C.-990 d.C. \\
\hline BETA 143588 & N1152W1360 & Carvão & $80 \mathrm{~cm}$ & 980 d.C. -1130 d.C. \\
\hline BETA 143589 & N1152W1360 & Carvão & $84 \mathrm{~cm}$ & 980 d.C. -1130 d.C. \\
\hline BETA 143592 & N1152W1360 & Carvão & $121 \mathrm{~cm}$ & 1040 d.C. -1170 d.C. \\
\hline BETA 143593 & N1152W1360 & Carvão & $130 \mathrm{~cm}$ & 890 d.C. -1020 d.C. \\
\hline BETA 145483 & N1152W1360 & Sep. 1 & $140 \mathrm{~cm}$ & 430 d.C. -540 d.C. \\
\hline BETA 145484 & N1152W1360 & Sep. 1 & $140 \mathrm{~cm}$ & 610 d.C. -670 d.C. \\
\hline BETA 178915 & N1155W1360 & Carvão & $146 \mathrm{~cm}$ & 1040 d.C. -1220 d.C. \\
\hline BETA 143595 & N1152W1360 & Carvão & $155 \mathrm{~cm}$ & 1020 d.C. -1160 d.C. \\
\hline BETA 143599 & N1152W1360 & Carvão & $192 \mathrm{~cm}$ & 660 d.C. -770 d.C. \\
\hline BETA 143583 & N1152W1360 & Carvão & $30-40 \mathrm{~cm}$ & 900 d.C. -1160 d.C. \\
\hline BETA 143584 & N1152W1360 & Carvão & $40-50 \mathrm{~cm}$ & 670 d.C. -870 d.C. \\
\hline BETA 242439 & N1152 W1360/59 & Sepultamento & $100-110 \mathrm{~cm}$ & 950 d.C. -1010 d.C. \\
\hline BETA 143591 & N1152W1360 & Carvão & $100-110 \mathrm{~cm}$ & 670 d.C. -870 d.C. \\
\hline BETA 143594 & N1152W1360 & Carvão & $140-150 \mathrm{~cm}$ & 1020 d.C. -1230 d.C. \\
\hline BETA 143596 & N1152W1360 & Carvão & $160-170 \mathrm{~cm}$ & 880 d.C. -1030 d.C. \\
\hline BETA 143597 & N1152W1360 & Carvão & $170-180 \mathrm{~cm}$ & 750 a.C. -150 a.C. \\
\hline BETA 143598 & N1152W1360 & Carvão & $180-190 \mathrm{~cm}$ & 890 d.C. -1020 d.C. \\
\hline BETA 178914 & N1155W1360 & Carvão & $108 \mathrm{~cm}$ & 1010 d.C. -1160 d.C. \\
\hline BETA 178917 & N1155W1360 & Carvão & $123 \mathrm{~cm}$ & 980 d.C.-1130 d.C. \\
\hline BETA 178918 & N1155W 1360 & Carvão & $172 \mathrm{~cm}$ & 1030 d.C. -1160 d.C. \\
\hline BETA 178916 & N1155W1360 & Carvão & $180 \mathrm{~cm}$ & 810 d.C. -970 d.C. \\
\hline WK 16222 & $M-I I 3 / 13$ & Carvão do solo & $60-65 \mathrm{~cm}$ & 400 a.C.-220 a.C. \\
\hline WK 16223 & $M-I I 3 / 21$ & Carvão do solo & $105-110 \mathrm{~cm}$ & 890 d.C. -990 d.C. \\
\hline WK 16224 & $\mathrm{M}-\mathrm{II} 3 / 33$ & Carvão do solo & $165-170 \mathrm{~cm}$ & 770 d.C. -890 d.C. \\
\hline BETA 202681 & & & & 1030 d.C. -1170 d.C. \\
\hline
\end{tabular}

Tabela 8 - Datações obtidas para o sítio Hatahara. 


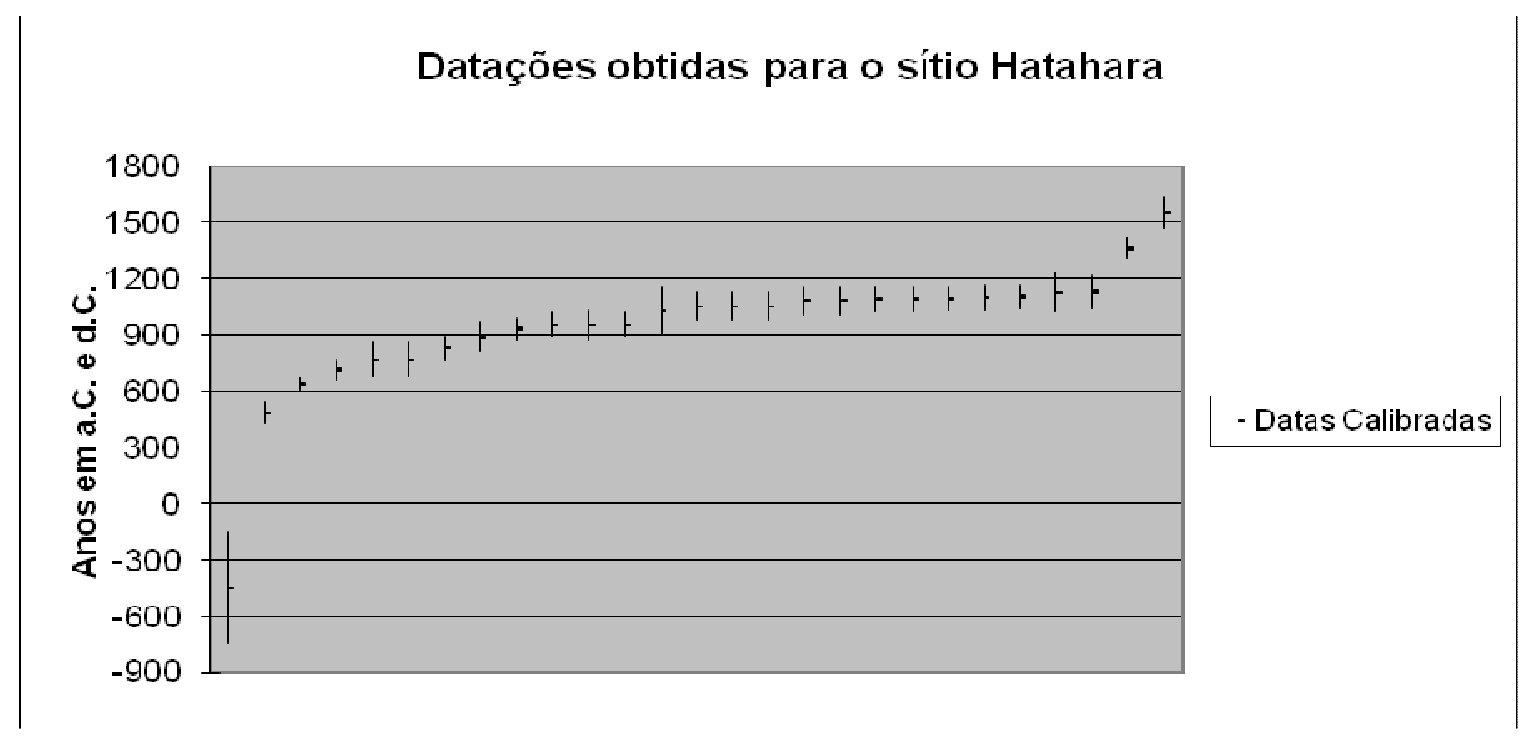

Gráfico 8 - Datações obtidas para o sítio Hatahara.

No momento, tem-se que, ao contrário do que se imaginava quando do início das atividades neste sítio arqueológico, ainda em 1997 e 1999, a ocupação mais recente do sítio, associada à fase Guarita, parece caracterizar um evento passageiro, datado entre os séculos XI e XIII d.C., portanto posterior à construção dos montículos e a um possível pico demográfico. O gráfico abaixo, apresentado por Machado (2005, p. 183), mostra a freqüência de fragmentos relacionados às fases Guarita e Paredão, no montículo 1. Como se pode ver, a ocorrência de materiais da fase Guarita se limita aos níveis superiores.

Além disso, o padrão de dispersão dessas cerâmicas, sempre superficiais, concentra-se nas áreas adjacentes ao limite do terraço, ao longo do eixo do Solimões. Em uma análise comparativa entre as características físico-químicas do solo e a dispersão dos vestígios cerâmicos no sítio, Rebellato indicou tratar-se este último período de ocupação de Hatahara, de um assentamento de forma linear, onde as casas estariam dispostas em linha e voltadas para o rio (2007, p. 178-179). Tais evidências vão de encontro aos relatos dos cronistas que por ali passaram à época da conquista. 


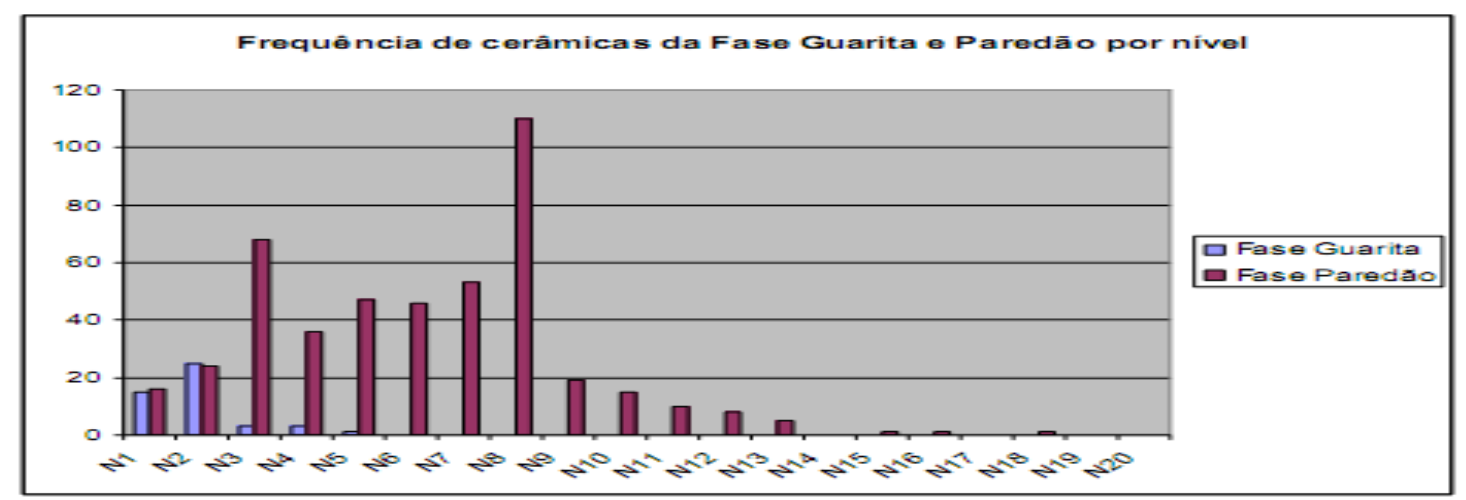

Gráfico 9 - Freqüência por nível de fragmentos relacionados às fases Guarita e Paredão no montículo 1 (Fonte: Machado, 2005, p. 167)

No entanto, ao que tudo indica, a configuração espacial de Hatahara era bem diferente em suas ocupações anteriores à fase Guarita. Os materiais relacionados à fase Paredão ocupam maior destaque neste caso, sendo os mais representativos na estratigrafia do sítio arqueológico como um todo, e relacionados diretamente com suas feições paisagísticas mais marcantes, os montículos artificiais. A disposição espacial de tais montículos, que se supõe serem contemporâneos, sugere tratar-se de um aldeamento circular, como já visto em análises de outros sítios dentro da área de pesquisa, sempre associados à ocupações Paredão.

Como já mencionado, foram realizadas escavações em dois desses montículos, M1 e M2, e tanto a análise estratigráfica quanto suas datas indicaram uma relação de contemporaneidade entre eles. As datações obtidas para ambos evidenciaram também a ocorrência de pelo menos dois períodos distintos de ocupação, bem definidos (Graf 10). Um deles está relacionado de forma direta aos montículos, com cerâmicas Paredão em sua maioria, e com uma variação cronológica em torno dos séculos IX ao XI d.C. Este seria, por suposição, o período em que o sitio foi mais densamente ocupado.

O outro evento de ocupação, mais antigo e, portanto, anterior à formação do montículo, tem uma seqüência que parece desvinculada do mesmo, e apresenta materiais relacionados à fase Açutuba, o que é corroborado pelas datas. 


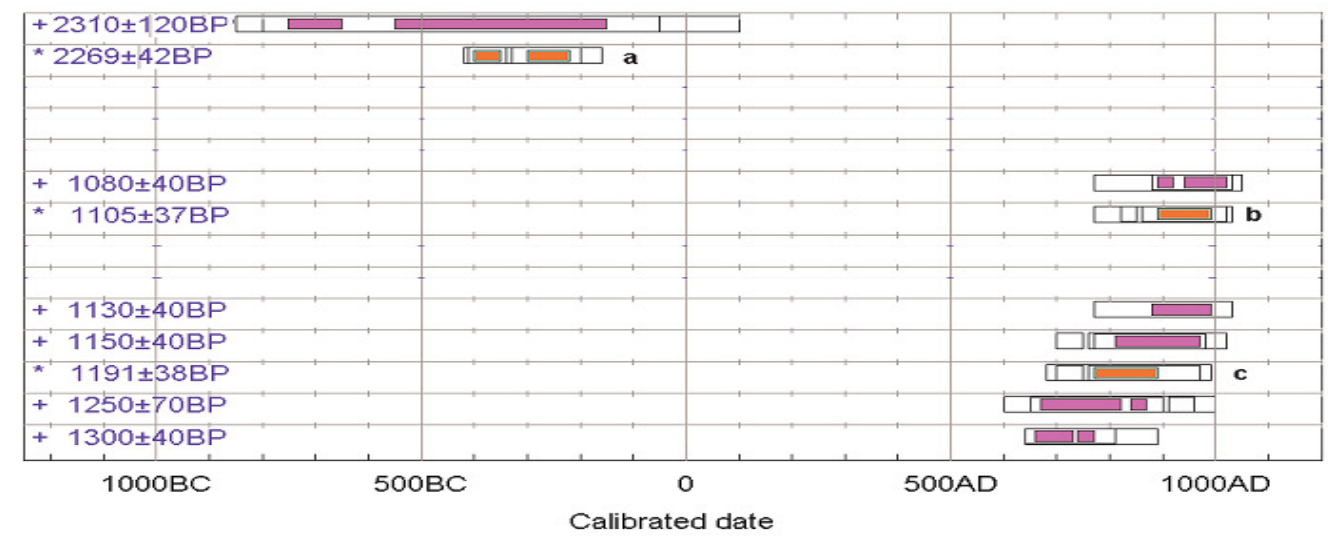

Gráfico 10 - Cronologia dos montículos M1 (lilás) e M2 (laranja). (Arroyo-Kalin, 2006 p. 19)

No caso das cerâmicas Manacapuru e Açutuba neste sítio, uma inferência de uso de espaço se torna mais complicada, devido ao fato destes materiais se encontrarem em depósitos sedimentares mais profundos. Contudo, a presença destes vestígios em M1, M2 e também na área oeste, limítrofe do sítio arqueológico, sugere uma ampla dispersão para estes conjuntos. Além disso, tamanha concentração de vasilhas Manacapuru inteiras ainda não era conhecida em nenhum sítio da região. Também não havia notícias de uma alta concentração de materiais, que aparentavam ser depositados intencionalmente, tão antigos quanto a fase Açutuba, como se viu na escavação das unidades no limite oeste do sítio.

A importância deste sítio para a construção de uma cronologia sólida, calcada em outros elementos que não apenas crono-estratigráficos, se mostra cada vez mais clara. De fato, Hatahara é um ótimo exemplo da conjugação de pesquisas multidisciplinares voltadas para o entendimento de vários aspectos de um mesmo sítio arqueológico. 


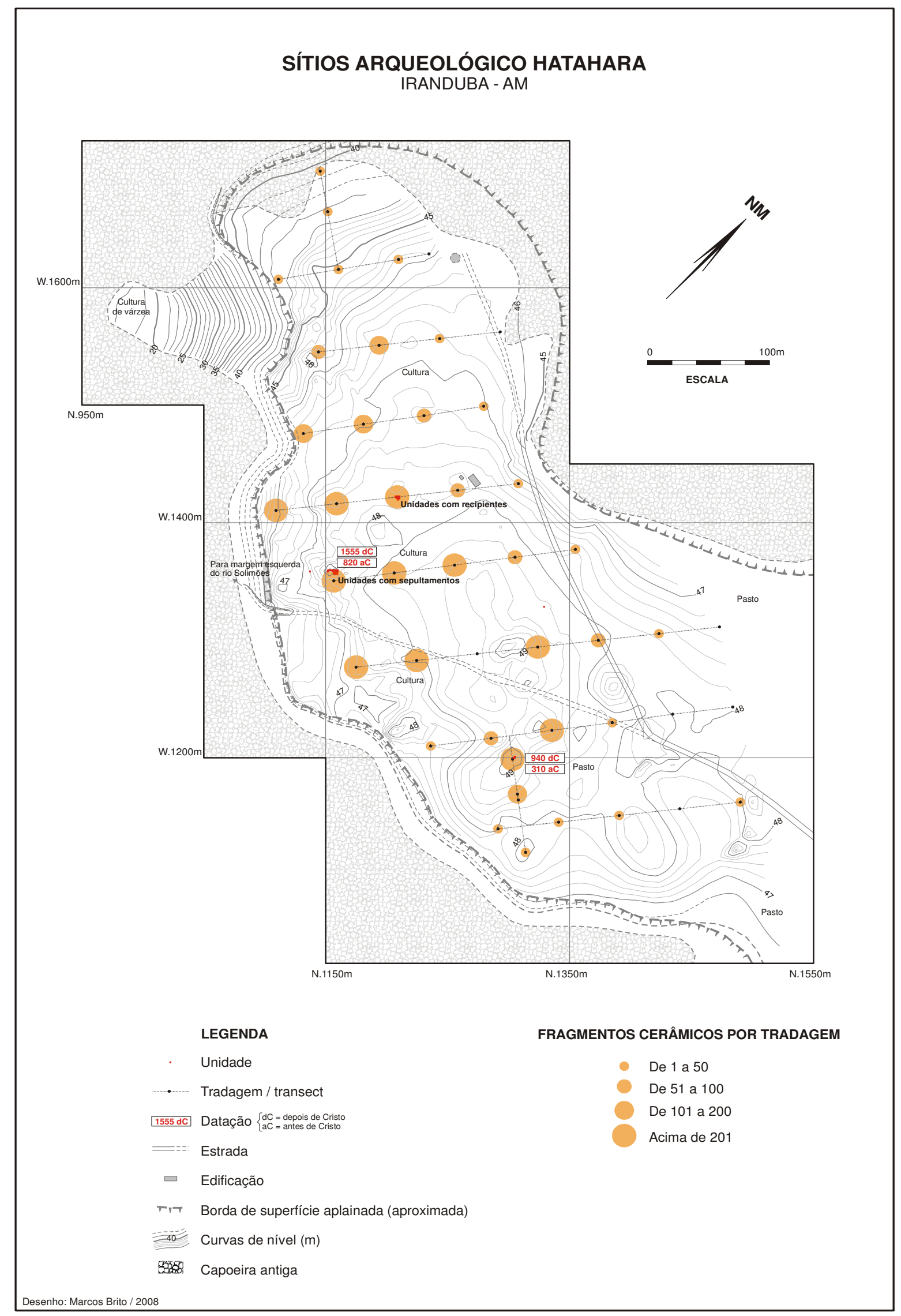

Figura 48 - Planta topográfica do sítio Hatahara, intervenções arqueológicas realizadas, densidades de vestígios e datações radiocarbônicas. 


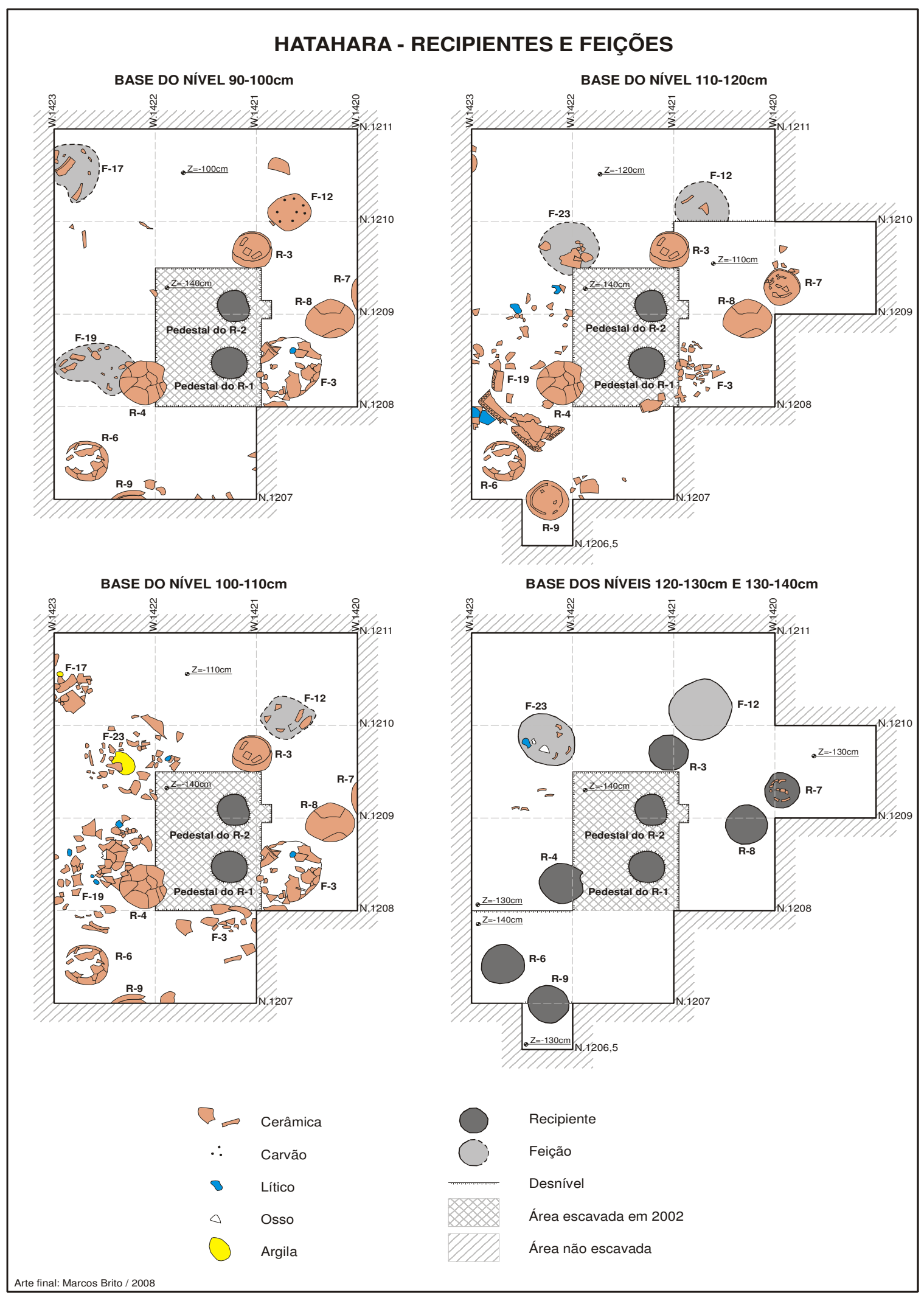

Figura 49 - Planta baixa das feições e recipientes escavados no sítio Hatahara. 


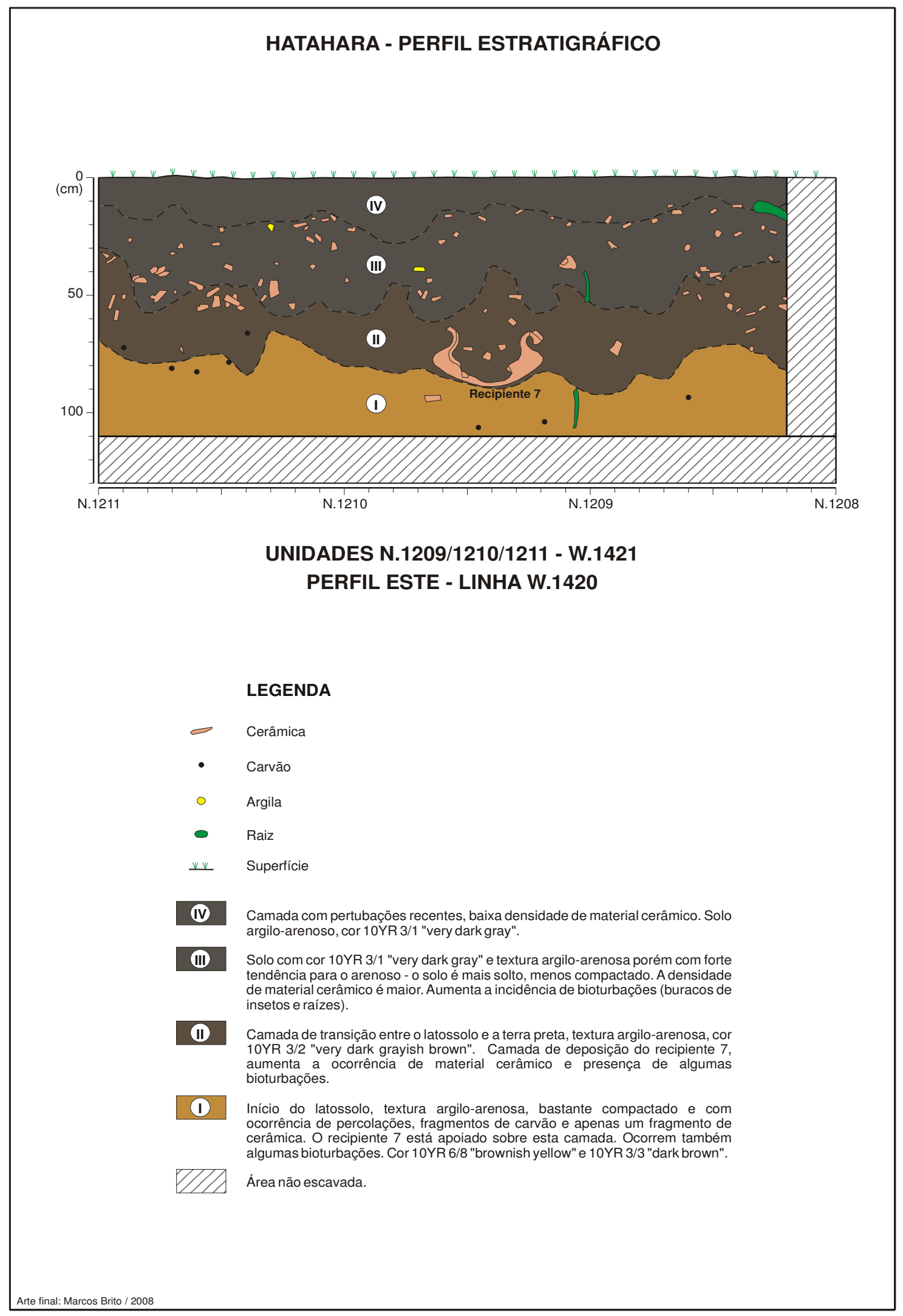

Figura 50 - Perfil da unidade N1209/10/11 W1421 do sítio Hatahara. 


\section{V. Os sítios arqueológicos do interflúvio}

\section{V. I. Sítio Jacuruxi}

Localiza-se às margens do Igarapé do Jacuruxi, num pequeno terraço não muito elevado, com vertentes suaves. O acesso ao sítio é somente fluvial, e pode ser feito a partir do km 51, da Rodovia Manoel Urbano (Cacau-PirêraManacapuru), via lago do Imanha, ou a partir do Ramal do Bujarú, km 53 da mesma rodovia, via Lago Preto. As duas opções de acesso foram utilizadas, sendo que a primeira tomou uma hora de caminhada, além do trecho fluvial; e a segunda em torno de uma hora e vinte minutos numa canoa com motor de 5.5HPs.

Trata-se de um sítio de dimensões reduzidas, de aspecto unicomponencial, com materiais cerâmicos associados à fase Manacapuru. Os vestígios arqueológicos não são visíveis em superfície. Trata-se de um pacote cultural discreto, com quinze a vinte centímetros de espessura, que ocorre abaixo de uma densa camada húmica, tão característica de áreas de Floresta Tropical. A vegetação que recobre a área do sítio é uma mata secundária muito antiga, com pelo menos cem anos de existência.

Os trabalhos neste sítio também foram realizados no âmbito do Gasoduto Coari-Manaus, e tiveram a duração de quarenta dias, realizados em duas etapas de vinte dias cada uma, compostas por duas equipes de seis pessoas. Durante este período foi realizada delimitação da área do sítio a partir de tradagens, o mapeamento topográfico, e a escavação de doze metros quadrados, divididos entre os locais com maior concentração de vestígios.

Foram realizadas tradagens com espaçamento de $25 \mathrm{~m}$, divididas em três linhas. Na linha leste-oeste, foram feitas quinze tradagens, abrangendo uma distância total de 325 metros. Este eixo passa por três pequenos topos e duas baixadas, além dos dois igarapés que marcam os limites da linha de tradagem. $O$ sítio arqueológico ocupa os dois topos mais a leste, e nestes locais se encontram as áreas com maior densidade de vestígios. A partir destes dois pontos foram marcadas duas novas linhas, no sentido norte-sul, a fim de delimitar a área do sítio arqueológico também neste sentido. As linhas foram puxadas a partir dos pontos N1000E1025 e N1000E1175, tradagens que renderam 47 e 45 fragmentos 
respectivamente. A maior densidade de vestígios está no topo mais a leste do sítio, que é também delimitado pelo maior igarapé, o Igarapé do Jacuruxi.

Doze metros quadrados foram escavados neste sítio, que representam uma amostragem importante, dadas suas pequenas dimensões. Elas foram divididas da seguinte maneira: três escavações de $1 \mathrm{~m}^{2}$; três com $2 \times 1 \mathrm{~m}$, e uma pequena trincheira com $3 \times 1 \mathrm{~m}$. Por apresentarem uma estratigrafia muito semelhante, apenas algumas delas serão descritas a seguir.

\section{Trincheira N1044-45-46 E1026}

A escavação foi marcada próximo ao limite norte do sítio, num topo aplainado. A princípio somente $1 \mathrm{~m}^{2}$ seria escavado, mas em virtude das feições nela evidenciadas, optou-se por expandi-la, formando assim uma pequena trincheira, com profundidade de $60 \mathrm{~cm}$. Como se pode ver na figura abaixo (fig 51), com exceção da feição 1, marcada no perfil, que era composta por grande concentração de cerâmicas, as demais sugerem tratar-se de buracos de esteio, sendo caracterizadas por manchas circulares.
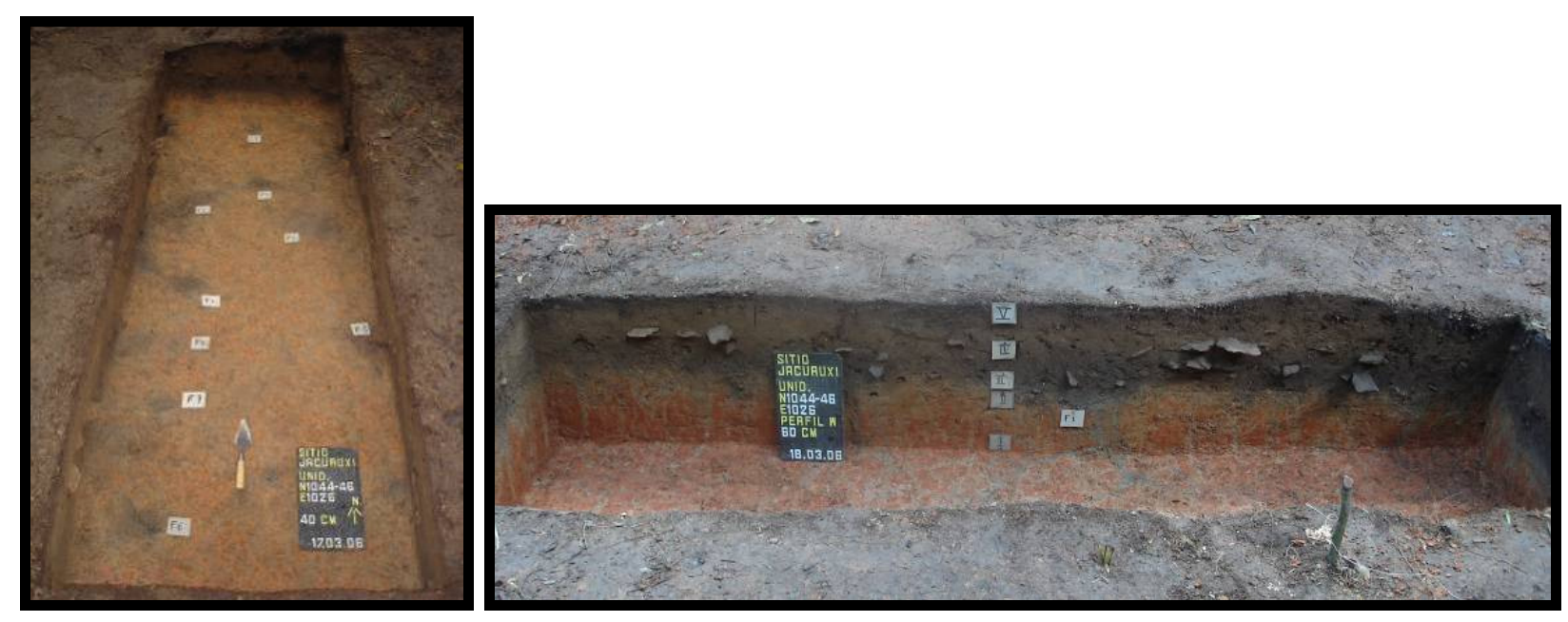

Figura 51 - Feições e Perfil da trincheira escavada no sítio Jacuruxi (fotos: Helena Lima). 


\begin{tabular}{|c|c|c|c|}
\hline Feição no & Localização & Diâmetro & Descrição \\
\hline 1 & Trinch.N1044-6 E1026 & $40 \mathrm{~cm}$ & $\begin{array}{l}\text { formato circular, com cerâmicas dispostas } \\
\text { também circularmente, em posicão diagonal }\end{array}$ \\
\hline 2 & Trinch.N1044-6 E1026 & $30 \mathrm{~cm}$ & formato circular, possível negativo de esteio \\
\hline 3 & Trinch.N1044-6 E1026 & $20 \mathrm{~cm}$ & formato circular, possível negativo de esteio \\
\hline 4 & Trinch.N1044-6 E1026 & $20 \mathrm{~cm}$ & formato circular, possível negativo de esteio \\
\hline 5 & Trinch.N1044-6 E1026 & $16 \mathrm{~cm}$ & formato circular, possível negativo de esteio \\
\hline 6 & Trinch.N1044-6 E1026 & $15 \mathrm{~cm}$ & formato circular, possível negativo de esteio \\
\hline 7 & Trinch.N1044-6 E1026 & $11 \mathrm{~cm}$ & formato circular, possível negativo de esteio \\
\hline 8 & Trinch.N1044-6 E1026 & $15 \mathrm{~cm}$ & formato circular, possível negativo de esteio \\
\hline 9 & Trinch.N1044-6 E1026 & $10 \mathrm{~cm}$ & formato circular, possível negativo de esteio \\
\hline
\end{tabular}

Tabela 9 - Feições escavadas no sítio Jacuruxi.

\section{Unidades N1000 E1003-1004}

Esta unidade marca o limite oeste do sítio. Situa-se no início do declive em direção ao Igarapé-açu, e foi escavada até os $90 \mathrm{~cm}$ de profundidade, embora o nível arqueológico se concentre dos 20 aos $40 \mathrm{~cm}$, assim como em outras áreas do sítio. Forneceu material lítico polido associado à cerâmica e, de acordo com o perfil, cinco camadas estratigráficas foram definidas. A primeira é o latossolo estéril; a segunda marca uma transição com solo mesclado entre latossolo e solo orgânico; e a terceira é caracterizada por poucos fragmentos cerâmicos, provavelmente deslocados por bioturbações. A quarta camada arqueológica apresenta maior concentração de vestígios, com espessura variando de 20 a 15 $\mathrm{cm}$. A quinta camada, superficial, é a camada húmica.

\section{Unidade N1002 E1126}

Esta unidade foi marcada num local entre duas áreas com maior concentração de material, as quais já haviam sido escavadas nos topos aplainados. De fato, a densidade de material arqueológico foi comparativamente mais baixa, mas sua estratigrafia é semelhante às demais áreas do sítio. Foi escavada até os $70 \mathrm{~cm}$. 

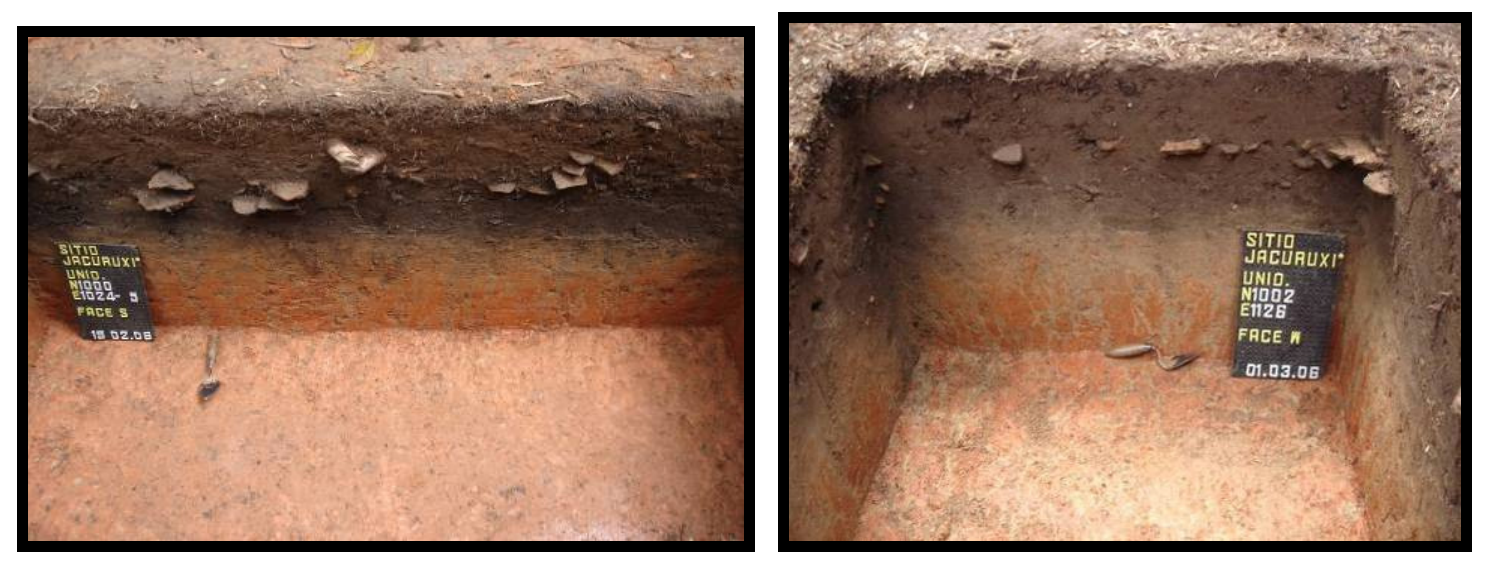

Figura 52 - Perfil Sul da unidade N1000 E1024-25 e perfil Oeste da unidade N1002 E1126 (Fotos: Helena Lima).

\section{Cronologia de ocupação e uso do espaço}

Jacuruxi é um sítio-chave para o entendimento do problema de pesquisa tratado neste doutorado. Se por um lado definiu-se a fase Açutuba e sua antigüidade em função da ausência de terras pretas em contextos a ela associados (Lima et al., 2006), por outro lado, Jacuruxi forneceu cerâmicas com características supostamente desta fase, mas numa matriz antrópica. Questões colocadas frente ao sítio foram: será a Fase Açutuba mais recente do que se pensou a princípio? Serão os processos que levaram à formação das terras pretas mais antigos do que se supôs?

As análises e as datações radiocarbônicas obtidas para este contexto ajudaram a entender melhor as relações entre Açutuba e Manacapuru, e o alcance temporal dessas duas fases. Este se configurava um problema central desta pesquisa. Duas amostras foram dadas, e situaram a ocupação de Jacuruxi, um evento bem discreto, num pequeno intervalo entre 570 e 790 d.C. (tabela 10), ou seja, intermediário entre as cronologias propostas para as fases Açutuba e Manacapuru (Lima et al., 2006).

\begin{tabular}{|c|c|c|c|}
\hline $\begin{array}{c}\text { Número do } \\
\text { Laborátorio }\end{array}$ & Proveniência & Profundidade & $\begin{array}{c}\text { Idade calibrada } \\
\mathbf{( 6 6 . 8 \% )}\end{array}$ \\
\hline BETA 242441 & N1001 E1180 & $21 \mathrm{~cm}$ & 540 d.C.-610 d.C. \\
\hline BETA 242442 & N1000 E1003 & $35 \mathrm{~cm}$ & 420 d.C. -540 d.C. \\
\hline
\end{tabular}

Tabela 10 - Datas Calibradas obtidas para o sítio Jacuruxi. 
As análises cerâmicas demonstraram tratar-se, na realidade, de um conjunto mais semelhante à fase Manacapuru, conforme se observará nos capítulos seguintes. Assim, as datações e os demais dados obtidos neste sítio vieram diminuir a lacuna existente entre essas duas fases, não apenas cronologicamente, mas também em termos contextuais. A composição físicoquímica dessa antiga matriz antrópica muito contribuirá para o entendimento da formação das terras pretas. Também em termos tecnológicos, observou-se uma semelhança maior do que aquilo outrora reportado para essas duas fases cerâmicas.

De fato, Jacuruxi parece mostrar que, tanto a formação das terras pretas como as relações entre Açutuba e Manacapuru se deram de um modo muito mais processual e contínuo do que se imaginava. Assim como o sítio NSP Socorro, também aqui mencionado, o Jacuruxi nos coloca no limiar do entendimento das reais significações das fases cerâmicas encontradas na Amazônia central. 


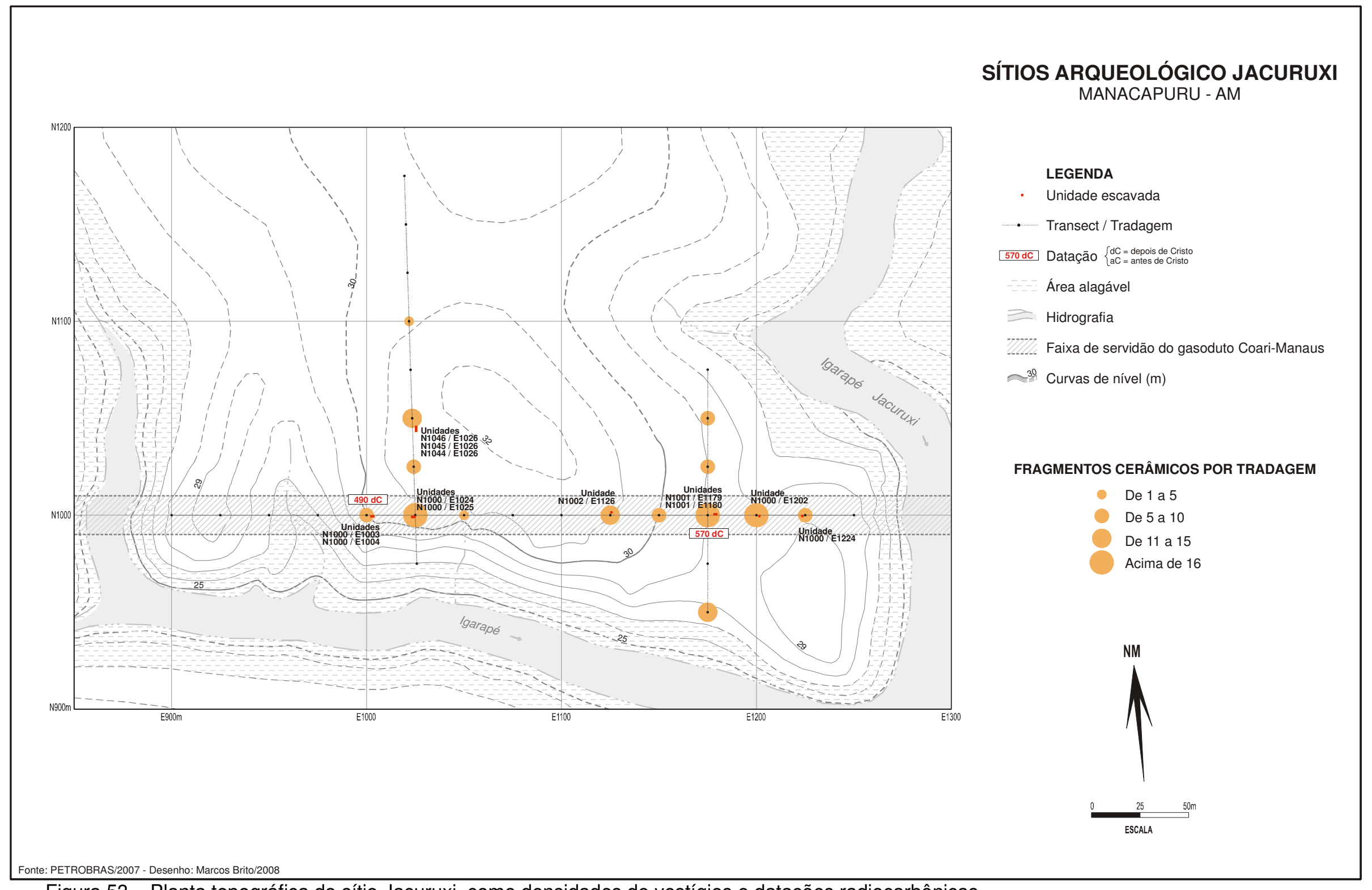

Figura 53 - Planta topográfica do sítio Jacuruxi, como densidades de vestígios e datações radiocarbônicas. 


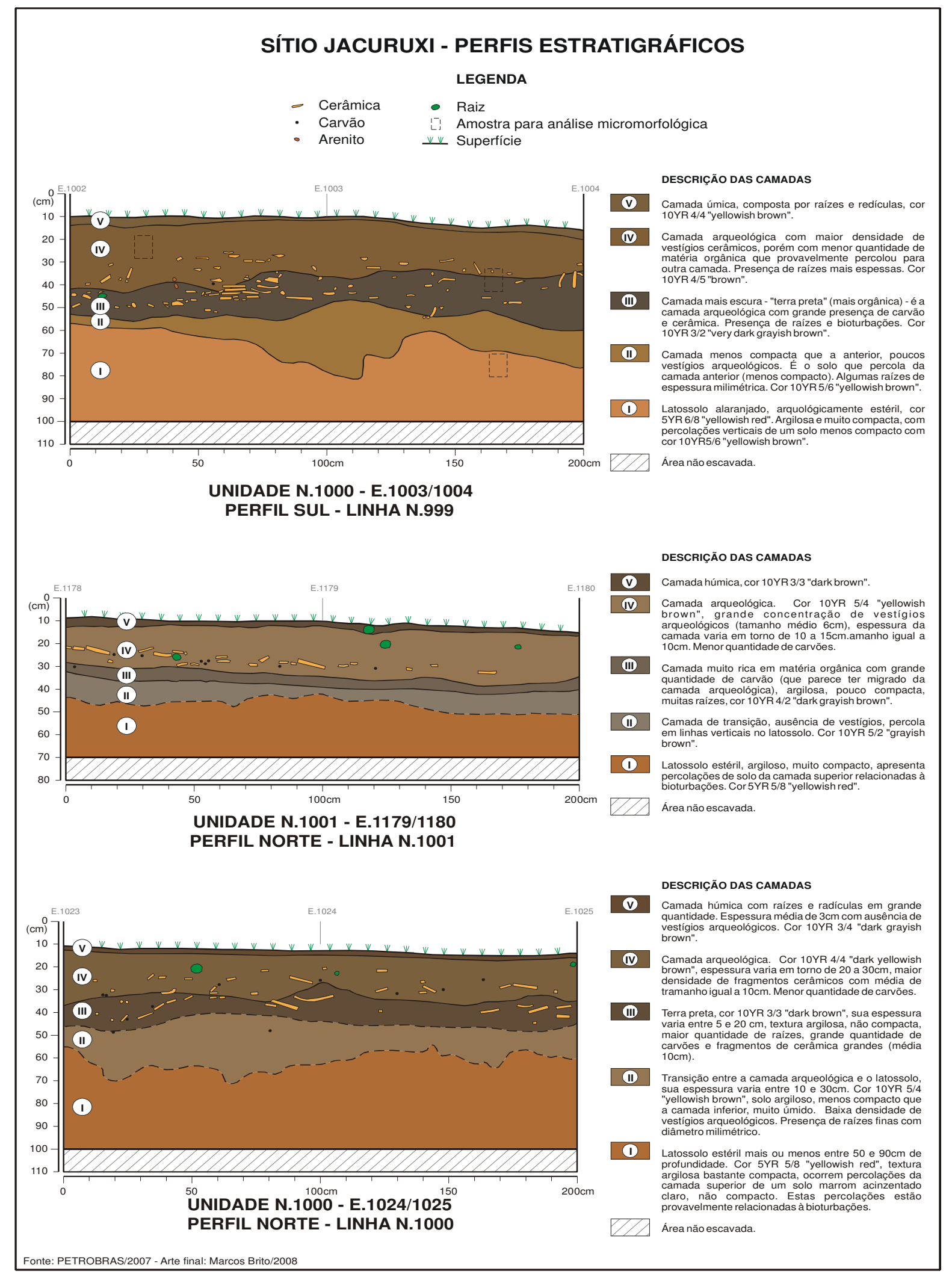

Figura 54 - Perfis das unidades escavadas no sítio Jacuruxi. 


\section{SÍTIO JACURUXI - PERFIS ESTRATIGRÁFICOS}

\section{LEGENDA}

- Cerâmica Bioturbação

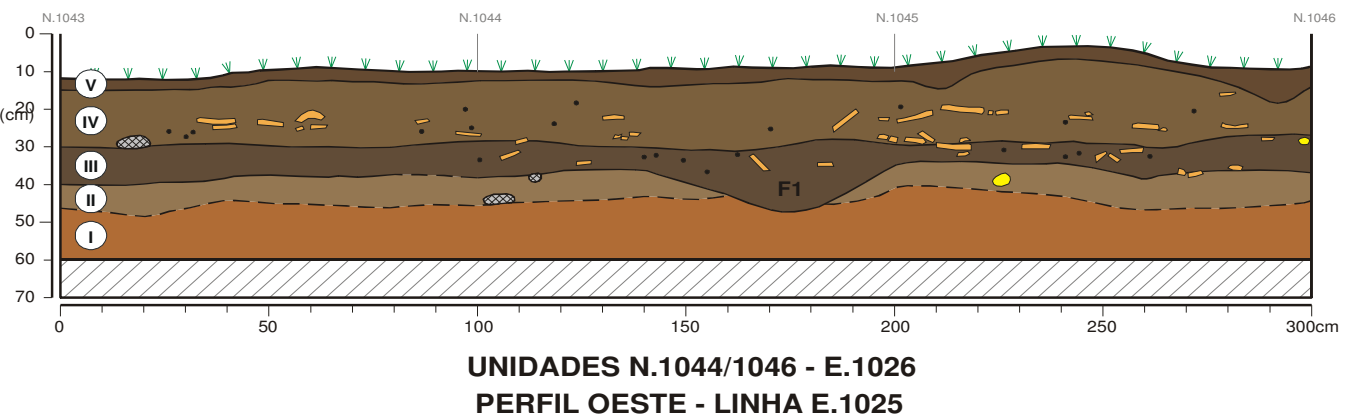

DESCRIÇÃO DAS CAMADA

V Camada húmica com raízes e radículas em grande quantidade. Espessura média de $3 \mathrm{~cm}$ com ausência de vestígios arqueológicos.

IV Camada arqueológica. Cor 10YR 4/4 "dark yellowish brown", espessura varia em torno de 20 a $30 \mathrm{~cm}$, maior densidade de fragmentos cerâmicos com média de tramanho igual a $10 \mathrm{~cm}$. Menor quantidade de carvões.

III Terra preta, cor 10YR 3/3 "dark brown", sua espessura varia entre 5 e $20 \mathrm{~cm}$, textura argilosa, não compacta, maior quantidade de raízes, grande quantidade de carvōes efragmentos de cerâmica grandes (média $10 \mathrm{~cm})$.

(II)

Transição entre a camada arqueológica e o latossolo, sua espessura varia entre 10 e 30cm. Cor 10YR 5/4 "yellowish brown", solo argiloso, menos compacto que a camada inferior, muito úmido. Baixa densidade de vestígios arqueológicos. Presença de raízes com diâmetro milimétrico. É cortada por uma feição (F1) com sedimento característico da camada anterior. Latossolo estéril mais ou menos entre 50 e $90 \mathrm{~cm}$ de profundidade. Cor $5 Y R$ F/8 "yellowish red", textura argilosa bastante compacta, provavelmente relacionadas à bioturbações.

Área não escavada.

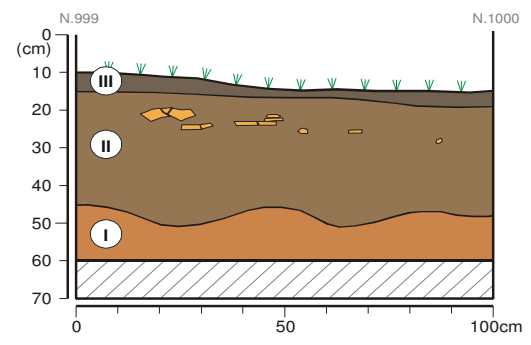

\section{DESCRIÇÃO DAS CAMADA}

Camada húmica (raízes e radículas).

arqueológica, baixa densidade de vestígios, argilo-arenosa,

Latossolo alaranjado estéril com percolações verticais de um solo menos /8 "yellowish red".

Área não escavada.

UNIDADE N.1000 - E.1202

PERFIL OSTE - LINHA E.1201

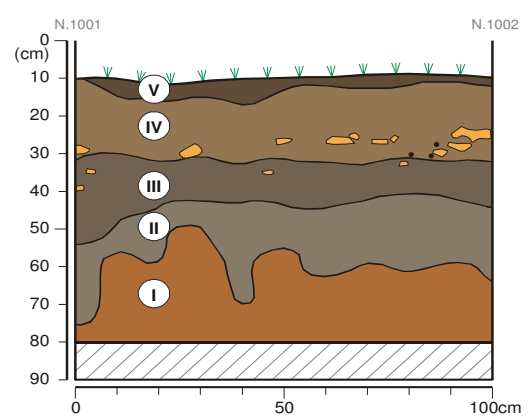

DESCRIÇÃO DAS CAMADA

Camada húmica, cor 10YR 3/3 "dark brown" Camada arqueológica, com concentração
carvōes. Cor 10YR $5 / 4$ "yellowish brown". OYR 4/2 "dark grayish brown".

Camada de transição, ausência de vestígios arqueológicos. Cor 10YR 5/2
"grayish brown".

UNIDADE N.1002 - E.1126

PERFIL OESTE - LINHA E.1125

Área não escavada.

Fonte: PETROBRAS/2007 - Arte final: Marcos Brito/2008

Figura 55 - Perfis das unidades escavadas no sítio Jacuruxi. 


\section{V. II. Sítio Osvaldo}

O sítio Osvaldo (Am-Ir-09) se localiza na região central da área de pesquisa do PAC, na área de interflúvio entre o Solimões e o Negro. Esta região é caracterizada por uma extensa rede de lagos e igarapés, que se conectam, sazonalmente, ora a um rio, ora ao outro, de acordo com o regime de vazão desses rios. Por suas dimensões e por ocupar uma posição central neste contexto ambiental, o Lago do Limão pode ser tanto de água preta, na vazão, quanto de água branca, quando o Solimões se encontra cheio, com seu ápice em meados de junho. Muitos são os sítios arqueológicos que ocupam suas margens. Um deles é o sítio Osvaldo, foco desta pesquisa, que se situa na margem sul do Lago.

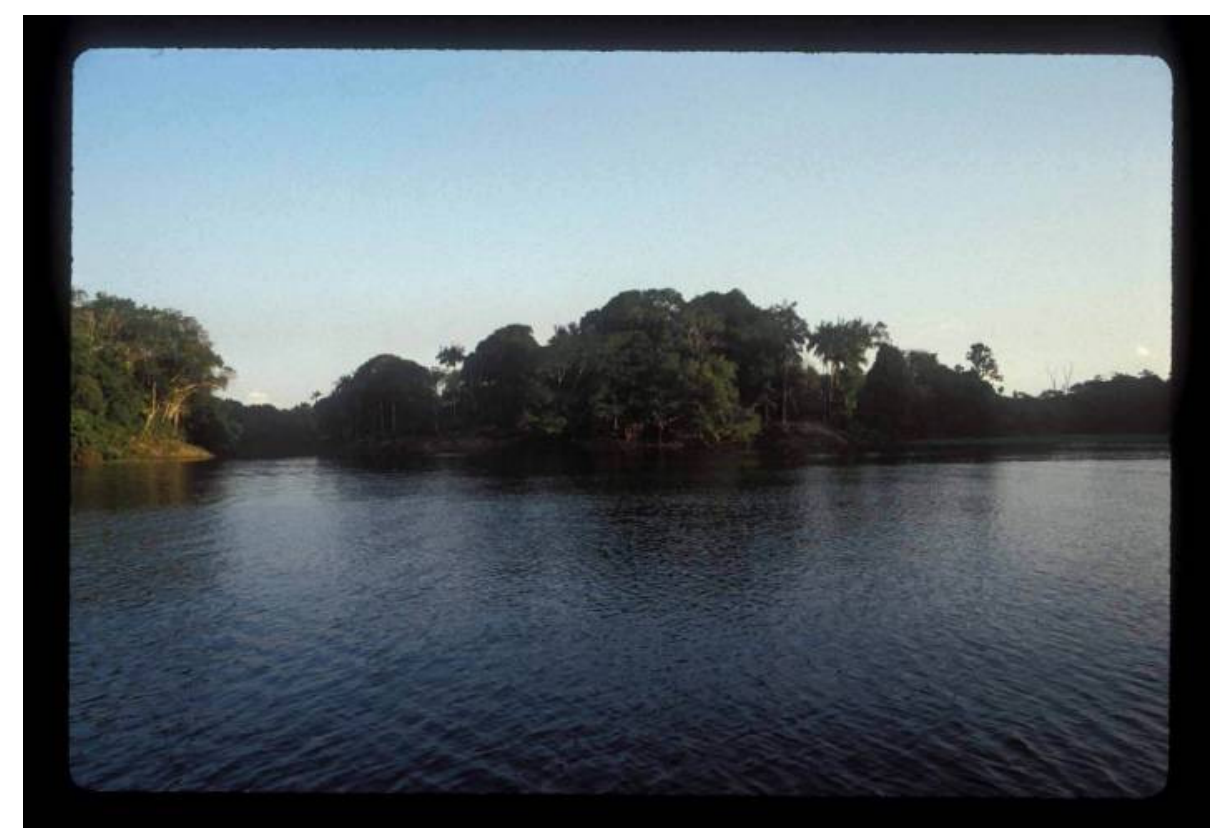

Figura 56 - Vista do sítio Osvaldo, a partir do Lago do Limão (Foto: R. Bartone 1999).

O trabalho de campo realizado neste sitio arqueológico ocorreu em 1999, e compreendeu a delimitação e topografia detalhada de sua área, estabelecimento de linhas de tradagens, escavação de sondagens de $1 / 2 \mathrm{~m}^{2}$, e de uma unidade de $1 \mathrm{~m}^{2}$ denominada S710 E1966. A área do sítio é de aproximadamente $700 \times 250 \mathrm{~m}$ e, sendo uma península, tem seus limites delimitados da seguinte forma: o lago a norte e pequenos igarapés a leste e oeste. $\mathrm{O}$ depósito arqueológico chega até a $1 \mathrm{~m}$ de profundidade, e é composto em sua maioria pelas terras pretas antrópicas e por cerâmicas da fase Manacapuru, num contexto unicomponencial, o que torna o estudo deste sítio relevante para a compreensão de padrões de assentamento e 
uso do espaço, bem como de questões cronológicas mais amplas da Amazônia central.

O exame do perfil da unidade de escavação e a análise dos vestígios cerâmicos confirmaram tratar-se de uma ocupação unicomponencial, apresentando alta densidade de vestígios cerâmicos associados à fase Manacapuru, que se encontravam depositados até uma profundidade de cerca de $90 \mathrm{~cm}$ (fig 48). A análise mostrou também a ocorrência de alguns fragmentos que seriam, tecnologicamente, vinculados à fase Paredão, confirmando o padrão de co-ocorrência entre esses dois conjuntos, observado no sítio Lago Grande e em outros sitos Paredão dentro da área de pesquisa, neste caso, com a predominância de materiais Manacapuru. Esta mesma observação foi feita por Portocarrero (2007) para as demais áreas do sítio.

\section{Cronologia de ocupação e uso do espaço}

A seqüência radiocarbônica estabelecida para o sítio Osvaldo foi obtida através de dezenove amostras datadas, distribuídas em quatro setores do sítio arqueológico (mapa, fig 47). Para que se obtivesse um maior controle estratigráfico dessas datas, priorizou-se a unidade de escavação S710 E1966, que obteve quinze amostras datadas ao longo de sua seqüência (Graf 12; Fig 58). A ampla variação cronológica indicada no gráfico abaixo, entre 20 e 720 d.C., comprova em certa medida o exame do perfil, sugerindo a ocorrência de dois níveis de ocupação, onde o mais recente seria mais denso e representativo, e o outro, mais discreto e antigo. Pode-se observar que, com uma exceção, as datas obtidas entre 30 e $70 \mathrm{~cm}$ situaram-se num intervalo curto, entre 600 e 720 d.C. A análise destes materiais atestou tratar-se de um conjunto com cerâmicas Manacapuru com discreta ocorrência de materiais Paredão. Tais elementos sugerem, para o sítio Osvaldo, um processo de ocupação intenso, conforme atestado pela Terra Preta, com duração de uma ou duas gerações, durante o final do século VII e o início do século VIII da era Cristã. (Abreu, 2000; Neves, 2000). 


\begin{tabular}{|c|c|c|c|c|}
\hline $\begin{array}{l}\text { Número do } \\
\text { Laborátorio }\end{array}$ & Amostra & Proveniência & Profundidade & $\begin{array}{c}\text { Idade calibrada } \\
(66.8 \%)\end{array}$ \\
\hline BETA 143611 & OS234 & S0710E1966 & $34 \mathrm{~cm}$ & 170 d.C. -420 d.C. \\
\hline BETA 143610 & OS499 & S0710E1966 & $35 \mathrm{~cm}$ & 620 d.C. -690 d.C. \\
\hline BETA 143612 & OS248 & S0710E1966 & $36 \mathrm{~cm}$ & 650 d.C. -770 d.C. \\
\hline BETA 143608 & OS497 & S0710E1966 & $41 \mathrm{~cm}$ & 430 d.C. -560 d.C. \\
\hline BETA 143609 & OS498 & S0710E1966 & $41 \mathrm{~cm}$ & 670 d.C. -770 d.C. \\
\hline BETA 143614 & OS368 & S0710E1966 & $42 \mathrm{~cm}$ & 610 d.C. -770 d.C. \\
\hline BETA 143613 & OS362 & S0710E1966 & $45 \mathrm{~cm}$ & 660 d.C. -780 d.C. \\
\hline BETA 143616 & OS170 & S0710E1966 & $50-60 \mathrm{~cm}$ & 640 d.C. -690 d.C. \\
\hline BETA 143615 & OS197 & S0710E1966 & $54 \mathrm{~cm}$ & 550 d.C. -660 d.C. \\
\hline BETA 143617 & OS435 & S0710E1966 & $61 \mathrm{~cm}$ & 640 d.C. -770 d.C. \\
\hline BETA143618 & OS505 & S0710E1966 & $66 \mathrm{~cm}$ & 640 d.C. -770 d.C. \\
\hline BETA 143619 & OS456 & S0710E1966 & $73 \mathrm{~cm}$ & 650 d.C. -780 d.C. \\
\hline BETA 143620 & OS457 & S0710E1966 & $76 \mathrm{~cm}$ & 650 d.C. -770 d.C. \\
\hline BETA 143621 & OS471 & S0710E1966 & $80-90 \mathrm{~cm}$ & 90 a.C. -130 d.C. \\
\hline BETA 143622 & OS474 & S0710E1966 & $90-100 \mathrm{~cm}$ & 200 a.C. -50 a.C. \\
\hline BETA 143627 & OS332 & S0700E1895 & $20-30 \mathrm{~cm}$ & 640 d.C. -770 d.C. \\
\hline BETA 143624 & OS267 & S0845E1921 & $50-60 \mathrm{~cm}$ & 240 d.C. -340 d.C. \\
\hline BETA 143623 & OS270 & S0845E1921 & $60-70 \mathrm{~cm}$ & 680 d.C. -780 d.C. \\
\hline BETA 143626 & OS581 & S0845E2046 & $40-43 \mathrm{~cm}$ & 890 d.C. -990 d.C. \\
\hline
\end{tabular}

Tabela 11 - Datas calibradas para o sítio Osvaldo.

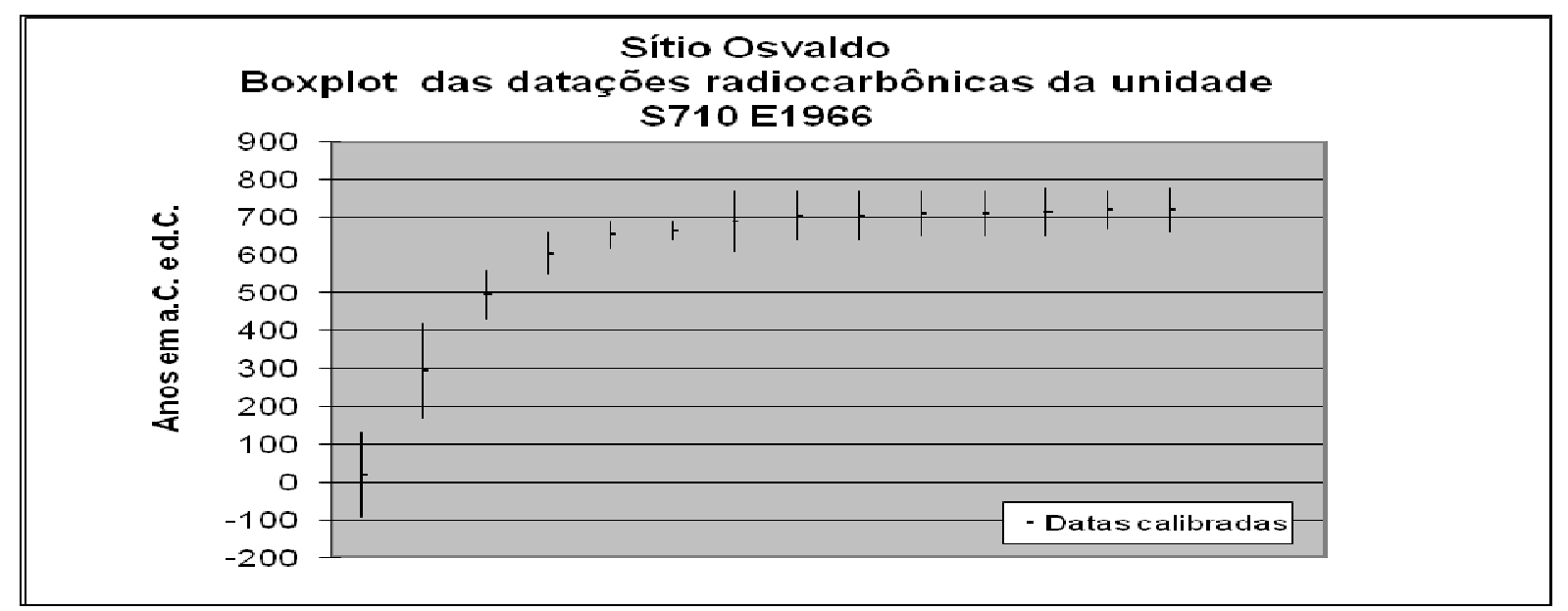

Gráfico 12 - Datações radiocarbônicas obtidas para a unidade S710 E1966 do sítio Osvaldo.

Nos níveis mais profundos desta mesma unidade foram registrados alguns fragmentos que se vinculam a fase Açutuba, e representariam as duas datações mais antigas obtidas para a unidade, de 125 a. C. no nível 90-100 e de 20 d.C. no nível 80-90 cm. Desta forma, pode-se dizer que, assim como Lago Grande, Osvaldo é caracterizado a princípio por um discreto nível Açutuba, de difícil caracterização, e tem, em seguida, sua área intensamente ocupada. No primeiro caso, a maior parte das cerâmicas é relacionada à fase Paredão e no segundo, às 
cerâmicas Manacapuru. A diferença cronológica entre estes dois sítios é em torno de dois séculos.

As pesquisas realizadas por E. Abreu (2000) e R. Portocarrero (2007), ambas sob orientação do PAC, visaram entender o tamanho e a forma da aldeia representada neste sítio. Os resultados destas pesquisas foram convergentes e apontaram para a grande relevância deste sítio para os temas deste doutorado: em primeiro lugar, revelaram tratar-se de um assentamento de forma circular, fornecendo fortes subsídios para o teste da hipótese inicialmente lançada por Lathrap (1970a) e mais tarde reavaliada por Heckenberger $(2002,2003)$ sobre a associação entre as cerâmicas Barrancóide (neste caso, Manacapuru) e as aldeias circulares, interpretadas como um correlato das migrações dos povos falantes das línguas do tronco Arawak. Esta questão tem um grande valor para o entendimento das relações entre diferentes representações das cerâmicas Borda Incisa na Amazônia e Barrancóide na Venezuela e Caribe.

As análises cerâmicas realizadas por Portocarrero demonstraram também um padrão de co-ocorrência entre as cerâmicas Manacapuru e Paredão em toda a área do sítio arqueológico. A proporção corrobora o que anteriormente notou-se na unidade S710 E1966, ou seja, uma maior proporção de materiais Manacapuru em relação ao Paredão. As proporções calculadas por Portocarrero (2007) encontram-se plotadas no mapa do sítio arqueológico (fig 58). Estes dados sustentam também as observações de Donatti (2003) e Tamura (2005) para o sítio Lago Grande, neste caso, com uma relação inversa entre os conjuntos. Mais uma vez, têm-se dados relevantes para uma reavaliação das relações entre as fases cerâmicas na Amazônia central.

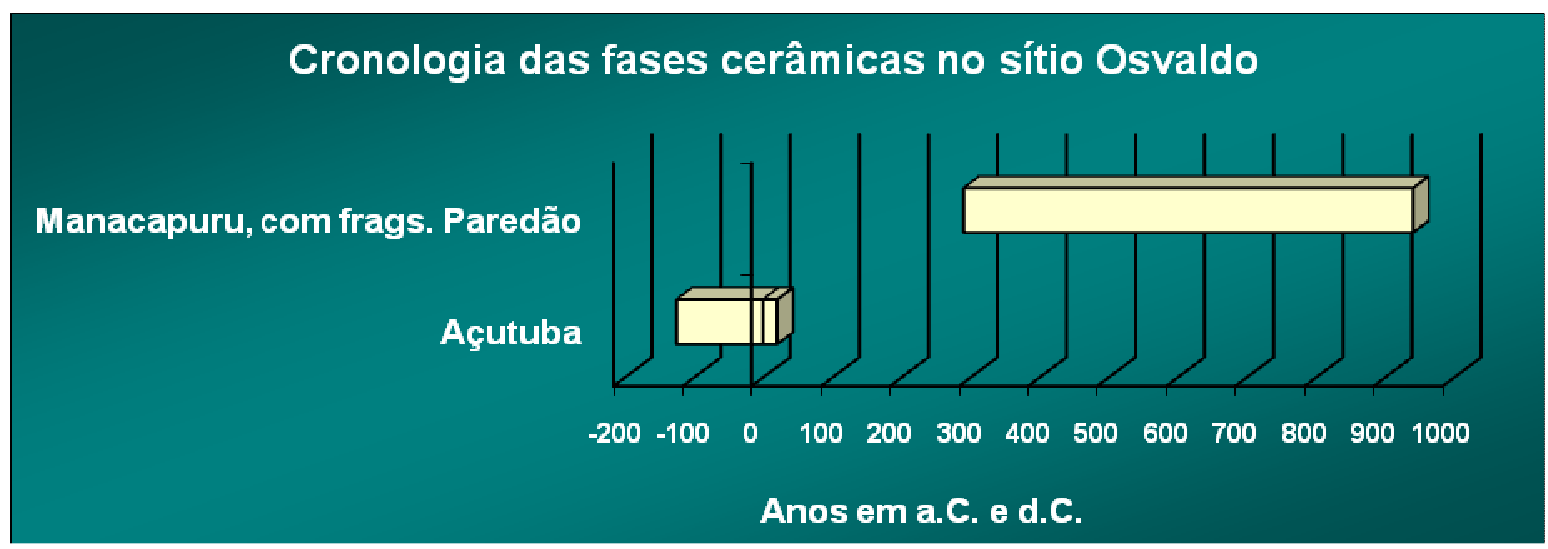

Gráfico 13 - Cronologia das ocupações no sítio Osvaldo. 


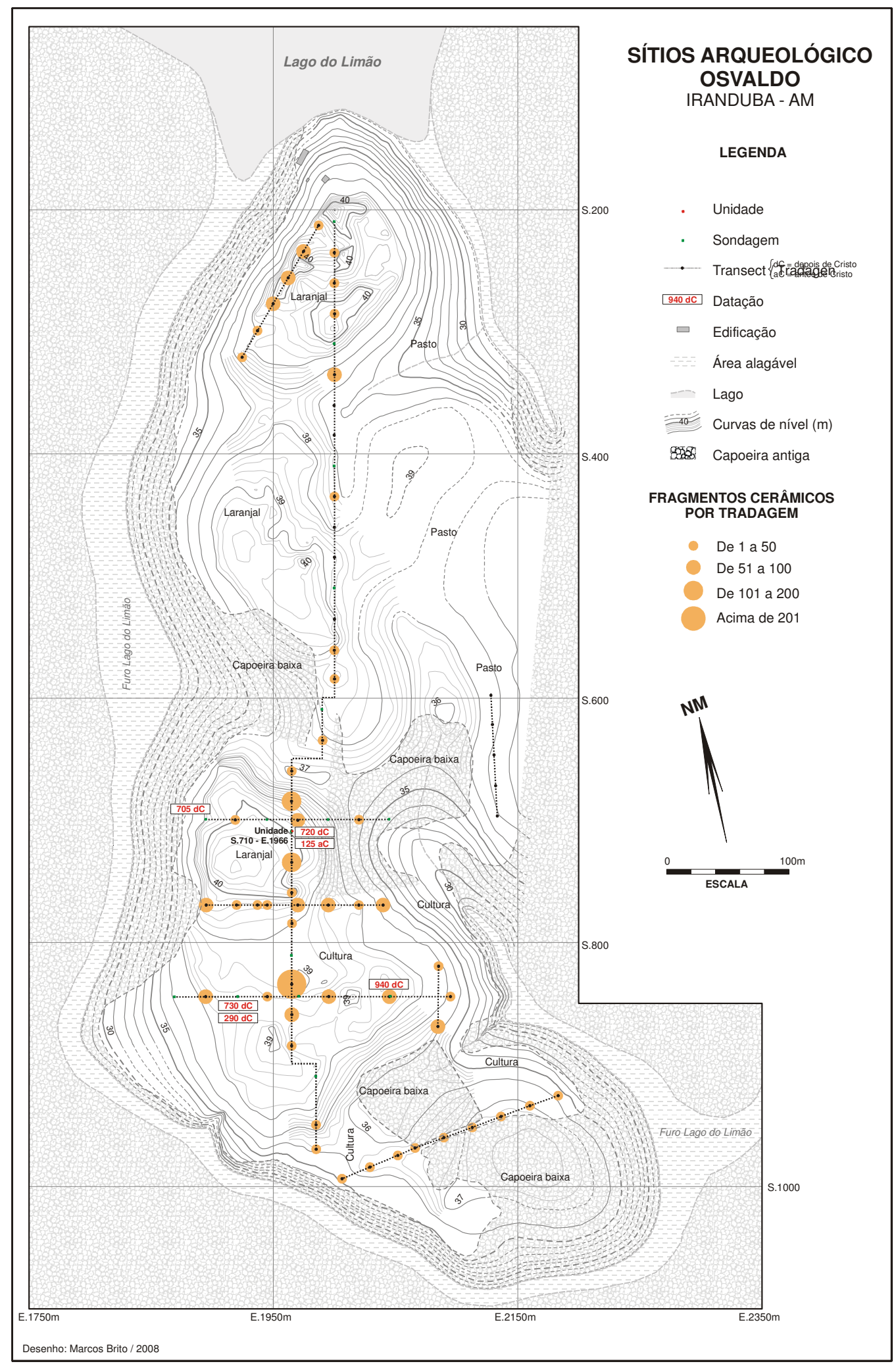

Figura 57 - Planta topográfica do sítio Osvaldo, com densidades de vestígios e datações radiocarbônicas. 


\section{SÍTIO ARQUEOLÓGICO DO OSVALDO PERFIL ESTRATIGRÁFICO}

UNIDADES S.710 - E.1965/1966

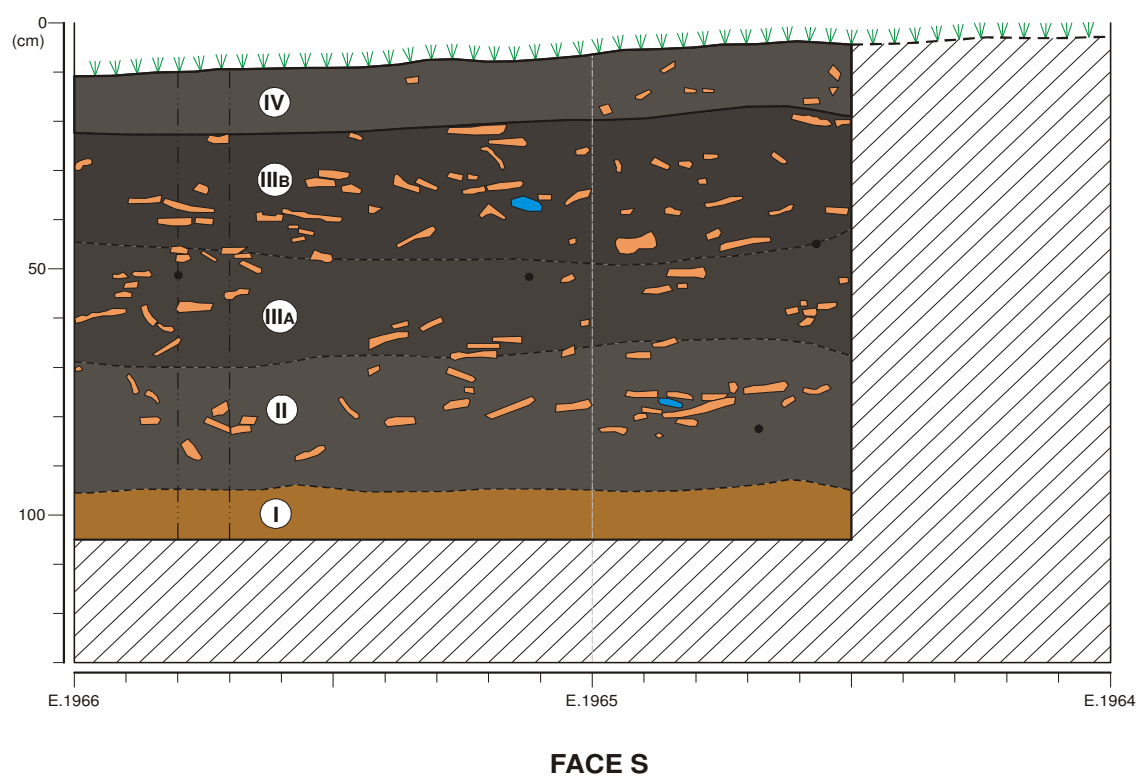

(IV) 10YR 3/1 : "Very dark gray", silte artiloso, bastante compacto, pertubado, área de cultivo.

(IIIB 10YR 2/1 - "Black", silte argiloso, bastante compacto, terra preta intacta.

IIIA 10YR 2/1 - "Black",. porém mais claro e visívelmente mais argiloso, mesclado com 10YR 5/8.

III 10YR 3/1 - "Very dark gray", base da terra preta, aumento da argila.

(I) 10YR 5/8 - "Dark yelowish brown", mesclado com 10YR 4/6, bastante compacto, argila intacta, subsolo sem depósitos culturais.

Área não escavada.

Figura 58 - Perfil da unidade S710 E1965-1966 


\section{IV.V.III. Sítio Lago Grande (Am-Ir-09)}

O sitio Lago Grande se localiza numa alta península, de topo aplainado e vertentes um tanto abruptas, no lago de mesmo nome, na parte oeste da área de pesquisa do PAC. Assim como ocorre com grande parte dos lagos de interflúvio nesta região, todas as penínsulas que margeiam o Lago Grande foram ocupadas no passado, dando lugar a diversos sítios arqueológicos.

Os trabalhos de campo ocorreram nas etapas de campo de 2001 e 2002 do PAC, e consistiram num mapeamento detalhado do sítio arqueológico e seus montículos, sua delimitação espacial e crono-estratigráfica através da realização de tradagens e da abertura de escavações de $1 \mathrm{~m}^{2}$. Este sítio foi objeto da pesquisa de mestrado e de uma iniciação científica (Donatti, 2003; Tamura, 2005), ambos no âmbito do PAC. Tais trabalhos mostraram tratar-se de uma ocupação da fase Paredão composta por montículos, dispostos na paisagem formando uma espécie de semicírculo. Ainda, Donatti demonstrou que, relacionado à ocupação Paredão no sítio, houve um evento de construção de uma vala, possivelmente defensiva, na área limítrofe do sítio arqueológico, no estreitamento da península (fig 59).

A análise do material cerâmico da unidade N500E500, escavada no montículo 1, indicou uma relação de co-variação quantitativa entre a indústria Paredão e Manacapuru, sendo que os tipos Manacapuru apareceriam proporcionalmente em relação aos tipos Paredão nas camadas estratigráficas da unidade (Donatti, 2003, p. 96). Também os materiais provenientes de duas outras unidades de escavação, situadas no montículo 2, analisados por A. Tamura (2005) revelaram relação semelhante, além de indicar um discreto pacote cultural num nível bastante profundo e abaixo da camada do montículo, com cerâmicas que poderiam estar relacionadas à fase Açutuba. As datações obtidas confirmaram tal ocorrência.

Assim, a seleção de Lago Grande como objeto da presente pesquisa se refere à avaliação de duas questões principais. Em primeiro lugar, do entendimento da co-ocorrência de vestígios das fases Manacapuru e Paredão, num sítio eminentemente relacionado a esta última, ao contrário de Osvaldo, por exemplo. Em segundo lugar, objetivou-se checar a possível ocorrência de um evento de ocupação mais antigo, relacionado à fase Açutuba, o que viria a confirmar um padrão na área de pesquisa, fornecendo elementos para a 
discussão colocada adiante, sobre o início da produção de cerâmica na Amazônia central.

\section{Cronologia de ocupação e uso do espaço}

Dezoito amostras de carvão foram datadas (gráfico 14), e demonstraram haver certa contemporaneidade na ocupação dos montículos datados, situando sua cronologia de ocupação entre fins do século VIII e início do XII d. C. As datas obtidas foram distribuídas da seguinte maneira: oito no montículo 1 , três no montículo 3, e cinco na unidade 4, uma na unidade 5 (esta deve ser descartada, pois datou de 1900 d.C.), além de uma data na trincheira. As variações cronológicas de cada área do sítio encontram-se representadas no mapa (fig 59).

Os dados sugerem tratar-se de uma mesma ocupação talvez contínua e com uma duração entre 250 e 300 anos, e com cerâmicas vinculadas às fases Manacapuru e Paredão. Análises anteriores mostraram uma predominância de cerâmicas da fase Paredão ao longo de toda a seqüência (Donatti, 2003; Tamura, 2005). O fato de tratar-se de uma única ocupação com cerâmicas das duas fases, sem diferenciação nas freqüências de uma ou de outra ao longo da cronologia ou dos níveis estratigráficos, reforça uma discussão que se colocará adiante, da vinculação entre fases cerâmicas e grupos culturais. Antes de vincular uma fase cerâmica a um determinado período de ocupação do sítio, ao contrário, as evidências de Lago Grande apontam para um único processo, contínuo e crescente, de ocupação, que teve seu ápice, como é suposto, em torno do século $X$ (data da construção da vala), seguido de seu abandono, supostamente em algum momento do século XII.

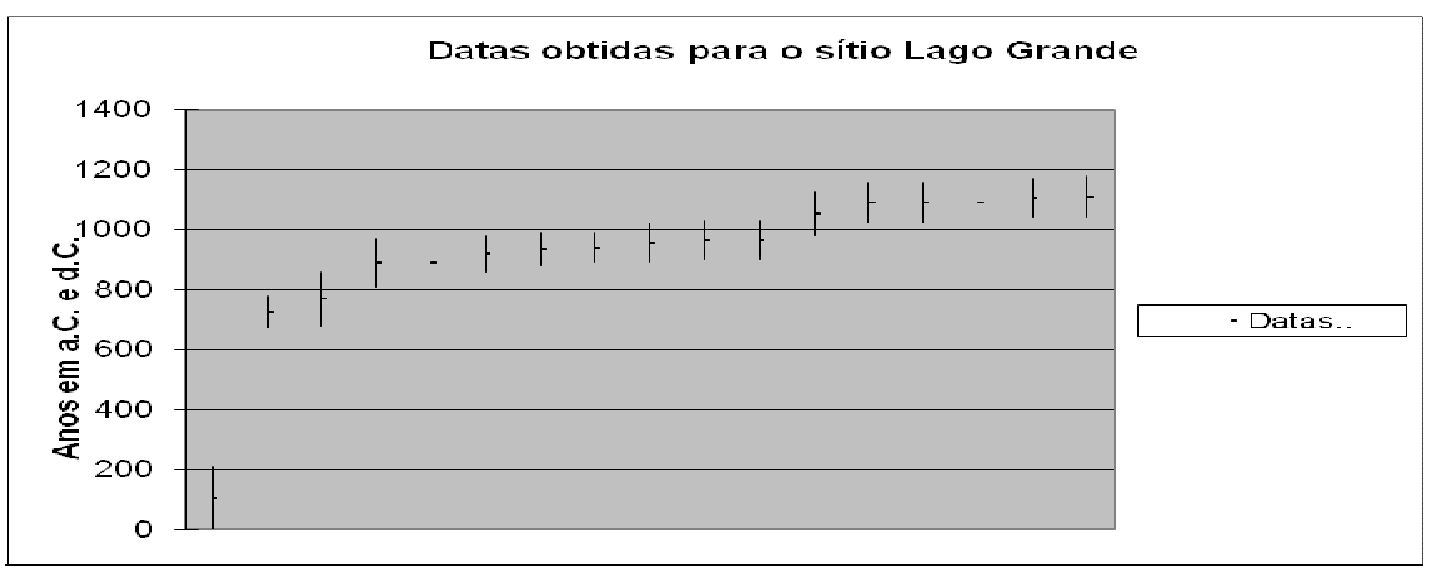

Gráfico 14 - Datações radiocarbônicas calibradas obtidas para o sítio Lago Grande. 


\begin{tabular}{|c|c|c|c|}
\hline $\begin{array}{l}\text { Número do } \\
\text { Laborátorio }\end{array}$ & Unidade & Profundidade & $\begin{array}{c}\text { Idade calibrada } \\
(66.8 \%)\end{array}$ \\
\hline BETA 143600 & Unidade 1 N0500 E500 & $36 \mathrm{~cm}$ & 900 d.C. -1030 d.C. \\
\hline BETA 143601 & Unidade 1 N0500 E500 & $75 \mathrm{~cm}$ & 1020 d.C. -1160 d.C. \\
\hline BETA 143602 & Unidade 1 N0500 E500 & $83 \mathrm{~cm}$ & 1020 d.C. -1160 d.C. \\
\hline BETA 143607 & Unidade 1 N0500 E500 & $89 \mathrm{~cm}$ & 1020 d.C. -1160 d.C. \\
\hline BETA 143604 & Unidade 1 N0500 E500 & $118 \mathrm{~cm}$ & 880 d.C. -990 d.C. \\
\hline BETA 143603 & Unidade 1 N0500 E500 & $123 \mathrm{~cm}$ & 810 d.C. -970 d.C. \\
\hline BETA 143605 & Unidade 1 N0500 E500 & $142 \mathrm{~cm}$ & 890 d.C. -990 d.C. \\
\hline BETA 143606 & Unidade 1 N0500 E500 & $158 \mathrm{~cm}$ & 670 d.C. -780 d.C. \\
\hline BETA 178921 & Unidade 3 & $37 \mathrm{~cm}$ & 1040 d.C. -1170 d.C. \\
\hline BETA 178919 & Unidade 3 & $50-60 \mathrm{~cm}$ & 1040 d.C. -1180 d.C. \\
\hline BETA 178920 & Unidade 3 & & 0.-210 d.C. \\
\hline BETA 178922 & Unidade 4 & $47 \mathrm{~cm}$ & 900 d.C. -1030 d.C. \\
\hline BETA 178925 & Unidade 4 & $56 \mathrm{~cm}$ & 980 d.C. -1130 d.C. \\
\hline BETA 178923 & Unidade 4 & $94 \mathrm{~cm}$ & 810 d.C. -970 d.C. \\
\hline BETA 178924 & Unidade 4 & $105 \mathrm{~cm}$ & 860 d.C. -980 d.C. \\
\hline BETA 178928 & Unidade 4 & $157-196 \mathrm{~cm}$ & 680 d.C. -860 d.C. \\
\hline BETA 178926 & Unidade 5 & $36 \mathrm{~cm}$ & 1890 d.C. -1910 d.C. \\
\hline BETA 178927 & Trincheira & $113-119 \mathrm{~cm}$ & 890 d.C. -1020 d.C. \\
\hline
\end{tabular}

Tabela 12 - Idades calibradas obtidas no sítio Lago Grande.

Tamura observou que a variabilidade encontrada entre as cerâmicas Paredão é maior na unidade 3 do que nas demais, e sugere que a distribuição diferenciada de vestígios cerâmicos por casa, indicaria uma diferenciação social dentro da aldeia, tal como proposto por Wüst e Barreto para aldeias circulares encontradas no Brasil central (1999, apud Tamura, 2003 p.18). Essa linha interpretativa se mostra bem interessante para o entendimento do uso do espaço em sítios arqueológicos relacionados às ocupações Manacapuru e Paredão na Amazônia central, onde só muito recentemente começou-se a entender as variações espaciais intra-sítio, assim como a interpretar seus possíveis usos e funcionalidades (os trabalhos de Moraes, 2006; Portocarrero, 2007; e Rebellato, 2007, tem se mostrado muito frutíferos nesta direção). Tais dados têm demonstrado, cada vez mais, íntima integração entre as fases Manacapuru e Paredão, em diversos aspectos, o que nos leva, mais uma vez, a re-pensar seus significados históricos e culturais.

Como o gráfico demonstra, obteve-se também uma data, mais antiga, de 105 d.C, para uma ocupação supostamente relacionada à fase Açutuba. Não se 
tem ainda muitos dados sobre tal ocupação no sítio, o que demandará novas etapas de campo. Mas as análises realizadas por Tamura indicaram tratar-se, de fato, de cerâmicas com características da fase Açutuba. Como se pode ver, as pesquisas levadas a cabo no sítio Lago Grande fornecem mais elementos para o entendimento das relações crono-estratigráficas entre as diferentes fases cerâmicas relacionadas à tradição Borda Incisa, além de trazer dados importantes para discussões sobre a espacialidade, demografia e relações sociais e políticas na região, por volta dos séculos XI e XII d.C.

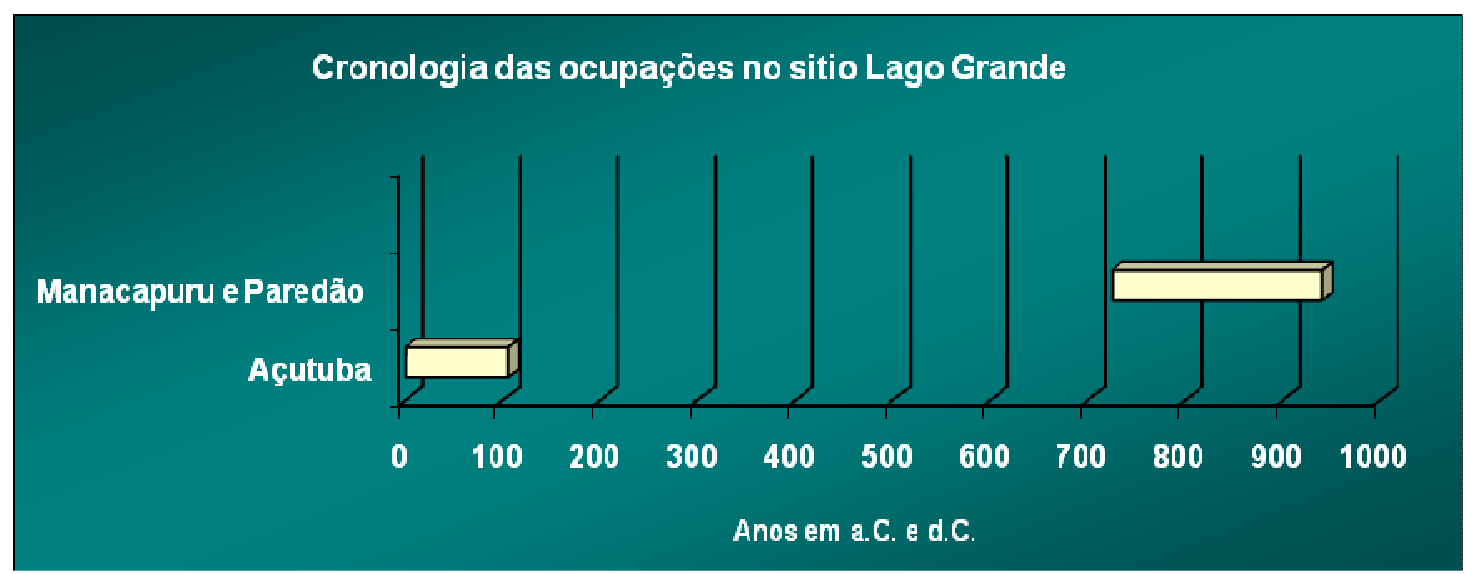

Gráfico 15 - Cronologia de ocupação do sítio Lago Grande. 


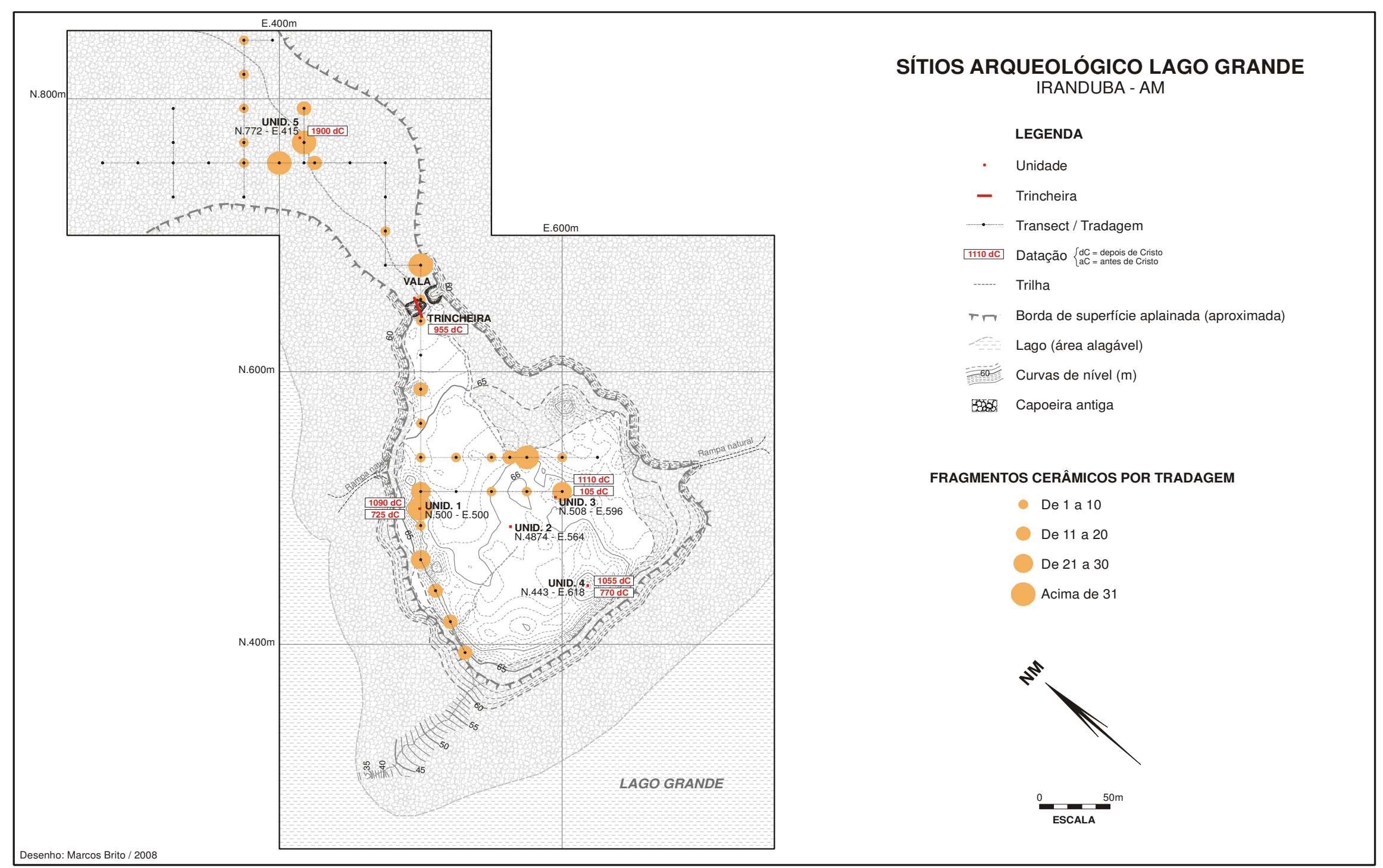

Figura 59 - Planta topográfica do sítio Lago Grande, com concentrações de vestígios e datações radiocarbônicas. 


\section{V.IV. Sítio Nova Cidade}

O sítio Nova Cidade localiza-se na zona urbana da cidade de Manaus, a cerca de $15 \mathrm{~km}$ de distância da margem esquerda do rio Negro (fig 60). Os trabalhos no sítio foram executados em duas etapas, em 2001 e em 2004, por meio do "Programa de Resgate Arqueológico do Sítio Nova Cidade", solicitado pela $1^{\circ} \mathrm{SR}$ do IPHAN e pelo Ministério Público Federal (AM), para avaliação dos danos causados ao acervo arqueológico, e de seu entorno, pelas obras de construção de casas populares no local.

O sítio se caracteriza pela presença de materiais cerâmicos e líticos expostos na superfície, numa ampla área, de aproximadamente 12,7 ha. As ocorrências ocupam um topo aplainado e vertentes suaves, com solo exposto de característica areno-argilosa e cor amarela, uma vez que os pacotes arqueológicos e a matriz sedimentar, composta pelas terras pretas antrópicas, foram removidos durante as obras de terraplanagem (Neves e Costa, 2001; Neves et al., 2004a).

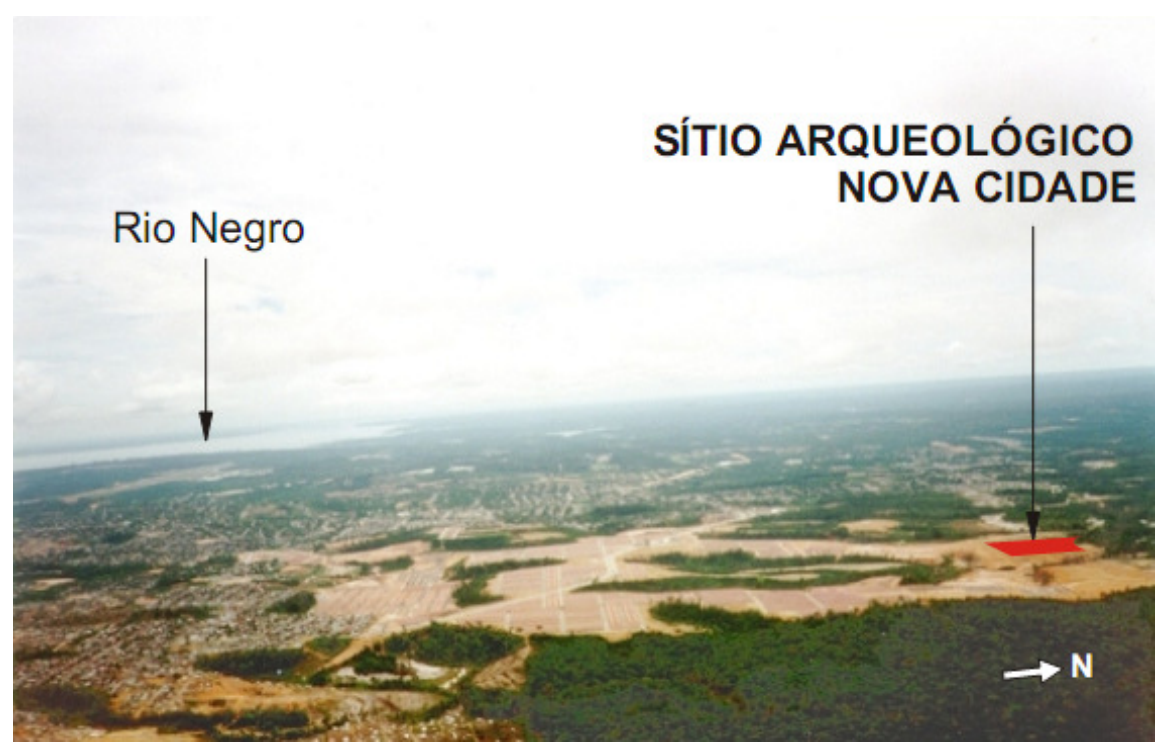

Figura 60 - Vista aérea do sítio arqueológico Nova Cidade, na zona urbana de Manaus (Neves e Costa, 2001).

Durante a etapa de 2001, foram mapeados mais de duzentos recipientes e 238 concentrações cerâmicas. Deste total, 13 recipientes foram exumados. Além dos materiais cerâmicos, foram coletados artefatos líticos lascados, polidos e picotados. O novo mapeamento, realizado entre junho e julho de 2004, indicou 
quarenta novos recipientes e onze concentrações de fragmentos que as chuvas evidenciaram, sendo que 140 recipientes foram perdidos pela ação erosiva. Outros dois recipientes cerâmicos e alguns fragmentos nos sítios do entorno foram coletados nesta última etapa (fig. 62)

Os materiais cerâmicos coletados são na maior parte associados à fase Paredão, mas há também alguns fragmentos da fase Manacapuru, e da fase Guarita. Um total de vinte recipientes foi total ou parcialmente recuperado entre as escavações de 2001 e 2004, que geraram as análises e tipologia apresentadas nas próximas sessões. Estes materiais foram selecionados para estudo na presente pesquisa por apresentarem uma amostra da indústria Paredão em boas condições de preservação - a tipologia foi obtida a partir de vasilhame total ou parcialmente remontado (fig. 61). Como já apontado, a possibilidade de se trabalhar com vasilhame inteiro ainda é oportunidade rara na Amazônia central.
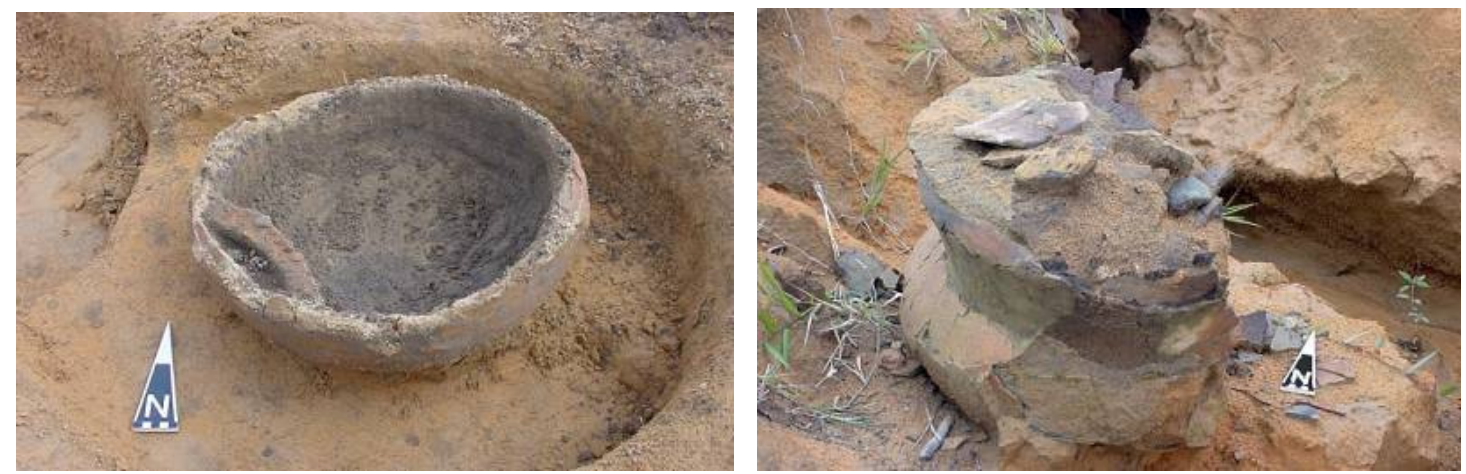

Figura 61 - Recipientes 9 e 10, exumados na etapa de 2001, no sítio Nova Cidade (Neves \& Costa 2001).

\section{Cronologia de ocupação e uso do espaço}

Embora muitas amostras de carvão em ótimo contexto tenham sido coletadas durante as escavações no sítio, ainda não se obteve nenhuma datação radiocarbônica. Ainda assim, Nova Cidade pode ser facilmente inserido na cronologia relativa da Amazônia central, isto porque a os materiais recolhidos no sítio apresentaram características diagnósticas dos conjuntos conhecidos na região. Não obstante, um entendimento mais detalhado sobre seu processo de formação e de ocupação já não é mais possível, por encontrar-se completamente 
destruído. Mesmo na ocasião da primeira etapa de campo, em 2001, o sítio já se encontrava em elevado grau de devastação, tendo sua camada cultural, composta pelas terras pretas antrópicas, arrancada pelas obras de terraplenagem. Por outro lado, foram estas mesmas obras responsáveis pela evidenciação das centenas de vasilhas, outrora enterradas.

Tais materiais apresentam características típicas da fase Paredão, tais como apliques antropomorfos e as clássicas urnas funerárias. Mais uma vez, materiais desta indústria aparecem associados a fragmentos da fase Manacapuru. De fato, com as análises, foi possível observar similaridades tecnológicas entre essas duas indústrias. Muitos desses recipientes continham ossos humanos em seu interior, indicando tratar-se de sítio-cemitério de grandes proporções. Materiais da fase Paredão estão sempre associados a contextos funerários, como ocorre nos sítios Açutuba, Nova Cidade, Puraquequara, Praça D. Pedro II e UDV. Os três últimos também se situam na zona urbana de Manaus.

Outro ponto que destaca o sítio Nova Cidade é o fato de se tratar de um assentamento de grandes dimensões composto pelas terras pretas antrópicas e localizado num ambiente de terra firme. Esse sítio reitera a necessidade de reavaliar os modelos de ocupação dos diferentes ecossistemas encontrados nas floretas tropicais. 


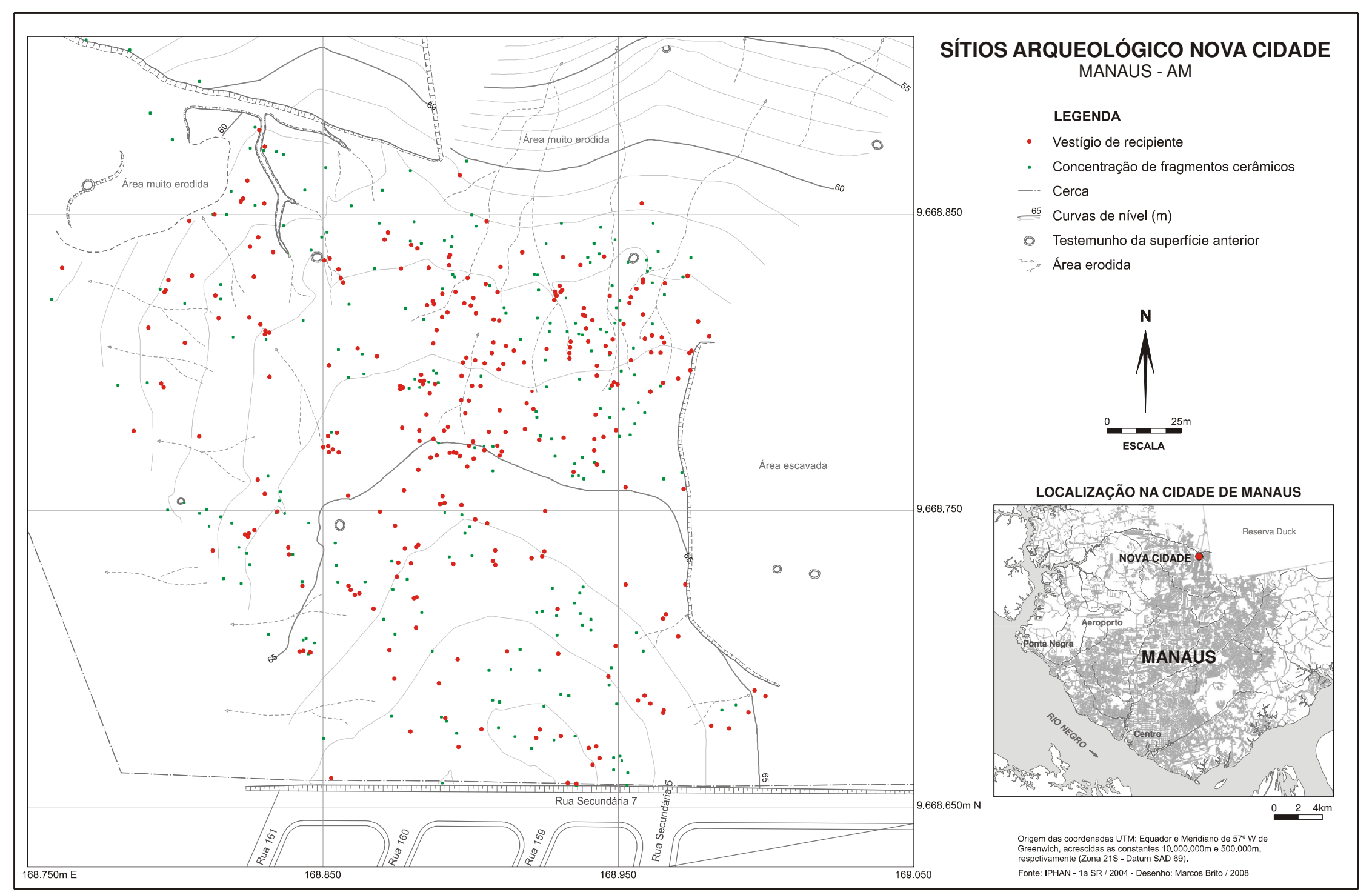

Figura 62 - Planta topográfica do sítio Nova Cidade, incluindo recipientes registrados em 2001 e 2004. 


\section{Capítulo V \\ O QUE, PORQUE E COMO ANALISAR}

"Classification, like statistics, is not an end in itself but a technique by means of which to attain specified objectives, and so it must be varied with the objective"

(Irving Rouse, 1960, p. 313)

\section{V.I. Introdução}

Há quem diga que nosso entendimento de mundo é fruto de nossas classificações. Se pensada dessa forma, é muito mais um processo cognitivo do que parâmetro de análise. Mas não pretendo chegar a tanto! Aqui, elas serão abordadas somente no que diz respeito à segunda opção. De acordo com o Novo Dicionário Aurélio da Língua Portuguesa (2004), a palavra classificar refere-se à distribuição [de objetos, no caso] em classes. Discutidas no âmbito da arqueologia, a intenção é lançar um olhar sobre os objetos com um fim específico: o de construir uma história cultural.

Se, como diz a epígrafe acima, classificações em última instância são não mais do que ferramentas usadas para se atingir certos objetivos, (neste caso, históricos), torna-se mister que os métodos analíticos empregados sejam flexíveis a ponto de variar de acordo com os problemas de pesquisa que se colocam frente ao universo que se pretende acessar. $O$ caso amazônico aqui tratado apresenta uma particularidade, pois, em decorrência de diversos fatores, tanto de ordem físico-ambientais, quanto históricos, as análises de cultura material foram sempre voltadas ao estudo privilegiado de uma categoria de objetos apenas, as cerâmicas. 
De fato, as cerâmicas pré-coloniais da Amazônia impressionam, não apenas por sua rara beleza, mas também pela enorme quantidade em que são encontradas. Mas isto se deu por outras razões. Por um lado, devido as suas melhores condições de preservação, são um vestígio extremamente abundante, em detrimento, por exemplo, dos materiais de origem orgânica, como fibras vegetais, edificações em madeira, restos alimentares etc. Embora hoje em dia tais categorias de vestígios sejam acessadas por meio de determinadas abordagens analíticas, essa incorporação é recente na arqueologia amazônica.

Além disso, este privilégio das cerâmicas se deu também por uma opção analítica que se refere ao contexto histórico em que as pesquisas na Amazônia se desenvolveram até então. Enquanto se tinha na cerâmica um vestígio em maior quantidade e com maior variabilidade, viu-se no estabelecimento de tipologias baseadas na tecnologia cerâmica um modo de se estabelecer cronologias relativas e comparações regionais. A própria escolha analítica - a seriação através do método Ford - reflete a postura teórica adotada por estes pesquisadores trabalhando na Amazônia. A premissa deste método de seriação, emprestado de classificações taxonômicas, se encarrega de estabelecer padrões de mudanças materiais calcados em princípios evolutivos (Ford, 1954, 1962), o que se enquadra bem nos paradigmas ambientais que permearam as hipóteses então vigentes sobre a ocupação da Amazônia (Meggers, 1948; 1954; 1990; Meggers e Evans, 1970).

Se outrora a predileção analítica pela cerâmica era quase unânime, hoje em dia não o é mais. As pesquisas atuais se utilizam de uma variedade de métodos analíticos que demonstram uma abrangência teórica que valoriza a multiplicidade do objeto arqueológico. Um exemplo disso, já citado, é o das terras pretas antrópicas, hoje ponderadas enquanto ecofatos, ou seja, resultantes de ações levadas a cabo por povos no passado, colocando-se como mais uma fonte de informações a ser conjugada a uma variada gama de dados, a fim de se entender modos de vida pretéritos.

Esta pesquisa também viu nas cerâmicas uma fonte privilegiada de informações culturais e históricas. O tamanho dos depósitos, a profusão de sítios e sua variabilidade (tanto formal quanto tecnológica e decorativa) foram fatores que me levaram a olhar a cerâmica também de modo preferencial, mas através de um ângulo peculiar, relacional. Seu potencial informativo, tanto maior quando 
contrastado com outras linhas de evidência (Schaan, 2007, p. 87), faz com que as análises cerâmicas tenham um papel importante na construção do conhecimento acerca de um passado cultural. Desde, é claro, que elas não sejam vistas como fonte única de informações, tampouco que o estabelecimento de tipologias se torne um fim em si próprio. Ao contrário, é essencial que estas análises sejam "desengessadas" e conjugadas a outras fontes de dados. Isso é uma tendência em atuais pesquisas arqueológicas no Brasil (Almeida, 2008; Bandeira, 2008; Schaan, 2004; Dias, 2003; Machado, 2005; Moraes, C. A. 2007; Silva, 2000)

Neste sentido, minha pesquisa encontra-se numa situação singular, na qual disponho de dados relativos a uma enorme diversidade de análises, por ser parte de um projeto maior e bem estruturado, como é o PAC. Deste modo, pude extrair de maneira mais proveitosa as inúmeras possibilidades informativas do registro arqueológico, ao contar com diversos trabalhos já realizados, ou em andamento, por colegas de equipe. Com isso, fui instigada a desenvolver uma metodologia de análise mais flexível, em função de meus problemas concretos de pesquisa e da variada base empírica com que contava. Cabe salientar que classificações de objetos são numerosas, e variam segundo os objetivos de quem as propõe, ou conforme os aspectos que se deseja realçar (Santos, 2002, p. 69).

Os preceitos metodológicos utilizados neste trabalho foram sintetizados no presente capítulo, que se estruturou em cinco itens principais. $O$ item primeiro trata do histórico das pesquisas na Amazônia, no que diz respeito às suas diretrizes metodológicas. A partir daí, são tecidas considerações teóricometodológicas sobre a interpretação dos vestígios arqueológicos, pensando como análises baseadas em sistemas tecnológicos podem ser fontes potenciais de informação histórica e cultural. Apresento também a metodologia desenvolvida, na qual traço todo um processo na busca de métodos analíticos aplicáveis ao problema de pesquisa, incluindo os muitos erros e alguns acertos. E mostro, ao final, a ficha de análise e seus parâmetros classificatórios na forma de um "guia de conceitos e terminologias" usados no trabalho. 


\section{V.II. Análises cerâmicas na Amazônia: antecedentes históricos}

Problemas relacionados à classificação cerâmica têm longa data no debate arqueológico. Uma das primeiras tentativas de ordenar a cultura material précolonial sul-americana data da primeira metade do século $\mathrm{XX}$, e baseou-se na busca de relações espaciais e temporais entre artefatos. As cerâmicas, nesse momento, eram classificadas através das noções de traço, estilo e complexo. Por traço entendia-se o componente mínimo na comparação dos artefatos; estilo era uma agregação recorrente de traços e, por fim, a categoria mais abrangente era 0 complexo, entendida como um agrupamento de estilos (Howard, 1943). Apesar da aparente clareza nessas definições, sua aplicação era por vezes confusa, sendo os conceitos de estilo e complexo sobrepostos em muitos casos (Raymond, 1995, p.225).

Mas classificação, particularmente aplicada à cerâmica, se tornou um assunto por demais debatido entre arqueólogos que trabalham na Amazônia, bem como nos demais contextos tropicais sul-americanos, em especial a partir das décadas de 50-60. Isto porque, como se viu, as hipóteses de ocupação da região divergiam em vários aspectos, assim como as interpretações dadas ao vestígio material, que por sua vez partiam de parâmetros classificatórios também distintos. O estabelecimento de formas sistemáticas de classificação da cultura material tornava-se imperativo para que se pudessem embasar tais modelos. Dessa maneira, métodos analíticos específicos passaram a ser utilizados por diferentes pesquisadores a fim de tornar possíveis inferências a respeito da história cultural a ser interpretada através dos contextos arqueológicos.

Nesse contexto, duas vertentes metodológicas são notáveis dentro da arqueologia amazônica. A primeira delas, vinculada a Meggers e seus seguidores, teve enorme influência não apenas na Amazônia, mas em todo o Brasil. A outra não teve expressão dentro das pesquisas desenvolvidas no âmbito nacional, mas teve relevância no contexto arqueológico das terras baixas tropicais.

A enorme variabilidade encontrada no registro arqueológico representaria um problema para o estabelecimento de um sistema universal de classificação. Buscando resolver tais questões, Meggers e Evans procuraram métodos classificatórios que dessem conta de tamanha variabilidade em termos espaciais e temporais. Nesse sentido, os métodos de classificação evolutiva das espécies 
utilizados nas ciências biológicas apresentavam-se aplicáveis também à cultura material. Assim, com vistas a classificar materiais cerâmicos e líticos em categorias significativas de abrangência crono-espacial, obteve-se o método então desenvolvido, a seriação, formulada a partir de uma adaptação do método de quantificação criado por James Ford em 1945 (Ford, 1954), associada a conceitos biológicos, tais como a taxonomia (a classificação evolutiva das espécies) e ao conceito de população (Meggers e Evans, 1970, p.3).

Esta perspectiva tem como foco o padrão de mudança, que ocorreria da mesma forma tanto em fenômenos orgânicos quanto nos culturais. As recorrências surgiriam, aumentariam em freqüência para, então, desaparecerem e darem origem a outras novas (Simpson, apud. Meggers e Evans, 1970, p. 114). Seguindo este parâmetro, a construção de escalas de tempo relativas era feita a partir da observação dos padrões de mudança de popularidade dos tipos cerâmicos, possibilitando estabelecer relações com quaisquer sítios que apresentassem tipos semelhantes (Meggers e Evans, 1970, p. 9). Seus procedimentos analíticos foram detalhados em diversas publicações, entre as quais "Como Interpretar a Linguagem da Cerâmica: Manual para Arqueólogos de autoria de Meggers e Evans" (1970).

Pressuposto metodológico básico da seriação era a amostragem: esta deveria ser aleatória (não selecionada), e representaria a variabilidade total da coleção (Meggers e Evans, 1970, p.12-13). As unidades passíveis de serem classificadas na seriação eram os fragmentos e não o vasilhame completo (idem, p. 25). A primeira divisão, em qualquer amostra, era feita entre fragmentos cerâmicos decorados e não decorados. Para cada uma dessas categorias um procedimento analítico distinto era utilizado, visando o estabelecimento de tipos ${ }^{11}$. Também este conceito de tipo foi inicialmente estabelecido por Ford, que os entendia como agregados de atributos, neste caso, cerâmicos, com significado histórico demonstrável em termos de padrões comportamentais (Ford, 1954; Willey \& Phillips, 1958), sendo assim capazes de revelar mudança sistemática através do tempo (Meggers e Evans, 1970, p. 22). Uma vez definidos os tipos, observava-se sua freqüência ao longo de um vetor temporal, que podia crescer

\footnotetext{
${ }^{11}$ Este assunto tem reflexos diretos para as tipologias estabelecidas na Amazônia, e serão considerados adiante.
} 
ou decrescer em popularidade de maneira regular e identificável, estabelecendo, assim, as cronologias relativas.

A seqüência seriada, formada a partir da construção desses diagramas de freqüências dos tipos, indicaria relações cronológicas entre diferentes sítios. Pretendia-se assim estabelecer "cronologias naturais" através da seriação cerâmica para grandes regiões (Meggers e Evans, 1970, p. 74-75).

O método de seriação tal como descrito pautava-se em escalas de contigüidade temporal, espacial e formal. No entanto, essas escalas não eram determinadas de maneira objetiva, abarcando valores diferentes em cada caso específico (Dunnell, 1986, p. 173). A necessidade de tornar tais categorias analíticas comparáveis levou ao estabelecimento de critérios hierárquicos de diferenciação que levassem em conta a variação tempo-espaço-forma. Estabelecia-se assim o sistema de tipo-variedade, uma classificação hierárquica de tipos em relação a variações temporais, espaciais e formais. Os dados gerados eram sistematizados através dos conceitos de fase e tradição, que por sua vez foram adaptados das discussões de Willey \& Phillips (1958). Os chamados Horizontes, Tradições e Fases arqueológicas marcam a literatura arqueológica brasileira até o presente, e a importância de tais categorias analíticas se deve ao mapeamento arqueológico de grande parte do território brasileiro, possibilitando em muitos casos comparações inter-regionais.

De fato, a questão assumiu certa importância em âmbito nacional devido à grande padronização metodológica oriunda, em parte, da enorme influência que o PRONAPA teve no Brasil. A metodologia implementada por este programa visava uniformizar o sistema de classificação arqueológica no Brasil e em outros países da América do Sul. A resultante unificação terminológica possibilitou a comparação do registro arqueológico de diferentes regiões, sustentando assim diversos modelos de ocupação, não apenas da Amazônia como também em todo o território nacional.

Apesar de utilizado em larga escala, o método de análise cerâmica por seriação não era a única opção disponível. O principal contraponto metodológico a este método, à época, foi a análise modal. Embora pouco difundido na arqueologia brasileira, foi bastante aplicado na Amazônia peruana, venezuelana, equatoriana, e nas terras baixas em geral. O método de análise modal foi desenvolvido entre as décadas de 30 e 40 por Irving Rouse, autor que dedicou 
grande parte de sua vida acadêmica a problemas de classificação de artefatos (Rouse, 1955, 1960). Essa metodologia foi utilizada por autores como Donald Lathrap e Warren DeBoer (DeBoer et al., 1996; DeBoer e Lathrap, 1979) no Peru e no Equador, respectivamente.

Também chamada de análise componencial, foi desenvolvida segundo princípios de classificação estrutural da lingüística descritiva e da etnologia. Ambas as disciplinas lidam com comunidades de indivíduos que compartilham dos mesmos hábitos e se comunicam numa única língua, e sua análise consiste na observação de conjuntos de regras culturais. O mesmo se daria na arqueologia. A utilização desse método no contexto arqueológico buscava identificar grupos que compartilhassem idéias e regras a respeito da produção e utilização da cultura material (Raymond, 1995, p. 227).

Desta forma, a análise modal procura abordar os potes cerâmicos através da apreensão de unidades mínimas de significado, denominadas modos, e de suas diferentes formas de interação. As regras que definem a estruturação das variáveis numa dada coleção de potes cerâmicos são criadas através de hipóteses êmicas. Tais hipóteses são construídas a partir da combinação recorrente entre atributos, indicando padronizações no conjunto, os modos, definidos como "qualquer padrão, conceito ou costume que regula o comportamento dos artesãos dentro de uma comunidade, que é transmitido de geração em geração, e que pode se difundir entre comunidades em distâncias consideráveis" (Rouse, 1960, p. 313).

Diferente do princípio da seriação, em que os fragmentos cerâmicos são o próprio universo pesquisado, este tipo de análise entende os fragmentos como partes de vasos inteiros. Assim, a primeira tarefa analítica do pesquisador consistiria em inferir, tanto quanto possível, as características formais do vasilhame. Uma vez que a variabilidade formal é conhecida, determina-se quais são variáveis significativas, ou definidoras das formas, os modos, utilizando-as para a comparação entre os diferentes vasos. Segundo esta metodologia, outros atributos da cerâmica, como a argila, o tempero e a queima, por exemplo, são variantes subordinadas aos modos de forma. Por fim, os motivos e as técnicas decorativas são analisados como um sistema estrutural separado da forma e do processo de fabricação do pote. A decoração é entendida como um conjunto de regras que estruturam a composição das unidades mínimas de sentido, formando 
os motivos e sua aplicação à forma do vaso. Portanto, assim como é necessário, ao menos em papel, construir vasos completos para a análise de suas formas, é necessário construir todos os parâmetros de seu design para que se entendam suas estruturas (Raymond, 1995, p. 229-230).

Definidos dentro dos conceitos classificatórios que sustentam os métodos de análise anteriormente discutidos (seriação e análise modal), os conjuntos artefatuais são os alicerces empíricos das hipóteses de ocupação da Amazônia, ou seja, bases para a construção de histórias culturais. Do mesmo modo, na análise aqui proposta, esses materiais fundamentam as interpretações que, neste caso, utilizam-se de conceitos explanatórios diversos, e tornam necessária a agregação de elementos conceituais à própria definição dos conjuntos artefatuais.

\section{V.III. Sobre a interpretação dos sistemas tecnológicos e mudança cultural}

Os atuais estudos sobre os sistemas tecnológicos se dividem em duas principais vertentes. Por um lado, a chamada visão tradicional de tecnologia utilizou conceitos explanatórios, tais como evolução e determinismo tecnológico, entendendo a tecnologia em última instância, como índice de adaptabilidade. Por outro lado, uma abordagem mais recente tem procurado explicações que levem em conta a dimensão simbólica, percebendo o fenômeno tecnológico como uma construção social, e criticando com severidade as tipologias historicamente definidas para diversas regiões do Brasil (Dias, 2003, 2007; Dias e Silva, 2001; Machado, 2005-2006; Schaan, 2004, 2007; Silva, 2000). Tais críticas pautavamse mais na forma como essas tipologias foram utilizadas, do que em como foram originalmente concebidas. Dentro desta perspectiva, o uso de certos conceitos classificatórios, na arqueologia brasileira, teria se tornado o fim último das pesquisas arqueológicas, e não um meio para a reconstrução histórica, esvaziando estes conceitos de seus significados culturais.

Hoje em dia tais críticas são feitas no sentido de que "muitos arqueólogos ainda estão à busca de uma receita de bolo que os permita estudar a cerâmica sem as deficiências ou o "mal-estar" trazido pelo modelo antigo" (Schaan, 2007, p. 87). Ou seja, desde os tão criticados trabalhos, em especial aquelas seriações desenvolvidas pelo PRONAPA, a arqueologia vinha tentando, sem muito êxito, superar questões classificatórias. Mais do que isso, essas considerações se colocam frente à própria falta de crítica da arqueologia brasileira pós-PRONAPA. 
Desde outros pontos de vista, pode existir uma conciliação entre essas visões, ditas opostas, através, por exemplo, da "combinação da metodologia ecológica estabelecida com um novo paradigma teórico essencialmente pós-processual, que entende tecnologia como uma construção cultural ao invés de uma força natural" (Loney, 2000, p. 647).

O foco neste caso volta-se ao entendimento da dinâmica comportamental subjacente aos sistemas tecnológicos, já que estes são o resultado de ações escolhas - levadas a cabo pelo artesão durante todo o processo de produção uso, reuso e descarte dos artefatos. Entende-se como escolha "apenas aquelas que para cada atividade (ou seqüência de atividades) havia alternativas, enumeradas pelo investigador moderno, que não foram escolhidas." (Schiffer \& Skibo, 1997). Estas podem resultar de diferentes fatores, tanto de ordem prática como simbólica.

Embora estas novas perspectivas teóricas tenham surgido como reações ao excesso de empirismo classificatório dos métodos histórico-culturais, num primeiro momento as escolhas tecnológicas foram pensadas por meio de um viés fortemente adaptativista, relacionado com as limitações e possibilidades do meio a que as populações estavam inseridas e de suas demandas sócio-econômicas (Dias, 2007, p. 63). Este movimento, que se deu nos países de língua inglesa na década de 60 (a chamada Nova Arqueologia), tinha como base a premissa de que o comportamento humano apresentaria uma grande padronização em relação às características formais e à espacialidade dos objetos por eles materializados. Estes comportamentos seriam, portanto, refletidos no registro arqueológico e passíveis de interpretação através de metodologias apropriadas (Trigger, 1989, p. 296). Certos autores que representam esta empreitada processual, como L. Binford (1983), em geral partem de uma perspectiva ambiental e entendem tecnologia como essencialmente pragmática, valorizando fatores adaptativos, tais como quantidade, qualidade e distância das fontes de matérias primas. Segundo essa perspectiva, as escolhas seriam orientadas a partir de uma equação de custo-benefício.

A partir da década de 80, alguns autores começaram a sugerir outras posturas para as análises tecnológicas. Absorvendo as contribuições e, especialmente, apontando críticas com relação à arqueologia processual, uma nova leva de arqueólogos se dedicou a pensar sobre "a compreensão da natureza 
da variabilidade tecnológica e qual a sua relação com o registro arqueológico" (Dias, 2007, p. 64). Autores como Bleed (2001), Chilton (1998), Schiffer \& Skibo (1997) passavam a pautar as explicações dadas às escolhas nos mais variados fatores, uma vez que sistemas tecnológicos são dinâmicos assim como os sistemas culturais. Entre estes fatores, estão os próprios limites do instrumento e a eficiência das características de performance. Esses autores acabaram por se aproximar do pensamento arqueológico desenvolvido então na França, à parte das reviravoltas teóricas dos países de língua inglesa, e que buscava explorar relações entre cognição e escolhas tecnológicas.

A sucessão dessas escolhas técnicas, desde a procura, seleção e preparo da matéria prima, técnicas de manufatura empregadas, acabamento de superfície e a decoração, geram o que foi definido inicialmente por Leroi-Gourhan e reavaliado por Lemonnier como cadeia operatória, ou seja, a seqüência de operações para a realização da transformação da matéria em artefato (Lemonnier, 1986). Esta interpretação mais abrangente dos sistemas tecnológicos como parte dos sistemas culturais pode ser atribuída também à herança da escola francesa deixada aos antropólogos por Marcel Mauss, que entendia tecnologia como uma construção social, o corpo humano como meio técnico e o objeto como gesto técnico: "O corpo é o primeiro e o mais natural instrumento do homem (...) e ao mesmo tempo meio técnico. (...) Antes das técnicas de instrumentos, há o conjunto das técnicas do corpo" (Mauss, 2003 [1935], p. 407). Vista desde uma perspectiva mais ampla, o estudo da tecnologia envolve todos os aspectos do processo de ação sobre a matéria, "whether scratching one's nose, planting sweet potatoes, or making jumbo jets" (Lemonnier, 1992, p. 1).

Neste estudo de caso, procura-se entender as escolhas ligadas à tecnologia cerâmica através de ambas as perspectivas, utilizando a cadeia operatória como a categoria analítica a ser descrita, e procurando, quando possível, fazer inferências sobre as escolhas tecnológicas envolvidas. As seqüências de ações, ou "o jeito de fazer", e suas conseqüentes escolhas, específicas de cada cultura, definem uma tradição ou sistema tecnológico. Cabe, assim, ao pesquisador moderno entender essa organização tecnológica (Hegmon, 1992) para que possa atingir o plano determinante das escolhas. Este é um problema que a arqueologia brasileira enfrentou durante muito tempo, pois as tradições historicamente definidas, tanto em termos de cerâmica como de lítico, 
tiveram uma perspectiva estanque dos artefatos, não pensando em tecnologia com a abrangência anteriormente apontada.

Como observa Dias (2003, p. 9), as diretrizes teórico-metodológicas dos programas de pesquisa existentes no Brasil nas décadas de 70 e 80 assumiram conotações paradigmáticas, passando a definição de fases e tradições a constituir o objetivo último do trabalho arqueológico. Desta forma, "a importância relegada aos métodos acabou por mascarar o corpo teórico que guiava os objetivos da pesquisa e conduziu a equívocos interpretativos quanto à capacidade explicativa dos conceitos utilizados" (Idem).

Isto acabou gerando uma necessidade de revisão do uso das fases e tradições, qual a que estamos propondo para o contexto amazônico, com foco na Tradição Borda Incisa. O que postulamos aqui não é a rejeição destes conceitos, mas pelo contrário, utilizá-los como ferramentas analíticas que nos permitam compreender os conjuntos de artefatos com os quais lidamos dentro de uma perspectiva cronológica e espacial, entendendo as continuidades e mudanças como processos culturais, sociais, políticos e históricos. Assim, o conceito de tradição tecnológica utilizado neste trabalho se refere às interações de cunhos social, econômico e simbólico recorrentes entre diferentes grupos humanos, abrangendo áreas com grande extensão geográfica e com longa duração cronológica, que projetam certas padronizações nos artefatos. Padronizações materiais estas que podem induzir o pesquisador desatento a confusões interpretativas. Devem ser consideradas variações das mais diversas naturezas, como as ambientais, sócio-políticas e culturais, locais, dentro da abrangência histórica de um determinado sistema, ou tradição, tecnológica.

Fases cerâmicas são aqui adaptadas a partir de sua concepção original, definida por Willey \& Phillips como "unidade arqueológica que possui traços suficientemente característicos para distingui-la de outras unidades (...) de uma localidade ou região cronologicamente limitada a intervalos de tempo relativamente breves” (1958, p. 22). A esta definição deve-se acrescentar que unidades arqueológicas refletem entidades sistêmicas, não sendo, portanto, estanques. Ao contrário de sua definição inicial, postula-se agora que seus limites jamais serão claramente definidos.

Os mecanismos envolvidos no estabelecimento, manutenção ou mudança das tradições tecnológicas são variados e dinâmicos, tal qual a cultura. Eles 
podem ser de ordem cognitiva, evolutiva, sociológica, ou prática - ambiental. Alguns autores evocam a necessidade como fator causal da mudança tecnológica. Deve-se, no entanto, atentar para o fato de que este é um conceito culturalmente definido, que varia de grupo para grupo. Uma mudança pode também estar associada a uma simples invenção. O que se deve entender, no entanto, são os mecanismos envolvidos na permanência - ou adoção - de um novo elemento em uma cultura: como e por que uma invenção se mantém (é adotada), tornando-se uma inovação; mudança resultante de processos históricos e que, portanto, deve ser "entendida num nível histórico e contextual" (Loney, 2000, p. 647).

Outro elemento que não pode deixar de ser mencionado ao se pensar na dinâmica de uma cultura, como ela muda ou se mantém, é a estrutura de ensinoaprendizagem inerente aos grupos humanos, já que " $O$ homem se distingue fundamentalmente dos animais por estas duas coisas: pela transmissão de suas técnicas e provavelmente pela sua transmissão oral." (Mauss, 2003 [1935], p. 407), pois "o ensino e aprendizagem são fundamentais, implicitamente ou explicitamente, para a adaptação humana, socialização, mudança cultural e, num nível mais amplo, para a produção e reprodução da cultura e da sociedade" (Pelissier, 1991, p. 75). No que se refere a mudanças de longa duração, Schiffer sugere que estão a rigor relacionadas à competição, e que são discerníveis no registro arqueológico (Schiffer, 2001, p. 215).

Assim, a questão a ser colocada é: como identificar mudança no registro arqueológico? Um primeiro passo está na observação dos vestígios em associação com outros elementos que não apenas o conjunto artefatual, a saber, o contexto e a tecnologia.

\section{V.IV. Discussão metodológica: o caminho percorrido}

Com base nas discussões apresentadas, procurei uma metodologia que fosse aplicável aos milhares de fragmentos cerâmicos disponíveis, e que esclarecesse as questões colocadas acerca do entendimento de uma suposta padronização, bem como da variabilidade interna dos conjuntos tratados. No entanto, os métodos analíticos a princípio desenvolvidos não forneceram os resultados esperados, sendo necessária uma avaliação crítica dos procedimentos adotados, que serão brevemente relatados a seguir. Ao final do processo, foi 
possível a determinação de um sistema tecnológico relacionado à Tradição Borda Incisa, a partir de uma contextualização abrangente dos conjuntos cerâmicos.

Em todas as suas etapas de amadurecimento, a análise procurou calcar-se na "história de vida do artefato": o processo de produção, uso, reuso e descarte, procurando assim tentar compreender seus possíveis significados culturais. Mesmo não tendo chegado tão longe, ao tratar os artefatos enquanto expoentes de sistemas tecnológicos e estes, por sua vez, enquanto a expressão material de atividades culturais (Lemonnier, 1992, p.2), os procedimentos analíticos adotados levaram a uma compreensão mais ampla dos significados da variabilidade dos conjuntos tratados, inclusive em termos históricos, uma vez que elementos contextuais foram também inseridos.

Assim sendo, as primeiras etapas do processo analítico, referentes à caracterização do sistema tecnológico tratado, foram voltadas à definição da cadeia operatória, com vistas à identificação das escolhas tecnológicas a ela vinculadas. Para tanto, foi desenvolvida uma metodologia na qual as diferentes etapas do processo de produção cerâmica eram agregadas em categorias de atributos, sem quaisquer relações de hierarquização entre elas.

A observação destes atributos presentes na superfície de cada fragmento foi orientada por uma ficha contendo a seguinte estrutura geral de categorias: proveniência (sítio, unidade, profundidade); informações métricas (comprimento, espessura); antiplástico; técnica de manufatura; tratamento e cor da superfície; local e padrões de decoração; marcas de uso. As informações foram registradas em planilhas do aplicativo Microsoft Excel e encaminhadas para o centro de estatística aplicada do Instituto de Matemática e Estatística da USP (IME-USP).

Cada atributo, bem como suas possibilidades de associações, era contemplado na ficha na forma de variáveis binárias, ou seja, que elencam a presença ou ausência desses atributos. A finalidade dessa ficha era a realização de uma análise multivariada que definisse as associações entre o maior número possível de atributos, sem qualquer hierarquização entre eles. A justificativa para este princípio era a eliminação da possibilidade de exclusão mútua entre atributos, e evitar também que nosso olhar sobre a cerâmica fosse permeado por pré-concepções - já que se tratavam de materiais anteriormente descritos (Hilbert, 1968). Desta forma, poder-se-ia observar variações consistentes na cerâmica que pudessem conter significados cronológicos ou culturais. Dentro de 
um método analítico, as fronteiras entre variáveis podem se tornar arbitrárias porque cerâmicas pertencem a uma classe de fenômeno em mudança contínua: variam geográfica e temporalmente.

No entanto, foi tão vasta a amplitude de variáveis que as análises estatísticas não puderam formar agrupamentos significativos. Também os princípios e a estrutura de nossa ficha não foram inicialmente compatíveis com as próprias possibilidades estatísticas. As análises estatísticas foram realizadas pelo Instituto de Pesquisas Energéticas e Nucleares (IPEN) e pelo Centro de Estatística Aplicada (IME-USP), e estão disponíveis nos seguintes relatórios: Borges \& Coelho (2003) (RAE - CEA - 03P12), Peixoto \& Okura (2003) (RAECEA - 03P32). Eles podem ser encontrados na biblioteca do Instituto de Matemática e Estatística da USP.

Outro problema revelado pela aplicação da estatística foi o fato de havermos considerado no mesmo nível hierárquico dois tipos diferentes de variáveis: descritivas (que contém informações sobre a proveniência dos fragmentos e dados métricos) e binárias (que elencam a presença ou ausência de atributos), produzindo um banco de dados confuso e com ruídos que prejudicaram a formação dos grupos.

Todas estas análises foram feitas no âmbito de minha Iniciação Científica (Lima, 2003), que teve, entre seus objetivos, desenvolver e testar esta ficha de análise, em contraposição aos métodos de seriação tradicionalmente aplicados na Amazônia. Tudo isso serviu como um aprendizado para o desenvolvimento das novas análises que consideram toda uma variada gama de atributos de maneira relacional. Além disso, as falhas apontadas neste processo levaram a uma reorientação da própria ficha, fazendo com que resultados mais efetivos fossem alcançados, como se verá a seguir. Mais do que isso, perdi a ilusão de que se poderia eliminar por completo os aspectos subjetivos de uma análise, acreditando que tal objetividade seria alcançada através de métodos estatísticos.

\section{V. Métodos aplicados}

Os problemas encontrados nas análises anteriores nos levaram a reestruturar a ficha de análise, reduzindo o número de variáveis para que fosse possível a formação de grupos consistentes, sem, no entanto, comprometer a qualidade da análise ou seu objetivo principal. A nova ficha manteve o mesmo 
princípio, possibilitando que elementos de diferentes naturezas fossem considerados também como definidores de tipos. As análises estatísticas exigiram que as informações referentes a cada uma das categorias gerais de fragmentos (bordas, bases, paredes, etc) fossem elencadas a priori, e que as informações de cada fragmento, gerais e específicas, referentes a cada uma destas das categorias fosse a elas ancorado. Tal procedimento possibilitou que os resultados estatísticos fossem mais consistentes. As modificações abrangeram também o item que se refere ao local e padrão de decoração, reduzindo-os a categorias mais gerais. Os métodos e resultados das últimas análises, também realizadas pelo Centro de Estatística Aplicada (IME-USP), podem ser encontrados em Magalhães et al. (2007) (RAE - CEA - 07P09).

A meu ver, estes resultados foram mais satisfatórios do que os anteriores, permitindo que, além de uma freqüência individual de atributos, a associação dos atributos formadores dos conjuntos cerâmicos (tipos) fosse comparada estatisticamente, através de cruzamentos multivariados. Mas fica, outra vez, um alerta: não se deve esperar que a estatística, por si só, dê luz aos conjuntos artefatuais, como se estes fossem naturalmente determinados. Enquanto categoria ética (em oposição às categorias êmicas), estes conjuntos devem ser formados a partir de contextualizações abrangentes, definidas a critério do pesquisador e seus problemas de pesquisa.

A ficha de análise, e sua apreciação posterior, foi pensada a partir de duas seqüências interpretativas. Uma delas quantitativa, em que foi elencada uma série de características observáveis nos fragmentos, produzindo uma gama de dados que pudessem ser comparados entre si, muitas vezes de uma maneira numérica e estatística. A outra, qualitativa, procurou entender os elementos da análise anterior, bem como a forma como os atributos se relacionavam, com intuito de empreender a formação de uma tipologia, cujos conjuntos foram agrupados por semelhanças. Com tais procedimentos foi possível empreender um refinamento analítico que levasse em conta dados de diferentes naturezas, possibilitando uma interpretação que acredito ser mais apurada, tanto do ponto de vista tecnológico quanto em relação à variabilidade estilística.

Os elementos considerados na definição dos tipos aproximam este método à análise modal, ou seja, a partir de sistemas reconhecidamente normativos que mostram estruturas hierárquicas e formam padrões de mudança contínua 
(Boomert, 2000, p. 4). Esses mesmos tipos, considerados cronologicamente, aproximam também esta análise aos "tipo-variedades" de Meggers e Evans (1970), com a diferença que, em nosso caso, o tempero não é o elemento definidor dos tipos.

Para os tipos e fases cerâmicas da Amazônia, definidos através de uma variação da seriação tal como já foi descrito, esta análise tem uma diferença fundamental. $\mathrm{Na}$ chamada seriação por gênero, os fragmentos eram seriados apenas com base no antiplástico. Nessa forma de seriação não eram levados em consideração quaisquer elementos decorativos ou tratamentos de superfície, por exemplo. Mesmo cientes de que tal categorização "não dá a atenção devida ao fato de que as técnicas decorativas e sua relativa freqüência são geralmente as características cerâmicas mais úteis para comparações inter-regionais e para traçar linhas de difusão" (Meggers \& Evans, 1970, p. 39) e conhecendo certos fatores negativos do uso da classificação de gênero, esse método foi largamente aplicado e os dados a partir dele gerados foram utilizados para comparações inter-regionais, como por exemplo, a atribuição exógena da complexa cerâmica policroma da Amazônia central (Miller, 1992; Meggers, 1971).

Em minha pesquisa, tanto fragmentos quanto vasos inteiros ou parcialmente remontados foram tratados segundo os mesmos parâmetros classificatórios, e foram agrupados em tipos a partir de suas semelhanças. Vale lembrar que dentro do universo de peças trabalhadas, é parca a presença de vasos inteiros (ou parcialmente remontados): as coleções são compostas, na grande maioria, por milhares e milhares de fragmentos com tamanhos diferenciados. Ainda assim, estes poucos exemplares inteiros foram fundamentais para o estabelecimento da tipologia. A partir do reconhecimento estrutural do vasilhame, que é dado principalmente por estes vasos, e das padronizações gerais conjugadas à sua variabilidade interna, é possível determinar graus de diferença e de semelhança, estabelecendo-se assim os conjuntos cerâmicos internos a uma fase arqueológica, os tipos, bem como as relações entre as próprias fases.

Os critérios utilizados para definição dos tipos foram discutidos: trata-se fundamentalmente de uma classificação qualitativa segundo modos de forma, pasta e decoração; da contraposição desta aos dados quantitativos dos atributos observados em cada fragmento ou vaso, ajustados através de uma estatística 
descritiva; e, quando possível, de uma posterior análise estilística estrutural. A combinação dos resultados dessas etapas gerou a tipologia. Conforme se poderá observar nas pranchas dos tipos definidos, apresentadas no apêndice desta tese, as variações que geraram tipos e subtipos são de natureza tanto morfológica quanto tecnológica ou decorativa.

Se, por um lado, valorizam-se os modos de forma, estes não são os únicos fatores definidores dos tipos, devendo ser considerados em conjunto com os demais atributos. A formação dos tipos a partir de uma observação qualitativa foi feita ao final da aplicação sistemática da ficha de análise. Seu objetivo é propor conjuntos hipotéticos a partir de semelhanças visíveis encontradas nos fragmentos que devem, ou não, ser corroborados pelas associações estatísticas e, a partir de então, contrapô-los aos resultados da análise quantitativa. Tal contraposição se mostra interessante tanto por confrontar os resultados de dois métodos de análise distintos, assim como por permitir que se discutam os resultados estatísticos com maior flexibilidade.

Finalmente, "existe um consenso de que se podem alcançar resultados significativos para a história cultural combinando-se a temática da distribuição de traços culturais com informações de outra ordem" (Newton, 1987, p.23), e isso foi considerado também na análise desenvolvida, que agregou às categorias geradas certas informações que julguei relevantes às interpretações. Assim, a diferenciação entre fases distintas não se deu apenas através da comparação entre os tipos cerâmicos (estes, muitas vezes, se interpolam em diferentes fases), mas principalmente através da observação dos contextos, tanto deposicionais (por exemplo, a presença ou ausência das terras pretas), como estratigráficos e distribucionais, intra e inter-sítio. Feita desta forma, a análise cerâmica extrapola os limites informativos dos fragmentos ao colocar-se em diferentes esferas analíticas, desde suas características físicas e sua representatividade espacial nas esferas local, micro-regional e macro-regional.

\section{V. I. Procedimentos laboratoriais}

Muitos e variados são os procedimentos adotados em relação aos vestígios depois de sua coleta no sítio arqueológico. Em relação às cerâmicas, que, como se viu, superam muito em quantidade às demais amostras, a seguinte seqüência é executada: limpeza, triagem, numeração, análise a partir da ficha, desenhos, 
reconstituições morfológicas, fotografias, análises arqueométricas. Claro, nem todas as centenas de milhares de fragmentos coletados passaram por todas as etapas. O tratamento dado a um fragmento ou a uma coleção variou de acordo com as perguntas que se colocaram frente a eles.

Apenas as duas primeiras etapas, a limpeza e a triagem, se aplicaram ao total de peças disponíveis. Em relação à limpeza, houve uma mudança, a meu ver muito positiva, no tratamento desses materiais. No início, os vestígios coletados eram transportados aos laboratórios do MAE-USP em São Paulo, onde eram lavados ao modo tradicional, ou seja, com água corrente e com o auxílio de escovas de dentes. Com o apoio de uma especialista em conservação e restauro do MAE, Silvia Cunha, foram desenvolvidos novos métodos de limpeza, que permitiram a preservação, na superfície dos fragmentos, de uma série de características tais como pigmentos, resinas, marcas de uso, outrora dificilmente reconhecíveis. Com a nova abordagem, a limpeza passou a ser feita em diferentes etapas, e de diferentes maneiras, para cada coleção tratada, variando, mais uma vez, de acordo com os objetivos de estudo estabelecidos para a coleção, bem como com a própria condição de preservação do material, que pode demandar diferentes procedimentos. Ou seja, a curadoria inicial passou a ser feita de modo mais integrado com a pesquisa e a coleção disponíveis.

Inicialmente a seco, o primeiro passo se restringe à remoção do excesso de sedimento da superfície do caco com o uso de um palito de madeira, o que já permite um tratamento inicial das peças tais como a quantificação e pesagem. Além da importante economia de água, o tempo gasto com este procedimento é bem menor, aplicando-se muito bem ao contexto amazônico, onde se lida com coleções compostas por milhares e milhares de peças. Feito isso, apenas os fragmentos que passarão por posteriores análises serão trabalhados. Estes serão limpos, agora, com um pouco de água e com pincéis de diferentes durezas, ou, em casos mais frágeis (com a presença de resinas ou pinturas), com pequenos pedaços de algodão presos a uma haste. Passando por esta etapa, os fragmentos estarão perfeitamente aptos a qualquer tipo de análise. Não sendo suficiente, ou quando se almeja uma maior limpeza, para peças que serão fotografadas ou expostas em museus, uma nova etapa ainda pode ser feita, novamente a seco, com o auxílio de um bisturi, com o qual se removerá as 
impurezas restantes na superfície. Esta última, mais delongada, foi utilizada apenas em alguns exemplares.

O próximo passo do processo curatorial, já classificatório, é a triagem, que consiste numa separação inicial, bem como na quantificação e pesagem das cerâmicas. Essa separação entre os fragmentos em classes genéricas de acordo com sua posição na vasilha, e entre decorados ou simples, como mostra a ficha abaixo, possibilita uma série de análises interpretativas sobre o sítio arqueológico, das mais variadas naturezas. É a partir da triagem e quantificação que se obtém, por exemplo, informações sobre a dispersão dos vestígios dentro do sítio, base para análises funcionais intra-sítio. Também as pesquisas visando 0 entendimento de formas de assentamento dentro do PAC pautaram-se nesse tipo de procedimento (por exemplo, Portocarrero, 2007; Rebellato, 2007). Análises cronológicas em bases estratigráficas também fundamentam suas informações em dados resultantes das triagens, abordando, por exemplo, as concentrações de vestígios em diferentes profundidades (a presente pesquisa utilizou-se muito disso na interpretação dos sítios arqueológicos). Nesta etapa são considerados todos os materiais coletados. A partir desses dados pode-se calcular, por exemplo, o índice de fragmentação da amostra (através de uma relação entre peso e tamanho dos fragmentos), que pode indicar a presença, por exemplo, de pisos de ocupação, de áreas mais ou menos intactas, orientando melhor as próprias intervenções futuras no sítio arqueológico. Da mesma forma, o estabelecimento das densidades relativas intra-sítio para ambos os aspectos analíticos, espacial ou cronológico, que permite o reconhecimento da dispersão dos vestígios, horizontal ou vertical, é condição para as subseqüentes inferências, tornando as possibilidades informativas da triagem ainda mais abrangentes.

Apesar da pequena quantidade de vestígios líticos presentes nas unidades de escavação dos sítios pesquisados, estes poucos fragmentos passaram pelos mesmos procedimentos de triagem e quantificação descritos acima para 0 material cerâmico. Quando possível, uma breve análise de sua constituição e morfologia foi levada a cabo, considerando, por exemplo, as matérias-primas utilizadas. 


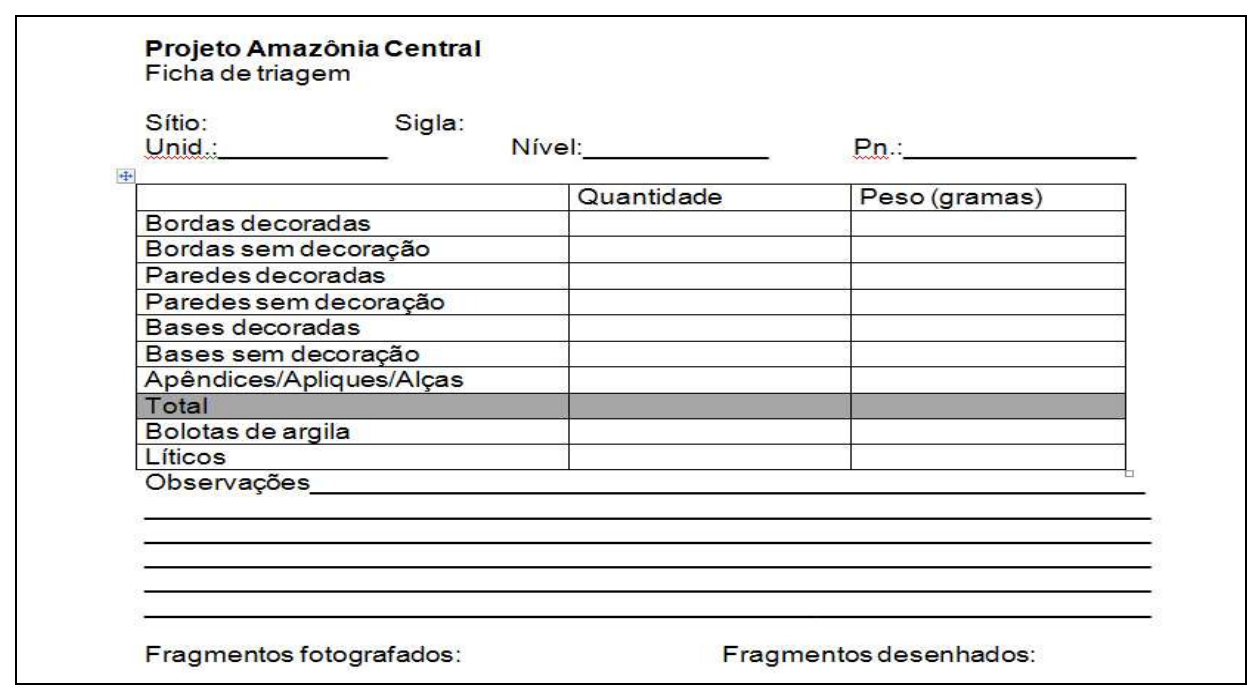

Figura 63 - Ficha de triagem.

Ainda em parceria com a equipe de conservação do MAE surgiu a idéia que resultou numa interessante experiência de "laboratório em campo", realizada na campanha de 2007. Através da montagem de uma estrutura laboratorial no próprio sítio arqueológico, foi possível tratar de imediato das cerâmicas coletadas nas escavações. Com um diagnóstico preliminar das densidades e características dos materiais recém coletados, principalmente na delimitação do sítio arqueológico através de tradagens, as aberturas de novas unidades de escavação, por exemplo, foram melhor orientadas e assim tiveram resultados mais efetivos.

A partir da triagem são selecionados os fragmentos que passarão pelas etapas analíticas subseqüentes. Elegem-se, em geral, aqueles que possam fornecer as informações buscadas. É por isso que a proporção de fragmentos analisados em relação ao total coletado / triado, varia. Aqueles que são selecionados (seja 100\% da amostra, seja uma parte dela, como apenas os decorados, ou apenas as bordas, por exemplo) passam por uma detalhada análise tecno-estilistica e morfológica, orientada a partir da ficha, que será apresentada e discutida em detalhes adiante. Todos os fragmentos analisados são numerados. A numeração é feita a partir da procedência de cada peça: o número do sítio, seguido pelo PN (número de proveniência, atribuído em campo, a uma única peça ou conjunto de peças, conforme anteriormente apresentado), e por um número seqüencial que se refere àquele fragmento específico. 
Nem todos os fragmentos analisados podem trazer as informações morfológicas necessárias ao reconhecimento de uma coleção. Assim, são desenhados apenas os perfis das bordas ou bases que permitam inferências formais. Através da determinação da posição do fragmento em relação ao vaso, estima-se, quando possível, a forma geral, o contorno, bem como o diâmetro do vaso a que pertenceu, medido através de um ábaco.

Finalmente, são desenhados e também fotografados aqueles fragmentos que se mostram relevantes para o tema analisado, seja por suas características físicas (decorativas, dos tratamentos de superfície, etc), seja por outros critérios. Durante todo o processo, em qualquer uma de suas etapas, são reservados também os fragmentos que passarão por outros tipos de análises, como as arqueométricas. Estas são muito variadas e respondem a perguntas de diferentes ordens. As secções delgadas das pastas cerâmicas auxiliaram a responder a questões sobre a mudança tecnológica ao longo do tempo. Estas foram realizadas no setor de laminação do Instituto de Geociências da USP (IGC-USP), e a microscopia ótica das lâminas feitas no laboratório de Dosemetria do Instituto de Física da USP (IF-USP).

O segundo tipo de análise arqueométrica realizada no âmbito desta pesquisa deu-se através de uma parceria com a equipe do Prof. Dr. Casimiro Munita, do IPEN, que realizou testes em materiais dos sítios Açutuba, Hatahara, Lago Grande e Osvaldo. Essas análises, de ativação com nêutrons, consistem em elencar os elementos-traço que compõem as argilas das pastas cerâmicas. Tratase de uma técnica analítica que permite a determinação da composição química de elementos presentes num determinado tipo de amostra, como também a análise quantitativa destes elementos ${ }^{12}$.

Através disso pretendia-se observar os padrões de escolhas das matérias primas nos diferentes sítios arqueológicos, representativos tanto geográfica como cronologicamente. Foi analisada ,mais de uma centena amostras. Com o apoio de um cuidadoso tratamento estatístico, essas análises visavam à formação de grupos de peças de acordo com as características dos elementos presentes em suas argilas, e que esses grupos tivessem alguma representatividade,

${ }^{12}$ As amostras são irradiadas com um fluxo de nêutrons que interagem com os núcleos dos isótopos dos elementos presentes na amostra formando os nuclídeos radioativos. Estes nuclídeos radioativos decaem de acordo com a sua meia-vida emitindo os chamados raios gama de decaimento, os quais devem ser medidos num detector (Nunes, 2008). 
interpretada em bases funcionais, temporais, ou da própria disponibilidade de matérias primas (cujas fontes, no caso do sítio Lago Grande, também foram prospectadas e encaminhadas à análise). Os agrupamentos foram feitos internamente aos sítios arqueológicos e, em alguns casos, entre eles. As discussões sobre estas análises serão apresentadas adiante, entretanto sua interpretação estritamente arqueológica demandaria um trabalho próprio, a parte da presente pesquisa. Essas análises e seus respectivos agrupamentos produziram uma série de gráficos e tabelas cuja validade para as questões tecnológicas colocadas, em termos culturais (das escolhas) e históricos, não puderam ainda, pelas razões mencionadas, ser avaliadas nessa pesquisa. $O$ tema será oportunamente retomado.

Ainda que o foco desta tese não esteja diretamente voltado às questões arqueométricas, com este trabalho foi possível avaliar o potencial informativo destas análises. Tais procedimentos realizados no âmbito deste doutoramento, no entanto, ainda não apresentaram resultados conclusivos, haja vista que a avaliação de cada um deles demandaria um trabalho delongado e específico, o que não foi possível desenvolver em tempo hábil. Estas análises, que deverão ser pensadas a posteriori, podem vir a refinar as interpretações aqui propostas.

Além do tratamento curatorial dado à cerâmica, aqui descrito com maior detalhamento, há ainda uma série de procedimentos relacionados aos outros materiais também coletados em campo. Assim, os carvões, por exemplo, são limpos de eventuais impurezas, secos em uma estufa por ao menos doze horas, e reembalados para envio aos laboratórios de datação - sempre com o cuidado de não manusear as amostras, evitando sua contaminação. Da mesma forma, o solo e outros vestígios coletados passam por procedimentos específicos, de acordo com a análise a que a amostra será submetida. 


\section{V. II. A ficha de análise e seus parâmetros metodológicos}

Para que a análise quantitativa fosse conduzida de forma a se considerar as diferentes etapas de todo o processo de produção cerâmica, os elementos técnicos, formais e decorativos foram agregados em categorias de atributos. A observação destes atributos presentes na superfície dos fragmentos coletados em campo foi orientada por uma ficha contendo a seguinte estrutura geral de categorias: proveniência (sítio, unidade, profundidade); informações métricas (comprimento, espessura); pasta (anti-plástico, técnica de manufatura, tratamento e cor da superfície); morfologia; decoração; e marcas de uso. Todas essas as informações, observadas em cada objeto ou fragmento, foram então registradas numa planilha do aplicativo Microsoft Office Excel. .

Uma vez que estamos lidando na maior parte dos casos com fragmentos e não com potes inteiros, a ficha e os princípios da análise se basearam na estrutura do pote. Assim, através de uma análise estrutural foi possível compilar, numa mesma ficha, atributos que dizem respeito a partes específicas dos objetos: as informações referentes a cada uma das categorias gerais de fragmentos (bordas, bases, paredes, etc) foram consideradas a priori, sendo que as informações de cada fragmento, gerais e específicas, referentes a cada uma das categorias, foi a elas ancorado.

Dentro desta sistemática, apesar de poucos, quando se trata de um objeto inteiro, todas as demais informações se aplicarão. Nos outros casos, apenas as informações específicas a cada componente do vaso serão observadas, ficando os demais itens do gabarito em branco.

A partir da observação sistemática dos objetos, gerou-se um corpus de informações que limita as diferentes categorias de atributos às possibilidades informativas inerentes a elas. Nesse momento, então, parte-se para a vinculação dos atributos de diferentes categorias e a conseqüente geração de conjuntos, como se pode ver no esquema apresentado a seguir. 


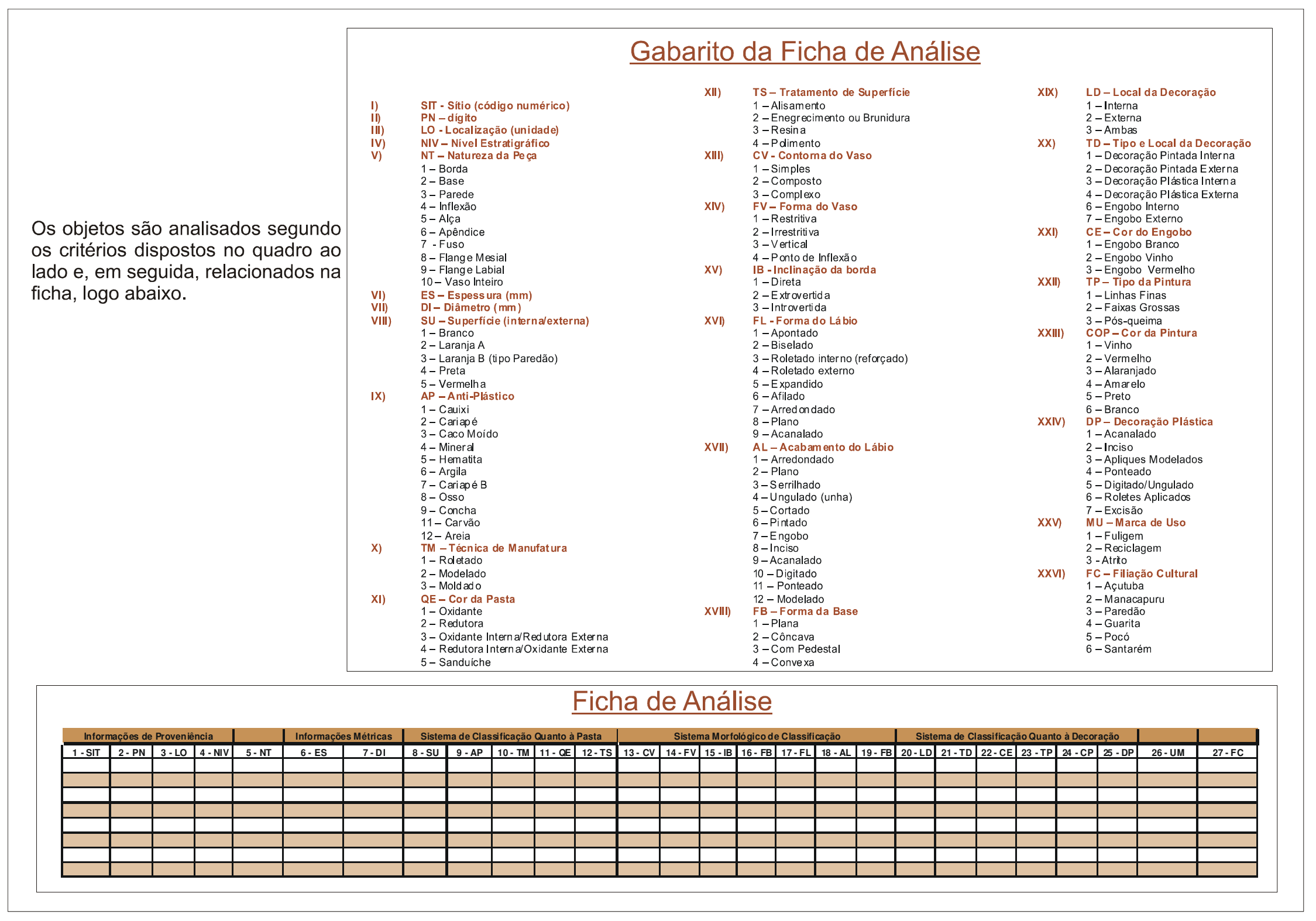

Figura 64 - Gabarito e Ficha de Análise 
Este esquema, feito em formato de organograma, parte das propriedades notadas nos fragmentos, e também de sua natureza (borda, base, parede etc.), para definir suas diferentes qualidades constitutivas. Somente então elas foram consideradas enquanto uma base de dados, comunicáveis entre si, possibilitando uma comparação em bases amplas. Este princípio estrutural de análises, que parte das características observáveis de componentes específicos dos vasos, possibilita que os fragmentos cerâmicos possam ser colocados sob o mesmo prisma interpretativo no que se refere aos dados quantitativos, mesmo em diferentes sítios e com elementos extremamente variados.

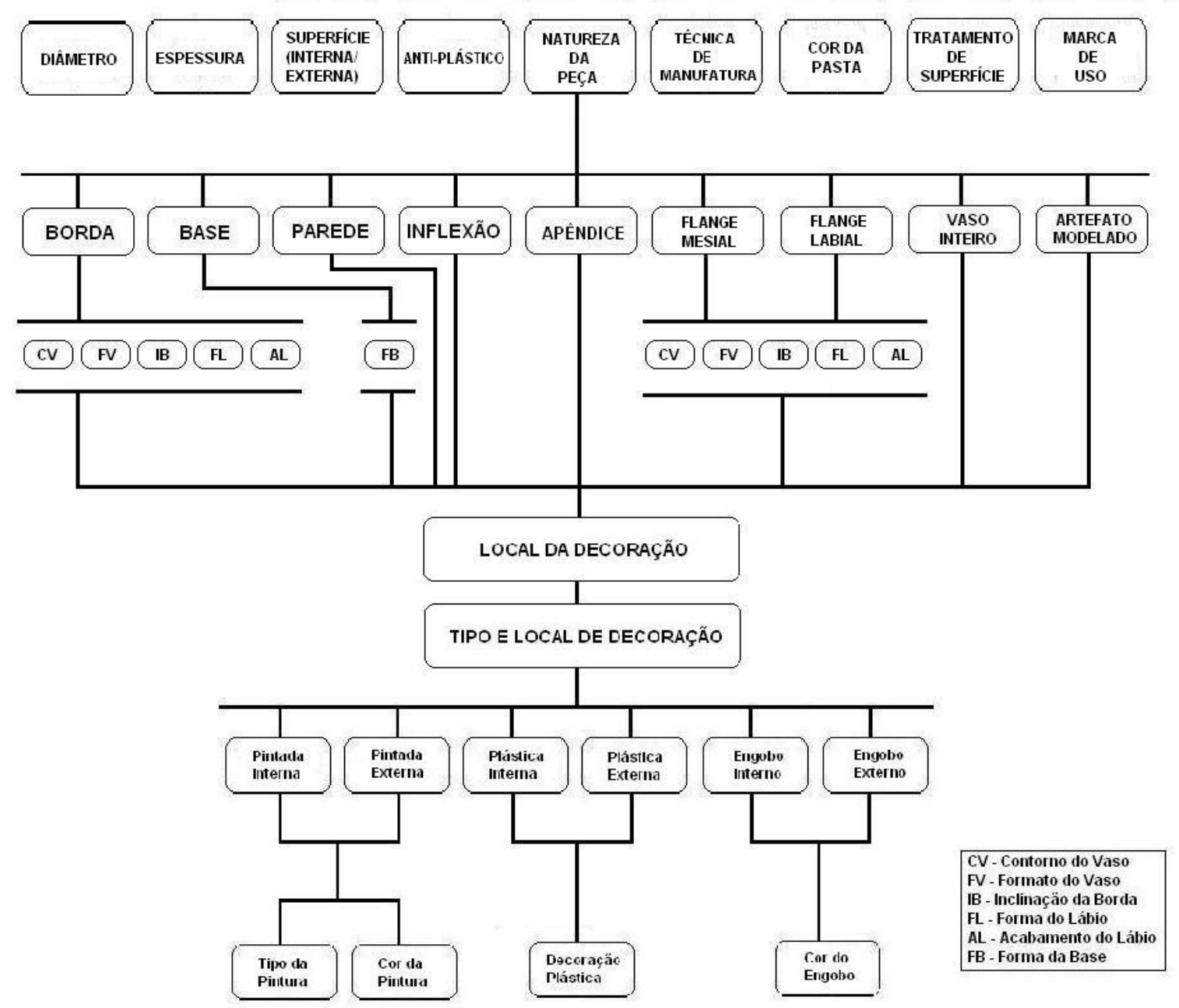

Figura 65 - Organograma de relacionamento entre as variáveis da ficha de análise. 
O formato de organograma empreendido à análise hierarquiza os grupos segundo elementos constituintes das peças, sejam eles tecnológicos, formais ou decorativos. A primeira linha do organograma mostra as variáveis morfológicas e de tecnologia, aplicadas a todos os tipos de natureza da peça, enquanto a segunda linha determina as possíveis naturezas das peças e a terceira, as variáveis inerentes às respectivas naturezas. A quarta e a quinta linha do organograma mostram as variáveis de decoração, sendo estas aplicadas a todos os tipos de natureza da peça. A sexta linha determina os tipos de decoração e, por fim, a sétima linha mostra as variáveis inerentes a esses tipos.

Ao final da aplicação sistemática da ficha de análise e de seu tratamento de acordo com o organograma, partiu-se para a segunda etapa da análise, na qual se empreende uma observação qualitativa dos objetos que apresentaram características distintivas. Estes vasos e fragmentos foram separados do conjunto total, compondo uma coleção diagnóstica para o sítio arqueológico em questão.

A análise qualitativa, que consiste no estabelecimento das tipologias, se restringiu às coleções diagnósticas. Seu objetivo é a formação e a descrição detalhada de conjuntos, os tipos, e eventualmente de subtipos. Procura-se agrupar os vasos e fragmentos através de suas similaridades, que ao mesmo tempo os distinguem dos demais conjuntos. Este exercício, um tanto subjetivo, mostrou que na maior parte dos casos são os elementos formais aqueles que mais diferenciam os grupos. Em diferente escala, os elementos tecnológicos e decorativos também se mostraram importantes agregadores e diferenciadores. Seu comportamento interfere mais em relação às diferentes coleções, oriundas de diferentes sítios arqueológicos, do que em relação aos tipos. Pontualmente, eles foram considerados, no âmbito interno aos tipos, como definidores dos subtipos. Dessa maneira, foi viabilizada uma abordagem que conjugasse os dados quantitativos e qualitativos. 


\section{VI. Guia de Conceitos e Terminologia}

A terminologia aqui apresentada foi adaptada a partir de conceitos outrora propostos por Sheppard (1956), Chymz (1966), Rye (1981), Rice (1987) entre outros estudiosos da tecnologia cerâmica. A estes conceitos foram agregadas informações em torno das características dos conjuntos estudados, tornando este guia aplicável ao caso amazônico tratado.

Neste item encontram-se as definições de termos técnicos utilizados na ficha de análise e nas pranchas descritivas dos tipos cerâmicos. Aquelas com sigla no título são contempladas na ficha de análise. As siglas se referem ao gabarito (a planilha em Excel) e ao quadro de relacionamento entre atributos (o organograma anterior), conforme já apresentado. Além destas, encontram-se também outras definições relevantes para a descrição dos artefatos cerâmicos.

\section{ANÁLISE CERÂMICA}

Sistemas classificatórios - gabarito de variáveis

Informações de proveniência

SIT - Sítio (código numérico)

$\mathrm{PN}$ - dígito

LO - Localização

NIV - Nível Estratigráfico

NT -Natu reza da Peça (Composição)

Informações métricas

ES - Espessura $(\mathrm{mm})$

DI - Diâmetro (cm)

Sistema morfológico de classificação do

vasilhame

CV - Conto mo do Vaso

FV - Forma do Vaso

IB - Inclinação da Borda

FB - Forma da Borda

FL - Forma do Lábio:

$\mathrm{AL}$ - Acabamento do Lábio:

FB - Forma da Base
Sistema de classificação do vasilhame quanto à

pasta

SU - Superfície (interna/externa)

AP - Anti-plástico

TM - Técnica de Manufatura

QE - Queima

TS - Tratamento de superfície

Sistema de classificação do vasilhame quanto à decoração

TD - Tipo e Local da Decoração

CE - Cor do Engobo

TP - Tipo de Pintura

$C P$ - Cor da Pintura

DP - Decoração Plástica

Evidências de utilização

Filiação Cultural

Figura 66 - Gabarito de variáveis da ficha de análise. 


\section{Informações de proveniência}

Fundamentais para a análise arqueológica de qualquer natureza, as informações de proveniência fornecem os dados contextuais, primordiais para o exercício interpretativo dos vestígios arqueológicos. Estes itens da ficha de análise aplicam-se tanto às análises cerâmicas que visam o estabelecimento de tipologias, como às análises crono-espaciais e distribucionais dentro de um sítio arqueológico. Para o problema de pesquisa em questão, que trata de contextualizar em tempo e espaço aspectos de diferentes conjuntos relacionados a uma mesma tradição tecnológica, esses dados contextuais devem necessariamente ser conjugados às análises dos artefatos. Por exemplo, elementos como a presença ou ausência das Terras Pretas de Índio auxiliam na própria definição crono-tipológica, assim como as datações obtidas para cada conjunto.

\section{SIT - Sítio (código numérico)}

Informa o sítio arqueológico de origem do material através de seu código numérico, em acordo com o Cadastro Nacional de Sítios Arqueológicos (CNSAIPHAN). Este código é dado a partir do Estado e Município ou área arqueológica brasileira onde se situa o sítio (Simões \& Araújo-Costa, 1978), seguido por uma numeração contínua, de acordo com o exemplo:

\section{PN - dígito}

É O "RG" do material arqueológico. É através deste número que se controla, com exatidão, sua procedência. A sigla vem do Inglês Provenience Number e indica o local, dentro de um determinado sítio arqueológico, de onde vem o material. Este local é sempre marcado a partir da malha estabelecida para o sítio (eixos $\mathrm{X}, \mathrm{Y}$ e $\mathrm{Z}$ de um plano cartesiano), geo-referenciado através de uma amarração entre determinados pontos da malha e suas coordenadas geográficas. Um PN pode ser atribuído a uma peça individual ou a um conjunto de peças, dentro, por exemplo, de um nível artificial numa unidade de escavação. Todos os vestígios, de qualquer natureza, retirados do sítio arqueológico recebem um PN. 


\section{LO - Localização}

Refere-se ao local dentro do sitio arqueológico de onde foi coletado o material, e indica também o procedimento de coleta (sondagem, unidade, tradagem ou coleta de superfície). O nome é sempre dado a partir das coordenadas norte e leste da malha estabelecida para o sítio arqueológico (num sistema cartesiano geo-referenciado). Por exemplo, N1000 E1000 significa mil metros a norte e mil metros a leste de um ponto "zero" arbitrário, mas georeferenciado, estabelecido para o sítio.

\section{NIV - Nível Estratigráfico}

Indica a profundidade da qual procede o material arqueológico coletado. Pode ser indicado através de um nível artificial, por exemplo, $10-20 \mathrm{~cm}$, ou através de uma profundidade específica, como $Z=15 \mathrm{~cm}$. Em geral, essas profundidades referem-se a um ponto "zero" marcado junto à superfície da sondagem, unidade ou tradagem, e são medidas com um nível de bolha. Este ponto zero é posteriormente adicionado à malha e à topografia do sítio através de instrumentos de leitura topográfica, como uma estação total ou um nível.

\section{NT - Natureza da Peça (Composição)}

São elementos estruturais que compõem um vaso ou artefato cerâmico. Este é o primeiro item divisor dos fragmentos dentro do princípio estrutural da análise. Quando se trata de um objeto inteiro, todas as demais informações se aplicarão. Nos demais casos, apenas as informações específicas a cada componente do vaso serão observadas, conforme o esquema antes apresentado. Quanto à sua estrutura, um vaso inteiro é minimamente composto pelas seguintes partes:

- Boca: abertura da vasilha, composta pela borda e lábio. Pode ser redonda, oval ou quadrada.

- Bojo: parte de maior diâmetro externo, formado pela circunscrição das paredes do vaso.

- Base: parte inferior da vasilha. 
À parte destes componentes mínimos, os fragmentos podem também ser classificados em: inflexão, alça, aplique/apêndice, fuso, flange mesial, flange labial, vaso inteiro, artefato modelado, carimbo ou asa.

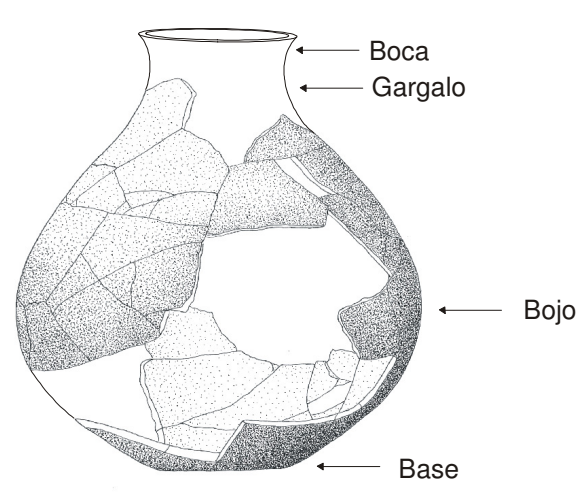

Outros elementos:

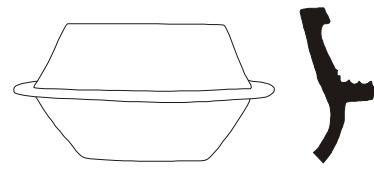

Flange mesial

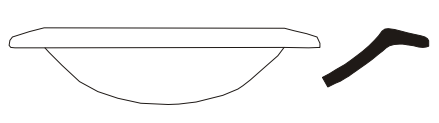

Flange labial

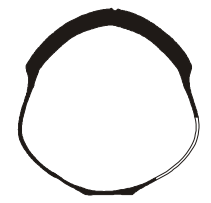

Alça
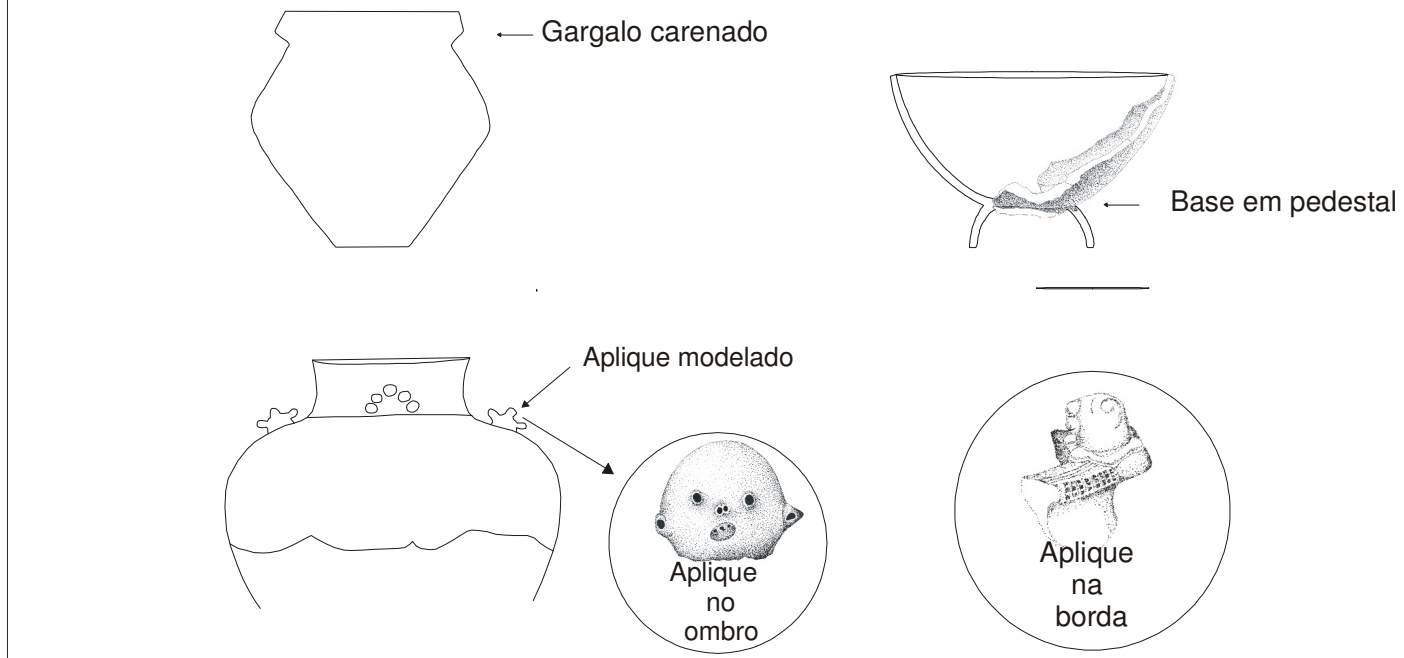

Figura 67 - Natureza da peça: informações estruturais das partes constituintes do vasilhame (prancha: Helena Lima e Claide Moraes). 


\title{
Informações métricas
}

Medições tomadas em todos os fragmentos analisados. Os dados métricos oferecem informações sobre tamanho médio, mínimo e máximo dos recipientes de um determinado conjunto. Vinculadas às questões relativas à função, possibilitam inferências interpretativas sobre o contexto em questão.

\section{ES - Espessura ( $\mathrm{mm}$ )}

Tomada com um paquímetro, sempre na parte mais espessa do fragmento. O registro é feito em milímetros.

\section{DI - Diâmetro (cm)}

Registra-se o diâmetro apenas quando se tem fragmentos cuja curvatura ou projeção tenham dimensões mínimas para a estimativa, que é orientada por um ábaco. Mede-se, em geral, a circunferência da boca ou da base da vasilha. $O$ registro é feito em centímetros.

\begin{abstract}
Altura (cm)
Medição tomada apenas quando se tem um objeto inteiro ou uma remontagem que permita a reconstrução da boca até a base. Seu registro também é feito em centímetros. É através da relação entre altura e diâmetro que se pode calcular, por exemplo, o volume do conteúdo de um recipiente.
\end{abstract}

\section{Sistema de classificação do vasilhame quanto à pasta}

\section{Pasta}

É o elemento constitutivo da cerâmica, ou seja, a argila mais os componentes agregados a ela que, quando expostos a altas temperaturas, dão origem à cerâmica. Diversos aspectos da pasta cerâmica podem ser observados durante a análise, tais como as argilas, a coloração da superfície, o anti-plástico, a queima e a técnica de manufatura. Através da análise desses elementos, podese obter importantes informações sobre as escolhas envolvidas no processo de fabrico da cerâmica. 


\section{Argila}

Principal matéria prima da fabricação dos artefatos cerâmicos, a argila é composta por partículas de sílica, alumínio e água, e sua principal característica física é a plasticidade quando misturada com água. Suas impurezas mais comuns são quartzo, hematita e matéria orgânica.

\section{SU - Superfície (interna/externa)}

Esta variável da ficha refere-se à coloração da superfície da cerâmica, que é resultante de uma conjugação entre as diferentes argilas selecionadas (cruas) e de sua reação quando expostas às altas temperaturas da queima, bem como de outros fatores tais como os tratamentos de superfície, decorações e o próprio uso. Neste item da ficha de análise é observada a coloração da superfície da vasilha ou fragmento cerâmico. São registradas as cores das faces interna e externa que, no caso analisado, podem ser classificadas em branca, alaranjada, preta ou vermelha.

\section{AP - Anti-plástico}

São elementos minerais ou orgânicos, presentes ou adicionados à argila ainda em estado plástico que alteram suas propriedades físicas antes ou depois da queima. Antes da queima, os anti-plásticos funcionam como retentores da umidade da argila, impedindo que a água evapore facilmente, o que torna o processo de secagem mais lento e estável, diminuindo o risco de rachadura, que é comum durante esse processo. Além disso, eles tendem a diminuir a plasticidade da argila facilitando seu manejo (Rye, 1981, p. 31).

Após a queima, a presença ou adição de anti-plásticos altera também as características de performance do recipiente depois de pronto. Por exemplo, temperos orgânicos contribuem para dar maior leveza e resistência ao impacto na cerâmica, enquanto que minerais aumentam sua capacidade de aquecimento (Machado, 2005, p. 220).

Os aditivos mais comumente encontrados nas cerâmicas amazônicas são o cauixi (esponja de água doce), o cariapé (entrecasca de árvore), caco moído e minerais (principalmente quartzo e hematita). Os primeiros, também chamados de temperos, são elementos exógenos à constituição das argilas. Por atuarem de 
modo semelhante, alguns minerais originalmente constitutivos das argilas podem ser deliberadamente mantidos na pasta cerâmica.

$\mathrm{Na}$ análise, a presença destes elementos nos fragmentos cerâmicos pode ser observada com o auxílio de uma lupa binocular, com aumento de até 50x. Os principais temperos têm o seguinte aspecto:

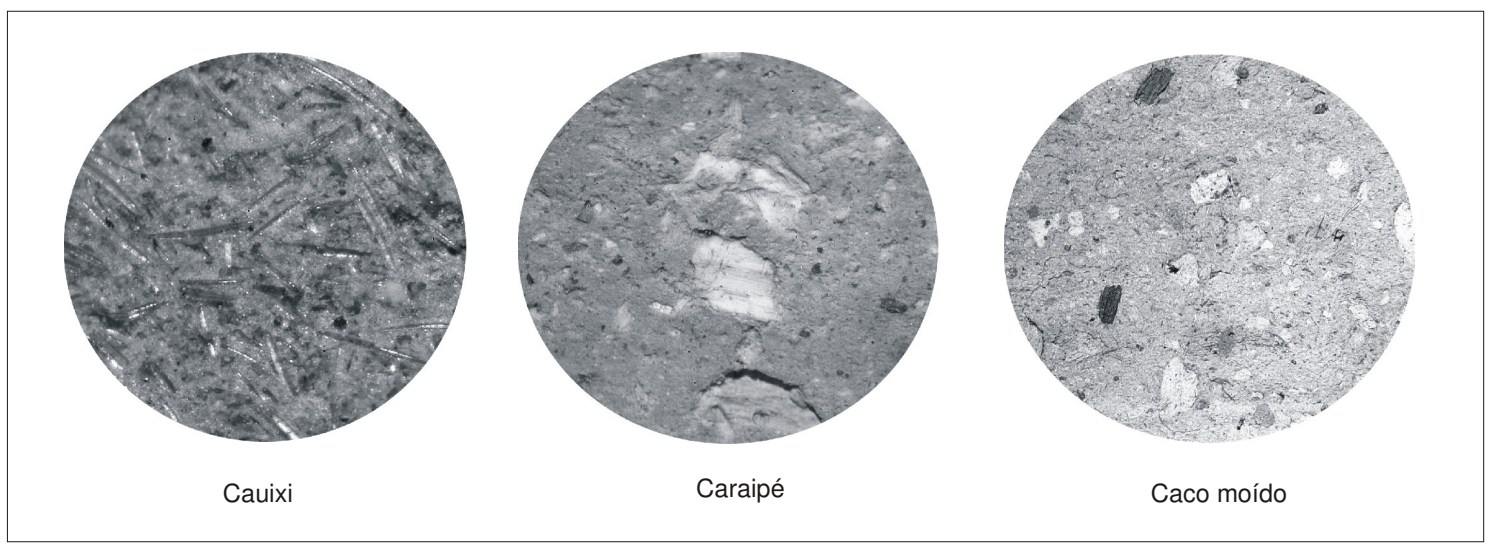

Figura 68 - Aspecto dos temperos mais comumente encontrados na Amazônia, vistos através de uma lupa binocular com aumento de 50x (fotos: Claide Moraes).

\section{TM - Técnica de Manufatura}

Traduz uma seqüência de gestos executados diretamente sobre a argila que dão forma à pasta, ou seja, à cerâmica ainda em estado plástico. Classificase em:

- Roletagem: consiste em sobrepor roletes de argila em sentido circular, dando forma à parede do vaso.

- Modelagem: manufatura da cerâmica à mão livre. É geralmente utilizada na manufatura de objetos como estatuetas ou de apliques.

- Moldagem: consiste em prensar a argila, criando formas discoidais planas.

É registrada também a presença de marcas de folha ou de esteira, que muitas vezes ficam impressas nas bases moldadas dos recipientes.

\section{QE - Queima}

A queima é definida como um processo físico-químico que consiste em transformar a pasta em cerâmica por meio de elevação de temperatura, durante o qual a maior ou menor presença de oxigênio determina a oxidação ou redução, 
evidenciada pela textura e cor da cerâmica (Chmyz, 1966, p. 18). Este processo consiste em três etapas: desidratação, que implica na perda de plasticidade da argila; oxidação, que é um processo químico que envolve o carbono e o ferro; e vitrificação. (Shepard, 1956, p. 75).

O processo de queima da cerâmica pode apresentar uma série de variações como o tipo e quantidade de combustível, duração e temperatura. Informações sobre o processo de queima das vasilhas podem ser obtidas através da observação das características das fraturas dos fragmentos. A queima pode se dar em dois tipos, combinantes entre si: oxidante ou redutora.

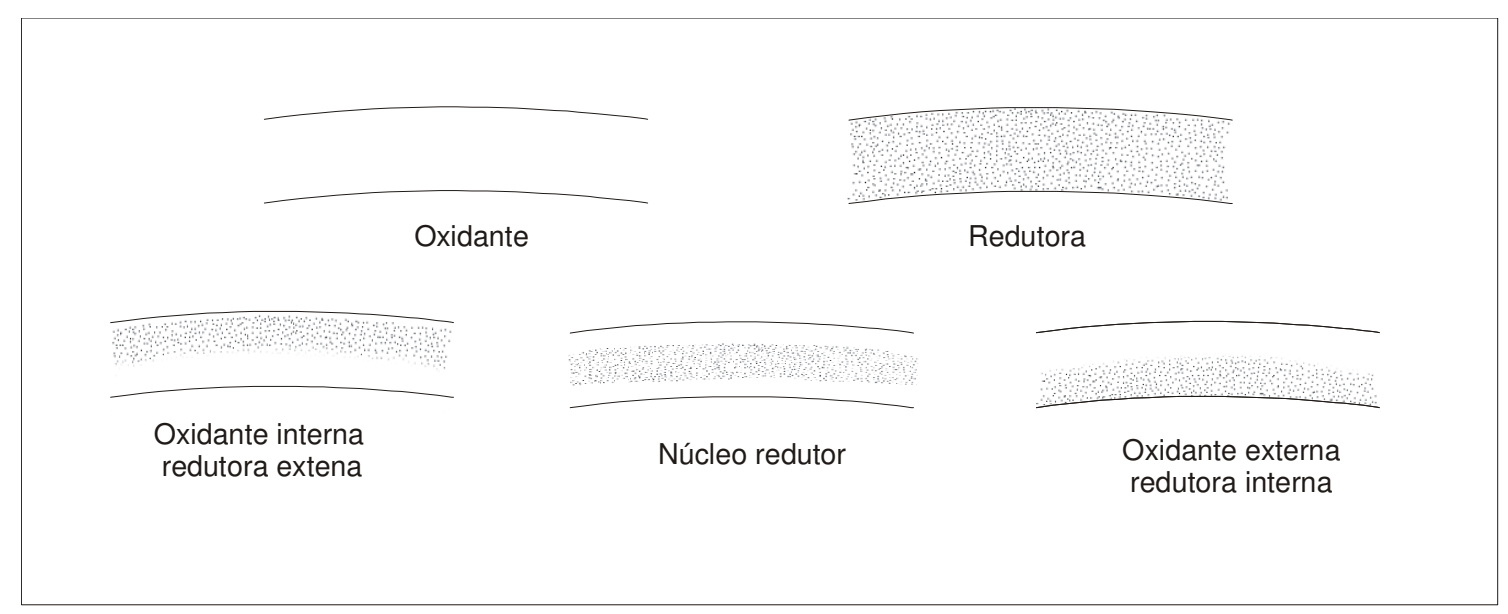

Figura 69 - Diferentes tipos de queima observáveis na fratura dos fragmentos (adaptado de Rye, 1981, p. 116).

\section{TS - Tratamento de superfície}

Uma vez manufaturados, os recipientes passam pela etapa de acabamento, que pode ser executada antes ou depois da queima. Entende-se por tratamento de superfície todas as ações cujas finalidades são dar um algum efeito na superfície da cerâmica, que pode ser funcional ou meramente estético. $\mathrm{O}$ acabamento é dado através do uso de diferentes instrumentos, como pedaços de seixo, fragmentos de cerâmica, sementes ou coquinhos, que dão à superfície cerâmica os aspectos desejados.

As técnicas mais utilizadas são:

- alisamento: processo de nivelação da superfície da cerâmica, no qual elimina-se eventuais irregularidades da superficie da cerâmica.

- polimento: técnica de complementação do alisado, que torna lustrosa a superfície da cerâmica, podendo ou não deixar estrias. 
- resina: consiste na aplicação de certos tipos de seiva vegetal à superfície da cerâmica, ainda incandescente, que a impermeabiliza.

- enegrecimento: técnica similar ao polimento, deixando a superfície da cerâmica com uma coloração escura. Pode resultar também da aplicação da resina.

Alguns sistemas classificatórios como, por exemplo, aquele desenvolvido por Anna Shepard (1956), incluem nesta categoria o engobo, que tem uma função utilitária, servindo como impermeabilizante, e também decorativa. No sistema ora proposto, utlizado para análise das cerâmicas amazônicas, engobo ficou icluído na categoria decoração, uma vez que na maior parte dos casos observados, o apelo estético do uso do engobo é extremamente forte, seja servindo como base para a aplicação da pintura, seja associado a decorações plásticas, ou mesmo quando aparece sozinho.

\section{Sistema morfológico de classificação do vasilhame}

O método de análise morfológica do vasilhame foi adaptado e modificado a partir da proposta de A. Shepard (1956). Trata-se de uma análise estrutural que procede a uma classificação formal com implicações funcionais. Inicialmente classificam-se os vasos de acordo com a forma (estrutura), que pode ser restritiva ou irrestritiva. Então, cada uma dessas categorias gerais de forma é subdividida de acordo com o contorno. As categorias subseqüentes, de acordo com o vaso, foram simplificadas de modo a aplicar-se melhor ao vasilhame analisado. Ficaram divididas entre contorno simples, composto ou complexo.

\section{FV - Forma do Vaso}

Pode ser restritiva ou irrestritiva.

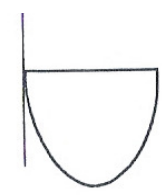

Limite entre forma restritiva e irrestritiva 
- vasos de forma restritiva: diâmetro da boca menor que diâmetro máximo do vaso. Retém o conteúdo, tornando o vaso mais adequado para armazenagem.

- vasos de forma irrestritiva: o diâmetro da boca é igual ou maior do que o diâmetro máximo do vaso. São mais bem adaptados para tarefas que requerem o uso das mãos dentro do vaso e também para deposição e secagem do conteúdo.

\section{CV - Contorno do Vaso}

Quanto ao contorno, um vaso pode ser classificado em simples, composto ou complexo, assim definidos:

- vasos de contorno simples: não apresentam nenhum ângulo em sua silhueta.

- vasos de contorno composto: apresentam seções unidas por um ângulo no contorno do vaso ou por uma curva suave, que forma um ponto projetado.

- vasos de contorno complexo: apresentam dois ou mais ângulos em seu contorno, ou pontos projetados, que definem a junção de diferentes partes do vaso.

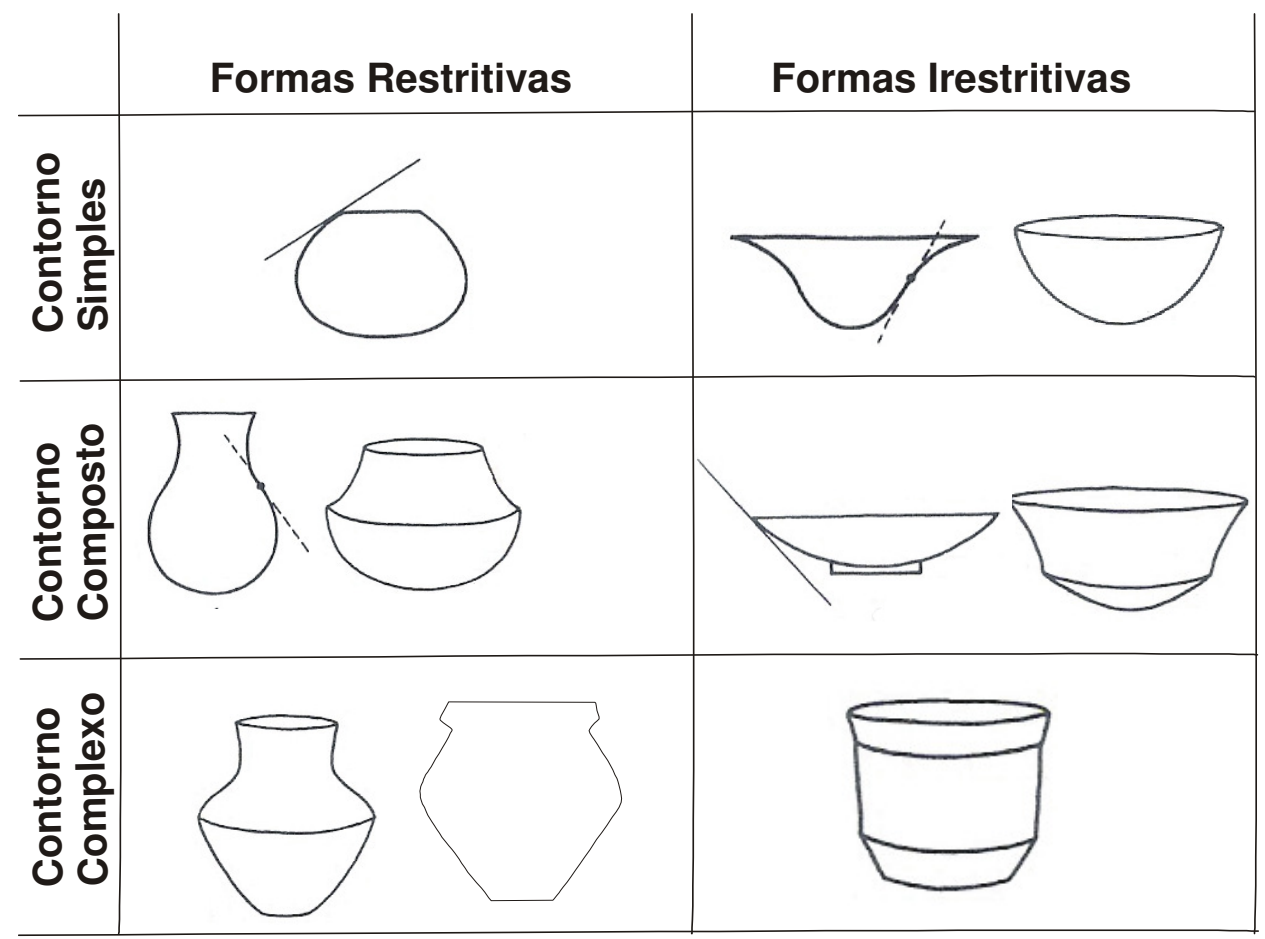

Figura 70 - Análise estrutural da morfologia do vasilhame. Relação entre forma e contorno (adaptado de Shepard ,1956) 


\section{Borda:}

Parte terminal do vasilhame junto à boca.

Quanto à inclinação, pode ser introvertida, direta, extrovertida ou extrovertida tipo flange.

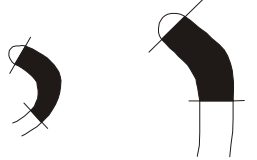

Introvertida

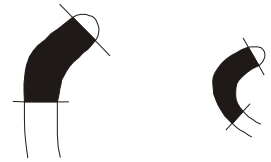

Extrovertida

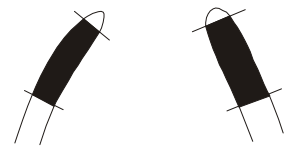

Direta

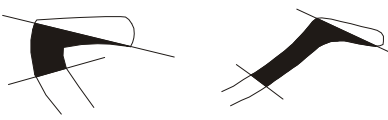

Extrovertida tipo flange

Quanto à forma, pode ser reta, expandida, contraída, roletada interna, roletada externa ou vazada.

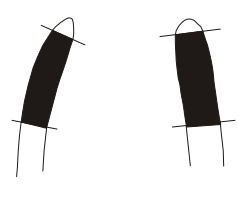

Reta

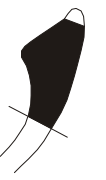

Roletada interna

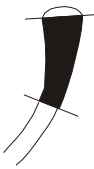

Expandida

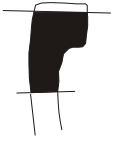

Roletada externa
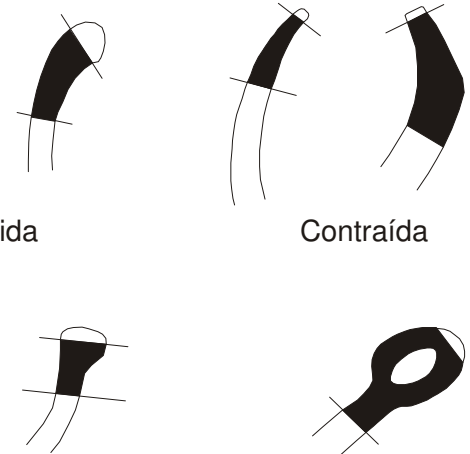

Vazada

Contraída

\section{Lábio:}

Extremidade da borda.

Quanto à forma, pode ser plano, arredondado, afilado ou biselado.

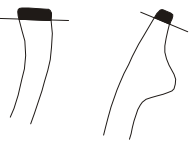

Plano

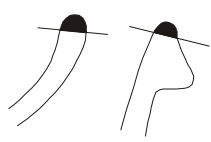

Arredondado

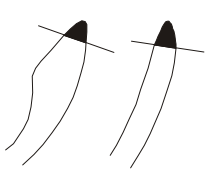

Afilado
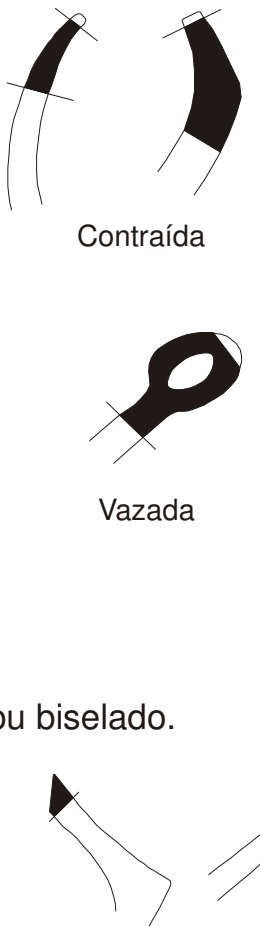

Biselado

Quanto ao acabamento, pode ser serrilhado, ungulado, cortado, pintado, engobado, inciso, acanalado, digitado, ponteado, modelado e exciso.

Figura 71 - Análise morfológica do vasilhame. Classificação das bordas e lábios. 
Base: Sustentação da vasilha.

\section{FB - Forma da Base}

Pode ser plana, convexa, côncava ou com pedestal.

\section{Sistema de classificação do vasilhame quanto à decoração}

Observa-se nos contextos amazônicos uma forte tendência ao uso continuado de diversos recursos decorativos aplicados à superfície dos objetos. Muito já se discutiu sobre as possibilidades interpretativas vinculadas às semelhanças entre conjuntos decorativos, tanto cronologicamente como geograficamente. Este tema mereceu, inclusive, um capítulo específico no volume 1 desta tese. São descritas aqui aquelas características presentes na ficha de análise, que aparecem nos contextos analisados. As técnicas decorativas podem ser divididas em plásticas e pintadas, e ambas podem ser aplicadas antes ou depois da queima.

\section{TD - Tipo e Local da Decoração}

Tão informativo quanto as técnicas decorativas utilizadas é o local onde são aplicadas. Neste campo da ficha, vincula-se o local ao tipo de decoração utilizado, classificando-se em:

- Decoração Pintada Interna

- Decoração Pintada Externa

- Decoração Plástica Interna

- Decoração Plástica Externa

- Engobo Interno

- Engobo Externo

\section{CE - Cor do Engobo}

- Engobo Vermelho: Consiste na aplicação de uma camada de tinta à base de óxido de ferro na superfície da cerâmica antes da queima. Existe uma grande variabilidade de tonalidades de vermelho, entre cores quase alaranjadas e róseas a tons bastante escuros, quase púrpuros. Na ficha, este item é especificado enquanto: alaranjado, vermelho e vinho. 
- Engobo branco: Consiste numa fina camada de argila branca aplicada na superfície da cerâmica antes da queima. Pode ter função utilitária, como impermeabilizante, ou decorativa, servindo como base para a aplicação da pintura.

\section{TP - Tipo de Pintura}

A pintura pode ser aplicada sobre uma camada de engobo ou diretamente sobre a superfície da cerâmica.

Uma vez que a ficha não contempla os motivos decorativos - são tratados numa outra etapa da análise - refere-se a eles, de maneira generalizante, apenas para fins comparativos. Divide-se em: linhas finas e faixas grossas.

\section{CP - Cor da Pintura}

A pintura apresenta uma variação cromática maior do que o engobo. A obtenção dessas tonalidades se dá a partir de procedimentos similares àqueles adotados para a obtenção dos pigmentos do engobo, com a diferença que, neste caso, ao invés de recobrir toda a superfície da cerâmica eles formam motivos. $\mathrm{Na}$ ficha, eles são classificados em: vinho, vermelho, alaranjado, amarelo, preto, branco e marrom.

\section{DP - Decoração Plástica}

A gama de decorações plásticas é enorme, e sua classificação leva em conta tanto o efeito que dá sobre superfície da cerâmica, quanto os gestos e instrumentos utilizados para sua execução.

Acanalado - Tipo de decoração plástica aplicada na superfície da cerâmica antes da queima, que consiste na retirada de uma faixa (ou canal) da argila da superfície do vaso com um instrumento como uma espátula, formando sulcos alongados, ou canais.

Incisões - Tipo de decoração plástica que consiste na execução de sulcos alongados na superfície da cerâmica, por meio da extremidade aguçada de instrumentos de diferentes formatos e dimensões. Pode ser executada depois da queima ou com a pasta ainda úmida. Os efeitos de uma e de outra são bastante distintos. 
Apliques modelados - Também chamados de apêndices, nesta categoria foram incluídas todas as adições de massas de argila modelada à superfície do vaso, podendo estas adições de argila serem ocas, vazadas ou maciças.

Ponteado - Tipo de decoração feito com pontas, deixando marcas independentes na superfície da cerâmica, podendo ter várias formas e tamanhos.

Digitado - Tipo de decoração em que se fixa na superfície da cerâmica as impressões das extremidades dos dedos.

Ungulado - Tipo de decoração composta de incisões produzidas pelas unhas sobre a superfície da cerâmica.

Excisões - Tipo de decoração plástica obtida através da retirada de áreas de argila da superfície do vaso, de modo a produzir um efeito de alto ou baixo relevo. Assim como as incisões, pode ser aplicada antes ou depois da queima.

Esferas aplicadas - Consiste na aplicação de pequenos círculos de argila à superfície da cerâmica, antes da queima.

Impressão de corda - Tipo de decoração que consiste em imprimir, na superfície da cerâmica ainda úmida, marcas de cordas.

Pinçado - Consiste em imprimir marcas na superfície da cerâmica através da ação contrátil simultânea das pontas dos dedos, em sentido oposto. 


\section{Capítulo VI \\ CERÂMICAS BORDA INCISA DA AMAZÔNIA \\ CENTRAL}

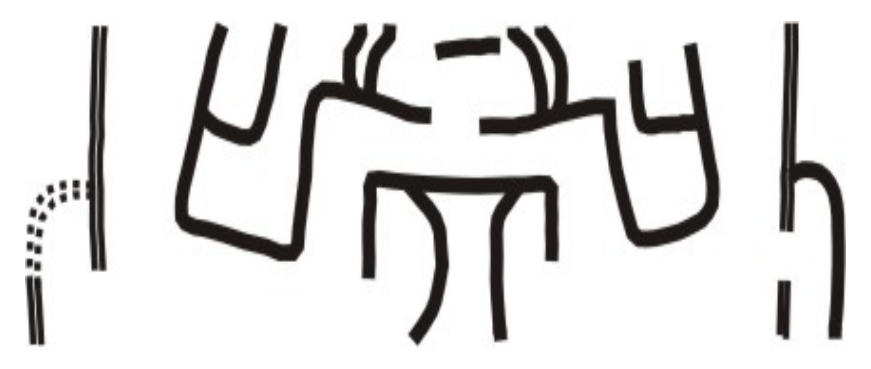

\section{VI.I. Caracterização dos contextos analisados}

Discutidos os parâmetros analíticos tanto teóricos quanto metodológicos e práticos, passemos aos resultados. Nesta sessão apresento a primeira parte dos resultados das análises realizadas em laboratório, a começar por uma caracterização dos materiais encontrados nos diversos sítios analisados, que são contextualmente bem diversificados. Essa caracterização se deu por meio da análise de atributos, realizada a partir da ficha de análise anteriormente discutida. A partir de uma análise interpretativa dos dados gerados, formaram-se as tipologias cerâmicas, que serão apresentadas como apêndice, no final deste trabalho. Junto à tipologia, serão apresentadas, em detalhe, as informações sobre as vasilhas inteiras coletadas nos sítios arqueológicos. É importante que se faça uma leitura conjugada do presente capítulo com as tipologias, para que se tenha uma visão mais completa do universo material tratado.

Os resultados das análises, quando apresentados e discutidos, serão sempre contrapostos a outros elementos contextuais para possibilitar interpretações mais profundas acerca de seus próprios significados, a fim de obter-se uma abordagem, da maneira mais completa o quanto for possível, sobre 
os modos de vida pretéritos com os quais estamos lidando. Vale lembrar que as diferentes coleções, advindas de sítios arqueológicos trabalhados em situações diferenciadas, tiveram também níveis de abordagem distintos. Por exemplo, o tratamento dado às cerâmicas do sítio Açutuba foi mais completo e detalhado do que aquele dado a boa parte das demais coleções. Isto se deu em função dos problemas de pesquisa e da própria disponibilidade dos materiais para estudo.

Os dados apresentados, relacionados à Tradição Borda Incisa e às fases Açutuba, Manacapuru ou Paredão, forneceram as bases para o desenvolvimento de uma espécie de glossário para o estudo das cerâmicas da Tradição Borda Incisa na Amazônia central, que será apresentado ao final da tese, sob o título "O universo material Borda Incisa". Ali foram compiladas as descrições detalhadas das cerâmicas e seus atributos, e uma discussão sobre a representatividade de algumas das características. 


\section{I. I. Cerâmicas do Açutuba}

Os materiais que agora apresento acabaram por gerar os parâmetros cronológicos e tecnológicos da Amazônia central como um todo. Carro-chefe da pesquisa, o sítio Açutuba suscitou diversas das questões e problemas colocados frente aos demais sítios e coleções estudados. Foi, inclusive, através dos materiais coletados neste sítio que se aventou a existência de um conjunto cerâmico distinto, mais antigo do que até então era conhecido na Amazônia central, a famigerada fase Açutuba. Não poderia ser diferente, então, que as análises dos vestígios cerâmicos ali encontrados se tornassem a base para os demais estudos, levados a cabo em outros sítios arqueológicos.

Os estudos cerâmicos em Açutuba tiveram seu início a partir de um problema de pesquisa de ordem comparativa, relevante para o assunto em questão. Os fragmentos coletados em duas áreas distintas do sítio foram comparados a fim de se testar uma hipótese, outrora apresentada, acerca da afinidade temporal entre elas. Tais relações e filiações culturais são hoje conhecidas (LIMA et al., 2006), mas os dados analíticos desses materiais nunca foram anteriormente colocados. Por esta razão, começo a apresentação de dados do Açutuba a partir de uma comparação entre os fragmentos coletados nas unidades T9-T10, relacionados à fase Açutuba, e os de T20, relacionados à fase Manacapuru.

Antes de tudo, vale a pena relembrar quais são os contextos dos quais estes materiais procedem (rever mapa do sítio, pág. 85). T9-T10 são duas unidades adjacentes de $1 \mathrm{~m}^{2}$ cada uma, escavadas em 1999 e 2001, respectivamente.

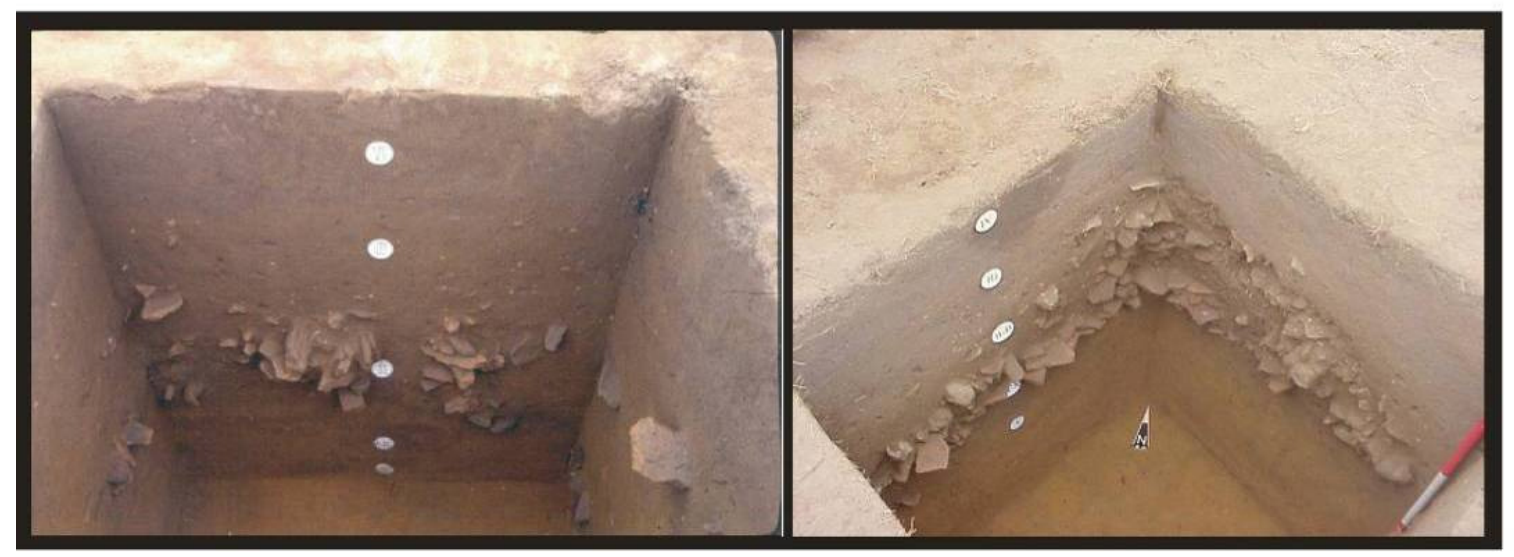

Figura 74 - Fotos dos perfis das unidades T9 e T10 (fotos: E. Neves). 
Como se pode ver através das fotos dos perfis (fig. 74), trata-se de um contexto deposicional interessante para análises cerâmicas, pois o pacote cultural é unicomponencial, bem definido e profundo, o que evita a possibilidade de intrusões ou inversões estratigráficas, facilitando, portanto, o trabalho interpretativo. Por outro lado, o material cerâmico coletado nessas unidades apresentou um pior estado de conservação em relação ao material proveniente de outras áreas do sítio. Isso se deve, provavelmente, à sua maior antigüidade (tratase de um contexto de mais de dois mil anos), mas principalmente às suas condições de deposição. A textura arenosa do solo desta área do sítio erodiu, em parte, a superfície dos fragmentos. Ainda assim, nos níveis mais profundos pôdese verificar a preservação, nos fragmentos, de características decorativas frágeis, como engobo e pintura.

Feita a limpeza e triagem inicial das cerâmicas coletadas, foram selecionados para análise os fragmentos que trouxessem, ao mesmo tempo, informações morfológicas e tecno-estilísticas, ou seja, as bordas, bases e paredes decoradas $^{13}$. A unidade T9 forneceu 1536 fragmentos cerâmicos, dos quais 226 foram analisados, que representam 14,7\%. Já a escavação de T10 resultou em 4484 fragmentos, dos quais 1597 foram selecionados para análise, o correspondente a $35,61 \%$ do total, conforme indicado no gráfico abaixo.

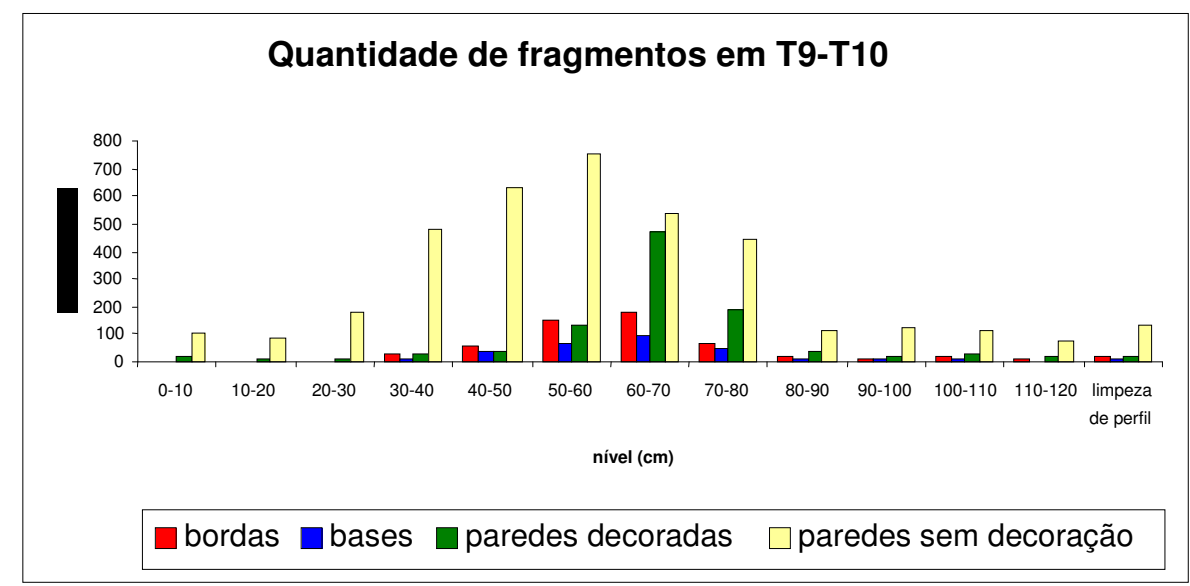

Gráfico 16 - Resultado da triagem do material cerâmico proveniente das escavações T9 e T10.

\footnotetext{
${ }^{13}$ Em função de questões levantadas no decorrer do trabalho, as análises cerâmicas posteriores, realizadas em outros sítios arqueológicos, contemplaram todos os fragmentos coletados nas escavações, incluindo as paredes simples.
} 
Já a segunda área do sítio, cujos fragmentos seriam comparados, mostrou-se de maneira bem distinta da anterior, a começar pela própria matriz, caracterizada pelas terras pretas antrópicas. O depósito arqueológico, também bem definido, tem uma menor profundidade, entre 35 e $50 \mathrm{~cm}$, com uma alta densidade de fragmentos associados à fase Manacapuru. Apareceram também alguns fragmentos da fase Guarita, até aproximadamente $20 \mathrm{~cm}$ que, por serem superficiais e em pequena quantidade, não

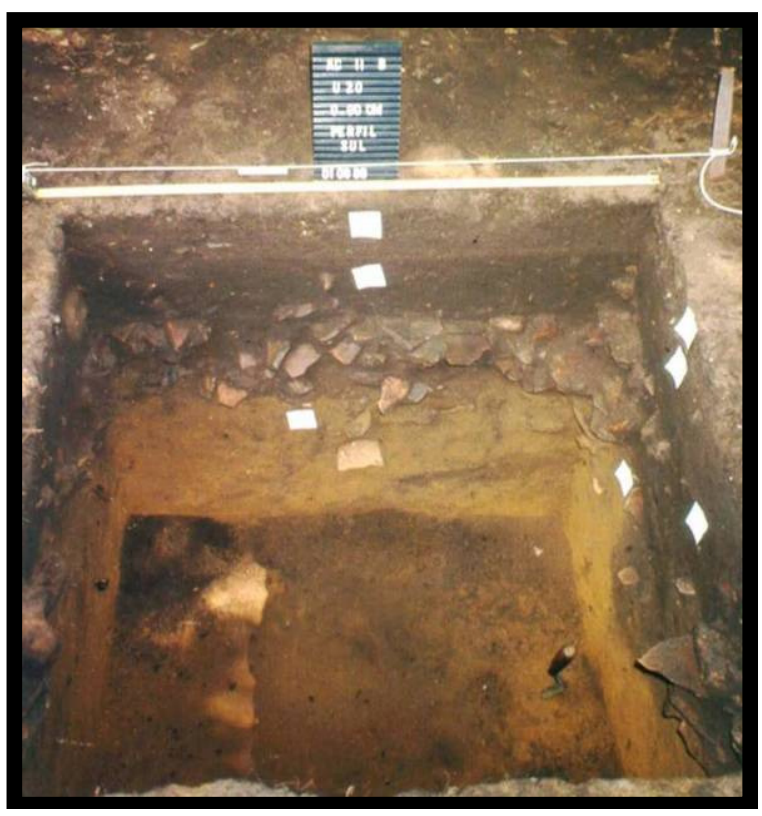

Figura 74 - Fotos do perfil Sul da unidade TU20 (foto: Helena Lima, 1999). prejudicaram a interpretação estratigráfica ou as análises tecnológicas.

Quando comparado com as unidades T9 e T10, o material cerâmico coletado em TU20 apresentou-se em bom estado de conservação. Preservaramse características decorativas bastante frágeis na superfície dos fragmentos, como polimento, brunidura e até um tipo de pintura que aparenta ser feito após a queima. Apesar do alto grau de fragmentação, foi possível, inclusive, reconstituir a variação morfológica da coleção. Essa unidade forneceu um total de 2802 fragmentos, dos quais 799 foram selecionados para análise. O gráfico abaixo demonstra a quantidade amostrada: bordas, bases e paredes decoradas, que representam $28,5 \%$ do total.

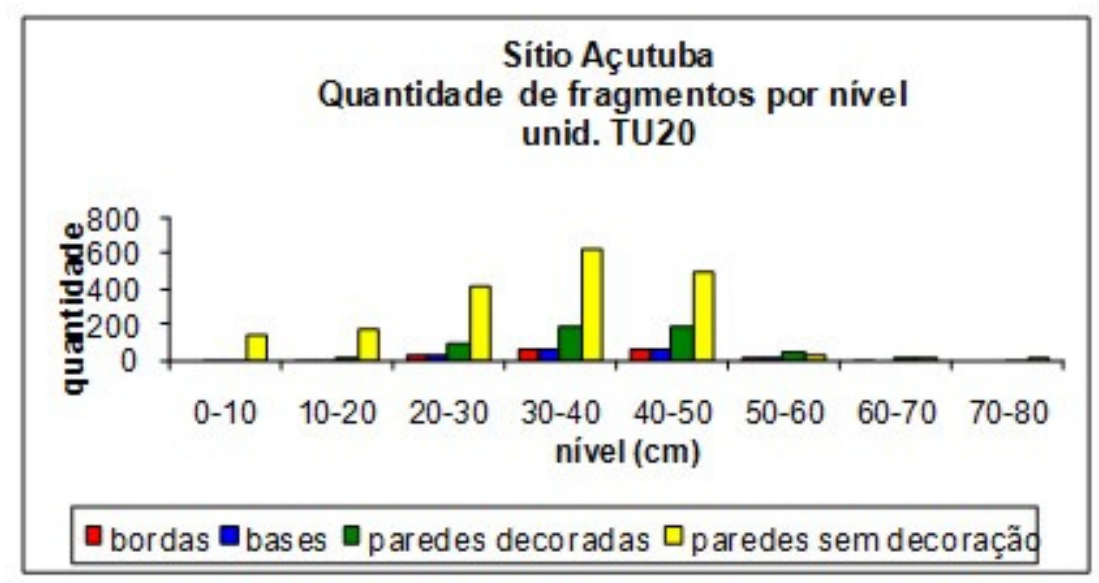

Gráfico 17 - Resultado da triagem do material cerâmico proveniente da unidade TU20. 
Esses materiais de Açutuba foram alvo de uma série de testes analíticos nos quais se buscava uma metodologia de análise adequada aos problemas de pesquisa em questão. Todo o processo de acertos e erros descrito no capítulo anterior levou a várias reestruturações da ficha de análise de seu tratamento. Os tratamentos estatísticos incorporados aos dados foram muitos; alguns deram resultados, outros não. No momento, a apresentação das cerâmicas de Açutuba se aterá aos elementos relevantes para a discussão presente. Então, como se verá adiante, os dados resultantes das análises cerâmicas de T9-T10 e TU20 foram organizados de modo a se obter, sempre, uma perspectiva comparativa entre elas.

Os gráficos de freqüência das características observadas, portanto, apresentam as proporções de ocorrência das mesmas nos dois contextos. Essas proporções já se encontram calculadas de acordo com as quantidades de fragmentos observados em T9-T10 e em TU20. Outro aspecto a ser esclarecido é o fato de que, por terem sido retirados diretamente dos relatórios produzidos pela equipe responsável pela estatística, eles estão ordenados de acordo com siglas que se referem aos atributos observados na ficha de análise cerâmica utilizada naquela ocasião que, como já discutido, se mostrou muito ampla, o que levou à sua reformulação. Ela encontra-se a seguir, a fim de indicar as siglas presentes nas legendas dos gráficos.

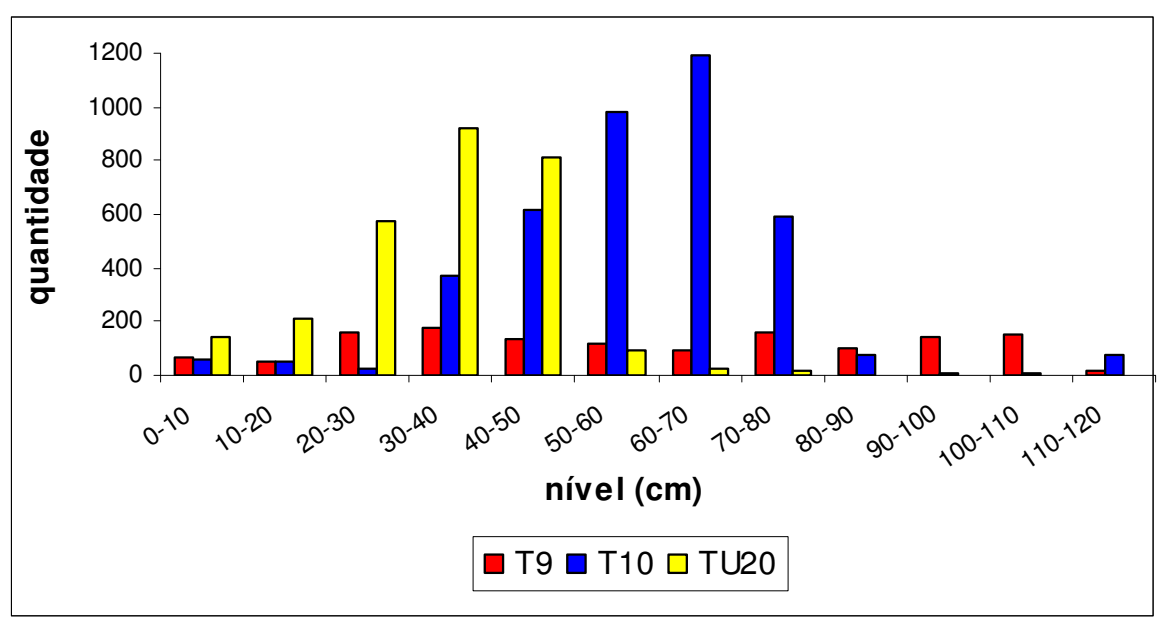

Gráfico 18 - Quantidade de fragmentos por unidade de escavação e por nível, base de cálculo das proporções. 


\begin{tabular}{|c|c|c|c|}
\hline \multicolumn{4}{|c|}{ III. VARIAVEIS BINARIAS (0=Ausente, $\mathbf{1 = P r e s e n t e )}$} \\
\hline \multicolumn{2}{|r|}{ 1. Características da pasta-antiplástico } & \multicolumn{2}{|c|}{ 8. Acabamento do lábio } \\
\hline PCX & Caúxi (menos de 50\%) & AAR & Arredondado \\
\hline PCP & Cauxi preponderante (mais de $50 \%$ ) & APL & Plano \\
\hline PCA & Cariape (menos de 50\%) & ASE & Serrilhado \\
\hline PAP & Cariape preponderante (mais de $50 \%$ ) & AUN & Ungulado (unha) \\
\hline $\mathrm{PCB}$ & Cariape tipo $\mathrm{B}$ (menos de $50 \%$ ) & CORT & Cortado \\
\hline PCM & Caco moido (menos de 50\%) & API & Pintado \\
\hline POP & Caco moido preponderante (mais de $50 \%$ ) & $\mathrm{AE}$ & Engobo \\
\hline PAR & Argila (menos de $50 \%$ ) & AIN & Inciso \\
\hline PGP & Argila preponderante (mais de $50 \%$ ) & ACA & Acanalado \\
\hline PMN & Mineral (menos de $50 \%$ ) & ADI & Digitado \\
\hline PMP & Mineral preponderante (mais de $50 \%$ ) & APO & Ponteado \\
\hline PHE & Hematita (menos de $50 \%$ ) & AMO & Modelado \\
\hline PHP & Hematita preponderante (mais de $50 \%$ ) & & \\
\hline \multicolumn{2}{|r|}{ 2. Técnica de manufatura } & \multicolumn{2}{|r|}{ 9. Tipo e local da decoração } \\
\hline TEM & Modelagem & DPI & Decoraçào pintada interna \\
\hline MOL & Moldagem & DPE & Decoraçāo pintada externa \\
\hline TER & Roletado & PLI & Decoraçäo plástica interna \\
\hline \multicolumn{2}{|c|}{ 3. Tratamentos de superficie } & PLE & Decoraçäo plàstica externa \\
\hline SAI & Alisamento interno & EIN & Engobo interno \\
\hline SAE & Ailisamento externo & EEX & Engobo externo \\
\hline SPO & Polimento interno (textura/estrias) & \multicolumn{2}{|r|}{ 10. Aspectos decorativos: cor do engobo } \\
\hline POE & Polimento externo (textura/estrias) & EGB & Engobo branco \\
\hline RES & Resina & EGV & Engobo vermelho \\
\hline SFO & Marcas de folha & EGC & Engobo vermelho claro \\
\hline SES & Marcas de esteira & \multicolumn{2}{|r|}{ 11. Tipo da pintura } \\
\hline SEM & Brunidura (brilho/textura) & \multirow{3}{*}{$\begin{array}{l}\text { LFI } \\
\text { FGR } \\
\text { PQU }\end{array}$} & \multirow{3}{*}{$\begin{array}{l}\text { Linhas finas } \\
\text { Faixas grossas } \\
\text { Pós-queima }\end{array}$} \\
\hline \multicolumn{2}{|c|}{ 4. Ambiente de queima } & & \\
\hline QO & Queima oxidante & & \\
\hline$Q R$ & Queima redutora & \multicolumn{2}{|r|}{ 12. Aspectos decorativos: cor da pintura } \\
\hline QOR & Queima oxidante externa e redutora interna & DVC & Vermelho claro \\
\hline QRO & Queima redutora externa e oxidante interna & DVE & Vermelho escuro \\
\hline QS & Queima "sanduiche" & DLA & Vermelho alaranjado \\
\hline \multicolumn{2}{|r|}{ 5. Posicionamento da borda } & DAM & Amarelo \\
\hline BVE & Vertical & DPR & Preto \\
\hline $\mathrm{BCO}$ & Cöncava & DBA & Branco \\
\hline $\mathrm{BCE}$ & Convexa & \multicolumn{2}{|r|}{ 13. Tipo da decoração plástica } \\
\hline \multicolumn{2}{|r|}{ 6. Forma da borda } & \multicolumn{2}{|r|}{ Incisa } \\
\hline FDI & Direta & LEA & Esferas aplicadas \\
\hline FEX & Extrovertida & LRP & Roletes aplicados \\
\hline FIN & Introvertida & LPT & Ponteado \\
\hline \multicolumn{2}{|r|}{ 7. Forma do lábio } & LAC & Acanalado \\
\hline LAP & Apontado & LDI & Digitado \\
\hline LBI & Biselado & LAN & Apéndice \\
\hline LRI & Roletado interno (reforçado) & ESC & Escovado \\
\hline LRE & Roletado externo & FLM & Flange mesial \\
\hline LEX & Expandido & FLL & Flange labial \\
\hline LAF & Afilado & EXC & Excisäo \\
\hline LDI & Direto & & \\
\hline
\end{tabular}

Figura 76 - Legendas das siglas utilizadas nos gráficos de freqüências das variáveis observadas na análise. 
Em muitos dos aspectos tecnológicos observados, não houve grande diferenciação entre as cerâmicas Açutuba e Manacapuru. Existe, de fato, uma coerência tecnológica, com mudanças aparentemente lentas e graduais ao longo do tempo, entre os conjuntos da Tradição Borda Incisa. Ao observar os gráficos abaixo se percebe que a variação de antiplásticos entre T9-T10 e TU20 é pequena. Ambas caracterizam-se pelo uso do cauixi, em constante associação com minerais como quartzo e hematita. Há ainda, em proporções menores, nódulos de argila e o cariapé. As variações se expressam num maior uso do caco moído, nas cerâmicas de TU20, e no cariapé, como tempero preponderante nos fragmentos de T9-T10.

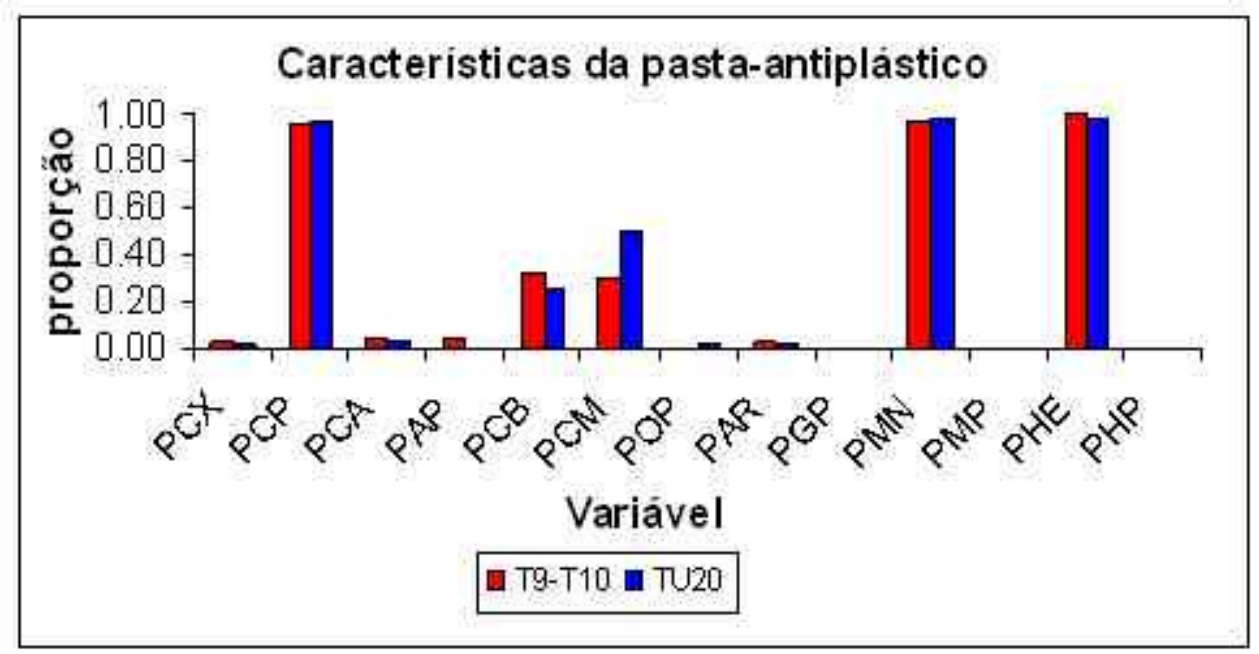

Gráfico 19 - Variação do antiplástico nos fragmentos de T9-T10 e de TU20.

Como se vê a partir do gráfico a seguir, a variação em termos de técnicas de manufatura é quase nula: as vasilhas foram fabricadas a partir da técnica de roletagem (sobreposição de roletes), havendo uma pequena proporção de modelagem, que se refere, em geral, ao fabrico dos apliques modelados e de alguns flanges labiais. Em alguns casos, em particular nos fragmentos não decorados, a cerâmica de T9-T10 é mais rude do que a cerâmica proveniente de TU20: os roletes são grosseiramente unidos, sobrando espaços vazios entre eles na pasta.

Variação tecnológica digna de nota refere-se aos tipos de queima. Percebe-se uma maior freqüência, nos materiais de T9-T10, de queima do tipo oxidada. Embora em T9-T10 a queima redutora também seja freqüente na mesma 
proporção, em TU20 aparecem, em maiores dimensões, queimas com núcleo redutor, dando às coleções aspectos diferenciados, tendo T9-T10 tendência a queimas oxidantes e TU20, ao contrário, a pastas escuras, sempre redutoras, mesmo que parcialmente.
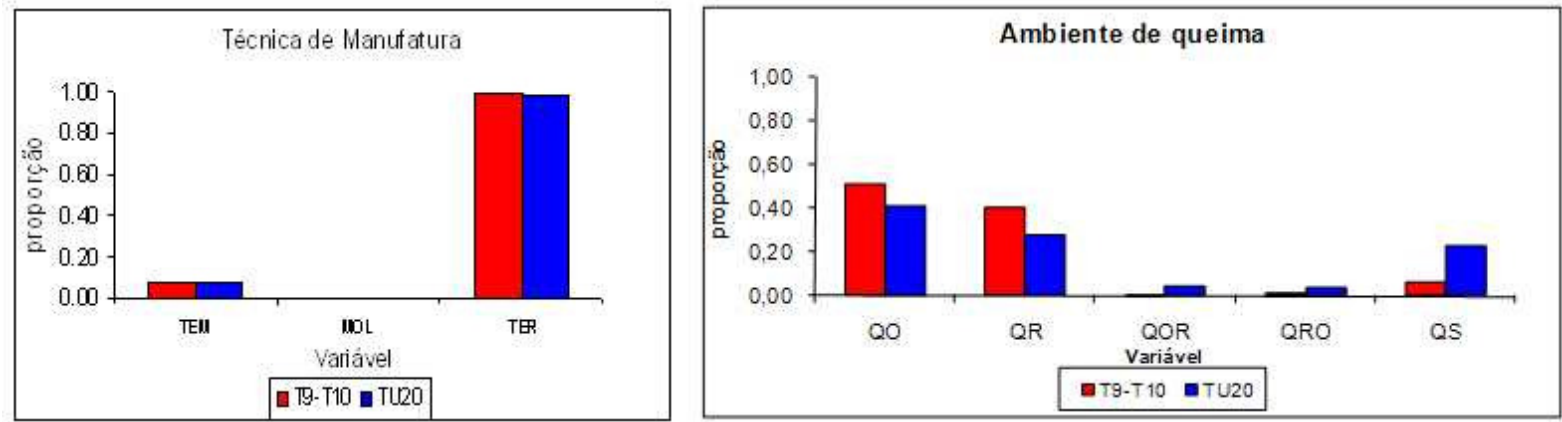

Gráfico 20 - Variação das técnicas de manufatura e ambiente de queima nos fragmentos de T9T10 e de TU20.

Quando se fala em acabamentos e tratamentos da superfície das vasilhas, tenham eles finalidades funcionais, decorativas, ou ambas, os materiais de T9T10 e de TU20 passam a se diferenciar com maior nitidez. Todos os fragmentos da fase Manacapuru analisados receberam algum tipo de tratamento de superfície; já no material proveniente da fase Açutuba, não foi possível verificar todos os fragmentos devido ao pior estado de conservação em que se encontram as cerâmicas. Pode-se notar a partir do gráfico abaixo que a proporção do polimento interno e externo e da brunidura (enegrecimento) é acentuadamente maior nos fragmentos da fase Manacapuru.

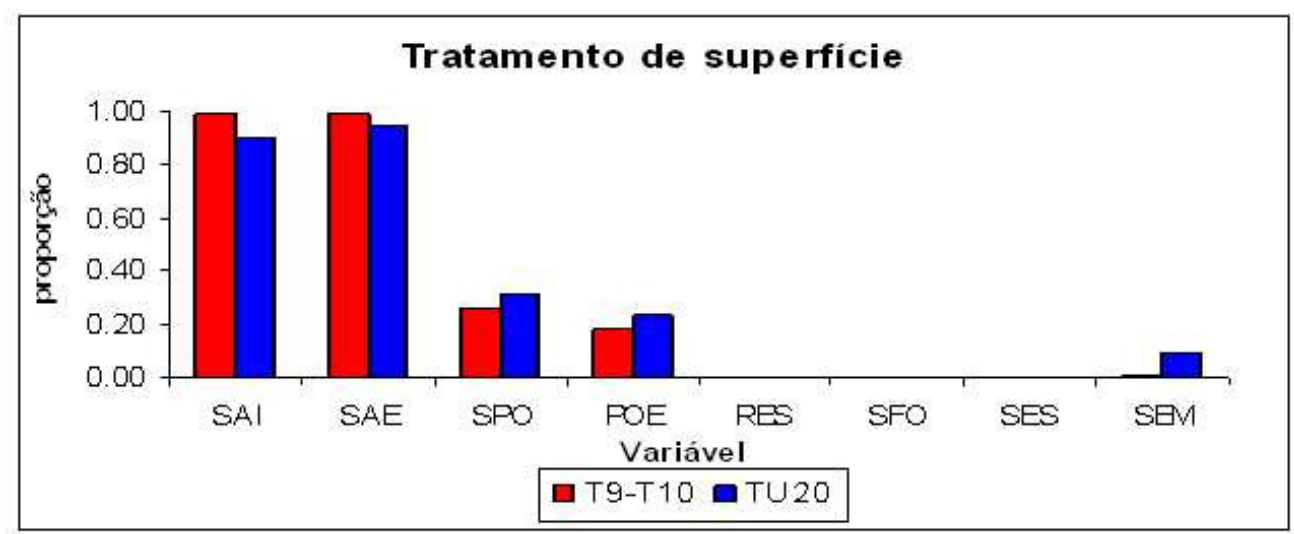

Gráfico 21 - Variação dos tratamentos de superfície dos fragmentos de T9-T10 e de TU20. 
As análises demonstraram tratar-se, em ambos os casos, de conjuntos artefatuais com ampla variabilidade, tanto morfológica quanto decorativa, e mesmo tecnológica. Pelas reconstituições formais obtidas, conclui-se que a variabilidade morfológica é maior em T9-T10. Foram identificadas, para as vasilhas Açutuba, 16 formas. Uma quantidade menor foi reconstituída para os fragmentos da fase Manacapuru, totalizando 12 formas (fig 77).

\section{SìTIO AÇUTUBA \\ variabilidade formal}

$$
\text { fase Açutuba }
$$

Formas abertas: Formas fechadas:
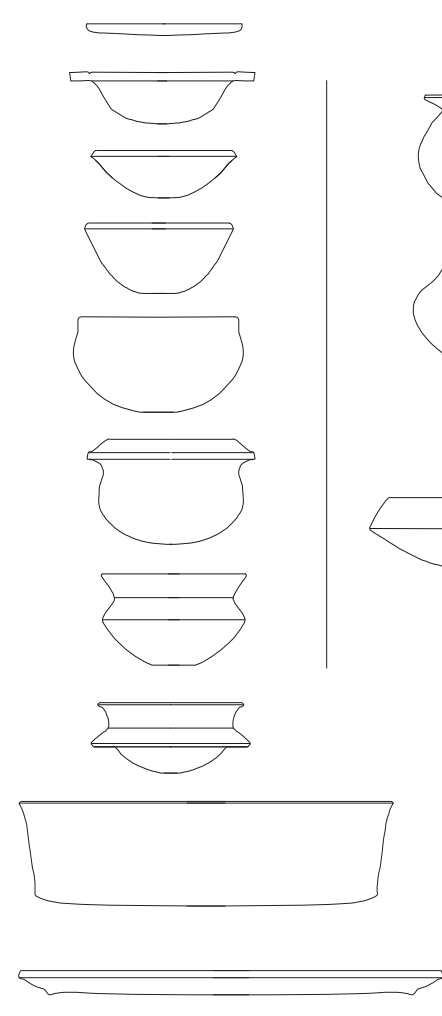

Figura 77 - Variabilidade formal das cerâmicas do sítio Açutuba, reconstituída a partir dos fragmentos de T9-T10 e de TU20. 
Observa-se também que, de modo geral, a freqüência de vasilhas abertas é maior nas unidades T9-T10 do que em TU20, que tem uma maior tendência de vasos com formas fechadas. Tais informações foram adquiridas em sua maioria através dos dados de posicionamento e forma das bordas, como indicam os gráficos abaixo. Em T9-T10, as bordas têm maior tendência a posicionamento convexo (indicando vasilhas abertas), sendo diretas ou extrovertidas. Ao contrário, as bordas de TU20 são quase sempre côncavas, com maior tendência a terem forma introvertida.
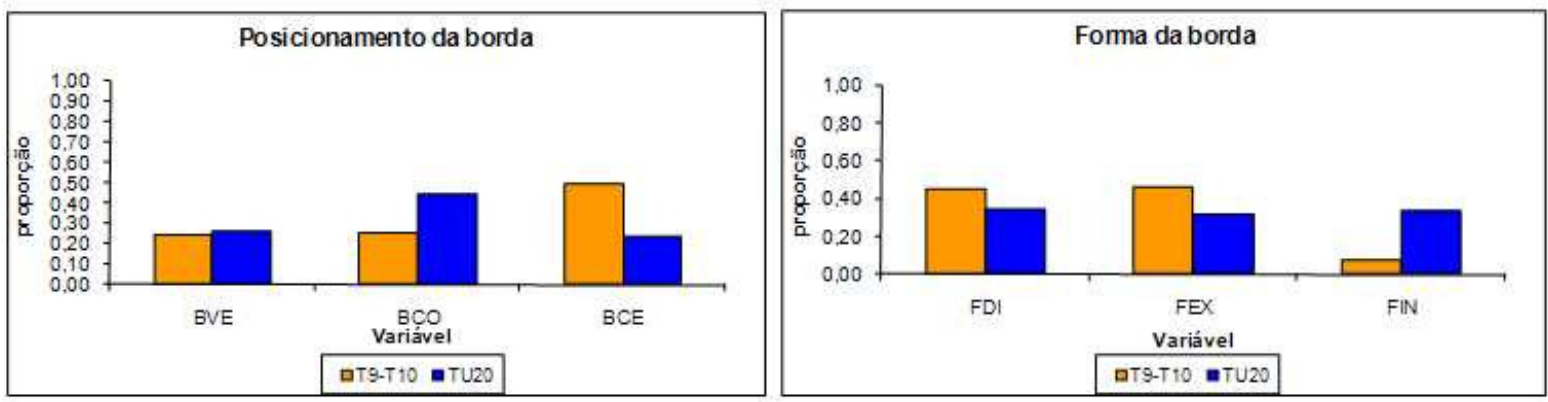

Gráfico 22 - Variáveis de posicionamento e forma das bordas de T9-T10 e de TU20.

Embora morfologicamente semelhantes (mesmo que em proporções diferentes), os recipientes de T9-T10 tiveram medidas ligeiramente maiores, como indicam os gráficos a seguir:
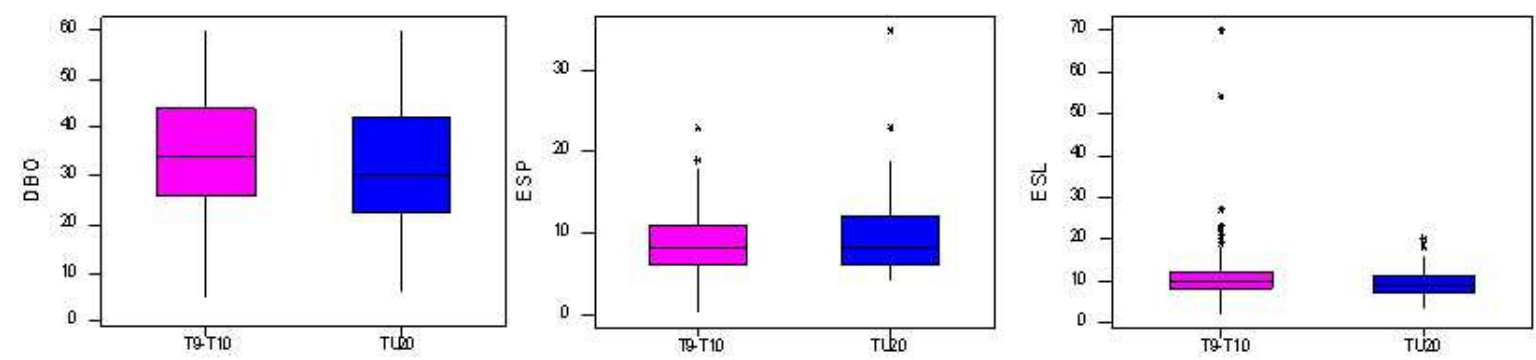

Gráfico 23 - Boxplots das medidas: diâmetro da borda, espessura da peça, e espessura do lábio, tomadas nos fragmentos de T9-T10 e de TU20.

Também nesses boxplots de medidas se pode perceber, em especial no conjunto de T9-T10, um sensível aumento da espessura do lábio em relação a espessura da peça. Congruente com este dado é notável a presença de modificações plásticas na região da borda das vasilhas, em ambos os conjuntos, 
com fins decorativos. São os característicos flanges labiais, muito freqüentes entre os materiais de T9-T10, e podem ser considerados como um traço diagnóstico da cerâmica Açutuba. A parte superior dos flanges labiais é preferencialmente utilizada como suporte para a aplicação de uma variada gama de técnicas e motivos decorativos. De fato, todos os flanges analisados são decorados. As decorações mais utilizadas são incisões e modelagens, que muitas vezes se associam a apêndices zoomorfos. Os lábios são sempre planos e cortados. Na fase Açutuba são em geral incisos e modelados, enquanto na fase Manacapuru estes são ponteados e ungulados, na maioria dos casos (fig 78).
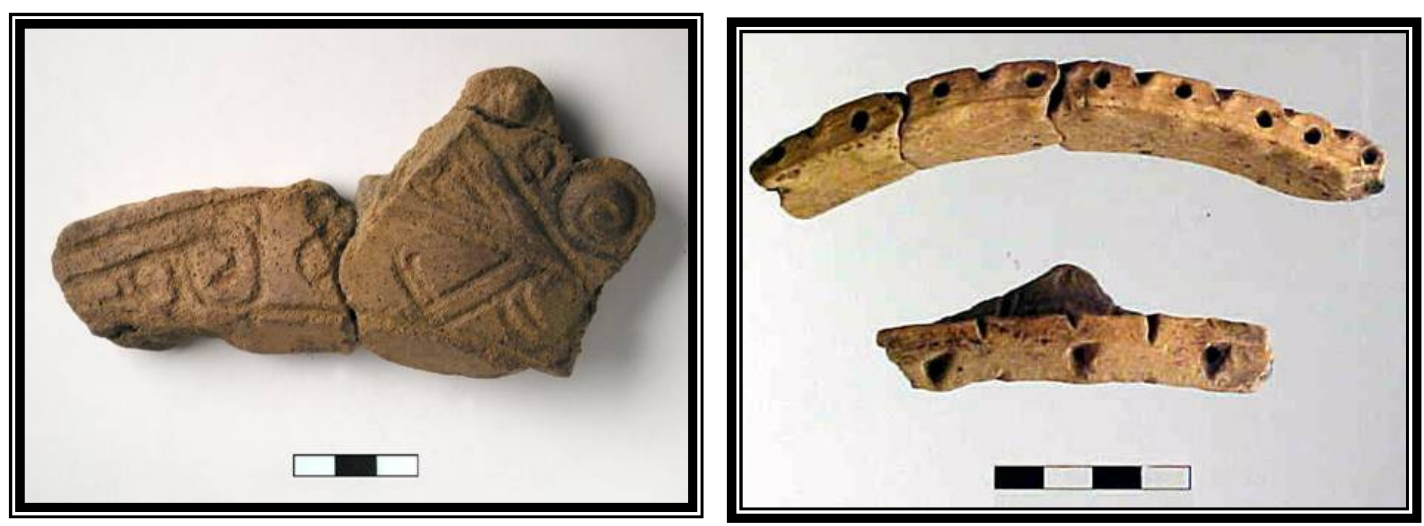

Figura 78 - a) flange labial da fase Açutuba; b) da fase Manacapuru (fotos: Vagner Souza).

Além de flanges labiais e lábios expandidos, característicos de ambas as indústrias, outros elementos formais se destacam. Eles estão sempre associados a traços decorativos, muito presentes nesses conjuntos artefatuais. São os apêndices modelados e as alças. Os primeiros ocorrem sempre nas bordas ou flanges labiais, e aparecem associados a outras técnicas decorativas, tais como incisões de todos os tipos, ponteados e pintura. Já as alças, embora sejam pouco representativas em termos numéricos e não tenham demonstrado a quais partes do vaso estariam associadas, têm relevância por apresentarem traços típicos da Tradição Borda Incisa. 

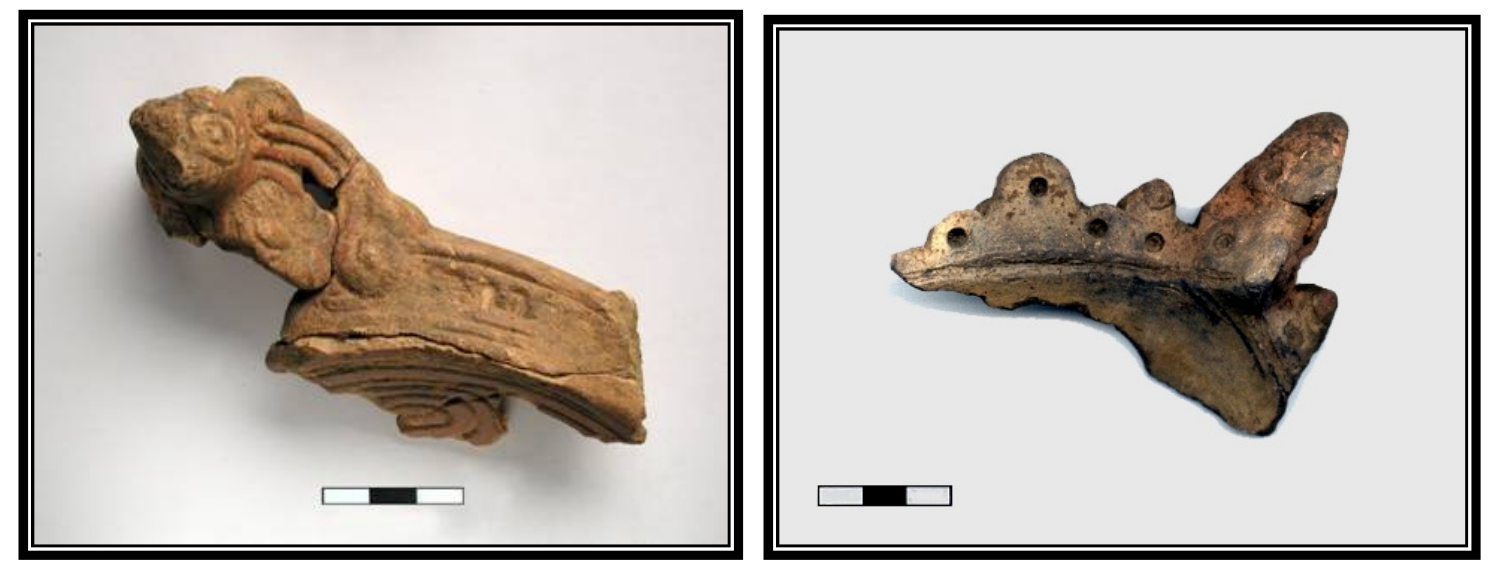

Figura 79 - a) apêndice modelado da fase Açutuba; b) da fase Manacapuru (fotos: Vagner Souza).

Além da clara preferência pelas bordas, flanges, lábios e, também, pelas alças e apêndices para aplicação das decorações, percebe-se que a gama de recursos decorativos, especialmente os plásticos utilizados nessas cerâmicas, é muito ampla. Dentre aquelas mais utilizadas estão as já mencionadas incisões e modelagem. Alguns elementos diferenciadores entre os conjuntos começam a se destacar (graf. 24). Excisões aparecem apenas nos fragmentos de T9-T10, enquanto os ponteados e ungulados somente ocorrem naqueles de TU20 (observar também fig. 78, da página anterior).
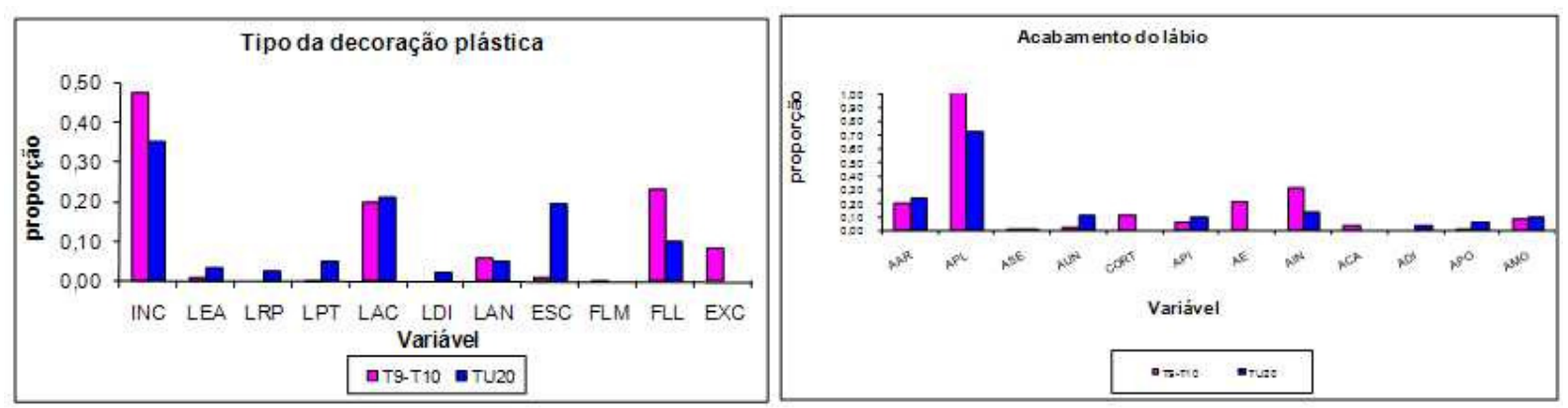

Gráfico 24 - Técnicas de decoração plásticas e tipos de acabamento dos lábios dos fragmentos de T9-T10 e de TU20.

Também os motivos das decorações plásticas variam de um conjunto para o outro. Em T9-T10 nota-se uma maior ênfase nas decorações em gregas e em motivos espiralados, que são geralmente obtidos através de incisões simples em linhas finas. Já nos fragmentos de TU20 o que se observa é uma maior tendência 
à obtenção de motivos retilíneos e suas linhas incisas são, via de regra, duplas ou múltiplas, como mostram as fotos abaixo (fig 80).
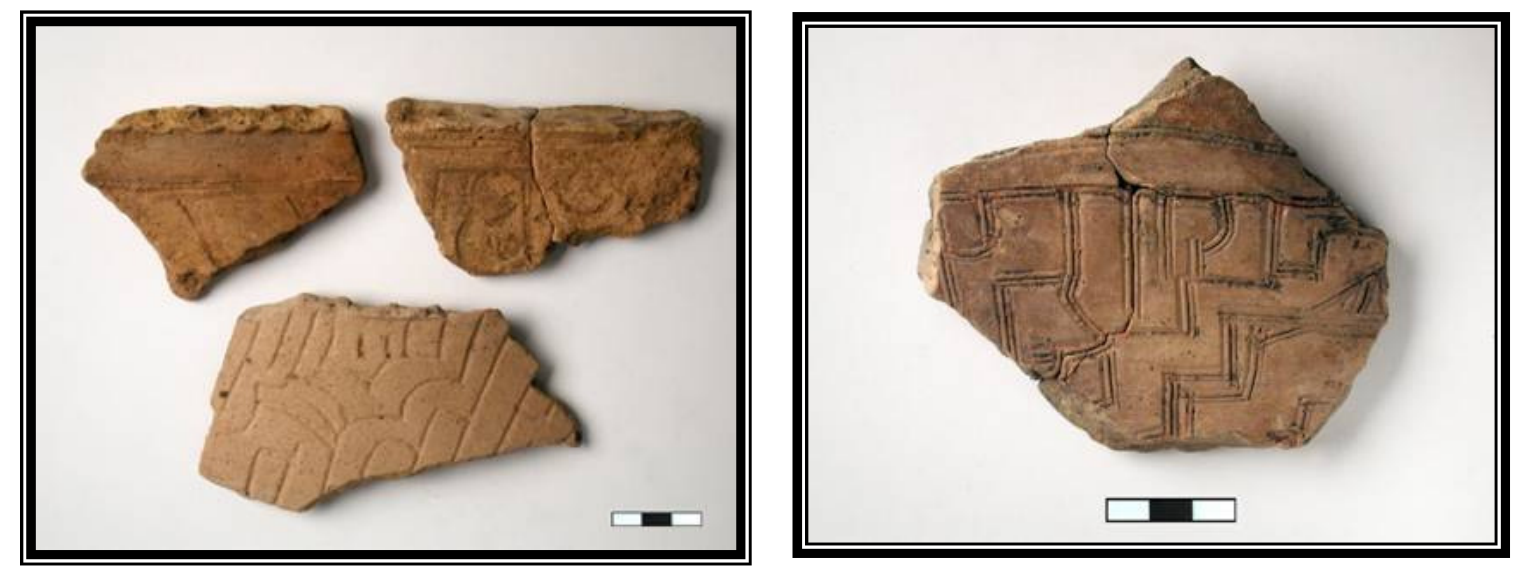

Figura 80 - a) motivos incisos da fase Açutuba; b) da fase Manacapuru (fotos: Vagner Souza).

Como se pode ver, as técnicas e motivos decorativos variaram dentre os materiais analisados. Além das já mencionadas decorações plásticas, encontramos ainda decorações crômicas, seja através de camadas de engobo vermelho ou branco, ou através da policromia, que aparece no conjunto mais antigo, apenas. O gráfico abaixo demonstra as proporções em que ocorrem as diferentes técnicas, bem como os locais onde são aplicadas: pintada interna e externa, plástica interna e externa, engobo interno e externo (Graf. 25).

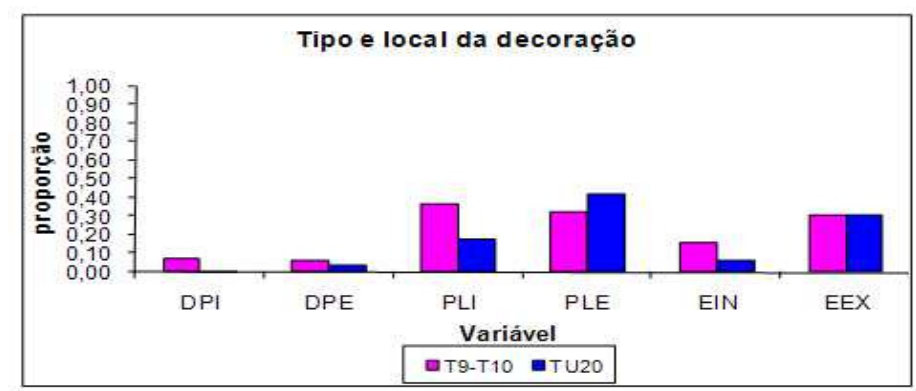

Gráfico 25 - Técnicas de decoração plástica e tipos de acabamento dos lábios dos fragmentos de T9-T10 e de TU20. 

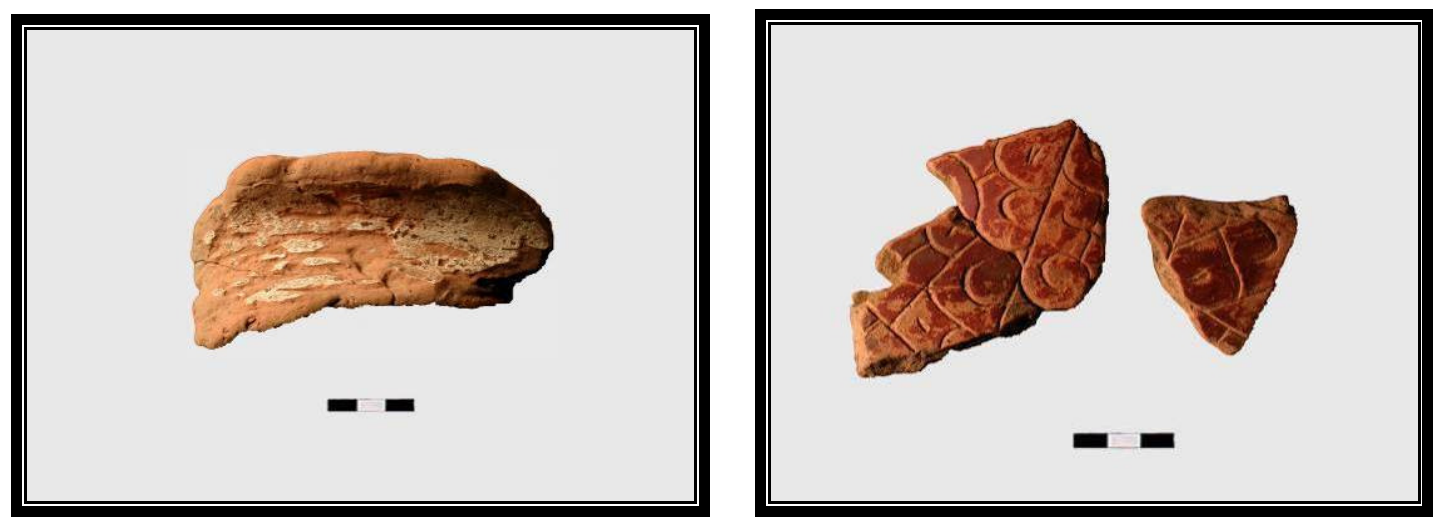

Figura 81 - Fragmentos cerâmicos da fase Açutuba com vestígios de engobo branco e de engobo vermelho (fotos: Vagner Souza).

Quanto a este último, aparece nos dois conjuntos em diferentes tonalidades de vermelho, variando do vermelho-claro ao vinho. Apenas nos fragmentos de T9-T10 aparece a cor branca. A presença do engobo branco está relacionada à policromia, recorrente apenas nesses vestígios. Este atributo, em associação com a presença de flanges mesiais, é encontrado apenas nos conjuntos Açutuba. Este é um fator intrigante, pois são características típicas da fase Guarita, da Tradição Policroma, que é a mais recente encontrada na região. Mais ainda, essas características desaparecem nos conjuntos intermediários, Manacapuru e Paredão. E neste sentido, assume relevância para o teste - e aparente invalidação - das proposições de Lathrap (1970a) acerca de uma suposta relação de mútuas influências entre as cerâmicas Guarita e Manacapuru, enquanto explanação da antigüidade de um hipotético sistema cultural Arawak e das origens amazônicas dos conjuntos Barrancóides da Venezuela e Caribe, ligadas ao mesmo. Tais temas serão discutidos a fundo mais adiante.
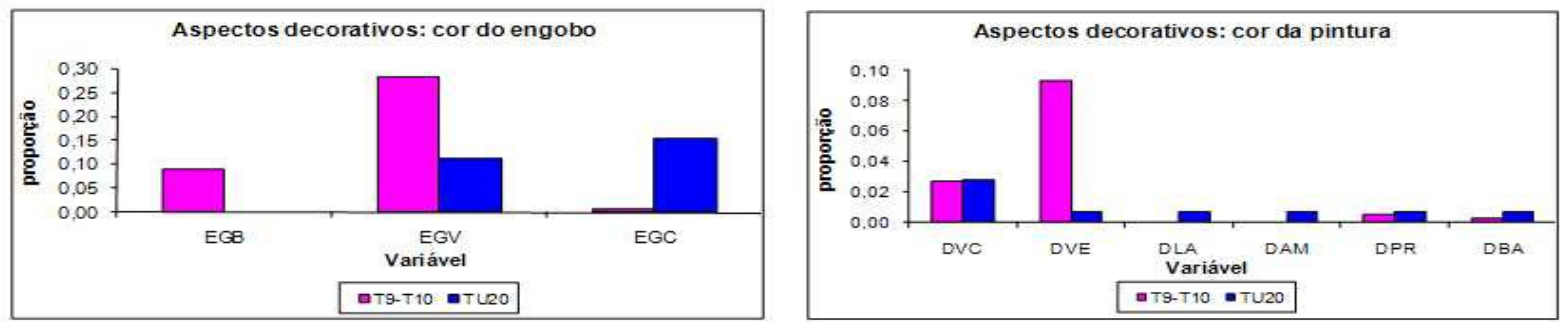

Gráfico 26 - Técnicas de decoração plástica e tipos de acabamento dos lábios dos fragmentos de T9-T10 e de TU20. 
A pequena quantidade de fragmentos pintados presentes na amostra impossibilitou a identificação das formas específicas de vasos aos quais essa técnica era aplicada. No entanto, percebe-se que havia uma seleção de argilas específicas para a decoração dos potes dessa maneira. A policromia é aplicada preferencialmente a vasos bastante finos e leves, constituídos por uma pasta de coloração alaranjada ou branca, e temperados com cauixi ou cariapé. Ocorre tanto em fragmentos de contorno simples, como em formas mais complexas com flanges mesiais e apêndices modelados.

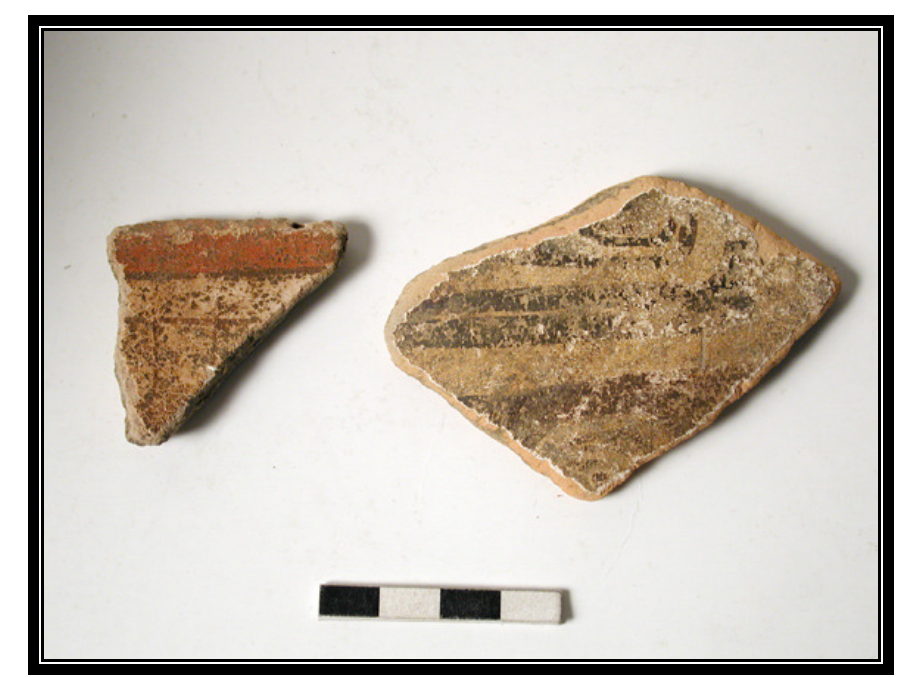

Figura 82 - Fragmentos cerâmicos da fase Açutuba com vestígios de pintura policroma (fotos: Vagner Souza).

Por fim, a escavação das unidades T9-T10 forneceu três fragmentos de artefatos que aparentam serem estatuetas. Um deles representa com nitidez as pernas de uma figura humana feminina; os outros dois têm uma forma parecida, porém estão bastante fragmentados, sendo visíveis apenas os pés. Em todos os casos, o padrão é o mesmo (descrito em detalhe na tipologia). Dentre os materiais de TU20, observou-se evidências de reutilização de alguns fragmentos, com finalidade distinta daquela para a qual foi produzida. É o caso de uma rodela de fuso, que provavelmente foi manufaturado a partir de um caco de cerâmica, tendo sido polidas as suas extremidades e feita uma perfuração em seu centro. 
Ainda como reforço ao argumento de que o afastamento entre materiais Açutuba e Manacapuru seria não apenas tecnológico, mas também estratigráfico, foram efetuadas análises dos vestígios procedentes da unidade 2, escavada em 1995, cujo contexto foi anteriormente discutido. A contabilização dos fragmentos indicou dois picos de densidade, bem marcados e distintos, como mostra o gráfico abaixo, que podem ser vinculados a dois momentos diferentes de deposição.

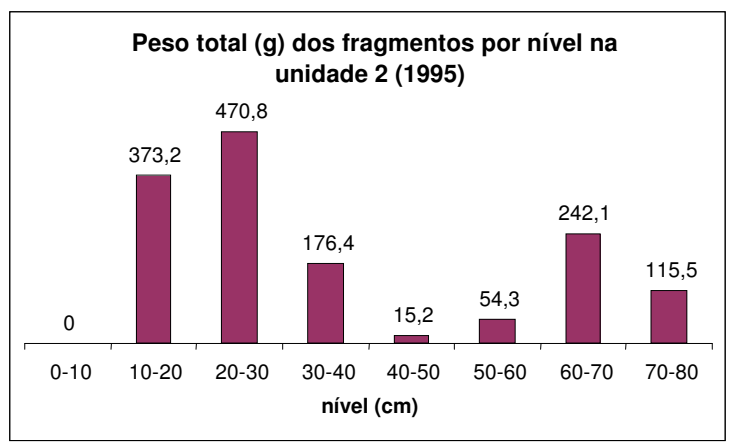

Gráfico 27 - Densidade de fragmentos cerâmicos por nível na unidade 2, escavada em 1995.

As análises demonstraram tratar-se, de fato, da sobreposição de materiais da fase Manacapuru pela fase Açutuba, como se desconfiava. Mais uma vez verificou-se a presença de policromia - antiga - nos estratos mais profundos, com evidência do uso de cores diferenciadas, entre o alaranjado, vermelho, vinho e preto, sempre sobre engobo branco. Igualmente enterrados, porém menos profundos e estratigraficamente separados, encontram-se fragmentos com traços típicos das cerâmicas Manacapuru, quais sejam, incisões em linhas duplas, formando motivos geométricos, flanges labiais e apliques modelados, com decoração também incisa ou ponteada.
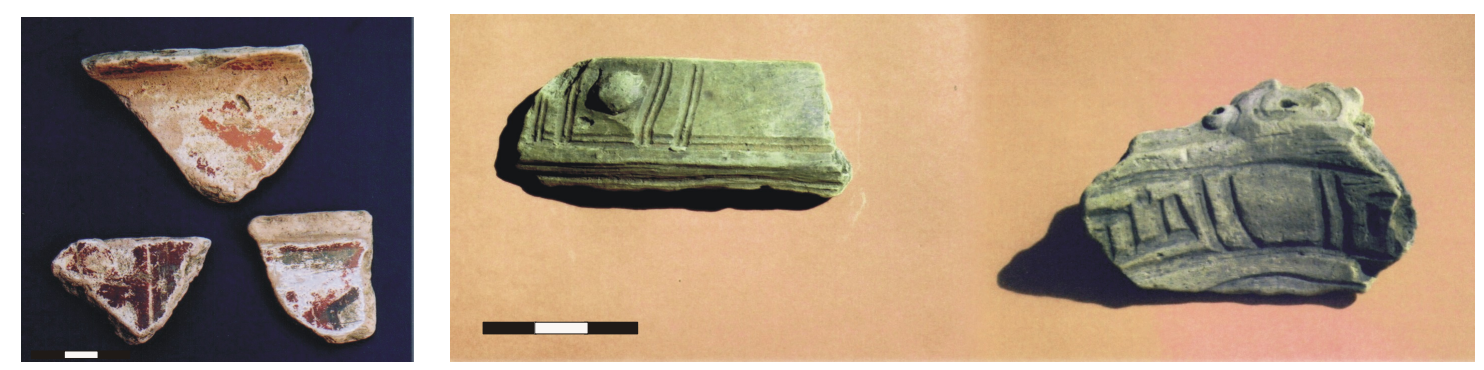

Figura 83 - Fragmentos cerâmicos coletados na unidade 2, escavada em 1995, relacionados às fases Açutuba e Manacapuru, respectivamente (fotos: Helena Lima). 
Apresentados em detalhe os vestígios de T9, T10 e TU20, que deram origem a uma relevante discussão sobre temas como o início da produção cerâmica na Amazônia central e os significados das fases cerâmicas ali encontradas (Lima et al., 2006), partiu-se para o aprofundamento de algumas questões. Especificamente, duas questões interessavam. A primeira tratava do entendimento, no sítio Açutuba, da cronologia dessas ocupações ceramistas iniciais, bem como da espacialidade de tais ocupações. Com o avanço da pesquisa e a consolidação dos problemas referentes a então definida fase Açutuba, houve, em 2004, uma nova etapa de campo no sítio na qual se explorou uma área com recorrência desses materiais, a aproximadamente 300 metros de T9-T10, ainda em contexto bem preservado. O trabalho ali foi focado majoritariamente na interpretação estratigráfica, através de perfis expostos pela escavação, feita pelo proprietário do terreno, de um imenso reservatório de água para agricultura (fig. 84).

Nessa ocasião foi realizada também uma série de tradagens, com o intuito de compreender o nível de ocupação Açutuba em termos de sua espacialidade. Mas, como mencionado no capítulo anterior, tal tarefa tornou-se um tanto complicada devido ao próprio contexto deposicional, de extrema profundidade e, portanto, não acessível através de tradagens. Ainda assim, interessantes feições, hipoteticamente associadas a diferentes usos do espaço, tais como as lixeiras e possíveis unidades habitacionais, foram aventadas, como mencionei também no prévio capítulo. De fato, este tema demandaria um projeto de pesquisa específico.

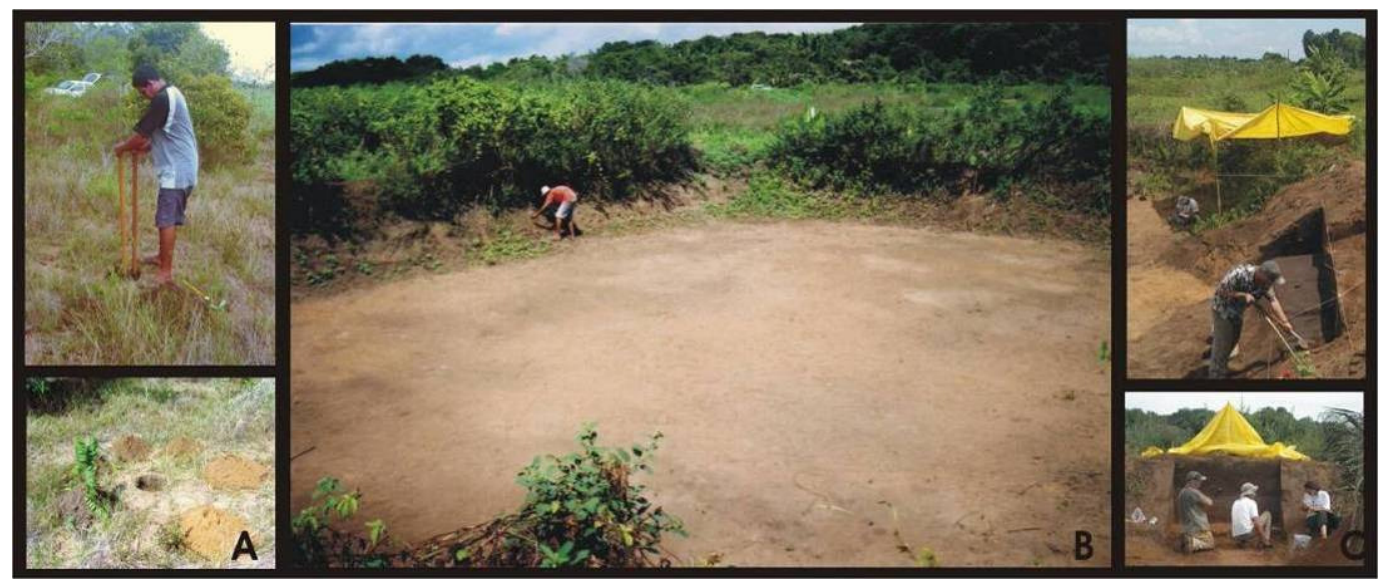

Figura 84 - Etapa de campo de 2004 no sítio Açutuba, tradagens, reservatório e escavação dos perfis no reservatório (fotos: Helena Lima, Eduardo Neves, 2004). 
Foram trabalhados, por meio da limpeza de perfis estratigráficos, doze metros lineares, sendo dois nos perfis oeste e leste, respectivamente, e quatro metros nos perfis sul e norte (os desenhos e informações estratigráficas encontram-se na pág. 87). Os fragmentos coletados por meio dessas limpezas totalizaram $5.044\left(71,361 \_\mathrm{kg}\right)$. Todos passaram pelos procedimentos básicos de limpeza e triagem. A exposição a seguir, dos elementos observados a partir da ficha, se concentrará em apenas um desses perfis, escavado na parede norte do reservatório, que forneceu uma interessante estratigrafia.

Trata-se do anteriormente mencionado contexto, encontrado abaixo do nível de ocupação Açutuba, que foi datado em 590 a.C. Esta datação, um tanto antiga, foi obtida para o nível $250-260 \mathrm{~cm}$. Esses dados são coincidentes com as freqüências de vestígios por nível, contabilizados na unidade. É, portanto, neste nível que se encontra um sensível aumento na quantidade de fragmentos, como indica o gráfico abaixo.

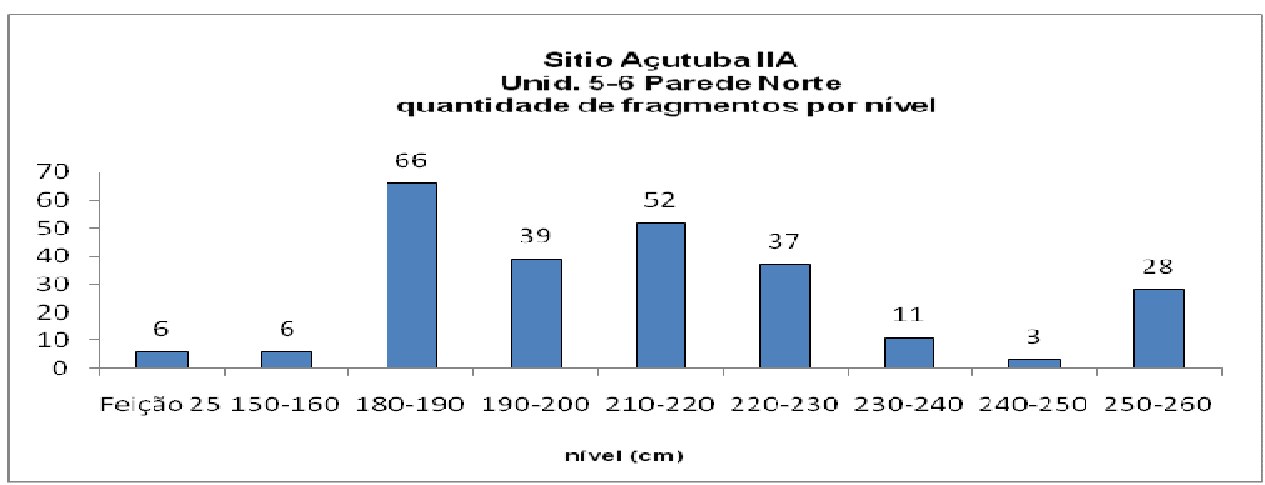

Gráfico 28 - Quantidade de fragmentos por nível coletados na unidade 5-6, parede norte.

Dos 248 fragmentos analisados, poucos apresentaram características diagnósticas que fossem capazes de distinguir os dois hipotéticos conjuntos, ainda que estes fossem semelhantes. Como se pode ver no gráfico seguinte, a coleção é formada em sua maioria por paredes simples, sendo pequena a proporção de bordas, bases, ou paredes decoradas. 


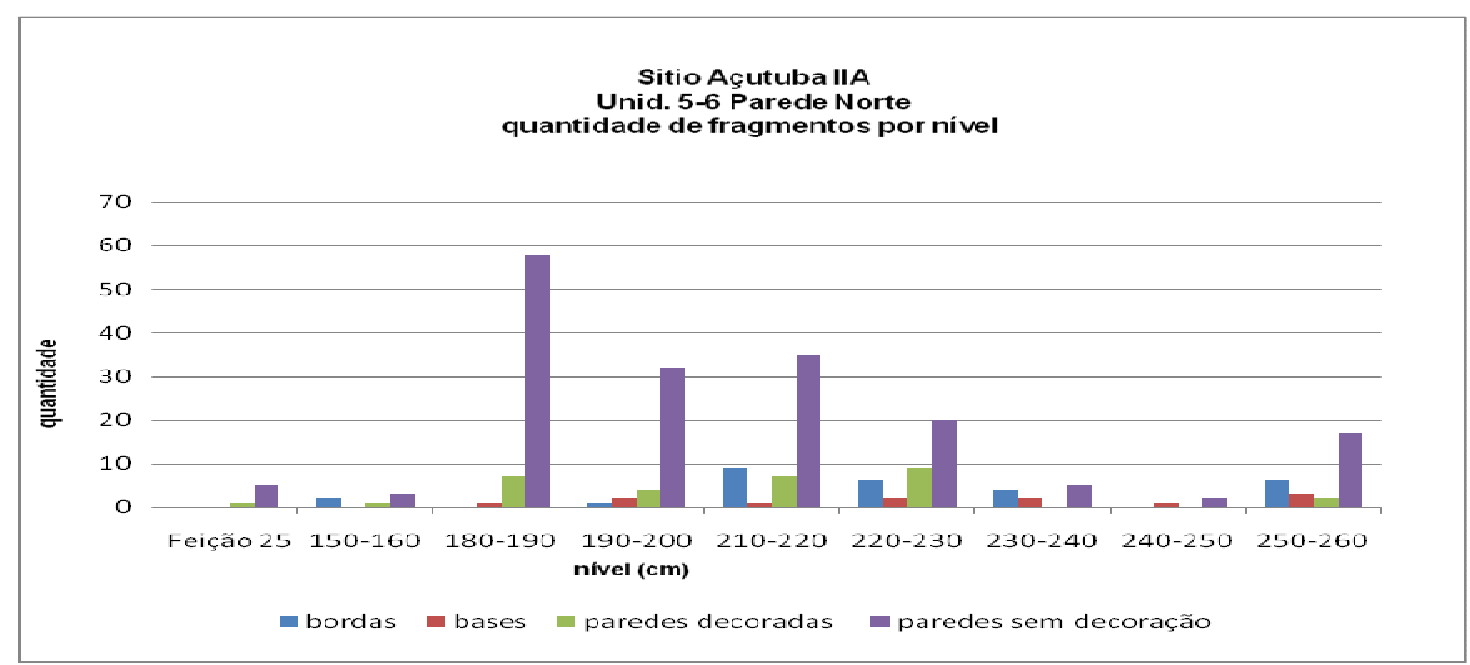

Gráfico 29 - Resultado da triagem dos fragmentos coletados na unidade 5-6, parede norte.

Por outro lado, quando se observa a freqüência de tipos de temperos por nível, um interessante dado é ressaltado. Nos gráficos abaixo se verifica que o uso de cauixi, em associação com outros elementos, tais como caco moído, argila e minerais, é constante. Já o uso de cariapé e carvão (ambos os temperos vegetais) se limitam aos níveis inferiores. Este dado, mais uma vez, é condizente com a expectativa de existência de um conjunto diferente, mais profundo e antigo. Embora a baixa densidade de vestígios não tenha permitido uma caracterização mais apurada desses artefatos, a própria presença do tempero de fibra, num contexto tão antigo e profundo, remete a uma discussão sobre o início da produção cerâmica nos trópicos sul-americanos.

Assim como verificado nos demais conjuntos Açutuba, das unidades T9 e T10, há clara predominância da queima do tipo oxidante nos fragmentos observados. Esta parece ser, de fato, característica deste contexto antigo, da mesma forma que as reconstituições morfológicas mostraram maior tendência a formas abertas, em geral com inflexões, sugerindo contornos compostos ou complexos. 


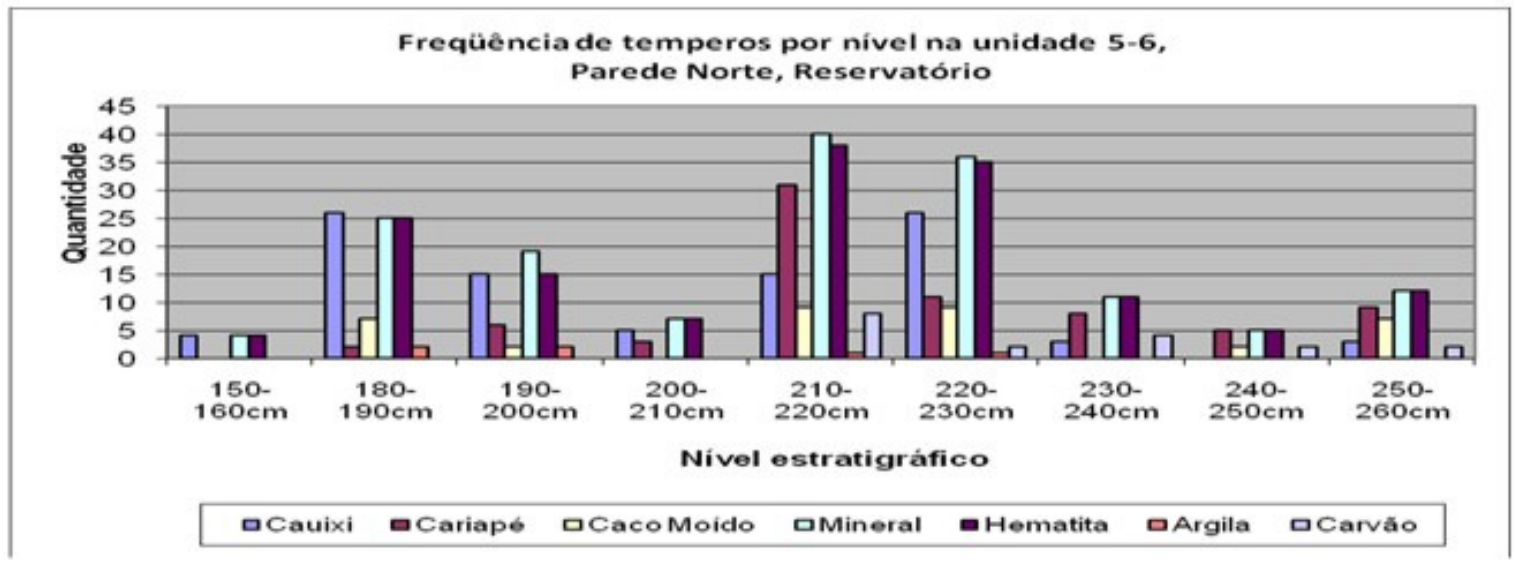

Gráfico 30 - Freqüência de temperos por nível na unidade 5-6, parede norte.

Gráfico 31 - Freqüência relativa de cauixi e cariapé como temperos preponderantes, por nível, na unidade 5-6, parede norte.

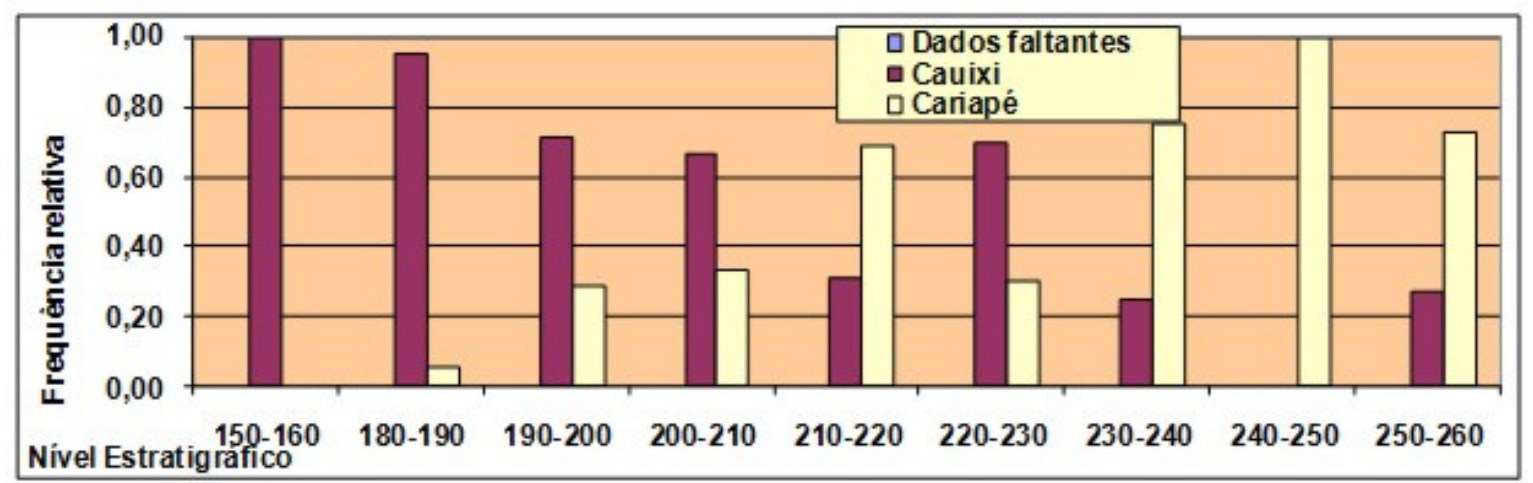

Gráfico 32 - Freqüência relativa dos tipos de queima, por nível, na unidade 5-6, parede norte.

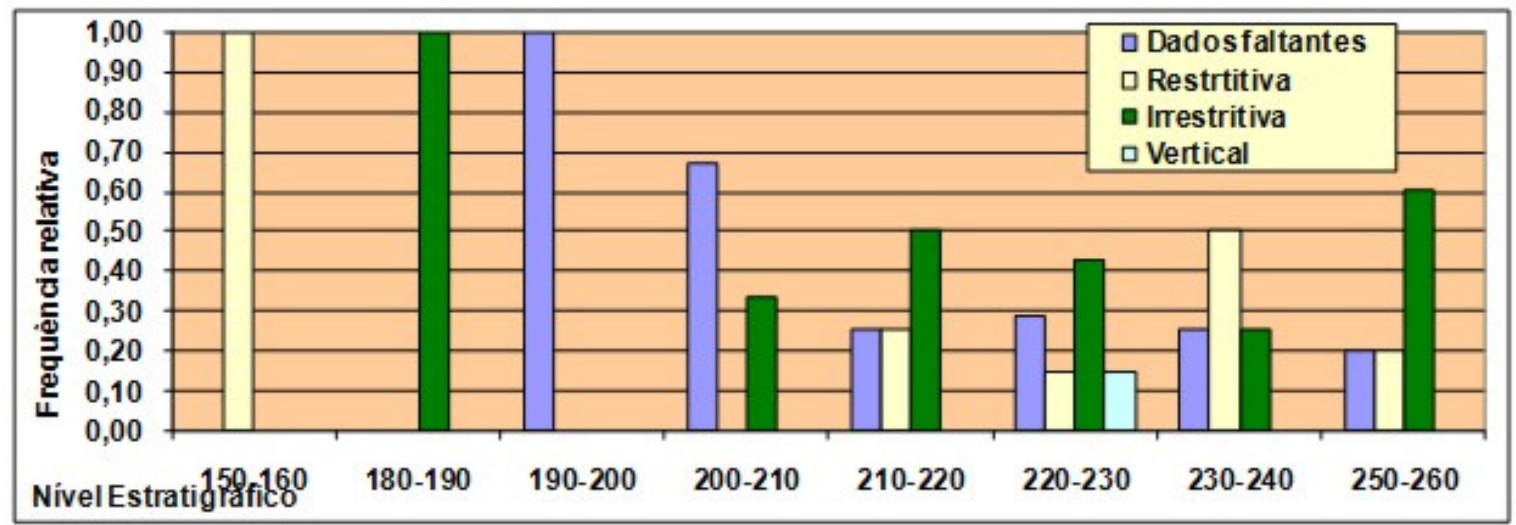

Gráfico 33 - Freqüência relativa da forma do vaso, por nível, na unidade 5-6, parede norte.

Em relação à decoração, pouco representada no conjunto, não se pode dizer muito estatisticamente: as freqüências relativas não indicaram padrões de mudança na estratigrafia. Mas, ao observar na primeira foto abaixo a presença de incisões muito finas e paralelas, executadas dentro de áreas definidas pelos acanalados, tem-se um padrão típico das cerâmicas da Tradição Hachurado Zonado. Assim, ainda que pareçam precoces as asserções sobre os reais 
significados do sítio Açutuba para este controverso tema, começa-se a corroborar a existência de uma tradição ainda mais antiga na Amazônia central, tal como proposto por Meggers, para outras áreas, como para a llha de Marajó e o baixo Amazonas.
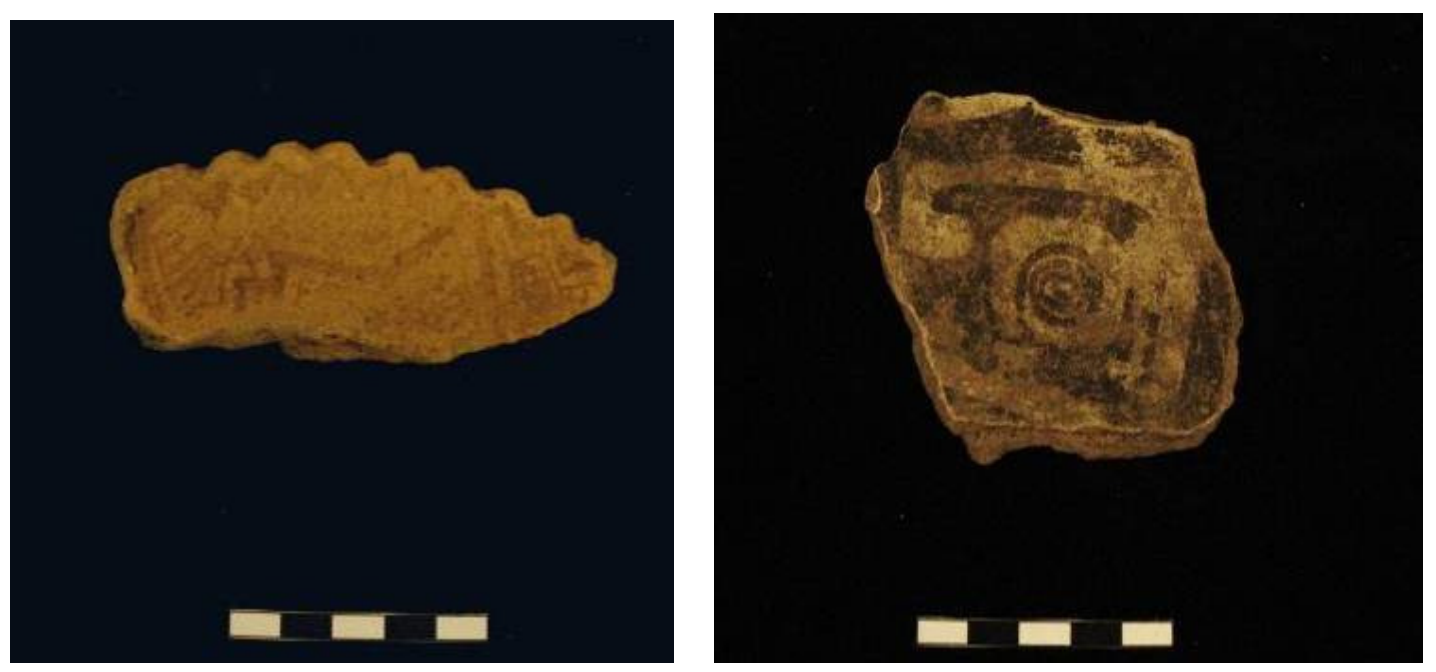

Figura 85 - Fragmentos cerâmicos coletados na unidade 5-6, parede norte do Reservatório (fotos: Val Moraes, Helena Lima).

Associações recorrentes entre a variabilidade formal e elementos tecnoestilísticos deram origem às tipologias apresentadas no apêndice deste trabalho. Com base nos materiais de T9-T10, e daqueles coletados no reservatório, foram definidos 15 tipos para a fase Açutuba. Para a fase Manacapuru, definiram-se onze tipos, a partir das observações dos fragmentos de TU20. 


\section{I. II. Cerâmicas do Cachoeira}

Ao contrário de Açutuba, o sítio Cachoeira forneceu uma quantidade reduzida de fragmentos, todos provenientes de uma mesma sondagem de $1,5 \mathrm{x}$ 1,5 m. De um total de 456 fragmentos coletados, apenas 55 foram passíveis de classificação, dado o reduzido tamanho geral dos cacos e a pequena porcentagem de bordas, bases ou paredes decoradas, conforme indica o gráfico abaixo. Não obstante, dois vasos inteiros e um parcialmente fragmentado foram recuperados, o que teve grande valia para as análises morfológica e estilística. Esses três recipientes estão descritos em detalhes na tipologia apresentada ao final desta tese. Trata-se de uma tigela mediana, com diâmetro de $28 \mathrm{~cm}$, decorada através de um complicado motivo inciso, uma pequena cuia com dois apliques nas bordas, indicando as partes frontal e caudal de um mesmo animal, e uma cuia simples, com uma linha incisa no lábio.

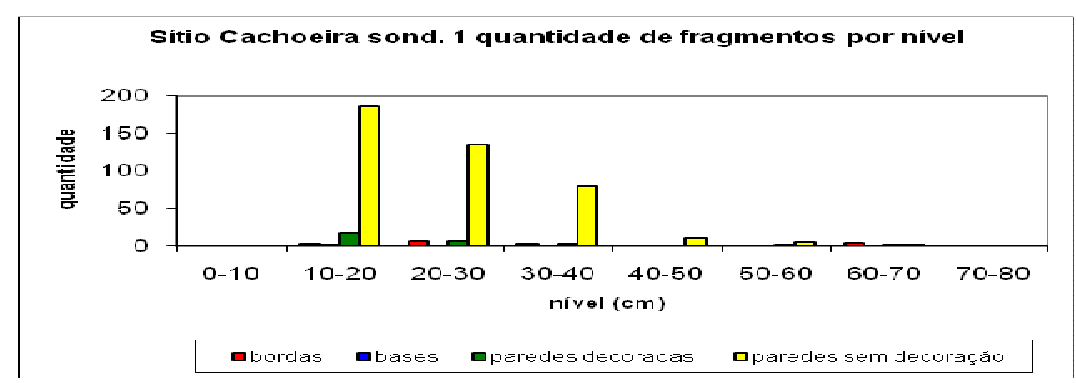

Gráfico 34 - Sítio Cachoeira. Resultado da triagem do material cerâmico.

Todos os fragmentos analisados apresentaram o cauixi como tempero principal. Em alguns deles havia uma associação com caco moído (10\%), minerais $(20 \%)$ ou argila (10\%). As argilas dividiram-se, quase proporcionalmente entre tonalidades de alaranjado e de marrom-acinzentado. Houve predominância de queima do tipo redutora. Não se observou decoração pintada, e mesmo os casos com decoração plástica, somente incisa, eram raros. Foram registrados alguns casos de polimento ou enegrecimento na superfície dos fragmentos, além do usual acabamento alisado (gráficos abaixo). Quanto aos líticos presentes na sondagem, pouco se pode falar. Foram encontrados cinco pequenos fragmentos, menores que dois centímetros, formados pelo arenito Manaus, típico do rio Negro, sendo que alguns deles sugeriram ser fraturas térmicas. 

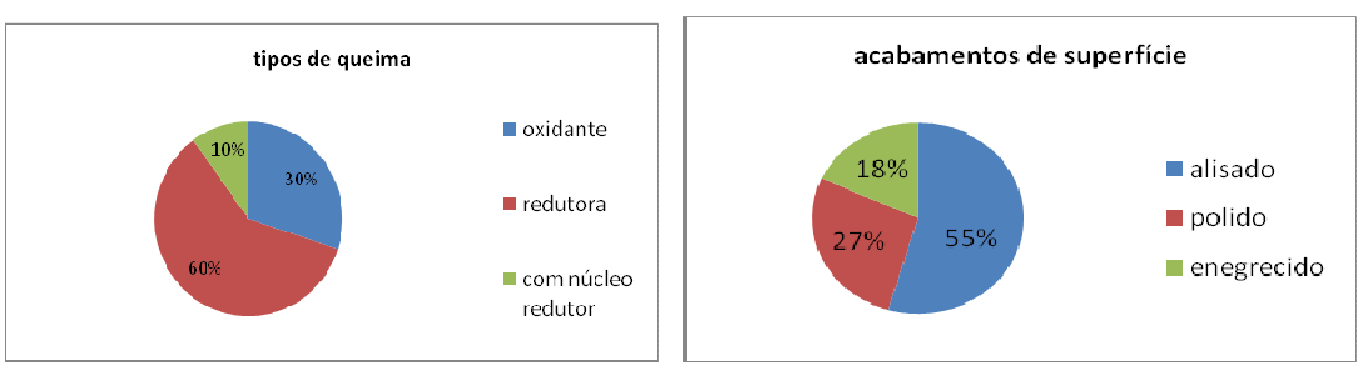

Gráfico 35 - Sítio Cachoeira. Tipos de queima e acabamento de superfície do material cerâmico

$\mathrm{Na}$ verdade, o alto índice de fragmentação deste material não permitiu que se fizesse uma reconstituição formal para além das mencionadas vasilhas. Por esta mesma razão, não foi possível realizar mais que uma caracterização um tanto genérica da coleção, sem chegar a uma tipologia, por exemplo, ou a responder a questão que se colocou ao se analisar o perfil dessa pequena escavação e as quantificações das cerâmicas coletadas. As características dos vasos, portanto, bem como do restante dos pequenos fragmentos coletados, geraram uma interessante questão que se refere à cronologia desse sítio arqueológico. O resultado da quantificação dos fragmentos indicou, para a hipótese da ocorrência de um nível de ocupação Manacapuru entre 10 e $40 \mathrm{~cm}$, que se associaria à terra preta encontrada no sítio. Um pequeno aumento da densidade de cerâmicas, entre 50 e $80 \mathrm{~cm}$ (local de onde foram coletados os vasos) indicaria a existência de um nível de ocupação mais antigo, da fase Açutuba, ao qual esses vasos pertenceriam.

$\mathrm{Na}$ ausência de carvões disponíveis para datação, e de materiais que permitam a observação de diferenças formais ou tecno-estilísticas entre os possíveis níveis de ocupação, a ocupação pré-colonial de Cachoeira permanece em caráter hipotético dentro da área de pesquisa.

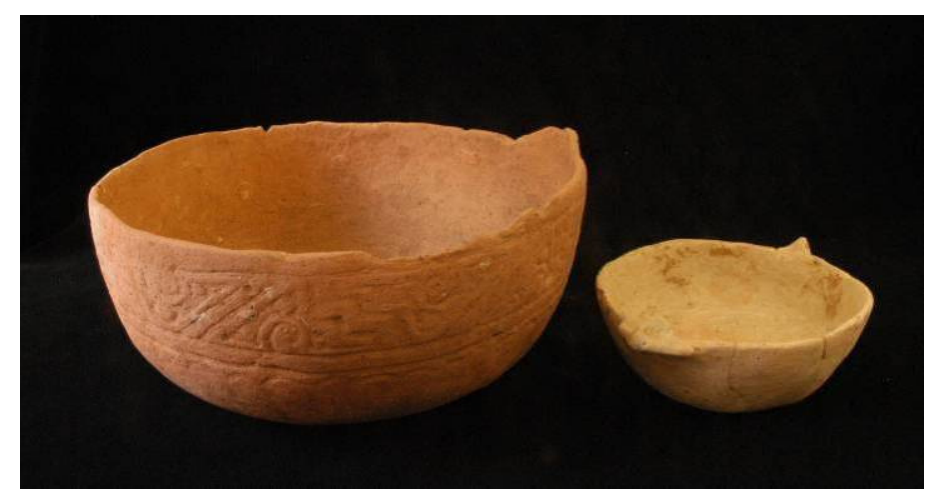

Figura 86 - Vasos coletados na sondagem 1, escavada no sítio Cachoeira (Foto: Val Moraes). 


\section{I. III. Cerâmicas do Paricatuba}

Como mencionado no capítulo anterior, os trabalhos neste sítio se deram por meio dos subsídios do Governo do Estado do Amazonas, em função da implantação de um sistema hidráulico na Vila de Paricatuba, local onde se encontra o sítio arqueológico. Trata-se de um sítio de relevância, pois está localizado às margens do rio Negro, a poucos quilômetros de Açutuba.

A etapa de campo em Paricatuba rendeu importantes informações acerca de sua configuração espacial e de sua cronologia relativa, razão pela qual foi incluído neste doutorado. Ocorre, no entanto, que as cerâmicas provenientes das escavações não puderam ser analisadas até o presente momento. Mesmo sem as informações sobre as análises cerâmicas, o sítio trouxe contribuições para a pesquisa. Em primeiro lugar, a associação contextual observada em campo dos fragmentos das fases Manacapuru e Paredão corrobora o padrão de coocorrência entre essas duas fases, se constituindo em mais um suporte empírico à hipótese de concomitância temporal e de inter-relacionamento entre elas.

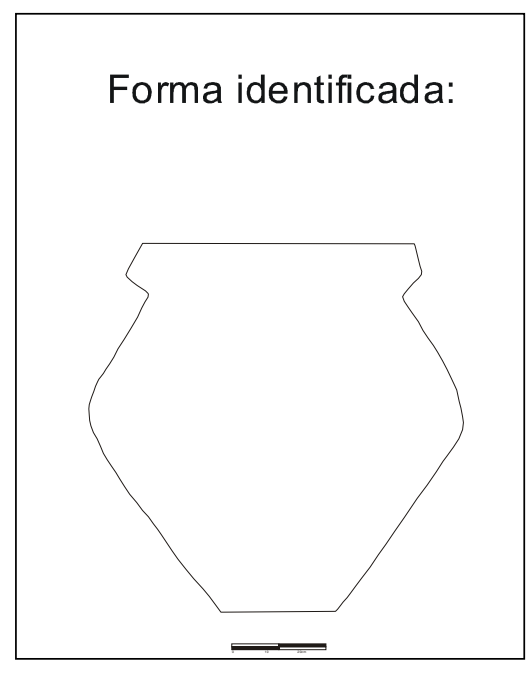

Figura 87 - Forma reconstituída do recipiente 1 do sítio Paricatuba

Em laboratório, foi feita a escavação, limpeza e preparação para o restauro de um grande vaso Manacapuru coletado em campo. Trata-se de um vaso piriforme com gargalo carenado, coberto por uma tampa (fig $\mathrm{x}$ ). Os dados referentes a esta clássica forma Manacapuru encontram-se disponíveis numa prancha da tipologia, anexa a esta tese. 


\section{I. IV. Cerâmicas do Nossa Senhora do Perpétuo Socorro}

Localizado às margens do lago de Manacapuru, NSP Socorro é um sítio unicomponencial com um nível arqueológico compacto, e uma espessura de aproximadamente $20 \mathrm{~cm}$. Encontra-se selado por uma camada estéril de cerca de $20 \mathrm{~cm}$ abaixo da superfície. Conforme já visto, o aspecto mais marcante desse sítio arqueológico é a enorme concentração de estruturas de combustão com formas e diâmetros variados. Foram registradas 84 feições, das quais se coletou amostras de seu conteúdo e das cerâmicas que as compunham.

Esses materiais foram limpos e triados. Eram compostos, em sua maioria, por pedaços de bases ou de paredes simples, sempre grandes e espessas. Tal composição se deve, provavelmente, ao uso que se deu às cerâmicas dentro das estruturas de combustão. O grande tamanho e espessura dos fragmentos, a quantidade e a disposição no interior das mesmas, sugerem que os fragmentos foram utilizados para compor a própria estrutura dos fornos ou fogueiras, servindo para aparar objetos bem como para direcionar o fluxo de ar em seu interior. Este é um interessante caso de reutilização das cerâmicas, com um propósito diferente daquele para o qual foram produzidas. Isso porque nas estruturas de combustão conhecidas em diversos sítios, incluindo NSP Socorro, existem sempre em quantidade as chamadas "bolotas de argila". São trempes ou utensílios feitos de argila, com freqüência mal-acabados, que servem para a mesma função anteriormente descrita. No caso deste sítio, preferiu-se reutilizar os fragmentos quebrados.

Além disso, com o fim de caracterizar a indústria cerâmica deste sítio, foram analisados os fragmentos provenientes de duas unidades de escavação, denominadas N1081E1183 e N1068 E1189, já descritas. A opção pela análise dos fragmentos advindos de escavações estratigráficas, e não das feições, foi feita de maneira consciente, pois os fragmentos reutilizados das feições não trariam as informações gerais buscadas. 


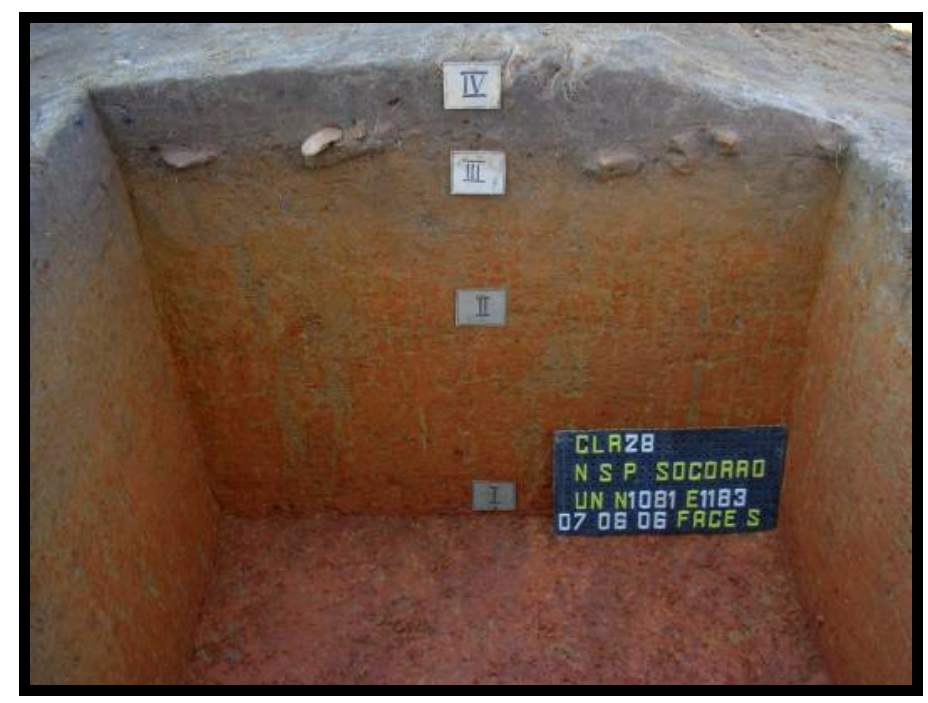

Figura 88 - Perfil sul da unidade N1081 E1182 (Foto: Helena Lima).

Como se vê no perfil estratigráfico de uma das unidades analisadas, a baixa densidade de vestígios por $\mathrm{m}^{2}$ no sítio, e a conseqüente pequena quantidade de fragmentos analisados, 232 no total, não permitiu mais do que uma caracterização geral do conjunto. Notar, através do gráfico abaixo, a predominância, quase absoluta, de paredes em relação às bordas e bases. São essas últimas que trazem, em geral, informações morfológicas. Apesar da impossibilidade de definir conjuntos formais e incluir a coleção na tipologia anexa, interessantes questões surgiram através das cerâmicas que NSP Socorro e de seu contexto.

A seqüência de gráficos abaixo demonstra tratar-se de um conjunto bastante homogêneo em vários aspectos, como a coloração geral da superfície e da pasta, sempre bege-alaranjado, com queima oxidante ( $96 \%$ da amostra). O tempero mais utilizado é o cauixi (99\%) em associação com minerais, principalmente hematita e quartzo. Os fragmentos encontram-se em condições de preservação ruins, sendo que em muitos casos não foi possível detectar a presença ou não de decorações ou outros tipos de tratamento de superfície. Da amostra total, apenas 21 fragmentos apresentaram qualquer tipo de decoração, plástica ou engobo (menos de 10\% da amostra). 


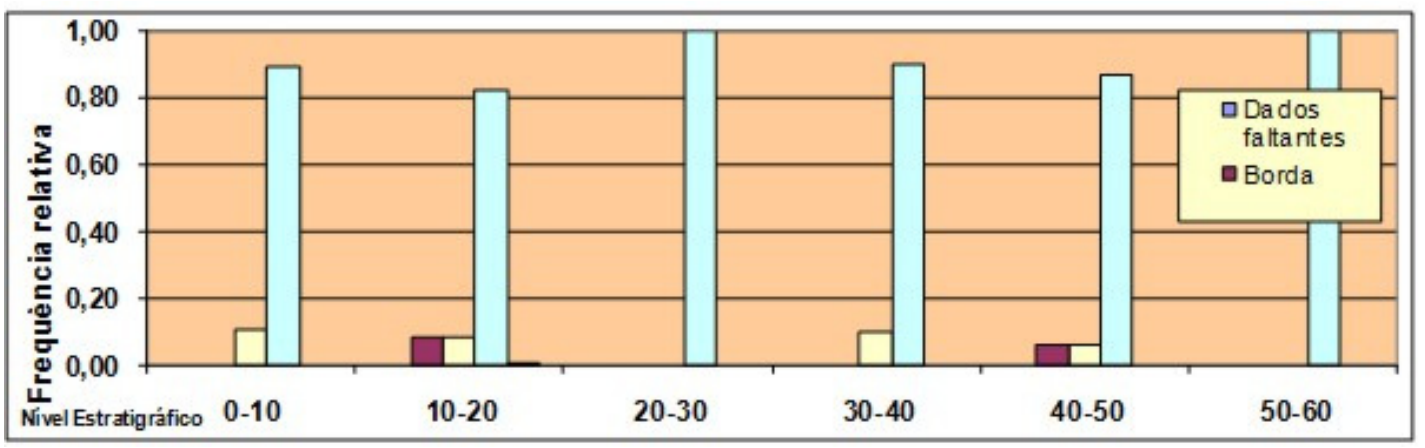

Gráfico 36 - Resultados da triagem dos fragmentos de N S P Socorro.

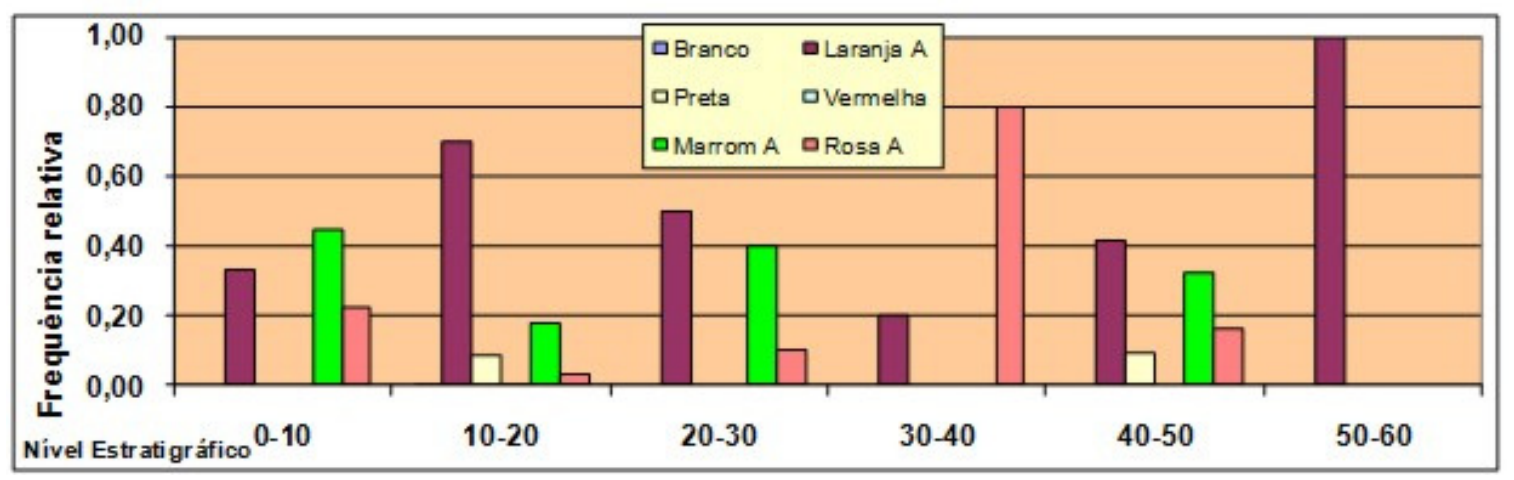

Gráfico 37 - Freqüência das cores da superfície, por nível, nas cerâmicas do NSP Socorro.

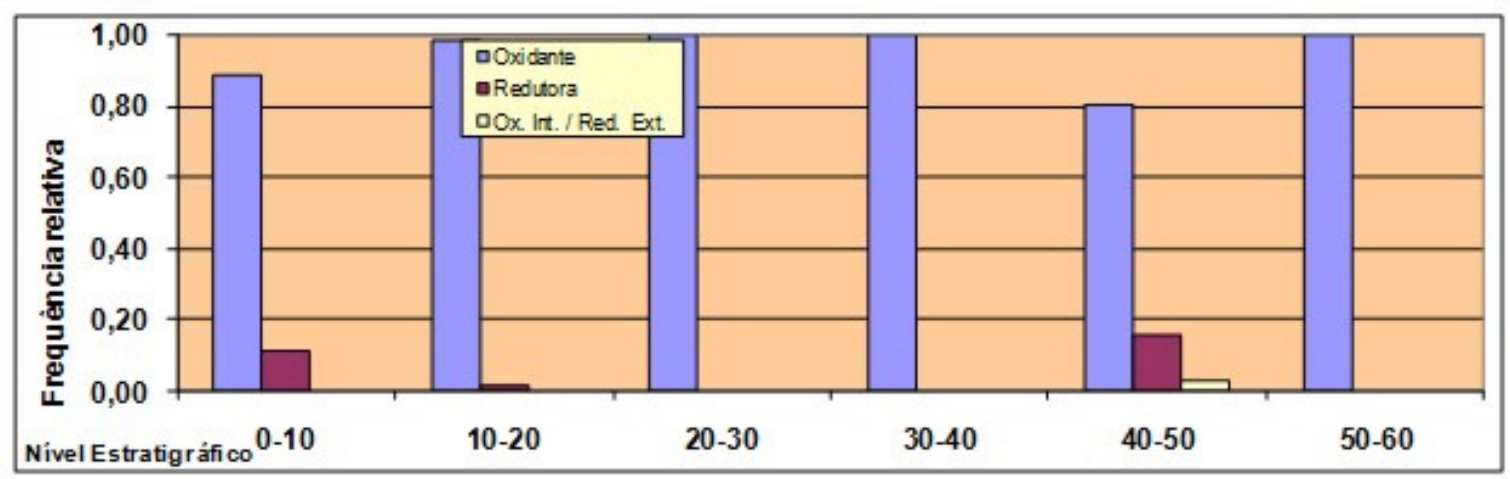

Gráfico 38 - Freqüência dos tipos de queimas, por nível, nas cerâmicas do NSP Socorro.

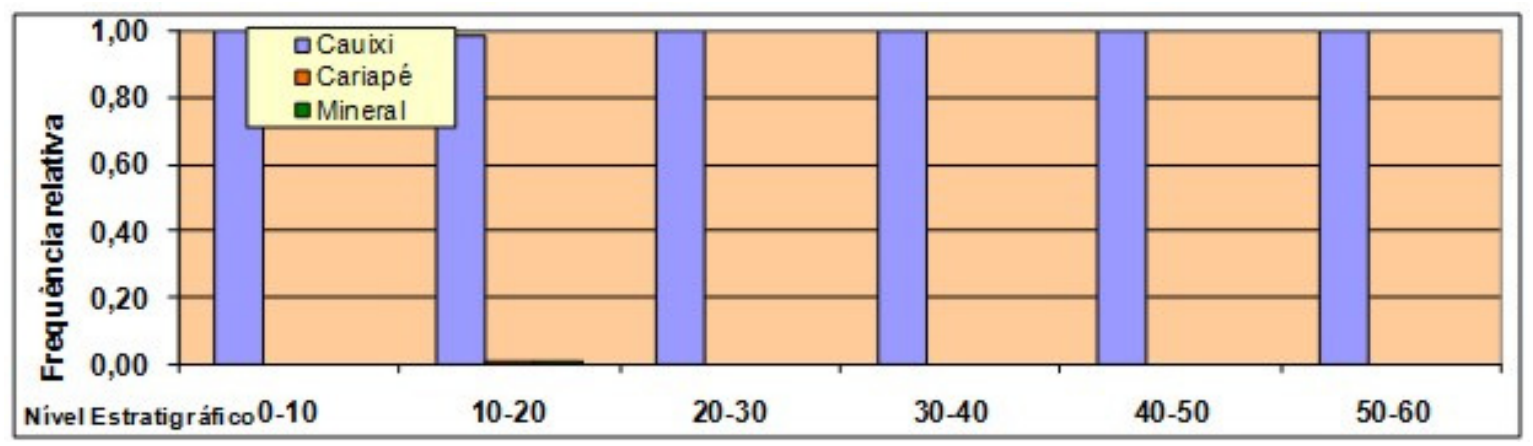

Gráfico 39 - Freqüência dos temperos preponderantes, por nível, nas cerâmicas do NSP Socorro. 
As decorações observadas são sempre aplicadas na região próxima das bordas das vasilhas, e consistem na maioria das vezes em incisões, simples ou duplas, formando motivos geométricos. Ocorrem flanges labiais e lábios cortados, elementos que associam, sem dúvida, estas cerâmicas com outros contextos da Tradição Borda Incisa.
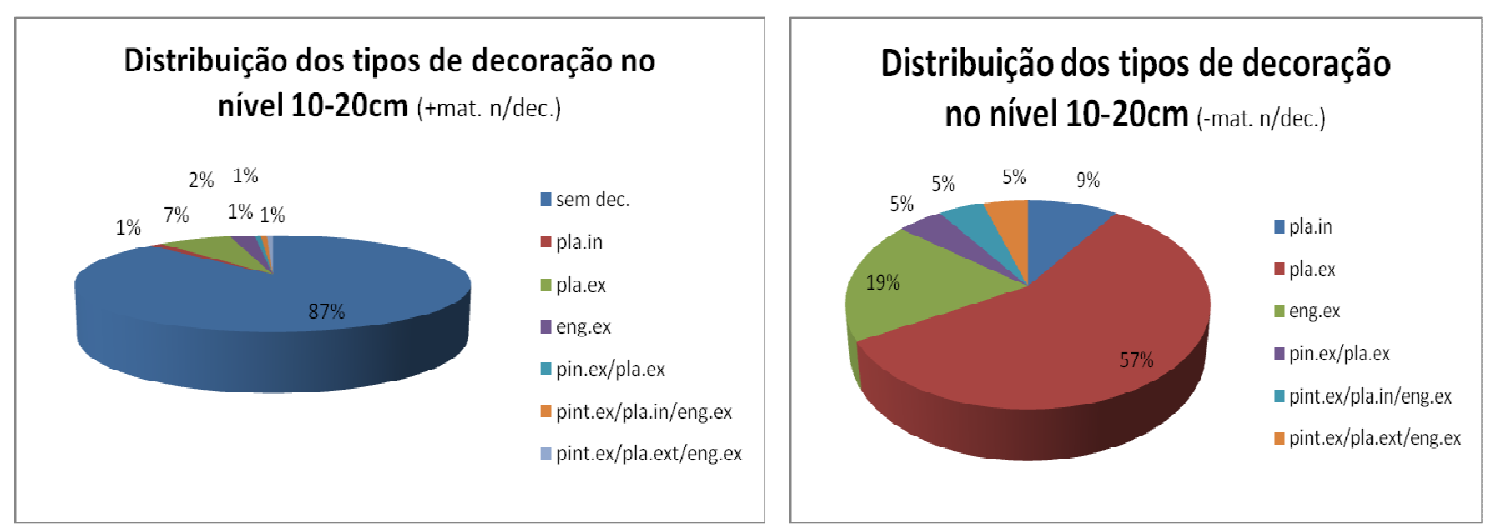

Gráfico 40 - Freqüência de tipos de decoração no nível 10-20, na unidade N1081 E1183, com e sem as peças simples, que representam $87 \%$ da amostra.

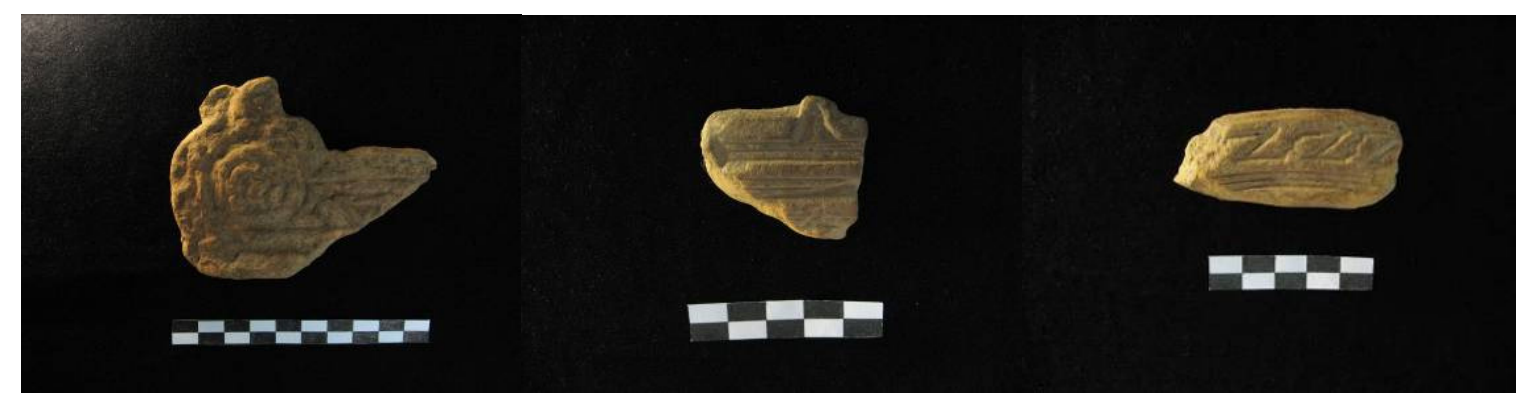

Figura 89 - Cerâmicas do NSP Socorro: aspectos gerais (fotos: Val Moraes).

No entanto, ao analisar os fragmentos de NSP Socorro, um intrigante dado chamou atenção. Suas características gerais vinculavam a coleção na Tradição Borda Incisa, mas não claramente às fases Manacapuru ou Açutuba. Os elementos distintivos de uma e de outra, discutidos ao longo da apresentação das cerâmicas do sítio Açutuba, pareciam diluir-se nessa coleção. Por exemplo, foram recorrentes fragmentos incisos com motivos em gregas, característica Açutuba, ao mesmo tempo em que apareciam incisões em linhas largas ou múltiplas, típicas do conjunto Manacapuru. Por outro lado, aspectos diagnósticos deste último, que são os ponteados, não apareceram na coleção analisada. Ao que parecia, NSP Socorro seria algo intermediário entre essas duas fases. 
As datações radiocarbônicas mostraram que o sítio foi ocupado num período de pelo menos 200 anos, datando do período entre 20 e 220 d.C., ou seja, num momento final do que outrora havia sido definido como limite cronológico da fase Açutuba (Lima et al., 2006). A associação entre as coleções cerâmicas de NSP Socorro e seu contexto, que data o início do processo de formação das terras pretas, passa assim a fazer sentido, pois a separação entre as fases Açutuba e Manacapuru é, antes de ser uma norma, um instrumento analítico que vem a auxiliar na compreensão do registro arqueológico na Amazônia central.

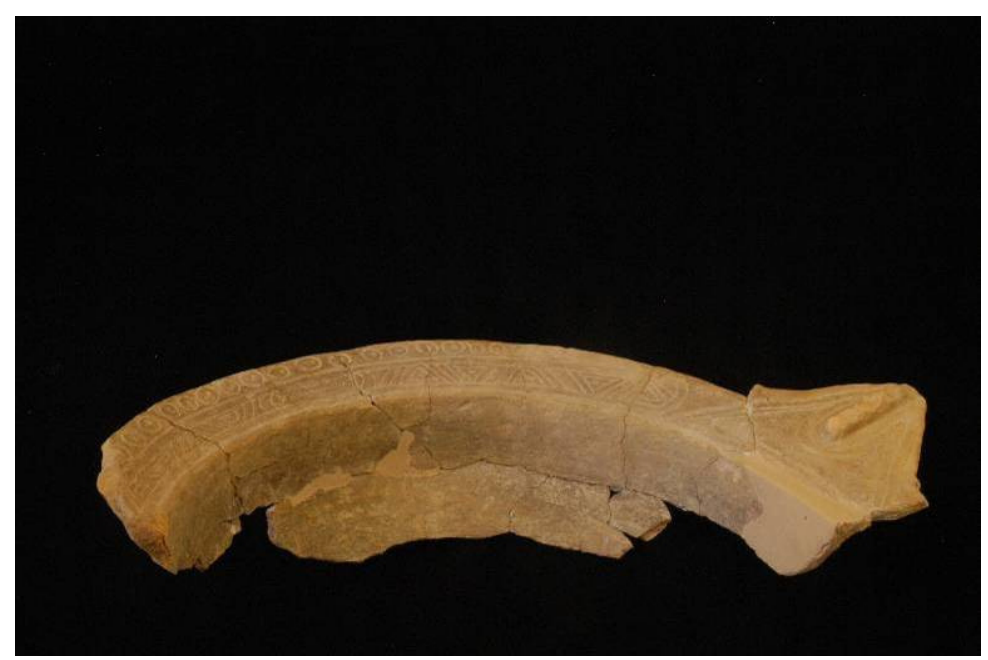

Figura 90 - Vaso coletado na feição 83, escavada no sítio NSP Socorro (Foto: Val Moraes). 


\section{I. V. Cerâmicas do Hatahara}

Situado num alto terraço às margens do Solimões, junto aos recursos da várzea e da terra firme, o sítio arqueológico Hatahara parece ter sido atraente às ocupações humanas em tempos pré-coloniais, o que é demonstrado por uma longa seqüência de ocupação, que vai desde o início de nossa era até aproximadamente o século XIII. A variabilidade das indústrias cerâmicas encontradas na Amazônia central, representadas nas fases Açutuba, Manacapuru, Paredão e Guarita é muito bem observada em Hatahara. Ali se encontram, também, as mais diversas feições arqueológicas já registradas na área de confluência, tais como as terras pretas, montículos, silos, fogueiras, sepultamentos diretos, primários, secundários, etc. Por estas razões, Hatahara é também o sítio arqueológico mais intensamente trabalhado no âmbito do PAC. Além deste doutorado, pelo menos mais três mestrados (Machado, 2005; Rebelatto, 2007; Py-Daniel, 2006) e três iniciações científicas (Machado, 2003; Farias, 2006; Tamanaha, 2006) foram realizadas com foco neste sítio, abordando as mais diferentes questões arqueológicas que a ele possam se vincular, através das mais diversas categorias de vestígios, tais como os ossos humanos, de fauna, cerâmicas, terra preta etc.

$\mathrm{Na}$ presente pesquisa, havia uma principal questão de interesse, ainda inexplorada, que diz respeito às suas ocupações mais remotas, vinculadas à fase Açutuba. Como já explicado antes, as cerâmicas vinculadas à fase Açutuba foram identificadas em dois locais dentro do sítio: sob o montículo 1 e em seu limite oeste, local onde se escavaram os vasos Manacapuru. As análises se concentraram nestes dois contextos com cerâmicas Açutuba pelas seguintes razões: a variabilidade das técnicas decorativas observadas em campo, a chance de se observar feições vinculadas a este conjunto, e até a possibilidade de se observar um piso de ocupação Açutuba em outro contexto que não o próprio sítio onde foi definida a fase.

Outra razão para a escolha de um único contexto cronológico para análise foi o fato de Hatahara ser um sítio extremamente complicado no se refere à interpretação de sua seqüência estratigráfica, bastante confusa, tanto na área das urnas como na área do montículo. Como já se viu, este sítio arqueológico é testemunho de diversos momentos subseqüentes de ocupação, e em cada um deles gerou-se uma quantidade de intervenções na paisagem que modificaram o 
registro arqueológico prévio. Exemplo disso é a formação dos montículos artificiais. Tal fato dificultaria que se procedesse a análises comparativas entre os conjuntos arqueológicos conhecidos e seus respectivos contextos, pois estes mesmos serviram como base para novos re-ordenamentos do registro arqueológico. Assim, em Hatahara, a análise cerâmica deste trabalho se ateve ao entendimento das questões relacionadas à presença de materiais da fase Açutuba.

Em relação à sua ocorrência na área do montículo 1, um exame de seu perfil estratigráfico deixa claro que elas precedem a sua construção. Essas cerâmicas encontram-se depositadas na matriz original do terreno, numa camada entre mais ou menos 150 e $200 \mathrm{~cm}$ de profundidade. Como se pode ver no gráfico abaixo, esses materiais apresentaram tamanhos maiores, o que demonstra estarem em melhor estado de conservação. Seu baixo índice de fragmentação e o fato de estarem depositados no latossolo (sua matriz original), indica que esses materiais não foram impactados pela construção do montículo.

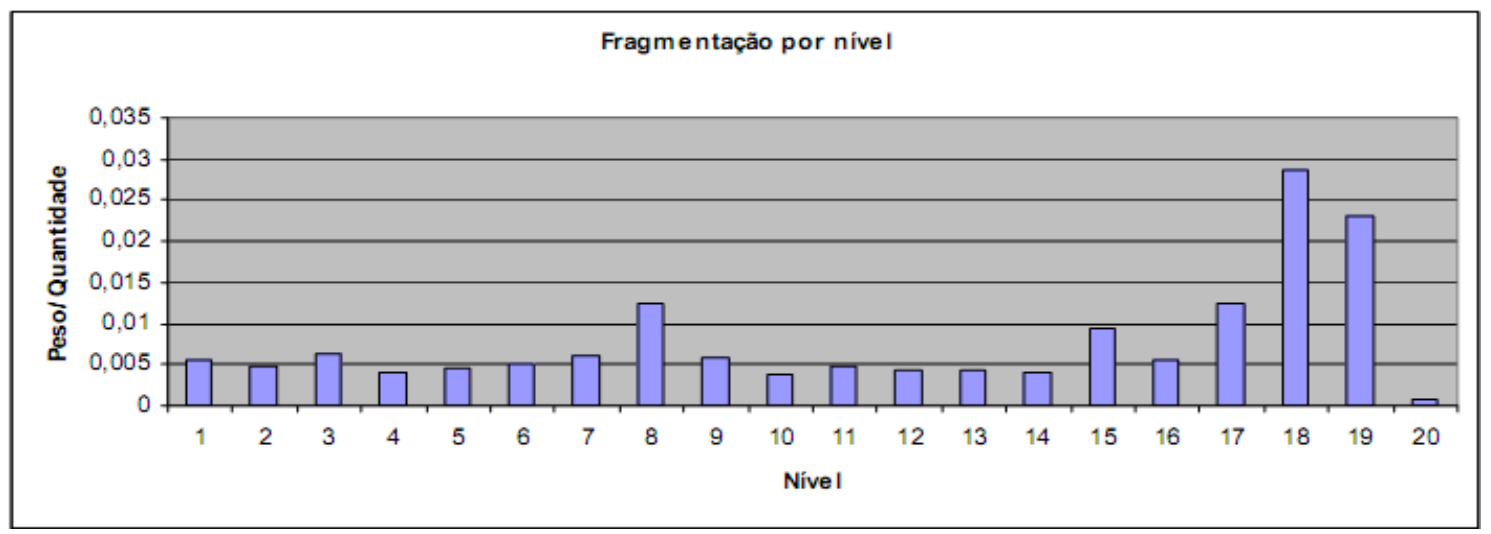

Gráfico 41 - Índice de fragmentação das cerâmicas que compõem o montículo 1 (fonte: Machado, 2005, p.154). Observar um aumento relativo do tamanho das peças nos níveis mais profundos, anteriores à construção do montículo, relacionados à ocupação Açutuba.

A análise de atributos realizada nestes materiais confirmou seu bom estado de conservação ao demonstrar que características frágeis, tais como as pinturas, se preservaram. A seqüência de gráficos abaixo se refere às características gerais da coleção, observadas a partir de 61 fragmentos, entre os níveis $140-150$ e $190-200 \mathrm{~cm}$. 


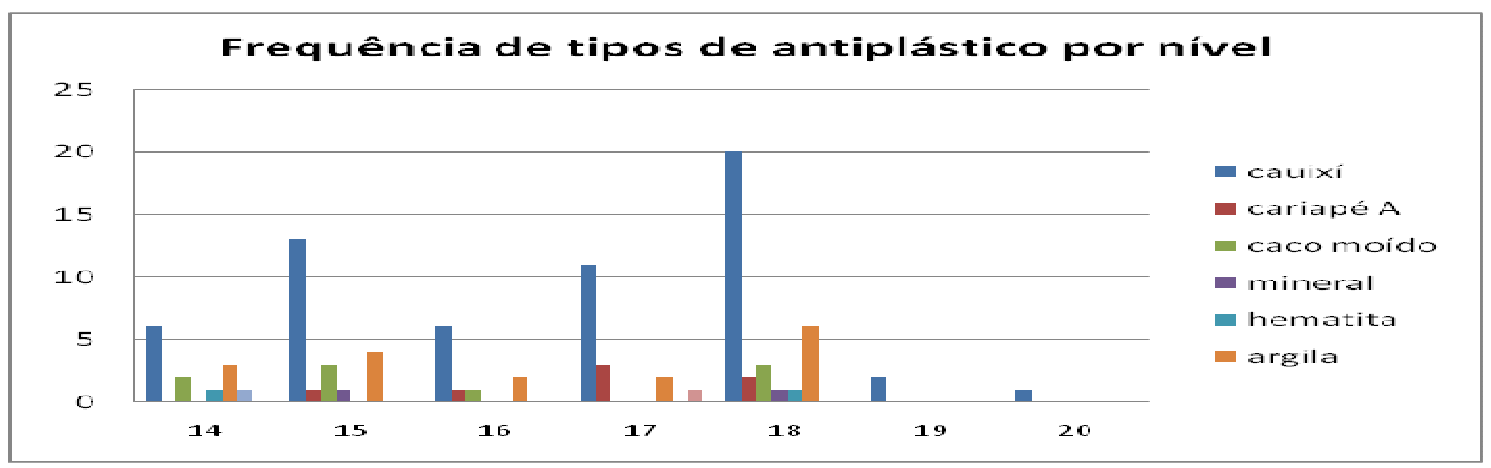

Gráfico 42 - Freqüência dos tipos de antiplástico, por nível, nas cerâmicas do Hatahara.

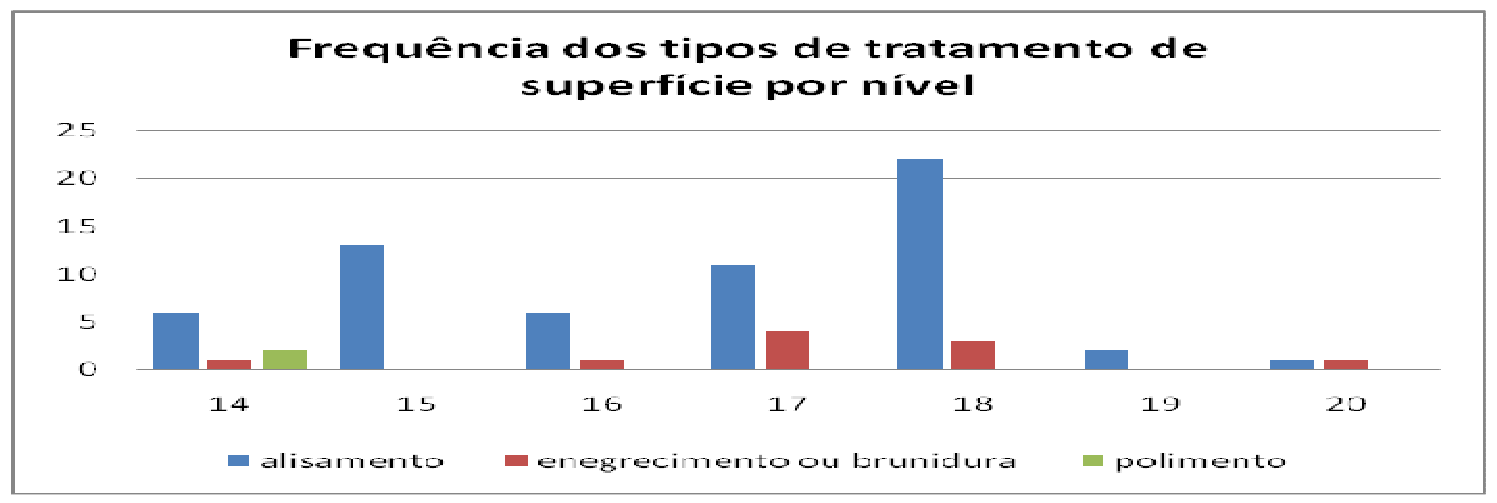

Gráfico 43 - Freqüência dos tipos de tratamento de superfície, por nível, nas cerâmicas do Hatahara.

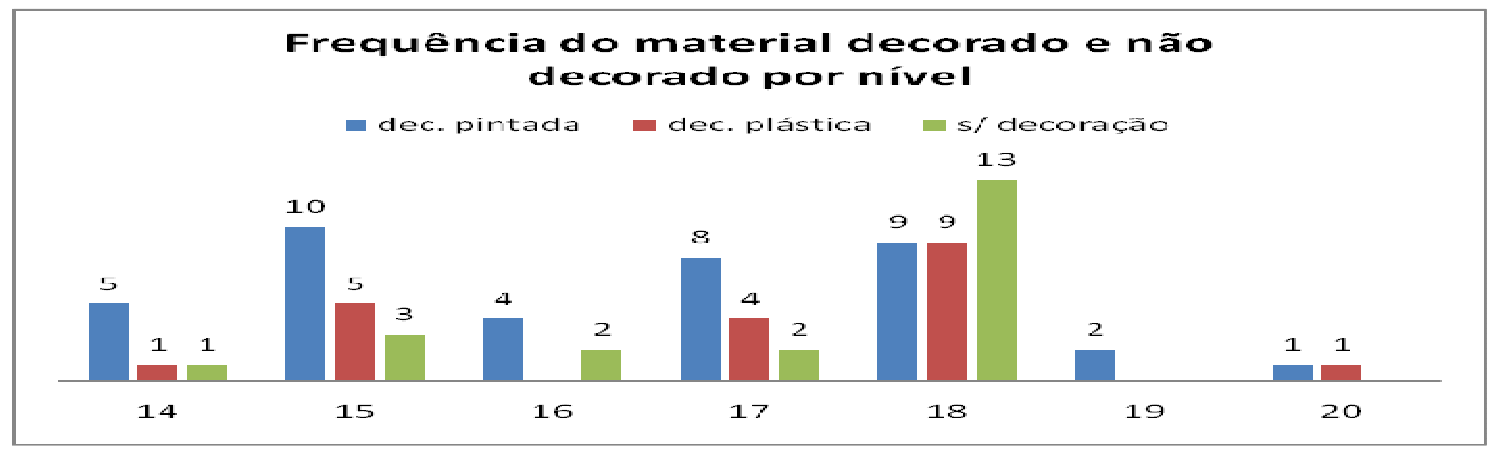

Gráfico 44 - Freqüência de decoração, por nível, nas cerâmicas do Hatahara.

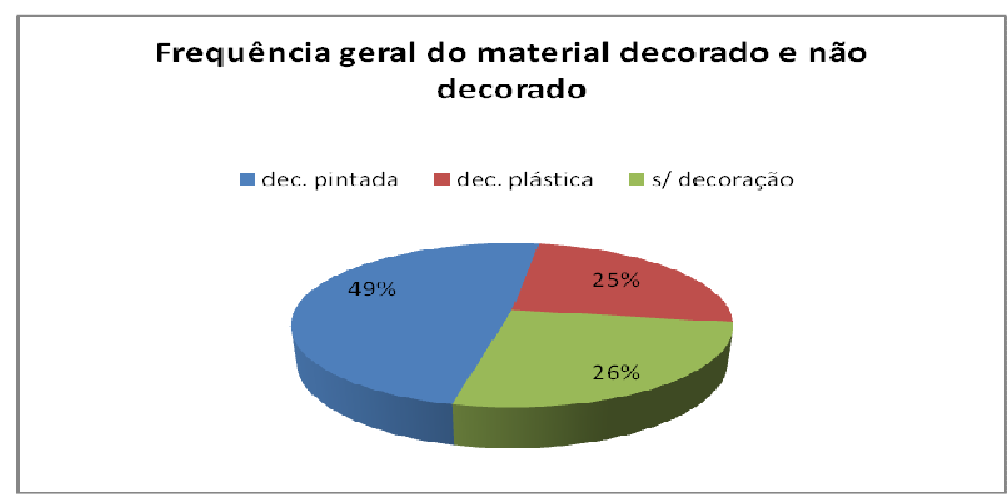

Gráfico 45 - Freqüência de decoração, geral, nas cerâmicas do Hatahara. 
Assim como os demais conjuntos Borda Incisa, as coleções analisadas de Hatahara têm como característica o uso em larga escala do cauixi como tempero principal, seguido por argila e também pelo cariapé e caco moído. Mais uma vez se percebe o cariapé, tempero historicamente utilizado na distinção entre fases em tipologias cerâmicas anteriores, co-ocorrendo com o cauixi em materiais da tradição Borda Incisa. A observação binocular do tempero apontou uma forte preponderância do cauixi em relação aos demais elementos (alguns deles oriundos das próprias argilas) nas amostras analisadas. Os padrões de queima são variados. Foram identificados, três tipos principais de argila, de cores branca, bege-alaranjada e bege-acinzentada. Com exceção das cerâmicas pintadas (que se associaram sempre a argilas de cores brancas ou alaranjadas), não parece haver ligações recorrentes entre o tipo de argila, forma ou decoração. Mais de uma centena de fragmentos foi encaminhada ao IPEN, onde estão sendo submetidas a análises arqueométricas por ativação com nêutrons, a fim de se identificar relações entre os tipos de argila e outras características das coleções, não apenas Açutuba, mas também de outros períodos cronológicos no sítio. Este é o tema de uma pesquisa de mestrado, ora em andamento naquele instituto, sendo que seus resultados, potencialmente informativos, ainda não se encontram disponíveis (Nunes, 2008).

Quanto à morfologia geral da coleção, percebe-se uma preferência pelos contornos compostos ou complexos, sendo que esta estrutura define as áreas do vaso a serem decoradas. Mais uma vez nota-se semelhanças entre conjuntos antigos em diferentes regiões. As decorações plásticas consistem principalmente em incisões: finas ou largas, simples ou duplas, formando sempre motivos retilíneos ou curvilíneos. São aplicadas, na maioria dos casos, na parte superior das vasilhas; nas bordas, flanges ou próximo a eles. As decorações pintadas consistem em engobo vermelho ou vinho, e engobo branco. Sobre este último ocorrem motivos pintados nas cores alaranjada, vermelha e vinho. A identificação dos motivos foi dificultada pela fragmentação da coleção e pelo desgaste da superfície de algumas peças. Elas, no entanto, se apresentam em linhas finas (com aproximadamente $2 \mathrm{~mm}$ ) ou faixas grossas (de 5 a $10 \mathrm{~mm}$ ), ou ainda, em áreas. 
Nos demais aspectos, uma característica chama atenção. Verifica-se, por um lado, a superioridade de fragmentos decorados em relação aos simples, bem como a alta incidência de técnicas decorativas pintadas em relação às plásticas, conforme mostraram os gráficos acima.

Em relação ao primeiro ponto, o uso acentuado de técnicas decorativas é observado na maioria dos conjuntos arqueológicos antigos da Amazônia central e adjacências. Esta é uma característica marcante da coleção Açutuba proveniente do sítio homônimo, assim como das cerâmicas Pocó em geral, como se verá adiante. Há, de fato, uma discussão na arqueologia tropical-americanista que versa sobre os primórdios da produção cerâmica e seu papel desempenhado nestas sociedades, em que sua relação de uso não implicaria necessariamente no processamento de alimentos, tal como visto em sociedades horticultoras. Antes, seu emprego estaria vinculado a elementos definidores de identidade social, de tal maneira que o elemento decorativo se tornaria chave nesta relação. Razão esta pela qual a abundância de decoração seria uma característica destes conjuntos antigos. (Oyuela-Caycedo, 2005, p. 2-3).

O segundo ponto de relevância tem a ver com a superioridade de técnicas decorativas pintadas em relação às plásticas na coleção analisada. Cabe salientar que as decorações plásticas, em especial aquelas incisas e modeladas, são uma característica quase definidora da Tradição Borda Incisa. A observação da recorrência de pintura policrômica na representação mais antiga desta tradição é algo novo nesta discussão, e vincula a Amazônia central aos clássicos debates acerca da ocorrência, da antigüidade e de sua relação com os conjuntos incisos e modelados dos trópicos da América do Sul. O tema será desenvolvido nos capítulos finais da tese.

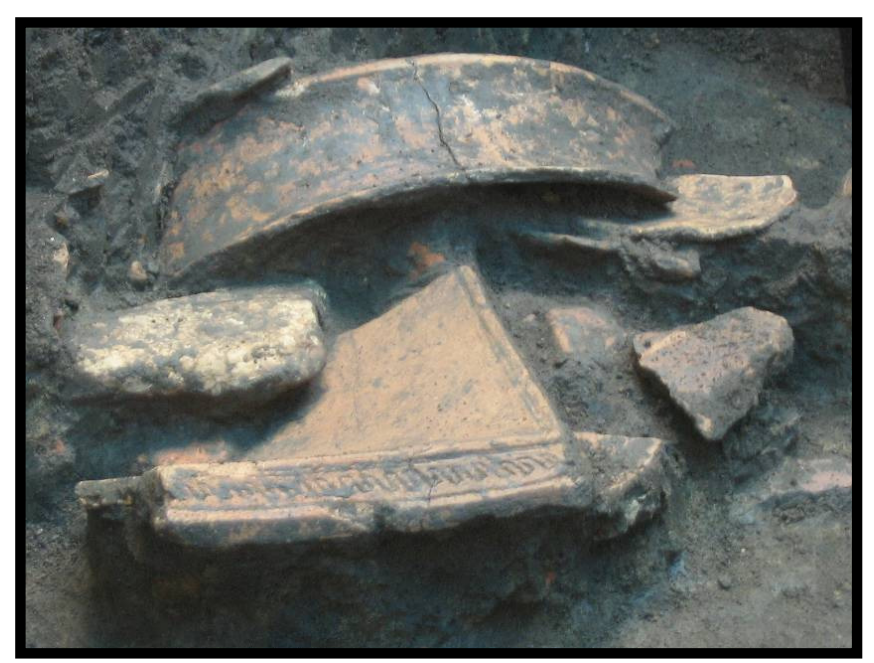

Figura 91 - Fragmentos decorados que compõem a feição 15 (foto: Val Moraes). 
Em relação à segunda área do sítio contemplada na pesquisa, foram analisados os materiais provenientes das feições vinculadas à fase Açutuba. Foi, portanto, a partir das feições 3,15, 19 e 27 (ver fig. 47, pág. 119) que se estabeleceu a tipologia da coleção Açutuba do sítio Hatahara. Estabeleceram-se dez tipos, entre essas cerâmicas e aquelas da área do montículo 1. A distribuição entre as cerâmicas nos tipos definidos se deu de modo homogêneo, com superioridade quantitativa de $\mathrm{F} 3$, mas em função de seu próprio tamanho em relação às demais. Como se poderá ver no apêndice, quando comparada a outros sítios, esta tipologia foi muito informativa, justamente em função do contexto em questão, que forneceu uma série de fragmentos bem preservados, em muitos casos remontáveis. Desta maneira, foi possível obter-se uma ótima idéia de sua variabilidade, tanto em termos formais como tecnológicos e decorativos, contribuindo assim para uma caracterização não apenas do conjunto em questão, de Hatahara, mas das cerâmicas Açutuba em geral, que são muitas vezes encontradas em pacotes muito discretos e condições ruins de preservação.

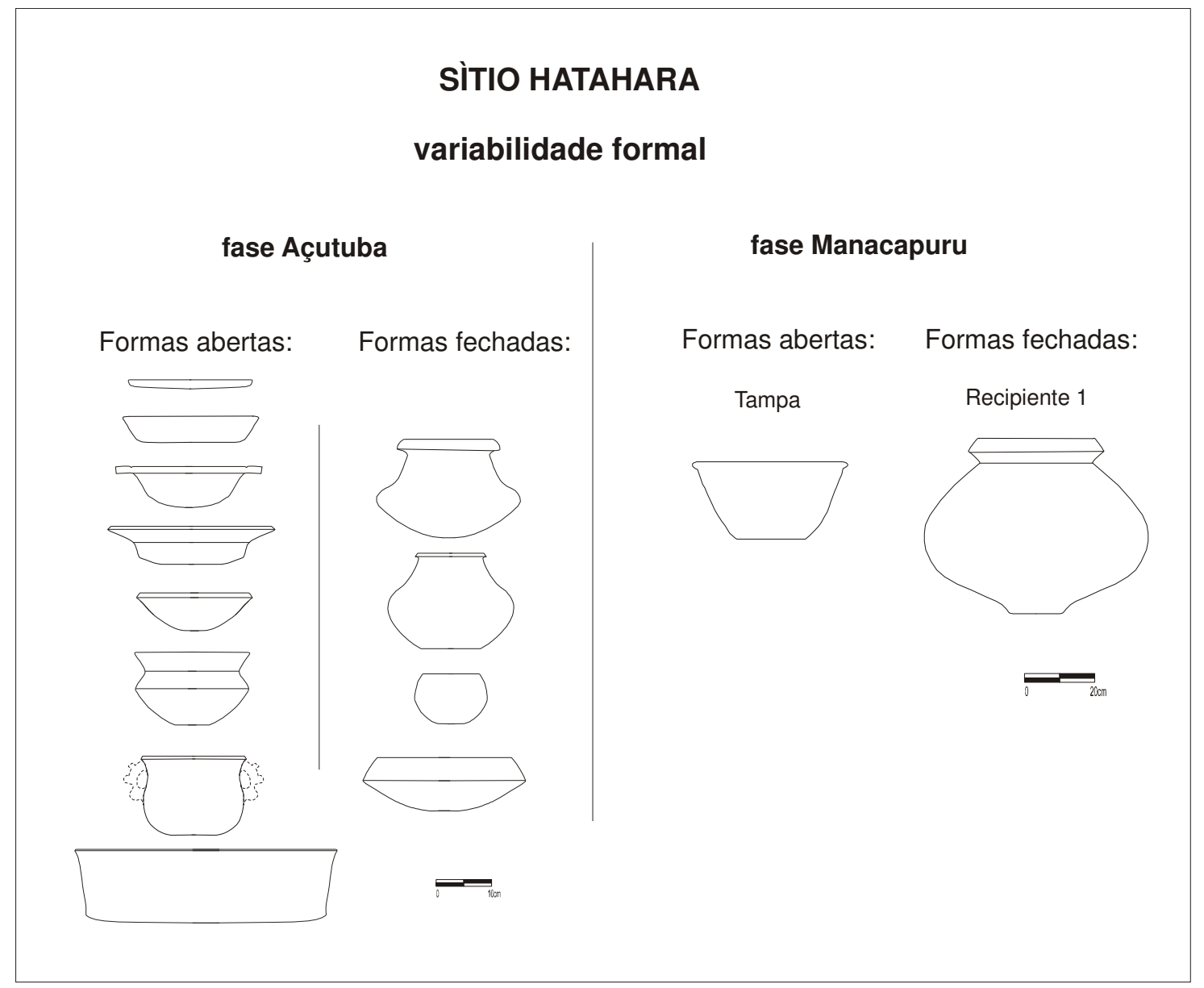

Figura 92 - Formas reconstituídas das cerâmicas do Hatahara, das duas áreas analisadas. 
Descrições detalhadas dos materiais de cada feição e de seu contexto encontram-se ao final deste tópico. Como se poderá ver, apenas uma das feições analisadas forneceu uma quantidade considerável de fragmentos, um total de 598 $(13,788 \mathrm{Kg})$. Ao contrário das demais feições Açutuba, pouco espessas e passíveis de serem confundidas com um piso de ocupação, esta foi a única que mostrou uma maior espessura, abrangendo pelo menos seis níveis estratigráficos, entre 70 e $130 \mathrm{~cm}$. Congruente com os dados das análises da outra área do sítio anteriormente discutidos, o que mais impressiona entre as cerâmicas de F3 é a proporção de vestígios decorados em relação aos não decorados, principalmente as bordas, e de fragmentos pintados em relação aos demais.

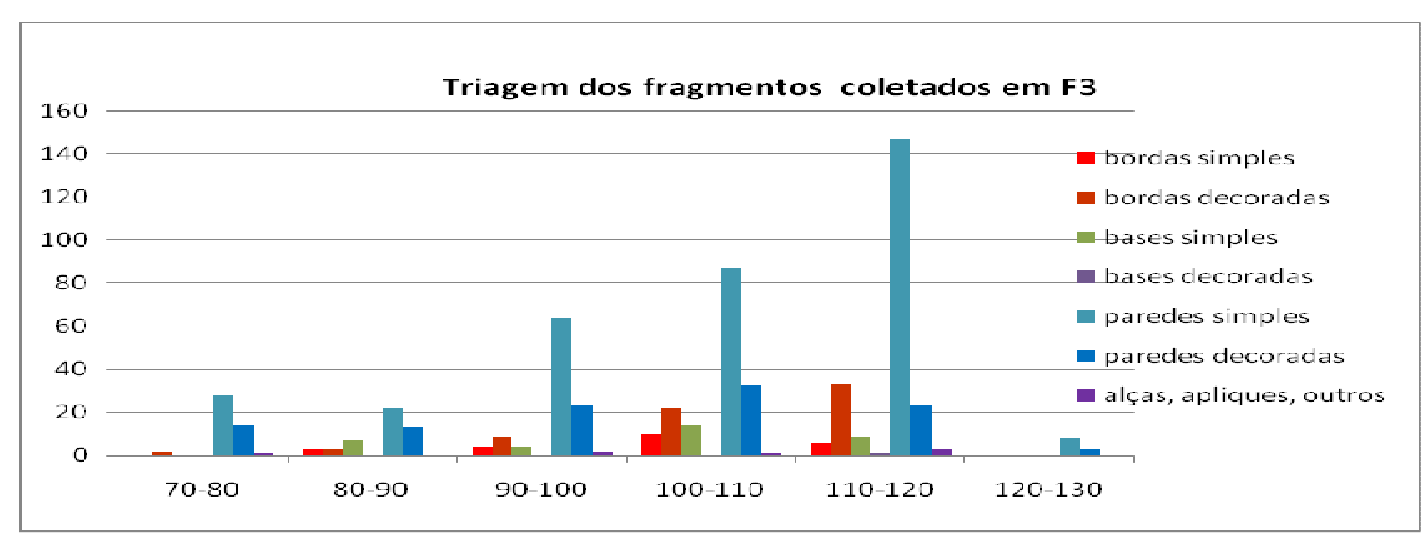

Gráfico 46 - Resultado da triagem das cerâmicas de F3, Hatahara. Notar a maior quantidade de bordas decoradas em relação às simples.

Sobre sua funcionalidade ainda não há conclusões, mas sabe-se que seu processo de deposição ocorreu em diferentes etapas. Durante a escavação, suas primeiras evidências apareceram aos $70-80 \mathrm{~cm}$ de profundidade, abaixo de dois níveis, com solo extremamente compacto e baixa freqüência de materiais arqueológicos. Ela se encontra numa profundidade e situação deposicional semelhante ao recipiente 7 (já em contato com o latossolo), que também foi vinculado à fase Açutuba. Ambos parecem estar in situ. Os fragmentos que compõem a feição encontram-se depositados em diferentes camadas (três ao todo), entremeadas por camadas de solo com 5 a $10 \mathrm{~cm}$, bastante compactas. É importante mencionar que fragmentos provenientes de diferentes camadas remontam. 
Além das cerâmicas Açutuba, contempladas pela tipologia anexa, os recipientes Manacapuru, tal como mencionados na descrição do sítio, eram um foco de interesse específico da pesquisa. Suas descrições detalhadas, coletadas em campo, encontram-se também ao final do tópico. Não foi possível proceder à análise de todos estes vasos, que foram coletados com solo em seu interior, o que exige um delongado processo curatorial. Apenas os recipientes 01 e 02 , retirados na campanha de 2002, que apresentavam engobo vermelho e tampa com decoração incisa na face externa, foram trabalhados em laboratório e passaram pelo completo processo de restauro e posterior análise. Por tratar-se de um processo lento e que demanda o trabalho de uma equipe de especialistas na área de restauração, os demais recipientes se encontram no anexo do laboratório do MAE-USP em Manaus, e serão trabalhados no futuro. Por conta disso, numa tentativa para que se pudesse reconhecer rapidamente o conteúdo interno dos vasos, eles foram submetidos ao raio $X$ de inspeção de bagagem, no Aeroporto Internacional de Manaus Eduardo Gomes. De fato, conhecer o conteúdo desses vasos é fundamental para que se entenda melhor esta área de atividade do sítio, que em pelo menos dois momentos distintos foi utilizada de maneira semelhante. No entanto, a interpretação das imagens não saiu a contento (fig. 93). Assim, sabe-se apenas que, nos três recipientes escavados até o momento, não se encontraram vestígios que sugerissem tratar-se de sepultamentos. Amostras de solo foram encaminhadas a análises paleobotânicas, que virão a contribuir para uma melhor compreensão do uso dessa área do sítio. Descrições coletadas em campo dos demais recipientes encontram-se a seguir, junto com os dados das feições.
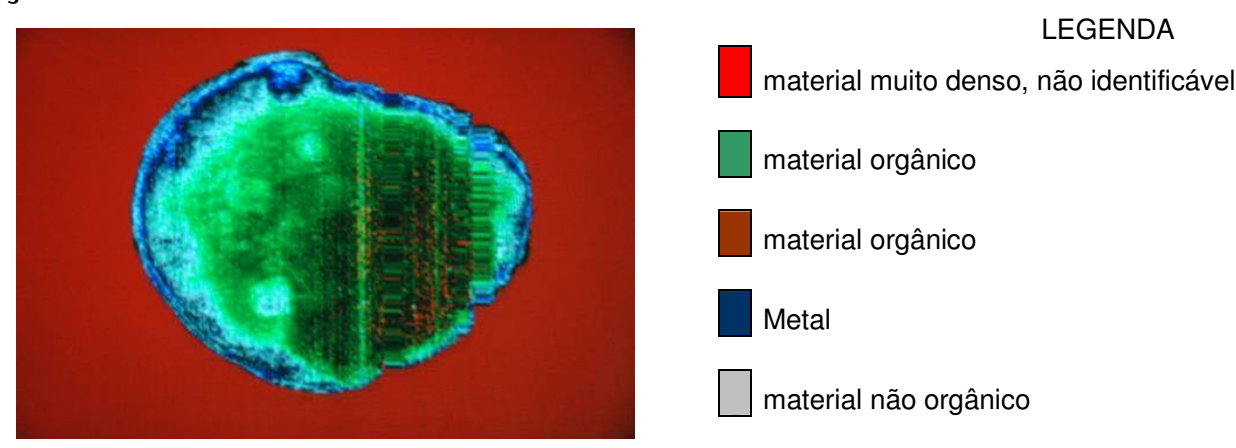

Figura 93 - Exemplo de imagem do interior de um recipiente, reproduzida pelo Raio X. À direita encontra-se a legenda interpretativa. Neste caso, somente o que se observou foi o preenchimento por material orgânico (o sedimento), e pontos circulares mais densos, indicados como metal ou material não orgânico, que devem ser, na realidade, os fragmentos de cerâmica retirados na escavação em laboratório. 
Descrições das feições e recipientes:

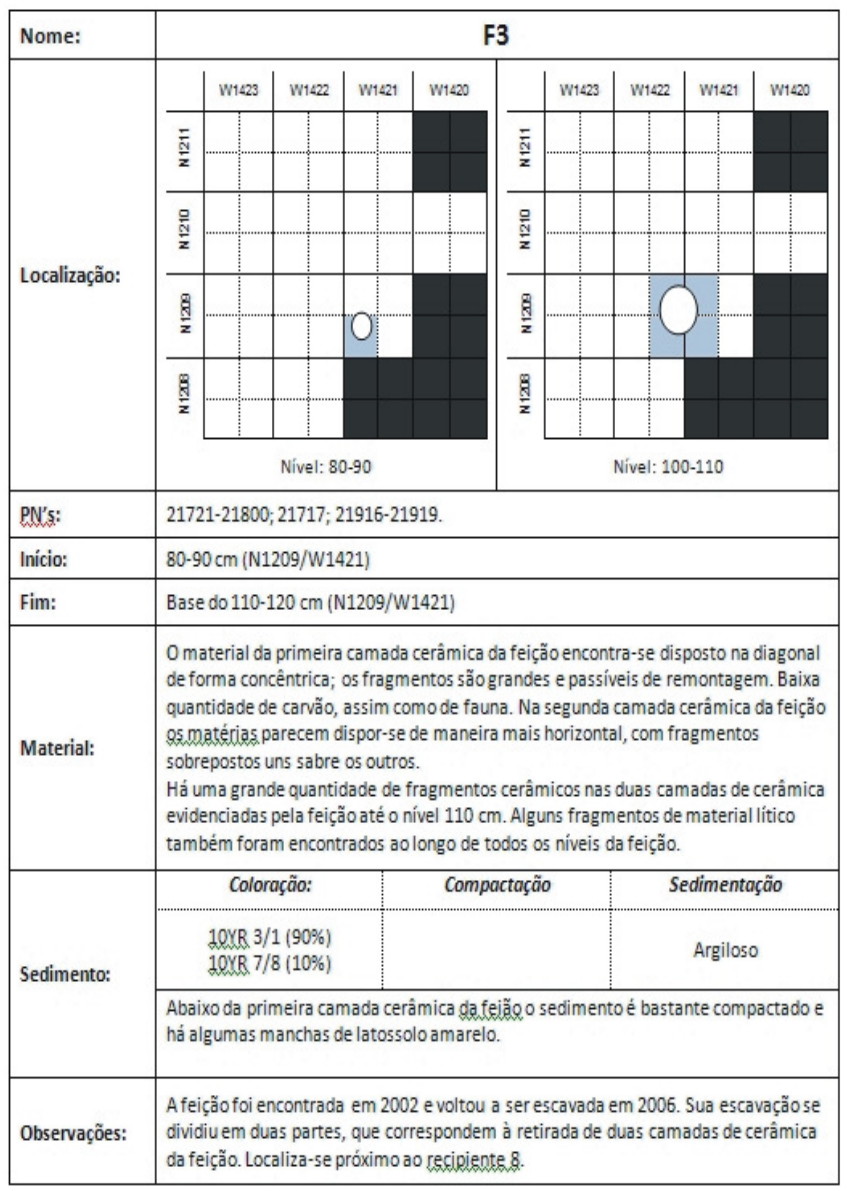

\begin{tabular}{|c|c|c|c|c|c|c|c|c|c|c|}
\hline Nome: & \multicolumn{10}{|c|}{ F12 } \\
\hline \multirow{11}{*}{ Localização: } & & W1423 & W1422 & W1421 & W1420 & & W1423 & W1422 & W1421 & W1420 \\
\hline & $\overline{\bar{N}}$ & & & & & $\overline{\bar{n}}$ & & & & \\
\hline & & & & & & $\bar{z}$ & & & & \\
\hline & 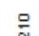 & & & & & 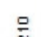 & & & & \\
\hline & $\frac{N}{2}$ & & & & & $\frac{N}{2}$ & & & & \\
\hline & & & & & & & & & & \\
\hline & มี & & & & & ले & & & & \\
\hline & $\bar{z}$ & & & & & $\frac{N}{z}$ & & & & \\
\hline & 10 & & & & & 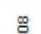 & & & & \\
\hline & $\frac{n}{2}$ & & & & & $\frac{\pi}{z}$ & & & & \\
\hline & \multicolumn{5}{|c|}{ Nivel: $40-50$} & \multicolumn{5}{|c|}{ Nivel: $100-110$} \\
\hline PN's: & \multicolumn{10}{|c|}{$21212 ; 21214 ; 21236 ; 21242-21245 ; 21520 ; 21521}$. \\
\hline Início: & \multicolumn{10}{|c|}{$40-50 \mathrm{~cm}$} \\
\hline Fim: & \multicolumn{10}{|c|}{$170-180 \mathrm{~cm}$ (?) } \\
\hline Material: & \multicolumn{10}{|c|}{$\begin{array}{l}\text { Em seus niveis iniciais foi encontrada uma pequena estaca de madeira }(+/-12 \mathrm{~cm}) \text { na } \\
\text { vertical dentro da feição com o restante pacote arqueológico; junto também haviam } \\
\text { fragmentos de fauna e carvão. Material cerâmico (grandes fragmentos; }+/-30 \mathrm{~cm} \text { ) } \\
\text { encontrado na vertical, "fincado" na feição. Material Manacapuru plotada }(\mathrm{PN} \\
\text { 21214). Material Paredão encontrado no nivel } 100-110 \mathrm{~cm} \text {. Grande quantidade de } \\
\text { carvão, alguns fragmentos de trempe e um aplique zoomorfo de macaco }(z=165 \mathrm{~cm}) \text {. }\end{array}$} \\
\hline \multirow{3}{*}{ Sedimento: } & \multicolumn{4}{|c|}{ Coloração: } & \multicolumn{3}{|c|}{ Compactação } & \multicolumn{3}{|c|}{ Sedimentação } \\
\hline & \multicolumn{4}{|c|}{$\begin{array}{l}10 Y R, 3 / 2 \text { (croqui) } \\
10 Y R \text { R } 2 / 1 \text { (fichas) }\end{array}$} & \multicolumn{3}{|c|}{ Pouco compactado } & & & \\
\hline & \multicolumn{10}{|c|}{$\begin{array}{l}\text { Menos compactado e mais escuro que o sedimento restante do lado externo à } \\
\text { feição a algumas bioturbacóes }(z=20 \mathrm{~cm}) \text {. Presença de raízes }(120-130 \mathrm{~cm}) \text {. }\end{array}$} \\
\hline Observações: & \multicolumn{10}{|c|}{ Encontra-se próximo (NE) do recipiente 3 e a menos de $1 \mathrm{~m}$ do recipiente 8.} \\
\hline
\end{tabular}

\begin{tabular}{|c|c|c|c|c|c|c|c|c|c|c|}
\hline Nome: & \multicolumn{10}{|c|}{ F15 } \\
\hline \multirow{11}{*}{ Localização: } & & W1423 & W1422 & W1421 & W1420 & & W1423 & W1422 & W1421 & W1420 \\
\hline & $\overline{\overline{\underline{N}}}$ & & & & & $\overline{\bar{N}}$ & & & & \\
\hline & & & & & & & & & & \\
\hline & $\frac{0}{2}$ & & & & & $\stackrel{\square}{a}$ & & & & \\
\hline & $\bar{z}$ & & & & & $\bar{z}$ & & & & \\
\hline & & & & & & & & & & \\
\hline & 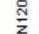 & & & & & $\frac{\pi}{2}$ & & & & \\
\hline & & & & & & & & & & \\
\hline & ๕్ & & & & & 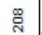 & & & & \\
\hline & $\bar{z}$ & & & & & $\bar{z}$ & & & & \\
\hline & \multicolumn{5}{|c|}{ Nivel: } & \multicolumn{5}{|c|}{ Nivel: } \\
\hline PN's: & \multicolumn{10}{|c|}{ 21025; 21037 (primeiro nivel cerâmico); 21019.} \\
\hline Início: & \multicolumn{10}{|c|}{$90-100 \mathrm{~cm}$ (?) } \\
\hline Fim: & \multicolumn{10}{|c|}{$120-130 \mathrm{~cm}$} \\
\hline Material: & \multicolumn{10}{|c|}{$\begin{array}{l}\text { Decorado com incisões e acanalados, algumas bordas apresentam engobo branco } \\
\text { (outros com engobo vermelho). Maior densidade de material cerâmico dentro do } \\
\text { limite demarcado da feição do que do lado externo. }\end{array}$} \\
\hline \multirow{3}{*}{ Sedimento: } & \multicolumn{3}{|c|}{ Coloração: } & \multicolumn{4}{|c|}{ Compactação } & \multicolumn{3}{|c|}{ Sedimentação } \\
\hline & & & & & & & & & & \\
\hline & \multicolumn{10}{|c|}{ Menos compacto e mais escuro que o lado externo da feição. } \\
\hline Observações: & \multicolumn{10}{|c|}{$\begin{array}{l}\text { O número correto da feição é } 15 \text {, no entanto desde o começo da sua escavação ela } \\
\text { foi chamada de } 17 \text {. }\end{array}$} \\
\hline
\end{tabular}

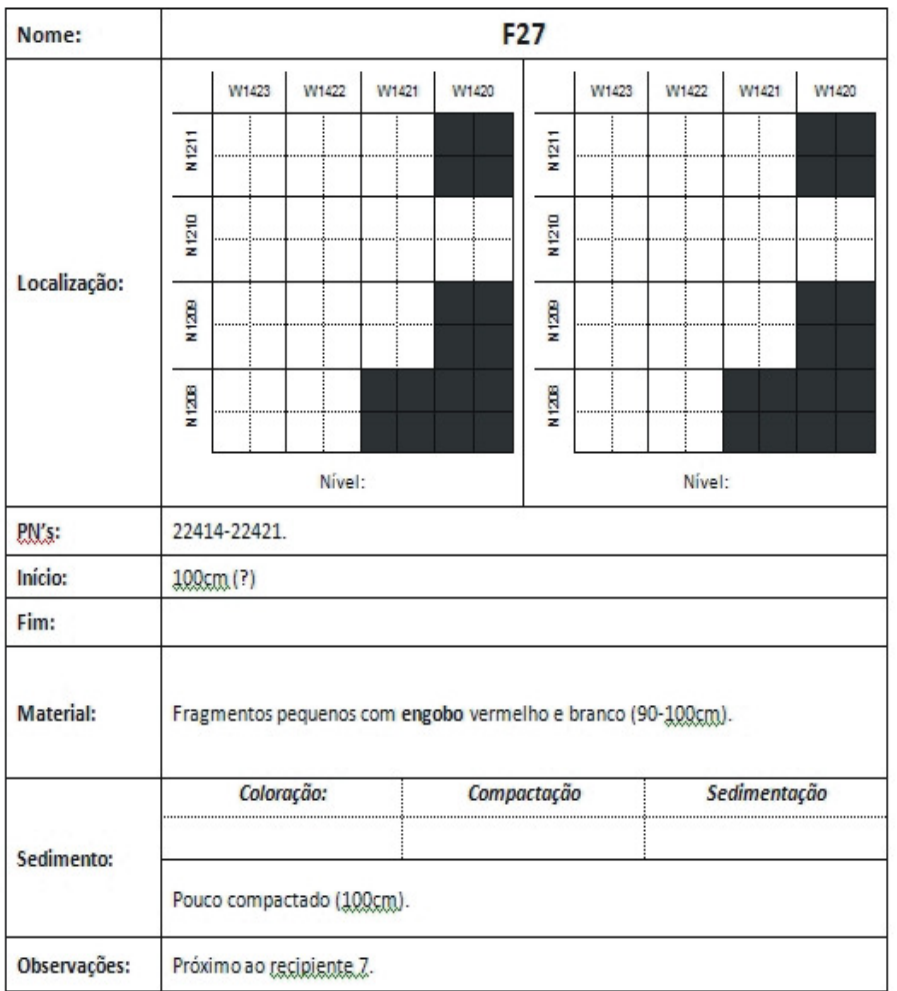




\begin{tabular}{|c|c|c|c|c|c|c|c|c|c|c|}
\hline Nome: & \multicolumn{10}{|c|}{ F19 } \\
\hline \multirow{10}{*}{ Localização: } & & w1123 & w11022 & w1421 & w1120 & & w1123 & w1 1222 & w1421 & w1420 \\
\hline & $\overline{\bar{g}}$ & & & & & $\overline{\underline{\underline{w}}}$ & & & & \\
\hline & & & & & & & & & & \\
\hline & $\frac{9}{\pi}$ & & & & & $\frac{a}{\pi}$ & & & & \\
\hline & & & & & & $\bar{z}$ & & & & \\
\hline & 8 & & & & & 8 & & & & \\
\hline & & & & & & $\frac{5}{z}$ & & & & \\
\hline & 8 & & & & & 8 & & & & \\
\hline & $\frac{d}{2}$ & & & & & $\frac{\pi}{2}$ & & & & \\
\hline & \multicolumn{5}{|c|}{ Nivel: } & \multicolumn{5}{|c|}{ Nivel: $155 \mathrm{~cm}$} \\
\hline PN's: & \multicolumn{10}{|c|}{$\begin{array}{l}\text { 21376; } 21377-21378 \text { (cerâmica diagnóstica); } 21379 ; 21620 ; 21626 ; 21629 ; 21631 \text { - } \\
21640 ; 23101-23123 ; 23111 ; 23114 \text {. }\end{array}$} \\
\hline Início: & \multicolumn{10}{|c|}{ 90-100 cm (N1209/W1423) } \\
\hline Fim: & \multicolumn{10}{|c|}{$140-150 \mathrm{~cm}(155 \mathrm{~cm}, \mathrm{~N} 1209 / \mathrm{W} 1423)$} \\
\hline Material: & \multicolumn{10}{|c|}{ 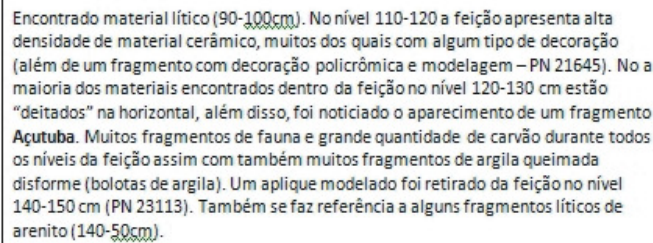 } \\
\hline \multirow{3}{*}{ Sedimento: } & \multicolumn{4}{|c|}{ Coloração: } & \multicolumn{3}{|c|}{ Compactação } & \multicolumn{3}{|c|}{ Sedimentação } \\
\hline & & & & & & & & & & \\
\hline & \multicolumn{10}{|c|}{$\begin{array}{l}\text { No centro da feição o solo é menos compactado e mais escuro que no restante da } \\
\text { unidade. }\end{array}$} \\
\hline Observações: & \multicolumn{10}{|c|}{ Possivelmente a feição está associada ao reckipiente 4 . } \\
\hline
\end{tabular}

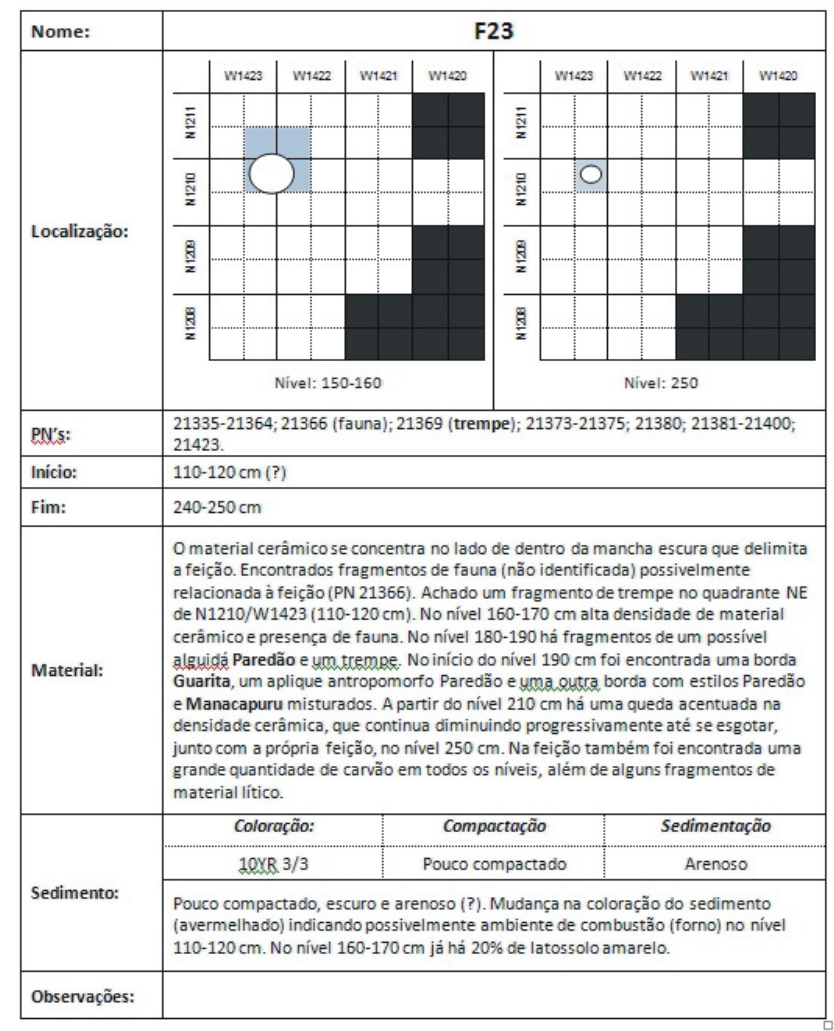

\section{Disposição dos recipientes e feições (nível: 130-140 cm)}

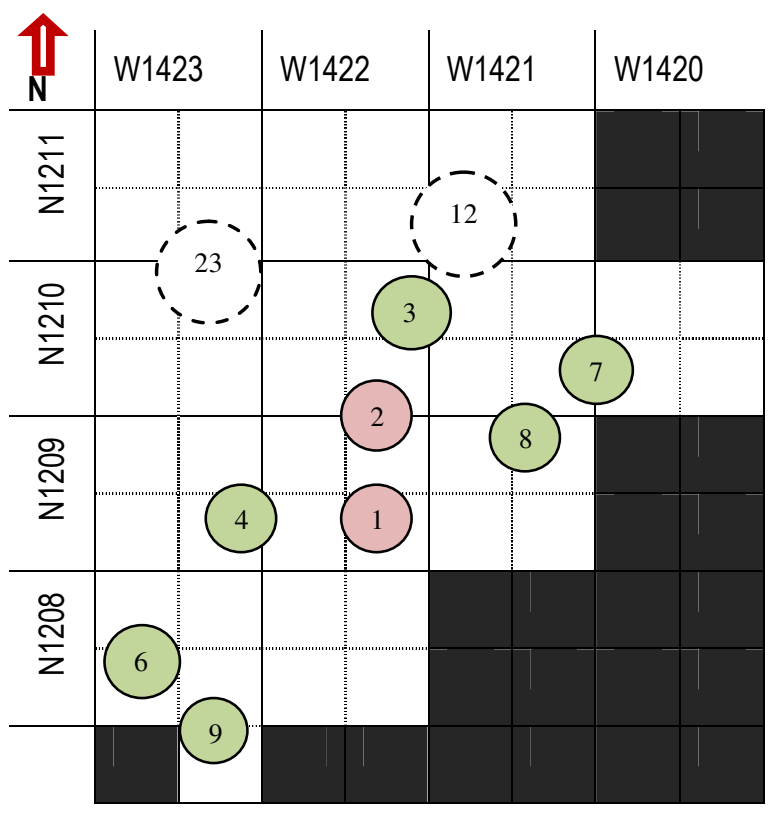

\section{Legenda:}

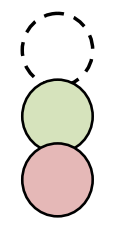

- Feição

- Recipiente (escavado em 2006)

- Pedestal com recipiente (já escavado e apenas retirado em 2006)

- Não escavado 


\begin{tabular}{|l|l|c|c|l|}
\hline Recipiente: & \multicolumn{4}{|l|}{} \\
\hline \multirow{2}{*}{ Localização: } & N1209/W1422 (SE) & N1209/W1422 (NE) & N1209/W1422 (SW) & \\
\cline { 2 - 5 } & $90 \%$ & $5 \%$ & $5 \%$ & \\
\hline
\end{tabular}

\begin{tabular}{|l|l|c|c|c|}
\hline Recipiente: & \multicolumn{4}{|l|}{$\mathbf{0 2}$} \\
\hline \multirow{2}{*}{ Localização: } & $\mathrm{N} 1209 / \mathrm{W} 1422$ (NE) & $\mathrm{N} 1210 / \mathrm{W} 1422$ (SE) & $\mathrm{N} 1209 / \mathrm{W} 1422(\mathrm{NW})$ & $\mathrm{N} 1210 / \mathrm{W} 1422(\mathrm{SW})$ \\
\cline { 2 - 5 } & $47,5 \%$ & $47,5 \%$ & $2,5 \%$ & $2,5 \%$ \\
\hline
\end{tabular}

\begin{tabular}{|c|c|c|c|c|}
\hline \multirow{2}{*}{$\begin{array}{l}\text { Recipiente: } \\
\text { Localização: }\end{array}$} & \multicolumn{4}{|l|}{03} \\
\hline & N1210/W1422 (NE) & N1210/W1421(NW) & N1210/W1422 (SE) & N1210/W1421(SW) \\
\hline & $73 \%$ & $20 \%$ & $5 \%$ & $2 \%$ \\
\hline Início/Fim: & \multicolumn{4}{|l|}{$70-80 \mathrm{~cm} / 100-110 \mathrm{~cm}$} \\
\hline Dimensões: & Altura: & $40 \mathrm{~cm}^{*}$ & Diâmetro: & $50 \mathrm{~cm}^{\star *}$ \\
\hline Filiação cultural: & \multicolumn{4}{|c|}{ Aparentemente pertencente à camada de ocupação Manacapuru. } \\
\hline PN`s: & \multicolumn{4}{|c|}{$21412,21417,21418$} \\
\hline Observações: & \multicolumn{4}{|c|}{$\begin{array}{l}{ }^{*} \text { Estimada a partir do início/fim da escavação do recipiente. } \\
{ }^{*} \text { Maior diâmetro entre todos os recipientes. } \\
\text { Não foi encontrada a tampa da urna. }\end{array}$} \\
\hline
\end{tabular}

\begin{tabular}{|c|c|c|c|c|}
\hline \multirow{2}{*}{$\begin{array}{l}\text { Recipiente: } \\
\text { Localização: }\end{array}$} & \multicolumn{4}{|l|}{04} \\
\hline & N1209/W1423 (SE) & N1209/W1422(SW) & N1209/W1423 (NE) & \\
\hline & $75 \%$ & $15 \%$ & $10 \%$ & \\
\hline Início/Fim: & \multicolumn{4}{|c|}{$70-80 \mathrm{~cm}^{*} / 100-110 \mathrm{~cm}$} \\
\hline Dimensões: & Altura: & $40 \mathrm{~cm}^{\star \star *}$ & Diâmetro: & $40 \mathrm{~cm}^{\star \star \star \star}$ \\
\hline Filiação cultural: & \multicolumn{4}{|c|}{$\begin{array}{l}\text { Forma "bojuda" e contorno simples. Aparentemente pertencente à camada de ocupação } \\
\text { Manacapuru. }\end{array}$} \\
\hline PN`s: & \multirow{2}{*}{\multicolumn{4}{|c|}{$\begin{array}{l}\text { 21612, 21623, 21616, 21622, 21624/21641 (cerâmica associada ao recipiente), } 23108 . \\
\text { *(neste nível; HPL/LMC/LR): "Algumas raízes dentro da urna. Embora estruturada, a } \\
\text { urna (recipiente 4) está fragmentada. Dentro do recipiente há pontos brancos e muita } \\
\text { bioturbação. Coletado solo para análise." (corrigido) } \\
{ }^{* *} \text { (nível: } 90-100 \text { ) possivelmente contemporâneo da feição } 19 . \\
{ }^{* * *} \text { Definidas a partir do início/fim da escavação do recipiente. } \\
{ }^{* * * *} \text { Maior diâmetro no nível: } 80-90 \mathrm{~cm} \text {. } \\
\text { Urna com tampa (alguidar de cabeça para baixo) e superfície desgastada. }\end{array}$}} \\
\hline Observações: & & & & \\
\hline
\end{tabular}

\begin{tabular}{|c|c|c|c|}
\hline Recipiente: & 05 & & \\
\hline \multirow[t]{2}{*}{ Localização: } & N1208/W1423 (SW) & N1208/W1423 (NW) & \multirow{2}{*}{$\begin{array}{l}\text { Localizado bem acima do recipiente } \\
6 .\end{array}$} \\
\hline & $80 \%$ & $20 \%$ & \\
\hline Início/Fim: & \multicolumn{3}{|l|}{$60-70 \mathrm{~cm} / 80-90 \mathrm{~cm}$} \\
\hline Dimensões: & \multicolumn{2}{|c|}{ Altura: $30 \mathrm{~cm}^{* *}$} & Diâmetro: indeterminado \\
\hline Filiação cultural: & \multicolumn{3}{|c|}{ Aparentemente pertencente à camada de ocupação Manacapuru. } \\
\hline PN`s: & \multicolumn{3}{|c|}{$21820,21824^{*}, 21825$ (o recipiente). } \\
\hline Observações: & \multicolumn{3}{|c|}{$\begin{array}{l}{ }^{*} \text { Fragmentos associados ao recipiente } 5 \text { e } 6 . \\
{ }^{* *} \text { Estimada a partir do iníciolfim da escavação do recipiente. }\end{array}$} \\
\hline
\end{tabular}

\begin{tabular}{|c|c|c|c|}
\hline \multirow{3}{*}{\begin{tabular}{|l|} 
Recipiente: \\
Localização:
\end{tabular}} & \multicolumn{3}{|l|}{06} \\
\hline & N1208/W1423 (SW) & N1208/W1423 (NW) & \multirow{2}{*}{$\begin{array}{l}\text { Localizado bem abaixo do recipiente } \\
5 .\end{array}$} \\
\hline & $80 \%$ & $20 \%$ & \\
\hline Início/Fim: & \multicolumn{3}{|l|}{$75 \mathrm{~cm} * 100-110 \mathrm{~cm}$} \\
\hline \multirow[t]{2}{*}{ Dimensões: } & Altura: & $5-30 \mathrm{~cm}$ & Diâmetro: $\quad 35-40 \mathrm{~cm}^{* *}$ \\
\hline & \multicolumn{3}{|c|}{ Bem menor que os demais recipientes, no entanto muito parecido morfologicamente. } \\
\hline Filiação cultural: & \multicolumn{3}{|c|}{ Aparentemente pertencente à camada de ocupação Manacapuru. } \\
\hline PN`s: & \multicolumn{3}{|c|}{$21821,21824^{*}, 21837$} \\
\hline Observações: & \multicolumn{3}{|c|}{$\begin{array}{l}{ }^{*} \text { Fragmentos associados ao recipiente } 5 \text { e } 6 . \\
{ }^{* *} \text { Maior diâmetro no nível: } 120-130 \mathrm{~cm} . \\
\text { Urna com tampa com engobo vermelho. }\end{array}$} \\
\hline
\end{tabular}




\begin{tabular}{|c|c|c|c|c|}
\hline \multirow[t]{2}{*}{ Localização: } & N1210/W1420(SW) & N1210/W1421(SE) & N1210/W1420(NW) & N1210/W1421(NE) \\
\hline & $47,5 \%$ & $47,5 \%$ & $2,5 \%$ & $2,5 \%$ \\
\hline Início/Fim: & \multicolumn{4}{|c|}{$40-50 \mathrm{~cm} /$ base do nível $60-70 \mathrm{~cm}$} \\
\hline Dimensões: & Altura: & $23-30^{* * *} \mathrm{~cm}$ & Diâmetro: & $\pm 45 \mathrm{~cm}^{* *}$ \\
\hline Dimensões: & \multicolumn{4}{|c|}{ (maior diâmetro no nível: $110-120 \mathrm{~cm}$ ); (altura). } \\
\hline Filiação cultural: & \multicolumn{4}{|c|}{$\begin{array}{l}\text { Morfologiacamente bastante diferente dos demais recipientes, com borda extrovertida, } \\
\text { contorno complexo e engobo branco. Possivelmente pertencente à fase Guarita. }\end{array}$} \\
\hline PN`s: & \multicolumn{4}{|c|}{22428 (retirado na unidade N1210/W1420) e 22429 (solo). } \\
\hline Observações: & \multicolumn{4}{|c|}{$\begin{array}{l}\text { *(nível: } 40-50 \mathrm{~cm} \text {; MEV, RP, CFC) "Mesmo estando no encontro com a camada 2, na } \\
\text { camada } 3 \text { não foi possível perceber qualquer cova ou mudança no sedimento que } \\
\text { comprovasse que o recipiente } 7 \text { pertencia à ocupação da camada } 3, \text { o que nos leva a } \\
\text { crer tratar-se sim de um recipiente depositado in situ, correspondente à ocupação da } \\
\text { camada } 2 . . . \text { [ilegível" . } \\
{ }^{* *} \text { Maior diâmetro no nível: } 110-120 \mathrm{~cm} \text {. } \\
{ }^{* * *} \text { Estimada a partir do início/fim da escavação do recipiente. }\end{array}$} \\
\hline
\end{tabular}

\begin{tabular}{|c|c|c|c|c|}
\hline Recipiente: & \multicolumn{4}{|l|}{08} \\
\hline \multirow[t]{2}{*}{ Localização: } & N1209/W1421 (NE) & N1210/W1421 (SE) & N1209/W1421 (NW) & N1210/W1421(SW) \\
\hline & $65 \%$ & $20 \%$ & $10 \%$ & $5 \%$ \\
\hline Início/Fim: & \multicolumn{4}{|c|}{$80-90 \mathrm{~cm}(?) 90-100 * / 120-130 \mathrm{~cm}$} \\
\hline Dimensões: & Altura: & $50 \mathrm{~cm}^{* *}$ & Diâmetro: & $80 \mathrm{~cm}^{\star * *}(?)$ \\
\hline Filiação cultural: & \multicolumn{4}{|c|}{ Aparentemente pertencente à camada de ocupação Manacapuru. } \\
\hline PN`s: & \multicolumn{4}{|c|}{21718 (carvão retirado entre o recipiente 8 e a feição 3). } \\
\hline Observações: & \multicolumn{4}{|c|}{$\begin{array}{l}{ }^{*} \text { Encontrado latossolo amarelo sobre a tampa do recipiente neste nível. } \\
{ }^{* *} \text { Estimada a partir do início/fim da escavação do recipiente. } \\
{ }^{* * *} \text { Maior diâmetro no nível: } 110-120 \mathrm{~cm} \text {. } \\
\text { Urna com tampa. }\end{array}$} \\
\hline
\end{tabular}

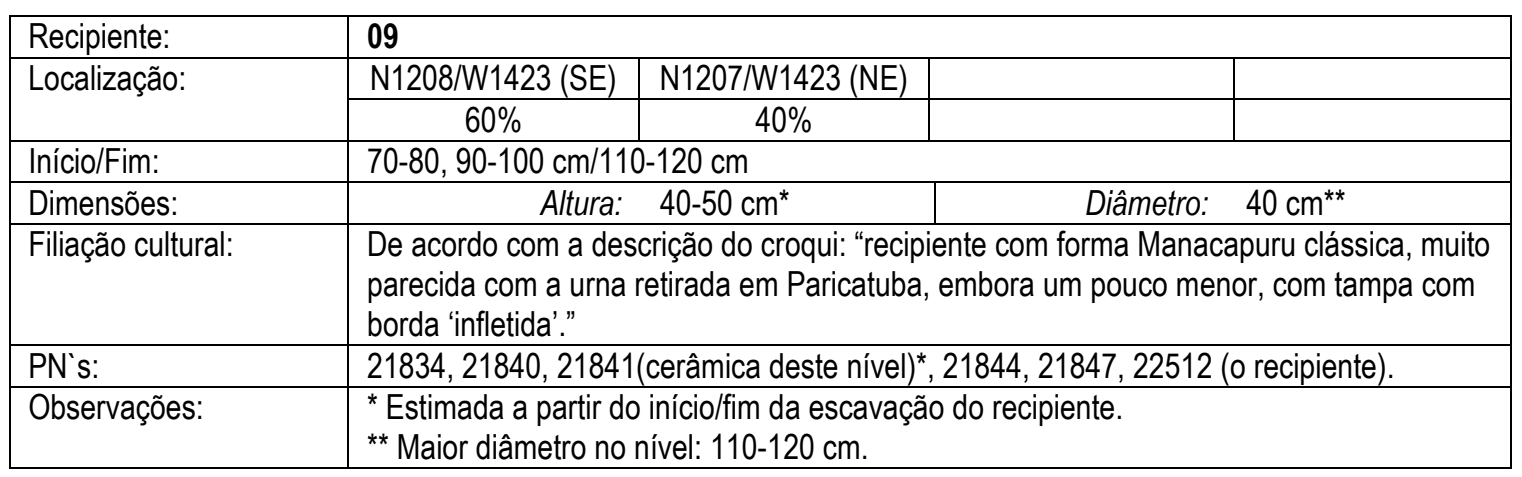




\section{I. VIII. Cerâmicas do Jacuruxi}

O que as análises das cerâmicas coletadas no sitio Jacuruxi mostraram vem a corroborar a proposta de entendimento de fases arqueológicas e tradições tecnológicas proposta neste trabalho.

É válido contar de forma resumida o histórico dos trabalhos ali realizados. Localizado na área de interflúvio entre os rios Negro e Solimões, município de Manacapuru, Jacuruxi foi selecionado para a pesquisa por apresentar um conjunto de cerâmicas aparentemente homogêneo e temporalmente vinculado à recém definida fase Açutuba. Logo que identificado, observou-se a pequena profundidade do pacote arqueológico, que não ultrapassava os $40 \mathrm{~cm}$, através da realização de tradagens (fig. 94).

Seria um caso único de cerâmicas supostamente Açutuba em contexto unicomponencial e tão próximos da superfície. Ao escavar o sítio, mais uma surpresa: tratava-se de um contexto de terra preta! Este era mais um dos elementos contextuais que distinguia as fases Açutuba, mais antiga, e Manacapuru, mais recente e expoente de mudanças ou intensificação de um modo de vida que levara ao surgimento das famosas terras pretas de índio, entendidas como marcadores cronológicos e culturais.

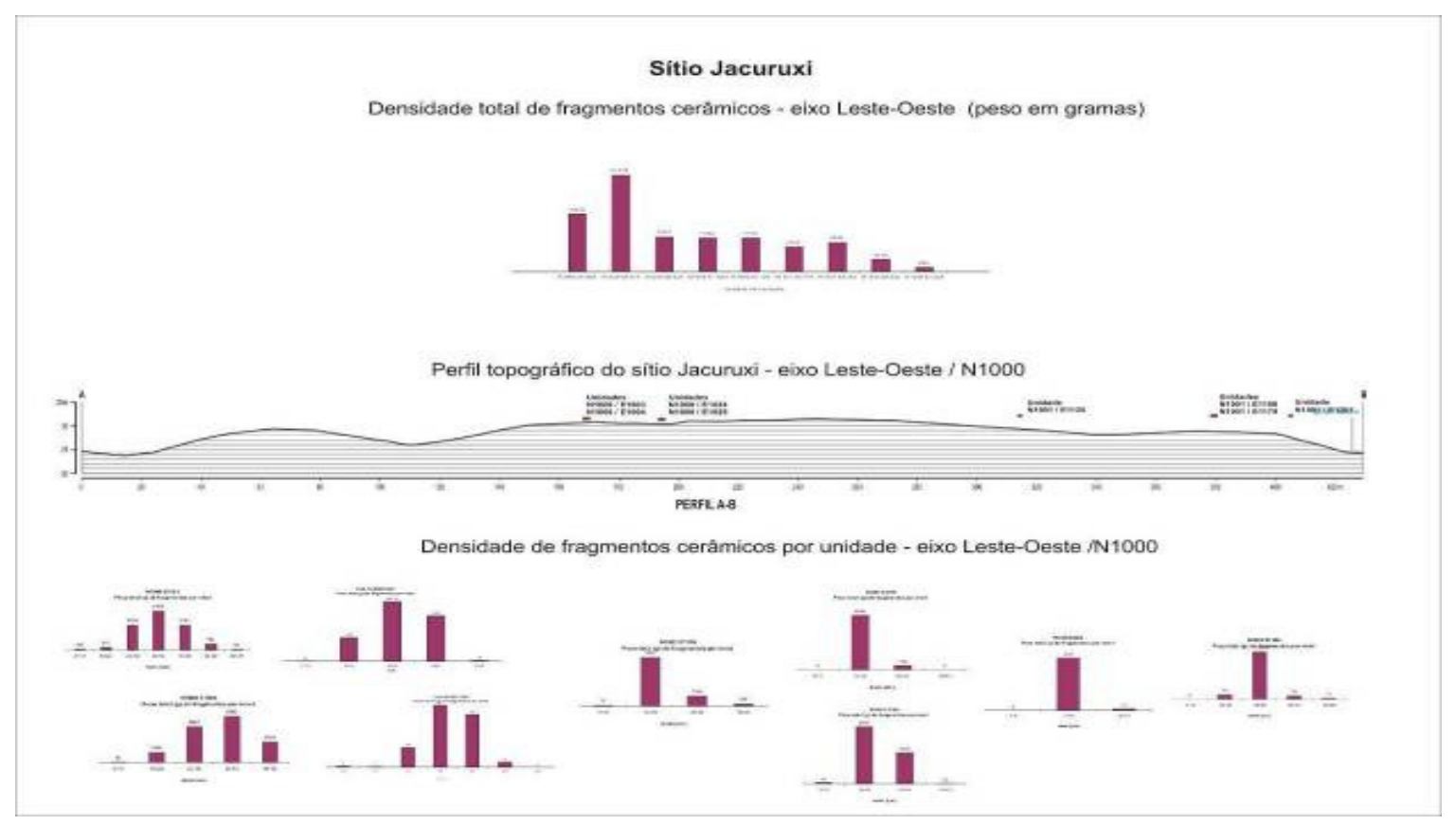

Figura 94 - Densidade total de fragmentos cerâmicos do sítio Jacuruxi. 
As análises mostraram que não podemos jamais nos ater às visões normativas dos conjuntos arqueológicos, mesmo quando nosso "olhar classificatório" tende a isso. As cerâmicas de Jacuruxi apresentam elementos comuns às fases Açutuba e Manacapuru, embora com uma tendência maior ao conjunto mais recente.

Um total de 9.096 fragmentos de cerâmica $(86,437 \mathrm{Kg})$ foi coletado em $12 \mathrm{~m}^{2}$ escavados no sítio. Todos aqueles com tamanho maior que $3 \mathrm{~cm}$ foram triados, numerados e analisados. A primeira parte da análise foi feita a partir da ficha elaborada pelo PAC, na qual se observam todas as características (atributos) inerentes a cada peça. Os atributos se referem aos resultados de todas as etapas do processo de fabricação da cerâmica (cadeia operatória), e de evidências de seu uso e descarte. A grande quantidade de fragmentos analisados permitiu uma boa caracterização tecnológica do acervo de Jacuruxi. Mais uma vez observa-se absoluta predominância de paredes em relação a outras partes do vaso, tais como bordas ou bases.

Esta análise inicial permitiu diagnosticar as principais características do conjunto. Os dados quantitativos encontram-se na seqüência de gráficos que se segue. Um tanto homogêneas, as cerâmicas do Jacuruxi são marcadas por técnicas decorativas elaboradas, com grande ênfase nas incisões e modelagem de apêndices e apliques. São sempre executadas nos lábios e bordas, ou na parede do vaso, mas sempre próximo à borda. Assim como ocorre em outros conjuntos desta tradição tecnológica, as bordas são sempre salientadas de maneira a fornecer um suporte visível para a aplicação da decoração. As incisões em linhas finas simples ou duplas, assim como as incisões em linhas largas, formam motivos geométricos retilíneos ou curvilíneos e em gregas, sendo estas últimas em menor proporção. Ocorrem também acanalados, ponteados, apliques modelados, etc. Enfim, técnicas que vinculam, sem deixar dúvidas, essas cerâmicas à Tradição Borda Incisa. A relação entre elas é que gerou as questões postas adiante.

Devido ao seu alto grau de desgaste e fragmentação, não foi possível identificar motivos decorativos. É justamente ao desgaste da superfície dos fragmentos que se deve a impressão de tratar-se de um conjunto "tosco". Verificase, no entanto, fragmentos melhor preservados que demonstram extremo esmero decorativo (fig. 95). Também por seu alto grau de desgaste, a observação de 
outras características, tais como dos acabamentos de superfície, pode não retratar a real caracterização do conjunto.
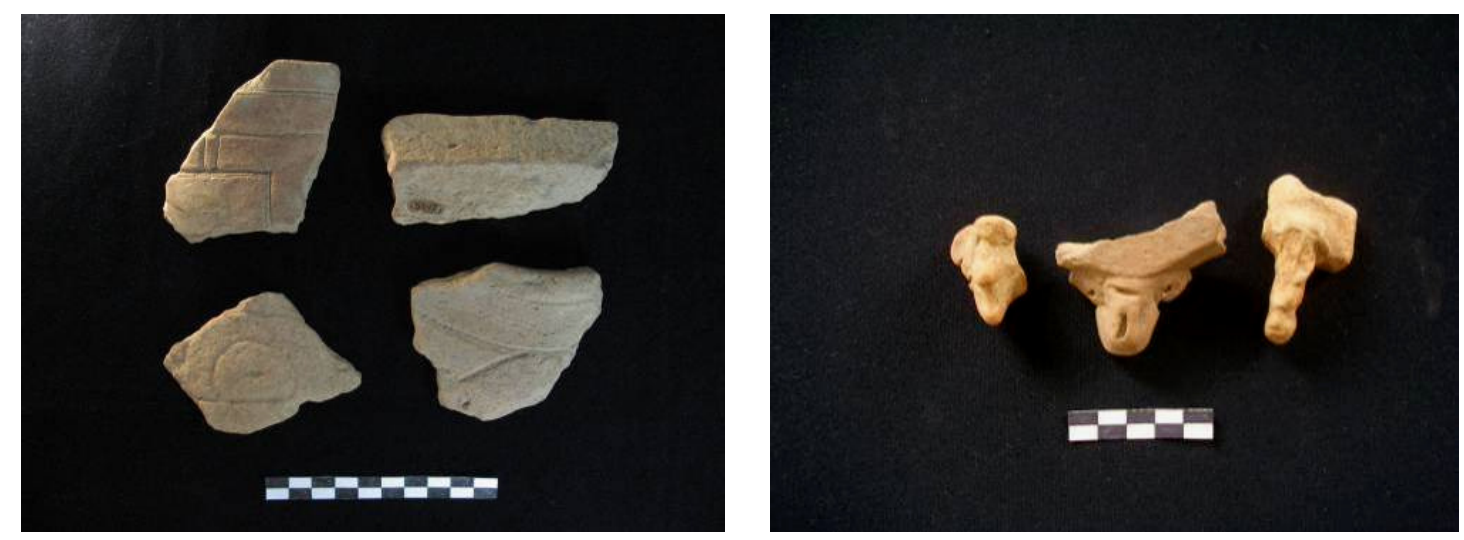

Figura 95 - Cerâmicas do Jacuruxi: aspectos gerais. Níveis $10-20 \mathrm{~cm}, 20-30 \mathrm{~cm}$ e $30-40 \mathrm{~cm}$ (fotos: Val Moraes \& Helena Lima).

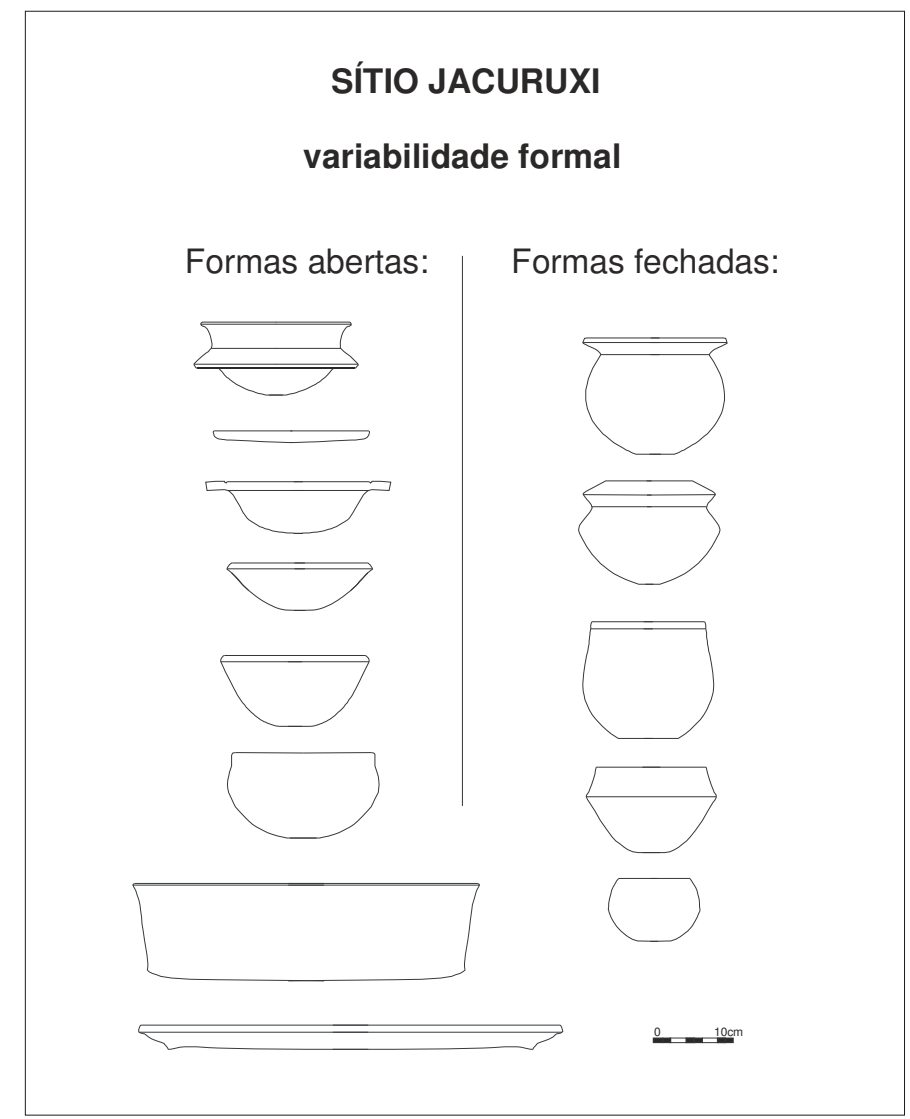

Figura 96 - Sítio Jacuruxi: perfil formas reconstituídas. 


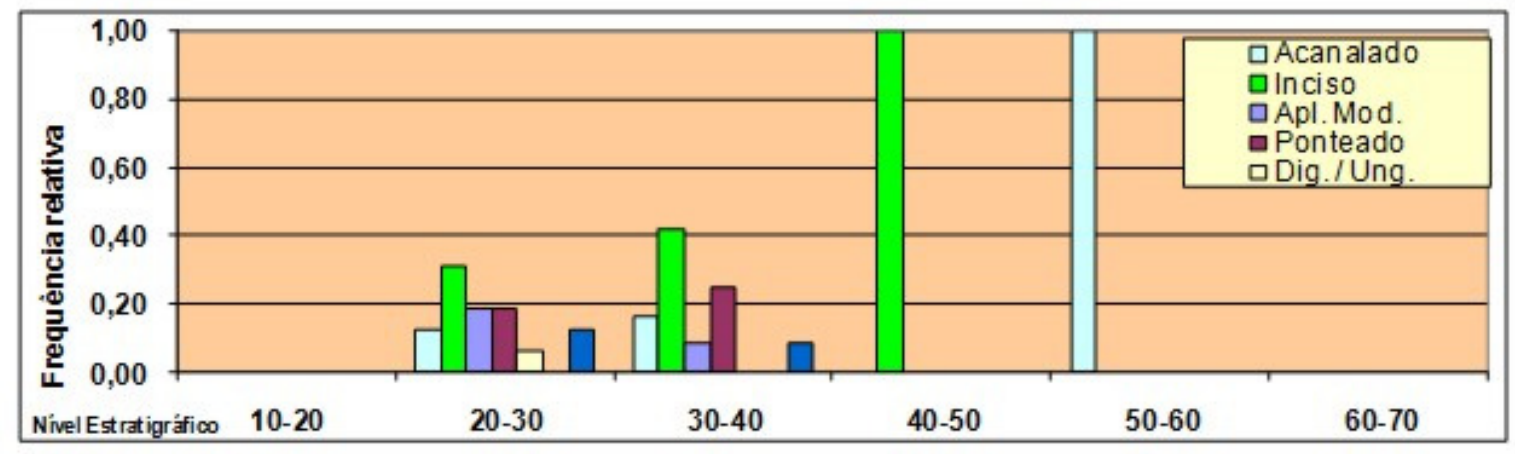

Gráfico 47 - Freqüência relativa das técnicas decorativas utilizadas no acabamento dos lábios, por nível, nas cerâmicas do Jacuruxi.

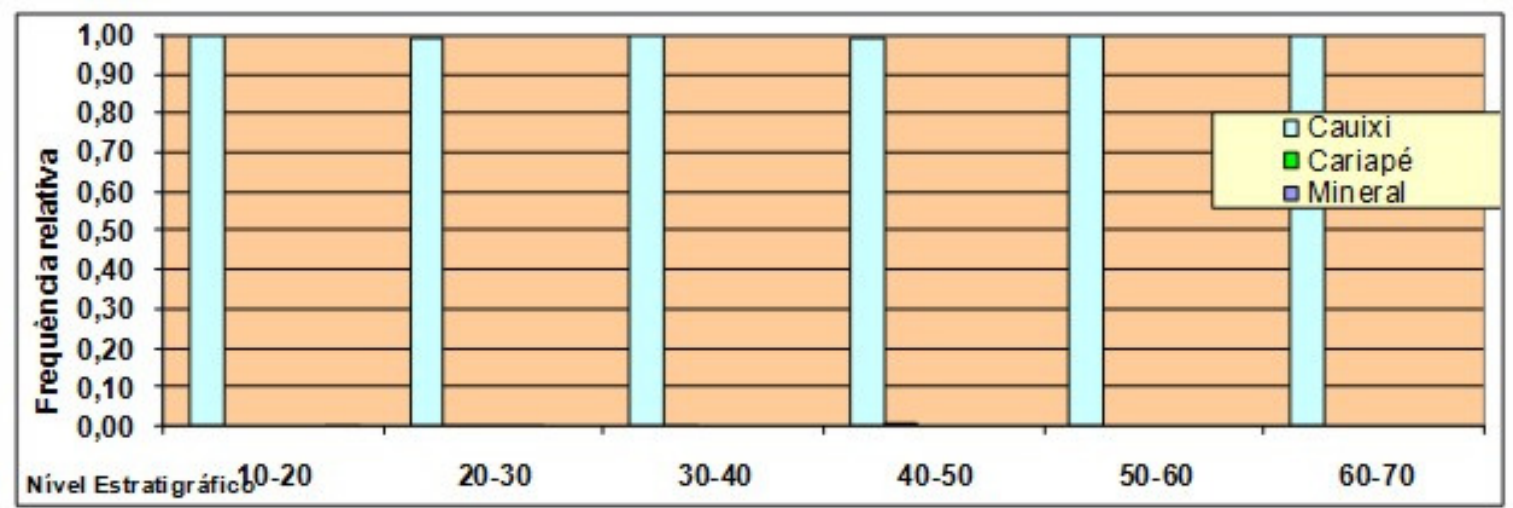

Gráfico 48 - Freqüência relativa do tempero preponderante observado, por nível, nas cerâmicas do Jacuruxi.

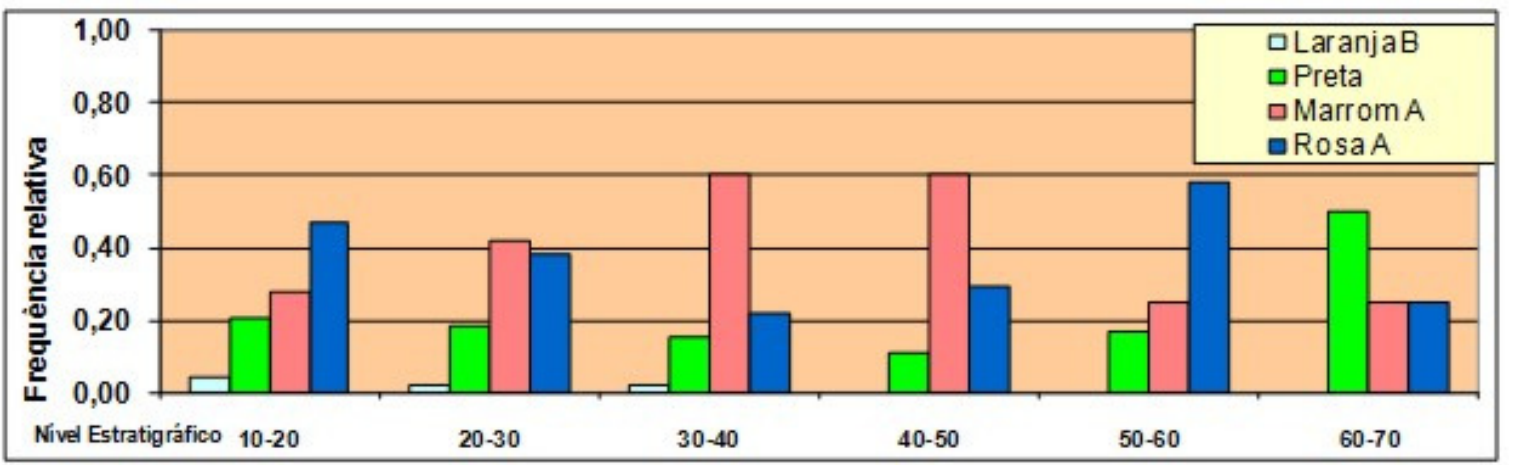

Gráfico 49 - Freqüência das cores da argila observadas, por nível, nas cerâmicas do Jacuruxi.

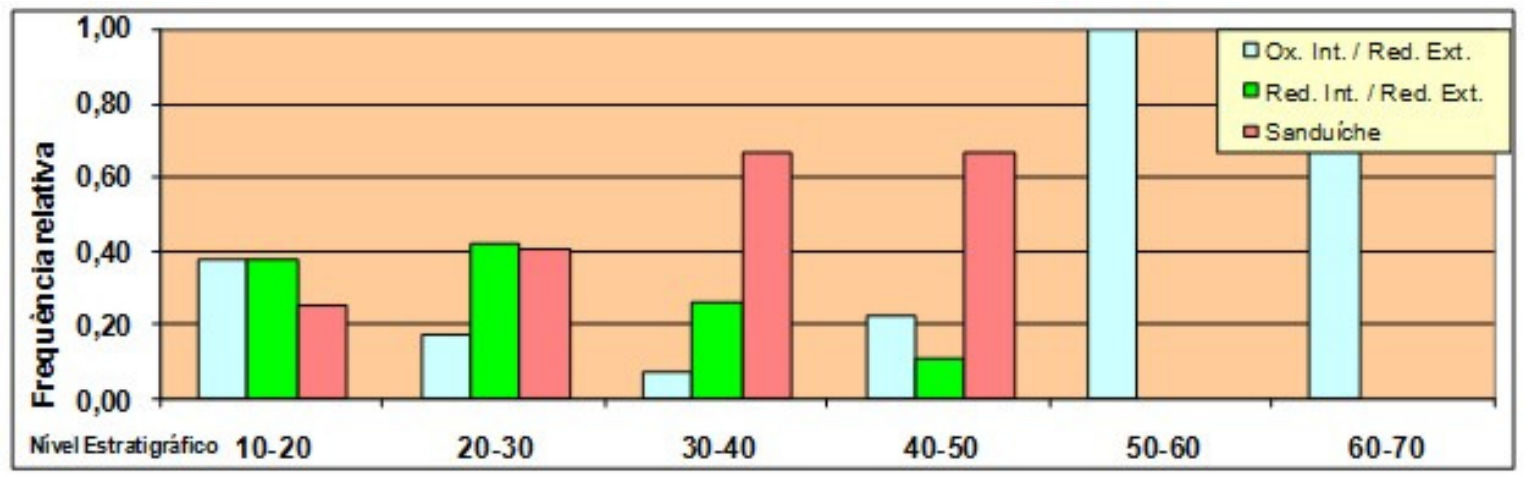

Gráfico 50 - Freqüência dos tipos de queima observados, por nível, nas cerâmicas do Jacuruxi. 
Apesar de certa homogeneidade, a associação das diferentes características do conjunto, representadas nos gráficos anteriores, permitiu um agrupamento da coleção. Quanto à pasta, as cerâmicas do Jacuruxi se dividiram em dois grupos principais, e um terceiro conjunto, mais discreto. $O$ primeiro, mais recorrente, apresenta uma coloração bege, com queima oxidante. É leve e porosa, com grande quantidade de cauixi, e minerais como quartzo e hematita, em menor porcentagem. Estes minerais, presentes nos dois grupos, são inerentes às argilas, deixados propositalmente, mas não adicionados à pasta quando de sua preparação. Diferentes elementos decorativos aparecem neste grupo (Fig. 97a).

O segundo grupo também é temperado majoritariamente com cauixi, mas em menor quantidade, e associado a outros temperos como caco moído e minerais. Sua coloração é mais escura do que o primeiro grupo, variando entre o laranja-acinzentado e o laranja-amarronzado. A queima é variável. De todo o conjunto analisado, suas pastas possuem o maior grau de dureza. Apresenta superfícies mais bem alisadas ou polidas, o que demonstra ser menos suscetível ao desgaste provocado pela ação do tempo. As características decorativas deste conjunto remontam às cerâmicas mais recentes, da fase Manacapuru, com presença marcante de incisões finas e ponteados nos lábios (Fig. 97b).

Finalmente o terceiro conjunto é composto por cerâmicas com coloração forte, de tonalidades variando do alaranjado ao róseo. Dos três grupos é o que apresenta a pasta mais leve e porosa. $O$ tempero é semelhante ao primeiro conjunto, mas com quantidades extremas de cauixi. Por suas características, as cerâmicas do terceiro grupo apresentaram um grau de erosão muito alto na sua superfície, sendo difícil diagnosticar seus elementos decorativos. Observam-se apenas vestígios de modelagem (Fig. 97c).
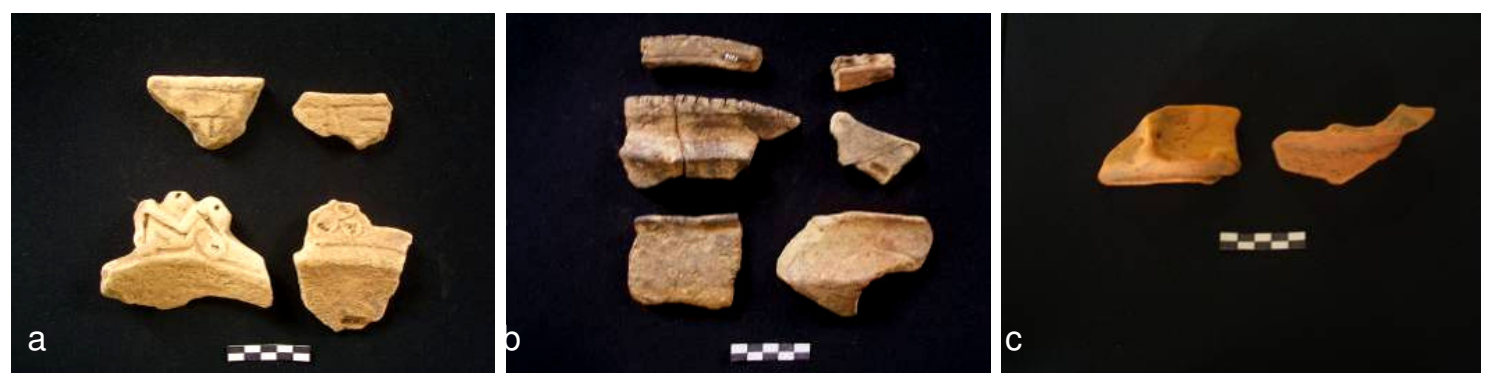

Figura 97 - Cerâmicas do Jacuruxi: diferentes tipos de pastas (fotos: Helena Lima). 
Esta diferenciação de pastas é um dos elementos que distingue cerâmicas das fases Açutuba e Manacapuru (Lima et al., 2006), e pode significar duas coisas, que têm conseqüências diretas para a interpretação do sítio arqueológico e sua inserção no quadro cronológico amazônico. A primeira hipótese interpretativa entenderia tais diferenças como, de fato, dois conjuntos cronologicamente distintos. Desta maneira, Jacuruxi teria sido habitado e possivelmente re-habitado durante alguns séculos. A segunda hipótese sugere que o material encontrado no sítio seja um expoente de mudanças culturais, que estariam em curso durante os primeiros séculos da Era Cristã. Desta feita, a convivência de distintas fases cerâmicas num mesmo tempo e num mesmo espaço é perfeitamente viável. A segunda hipótese é, no meu entender, plausível, uma vez que o conceito fase não é algo normativo e fechado, e não se vincula diretamente a grupos étnicos ou lingüísticos. Um mesmo grupo social pode, sim, dispor de diferenciações em sua cultura material da mesma maneira que diferentes grupos podem apresentar padronizações materiais.

A convivência espaço-temporal de diferentes fases cerâmicas é observável ao longo da história pré-colonial amazônica. Como exemplos disso na Amazônia central há as já discutidas fases Manacapuru e Paredão. Numa perspectiva normativa de fases cerâmicas, tais conclusões pareceriam confusas, mas como se pode perceber, os limites materiais - observáveis entre uma e outra fase são extremamente fluidos. E isso não é uma particularidade destes dois conjuntos: como pretendo demonstrar, a fluidez de limites é inerente aos conjuntos artefatuais amazônicos, uma vez que estes são intimamente conectados, histórica e culturalmente.

Assim, o que nos levou a pensar ser a segunda hipótese mais viável foi a distribuição das cerâmicas: não há diferenciações marcadas entre os conjuntos e os níveis estratigráficos. Do mesmo modo, o pacote cultural é discreto, com uma espessura variando entre $15 \mathrm{e}$ $20 \mathrm{~cm}$, enterrado abaixo de uma espessa camada húmica (fig. 98). Em adição, as

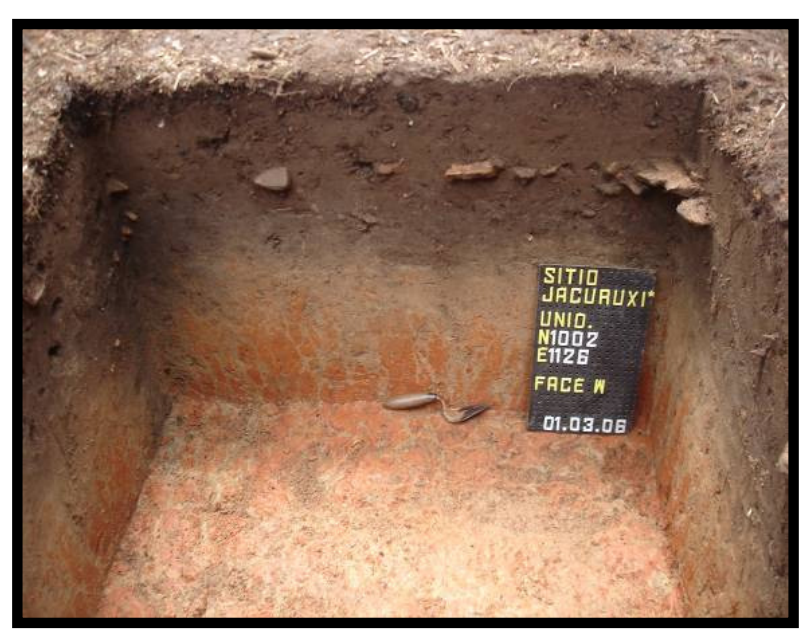

Figura 98 - Sítio Jacuruxi: perfil oeste da unidade N1002 E1126 (foto: Helena Lima). 
próprias datações radiocarbônicas obtidas para o sítio ficaram situadas num pequeno intervalo entre 570 e 790 d.C., ou seja, intermediário entre as cronologias propostas para as fases Açutuba e Manacapuru.

Feita a primeira etapa da análise, os fragmentos diagnósticos foram selecionados para composição dos tipos - conjuntos formados a partir das semelhanças ou diferenças de forma, tecnologia e decoração. A formação e descrição dos tipos demonstraram que os conjuntos se aproximavam mais da fase Manacapuru do que da fase Açutuba, embora apresentassem alguns elementos comuns a esta última. A própria ausência da policromia é um forte indicativo de vinculação ao conjunto mais recente. Foram identificados quatorze tipos para este sítio, sendo que a maior parte tem conexões com tipos Manacapuru. Três deles, entretanto, associaram-se aos tipos Açutuba, que são as vasilhas com flanges mesiais, as tampas ou banquetas e as gamelas poligonais.

Além disso, apesar de numericamente pouco significativos, foram encontrados dois fragmentos de base em pedestal e um fragmento de gargalo. As decorações presentes nestas bases têm claras características dos conjuntos mais antigos, como as excisões, ao mesmo tempo em que suas formas aproximam tais fragmentos das tipologias Paredão. Sendo assim, apesar de estes fragmentos não serem geradores de tipos devido à baixa ocorrência, sua presença ilustra o que este sítio representa: uma intermediação entre diferentes processos, seja a formação das terras pretas ou as tipologias cerâmicas previamente estabelecidas. A descrição detalhada de cada um dos tipos encontra-se no apêndice desta tese.
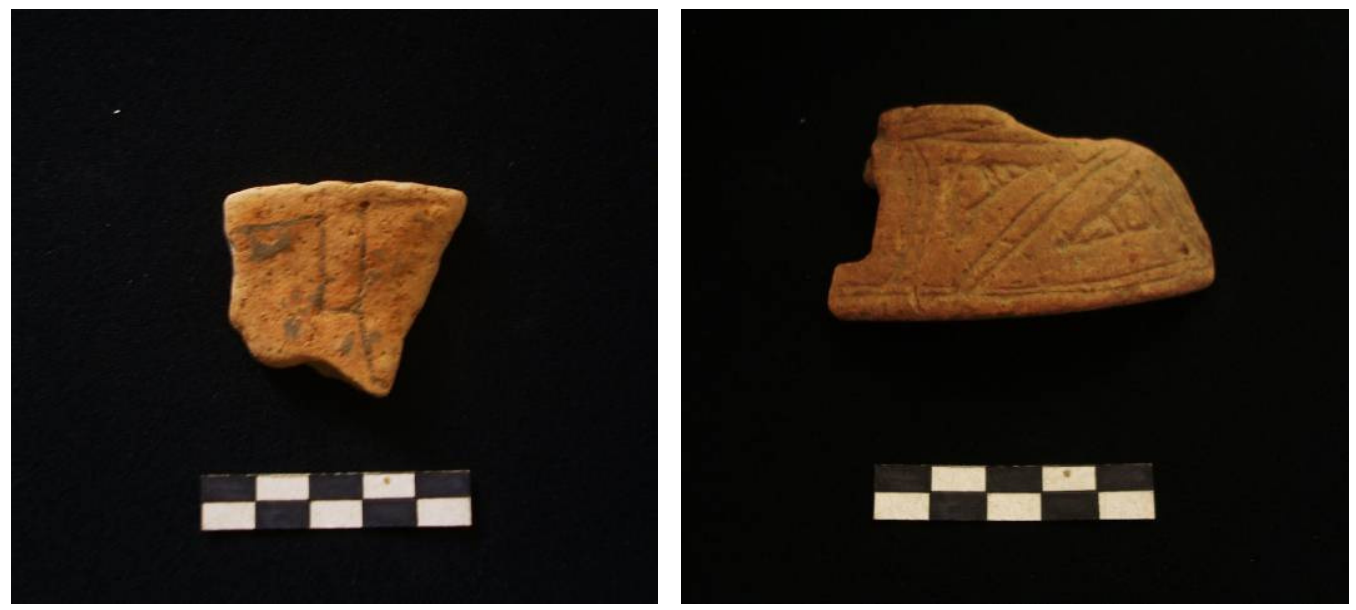

Figura 99 - Fragmento de gargalo e de base em pedestal (fotos: Val Moraes). 


\section{I. VIII. Cerâmicas do Osvaldo}

No sitio Osvaldo, a unidade denominada S710 W1966 foi selecionada para análise. O objetivo principal da etapa de campo realizada neste sítio arqueológico era sua delimitação e a compreensão dos padrões de uso do espaço. Por essa razão, foi trabalhado majoritariamente através de tradagens e sondagens de $0,5 \mathrm{x}$ 0,5 m. A única exceção foi a mencionada unidade, de $1 \times 1,5 \mathrm{~m}$, escavada no sítio.

As datações obtidas para diferentes áreas do sítio, bem como o padrão de dispersão dos vestígios demonstram, sem deixar muito espaço a dúvidas, que se trata de uma aldeia intensamente ocupada entre fins do século VII e início do VIII, com padrão de dispersão das casas em formato circular ou elipsoidal (observar outra vez o mapa topográfico do sítio, na pág. 139, que apresenta as densidades de vestígios e as datações radiocarbônicas obtidas para as áreas de concentração). Sua ocupação foi vinculada a produtores de cerâmicas da fase Manacapuru (Abreu, 2000; Neves, 2000; Lima et al., 2006; Portocarrero, 2007).

O problema de pesquisa colocado frente a esta análise no sítio Osvaldo está relacionado, principalmente, à sua cronologia de ocupação. Uma análise crono-estratigráfica fez-se importante para a avaliação das tais questões, bem como daquelas arroladas à espacialidade do sítio, já abordadas em pesquisas anteriores (idem). Foi na tentativa de obter uma resposta que complementasse os dados obtidos em outros trabalhos que selecionei para a análise os materiais provenientes da unidade escavada, que se situa numa das áreas de concentração, que obteve treze datações radiocarbônicas em torno de 700 d.C.
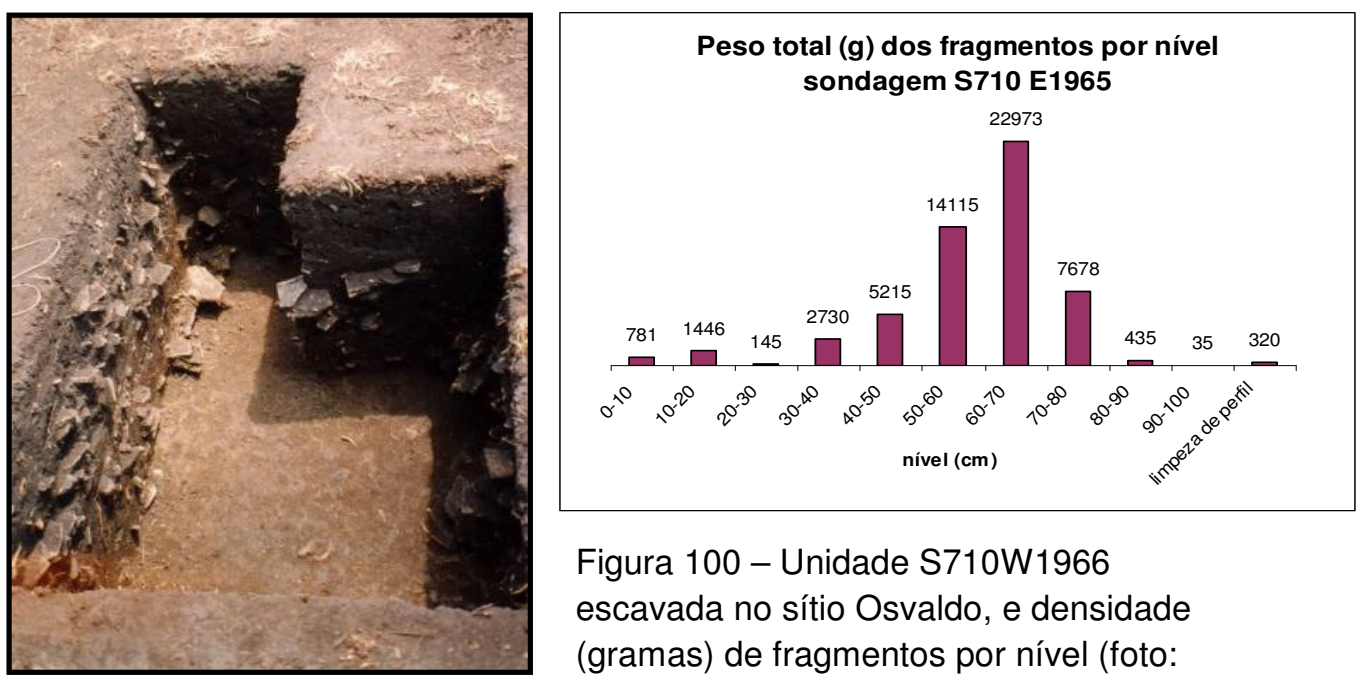

Figura 100 - Unidade S710W1966 escavada no sítio Osvaldo, e densidade (gramas) de fragmentos por nível (foto: Helena Lima). 
Duas questões primordiais foram colocadas frente à análise cerâmica. A primeira delas tratava do entendimento das relações entre as cerâmicas Manacapuru e Paredão, que aparecem consistentemente na estratigrafia da unidade, ambas relacionadas às datações citadas. A segunda questão aludia às datações mais antigas obtidas para essa área, em torno do anno domini. Essas duas datas, concentradas nos níveis 80-90 e 90-1000, indicariam um possível evento de ocupação anterior à aldeia circular já referida. Assim, a análise descritiva e a tipologia cerâmica tiveram como finalidade caracterizar em maior detalhe a indústria Manacapuru do sítio Osvaldo, entender a relação de coocorrência com as cerâmicas da fase Paredão e observar diferenças consistentes entre os níveis estratigráficos a fim de identificar ou não um nível de ocupação anterior, em um sítio supostamente unicomponencial.

\begin{tabular}{|c|c|c|c|}
\hline $\begin{array}{l}\text { Número do } \\
\text { Laboratório }\end{array}$ & Unidade & Profundidade & $\begin{array}{c}\text { Idade calibrada } \\
(66.8 \%)\end{array}$ \\
\hline BETA 143611 & S0710E1966 & $34 \mathrm{~cm}$ & 170 d.C. -420 d.C. \\
\hline BETA 143610 & S0710E1966 & $35 \mathrm{~cm}$ & 620 d.C. -690 d.C. \\
\hline BETA 143612 & S0710E1966 & $36 \mathrm{~cm}$ & 650 d.C. -770 d.C. \\
\hline BETA 143608 & S0710E1966 & $41 \mathrm{~cm}$ & 430 d.C. -560 d.C. \\
\hline BETA 143609 & S0710E1966 & $41 \mathrm{~cm}$ & 670 d.C. -770 d.C. \\
\hline BETA 143614 & S0710E1966 & $42 \mathrm{~cm}$ & 610 d.C. -770 d.C. \\
\hline BETA 143613 & S0710E1966 & $45 \mathrm{~cm}$ & 660 d.C. -780 d.C. \\
\hline BETA 143616 & S0710E1966 & $50-60 \mathrm{~cm}$ & 640 d.C. -690 d.C. \\
\hline BETA 143615 & S0710E1966 & $54 \mathrm{~cm}$ & 550 d.C. -660 d.C. \\
\hline BETA 143617 & S0710E1966 & $61 \mathrm{~cm}$ & 640 d.C. -770 d.C. \\
\hline BETA143618 & S0710E1966 & $66 \mathrm{~cm}$ & 640 d.C. -770 d.C. \\
\hline BETA 143619 & S0710E1966 & $73 \mathrm{~cm}$ & 650 d.C. -780 d.C. \\
\hline BETA 143620 & S0710E1966 & $76 \mathrm{~cm}$ & 650 d.C. -770 d.C. \\
\hline BETA 143621 & S0710E1966 & $80-90 \mathrm{~cm}$ & 90 a.C. -130 d.C. \\
\hline BETA 143622 & S0710E1966 & $90-100 \mathrm{~cm}$ & 200 a.C.-50 a.C. \\
\hline
\end{tabular}

Tabela 13 - Datações radiocarbônicas obtidas para a unidade S710 W1966 no sítio Osvaldo.

A proposta de tratar a coleção como um todo foi deliberada, a fim de não recorrer em erros classificatórios ao tratar as fases cerâmicas como conjuntos dados, pré-estabelecidos. Assim, os atributos formais, tecnológicos e decorativos foram observados na totalidade dos fragmentos para que os padrões e discrepâncias fossem identificados, e somente então interpretados enquanto fases, cultural ou cronologicamente distintas. Pretendia-se dessa maneira compreender a natureza das semelhanças ou diferenças entre as fases 
cerâmicas reconhecidas na região. A análise descritiva inicial, tal como apresentada a seguir, demonstrou certa homogeneidade interna ao conjunto analisado, o que dificultou um pouco a diferenciação entre fases cerâmicas. A esta questão somou-se o fato de que a coleção, totalizando 363 peças, é, em sua maioria, composta por paredes simples, o que restringe a possibilidade informativa dos fragmentos. Assim, a análise interpretativa teve que contar também com os dados provenientes das cerâmicas de outras áreas do sítio arqueológico.

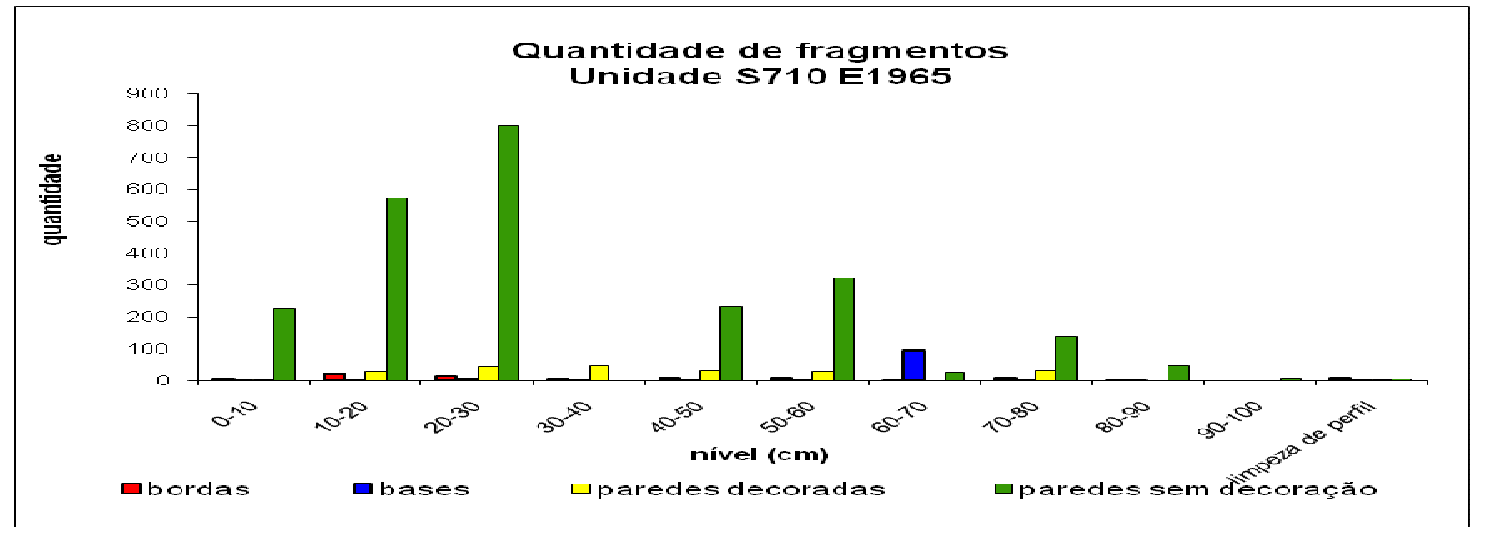

Gráfico 51 - Triagem dos fragmentos coletados na unidade S710 W1966.

Como se verá na seqüência de gráficos a seguir, em relação ao tempero, o uso do cauixi é preponderante em toda a coleção. Notar, no entanto, uma pequena ocorrência do cariapé apenas nos níveis $60-70$ e $70-80 \mathrm{~cm}$. Em todos os níveis, o alisamento aparece como acabamento de superfície mais recorrente, seguido, em proporções semelhantes, pelo polimento e enegrecimento. Já as decorações, em especial as plásticas, mostram certa variação, ainda que discreta. As técnicas mais recorrentes são sempre as incisões e acanalados, em todos os níveis. Quando se exclui essas duas, o gráfico começa a apresentar maior variação. Em primeiro lugar, técnicas como o digitado e ungulado, típicas das indústrias Manacapuru e Paredão, porém não recorrentes entre as cerâmicas Açutuba, aparecem na seqüência estratigráfica até $80 \mathrm{~cm}$, mas não nos níveis mais profundos, até $100 \mathrm{~cm}$. A excisão, característica dos conjuntos antigos, aparece em um nível apenas, em 70-80 cm. As demais técnicas se apresentam de maneira uniforme nos níveis estratigráficos. 


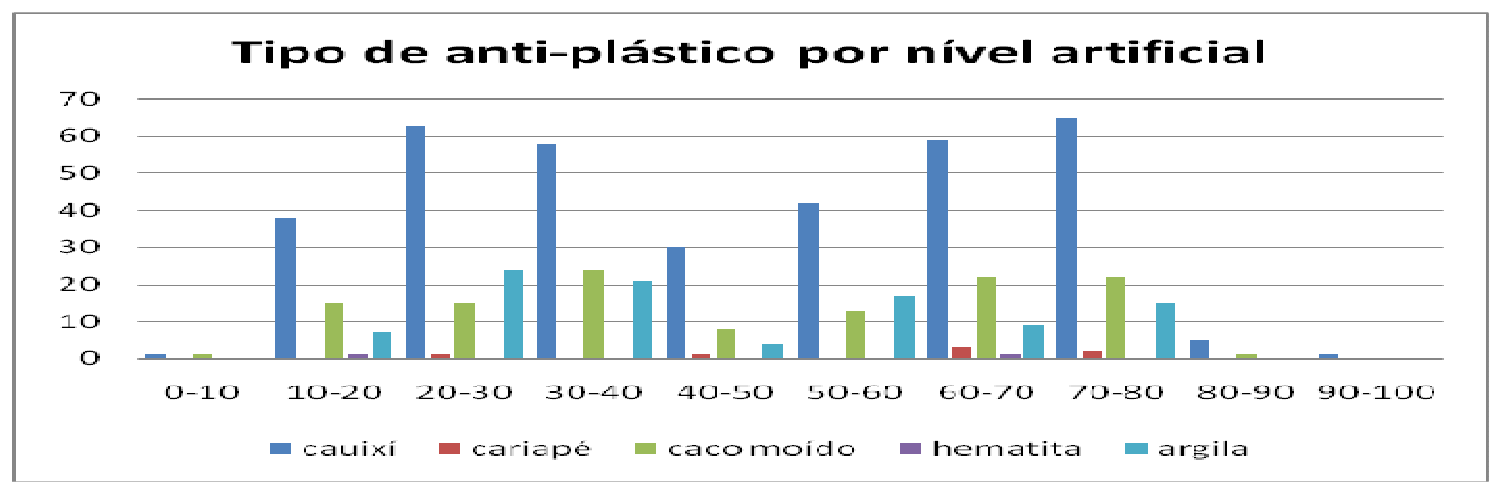

Gráfico 52 - Tipos de anti-plásticos observados por nível nos fragmentos da unidade $\$ 710$ W1966.

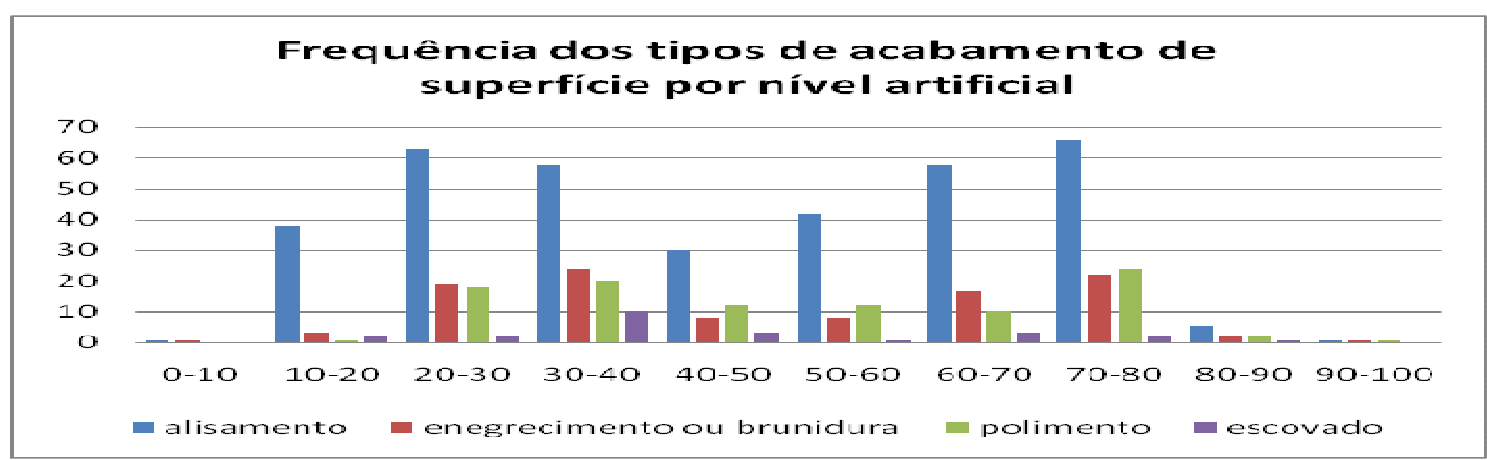

Gráfico 53 - Tipos de acabamentos de superfície observados por nível nos fragmentos da unidade S710 W1966.

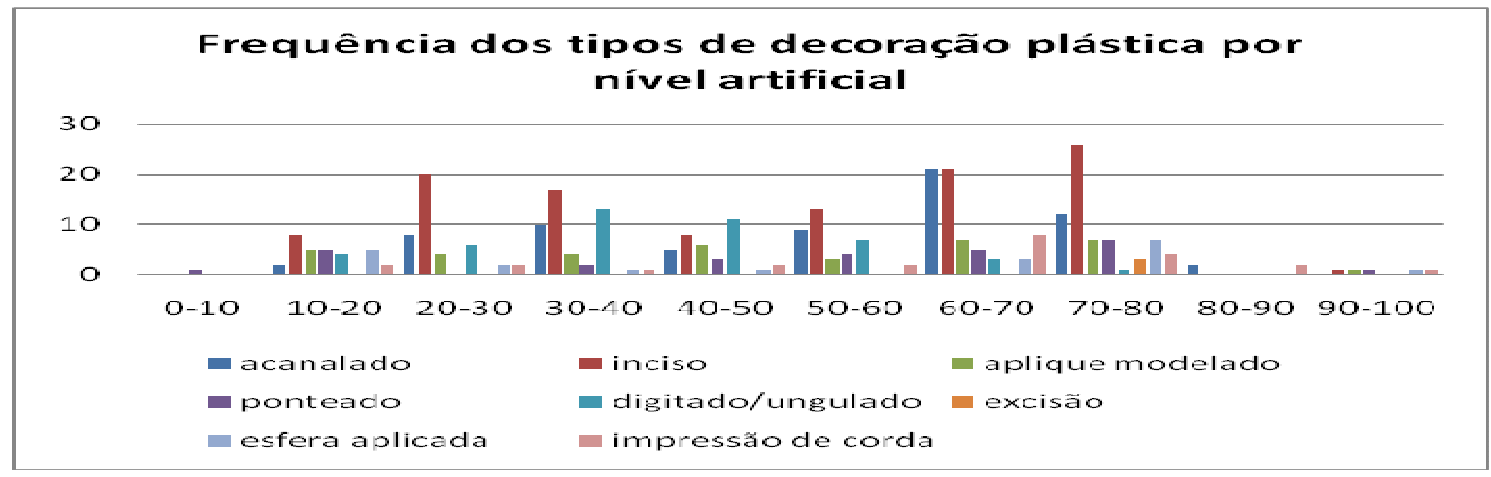

Gráfico 54 - Tipos de decoração plástica observados por nível nos fragmentos da unidade S710 W1966.

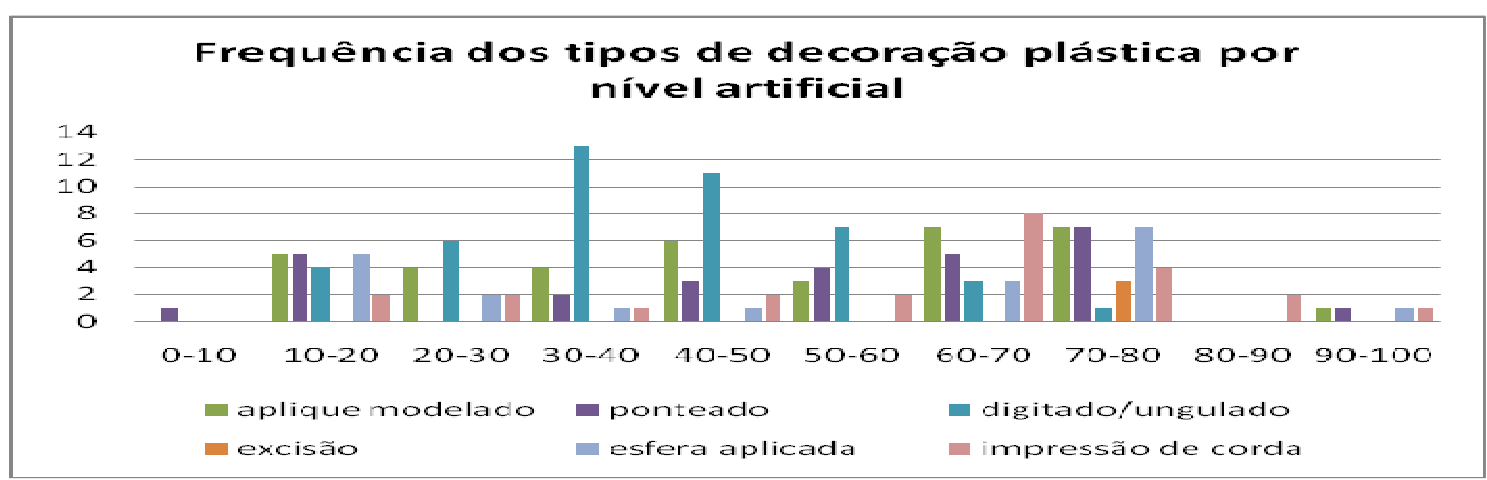

Gráfico 55 - Tipos de decoração plástica observados por nível nos fragmentos da unidade $\mathbf{S 7 1 0}$ W1966 (excluídos incisão e acanalado). 
Em relação aos vestígios líticos encontrados na unidade S710 W1966, apenas uma pequena quantidade foi coletada, pouco representativa frente ao universo cerâmico. Consiste, na maioria dos casos, em pequenos blocos ou lascas térmicas de arenito do tipo Manaus, cujas fontes encontram-se apenas nas proximidades do rio Negro. Observou-se, ainda, fragmentos de lâminas de machado polido de basalto, comumente encontrados entre as ocupações ceramistas de modo geral. Os vestígios líticos coletados na escavação da unidade S710 W1966 estão descritos na tabela a seguir:

\begin{tabular}{|c|c|c|}
\hline \multicolumn{3}{|c|}{ Freqüência de fragmentos líticos presentes na unidade S710 E1966 } \\
\hline Nível & Quantidade e descrição & \\
\hline \multicolumn{2}{|l|}{$0-10 \mathrm{~cm}$} & \\
\hline $\begin{array}{l}10-20 \mathrm{~cm} \\
20-30 \mathrm{~cm}\end{array}$ & $\begin{array}{l}01 \text { corante amarelo } \\
02 \text { fraamentos de machado polido }\end{array}$ & \\
\hline $20-30 \mathrm{~cm}$ & $\begin{array}{l}02 \text { tragmentos de machado polido } \\
\text { (basalto) } \\
07 \text { fragmentos de arenito } \\
\text { (tipo Manaus) queimado, }<2 \mathrm{~cm}\end{array}$ & \\
\hline $30-40 \mathrm{~cm}$ & $\begin{array}{l}07 \text { fragmentos de arenito queimado, } \\
\text { entre } 5 \text { e } 10 \mathrm{~cm} \\
12 \text { fragmentos de arenito queimado, } \\
<2 \mathrm{~cm}\end{array}$ & \\
\hline \multicolumn{3}{|c|}{ - } \\
\hline \multirow[t]{2}{*}{$50-60 \mathrm{~cm}$} & 01 fragmento de machado polido & \\
\hline & $\begin{array}{l}\text { (basalto) } \\
05 \text { fragmentos de arenito queimado, } \\
\text { entre } 5 \text { e } 10 \mathrm{~cm}\end{array}$ & $\begin{array}{l}\text { Figura } 101 \text { - Fragmento de lâmina de } \\
\text { machado da unidade S710 W1966. }\end{array}$ \\
\hline $60-70 \mathrm{~cm}$ & 03 fragmentos de arenito queimado, $<2 \mathrm{~cm}$ & \\
\hline \multirow[t]{3}{*}{$70-80 \mathrm{~cm}$} & 02 corantes amarelos? & \\
\hline & 02 fragmentos de arenito queimado, entre 5 e $10 \mathrm{~cm}$ & \\
\hline & 03 fragmentos de arenito queimado, $<2 \mathrm{~cm}$ & \\
\hline
\end{tabular}

Tabela 14 - Descrição dos vestígios líticos coletados na unidade S710 E1966.

Em sua análise das cerâmicas provenientes das sondagens e tradagens do sítio Osvaldo, Portocarrero identificou 15 formas (2007, p. 93-94). Elas podem ser agrupadas em sete categorias gerais, que são congruentes com a variabilidade formal identificada para a unidade analisada, cuja tipologia pautouse nestes conjuntos formais em associação a outros atributos, totalizando nove tipos, todos vinculados à fase Manacapuru, que se encontram descritos no apêndice deste trabalho. É importante mencionar que esses tipos limitaram-se apenas até o nível $70-80 \mathrm{~cm}$, dando consistência à divisão crono-estratigráfica proposta. Por serem numericamente pouco representativos, os materiais dos níveis mais antigos não foram vinculados à tipologia. 


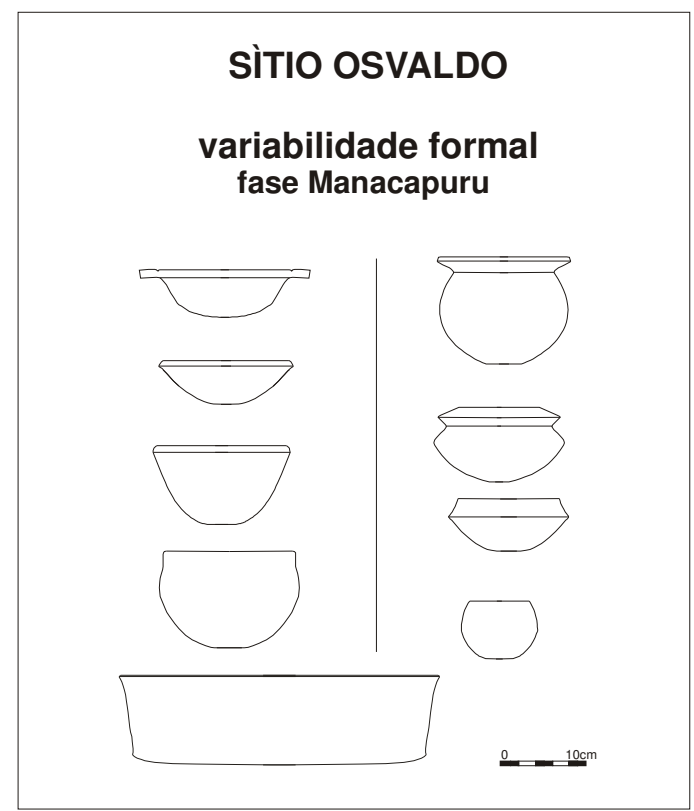

Figura 102 - Variabilidade formal identificada nas cerâmicas da unidade S710 W1966, sítio Osvaldo.

A pequena quantidade de fragmentos diagnósticos, aliada a certa padronização do conjunto que levou à caracterização da fase Manacapuru do sítio, não permitiu uma clara diferenciação entre essas e as cerâmicas Paredão, que acabou sendo feita qualitativamente. Observou-se a presença de poucos fragmentos claramente Paredão nos níveis estratigráficos. Esta homogeneidade da coleção se mostrou também nas análises arqueométricas (das pastas por ativação de nêutrons), realizadas em doze fragmentos cerâmicos entre os níveis 20-30 e 80-90 cm, e oito pedaços de argila queimada, coletados nesses mesmos níveis da unidade. Formaram-se três grupos de argila; um deles, o grupo 3, aglutinou os referidos blocos de argila queimada, bem distantes estatisticamente dos demais. O grupo 1 congregou o maior número de fragmentos, e entre eles as cerâmicas Paredão (3 fragmentos) e Manacapuru (5 fragmentos), distribuídas pelos níveis estratigráficos. Por fim, o grupo 2 congregou 4 fragmentos também dispersos pela estratigrafia.

Ainda de maneira qualitativa, fragmentos associados à fase Açutuba foram identificados apenas nos níveis inferiores. Aí foi possível observar diferenças estratigráficas, mesmo que sutis, entre os níveis da unidade com cerâmicas Manacapuru e Paredão (de 0 a $80 \mathrm{~cm}$ ) e os mais profundos, como demonstraram os gráficos que já foram discutidos. A identificação deste discreto conjunto consolidou as datações antigas obtidas para a unidade. Dessa forma, os 
objetivos iniciais estabelecidos para os estudos das cerâmicas nesse sítio foram contemplados de modo a demonstrar uma ocorrência discreta, bem anterior à aldeia circular, outrora identificada como relacionada a produtores das cerâmicas com características da fase Manacapuru; e também, mostrou a recorrência, na seqüência estratigráfica, de cerâmicas Paredão, em reduzida quantidade. Os elementos químicos de suas argilas, no entanto, não se diferenciaram das demais, o que pode sugerir, ainda que em caráter hipotético, que essas cerâmicas tecnologicamente distintas, e com características decorativas diferentes, foram produzidas num contexto semelhante. Explicações simplistas para a co-ocorrência de fases distintas num mesmo conjunto arqueológico, como a "troca", caem por terra frente aos dados colocados.

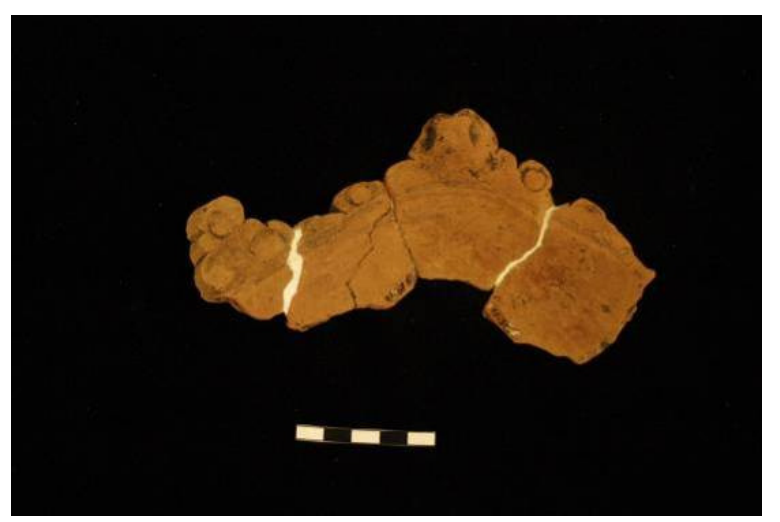

Figura 103 - Cerâmica Manacapuru do sítio Osvaldo (foto: Val Moraes). 


\section{VII.I.IX. Cerâmicas do Lago Grande}

De cinco escavações de $1 \mathrm{~m}^{2}$ realizadas no sítio Lago Grande, três foram analisadas, sendo a unidade 1 (N500 E500) trabalhada por P. Donatti em seu mestrado (2003), e as unidades 3 (N508 E596) e 4 (N443 E618) através de uma iniciação científica desenvolvida por A. Tamura (2005). Todos os contextos dizem respeito a montículos. Entretanto, diferente de Hatahara, onde este fato se mostrou bastante complicado no que se refere à interpretação crono-estratigráfica do sítio, em Lago Grande a seqüência foi mais facilmente compreendida. Isso porque, como mencionado antes, a cronologia de ocupação do sítio Lago Grande é menos longa e sua indústria cerâmica é composta na maioria por um único componente, relacionado à fase Paredão.

Através das mencionadas análises, a estratigrafia dos montículos foi detalhada, chegando-se a uma caracterização das cerâmicas Paredão que os compõem, em todos os níveis, e aos quais se vinculou o próprio evento de construção dos mesmos. Neste caso, aventou-se tratar de refugos relacionados a unidades habitacionais no sítio (Tamura, 2005 p. 5). Desta forma, o sítio foi considerado unicomponencial, Paredão, com forma semicircular (Donatti, 2003; Tamura, 2005).

As cerâmicas Paredão são, em geral, muito finas, bem acabadas e queimadas e, assim como os demais materiais Borda Incisa, são sempre temperados majoritariamente com o cauixi. Trata-se de um conjunto conciso e com pequena variabilidade interna, sobretudo quando comparado com as demais fases arqueológicas encontradas na Amazônia.
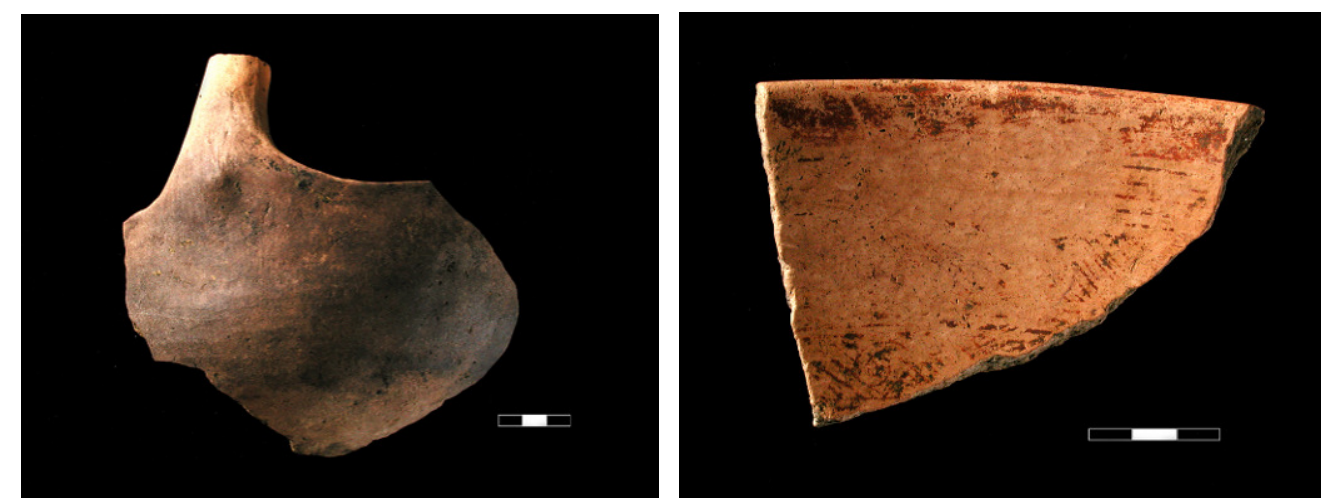

Figura 104 - Fragmentos diagnósticos da fase Paredão encontrados no sítio Lago Grande: cuia pintada e cesta com alça (fonte: Donatti, 2003, p. 139-140). 
Em continuidade às análises realizadas nos materiais provenientes da unidade 1 do sítio Lago Grande, foram realizados alguns testes nos quais os dados brutos (da ficha de análise) foram submetidos a comparações estatísticas em relação aos materiais da unidade TU20 do sítio Açutuba. A proposta, neste caso, foi a de comparar estatisticamente uma amostragem representativa da variabilidade da indústria Paredão (da unidade um), com os fragmentos que representassem a variabilidade da fase Manacapuru (da unidade TU20, como já descrita). As análises foram extensas, não cabendo aqui reportar seus detalhes. Estes dados encontram-se no relatório produzido pelo CEA (Borges e Coelho, 2003). Além de propor alguns agrupamentos hipotéticos internos aos conjuntos através de diferentes procedimentos inferenciais (idem, p. 12-13), tais testes confirmaram uma menor variabilidade interna Paredão, demonstrada através do pequeno número de variáveis diferenciadoras (ou seja, atributos que indiquem variação) na coleção, em especial no que se refere aos materiais do sítio Açutuba (idem, p. 18).

A homogeneidade da coleção, tal como observada entre os fragmentos da unidade 1, foi confirmada pelas análises posteriores realizadas por Tamura: "como resultado das análises, percebe-se que, com uma pequena variabilidade, o material cerâmico Paredão encontrado nas três unidades escavadas é muito semelhante entre si, além de ser contemporâneo" (2005, p. 17).

Em relação às argilas utilizadas na fabricação dessas cerâmicas, as análises arqueométricas (por ativação de nêutrons) realizadas pelo IPEN em 50 amostras indicaram a formação de três grupos de composição química. Os três grupos se encontram distribuídos por toda a sequência estratigráfica das unidades testadas, não indicando, portanto, alterações significativas das escolhas tecnológicas ao longo do tempo. Do mesmo modo, as variações desses grupos não se mostraram congruentes com outras variáveis, tais como a forma da vasilha, o que poderia trazer, por exemplo, valiosas informações sobre a relação entre as formas e as características de performance das argilas. Desta feita, a natureza das escolhas não foi identificada através deste tipo de análise, sendo necessária uma reavaliação de seus resultados e potenciais informativos.

Observou-se também que há pouca variação na decoração entre os materiais de base e de superfície no sítio arqueológico (Donatti, 2003, p.96). Esse estudo inicial identificou nove formas (idem, p.76 a 88), enquanto no segundo 
foram identificadas dez. A tipologia proposta neste trabalho, apresentada no apêndice, estabeleceu oito tipos, com base nas formas e características identificadas por esses dois trabalhos prévios.

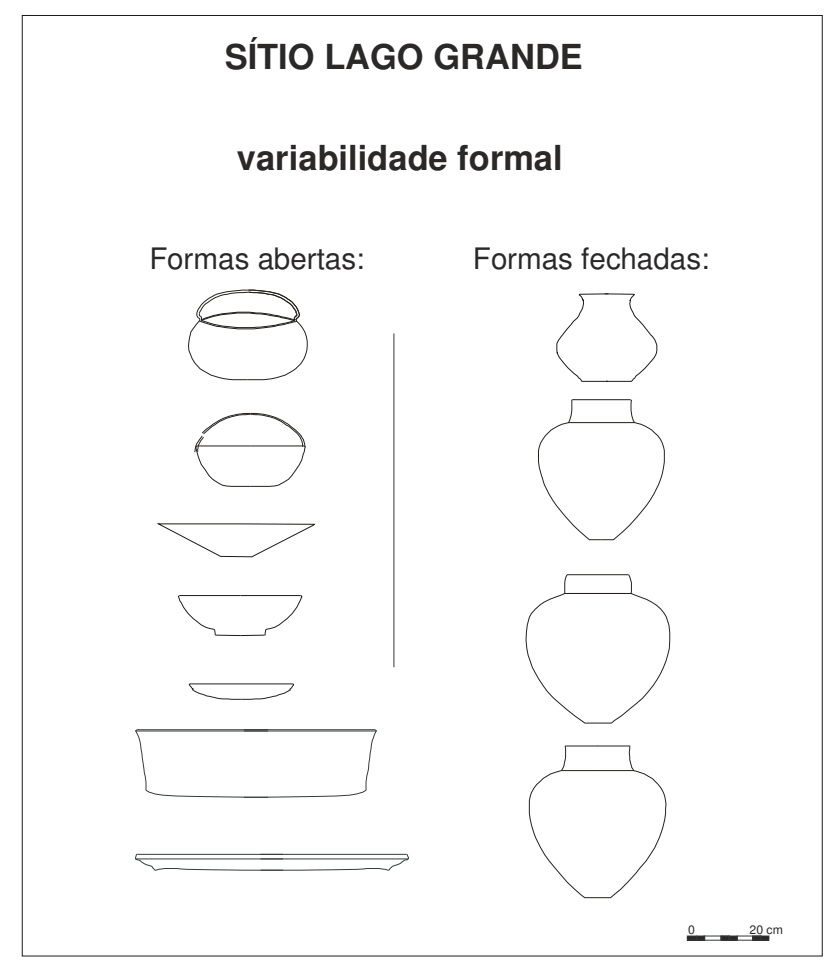

Figura 105 - Variabilidade formal identificada nas unidades 1 , 3 e 4 do sítio Lago Grande (de acordo com Donatti, 2003 e Tamura, 2005).

De maneira intrigante, as análises identificaram uma co-ocorrência regular entre materiais das fases Paredão e Manacapuru, do mesmo modo como ocorria no sítio Osvaldo. Entretanto, este caso apresenta uma proporção inversa, ou seja, de superioridade quantitativa da primeira em relação à segunda.

Diferente das interpretações já propostas, que sugerem tratar-se do resultado de relações de troca entre ocupações contemporâneas das fases Manacapuru e Paredão, situadas respectivamente no Lago do Limão e no Lago Grande (Donatti, 2003, p. 96; Tamura, 2005, p.18), acredito tratar-se de uma relação um tanto mais complexa. Nos termos quais anteriormente colocados, uma fase cerâmica se vincularia direta e exclusivamente a uma determinada ocupação. Quando o viés interpretativo se abre e volta-se a um entendimento mais integrado e abrangente de tais categorias, pode-se chegar a considerar sítios contemporâneos, sejam eles caracterizados por componentes arqueológicos semelhantes ou distintos, dentro de um mesmo sistema de 
interação, que incluiria outros aspectos sociais que não apenas relações de troca, sendo estes os geradores de tal variabilidade, bem como das padronizações encontradas.

Este ponto de vista se torna ainda mais sustentável frente à informação de que "algumas cerâmicas escavadas na unidade 4 apresentam características que possivelmente indicam influência, em sua produção, de traços das cerâmicas Manacapuru: trata-se de artefatos que, pela pasta, queima e tempero são caracteristicamente Paredão, mas cuja decoração é visivelmente Manacapuru" (Tamura, 2005, p. 17). Assim, começa-se a incorporar uma nova visão, menos normativa, ao entendimento das relações entre essas duas fases cerâmicas.

Enfim, mesmo a princípio considerado como um sítio unicomponencial (o que de fato aparenta ser em relação aos componentes Manacapuru e Paredão), o sítio Lago Grande apresentou, como no sítio Osvaldo e em outros tantos da Amazônia central, um componente mais antigo, bem discreto, anterior à formação das terras pretas e com cerâmicas relacionadas à fase Açutuba. Como apontado por Tamura, de início, as datações feitas para a unidade 3 apresentavam uma anomalia, referente a uma data em torno de 105 d.C., não compatível com a interpretação então corrente de tratar-se apenas de uma ocupação Paredão do século $X$ d.C. Foi somente a partir da definição da fase Açutuba, e de seu contexto, que se compreendeu a ocorrência, não apenas em Lago Grande, de datas antigas, sempre em torno do Anno Domini. Assim, a análise de Tamura demonstrou tratar-se, na verdade, de um evento mais antigo de ocupação, relacionado à fase cerâmica Açutuba, cujos materiais caracterizam-se por estar em pior estado de conservação em relação aos materiais dos níveis acima, em um processo de decomposição mais avançado, mas, ainda assim, com algumas características decorativas preservadas, tais como a própria policromia (2005, p.16). Começa-se a observar recorrências geradoras de padrões na região, e que serão discutidas com maior profundidade adiante. 


\section{I. X. Cerâmicas do Nova Cidade}

O sitio Nova Cidade se caracteriza pela grande quantidade de vestígios cerâmicos espalhados por sua superfície, que vão desde pequenos fragmentos de difícil caracterização, até vasilhas de diferentes tamanhos e formas quase completas. Apesar de apresentarem condições de preservação razoáveis in situ, o processo de exumação e transporte para o laboratório, além do longo período que se passou entre a escavação de alguns deles (em 2001) e a análise (ocorrida em 2004), comprometeu sua integridade e, em alguns casos, pouca informação pôde ser recuperada.

Assim como nas demais coleções, a primeira etapa de curadoria do material cerâmico coletado em campo foi a limpeza. Uma vez limpos, os fragmentos foram separados em duas categorias gerais, de acordo com o procedimento adotado em campo: 1) coletas sistemáticas de superfície e 2) recipientes cerâmicos passíveis de remontagem. Procedimentos analíticos distintos foram adotados para cada uma delas.

\section{1) As coletas de superfície}

Os fragmentos coletados em superfície (bordas, paredes decoradas, apliques e alças) representam um bom parâmetro da variabilidade decorativa das cerâmicas encontradas no sitio arqueológico. No entanto, o elevado estágio de degradação em que se achava o sítio não permitiu quaisquer inferências estratigráficas. Esses materiais foram descritos e triados segundo categorias morfológicas; foram quantificados e pesados, mas não passaram pela análise de atributos tal como as demais coleções.

\section{2) Os recipientes}

Embora bastante fragmentados em função de obras realizadas sobre 0 sítio arqueológico e da própria ação do tempo, alguns recipientes cerâmicos puderam ser parcialmente recuperados. O primeiro passo foi, portanto, a remontagem, que permitiu a reconstituição formal do vasilhame. A remontagem é como um imenso quebra-cabeça, do qual não se conhece o desenho final, e nem se sabe se todas as peças que o compõem estão disponíveis. É um processo lento que exige muita paciência: as peças são conectadas até que se obtenham as vasilhas total ou parcialmente completas. Em alguns casos, a utilização de 
gesso foi necessária para se chegar à forma final.

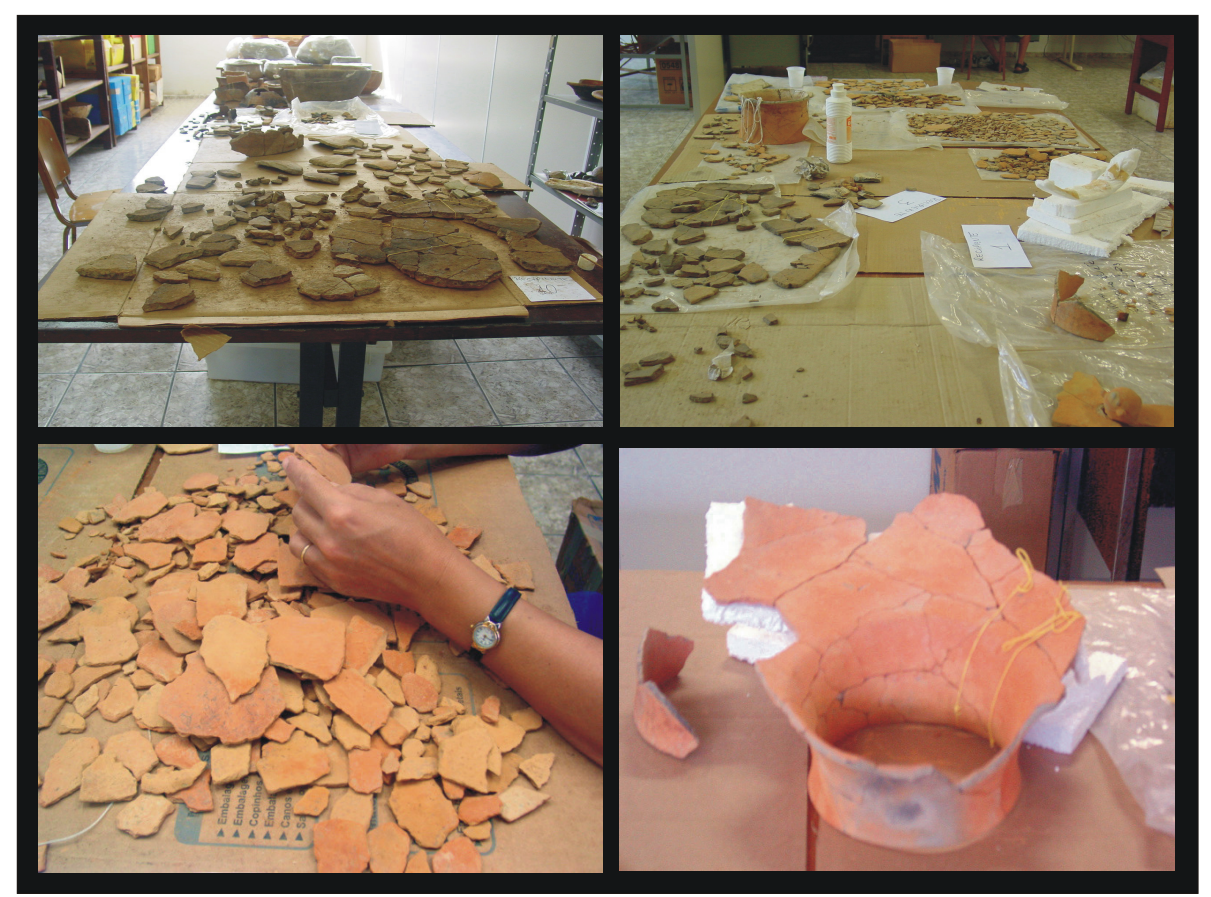

Figura 106- Fragmentos cerâmicos e recipientes parcialmente remontados (fotos: Helena Lima, 2004).

Foi a partir da análise de tais vasilhas que se estabeleceu a tipologia apresentada no apêndice desta tese. Foram agrupadas em seis conjuntos, a partir da associação entre sua variabilidade formal e as demais características tecnológicas. Observou-se uma pequena variabilidade formal destes materiais, quando comparados com grande parte dos vestígios dos demais sítios arqueológicos. Esta é, de fato, uma característica da fase Paredão, à qual a maior parte das vasilhas coletadas foi vinculada. Há, também, alguns fragmentos da fase Manacapuru, e outros da fase Guarita. Um total de vinte recipientes foi total ou parcialmente recuperado entre as escavações de 2001 e 2004 (tabela 15), além dos fragmentos coletados em superfície, que permitiram uma caracterização geral dos materiais do sítio Nova Cidade, especificamente no que se refere à sua coleção Paredão. 


\begin{tabular}{|c|c|c|c|c|c|}
\hline RECIPIENTE & SETOR & FASE & DIÂMETRO & ANTIPLÁSTICO PREPONDERANTE & FORMA \\
\hline 1 & B & Paredão & $28 \mathrm{~cm}$ & Cauixi & Urna \\
\hline 2 & B & Paredão & $30 \mathrm{~cm}$ & Cauixi & Urna \\
\hline $3 A$ & B & Paredão & $33 \mathrm{~cm}$ & Cauixi & Urna \\
\hline $3 B$ & B & Paredão & $33 \mathrm{~cm}$ & Cauixi & Alguidar/ \\
\hline 4 & B & Paredão & $25 \mathrm{~cm}$ & Cauixi & Urna \\
\hline $5 \mathrm{~A}$ & B & Paredão & $30 \mathrm{~cm}$ & Cauixi & Alguidar \\
\hline 5 & B & Guarita & $30 \mathrm{~cm}$ & Cariapé & Tigela \\
\hline 6 & B & Guarita & $20 \mathrm{~cm}$ & Cariapé & Tigela \\
\hline 7 & B & Paredão & $28 \mathrm{~cm}$ & Cauixi & Torrador \\
\hline $8 \mathrm{~A}$ & B & Paredão & $62 \mathrm{~cm}$ & Cauixi & Alguidar \\
\hline $8 B$ & B & Paredão & $62 \mathrm{~cm}$ & Cauixi & Tampa \\
\hline 9 & B & Paredão & $52 \mathrm{~cm}$ & Cauixi & Urna \\
\hline $10 \mathrm{~A}$ & $B$ & Paredão & $60 \mathrm{~cm}$ & Cauixi & Urna \\
\hline $10 \mathrm{~B}$ & B & Paredão & $60 \mathrm{~cm}$ & Cauixi & Alguidar \\
\hline 11 & B & Paredão & $32 \mathrm{~cm}$ & Cauixi & Cuia \\
\hline 12 & B & Paredão & $26 \mathrm{~cm}$ & cariapé & Cuia \\
\hline $13 \mathrm{~A}$ & A & Paredão & $50 \mathrm{~cm}$ & Cauixi & Alguidar \\
\hline 13B & A & Paredão & $50 \mathrm{~cm}$ & Cauixi & Tampa \\
\hline 14 & $?$ & Paredão & $?$ & Cauixi & Alguidar \\
\hline 15 & $?$ & Paredão & $?$ & Cauixi & Cuia \\
\hline 16 & Nova Cidade II & Guarita & 20 & cariapé & Tigela \\
\hline
\end{tabular}

Tabela 15 - Relação dos recipientes cerâmicos coletados no sítio Nova Cidade.

A tecnologia da indústria Paredão encontrada em Nova Cidade é caracterizada pelo ótimo acabamento de superfície através de um fino alisamento ou polimento. Observa-se que a seleção e limpeza das matérias primas (argilas e antiplásticos) eram muito acuradas. A análise do antiplástico também indica investimento no tratamento das argilas. O uso do cauixi é predominante, podendo estar associado à hematita, cacos moídos e também ao cariapé. O cauixi triturado é distribuído homogeneamente por toda a pasta. Em alguns casos há também grãos de quartzo, que são elementos muito comuns nas argilas cruas, no entanto, poucos permanecem na pasta após a limpeza da argila, provavelmente devido à preocupação com fino acabamento da superfície dos vasos. O tipo de queima 
predominante é oxidante, caracterizada pela coloração clara (bege ou branca) da superfície da cerâmica.

A roletagem é a técnica mais utilizada na fabricação dos artefatos cerâmicos. Os roletes são em geral finos e bem unidos. A técnica da modelagem é utilizada apenas na fabricação dos apliques, que são características decorativas típicas da cerâmica Paredão. Os apliques representam cabeças antropomorfas ou zoomorfas, ou formas abstratas. Geralmente estão associados a técnicas decorativas como as incisões e o ponteado.

Duas categorias de vasos recebem apliques: urnas funerárias e alguidares. As urnas recebem dois apliques, na maioria das vezes ocos, nos ombros. A variabilidade de apliques é bem grande, com representações desde cabeças humanas quase naturalistas, até formas abstratas, sempre relacionadas a cabeças de animais. Os alguidares, que são vasilhas com grandes dimensões, recebem dois, três ou quatro pequenos nódulos maciços aplicados na parede externa, próximos da borda, funcionando como alças.

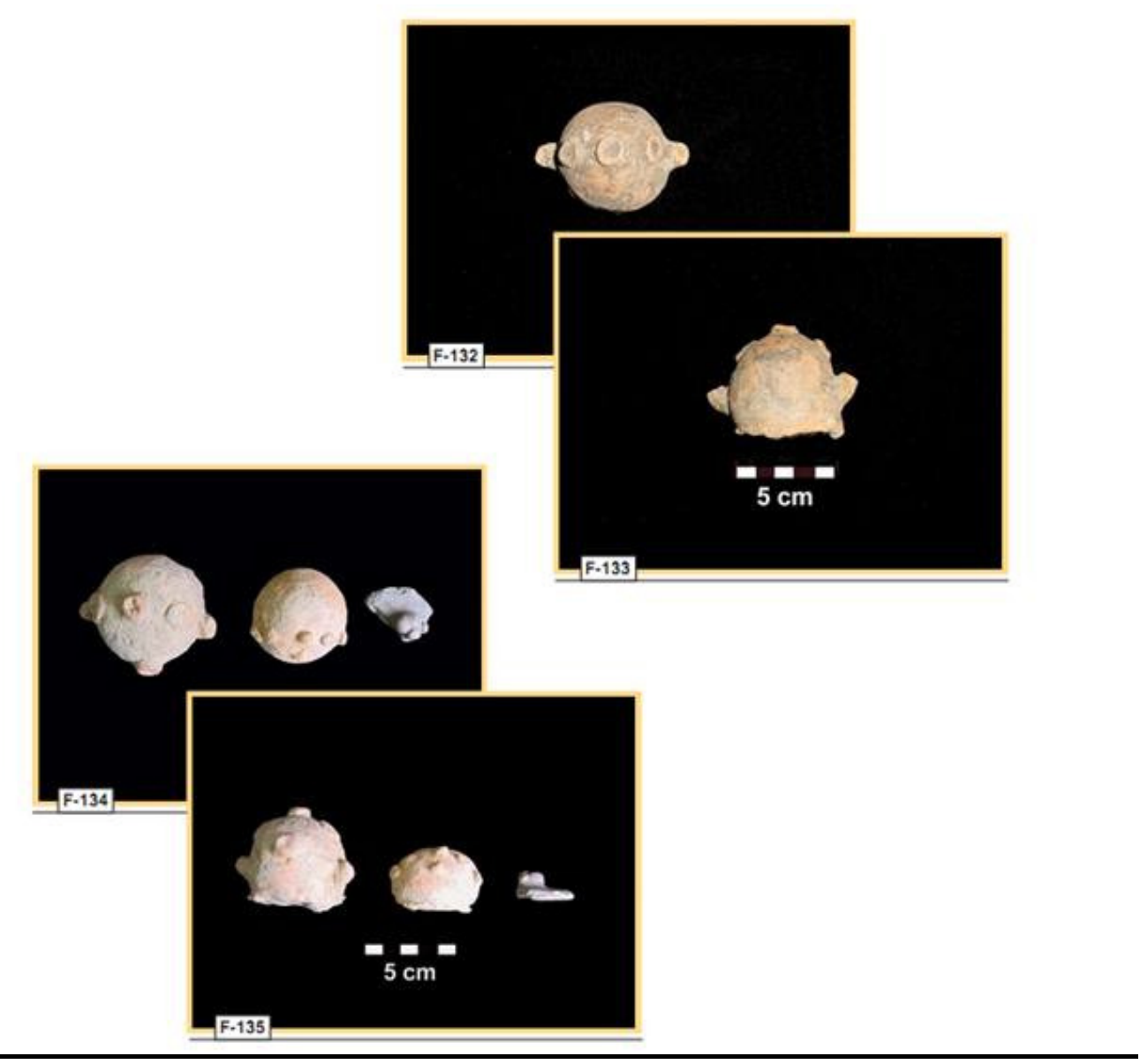

Figura 107 - Apliques modelados encontrados no sítio Nova Cidade (fonte: Neves \& Costa 2001). 
Assim como os demais conjuntos Borda Incisa, observa-se dentre as cerâmicas de Nova Cidade ampla utilização de incisões como recurso decorativo. As incisões podem ser simples ou duplas, e são em geral executadas na região próxima da borda ou no fundo da face interna de vasos em forma de cuia. A variabilidade estrutural dos motivos não é grande, sendo formada por composições geométricas, como triângulos e retângulos espelhados, gregas, ou linhas paralelas simples. As incisões em cuias são em regra compostas por motivos geométricos ou em espirais.

\section{SITIO NOVA CIDADE}

variabilidade formal

Formas abertas: Formas fechadas:
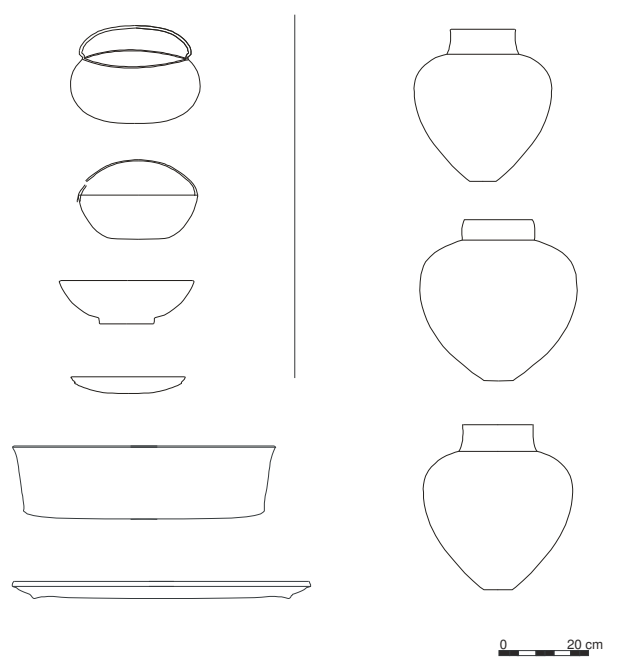

Figura 108 - Formas reconstituídas do sítio Nova Cidade.

Outras técnicas decorativas são utilizadas em menor escala, como o digitado e o ungulado, aplicadas nos lábios ou sobre um rolete adicional afixado na parede externa do vaso, alguns centímetros abaixo da borda. Foram observados poucos vestígios de pintura. Isto se deve, provavelmente, às más condições de preservação do sitio, que possui solo arenoso susceptível a erosão.
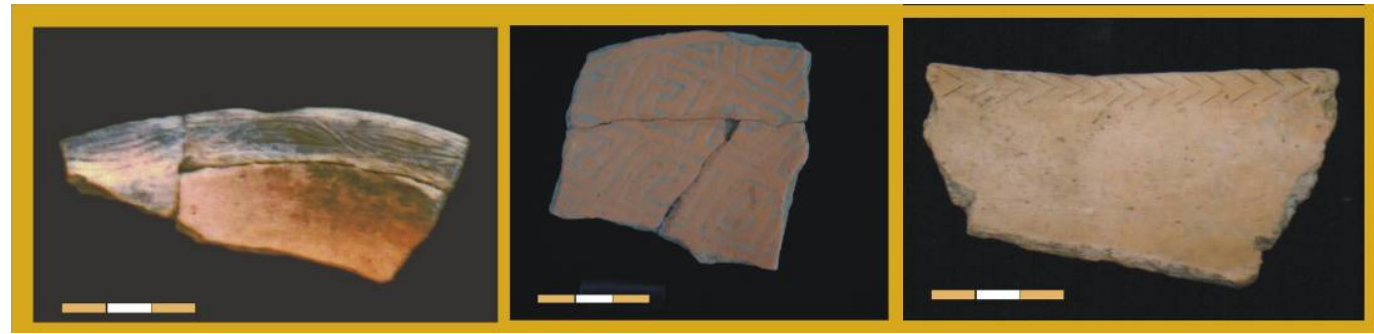

Figura 109 - Decoração plástica: fragmentos cerâmicos incisos do sítio Nova Cidade (foto: Helena Lima). 
Devido à quase completa destruição da camada arqueológica em que se encontrava o sítio, os procedimentos de coleta dos vestígios foram diferentes em Nova Cidade em relação aos demais sítios descritos. Não houve, por exemplo, cortes estratigráficos e, portanto, a maior parte da coleção do sítio é oriunda das coletas de superfície, à exceção dos recipientes exumados. Por esta razão, a coleção de artefatos líticos foi muito maior do que de qualquer outro sítio trabalhado através de métodos amostrais.

A análise do material lítico foi realizada por F. Costa, que aqui será brevemente apresentada; pode ser encontrada com mais detalhes em Neves et al., 2004a, p. 44-55. Foram contempladas todas as peças líticas coletadas: lascadas, polidas, picoteadas e usadas sem modificação, além do lítico queimado. Os principais atributos tecnológicos dos refugos de lascamento (lascas e núcleos) unipolar e bipolar, dos artefatos retocados e dos artefatos brutos, foram registrados no sentido de obter uma caracterização detalhada das peças.

A região do sítio Nova Cidade é rica em afloramentos de rochas que podem ser utilizadas na fabricação de artefatos líticos lascados. A matéria-prima disponível que foi amplamente utilizada é o arenito-silicificado da unidade Manaus. Muitas das peças analisadas foram fabricadas a partir de suportes desse arenito. Também foram encontradas peças picoteadas fabricadas a partir de suportes pouco silicificados e de granulação heterogênea. Além dele, ocorre na área, em menor freqüência, uma variedade de argilito-silicificado, mas que não foram explorados intensamente devido às pequenas dimensões dos blocos existentes. Os artefatos polidos, por outro lado, foram produzidos com rochas vulcânicas que não se prestam ao lascamento; através da técnica de polimento, porém, é possível produzir artefatos das mais diferentes formas e funções. No sítio Nova Cidade, assim como em diversos sítios estudados, a maioria dos objetos líticos são lâminas polidas. As prováveis fontes dessas rochas distam pelo menos $100 \mathrm{~km}$ de

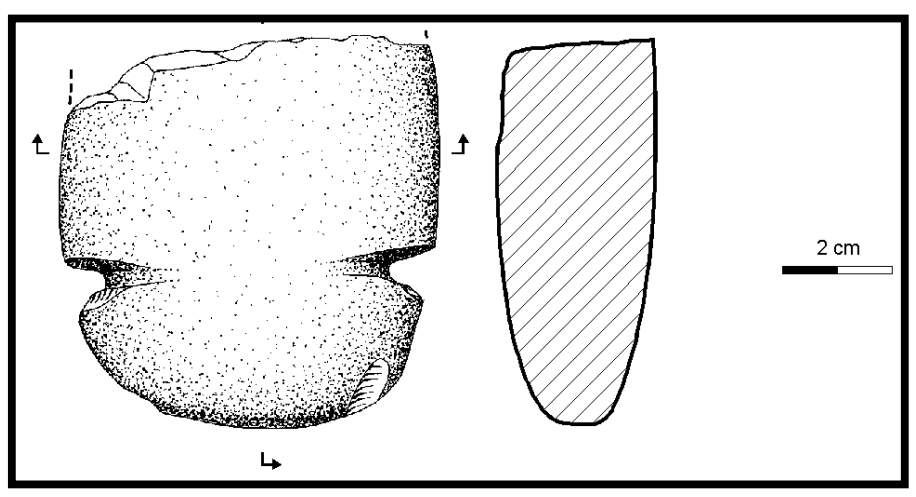

Figura 110 - Fragmento de lâmina polida encontrada no sítio Nova Cidade (desenho: Marcos Brito). 
Manaus (Neves et al., 2004a).

\section{II. $O$ estabelecimento das tipologias e a vinculação às fases cerâmicas}

Longe de ser uma região arqueologicamente virgem, a Amazônia central foi foco de distintas hipóteses de ocupação do norte da América do Sul, tendo tido sua arqueologia explorada desde a primeira metade do século $\mathrm{XX}$, ainda que tais pesquisas tivessem um caráter pontual. As coleções resultantes dessas pioneiras pesquisas, como as que P. Hilbert iniciou entre 1955 e 1961, lançaram as bases tipológicas para o estudo da região (1968). Também a atuação de M. Simões, entre as décadas de 70 e 80 , fez-se marcante para estudos posteriores. Nessa ocasião foram registrados pelo menos vinte e quatro sítios arqueológicos nas áreas rural e periférica do Município de Manaus (1970; 1974).

O foco deste trabalho visava um maior entendimento dos materiais vinculados à Tradição Borda Incisa (Meggers e Evans, 1961; 1983). Para tanto, voltou-se a uma revisão das tipologias anteriormente propostas através do estudo de materiais provenientes de sítios arqueológicos situados na área de confluência entre os rios Negro e Solimões, aparentemente associados às fases Manacapuru e Paredão, definidas por Hilbert (idem). Estas fases cerâmicas foram estabelecidas através da aplicação do método de seriação a coleções originárias de sítios da área desta pesquisa, como os sítios Manaus, Refinaria, Base Naval e Paredão, situados na capital amazonense e em seu entorno.

Como passo inicial da presente pesquisa, procedeu-se a um refinamento da tipologia de Hilbert, calcado nas coleções arqueológicas dos sítios escavados pelo PAC. Um dos resultados deste estudo foi a identificação de outra fase cerâmica, que surgiu como um desmembramento da fase Manacapuru, tal como pensada por Hilbert (Lima et al, 2006). O estabelecimento de uma nova fase se deu por questões que refletem não só as escolhas metodológicas, mas também o próprio entendimento dos conceitos envolvidos neste trabalho.

A metodologia de Hilbert difere bastante da que utilizei, não sendo as tipologias resultantes diretamente comparáveis (observá-las no apêndice). No entanto, as características com as quais ele desenvolveu tais fases cerâmicas convergiram, em muitos aspectos, com o que identifiquei neste trabalho. Ou seja, as duas tipologias, estabelecidas através de diferentes sítios arqueológicos e de outros métodos, levaram a resultados semelhantes, o que veio a corroborar certa coerência dos conjuntos, para além dos subjetivos parâmetros classificatórios. 
Neste caso, porém, se procurou ultrapassar a simples identificação de fases arqueológicas e sua circunscrição geográfica. Mais do que isso, visava-se entender as relações culturais e históricas subjacentes a elas. Neste sentido, este estudo não se resume a uma simples revisão de trabalhos anteriores, mas sim reflete um aprofundamento de questões já clássicas na arqueologia amazônica, tais como a validade heurística e epistemológica da Tradição Borda Incisa, de onde vem seu ineditismo.

Os critérios para estabelecimento dos tipos cerâmicos foram anteriormente discutidos. É importante mencionar que não houve divisão a priori entre as fases, razão pela qual muitos dos tipos ocorrem em diferentes fases. Estas últimas foram estabelecidas a partir de elementos que extrapolam a materialidade dos objetos: além de suas características físicas, analisou-se o contexto no qual se inserem, ou seja, buscou-se compreender os objetos e seus elementos constitutivos a partir do que se apreendeu de seus significados. Por exemplo, um mesmo tipo de grandes vasilhas denominado "alguidar"14 ocorre em abundância nas três fases identificadas. Seus elementos definidores são semelhantes: basicamente sua forma e seu fabrico. Assim sendo, a ausência de informações contextuais impossibilitaria a vinculação deste tipo de vasilhas a uma ou outra fase cerâmica. É apenas quando olhamos toda a conjuntura na qual se insere o objeto que conseguimos identificar sua filiação. Ao ver o alguidar emborcado sobre uma clássica urna funerária Paredão, num sítio cemitério composto por terra preta, é que fazemos a ação lógica de vincular esta ordinária vasilha à fase Paredão, que neste caso assume uma função outra que a doméstica, passando a ser um aparato funerário (a tampa da urna). Desse modo, a ocorrência deste mesmo tipo de vasilha associado a estruturas de combustão ou marcas de utilização remetendo ao cozimento, em uma estratigrafia profunda e em uma matriz de solo não modificado antropicamente e com datações antigas, nos leva a associá-la à fase Açutuba, que tem características condizentes.

Assim, mais do que a associação a fases cerâmicas, o objetivo se torna entender o papel do artefato dentro do contexto em que se encontra. E a coocorrência de um mesmo tipo em diferentes fases pode ter diversos significados, e é este o objetivo pleiteado. Esta escolha metodológica de priorizar os tipos às

\footnotetext{
${ }^{14}$ Alguidar é a denominação local dada a grandes bacias utilizadas nas atividades domésticas.
} 
fases foi, portanto, intencional, ao evitar que o normativismo inerente à aplicação tradicional dos conceitos de fase e tradição fosse uma restrição classificatória e interpretativa.

Feitas as tipologias, as fases acabaram por ser definidas com base em outros elementos que não apenas a variabilidade cerâmica. Entraram em discussão datas, estratigrafia, inferências de uso, características ambientais etc., ou seja, uma série de indicativos contextuais que levaram à vinculação dos conjuntos tipológicos às fases em questão. Como se viu nas descrições das coleções cerâmicas anteriores, esta filiação não é nada simples e, obviamente, está sujeita a modificações à medida em que novos trabalhos sejam feitos e avancem nas questões aqui colocadas. Da imensa quantidade de cerâmicas analisadas, poucos foram os fragmentos ou vasos que puderam ser enquadrados nos tipos ou fases cerâmicas, o que torna esta análise bastante conservadora, em certo sentido.

Foi analisado um total de 7.789 fragmentos ou vasos, distribuídos de maneira não uniforme em nove sítios arqueológicos da área de pesquisa do PAC (tabela 16). Nem todas as coleções analisadas resultaram em tipologias, pois para o estabelecimento dos tipos é necessário que os fragmentos apresentem um grau mínimo de preservação, nem sempre visto nos sítios estudados. Ao final, ficaram estabelecidos vinte tipos cerâmicos para a Tradição Borda Incisa, sendo dezesseis vinculados à fase Açutuba, treze à fase Manacapuru e dez à Paredão (tabela 17).

\begin{tabular}{|l|c|}
\hline Sítios arqueológicos & Qtd. de fragmentos analisados \\
\hline Açutuba & 2622 \\
\hline Cachoeira & 55 \\
\hline Paricatuba & $1 *$ \\
\hline NSP Socorro & $232+1^{*}$ \\
\hline Hatahara & 659 \\
\hline Jacuruxi & 3139 \\
\hline Osvaldo & 363 \\
\hline Lago Grande & 951 \\
\hline Nova Cidade & $21 *$ \\
\hline
\end{tabular}

* vasos inteiros

Tabela 16 - Quantidade de fragmentos ou vasos inteiros analisados em cada coleção arqueológica. 
Das tipologias realizadas, se apreende que a variabilidade interna inerente à fase Açutuba é bem maior do que nas outras fases, sugerindo que, caso haja uma continuidade cultural, como proponho, haveria um aumento da quantidade de peças produzidas concomitante a uma crescente padronização interna às fases. $\mathrm{O}$ argumento será desenvolvido adiante.

Como se pode ver, seis dos vinte tipos estabelecidos ocorrem nas três fases arqueológicas, ou seja, têm uma persistência temporal de pelo menos mil anos. São eles as cuias, os assadores, alguidares, tigelas, vasos globulares e pratos, majoritariamente objetos de uso cotidiano, relacionados ao processamento ou armazenamento de alimentos ou utilizados para servir. As freqüências relativas destes tipos aumentam ao longo do tempo, ao passo em que a variabilidade geral diminui. Em relação às demais categorias de objetos, ressalta-se a maior semelhança entre os materiais das fases Açutuba e Manacapuru do que destes em relação à fase Paredão. Um fator explicativo pode ser o forte adensamento populacional observado neste período mais recente: a quantidade de sítios e a densidade de vestígios vinculados a esta fase supera qualquer outro período, anterior ou posterior, da história pré-colonial regional.

Dois dos tipos que diferenciam os materiais Açutuba daqueles da fase Manacapuru, as vasilhas com flanges mesiais e os vasos com colo, merecem especial atenção. Eles, em conjunto com algumas características como a pintura policrômica, apresentam uma semelhança muito forte com os materiais mais recentes da área de pesquisa, relacionados à fase Guarita da Tradição Policroma e remetem a outra história, aparentemente desvinculada do continuum entre as fases apontado neste trabalho. Também aqui há uma discussão que será retomada em detalhe mais adiante. Os dois outros tipos cerâmicos que diferenciam essas fases, as tampas ou baquetas e as gamelas poligonais, apresentam um tratamento decorativo bastante aprimorado, aplicado a pastas relativamente porosas. Esta constatação nos remete mais uma vez ao fato apontado de que, quanto mais antigo for o conjunto, mais rebuscada será sua decoração, e menor o esmero tecnológico. A validade de tal observação se restringe ao caso estudado na Amazônia central.

Finalmente, merecem atenção os tipos que diferenciam a fase Paredão das anteriores: as cestas com alças, os vasos com pescoço e potes com gargalo. Este último tipo refere-se às "clássicas" urnas funerárias, encontradas em abundância 
nos sítios arqueológicos da região. Trata-se de grandes vasos que têm alguma semelhança morfológica com um tipo Manacapuru de vasos com contorno complexo, encontrados com menos freqüência, e não em contextos funerários. Pode-se aventar a ocorrência de uma interessante apropriação de certa categoria de vasos para dar a ela um novo fim. Isto, no entanto, ainda não está claro.

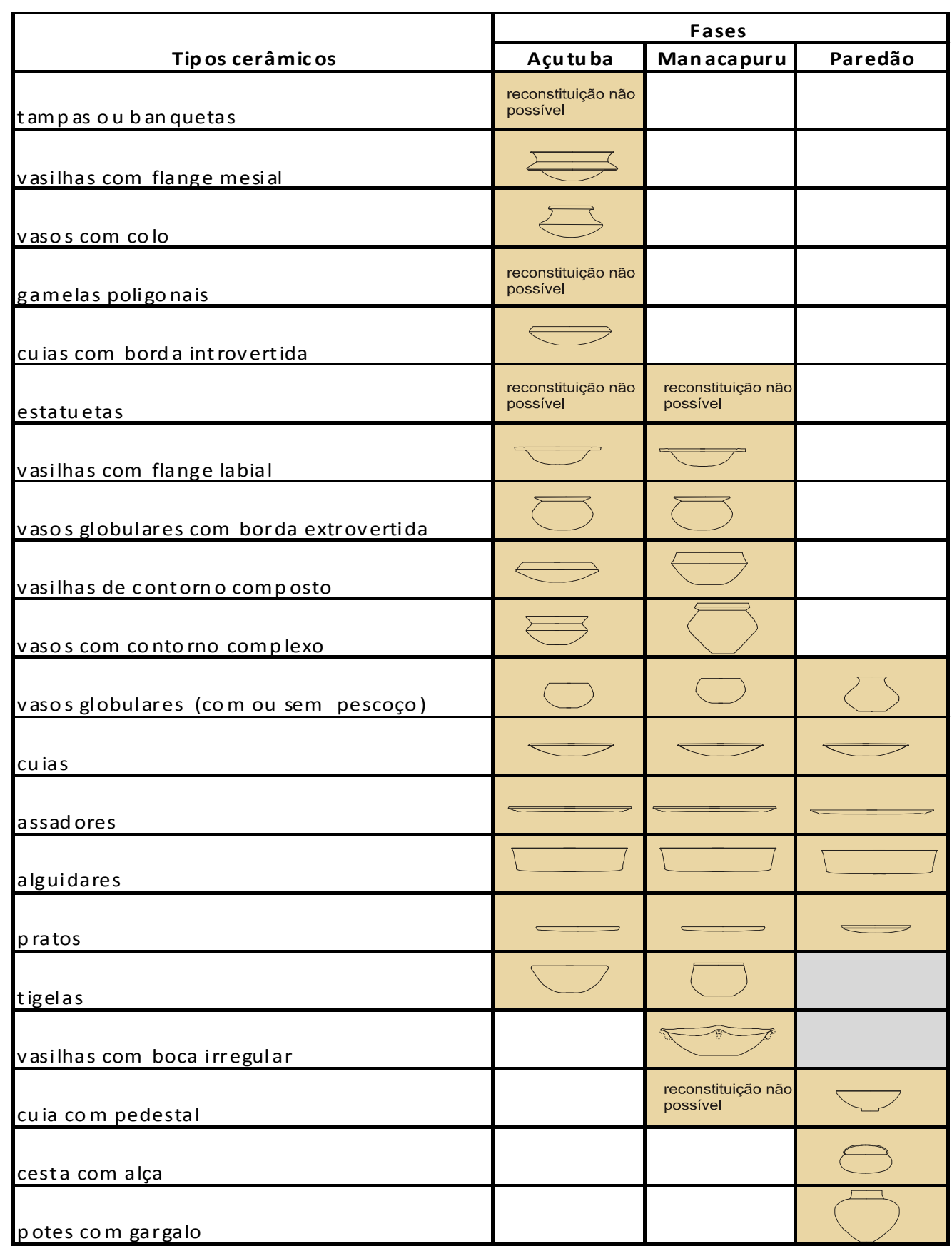

Formas identificada na tipologia Paredão de Moraes (2006) para cerâmicas de sítios arqueológicos do Lago do Limão, mas não encontradas nos materiais analisados.

Tabela 17 - Tipos cerâmicos por fase arqueológica. 
Da mesma forma, as freqüências dos tipos cerâmicos podem dar valiosas informações sobre a passagem do tempo. Por exemplo, os já mencionados tipos que co-ocorrem nos três períodos, a saber, cuias, alguidares, assadores e pratos (objetos de uso doméstico e cotidiano), tendem a aumentar em freqüência relativa ao longo do tempo com a fase Paredão, o que é um indicativo de uma maior necessidade de produção destes itens, que se daria no caso de adensamento populacional: mais gente, mais objetos necessários ao uso cotidiano. Esta tendência vem acompanhada da redução dos tipos decorados, em detrimento dos simples, em toda a coleção.

Mas, inferências desta natureza devem ser tomadas com certa ressalva. Tal como apresentadas na tabela a seguir, as freqüências não podem ser tomadas como no método quantitativo da seriação, que refletiriam a popularidade dos tipos cerâmicos ao longo de um vetor temporal. Como vimos, para que tal método surtisse o efeito desejado, a amostragem deveria ser de, no mínimo, cem cacos, e estes representariam a variabilidade encontrada no sítio arqueológico (Meggers, 1970, p.12-13). Neste caso, as amostragens utilizadas diferem muito de sitio para sitio, além da própria natureza das coleções, algumas compostas majoritariamente por fragmentos, enquanto outras foram compostas apenas por recipientes inteiros.

Assim, para embasar inferências cronológicas, tanto entre quanto intrafases, a análise tipológica foi associada a uma observação modal, ou seja, um registro (neste caso, qualitativo) de conjuntos de atributos que permeiam os diferentes tipos. Tal observação somente pôde ser empreendida após o estabelecimento da tipologia e conseqüente reconhecimento da variabilidade formal das coleções, uma vez que estes conjuntos de atributos, denominados modos, vinculam forma e as demais características da cerâmica. Neste sentido, a identificação dos modos nada mais é do que uma tentativa de apreensão das unidades mínimas de significado, inerentes às coleções (Rouse, 1996). E, neste sentido, a decoração é entendida como um conjunto de regras que estruturam a composição das unidades mínimas de sentido, formando os motivos e sua aplicação à forma do vaso (Raymond, 1985, p. 230). Suas recorrências são estruturadas quase como um vocabulário que diz respeito a determinados períodos internos às fases e, como dito, entre elas. Essas considerações são apresentadas ao final da descrição de cada fase cerâmica, que se encontra a 
seguir. Assim, buscou-se o comportamento associado ao artefato: tanto em termos de como ele foi feito (comportamento de manufatura), quanto em termos de como foi utilizado (sua função) (Rouse, 1996).

Tais observações foram realizadas no sentido de embasar a hipótese de trabalho, que pleiteia que a fase Manacapuru, e posteriormente a Paredão, seriam desenvolvimentos in loco da fase Açutuba na Amazônia central, mas sob forte influência de uma esfera de interações culturais, que abrangeu as terras baixas da América do Sul setentrional, da qual esta região seria parte. Para tanto, foi necessário identificar mudanças cronológicas também internas às fases cerâmicas, tal como se discutirá a seguir.

\begin{tabular}{|l|c|c|c|c|c|c|c|}
\hline \multicolumn{1}{|c|}{ Tategorias } & \multicolumn{6}{c|}{ Fases X Sítios arqueológicos } \\
\hline & Hat & Jacu & Açut & Osv & Jacu & NC & LG \\
\hline & $1 \%$ & $11 \%$ & $2 \%$ & & & & \\
\hline tampas ou banquetas & & $56 \%$ & $2 \%$ & & & & \\
\hline vasilhas com flange mesial & & $33 \%$ & $2 \%$ & & & & \\
\hline gamelas poligonais & $6 \%$ & & & & & & \\
\hline vasos com colo & $6 \%$ & & & & & & \\
\hline cuias com borda introvertida & & & $3 \%$ & $39 \%$ & $6 \%$ & & \\
\hline Tigelas & & & $2 \%$ & $1 \%$ & & & \\
\hline Estatuetas & $27 \%$ & & $36 \%$ & $8 \%$ & $12 \%$ & & \\
\hline vasilhas com flange labial & $5 \%$ & & $9 \%$ & $9 \%$ & $8 \%$ & & \\
\hline vasos globulares com borda extrovertida & $8 \%$ & & $2 \%$ & $2 \%$ & $3 \%$ & & \\
\hline vasilhas de contorno composto & $12 \%$ & & $2 \%$ & $7 \%$ & $13 \%$ & & \\
\hline vasos com contorno complexo & $3 \%$ & & $6 \%$ & $9 \%$ & $3 \%$ & & $4 \%$ \\
\hline vasos globulares (com ou sem prescoço) & $12 \%$ & & $9 \%$ & $19 \%$ & $31 \%$ & $5 \%$ & $40 \%$ \\
\hline Cuias & & & $5 \%$ & & & & $3 \%$ \\
\hline Pratos & $20 \%$ & & $16 \%$ & $6 \%$ & $17 \%$ & $17 \%$ & $11 \%$ \\
\hline alguidares & & & $4 \%$ & & $1 \%$ & $2 \%$ & $4 \%$ \\
\hline Assadores & & & & & $5 \%$ & & \\
\hline vasilhas com boca irregular & & & & & $1 \%$ & $2 \%$ & $*$ \\
\hline cuia com pedestal & & & & & & $61 \%$ & $27 \%$ \\
\hline cesta com alça & & & & & & $13 \%$ & $11 \%$ \\
\hline potes com gargalo & & & & \\
\hline
\end{tabular}

* tipo contabilizado junto à cuias.

Tabela 18 - Freqüências de tipos coleções mais representativas. 


\section{III. As fases propriamente ditas}

Com base no que já foi exposto, desde as descrições detalhadas de cada sítio arqueológico, de cada coleção tratada e as tipologias resultantes, procedeuse à caracterização das fases cerâmicas, cujos componentes artefatuais são apresentados a seguir.

\section{III. I. Cerâmicas da fase Açutuba}

Materiais relacionados a esta fase aparecem em quantidade considerável, o que poderia remeter a uma ocupação mais intensa, apenas em dois sítios: Hatahara e Açutuba. Apesar disso, se percebe que ela se encontra espalhada por vários locais da Amazônia central, em torno de dois mil anos atrás, em pequenas concentrações de material, sempre em substratos profundos e em matrizes de solo não antrópicas. Esses materiais também foram encontrados em alguns dos sítios trabalhados por esta pesquisa, como Osvaldo e Lago Grande. Em relação aos locais em que o material aparece em profusão, tais concentrações, apesar de não serem tão bem compreendidas, podem ter uma seqüência cronológica bastante longa e, quiçá, contínua. Apesar de serem assentamentos sedentários, seu tamanho é reduzido. Embora haja uma grande quantidade de cerâmica com funções domésticas e utilitárias, impressiona o número de fragmentos decorados em relação ao total, o que pode ter implicações interessantes para a compreensão de tal variabilidade.

Vinculada a essa fase cerâmica, nos sítios que indicam uma ocupação mais intensa, encontra-se uma série de estruturas associadas a esses materiais. Ainda que não tenhamos entendido perfeitamente suas funções, elas aparentam ser de dois tipos. Um deles foi interpretado como uma espécie de "midden" (lixeira), um acúmulo intencional de refugos de uso cotidiano, que tem como diferencial a grande quantidade de fragmentos decorados em sua composição, da mesma forma que em todo o piso de ocupação encontrado em ambos os sítios. $\mathrm{O}$ outro tipo, comumente percebido como feições de solo produzidas em diferentes eventos deposicionais, conta com uma altíssima quantidade de material cerâmico decorado, em número bastante superior ao encontrado no piso de ocupação. Tais feições não puderam ter sua finalidade inferida, mas certamente elas se inserem em um contexto de transformação da paisagem vigente. A dificuldade de acesso, principalmente por ocupar camadas estratigráficas profundas, se coloca como um 
fator de impedimento para que se encontrem outros sítios que apresentem um maior adensamento de materiais, e que possibilitem inferências mais precisas acerca destas estruturas.

Além de serem apenas dois os sítios encontrados que forneceram cerâmicas em grande quantidade, nem sempre os materiais estão bem preservados. Ao contrário do que acontece no sítio Açutuba, as condições do sítio Hatahara propiciaram ao contexto um melhor estado de preservação, permitindo que fossem identificados vestígios faunísticos (principalmente de quelônios) em meio ao piso de ocupação. Entretanto, não foram encontrados resquícios ósseos humanos, em nenhuma circunstância. Aliado a isso, é importante salientar a ausência de aparatos funerários em meio à indústria cerâmica, ao menos dentre as funções que puderam ser inferidas.

As cerâmicas que compõem a fase Açutuba apresentam pastas com características variadas, mas quase sempre são leves e porosas. Alguns tipos de pasta se destacam. Uma primeira, de cor branca, aparece sempre associada a uma categoria de vasilhas, com formas de contorno complexo e com pintura policrômica. A segunda, também bastante característica dessa fase, tem um forte tom alaranjado e sua leveza e porosidade se destacam entre as demais. Esta pasta apresenta uma grande abundância de cauixi como tempero, apesar de este estar presente na maior parte dos fragmentos. Outro traço marcante desta pasta é a sua associação com a pintura e com alguns tipos cerâmicos bem característicos desta fase, como as estatuetas modeladas e as formas poligonais. As demais pastas, que ordinariamente aparecem distribuídas por todas as categorias, variam em tonalidades de bege-alaranjado, laranja-amarronzado e cinza. Além do cauixi, apresentam em menor proporção outros anti-plásticos misturados, como grãos de quartzo e hematita, componentes das próprias argilas. Outros aditivos também são utilizados, podendo aparecer em menor proporção junto ao cauixi ou podem, em casos mais raros, ser o componente principal do tempero. São eles, em ordem de freqüência, o cariapé (fibras de entrecasca queimada de certas árvores da espécie Licania), o caco moído e nódulos de argila.

Também as queimas apresentam certa variação no tocante às formas e, principalmente, tipos de pastas. No entanto, observa-se uma maior freqüência de queimas em ambientes oxidantes. Como exemplo, as pastas anteriormente citadas, nas cores branca e laranja-forte, são sempre oxidadas, enquanto as 
demais variedades de pasta apresentam uma grande variabilidade. Devido às condições gerais de preservação, que variam entre os sítios e, talvez, à sua antigüidade, as características de sua superfície nem sempre puderam ser observadas. Dessa forma, o tratamento de superfície mais detectado foi o alisamento seguido pelo escovado, em detrimento de outras técnicas mais elaboradas, como a aplicação de resinas ou o polimento.

Essas cerâmicas são caracterizadas por uma variação formal extremamente ampla. Como se pode ver na figura 112, há certa tendência para as formas irrestritivas. Ao rebuscamento da decoração, soma-se uma grande complexidade dos contornos dos vasos. A região próxima da borda (pescoço ou flange) é sempre mais espessa do que o corpo da vasilha, de maneira geral, sendo uma região preferencial para a aplicação da decoração. Esta, quando ocorre no bojo dos vasos, é uma extensão dos motivos das bordas, relacionada à composição da decoração total da vasilha. Neste mesmo sentido, os flanges labiais, que ocorrem com bastante freqüência, são locais onde a decoração também é recorrente: todos apresentaram algum tipo de tratamento decorativo.

Os flanges labiais, assim como os lábios expandidos, consistem numa acentuada expansão externa da borda, a partir de um ponto de inflexão que geralmente dista entre 2 e $5 \mathrm{~cm}$ do lábio. São fabricados em separado, obtidos pela união de dois ou mais roletes, que são posteriormente afixados no corpo do vaso, já no estágio de secagem. A união entre o rolete do corpo e o rolete do flange é feita através de um encaixe: fissuras em sentido oposto ao do rolete, obtidas por um instrumento pontiagudo ou pela própria unha, são feitas sobre as extremidades a serem unidas, criando um encaixe. Uma vez afixado o flange, o ponto de união é recoberto por uma camada de argila em estado bastante plástico, e posta para secar. Flanges labiais são muito freqüentes entre os materiais da fase Açutuba, podendo ser considerados como um traço diagnóstico desta fase cerâmica. Uma variada gama de técnicas e motivos decorativos são aplicados em sua face superior, a mais visível. Entre as técnicas utilizadas, excisões, incisões e modelagens muitas vezes se associam a apêndices zoomórficos. Os lábios são sempre planos e cortados.

Além dos flanges labiais, outros elementos morfológicos e estruturais característicos são flanges mesiais, apliques, apêndices modelados e estatuetas. Estes últimos, em geral com fins decorativos, são produzidos através de 
modelagem. Com exceção deles, a técnica de produção dos vasos é sempre a de sobreposição de roletes.

Os flanges mesiais são formados pela adição de um ou mais roletes a meia altura da parede externa dos vasos, dando-Ihes uma forma bastante singular. Embora sejam um elemento típico da fase Guarita da Tradição Policroma da Amazônia, os flanges mesiais ocorrem também entre os materiais da fase Açutuba, em pequena quantidade. É interessante notar que um elemento definidor da fase Guarita ocorre também na fase Açutuba, mas não nas fases Manacapuru e Paredão, intermediárias a elas.

Como mencionado, esta indústria se utiliza largamente da modelagem como recurso decorativo. Trata-se, em geral, de apêndices aplicados na borda ou no lábio dos vasos, representando figuras antropomorfas, zoomórficas (especialmente répteis e aves), e abstratas. Estão sempre associados a outras técnicas decorativas, como incisões de todos os tipos e pintura. Em pratos ou vasilhas muito abertas os apêndices são uma extensão modelada de flanges labiais. Ocorrem também em grandes tigelas, provavelmente adquirindo função utilitária, como alça.

Traço diagnóstico das cerâmicas Açutuba é o rebuscamento das decorações plásticas. As incisões, finas ou largas e, na maioria das vezes, em linhas simples, são o componente decorativo mais recorrente nestas cerâmicas. Estão presentes na quase totalidade dos fragmentos decorados, associadas com freqüência a outras técnicas decorativas como a modelagem e a pintura. Um tipo característico de incisão que aparece quase sempre nestes materiais é aquele executado sobre a superfície da cerâmica já seca e queimada, e com engobo vermelho. É uma prática realizada com uso de instrumento pontiagudo, dando um efeito bem diverso daquela feita antes da queima. Esta técnica é comumente encontrada com excisões, nos materiais da fase Marajoara (tradição Policroma).

Aparecem também excisões e acanalados, sendo estes últimos geralmente aplicados na face externa dos vasos, na região logo abaixo do flange labial ou do pescoço. Podem ser recobertos por engobo vermelho ou por pintura em cores. A quantidade de fragmentos pintados é proporcionalmente inferior àqueles que recebem decoração plástica, mas a presença desta técnica em materiais tão antigos na Amazônia central chama atenção por diversos fatores, alguns deles já mencionados. Suas características técnicas são a aplicação de 
uma prévia camada de engobo branco sobre a superfície do pote, e posterior pintura em linhas finas, faixas grossas ou em áreas, em diferentes tonalidades de alaranjado, vermelho, marrom e vinho. São muito semelhantes, em diversos aspectos, às cerâmicas Pocó, do baixo Amazonas. A estes conjuntos foi atribuída uma influência Saladóide, como se verá adiante. Cabe salientar que, a esta pintura, quando encontrada em contextos profundos, pode ser atribuído um caráter diagnóstico desta fase cerâmica.

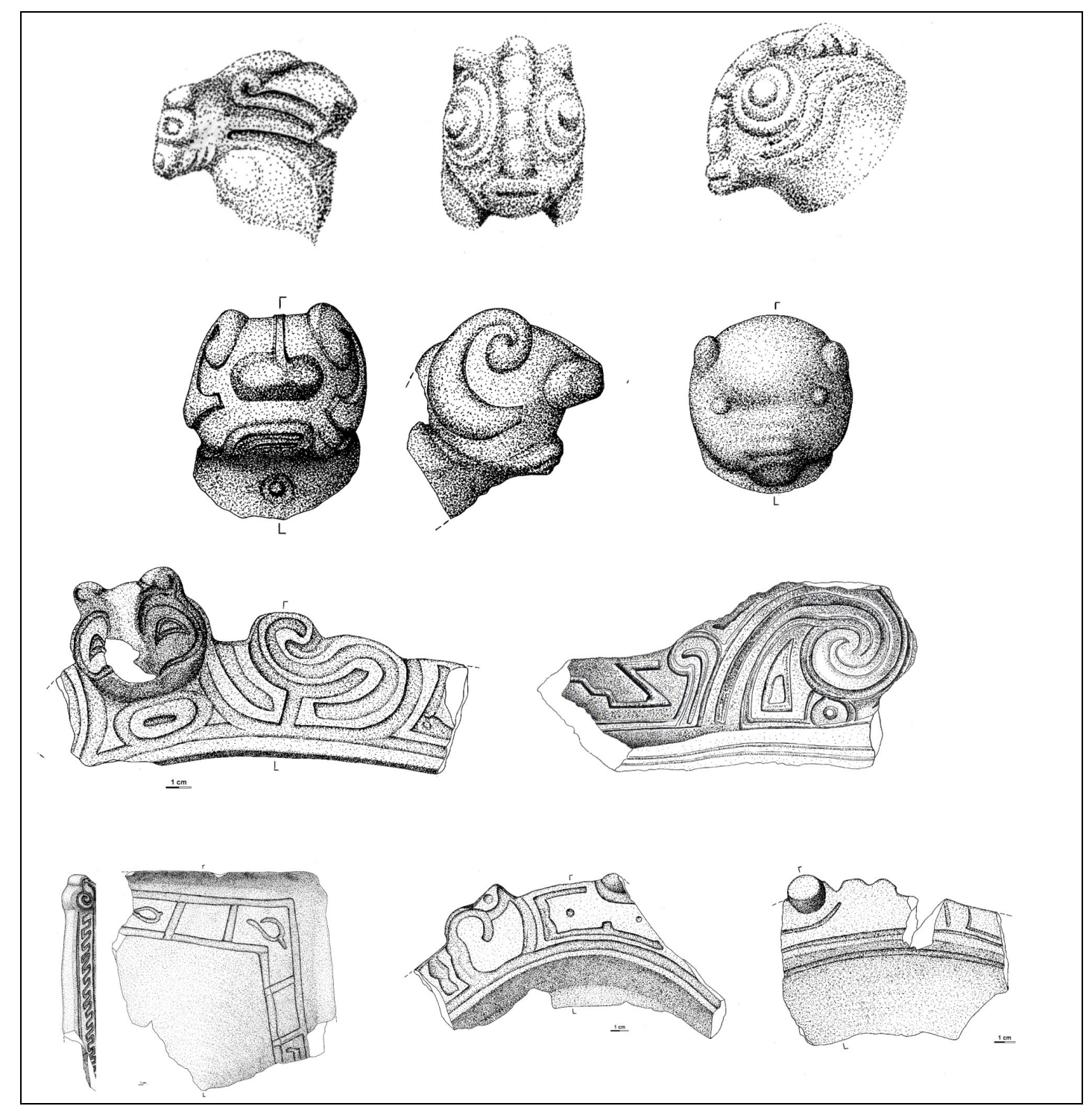

Figura 111 - Apliques modelados e fragmentos decorados Açutuba, dos sítios Açutuba e Hatahara (desenhos: Val Moraes e Marcos Brito). 


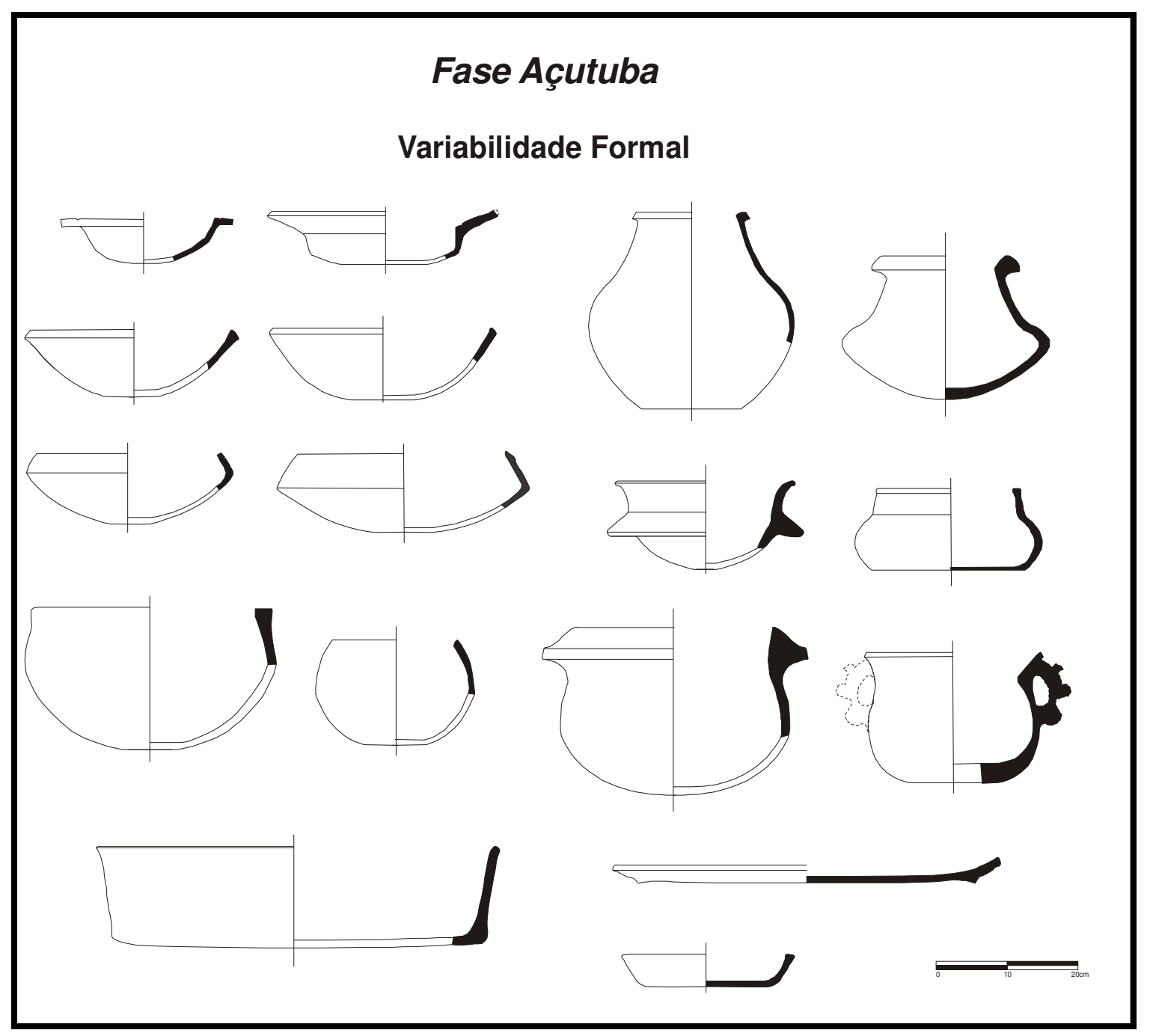

Figura 112 - Variabilidade formal Açutuba

\section{Modos com implicações cronológicas}

Fase Açutuba, modo Pintura Saladóide

A pintura policrômica é aplicada num tipo especifico de argila, leve e pouco densa, de coloração branca ou bege. Os tipos cerâmicos que recebem este tratamento são caracterizados por vasilhas de contornos compostos ou complexos. Esses materiais são similares aos da série Saladóide encontrada na Venezuela e Caribe, e às cerâmicas Pocó, do baixo Amazonas. Tanto no sítio Açutuba como Hatahara estes fragmentos ocorrem apenas nos níveis mais profundos: seu uso é abandonado, em detrimento das decorações plásticas. 
Fase Açutuba, modo Incisões em Gregas

Este modo apresenta variações, porém sempre obedecendo a certos padrões. Incisões em linhas finas com motivos em gregas, zig-zag, ou ondulados, sempre simétricos, são aplicadas na parte superior dos flanges labiais. Incisões lineares simples ou duplas são aplicadas nas extremidades das mesmas, funcionando como divisores que delimitam a área decorada. Na parte inferior dos flanges, na divisão entre esta e o corpo da vasilha, aplicam-se acanalados lineares, que dividem as duas secções do vaso. Essas linhas acanaladas podem ou não dar continuidade a motivos geométricos que são aplicados na face externa, onde pode também ocorrer engobo vermelho. As gregas e variantes são substituídas ao longo da seqüência estratigráfica por motivos mais curvilíneos e mais rebuscados.

\section{Fase Açutuba, modo Incisões Rebuscadas}

As regras de aplicação deste motivo inciso são as mesmas que regem o modo anterior. De fato, estas parecem substituir as incisões em gregas, sendo, provavelmente, mais recentes. São mais comuns no sitio Hatahara.

\section{III. II. Cerâmicas da fase Manacapuru}

Os sítios em que se encontram materiais relacionados à fase Manacapuru são bem mais numerosos do que os sítios com materiais Açutuba. Possuem geralmente depósitos mais extensos e, via de regra, estão sobre solos antrópicos, as terras pretas de índio. É interessante também que esta associação entre materiais da fase Manacapuru, o tamanho dos sítios e a presença de terra preta já havia sido feita por Hilbert (1968) e confirmada pelos trabalhos realizados pelo Projeto Amazônia Central, ao encontrar sítios com estas mesmas características, como os sítios Osvaldo, Açutuba e Hatahara, sem mencionar muitos outros que não constam neste doutoramento.

Mais interessante ainda é notar que também foram encontrados sítios contendo materiais associados à fase Manacapuru com datações antigas, em matrizes de solo modificadas antropicamente, com depósitos rasos e que ainda não possuem as tonalidades peculiares às terras pretas, sendo mais claras e com menor densidade de material orgânico, o que indicaria um caminho intermediário no processo de constituição desses solos. Conforme estabelecido pelos 
parâmetros de Hilbert, e seguido pelo PAC durante certo tempo, esta fase cerâmica era pensada dentro de uma seqüência cronológica que ia do séc. VI ao IX, de acordo com os estudos dos sítios até então realizados. No entanto, evidências de materiais mais antigos desta fase, advindos de sítios identificados a partir da intensificação dos trabalhos, como o Jacuruxi e Nossa Senhora do Perpétuo Socorro, acabaram por fornecer datas recuadas, este último entre os séculos I e III. Dentro de uma perspectiva normativista seria compatível com a ocupação Açutuba, mas foi justamente o contexto observado em sua totalidade que nos permitiu inferir sua filiação a uma e não à outra fase: tamanho do sítio, presença de terras pretas em processo de formação, ausência de características diagnósticas no material cerâmico (como a policromia, por exemplo), entre outros. Este sítio é uma peça-chave para entender a relação que há entre estas duas fases.

Estudos realizados no âmbito do PAC também têm caracterizado formas de assentamento circulares relacionadas à fase Manacapuru, como é o caso do sítio Osvaldo (Abreu, 2000; Portocarrero, 2007).

Quando se pensa na caracterização das cerâmicas deste conjunto, há uma questão importante que se coloca. A fase anteriormente descrita, Açutuba, tem um caráter quase inédito, à exceção de um único artigo publicado por membros da equipe do PAC (Lima et al, 2006). Já a fase Manacapuru foi descrita em detalhes por P. Hilbert, tendo sido definidos seis tipos que, de certa forma, já dão conta de uma caracterização geral do conjunto. Dentro destes tipos há o nãodecorado, que perfaz $85 \%$ do total de fragmentos, sempre temperados com 0 cauixi. Os outros tipos são assim denominados: engobo vermelho, incisão em linhas finas, incisão em linhas largas, incisões duplas e modelado (os tipos de Hilbert encontram-se descritos no apêndice).

As cerâmicas contam com um número relativamente grande de fragmentos decorados, mas a proporção é bem menor do que o observado nas cerâmicas mais antigas. Assim como em qualquer coleção, essas cerâmicas são bastante diversificadas e, em relação à pasta, que varia de acordo com uma série de fatores, somente um tipo se destaca nesta indústria. Este possui, em geral, coloração marrom-acinzentada, queima preferencialmente redutora, e uma consistência densa e pesada, com um maior grau de dureza. $\mathrm{O}$ fato da queima ser feita em ambiente redutor não faz com que sua qualidade diminua. Ao 
contrário, essas pastas são mais duras e resistentes do que aquelas da fase Açutuba. Ainda quanto à pasta, o cauixi é o tempero preponderante, com incidência de outros anti-plásticos misturados a ele, em menor proporção, como o caco moído, nódulos de argila e o cariapé, que é quase inexistente. Há quartzo e hematita na quase totalidade dos fragmentos analisados. Quanto aos acabamentos de superfície, a quantidade de fragmentos que apresentaram polimento ou algum tipo de enegrecimento foi bem maior do que se pôde perceber nas cerâmicas Açutuba. Entretanto, a principal causa deste fato pode ter sido o estado de conservação destes materiais, como já explicitado.

A variabilidade formal, tal como se pode ver na figura 112, é menor e há uma sensível tendência a vasos com formas mais restritivas. Foram encontrados, em diversos sítios, grandes vasos com gargalo carenado (tipo contorno complexo), recobertos por alguidares emborcados sobre eles, que assumiram a função de tampa, muito semelhante àquelas encontradas em urnas, localizadas em sítios-cemitério Paredão, embora o contexto aqui não seja funerário. Mais uma vez não se observaram evidências de aparato funerário, embora a conservação possa ser um dos motivos para tanto.

Do mesmo modo que na fase Açutuba, há uma recorrência em modificar a estrutura do vaso com vistas a tornar os lábios e pescoços dos vasos mais visíveis, proeminentes. Estas serão as áreas preferencialmente utilizadas para aplicação da decoração, em geral, plástica. Mais uma vez, a plasticidade é uma marca desta indústria, tanto no que tange às formas quanto às decorações. De fato, pela tendência a formas restritivas, a presença de flanges labiais é menor que na fase Açutuba, e estes são substituídos pelas bordas extrovertidas. A técnica e o objetivo desta extroversão são sempre os mesmos nos flanges e nos lábios expandidos. A diferenciação entre um e outro é a alteração do volume do vaso. Os flanges labiais não alteram o volume, enquanto os lábios expandidos, sim. Há também uma recorrência de apêndices e apliques modelados, bem como alguns exemplares de estatuetas, sempre decorados através de uma combinação de técnicas que, assim como em Açutuba, apresenta uma grande quantidade de motivos zoomórficos, com preferência pelas aves. Flanges mesiais são ausentes.

Engobo vermelho foi considerado por Hilbert como um tipo da fase Manacapuru, apesar do autor ter notado que em alguns casos ele surge em associação com outras técnicas decorativas, principalmente as incisões. Nossa 
análise confirmou essa observação de Hilbert, percebendo-se que essa técnica decorativa ocorre na grande maioria das vezes associada a outras, e quase nunca é exclusiva em um fragmento. Concluiu-se, portanto, que o engobo vermelho, ao invés de elemento definidor de tipo, é um complemento das diversas técnicas decorativas. Como diferenciador entre as cerâmicas Manacapuru e Açutuba, no que diz respeito às decorações incisas, está uma maior freqüência de incisões duplas ou múltiplas, em geral formando motivos retilíneos e geométricos, ao invés das incisões simples, com motivos curvilíneos e circulares do conjunto mais antigo. Técnicas que deixam de aparecer por completo são as excisões e a pintura policrômica. Surgem como acabamentos decorativos as técnicas de ponteado, ungulado e digitado, aplicados comumente nos lábios, e que são muito encontrados também na fase Paredão.

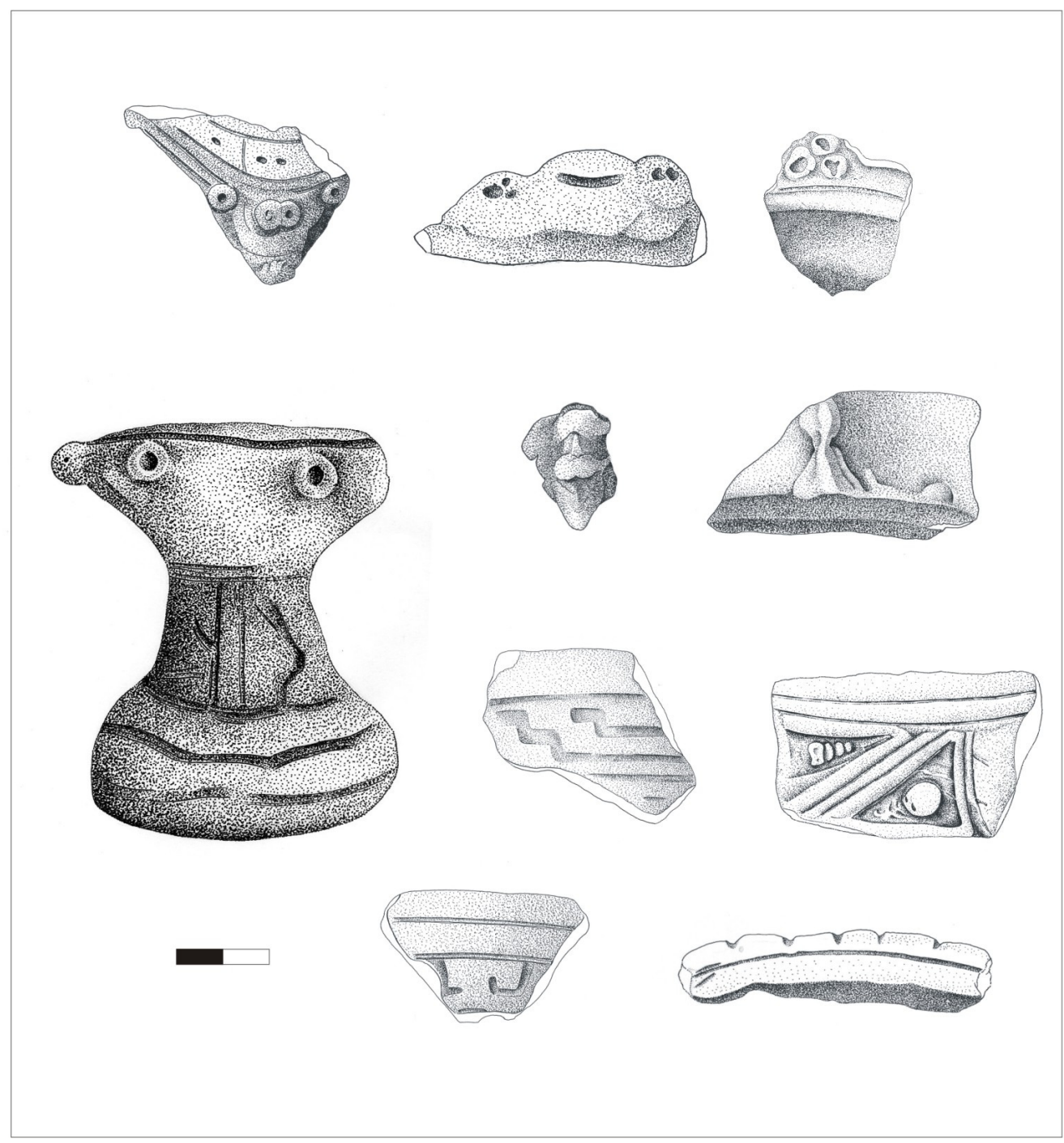

Figura 113 - Fragmentos decorados Manacapuru, dos sítios Osvaldo e Jacuruxi (desenhos: Val Moraes). 


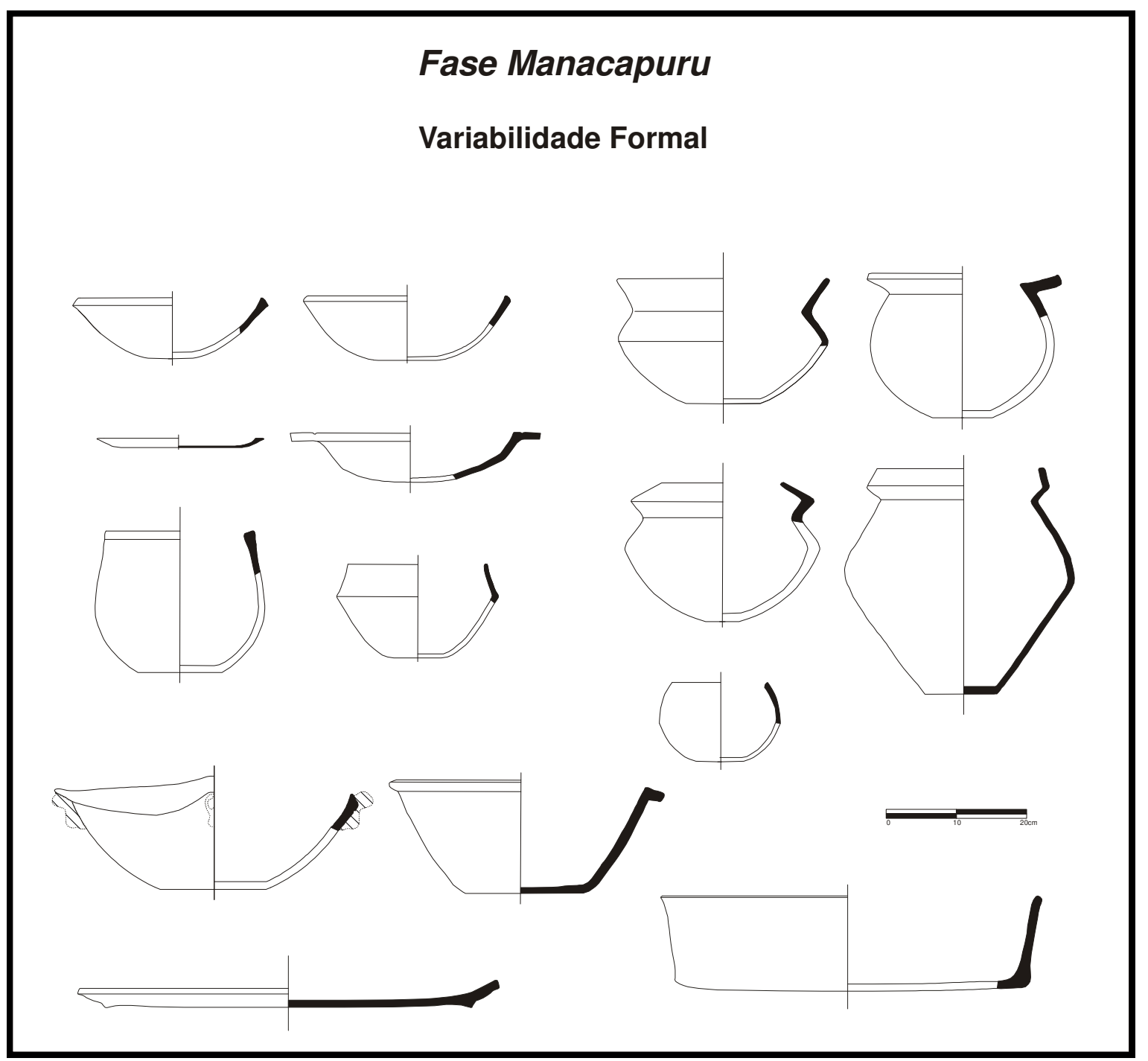

Figura 114 - Variabilidade formal da fase Manacapuru

\section{Modos com implicações cronológicas}

Fase Manacapuru, modo Incisões Múltiplas e Duplas

As incisões em linhas largas e os acanalados tão comuns na fase Açutuba parecem ser substituídos pelas incisões duplas e múltiplas. Estas últimas representariam os momentos mais antigos da fase Manacapuru. As formas de vasos onde elas são aplicadas também mudam: já que os flanges labiais não são mais recorrentes e dão lugar aos vasos com bordas extrovertidas, essas incisões passam a ser executadas na face externa de tigelas de contorno simples, de forma direta ou levemente expandida. 
Fase Manacapuru, modo Lábio Ponteado ou Ungulado

Ocorre apenas nos períodos mais recentes de ocupação Manacapuru (séc. VII-VIII), quando esta co-existe com a fase Paredão, que apresenta o mesmo traço.

\section{III. II. Cerâmicas da fase Paredão}

Ao comparar as três fases cerâmicas e seus contextos, da forma como aqui proposta, veremos que os sítios Paredão se encontram no extremo de uma série de características que continuam e que se acentuam ao longo do tempo. Deste modo, há uma profusão maior de sítios na área de pesquisa, assim como suas dimensões também crescem, indicando um aumento da densidade demográfica. Mais do que isso, uma imensa soma de materiais cerâmicos é encontrada, enterrada sob um profundo e denso pacote de terras pretas antrópicas, carregadas de matéria orgânica. Há, então, evidências mais claras de assentamentos circulares e elipsoidais, compostos por uma série de montículos (mounds e middens), dispostos ao redor de grandes áreas centrais com ausência de materiais, indicando um uso de espaço diferenciado, bem como de outras estruturas que nos informam sobre uma maior alteração da paisagem. A maioria das datações realizadas pelo PAC é de materiais relacionados a esta fase, tornando-a a mais bem conhecida, dentro do projeto, no que concerne à sua cronologia. As datas se concentram em torno dos séculos IX ao XII.

Também este conjunto foi definido por P. Hilbert (1968), em um sítio nos arredores da cidade de Manaus. Ele definiu seis tipos para este material, sendo eles: tipo não-decorado (atende $88 \%$ do material), incisões em linhas finas, pintura vermelha (engobado), incisões duplas, escovado, modelado. Estes tipos foram revistos, justamente em função do grande volume de pesquisas, dentro do PAC, tais como as pesquisas de Donatti (2003), Tamura (2005) e Moraes (2007). Minha tipologia se baseou nestes trabalhos, em grande parte, o que permitiu a caracterização a seguir.

Comparativamente pode-se dizer que estas cerâmicas apresentam uma pasta peculiar. São quase sempre temperadas por cauixi, embora tenham outras misturas, em menor proporção, como caco moído, quartzo e hematita, e ainda carvão, tal como descrito por Moraes (2007). Embora apresentem um núcleo redutor, em sua maioria, estas cerâmicas são muito bem queimadas, 
apresentando um alto grau de dureza. Têm cores, em geral, alaranjadas, e paredes muito finas - esta que, afinal, se mostra outra característica deste conjunto -, mesmo em se tratando de vasilhas de grandes dimensões, o que demonstra um altíssimo controle da matéria-prima e dos processos de fabricação. Ao contrário das cerâmicas Açutuba ou Manacapuru, em que há uma tendência a uma maior espessura nas extremidades labiais e não nas paredes, as cerâmicas Paredão apresentam uma grande quantidade de lábios afilados, invertendo esta tendência.

Ainda que haja variações, a pasta mais característica Paredão é a anteriormente mencionada de cor alaranjada, apresentando este acentuado esmero (trata-se do "Laranja A" da ficha de análise e da tipologia Paredão apresentada por Moraes, 2007, p. 144). Exceto os apliques modelados, a técnica utilizada para a produção desta cerâmica é a de roletes sobrepostos. Embora os tratamentos de superfície mais utilizados sejam o alisamento, seguido pelo polimento, o aspecto deste alisamento é bastante diferenciado dos conjuntos anteriores, devido à maior acuidade no tratamento da pasta.

A variabilidade formal diminui, tornando-se mais padronizada e mais característica, sendo apenas oito as variações formais nos sítios estudados. Entre elas, destacam-se as grandes urnas funerárias, com o formato piriforme e presença de gargalos. Característicos destas urnas são os apliques antropomórficos (as cabecinhas), colocadas em dois pontos opostos ao longo do ombro destes vasos. Além disso, tem-se o largo uso de pedestais e alças. Estes são, de fato, elementos diagnósticos desta indústria. Em suma, a variabilidade formal vista nos conjuntos anteriores é substituído por uma maior padronização destas formas, ao passo em que o rebuscamento da decoração parece dar lugar ao esmero da preparação das pastas.

Outro elemento diferenciador desta fase cerâmica é a larga presença de aparatos funerários. São as já mencionadas urnas, que aparecem em grandes concentrações, e geralmente agrupadas em contextos que aparentam ser exclusivamente funerários. Além disso, os montículos funerários também são um indicativo destas práticas. Em oposição a este aparato específico são observados aqueles elementos de uso cotidiano, tais como assadores e alguidares, cuja manufatura não se diferencia muito dos conjuntos anteriormente descritos, e que constituem um número por demais elevado de fragmentos sem características 
diagnósticas. Ainda em relação aos contextos ligados às atividades quotidianas, há uma enorme abundância de feições associadas a estruturas de combustão, constituídos de trempes feitos a partir de fragmentos grandes e espessos, ou mesmo com barro queimado (Moraes, 2007).

As técnicas decorativas mais observadas são as incisões, neste caso executadas com um instrumento pontiagudo muito fino. Trata-se de materiais pertencentes à Tradição Borda Incisa e, de fato, as técnicas decorativas são preferencialmente executadas em regiões próximas à borda. No entanto, deixa-se de observar aquela tendência a uma maior modificação estrutural dos vasos com vistas a acentuar as decorações em suas proximidades distais, fazendo com que esta área tenha menos exclusividade na escolha de onde se aplicar a decoração. Por exemplo, é comum observarmos pedestais decorados, assim como a face interna e inferior de cuias. Estas cuias, quando decoradas, têm incisões espiraladas em seu fundo na face interna, enquanto os pedestais podem ter incisos lineares finos e apresentar engobo vermelho.

As incisões são, na maioria das vezes, em linhas finas e profundas, realizadas por um instrumento pontiagudo, como mencionado. Estas linhas formam motivos geométricos ou espiralados, em sua maioria. Assim como ocorre na fase Manacapuru, a extremidade dos lábios pode ter um acabamento ungulado ou ponteado. Pequenas esferas aplicadas e, novamente, ponteado, junto às incisões, são utilizadas nas decorações das cabecinhas. Existe também uma outra categoria de apliques, que são pequenos nódulos de argila modelada, aplicados aos alguidares, em dois ou quatro pontos simétricos, com a função de pequenas alças.

As técnicas de pintura voltam a aparecer, mas possuem certas particularidades que as diferenciam tanto das cerâmicas pintadas Açutuba quanto das Guarita (Tradição Polícroma Amazônica). São aplicadas diretamente sobre a superfície polida da cerâmica, e não sobre camadas de engobo. Têm cores vermelho-escuro ou preto, executadas sobre linhas finas, formando motivos geométricos, espiralados ou em gregas, em muitos casos semelhantes aos motivos incisos. Cabe salientar que a variabilidade estrutural dos motivos Paredão não é grande. Como mencionado acima, seus motivos se apresentam como composições geométricas, triângulos e retângulos espelhados, gregas ou linhas paralelas simples. Há também os motivos curvilíneos e espiralados. 


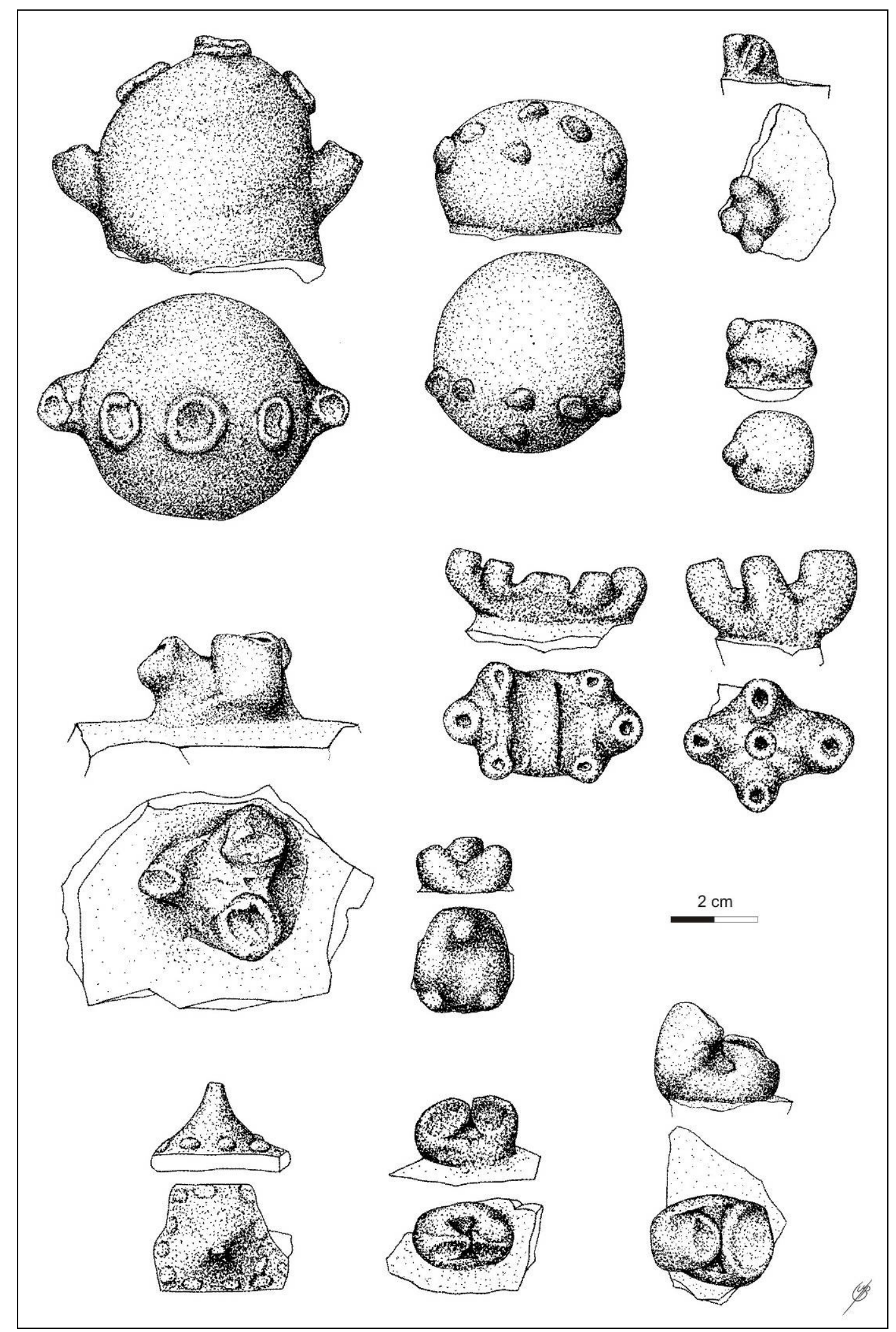

Figura 115 - Apliques modelados Paredão, do sítio Nova Cidade (desenhos: Marcos Briro). 


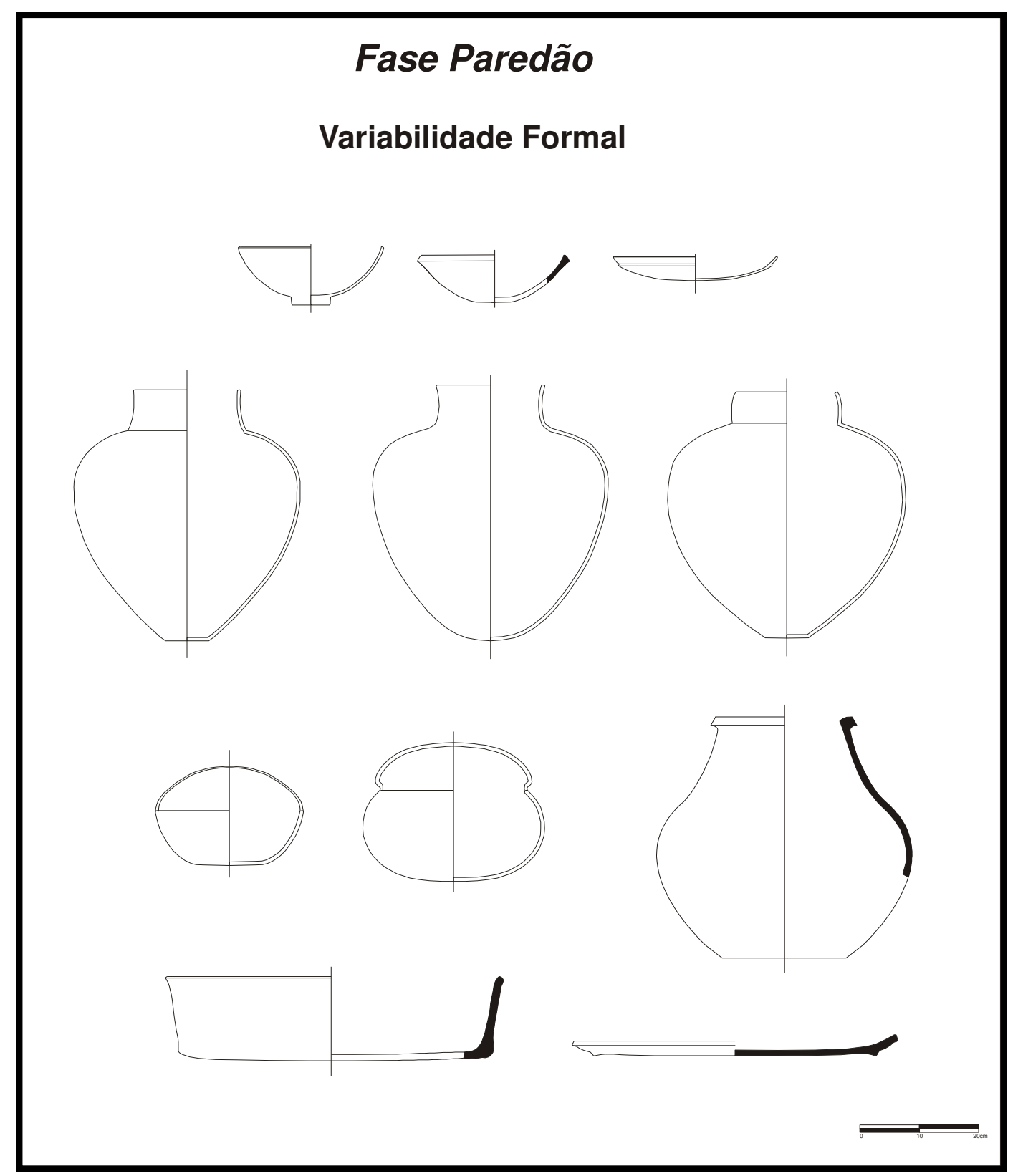

Figura 116 - Variabilidade formal da fase Paredão 


\section{IV. A Tradição Tecnológica Borda Incisa, finalmente}

Pensar em coleções cerâmicas pressupõe a contemplação de todo os elementos envolvidos no processo de produção, uso, reuso e descarte dos diferentes artefatos. As seguintes etapas foram apreciadas no presente estudo:

1) Seleção, coleta e preparo das argilas.

2) $O$ processo de fabricação do vasilhame, incluindo a secagem, queima e os acabamentos de superfície.

3) A estrutura do pote.

4) Os tratamentos decorativos, das técnicas aos motivos.

5) Evidências de utilização, reutilização e descarte.

A divisão aqui proposta (argila, tempero, técnica de manufatura, forma e decoração, uso e reuso) tem fins apenas didáticos, já que, em termos culturais, a combinação desses elementos se dá de maneira interligada, uns influenciando aos outros de acordo com suas propriedades e características de performance. Neste momento, as características das coleções são encaradas de uma perspectiva cronológica, ou seja, são salientados dentro da tecnologia cerâmica os elementos indicativos de continuidade e de mudanças ao longo do tempo, dentro desta tradição tecnológica.

\section{Escolhendo e preparando a argila}

Matéria-prima da cerâmica por excelência, sua seleção leva em conta diversos fatores, como a oferta geográfica e sazonal, suas propriedades físicoquímicas, ou fatores de ordem simbólica. Contudo, materiais específicos estão normalmente correlacionados a funções específicas (Rye, 1981, p. 26) e, portanto, sua identificação leva a um melhor entendimento de seus usos e significações.

Fontes de argilas são abundantes na Amazônia central, fornecendo inúmeras possibilidades de escolhas tecnológicas. Com a colaboração do Dr. Casimiro Munita (IPEN), este estudo procurou identificar a composição química de fragmentos cerâmicos e de amostras de argila da região, através das mencionadas análises por ativação por nêutrons. Essas análises comparativas propunham verificar a ocorrência ou não de evidências de continuidade nos padrões de escolha tecnológica na produção cerâmica entre as fases Açutuba, 
Manacapuru e Paredão, e também destas em relação à fase Guarita. Como já mencionado, os resultados não permitiram que estes objetivos fossem alcançados a contento, visto que demandam um estudo específico e focado exclusivamente em tais questões, o que não era o caso. Por outro lado, diversas análises das pastas cerâmicas vinculadas a esses conjuntos permitiram o mapeamento objetivado.

Conjugados às informações das argilas, os dados sobre a seleção dos temperos compuseram tal mapeamento, que permitiu uma interpretação sobre a própria organização tecnológica dos conjuntos tratados. É sabido que o uso de anti-plásticos na argila reduz sua plasticidade e facilita seu manuseio, gera uma secagem mais lenta, uma queima mais uniforme, além de dar à cerâmica resistência ao choque térmico e ao impacto (Machado, 2005; Rye, 1981; Schiffer e Skibo, 1992; Shepard, 1956). A análise de argilas e pastas da cerâmica da Amazônia central demonstrou que, durante o processo de seleção e tratamento (limpeza) da argila, houve deliberada intenção na manutenção de algumas de suas impurezas, como grãos de quartzo e hematita. Estes minerais estão presentes em todos os fragmentos analisados, em proporções variadas. A quantidade varia de acordo com os tipos de argila e de formas de vasos, sugerindo que neste caso a escolha - pragmática - do anti-plástico se deu em função da característica de performance da argila em relação ao uso que se pretendia dar aos vasilhames cerâmicos.

Assim, uma vez selecionadas, limpas e tratadas, diferentes argilas são misturadas, e a elas se adiciona o anti-plástico (ou tempero), obtendo-se a pasta que é usada na confecção da cerâmica. Além dos minerais, as pastas analisadas apresentaram também outros tipos de tempero. $O$ aditivo mais recorrente é o cauixi (esponja de água doce), que pode estar distribuído de modo homogêneo por toda a pasta (em maior ou menor quantidade) ou em forma de pequenos feixes. O cauixi pode ser considerado como uma escolha cultural característica da Tradição Borda Incisa e serviu como base para as tipologias realizadas nas décadas de 50 a 70 na Amazônia, através da seriação por gênero (Meggers e Evans, 1970).

Sua disponibilidade é um fator que merece atenção especial. Em primeiro lugar, é encontrado apenas em ambientes relacionados às águas pretas (sejam do rio Negro, de lagos ou de pequenos igarapés). Seu uso é indiscriminado em 
todo o tipo de ambiente, incluindo aqueles sítios às margens do Solimões, e sua escolha pode ser qualificada como uma opção, em detrimento de outras possíveis, que não foram selecionadas. Aliás, esta opção parece permear toda a Tradição Borda Incisa. Outro fator importante é a sazonalidade de sua oferta: a coleta somente é possível em uma época do ano, quando as águas baixam. Assim, percebe-se que a escolha não se deu ao acaso. Apesar de sua coleta só poder ser feita numa época do ano, quando os rios estão na vazante, seu uso é encontrado em abundância nas cerâmicas Borda Incisa de qualquer período. $O$ cauixi aparece ainda na composição das cerâmicas existentes em sítios de água branca, como é o caso do Hatahara, ou seja, além do evidente armazenamento, havia também o transporte.

"Como explica Paes de Souza Brasil 'é o cauixy um espongiário de água doce, que prolifera nas águas estacionárias, preso ao solo inundado, aos troncos de árvores, aos cascos das embarcações, das madeiras, ou mesmo às folhas caídas, com a condição de estarem em água permanentemente (....) Medem os espículos em média 1/4 de milímetro. Têm a forma de crescente, quase retos, sendo os cornos ou pontas bastante agudos, com belo aspecto de cristal de rocha, perfeitamente hialino, superficialmente lisos e polidos (Hilbert,

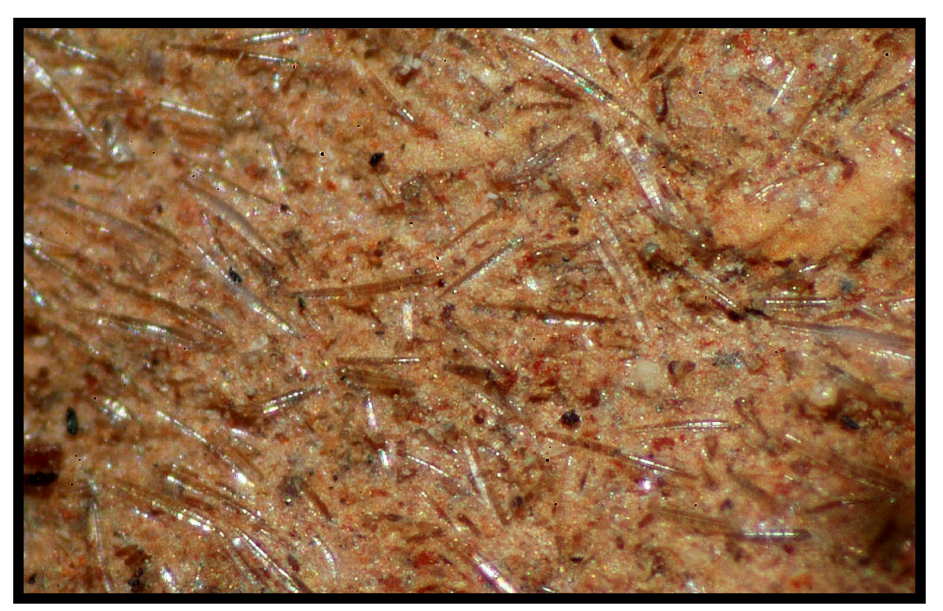

Figura 117 - Espículas silicosas do cauixi presentes na pasta cerâmica, tal como vistas numa lupa binocular com aumento de $50 \times$ (Foto: Claide Moraes).

À parte da presença do cauixi, que poderia ser um elemento homogeneizante de toda esta tradição tecnológica, observam-se importantes variações de seu uso. O próprio tamanho e orientação das espículas varia internamente às fases, de acordo com suas pastas e formas. Entretanto, se olharmos de uma perspectiva mais geral, as cerâmicas mais recentes Paredão, em especial a argila mais característica desta fase, alaranjada, apresentam uma melhor preparação da pasta, em que este cauixi é melhor pilado e sua pasta mais limpa. De fato, a maneira como o cauixi é processado e utilizado difere 
perceptivelmente, de uma fase à outra, mesmo sendo visualizado apenas em lupas. Desta forma, o que seria um elemento que homogeneizaria estes conjuntos, na verdade se torna também um diferencial.

A observação das pastas cerâmicas através de lâminas petrográficas serviu como um exemplo ilustrativo desta situação. Foram analisadas três amostras do sítio Açutuba, duas do lago Grande e quatro do sítio Hatahara. $\mathrm{O}$ critério para seleção das amostras foi cronológico dentro de um mesmo sítio e entre as fases cerâmicas. Como se pode observar na prancha a seguir (fig. 118), todos os fragmentos analisados são diagnósticos de cada uma das fases cerâmicas encontradas nesses sítios. Em todas as amostras, com exceção da primeira (PN 02-2617-26), o cauixi esteve presente, mas não como elemento homogeneizador. As imagens mostram diferentes configurações deste elemento na pasta cerâmica. A variação vai desde o tamanho das espículas, quantidade e orientação, além da diferenciação da própria pasta. Tais diferenças são frutos de peculiaridades dentro do processo produtivo, por exemplo do tratamento da argila, do processamento do tempero e posterior queima. As lâminas mostram semelhanças entre materiais cronologicamente contíguos, mesmo em sítios diferentes. Esta afinidade supõe certa proximidade entre seus processos produtivos, sugerindo interações entre sítios arqueológicos, em alguma medida, contemporâneos.

Uma possível exceção, que também se faz interessante, é a relativa similaridade entre fragmentos de fases distintas, num mesmo sítio arqueológico: retoma-se aqui a discussão sobre a co-ocorrência de fragmentos Manacapuru e Paredão, como ocorre no sítio Lago Grande. As diferentes fases, neste contexto, não sugerem distanciamento cronológico. Ao contrário, estes dois fragmentos, cujas características remetem às nossas categorias classificatórias Manacapuru e Paredão, advêm de um mesmo nível estratigráfico e, provavelmente, de um mesmo contexto de fabricação. 


\section{Cerâmicas das fases Açutuba, Manacapuru, Paredão e Guarita, e respectivas lâminas (secções delgadas).}

Sítio Açutuba

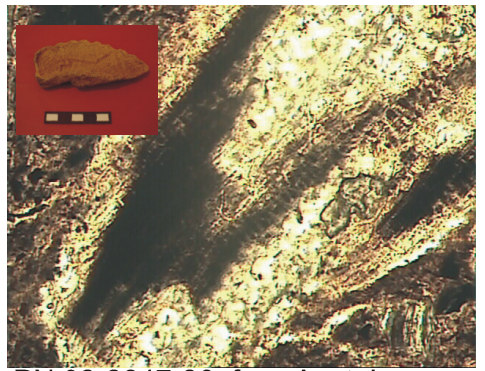

PN 02-2847-26, fase Açutuba

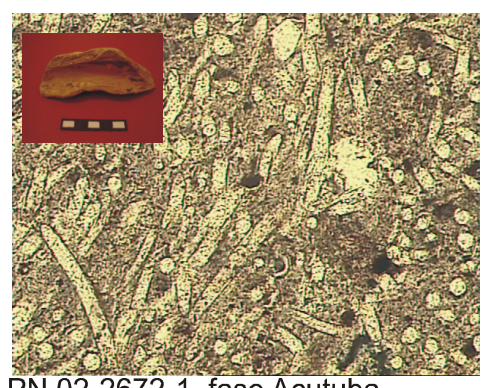

PN 02-2672-1, fase Açutuba

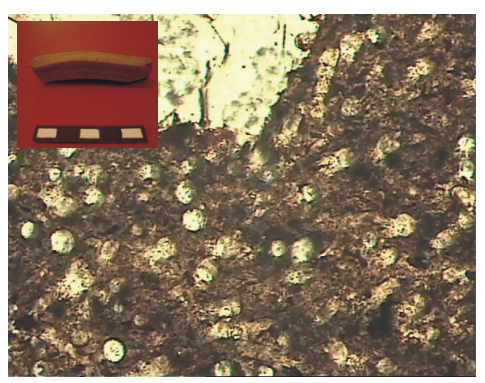

PN 02-1587-81, fase Manacapuru
Sítio Hatahara

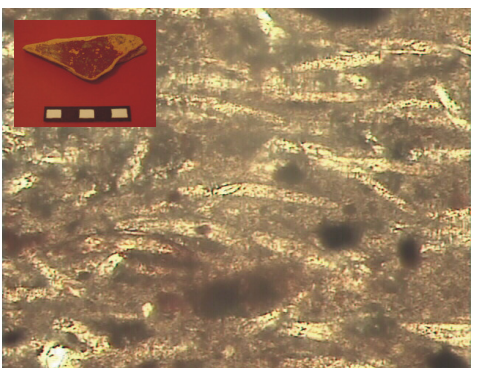

PN 13-21741-4, fase Açutuba

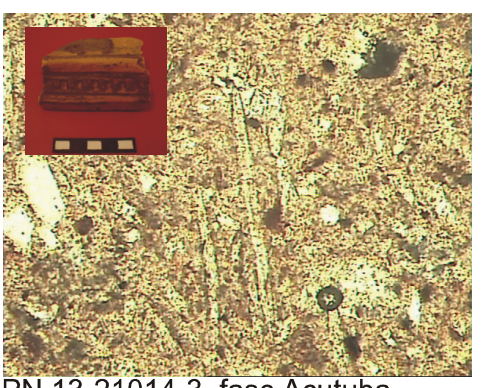

PN 13-21014-3, fase Açutuba

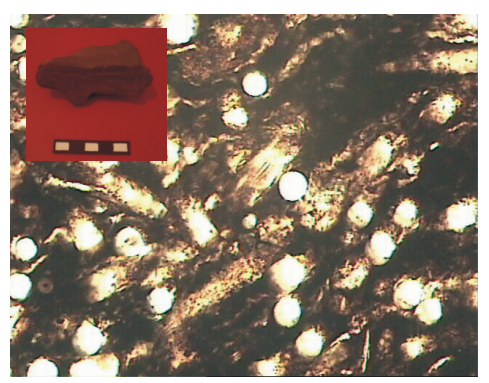

PN 13-21214-1, fase Manacapuru

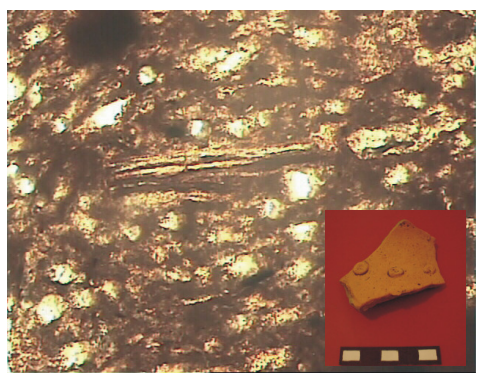

PN 13-312-25, fase Paredão
Sítio Lago Grande

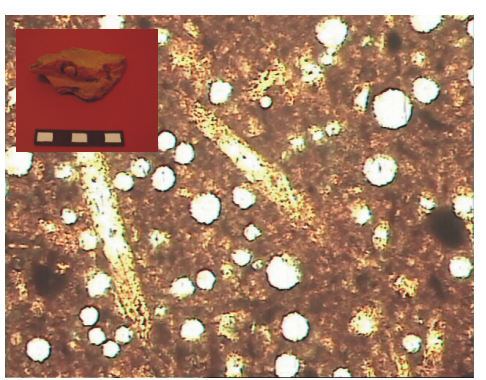

PN 12-1151-91, fase Manacapuru

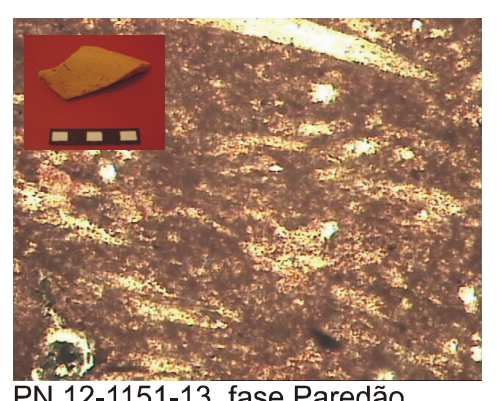

PN 12-1151-13, fase Paredão

Secções delgadas realizadas pelo Departamento de Laminação do IGC-USP. Microscopia ótica realizada no Departamento de Dosemetria do IF-USP, aumento binocular de 10x, objetiva com 20x. Ampliação total de 200x.

Figura 118 - Secções delgadas das pastas cerâmicas de diferentes fases e sítios arqueológicos (fotos: Helena Lima). 
Em todos os contextos analisados, conforme já visto, identificaram-se, embora em menor proporção, outros tipos de tempero: o cariapé (entrecasca de árvore da espécie Licania queimada), caco moído e nódulos de argila. Eles aparecem em proporções reduzidas, e apenas em parte dos fragmentos. No entanto, é importante ressaltar que houve preponderância do cariapé em alguns fragmentos da fase Açutuba em relação aos conjuntos mais tardios, como se vê no primeiro fragmento mostrado na prancha a seguir, com as imagens das lâminas petrográficas. Saliento novamente que estas análises foram feitas em caráter experimental, com o intuito de reforçar as análises laboratoriais empreendidas. No entanto, ficou claro seu elevado potencial para enriquecer as análises desta complexa cultura material.

\begin{tabular}{|l|l|l|l|l|l|}
\hline Amostra & Sítio & Nível & Fase & Contexto & Observações \\
\hline $13-21741-4$ & Hatahara & $100-110 \mathrm{~cm}$ & Açutuba & F3 & pintura policrômica, contorno complexo \\
\hline $13-21014-3$ & Hatahara & $90-100 \mathrm{~cm}$ & Açutuba & F15 & flange labial com incisões em gregas \\
\hline $13-21214$ & Hatahara & $50-60 \mathrm{~cm}$ & Manacapuru & N1211W1421 & borda extrovertida com incisões largas \\
\hline $13-312-25$ & Hatahara & $20-30 \mathrm{~cm}$ & Paredão & N1252E1360 & esferas aplicadas \\
\hline $02-2847-26$ & Açutuba & $210-220 \mathrm{~cm}$ & Açutuba & Reservatório & temperado com fibras, decoração zonada \\
\hline 02-2672-1 & Açutuba & $60-70 \mathrm{~cm}$ & Açutuba & T9-T10 & flange mesial, com pintura policrômica \\
\hline 02-1587-81 & Açutuba & $40-50 \mathrm{~cm}$ & Manacapuru & TU20 & borda extrovertida com incisões largas \\
\hline $12-1151-91$ & Lago Grande & $90-100 \mathrm{~cm}$ & Manacapuru & M1 & incisões \\
\hline $12-130-140$ & Lago Grande & $90-100$ & Paredão & M1 & pasta "laranja-A" \\
\hline
\end{tabular}

Tabela 19 - Fragmentos cerâmicos selecionados para realização das secções delgadas.

\section{A fabricação da vasilha}

Grosso modo, a manufatura da cerâmica mostra-se pouco variável no tempo e espaço. Os vasos analisados são sempre fabricados a partir da técnica de sobreposição de roletes, cujas variações aparecem nas bases, em geral moldadas, ou em alguns apêndices modelados. Contudo, um olhar mais acurado sobre esta técnica ordinária trouxe informações sobre a mudança cronológica neste sistema. Em alguns fragmentos da fase Açutuba pode-se perceber claramente o ponto de junção dos roletes e, em alguns casos, há espaços ocos entre os mesmos, mesmo com todo o rebuscamento decorativo. Quando observamos a junção dos roletes na fase Paredão, estes nem mesmo aparecem, 
o que demonstra mais uma vez o grande cuidado com o preparo da matéria-prima e o processo de fabrico destas vasilhas mais recentes.

Feita sua estrutura, o pote será seco para somente então passar pelo processo de queima, e é depois da queima que a argila se torna cerâmica. Conforme já explanado, as características da pasta cerâmica derivam de diversos fatores, entre eles o processo de queima. As variações observadas entre os conjuntos analisados dizem respeito, provavelmente, ao grau atingido pela cerâmica durante a queima.

Também quanto aos acabamentos dados à superfície dos objetos cerâmicos é necessário um olhar apurado, para perceber sutis diferenças entre as indústrias, mesmo em relação ao alisamento, que é sempre o mais utilizado. A este efeito que se nota em certos fragmentos, obtidos a partir de um bom alisamento e que causa uma impressão de polimento, se deve justamente ao tratamento dado a argila paredão. À exceção do alisamento, se observarmos as freqüências dos tratamentos nos diferentes sítios descritos, percebe-se uma maior freqüência de acabamentos tais como polimento e até a aplicação de resina nos fragmentos mais antigos.

As cerâmicas apresentam padrões de queima variados, mas pode-se perceber uma mudança entre as fases Açutuba e Manacapuru. A fase mais recente apresenta, na maioria dos fragmentos, queima não oxidada, enquanto que na fase Açutuba, a maior parte dos potes são oxidados. Essa diferença não acarreta na qualidade da queima já que, neste caso, as cerâmicas com queima em ambiente não oxidado parecem ter maior grau de dureza.

A queima paredão é um caso à parte. As análises das fraturas dos fragmentos indicam uma cor acinzentada, típica de uma queima feita em ambientes redutores. É uma queima completa, que quase atinge o estágio de vitrificação da argila. De fato, a cerâmica paredão é muito característica tanto por sua cor alaranjada como pela sua maior dureza.

\section{Estrutura do Pote: variabilidade formal}

O tema já foi bastante explorado nas páginas anteriores. Os pontos que valem ser salientados residem, basicamente, na perspectiva cronológica. Tanto a variabilidade formal quanto a complexidade dos contornos apresentam sensíveis 
alterações ao longo do tempo. A começar pelas cerâmicas da fase Açutuba, onde se vê uma profusão de formas, diminuindo em relação à fase Manacapuru e reduzindo ainda mais na fase Paredão - respectivamente, dezesseis, treze e oito tipos identificados nos materiais trabalhados. A essa redução da variabilidade, soma-se um aumento da quantidade de materiais e, principalmente, uma crescente padronização das formas.

À parte da variabilidade inerente às coleções cerâmicas, que remetem a funções dadas (formas restritivas e irrestritivas), é a estrutura geral do vasilhame que varia ao longo do tempo. Um exemplo disso, como se viu, é a tendência a modificar estruturalmente o pote de forma a salientar o local a ser decorado, com o uso de diversos artifícios. É o caso, no conjunto mais antigo, dos flanges labiais, bordas extrovertidas e lábios expandidos, que sempre serão decorados. Esta tendência continua, embora os recursos sejam diferentes. No conjunto mais recente, Paredão, já não se vê uma maior espessura dos lábios, ao contrário, estes são afilados. Neste sentido, um flange, um pedestal ou um gargalo não são apenas suportes à aplicação de uma ou outra decoração, mas são também uma decoração em si. Assim, a própria forma se mostra um vetor de mensagens, tanto quanto uma decoração plástica ou pintada, que pode impingir sentidos muito variados, como marcadores de identidade ou de status social.

\section{Tratamentos decorativos}

\section{A arte de dar forma ao barro: decorações plásticas}

A plasticidade é a característica mais marcante dessas cerâmicas. A modificação formal das bordas para a obtenção de flanges, gargalos e pescoços, anteriormente mencionada, pode ser considerada como um elemento decorativo, uma vez que a intenção é não só criar um suporte visível para a aplicação da decoração, mas que a forma do vaso adquira um aspecto decorativo. As incisões de todos os tipos, finas, largas, simples, duplas ou múltiplas são os elementos decorativos mais recorrentes nestas cerâmicas. Outras técnicas também são utilizadas, como o ponteado, geralmente aplicados nos lábios e nos apêndices da fase Manacapuru e Paredão. Há também nestas duas fases o uso do ungulado que, da mesma forma que o ponteado e o digitado, são aplicados na extremidade dos lábios. Este último é quase ausente na fase Açutuba. 
No que se refere à decoração plástica, as fases Açutuba e Manacapuru apresentam alguns pontos em comum, como as incisões e a modelagem. Estas duas técnicas aparecem na cerâmica Paredão, tendo as incisões uma proporção muito maior que a modelagem. No entanto, outras técnicas marcam sensivelmente as diferenças entre este $s$ três conjuntos. As cerâmicas Paredão e Manacapuru priorizam a decoração incisa simples ou dupla, respectivamente, sempre em linhas finas, formando motivos geométricos. O ponteado profundo é também muito utilizado nos dois conjuntos. Já nas cerâmicas da fase Açutuba verifica-se maior ênfase à modelagem, ao acanalado e à excisão, enquanto as incisões priorizam motivos curvilíneos e espiralados, do mesmo modo como a cerâmica Paredão. De fato, o ponteado é raríssimo na fase Açutuba, assim como não ocorre excisão na cerâmica Manacapuru.

Quanto aos apliques, os motivos zoomórficos são muito comuns nas fases Açutuba e Manacapuru, e também ocorrem na fase Paredão. No entanto, nesta última aparece outra categoria de apliques, em formas antropomórficas, as famosas "cabecinhas", aplicadas nos ombros das urnas.

\section{Um toque de cor: decorações crômicas}

Ainda que as decorações plásticas sejam marca desta tradição tecnológica, a presença de cores também é muito recorrente. Na verdade, a grande recorrência é devida ao engobo vermelho. Este consiste na aplicação de uma camada de tinta à base de óxido de ferro na superfície da cerâmica antes da queima. Existe uma grande variação de tonalidades de vermelho, entre cores quase alaranjadas e róseas a tons bastante escuros, quase púrpuros. As duas fases descritas por Hilbert tiveram tipos definidos pela presença do engobo vermelho, que sempre aparece junto a outras técnicas de decoração plástica, geralmente incisões. A fase Açutuba, identificada num momento posterior, não é diferente, ou seja, este é um traço característico em todos os conjuntos Borda Incisa.

Um diferencial da fase Açutuba é o engobo branco, uma fina camada de argila branca aplicada na superfície da cerâmica antes da queima. Pode ter função utilitária, como impermeabilizante, ou decorativa, servindo como base para a aplicação da pintura. Apesar de ser traço diagnóstico das cerâmicas associadas à fase Guarita, a utilização do engobo branco como recurso decorativo é uma 
característica diagnóstica também da fase Açutuba, e define, juntamente com outros atributos, essa indústria. Na verdade, Meggers notou a presença de engobo branco em alguns fragmentos da então chamada fase Manacapuru (desmembrada como fase Açutuba), porém os considerou como ocorrências isoladas. A alta incidência de engobo branco em contextos unicomponenciais da fase Açutuba, bem preservados e caracterizados, e sua aplicação em cerâmicas cujos elementos tecnológicos são muito distintos dos materiais correspondentes à fase Guarita, excluem qualquer possibilidade de intrusão. Assim, consideramos o engobo branco como traço diagnóstico também da fase Açutuba, junto à pintura policrômica, detectada entre os materiais associados à fase Açutuba em todos os sítios estudados. Essa técnica consiste na aplicação de pintura em diferentes tonalidades de vermelho ou preto, sobre uma camada de engobo branco.

A observação dos fragmentos pintados nos permitiu inferir a seqüência de operações requeridas à realização desta decoração. Uma primeira camada de engobo branco era aplicada ao pote já constituído e parcialmente seco. O engobo branco pode ser obtido a partir de um tipo específico de argila, o caulim, bastante comum na região. A essa camada sobrepõe-se uma fina e delicada pintura, que pode ser preta ou de diferentes tonalidades de vermelho ou vinho. Essas cores compõem motivos geométricos, retilíneos e/ou curvilíneos. A etapa seguinte consistia na queima dos vasos, que deve ter ocorrido sob alta temperatura em ambiente fechado, já que a pasta tem coloração clara e homogênea. Finalmente, uma última camada de pintura alaranjada podia ser aplicada, completando a composição final do motivo.

Com exceção da fase Pocó, no baixo Amazonas, até o presente momento não havia registros da presença de policromia tão antiga na Amazônia brasileira. Nas terras baixas, ela foi detectada apenas na bacia do rio Orinoco, Venezuela, e no Caribe. Foi atribuída à série Saladóide, cujas formas de relação com a série Barrancóide também fomentou acirrados debates. De qualquer modo, a relação entre essas duas tradições é clara na Venezuela, e parece ocorrer também na Amazônia central, nos materiais associados à fase Açutuba. Mais uma vez, podemos observar a presença de características típicas da fase Guarita ocorrendo em cerâmicas da fase Açutuba, que é pelo menos mil anos mais antiga. Embora as cerâmicas correspondentes a essas duas fases sejam 
decoradas através da mesma técnica apresentada antes, a policromia, ela ocorre de maneira bastante diferente, com um resultado final que é também distinto.

Mas a presença de pintura não é exclusiva da fase Açutuba. Conquanto muito diferente, ela aparece na fase Paredão. Ao invés de ocorrer sobre engobo, ela é aplicada diretamente sobre a pasta cerâmica, em algumas ocasiões muito bem alisada ou polida, e consiste em linhas finas nas cores preta e vermelha, formando motivos geométricos, em gregas ou espiralados, semelhantes aos motivos incisos. Não há, porém, qualquer associação entre este tipo de pintura e as demais decorações plásticas no mesmo fragmento ou vasilha.

\begin{tabular}{|c|c|c|c|}
\hline Atributos & Fase Açutuba & $\begin{array}{c}\text { Fase } \\
\text { Manacapuru }\end{array}$ & Fase Paredão \\
\hline Queima & $\begin{array}{l}\text { Oxidada } \\
\text { predominante }\end{array}$ & Não-oxidada & Não-oxidada \\
\hline Cauixi como tempero & Presente & Presente & Presente \\
\hline Cariapé como tempero & Presente & Raro & Raro \\
\hline Formas abertas & Mais freqüentes & Menos freqüentes & \begin{tabular}{|l} 
Menos \\
freqüentes
\end{tabular} \\
\hline Formas fechadas & Menos freqüentes & Mais freqüentes & $\begin{array}{l}\text { Mais } \\
\text { freqüentes }\end{array}$ \\
\hline Incisões retilíneas simples ou duplas & Menos freqüentes & Mais freqüentes & $\begin{array}{l}\text { Mais } \\
\text { freqüentes }\end{array}$ \\
\hline Incisões curvilíneas simples ou duplas & Mais freqüentes & Menos freqüentes & $\begin{array}{l}\text { Mais } \\
\text { freqüentes }\end{array}$ \\
\hline $\begin{array}{l}\text { Excisão ou incisão sobre engobo } \\
\text { vermelho }\end{array}$ & Presente & Ausente & Ausente \\
\hline Ponteado & Ausente & Presente & Presente \\
\hline Acanalado & Presente & Ausente & Ausente \\
\hline Apêndices zoomorfos modelados & Presentes & Presentes & Presentes \\
\hline Lábios cortados & Presentes & Presentes & Presentes \\
\hline Flanges Labiais & Presentes & Menos freqüentes & Ausentes \\
\hline Flanges Mesiais & Presentes & Ausentes & Ausentes \\
\hline Engobo vermelho & Presente & Presente & Presente \\
\hline Engobo branco & Presente & Ausente & Ausente \\
\hline Pintura monocrômica & Ausente & Ausente & Presente \\
\hline Pintura policroma & Presente & Ausente & Ausente \\
\hline
\end{tabular}

Tabela 20 - Comparação dos atributos entre as diferentes fases cerâmicas. 


\section{Forma, função e características de performance}

Para um entendimento mais amplo de um conjunto arqueológico é importante que se entenda os significados de sua variabilidade formal. A forma está intrinsecamente ligada aos usos que serão dados aos objetos, depois de prontos. Este foi um ponto abordado na variabilidade tipológica e, mais do que isso, as características morfológicas foram definidoras dos tipos, como um meio de se compreender aspectos mais gerais das sociedades que produziram, utilizaram e descartaram esses objetos. Está claro que formas específicas exigem tipos particulares de argila, tempero e tratamento, e que isto está relacionado às diferentes utilizações que terão os artefatos cerâmicos, bem como as suas características de performance. Embora aí resida boa parte do entendimento das escolhas tecnológicas, tais aspectos variam muito dentro de cada indústria. Sua análise foi feita, mesmo abordando apenas traços pontuais, por meio das comparações tipológicas e das próprias fases cerâmicas.

Como já discutido em parágrafos anteriores, através da análise destes materiais foi possível detectar que determinadas categorias de objetos, com inferências de finalidades cotidianas, estão vinculadas a uma maior variabilidade em termos de processos de fabricação e de escolhas de matéria-prima, mas não de sua morfologia, que sofre pequenas mudanças com o passar das gerações. Ao contrário, materiais que apresentam decorações específicas, que os tornam diagnósticos de diferentes períodos cronológicos, apresentam uma menor variação interna às formas ou tipos, mas são suscetíveis a uma drástica mudança formal, tecnológica e decorativa.

\section{Uso e reuso: evidências de utilização, reutilização e descarte}

Muitas vezes, a utilização deixa marcas na superfície da cerâmica que podem ser, posteriormente, observadas e inferidas. Exemplos disso podem ser as marcas de atrito e desgaste de um vaso e os vestígios de fuligem de um artefato que vai ao fogo. Porém, boa parte dos materiais apresentava sinais evidentes de desgaste relacionado à passagem do tempo e às condições de preservação, nem sempre compatíveis a observações desta natureza. A análise atentou para estes fatores, embora não tenha tido o sucesso desejado, com exceção da fuligem, que se preserva com mais facilidade. $\mathrm{Na}$ verdade, muitos dos fragmentos apresentaram estas marcas, e corroboraram em parte nossas suposições de uso, 
uma vez que estavam sempre presentes nos assadores, alguidares e cuias embora estivessem também presentes em alguns materiais decorados. Isto baseou, inclusive, algumas das suposições sobre continuidades e mudanças ao longo do tempo.

Os próprios padrões de descarte podem trazer muitas questões importantes sobre os povos que ali estiveram, como é o caso dos pequenos montes de refugos (middens), que congregavam tudo aquilo que se encontrava fora de uso, a partir de um descarte em locais específicos, provavelmente próximos das habitações.

Alguns dos fragmentos analisados também apresentaram evidências de usos para os quais não tinham sido originalmente criados, em uma forma de reutilização. De fato, estas evidências de reutilização estão presentes em todo o registro da Amazônia central, em duas escalas. Uma delas remete ao próprio objeto, em que cacos de potes de diferentes tamanhos e espessuras foram aproveitados para outras funções, diferentes daquelas dos quais foram inicialmente produzidos. Este foi o caso das rodelas de fuso, dos vasos remendados e das trempes provenientes de coleções advindas de diversos sítios. Uma segunda categoria tem uma amplitude muito maior, e nem sempre este reuso foi feito pelas populações que outrora produziram os vasos, agora reduzidos a cacos. É o caso, por exemplo, da construção dos montículos artificiais, bem como de diversas feições encontradas nos sítios em questão. Desta forma, a cerâmica utilizada como material construtivo de estruturas de tal magnitude é um perfeito exemplo de reutilização de artefatos após seu descarte. 


\section{Capítulo VII}

\section{UMA MUDANÇA DE ESCALA}

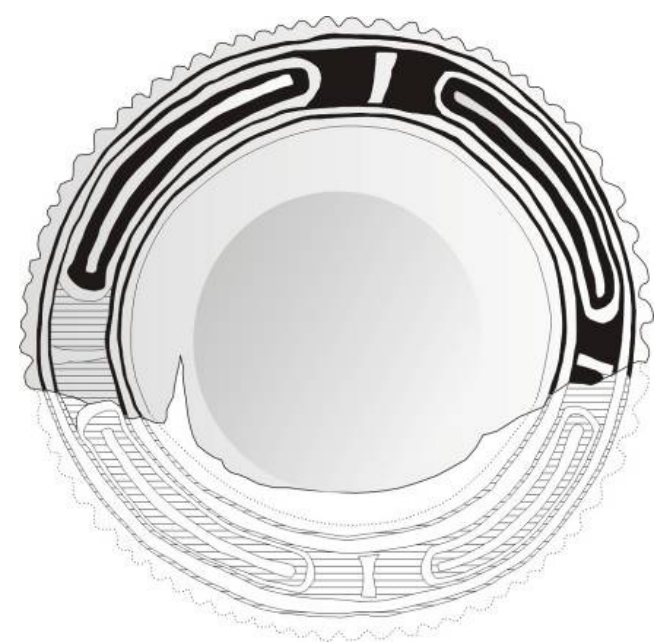

\section{I. Levantamentos regionais. Mais sítios? Pra que?}

Embora a maioria dos trabalhos em arqueologia estruture-se de forma a ter os levantamentos arqueológicos - prospecções visando a identificação de novos sítios - anteriores ou paralelos às escavações, no caso desta pesquisa, ocorreu o contrário. Explico: os levantamentos tiveram um papel de complementação ao estudo e interpretação dos sítios arqueológicos da Amazônia central já conhecidos, cujos dados e problemas foram apresentados nos capítulos anteriores. Foi através da obtenção de informações sobre os sítios de outras regiões que se chegou a um viés interpretativo mais apurado do registro arqueológico, tanto da área de confluência dos rios Negro e Solimões, como de sua inserção num quadro regional mais amplo, fundamental para uma compreensão mais abrangente de uma história pré-colonial amazônica.

Desta forma, as informações obtidas através dos levantamentos arqueológicos empreendidos em diferentes sub-regiões amazônicas, vieram a complementar os trabalhos já feitos anteriormente, de delimitação, escavação e compreensão dos sítios arqueológicos da Amazônia central. 
Dentro da área de pesquisa do PAC, a quantidade de sítios arqueológicos conhecidos é grande. O amadurecimento do projeto ao longo de sua história, que já soma treze anos, permitiu que diversas pesquisas com foco em levantamentos arqueológicos fossem empreendidas (por exemplo, L. Lima, 2003; Moraes, 2007). Aliado a isso, algumas parcerias bem sucedidas foram realizadas, culminando em levantamentos regionais cada vez mais extensos, extrapolando, inclusive, sua área inicialmente proposta. Dentro de tamanha amplidão, duas áreas mostraramse de interesse para a presente pesquisa, em função dos problemas tratados. Foram elas: o médio-baixo Solimões (trecho entre os municípios de Coari e Manaus) e o baixo Amazonas (que abrangeu onze municípios do Estado do Amazonas, entre Manaus e Nhamundá, na fronteira com o Pará).

Tais parcerias se deram com órgãos públicos, empresas, e outros projetos sediados no Amazonas. Os levantamentos arqueológicos da primeira área ocorreram no âmbito de dois diferentes projetos. O primeiro, o Projeto PIATAM (Possíveis Impactos Ambientais no Transporte Fluvial de Petróleo e Gás Natural na Amazônia), realizado pelo CCA-UFAM (Centro de Ciências Ambientais da Universidade Federal do Amazonas), INPA (Instituto Nacional de Pesquisa na Amazônia), USP, Petrobras, entre outros, que permitiu a identificação de uma série de sítios interligando, em termos de pesquisas, o médio Solimões à Amazônia central. Com os trabalhos do Gasoduto Coari-Manaus, empreendimento feito pela Petrobras e que abrange uma extensão territorial relativamente grande, que inclui a área de pesquisa do PAC, foi possível estender ainda mais o número de sítios conhecidos, não somente na Amazônia central como também em localidades no rio Solimões, estendendo até mesmo o objeto desta pesquisa.

Junto à $1{ }^{a}$ SR do IPHAN foram desenvolvidos dois projetos principais. $O$ Levantamento Arqueológico no Município de Manaus (LAMA), foi um deles, realizado em 2005-2006, ocasião em que foram identificados 35 sítios, nas áreas urbana e rural de Manaus. Já o Projeto Baixo Amazonas (PBA), que teve seu início em 2004 e vem se desenvolvendo até hoje, rendeu belos frutos, inclusive para o problema tratado neste doutorado. No âmbito do PBA, nada menos que 107 sítios arqueológicos foram identificados, numa ampla região que guarda importantes questões arqueológicas que remetem aos primórdios da produção cerâmica na Amazônia. 
A inserção de tais levantamentos nesta pesquisa de doutorado, portanto, não se deu por obra do acaso. Os estudos aqui tratados contemplaram duas regiões adjacentes à área de pesquisa do PAC, cujos dados arqueológicos disponíveis as tornam importantes para o problema ora discutido, que trata da compreensão do registro arqueológico tal como ele se configura na Amazônia central. O foco está em sua cronologia de ocupação e no entendimento das relações entre as diferentes feições arqueológicas ali encontradas, tais como o são as terras pretas antrópicas e as controversas fases cerâmicas e tradições regionais. Assim, embora não estivessem previstos na proposta inicial, o desenvolvimento das questões arqueológicas trabalhadas, e as facilidades logísticas proporcionadas por projetos de pesquisa bem estruturados na região, me levaram a tomar parte em tais expedições de prospecção, a fim de confrontar os dados obtidos com minhas hipóteses sobre o assunto.

\section{II. Metodologia}

As prospecções arqueológicas visam à identificação e cadastramento de sítios arqueológicos. Na Amazônia, entretanto, há certas peculiaridades que influem na escolha das estratégias metodológicas utilizadas. Os sítios resultantes de ocupações dos povos agricultores ceramistas na Amazônia estão, como mencionado, associados à ocorrência das terras pretas. Em função de sua alta fertilidade e de sua localização, geralmente próximos aos recursos da várzea e da terra firme, os locais com terra preta foram constantemente habitados. No presente, cidades de pequeno porte e comunidades ribeirinhas e seus roçados se estabelecem sobre os sítios arqueológicos. Assim sendo, o arrolamento oral oportunístico se impõe como técnica mais proveitosa para uma abordagem inicial, uma vez que os habitantes locais desempenham um papel fundamental na pesquisa arqueológica, visto serem eles os conhecedores da localização dos sítios. Basta se informar acerca dos locais de ocorrência de terra preta (o que todo mundo sabe!), para chegar aos sítios. O levantamento oral junto às comunidades procurou atentar também às áreas de concheiros e de areais, dado que é onde geralmente se encontram também outros tipos de sítios, evidências de populações ainda mais antigas, de caçadores-coletores, que produziram uma sofisticada indústria lítica (Costa, 2003). 
Segundo Schiffer (1978), os levantamentos arqueológicos devem ser feitos em três distintas etapas. Na primeira delas, deve-se empreender um estudo do meio e do entorno dos locais a serem trabalhados. Depois disso, procede-se a um reconhecimento da área para, só então, começar os levantamentos intensivos (intensive survey). Desse modo, as entrevistas se enquadram na etapa de reconhecimento, permitindo que conheçamos estas áreas, que se caracterizam como marcos na paisagem para os seus moradores, antes que levantamentos intensivos sejam feitos. Além das informações orais, procuramos realizar caminhamentos que contemplassem a diversidade de compartimentos topográficos e de nichos de recursos, como os topos dos terraços, vertentes, beira de igarapés, margens dos rios, etc. $O$ objetivo dos caminhamentos é sempre identificar vestígios arqueológicos em superfície. Este tipo de amostragem probabilística se mostra frutífera, dada a marcada recorrência de sítios encontrados nestes locais.

É importante ressaltar que em cada uma das parcerias já mencionadas, dadas as suas diferentes naturezas, os procedimentos metodológicos foram modificados para que se adequassem melhor às propostas de cada um dos trabalhos. Em relação ao PIATAM e ao Projeto Baixo Amazonas, por exemplo, não foram realizadas intervenções em sub-superfície, tendo os sítios sido identificados apenas por meio de informações obtidas com os moradores daqueles locais, o que permitiu uma abordagem rápida, gerando muitos sítios identificados. Por outro lado, as interpretações ficaram limitadas por perder as informações estratigráficas, tão importantes para o problema de pesquisa aqui tratado. Em alguns casos havia certas características e estruturas - construções, cortes de estrada, erosão - que permitiram, por exemplo, observar a estratigrafia e a profundidade da terra preta.

Já em outros trabalhos, como o Gasoduto Coari-Manaus, foram feitos levantamentos sistemáticos em sub-superfície em todo o seu traçado, já que quaisquer sítios que por ventura estivessem nestes locais estavam propícios a uma destruição iminente. A maioria das prospecções em sub-superfície foi feita com cavadeira manual de tipo boca-de-lobo, com copo de $20 \mathrm{~cm}$ de diâmetro e alcance máximo de $100 \mathrm{~cm}$ de profundidade, garantindo uma intervenção rápida e de baixo impacto. Este procedimento se mostra muito útil nas prospecções em locais florestados, com baixa visibilidade da superfície do terreno (como é o caso 
do Solimões), bem como na avaliação da profundidade, variabilidade e densidade de eventuais sítios encontrados. Neste caso, a quantidade e diversidade dos vestígios determinavam seu registro enquanto ocorrências, caracterizadas por baixa quantidade e diversidade de vestígios, ou enquanto sítios arqueológicos, caracterizados por alta quantidade e diversidade de vestígios. A partir daí, os sítios, coleções e objetos arqueológicos encontrados foram sistematicamente catalogados a partir do preenchimento de fichas cedidas pelo IPHAN, que alimentaram o banco de dados do Sistema de Gerenciamento do Patrimônio Arqueológicos - SGPA.

As principais etapas do levantamento foram registradas em fotografia, bem como todos os pontos de tradagens, os sítios e ocorrências arqueológicos identificados foram georeferenciados através de um receptor GPS (Global Positioning System), utilizando coordenadas geográficas e UTM (Universal Trade Mercator). Com as coordenadas registradas, o material levantado foi plotado em bases cartográficas. 


\section{III. Um contexto antigo no médio Solimões}

Assim como nas regiões antes apresentadas, o médio Solimões, nas proximidades dos atuais municípios de Tefé e Coari, foi inicialmente caracterizado e reconhecido pelo seu potencial arqueológico através dos pioneiros trabalhos de P. Hilbert, nas décadas de 50-60. Nas proximidades de Tefé, Hilbert definiu as fases Caiambé, Tefé e São Joaquim (1968). A maior parte dos conjuntos por ele descritos é relativamente recente e caracterizada por traços distintivos do então definido como terceiro horizonte estilístico, Policrômico (Meggers e Evans, 1961). Tais características, como a pintura policroma, acanalados e tempero através do cariapé, Hilbert vinculou de maneira mais direta à Amazônia central (área de confluência), e aos materiais Guarita ali encontrados. Na própria sede do município de Coari, Hilbert definiu duas outras fases, ligadas, respectivamente, às Tradições Borda Incisa e Policroma, com base nas coletas e escavações realizadas nos sítios da própria área urbana e seu entorno (1968, p. 97). Interessa, aqui, o conjunto mais antigo.

A região só voltou a ser arqueologicamente trabalhada em fins da década de 90, num contexto de arqueologia de contrato. Foi nas prospecções vinculadas ao Poliduto Urucu-Coari, empreendimento da Petrobras, que se identificou o sítio Nova Esperança, do qual iremos tratar a seguir. Os trabalhos então realizados, através de um resgate preliminar, identificaram um contexto profundo, contando com datações bastante antigas (Caldarelli, 1997).

Os novos trabalhos no sítio se deram, mais uma vez, no âmbito da arqueologia de contrato, e também subsidiados pela Petrobras. Neste caso, foi em função da implementação do Gasoduto Coari-Manaus. Assim, era natural que novas intervenções arqueológicas fossem empreendida em Nova Esperança, tendo em vista que o sítio seria mais uma vez impactado. Era esperado também que seus dados fossem incorporados a esta tese, já que a presença de um contexto antigo era então conhecida. 


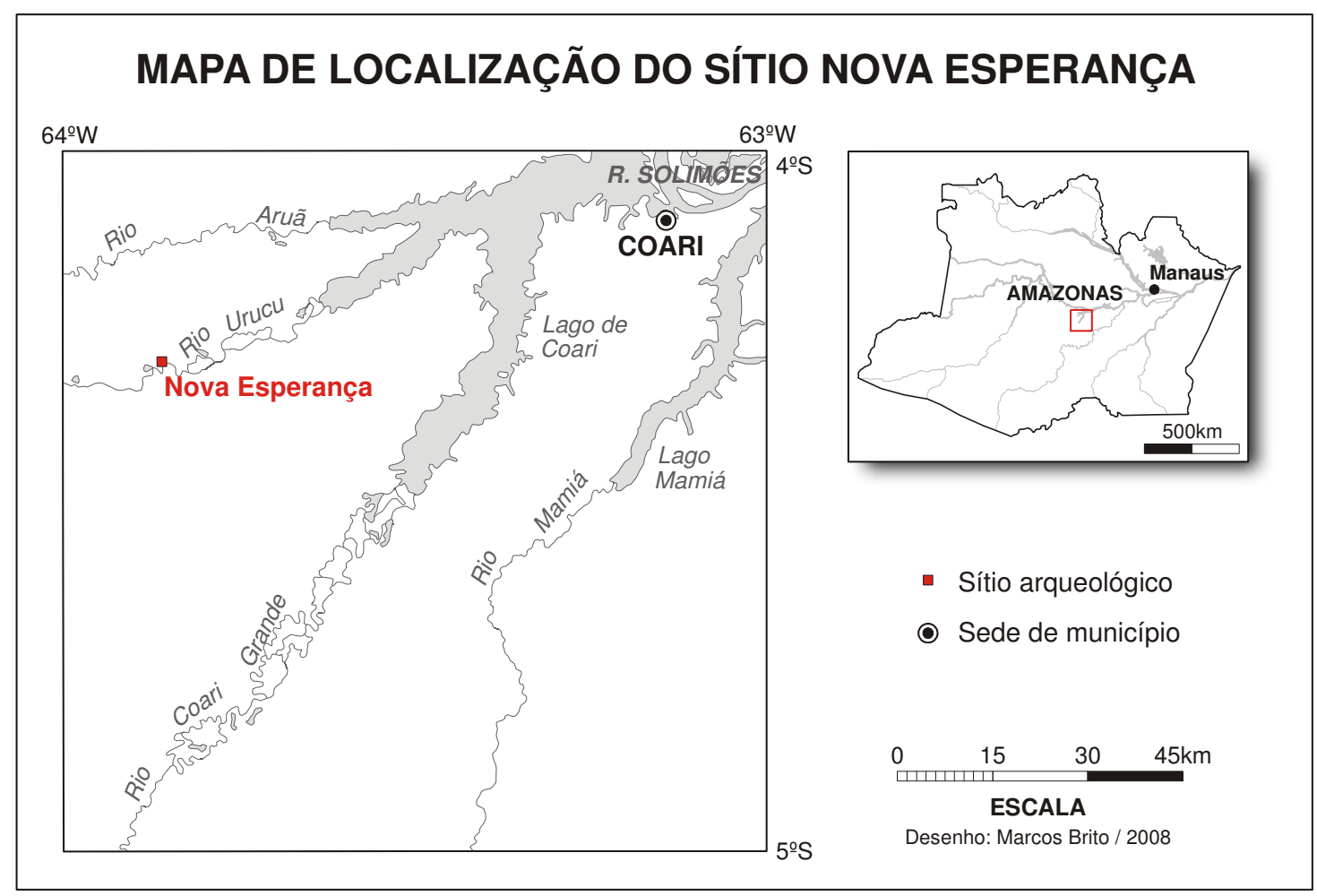

Figura 199 - Localização do sítio arqueológico Nova Esperança.

O sítio se situa numa área de terra firme, a $50 \mathrm{~m}$ da margem esquerda no rio Urucu, afluente do Solimões (fig 119), distante $82 \mathrm{~km}$, em linha reta, da cidade de Coari. O material arqueológico encontra-se disperso nos topos planos e nas vertentes do terreno. Trata-se de um sítio multicomponencial de grandes dimensões (cerca de $300 \times 100 \mathrm{~m}$ de área). A profundidade da terra preta chega, em alguns setores do sítio, até a $120 \mathrm{~cm}$.

Sua ocupação mais recente é representada por cerâmicas da Tradição Policroma da Amazônia, que afloram por toda a superfície do sítio arqueológico, bem como nas camadas estratigráficas mais superficiais. Quantitativamente é o conjunto mais representativo. Já o momento de ocupação mais antigo, cujos vestígios ocupam níveis profundos, está relacionado à Tradição Borda Incisa. Como já mencionei, existem para este sítio datações bastante antigas, de 100 d.C. e 1965 a.C., em níveis profundos, em 70-80cm e 110-120 cm, respectivamente (Caldarelli, 1999, p. 81-84). Entretanto, o contexto cronoestratigráfico e tecnológico destes materiais ainda não havia ainda sido explorado de forma acadêmica. 


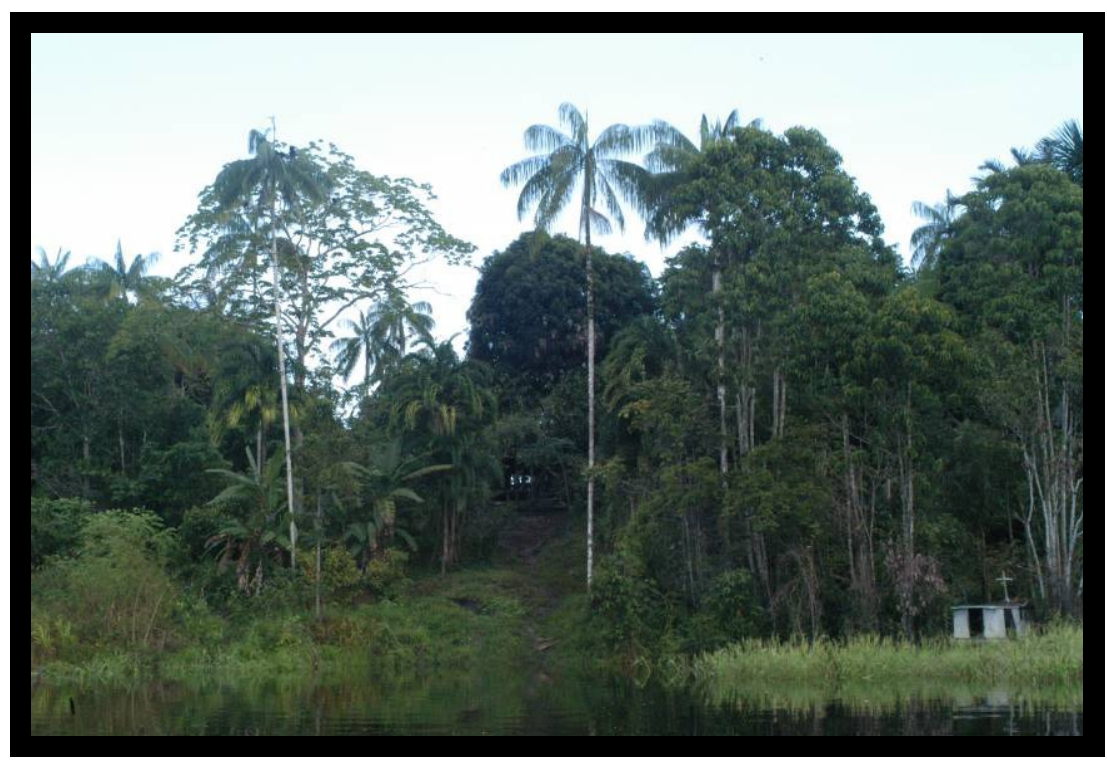

Figura 200 - Vista do sítio Nova Esperança a partir do rio Urucu (Foto: Helena Lima, 2005).

A etapa de campo ocorrida em 2005 deu-se pela necessidade de reutilização da área do sítio, onde se abriu uma clareira para depósito de tubos e circulação de maquinário. Hoje suas áreas mais destruídas são a clareira, que tem $100 \times 40$ m, e um canal de drenagem, com $188 \times 3$ m, que corta o sítio em seu maior eixo, no sentido leste-oeste (fig. 201). Nesses locais, centenas de fragmentos cerâmicos foram exumados e ficaram expostos na superfície do terreno. Os trabalhos no sítio foram divididos em quatro etapas principais: 1) topografia e estabelecimento do grid; 2) delimitação da área do sítio através de linhas de tradagens; 3) verificação da área de concentração de vestígios ósseos em superfície; e 4) escavação de 5 unidades de $1 \mathrm{~m}^{2}$.

A topografia e o grid foram feitos com o auxílio de uma estação total, pela equipe de topografia do exército. Um grid com coordenadas cartesianas foi marcado a partir de um ponto arbitrário do vértice SE da clareira. Dois eixos ortogonais foram estabelecidos, norte-sul e leste-oeste. A linha N-S está a $17^{\circ}$ leste do norte magnético. Esta etapa resultou na elaboração de um mapa com as principais feições do terreno, tais como edificações, feições geomorfológicas, etc., e com a localização das intervenções arqueológicas realizadas no sítio (fig. 207).

Embora ocorressem centenas de materiais arqueológicos em superfície, a delimitação do sítio exigiu que se levasse em conta também a presença de vestígios e de terra preta em sub-superfície. Esta etapa foi feita através de quatro 
linhas de tradagens, permitindo a delimitação da área do sítio, que tem uma área 13,8 ha. As tradagens revelaram baixa densidade de vestígios, distribuídos verticalmente em dois principais conjuntos: nos níveis superficiais, entre 0 e $30 \mathrm{~cm}$, e nos níveis mais profundos, entre $60 \mathrm{~cm}$ e $1 \mathrm{~m}$. Em alguns pontos, a profundidade da terra preta é superior a $1 \mathrm{~m}$. Também a distribuição horizontal dos vestígios apresenta um padrão interessante, com áreas de concentração intermediadas por espaços com ausência total de material. Essas concentrações ocorrem em diferentes locais, sendo que as tradagens realizadas na área central do sítio não apresentaram vestígios.

As cinco unidades de $1 \mathrm{~m}^{2}$ escavadas foram distribuídas ao longo da área do sitio, a fim de obter-

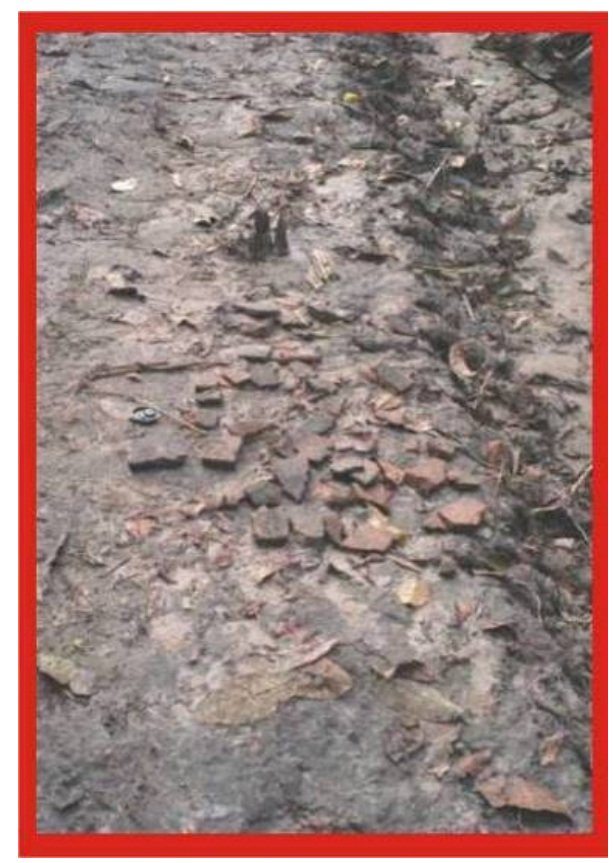

Figura 201 - Fragmentos cerâmicos aflorando na superfície da clareira 11 (foto: Helena Lima). se uma amostra representativa da variabilidade artefatual dentro do sítio. As descrições de cada uma delas são apresentadas a seguir, com ênfase maior apenas naquelas relevantes para o problema de pesquisa em questão, que tratou de compreender a antigüidade da ocupação deste sítio arqueológico, e de compará-lo com as ocupações ceramistas antigas da área de confluência do Negro e Solimões.

\section{Unidade N994 E1070}

Escavada ao lado de uma casa onde vive uma família de ribeirinhos. Os níveis superficiais apresentaram cerâmica arqueológica e terra preta associadas a materiais recentes, como cacos de vidro, ferro, etc, confirmando tratar-se de uma lixeira recente sobre o sítio arqueológico. O pacote cultural chega até a $60 \mathrm{~cm}$ de profundidade, mas a unidade escavada, até $120 \mathrm{~cm}$, com cinco níveis arqueologicamente estéreis (latossolo amarelo). 

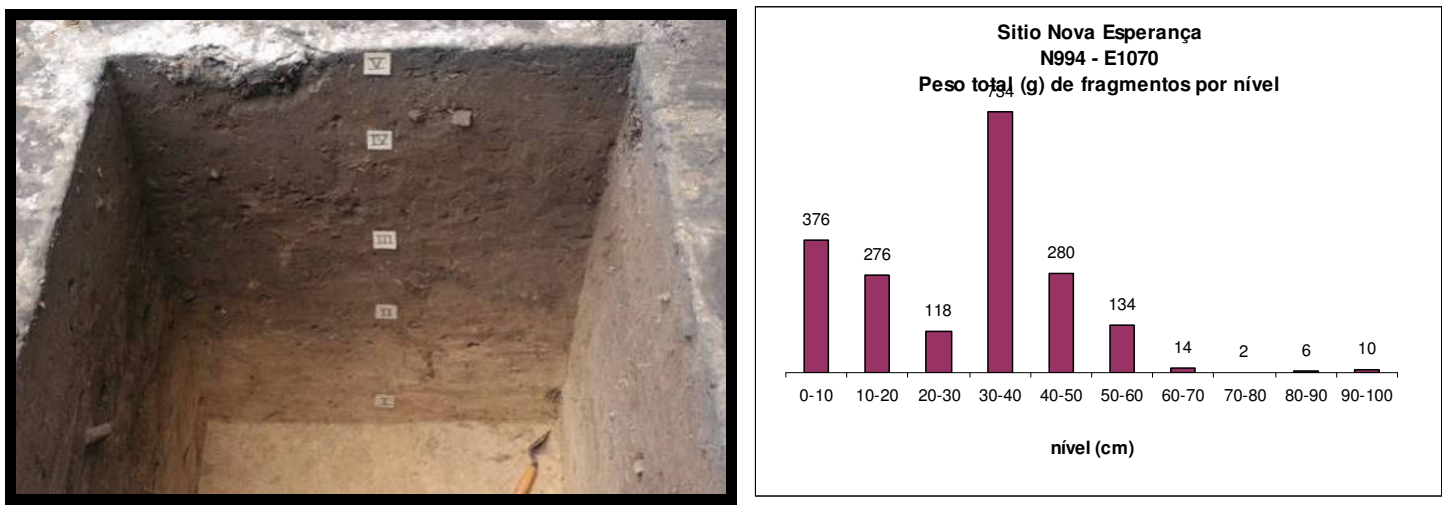

Figura 202 - Perfil Norte da unidade N994 E1070, densidade de fragmentos por nível (fotos: Helena Lima).

\section{Unidade N1045 E1158}

Localizada no limite leste do canal de drenagem, numa área com grande quantidade de material exumado pela abertura do mesmo. Esta foi a escavação que apresentou maior densidade de vestígios, e foi explorada até $110 \mathrm{~cm}$ de profundidade, com dois níveis estéreis. A densidade de vestígios teve seu pico entre 40 e $60 \mathrm{~cm}$, sendo que, a partir dos $60 \mathrm{~cm}$, a quantidade é reduzida até findar-se aos $90 \mathrm{~cm}$.

\section{Unidade N1037 E1051}

Localizada na área central do sítio, numa área de capoeira. Apresentou maior densidade de vestígios entre 40 e $70 \mathrm{~cm}$ de profundidade. No nível 60-70 coletamos um recipiente cerâmico de pequenas dimensões, parcialmente fragmentado in situ. A quadra foi escavada até $120 \mathrm{~cm}$, com dois níveis totalmente estéreis.

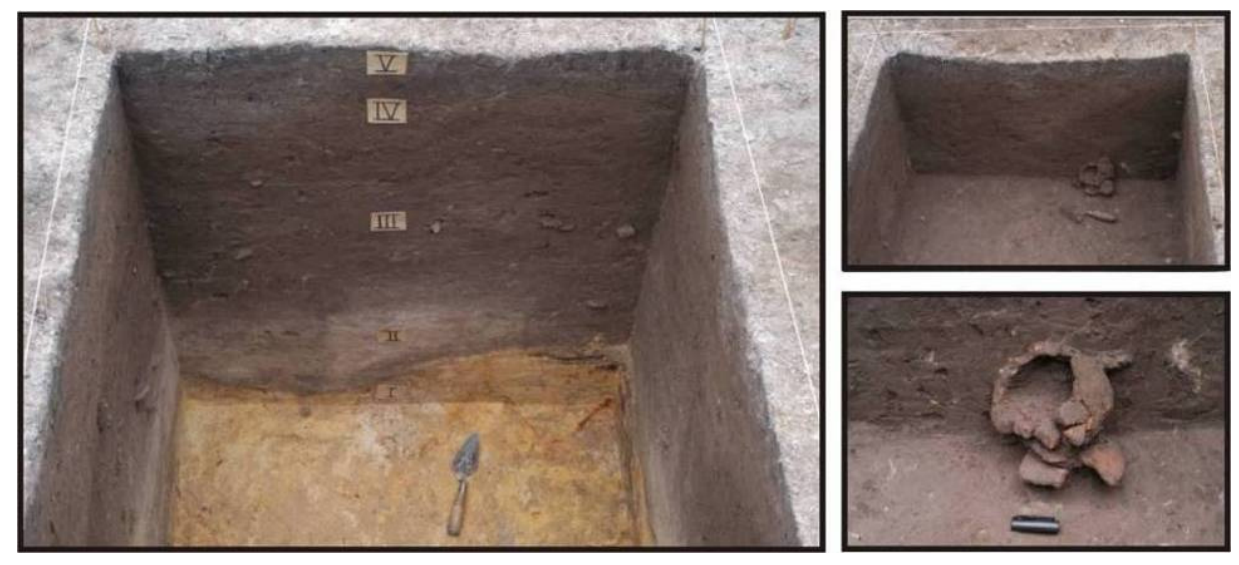

Figura 203 - Perfil Norte da unidade N1037E1051, recipiente cerâmico evidenciado na base do nível $70 \mathrm{~cm}$ (fotos: Helena Lima). 


\section{Unidade N1052 E1000}

Localizada junto ao vértice NE da clareira, próxima de uma tradagem que forneceu material arqueológico até $120 \mathrm{~cm}$ de profundidade. A quadra foi escavada até 2,5 $\mathrm{m}$ devido à presença de uma bioturbação profunda, que transportou material para até $2,30 \mathrm{~m}$. O restante da quadra atingiu o latossolo amarelo a $1 \mathrm{~m}$ de profundidade.
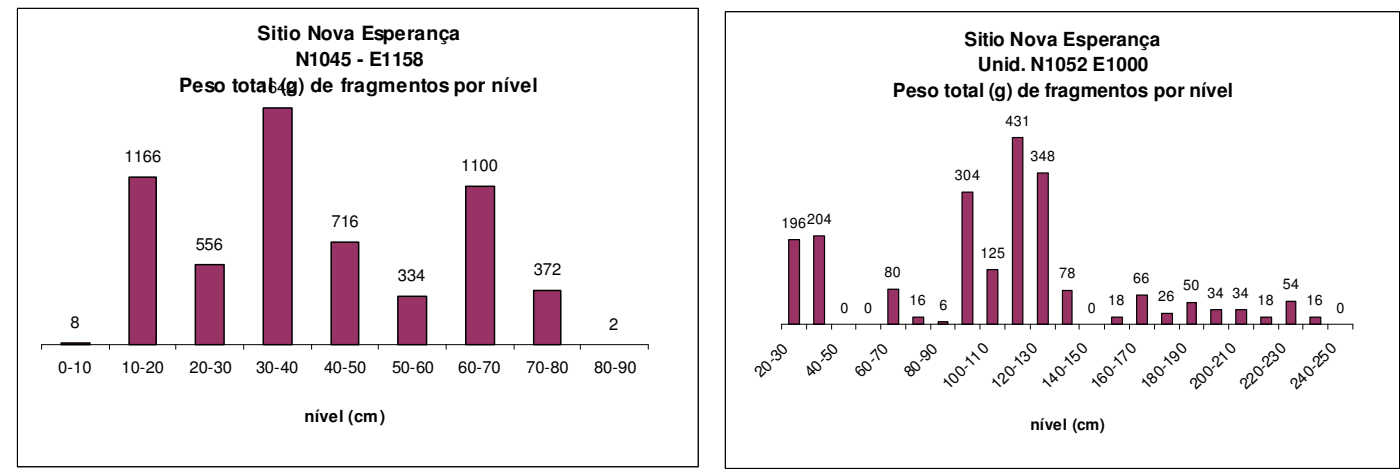

Gráfico 56 - Sítio Nova Esperança, densidade de vestígios arqueológicos por nível.

\section{Unidade N1000 E801}

Foi escavada a oeste da clareira, próximo de uma tradagem que apresentou material arqueológico em todos os níveis, até $120 \mathrm{~cm}$ de profundidade. A unidade apresentou baixíssima densidade de vestígios até o nível 80-90 cm, quando a quantidade de cerâmica aumenta consideravelmente, seguindo dessa maneira até $110 \mathrm{~cm}$. A escavação findou-se aos $130 \mathrm{~cm}$ de profundidade, com dois níveis estéreis.

Esta configuração foi muito interessante para o problema de pesquisa tratado, já que neste caso o pacote cultural mostrou-se bastante profundo e não associado à terra preta, indicando uma ocupação possivelmente mais antiga do que aquela superficial do restante do sítio arqueológico. De fato, as cerâmicas coletadas nesta unidade apresentam características tecnológicas que remetem aos estilos mais remotos encontrados na região, tais como incisões paralelas em linhas finas, engobo vermelho e o tempero, em geral, é o cauixi. Amostras de carvão coletados nesta unidade foram enviadas para datação, e corroboraram a hipótese de antigüidade e cronologia de ocupação do sítio, e nos levaram a situar este conjunto na Tradição Borda Incisa. 
Pode-se observar, na figura abaixo, que apesar de não se tratar de uma terra preta strictu sensu, aparecem dois pacotes orgânicos associados a uma maior densidade de vestígios. Ambos foram datados.
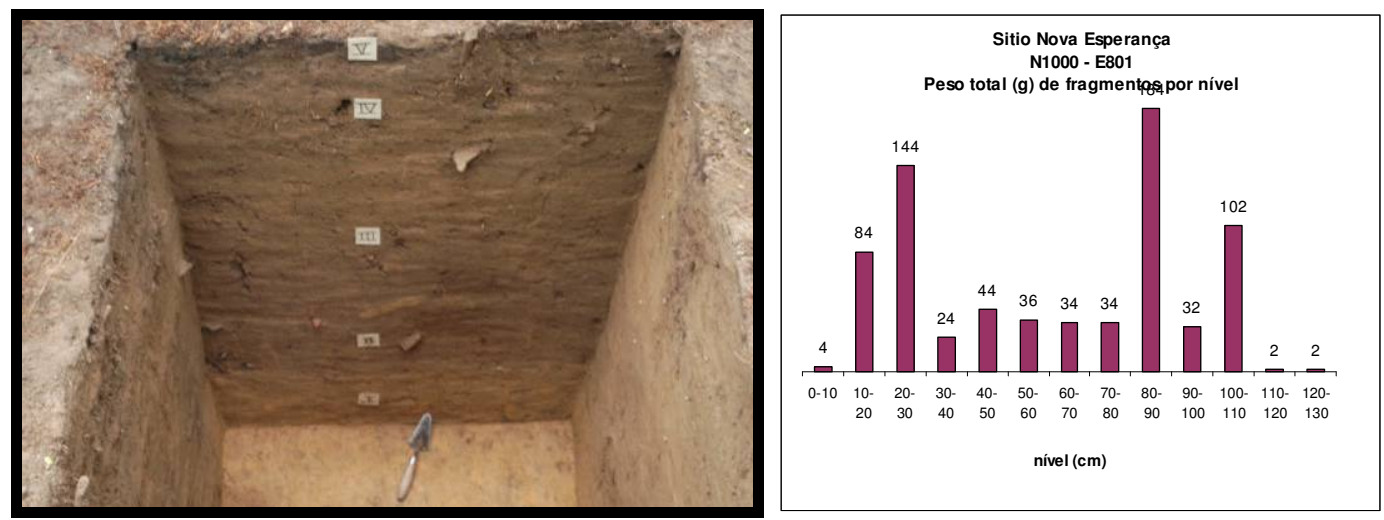

Figura 204 - Perfil Norte da unidade N1000 E801, densidade de fragmentos por nível (fotos: Helena Lima).

\section{III. I. Cerâmicas do Nova Esperança}

Passaram pela primeira etapa da análise, na qual se registra as características (atributos) de cada peça coletada, todas aquelas maiores que três centímetros, decoradas ou não. Assim, das cinco unidades de $1 \mathrm{~m}^{2}$ escavadas no sítio, foram observadas 763 peças, que forneceram um diagnóstico geral da indústria cerâmica encontrada em Nova Esperança. As análises cerâmicas confirmaram as informações fornecidas em campo pelos cortes estratigráficos. Trata-se de um sítio multicomponencial com dois conjuntos cronológica, estratigráfica e tecnologicamente diferenciados.

De modo geral, os materiais de Nova Esperança encontram-se em baixas condições de preservação, sendo que muitos fragmentos tiveram sua superfície desgastada em sua totalidade (observar figura 205). Por esta razão, apesar da quantidade significativa de peças que passaram pela primeira análise, poucos foram os fragmentos diagnósticos que permitiram, por exemplo, a formação e caracterização de conjuntos, bem como a reconstrução das formas. 

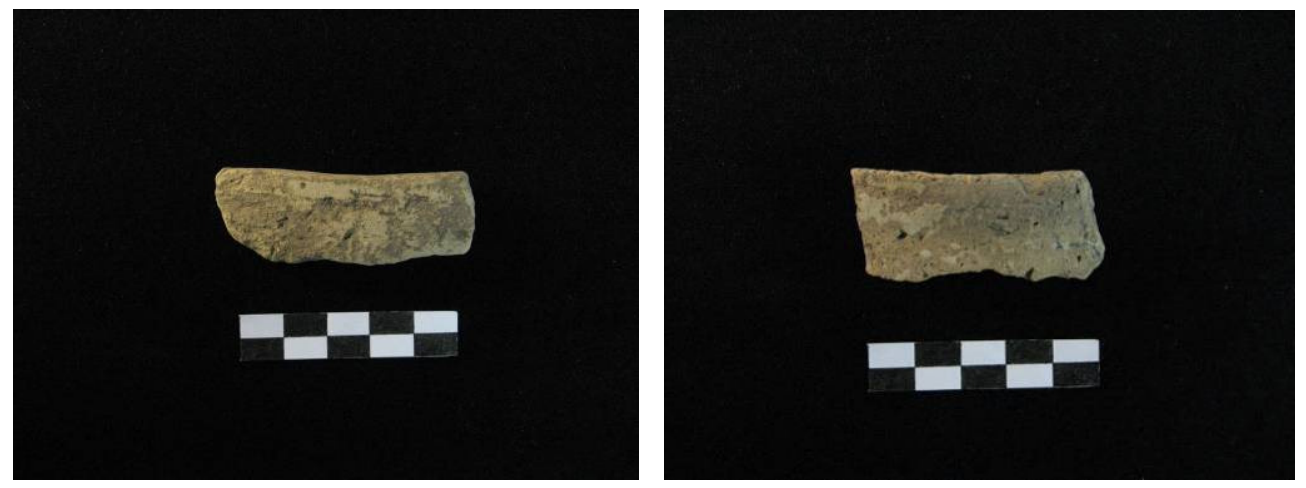

Fig 205 - Cerâmicas do Nova Esperança: aspectos gerais (fotos: Val Moraes).

As análises confirmaram que, em Nova Esperança, sua ocupação mais recente é representada por cerâmicas da Tradição Policroma da Amazônia, que afloram por toda a superfície do sítio arqueológico, bem como nas camadas estratigráficas menos profundas. Quantitativamente é, de longe, o conjunto mais representativo. A própria tipologia da coleção gerou sete conjuntos relacionados à Tradição Policroma e apenas dois, semelhantes entre si, afiliados à Tradição Borda Incisa (os tipos objetos da pesquisa encontram-se descritos no apêndice). Estes escassos materiais refletem o momento de ocupação mais antigo do sítio, cujos vestígios ocupam os níveis profundos, bem como sua área periférica, a oeste do sítio.

Despertam maior atenção esses materiais supostamente mais antigos. As pranchas descritivas e os gráficos foram organizados da seguinte maneira: primeiro são apresentadas informações referentes a todos os vestígios do sítio, a fim de se ressaltar as diferenças existentes entre os conjuntos cronológica e estratigraficamente distintos. Em seguida, ao se observar a presença de características diferenciadoras marcantes, novos gráficos são apresentados, atendo-se nestes materiais mais antigos como foco direto da pesquisa.

Para efeito dessas últimas análises quantitativas, foram utilizados apenas os dados da unidade N1000 E8101, que garante certa integridade aos resultados. Isto porque neste local, na periferia do sítio arqueológico, não se encontram vestígios superficiais associados à tradição policroma, do mesmo modo em que daí são oriundos os pacotes mais remotos e profundos do sítio. Como mencionei na descrição da estratigrafia desta unidade, não se trata de terra preta, e sim de 
um pacote orgânico associado a uma maior densidade relativa de vestígios, concentrados em dois picos (observar novamente figura 204).

Além da baixa densidade e reduzido tamanho dos fragmentos, poucos foram aqueles que podiam dar informações morfológicas, em especial nos níveis mais profundos, que são o objeto da pesquisa, como se pode ver através do resultado da triagem dos fragmentos, no gráfico de triagem a seguir (gráf. 58).

Também em função da pequena quantidade de fragmentos nos níveis mais profundos, a observação de uma série de características não pareceu verossímil. Assim, a aparente homogeneidade dos materiais presentes nos níveis inferiores a um metro parece ser um viés amostral. Nestes níveis, uma série de características encontra-se ausente, como mostra a seqüência de gráficos a seguir.

Em relação ao tempero, a preponderância de cariapé associada aos níveis superiores está ligada aos fragmentos da Tradição Policroma, que na maioria das vezes apresentam uma boa proporção do uso deste tipo de tempero, ao menos na Amazônia central. Há uma contínua redução em sua ocorrência, até ter seu fim no nível $120-130 \mathrm{~cm}$, voltando a aparecer nos níveis mais profundos, agora com uma predominância do cauixi, com exceção do nível $220-230 \mathrm{~cm}$. Lembrar, ao interpretar o gráfico abaixo, que se trata de freqüências relativas e, especialmente nos inferiores, a quantidade de fragmentos analisados é pequena. $E$, quanto menor a quantidade de observações feitas menor também a variabilidade encontrada num nível. Apenas para os materiais de N1000 E801, contexto Borda Incisa, a proporção entre cauixi e cariapé é como segue:

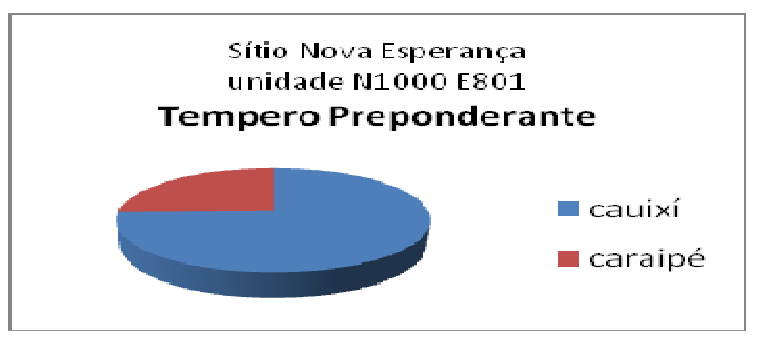

Gráfico 57 - Temperos preponderantes observados nos fragmentos da unidade N1000 E801 do sítio Nova Esperança. 


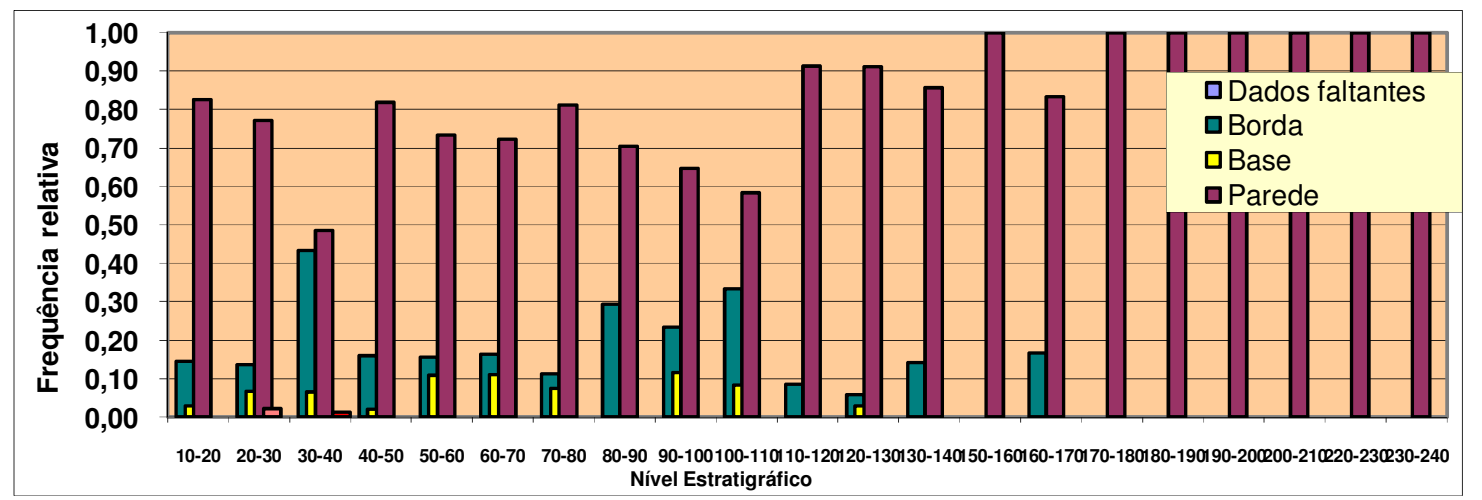

Gráfico 58 - Resultado da triagem dos fragmentos do sítio Nova Esperança.

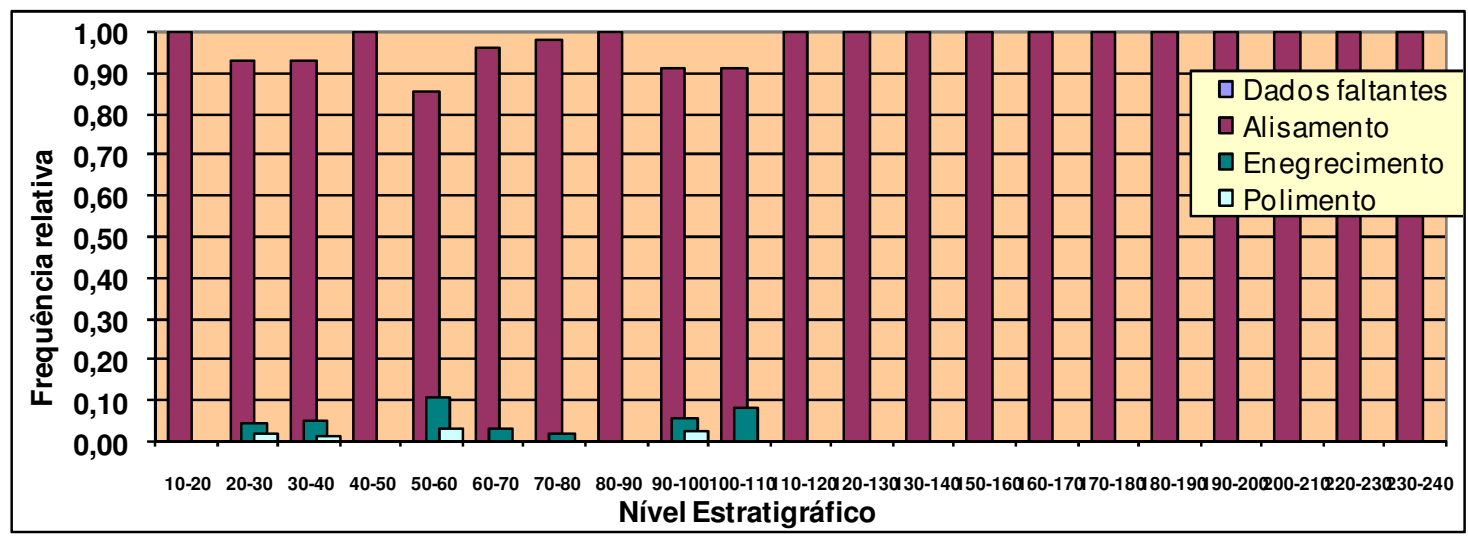

Gráfico 59 - Tratamentos de superfície observados nos fragmentos do sítio Nova Esperança.

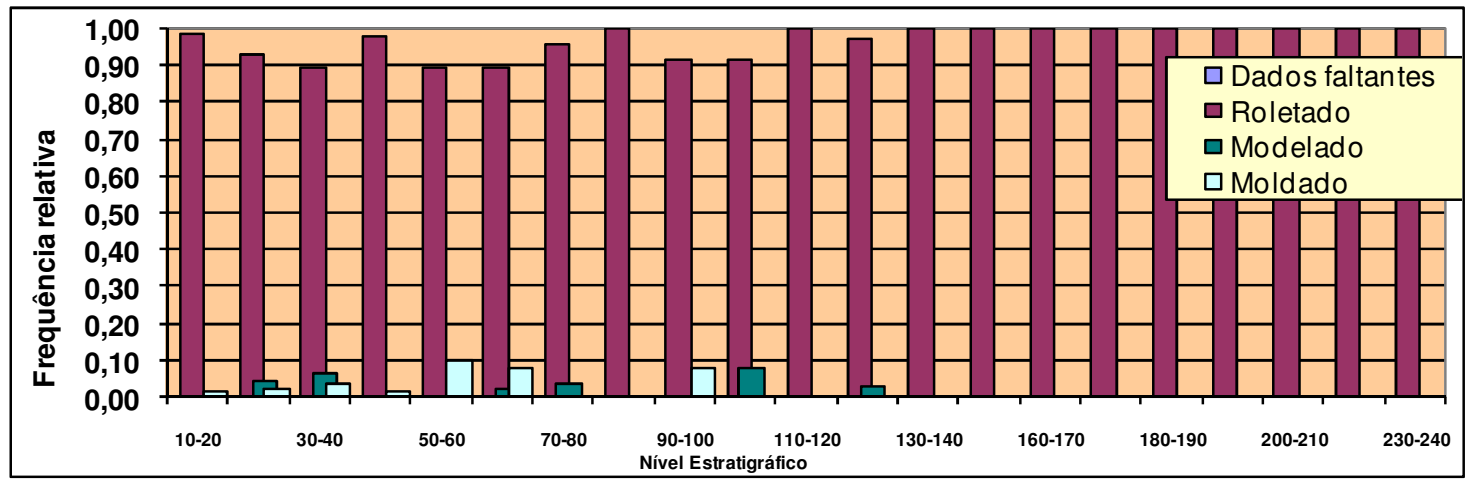

Gráfico 60 - Técnicas de manufatura observadas nos fragmentos do sítio Nova Esperança.

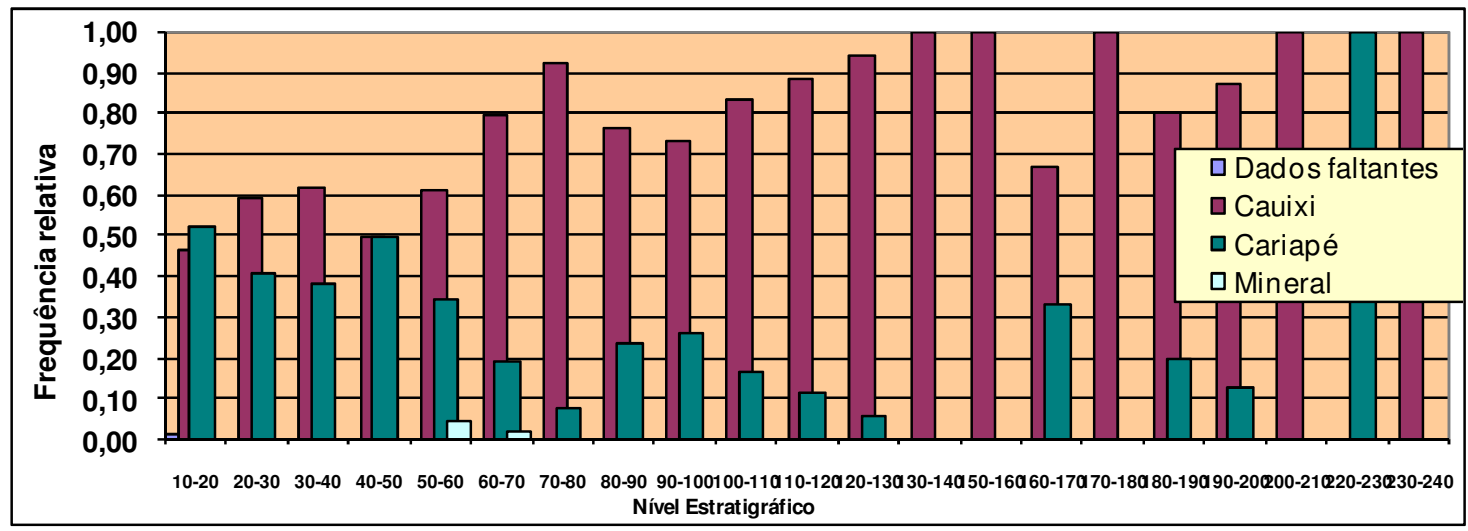

Gráfico 61 - Temperos preponderantes observados nos fragmentos do sítio Nova Esperança. 
Pelas mesmas razões já expostas, a verificação quantitativa de atributos decorativos não surtiu o efeito desejado. Observa-se uma variabilidade alta dentre os fragmentos mais superficiais, associados principalmente à Tradição Policroma, incluindo, dentre as decorações plásticas, acanalados, incisões, e digitados ou ungulados. Em níveis profundos, apenas incisões se salientaram. Também as decorações crômicas se concentram nos níveis superiores, através do uso de vermelho e branco, típicos dessa Tradição.

Embora quantitativamente precárias, as análises qualitativas renderam interessantes dados. Elas demonstraram que as características tecnológicas do conjunto de interesse remetem, de fato, aos estilos mais antigos encontrados na região, tais como: incisões em linhas finas paralelas e inter-cruzadas e engobo vermelho. Amostras de carvão foram enviadas para datação, o que comprovou a hipótese de antigüidade de ocupação da área, para compor o quadro cronoespacial do sítio e da região como um todo, como se discutirá adiante.

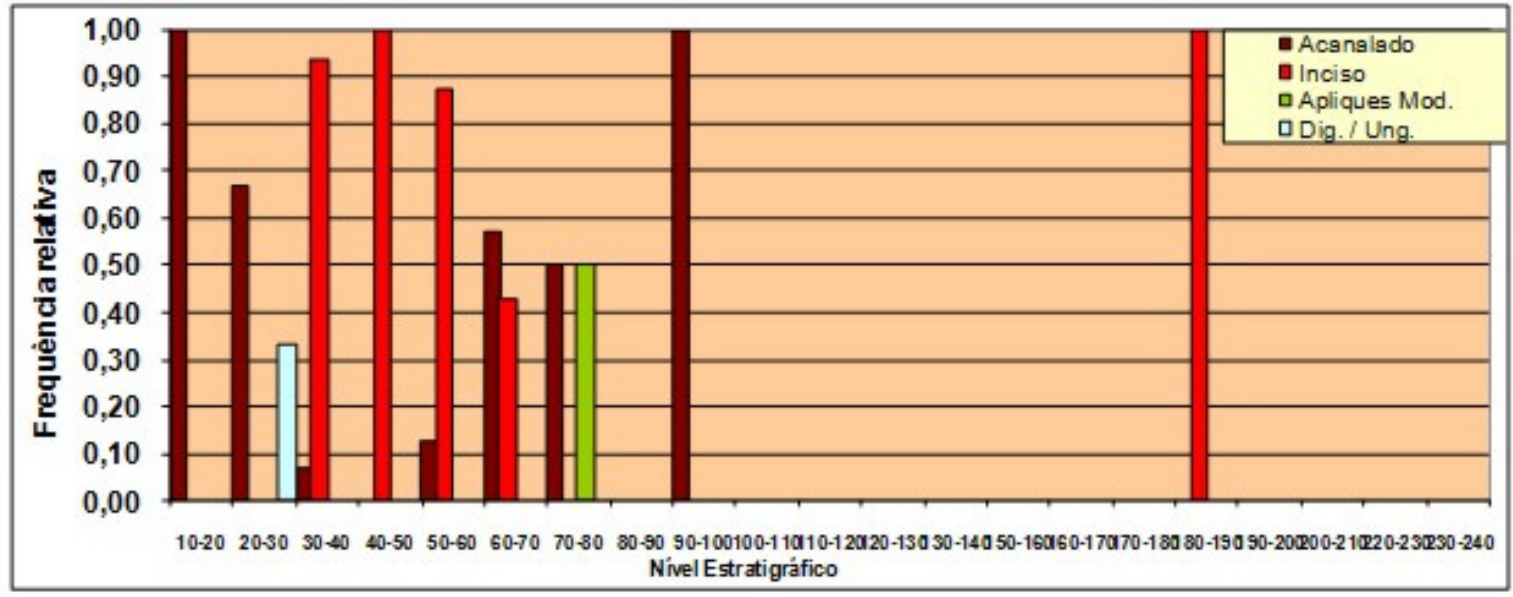

Gráfico 62 - Decorações plásticas observadas nos fragmentos do sítio Nova Esperança.

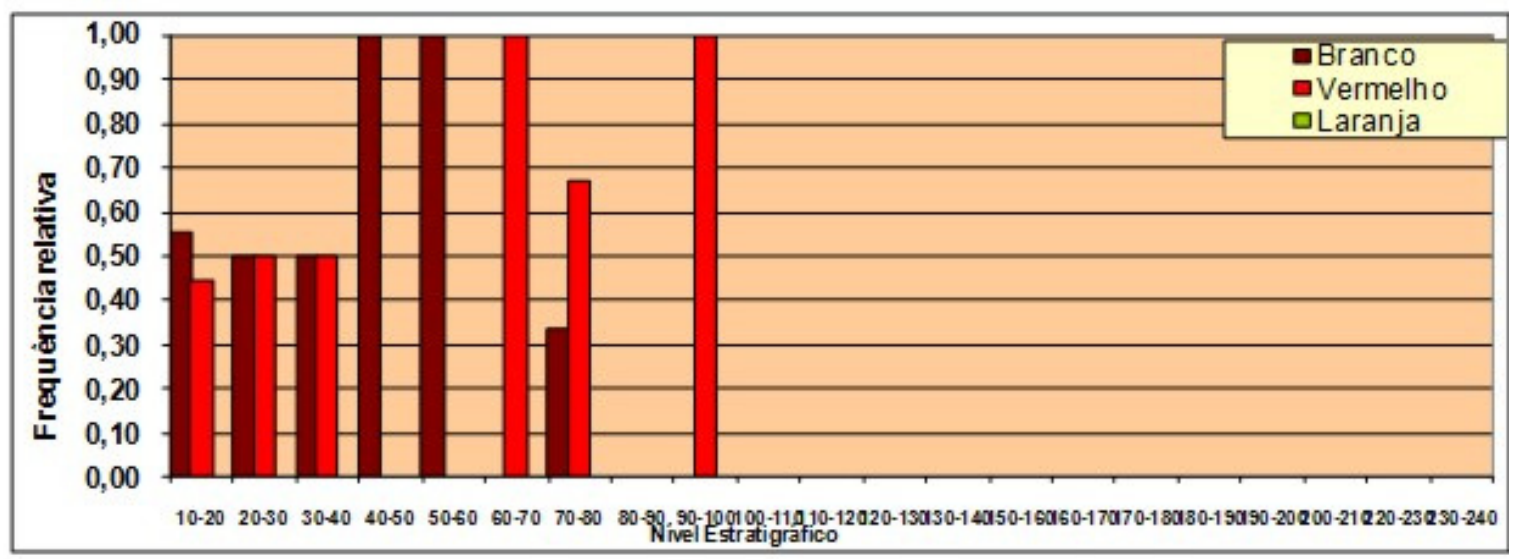

Gráfico 63 - Decorações crômicas observadas nos fragmentos do sítio Nova Esperança. 


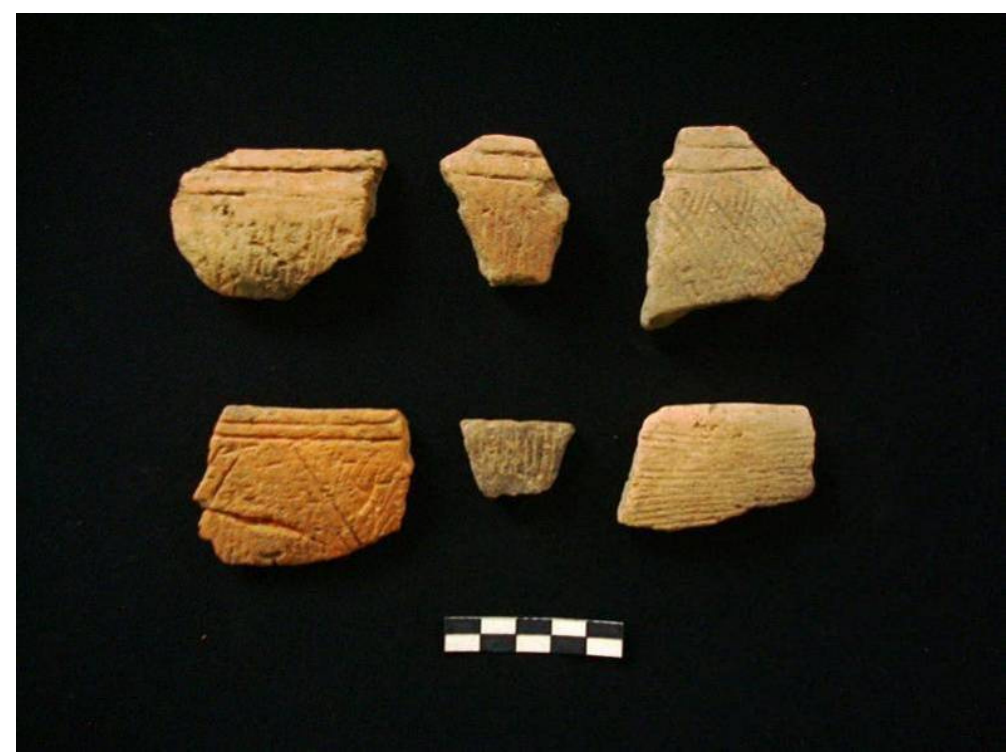

Figura 206 - Cerâmicas antigas do Nova Esperança (foto: Helena Lima).

\section{Cronologia de ocupação}

Como se pôde ver através das unidades escavadas em Nova Esperança, ocorrem pelo menos dois níveis distintos de ocupação. O mais recente apresenta afloramentos cerâmicos abundantes em superfície, sempre associados às terras pretas. As cerâmicas têm características tipicamente relacionadas à Tradição Policroma da Amazônia, tais como pinturas (vermelha e preta sobre engobo branco), fragmentos das tradicionais urnas antropomórficas e flanges mesiais com decoração acanalada. Para esta ocupação superficial e recente, há uma data póscontato, situada já século XVII d.C, obtida no âmbito dos resgates arqueológicos do Poliduto Urucu-Coari (Caldarelli, 1997, p. 81-87).

\begin{tabular}{|c|c|c|c|}
\hline Numero do Lab & Quad. & Nivel & Data \\
\hline BETA 124236 & E80 & $20-30 \mathrm{~cm}$ & 1670 d.C \\
\hline BETA 124940 & N160 & $70-80 \mathrm{~cm}$ & 100 d.C. \\
\hline BETA 124235 & N160 & $110-120 \mathrm{~cm}$ & 1965 a.C. \\
\hline
\end{tabular}

Tabela 21 - Datações radiocarbônicas obtidas para o sítio Nova Esperança (Clareira 11), pelo Projeto de Regate Arqueológico do Poliduto Urucu-Coari (Caldarelli, 1997, p.81-84).

Interessam aqui as ocupações mais antigas do sítio, por esta razão, optouse por focar o trabalho na unidade N1000E801 descrita em detalhe anteriormente, e datar mais duas amostras de carvão desta mesma unidade, que fora escavada numa área periférica do sítio, mas que apresentou um interessante nível de 
ocupação, mais profundo, não associado à terra preta, e com uma antigüidade compatível, por hipótese, com outros conjuntos relacionados à Tradição Borda Incisa.

As datas apresentadas na tabela abaixo foram obtidas através de carvões coletados junto aos dois picos de ocupação, registrados na seqüência estratigráfica da unidade. Em ambos os níveis, as amostras de cerâmica, embora reduzidas, demonstraram claras afinidades com conjuntos Borda Incisa conhecidos. Também as datas obtidas, situadas num intervalo cronológico entre os séculos VIII e XIII d.C., são com compatíveis com esta Tradição.

\begin{tabular}{|c|c|c|c|}
\hline $\begin{array}{c}\text { Número do } \\
\text { Laboratório }\end{array}$ & Proveniência & Profundidade & $\begin{array}{c}\text { Idade Calibrada } \\
\mathbf{( 6 6 . 8 \% )}\end{array}$ \\
\hline BETA 242447 & N1000 E801 & $30-40 \mathrm{~cm}$ & $1160-1230$ d.C. \\
\hline BETA 242448 & N1000 E801 & $80-90 \mathrm{~cm}$ & $800-780$ d.C. \\
\hline
\end{tabular}

Tabela 22 - Datas Calibradas obtidas para o sítio Nova Esperança.

Uma posterior substituição de tais conjuntos pelas cerâmicas policromas, supostamente ocorrida em torno dos séculos XIII ou XIV, coloca este evento de substituição, observado na Amazônia central nos séculos XII-XIII, numa cronologia pouco mais recente, algo em torno de uma única geração, quando comparados. Esses dados, todavia incipientes e especulativos, fornecem subsídios para a inserção deste sítio e desta região arqueológica num quadro regional mais amplo, e lançam luz a problemas de pesquisa tão caros à arqueologia amazônica quanto aqueles tratados diretamente neste doutorado. Por oportuno, o estabelecimento de uma cronologia preliminar de ocupação deste sítio arqueológico priorizou apenas os eventos mais antigos. Deixo para estudos posteriores o entendimento de sua configuração mais recente. 


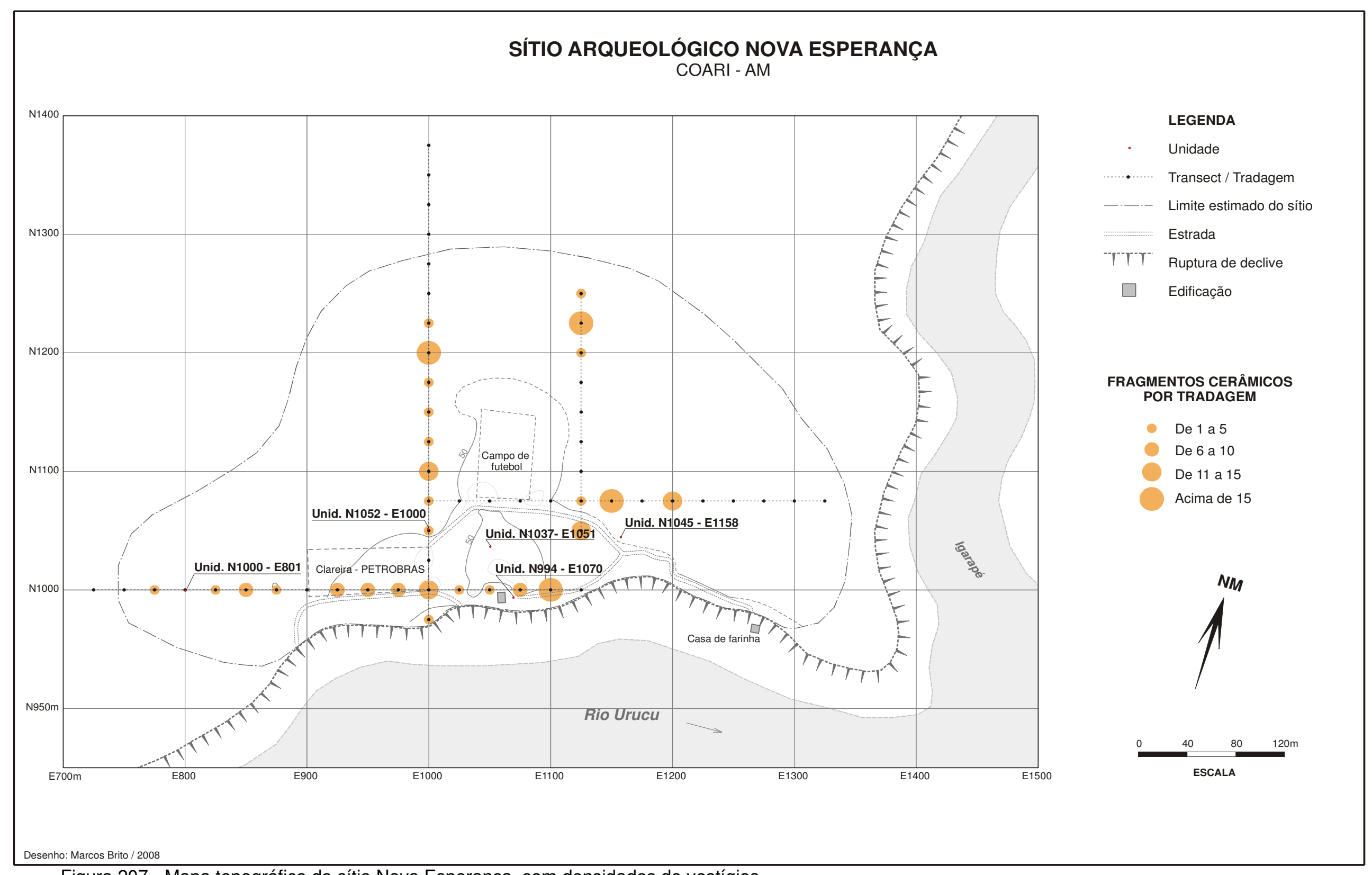

Figura 207 - Mapa topográfico do sítio Nova Esperança, com densidades de vestígios. 


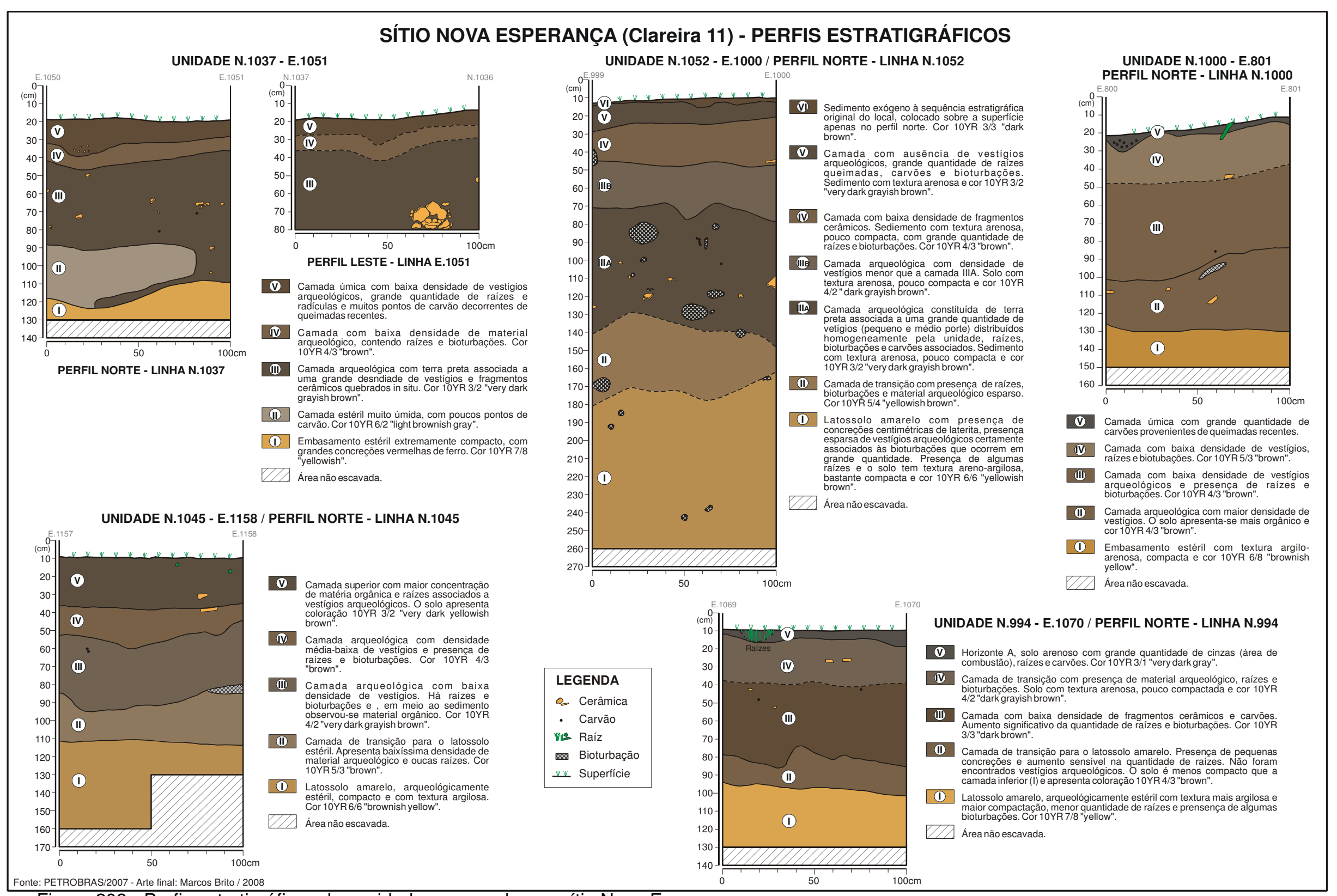

Figura 208 - Perfis estratigráficos das unidades escavadas no sítio Nova Esperança. 


\section{IV. O baixo Amazonas e o contexto Pocó}

A identificação deste contexto arqueológico antigo se deu por ocasião das pesquisas de Peter Hilbert na região do Baixo Amazonas, no baixo curso dos rios Trombetas e Nhamundá, no Estado do Pará. Essas pesquisas tiveram início na década de 50. Foi das escavações realizadas, em 1975, por ele e K._Hilbert em dois sítios arqueológicos, Pocó (que gerou a definição da fase homônima) e Boa Vista, que surgiu a publicação de um artigo no qual definiram as principais características destas cerâmicas, e apresentaram datações bastante antigas para este contexto, todas em torno do anno domini, ou mais antigas (Hilbert \& Hilbert, 1980).

A região como um todo já era bem conhecida por seu potencial arqueológico, pois guarda vestígios de ocupações em grandes extensões de terras pretas, com cerâmicas da fase Konduri - termo provavelmente cunhado por Nimuendaju à cerâmica encontrada no baixo Nhamundá (Hilbert, 1955, p. 11) - que chamam a atenção por sua rara beleza registrada em motivos geométricos e na decoração plástica rebuscada. Além de Nimuendaju, vários outros pesquisadores passaram pela região, em função da grande quantidade de sítios, quase sempre associados às terras pretas.

Os materiais relacionados à fase Pocó foram no início identificados em dois sítios arqueológicos, Pocó e Boa Vista. O primeiro se localiza na margem direita da boca do igarapé do Pocó, afluente da margem esquerda do rio Nhamundá, em seu baixo curso. O sítio se estende paralelamente à margem do rio sobre uma praia de várzea baixa, com depósitos até $1,20 \mathrm{~m}$ de espessura, cobertos por dunas de areia fina e siltosas (Hilbert \& Hilbert, 1980, p. 2) - contexto similar ao do sítio Açutuba. A terra preta ocupa uma área de cerca de 400×150 metros de extensão, a 3 metros acima do nível do igarapé. A dimensão exata do sítio ainda não foi determinada, pois as camadas de ocupação encontram-se soterradas sob uma camada de areia de $15-25 \mathrm{~cm}$ de profundidade, praticamente ausente de material arqueológico na superfície (Hilbert, K., 2007, comunicação pessoal).

Já o sítio Boa Vista tem um padrão deposicional diferenciado. Ocupa a margem direita do rio Trombetas, numa margem alta da terra firme. Seus depósitos são menos profundos, chegando até, no máximo, $70 \mathrm{~cm}$ (Hilbert \& Hilbert, 1980, p. 2). 
Ambos os sítios se caracterizam pela sobreposição de componentes cerâmicos na estratigrafia. $E$ foi este $o$ fato que levou à identificação do conjunto mais profundo e antigo, até então desconhecido. As datações obtidas para o sítio Pocó se situam ao redor do anno domini: 65 a.C., 110 e 205 d.C. Já as datas do sítio Boa Vista são ainda mais antigas, e acusaram 1330 e 1000 a.C. Estas últimas, no entanto, foram "rejeitadas por não corresponderem com datações aceitas para o sítio-tipo" (Hilbert \& Hilbert, 1980, p. 9).

Com o retorno de K. Hilbert à região, em 1992, definiu-se que materiais relacionados a esta fase estariam representados em três sítios arqueológicos: Pocó e São José no rio Nhamundá e Boa Vista, no Trombetas (fig. 209). Posteriormente, a partir de 2001, o estabelecimento de um projeto de arqueologia de contrato deu às pesquisas na área do rio Trombetas um novo fôlego, o que a tornou mais consistentemente conhecida em seu aspecto arqueológico. Por ocasião do "Projeto Salvamento Arqueológico em Porto Trombetas", realizado pela equipe do Museu Paraense Emílio Goeldi, o sítio Boa Vista foi re-escavado, além de uma série de outros contextos identificados e trabalhados. Os resultados renderam uma recente pesquisa de doutorado (Guapindaia, 2008).

A idade recuada de tais contextos, bem como as características tecnológicas das cerâmicas a eles associadas, despertou interesse dentro de minha pesquisa, que trata de conjunturas sociais, políticas, econômicas e ambientais antigas na Amazônia, que levaram a processos como sedentarização dos grupos humanos, intensificação agrícola e a produção intensiva de cerâmica. Tais processos parecem ter ocorrido em períodos semelhantes numa ampla região da Amazônia, e seus resultados materiais nos são apresentados hoje de maneira similar: sítios arqueológicos com terra preta e uma impressionante padronização estilística e tecnológica da cultura material. 


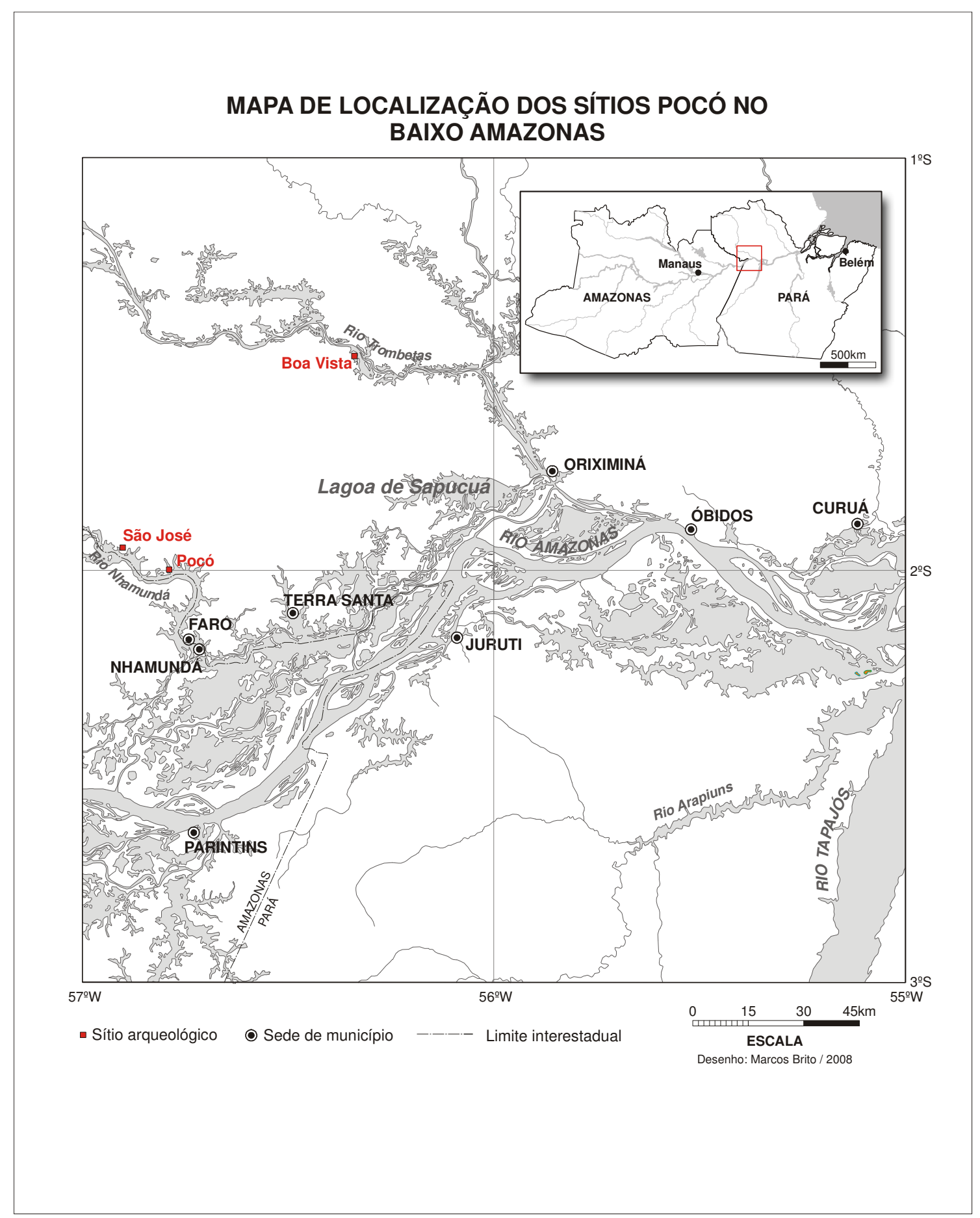

Figura 209 - Sítios arqueológicos da região do baixo Trombetas-Nhamindá, com a ocorrência de cerâmicas Pocó. 


\section{IV. I. Cerâmicas POcó}

Para análise, foram selecionados os materiais cerâmicos provenientes de uma escavação de 1,5 m x 1,5 m, realizada por K. Hilbert no sítio Pocó, em 1992. Denominada sondagem 1, esta intervenção foi realizada a $30 \mathrm{~m}$ ao sul de uma escavação de 1975, reportada no artigo de 1980 (Hilbert, K., 3-4/12/1992). Estes materiais não estavam disponíveis quando da publicação de 1980 e, portanto, podem trazer contribuições não redundantes às caracterizações anteriormente propostas.

As análises foram realizadas no laboratório de arqueologia da PUC-RS, em novembro de 2006 e janeiro de 2007. Os materiais, bem como a infra-estrutura necessária às análises, foram gentilmente cedidos pelo Dr. Klaus Hilbert, docente desta instituição e exímio conhecedor destas cerâmicas, que muito me auxiliou durante o trabalho.

A sondagem 1-92 apresenta uma estratigrafia que pode ser considerada típica dos sítios do Baixo Trombetas - Nhamundá. As camadas superficiais, compostas por uma escura Terra Preta de Índio, apresentam cerâmicas da fase Konduri (Tradição Incisa e Ponteada). É apenas a partir de aproximadamente 50 ou $60 \mathrm{~cm}$ que começam a aparecer fragmentos com claras características Pocó, que seguem até $1 \mathrm{~m}$ de profundidade. Nesta mesma profundidade, ou seja, num nível com características Pocó, foi coletado um vaso completo, fragmentado in situ, demonstrando um bom padrão de preservação do contexto. Na foto abaixo, ele encontra-se em parte remontado, na posição emborcada.

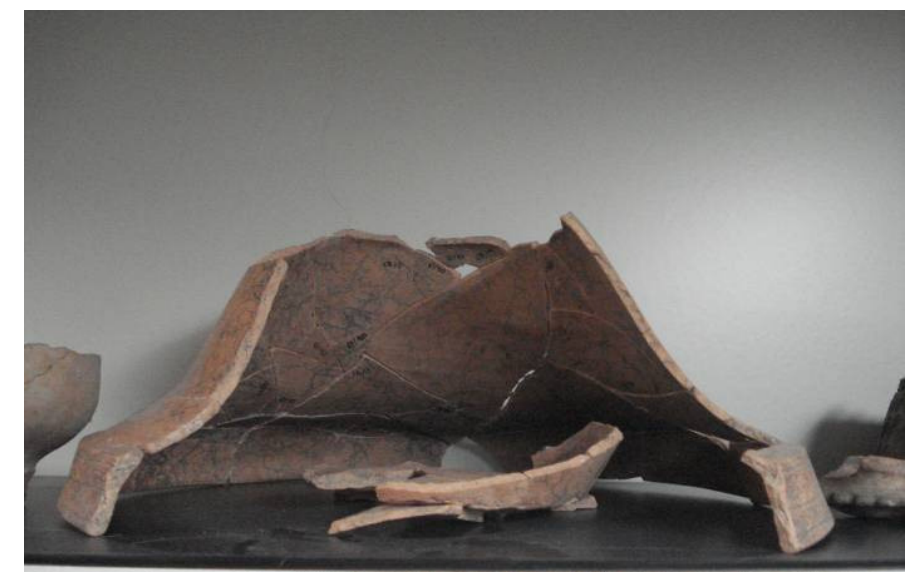

Fig 210 - Vaso cerâmico Pocó, escavado na base da sondagem 1 - 92 (foto: Helena Lima). 
As informações estratigráficas da sondagem 1 - 92 constam na tabela abaixo, cujos dados também foram cedidos por K. Hilbert.

\section{Sondagem 1 - 1992}

\begin{tabular}{|c|c|c|}
\hline Nível & Descrição sumária & Datas de C14 \\
\hline $0-10 \mathrm{~cm}$ & $\begin{array}{l}\text { Solo arenoso pouco compactado, de coloração cinza amarronzada. } \\
\text { Nível composto por radículas e baixa densidade de cerâmica Kondurí. }\end{array}$ & \\
\hline $10-20 \mathrm{~cm}$ & $\begin{array}{l}\text { Solo arenoso pouco compactado, de cor acinzentada, com poucos } \\
\text { fragmentos cerâmicos. }\end{array}$ & \\
\hline $20-30 \mathrm{~cm}$ & $\begin{array}{l}\text { Solo arenoso pouco compactado, com poucos fragmentos cerâmicos e } \\
\text { grande quantidade de carvão. }\end{array}$ & $\begin{array}{l}1390 \text { d.C. }-1510 \\
\text { d.C. }\end{array}$ \\
\hline $30-40 \mathrm{~cm}$ & Solo arenoso acinzentado e estéril arqueologicamente. & \\
\hline $40-50 \mathrm{~cm}$ & $\begin{array}{l}\text { Solo arenoso amarronzado e alguns fragmentos cerâmicos da fase } \\
\text { Pocó. }\end{array}$ & \\
\hline $50-60 \mathrm{~cm}$ & Terra Preta arenosa solta, associada à cerâmica Pocó. & \\
\hline $60-70 \mathrm{~cm}$ & $\begin{array}{l}\text { Terra Preta arenosa, alta densidade de fragmentos cerâmicos da fase } \\
\text { Pocó, (Punctaded, rocker-stamp, e polychrom) e carvão. }\end{array}$ & 140 d.C. - 260 d.C. \\
\hline $70-80 \mathrm{~cm}$ & $\begin{array}{l}\text { Terra Preta, arenosa mais clara e areia mais grossa, com manchas de } \\
\text { areia clara devido a bioturbações (formigas) e grande quantidade de } \\
\text { cerâmica e carvão. }\end{array}$ & 30 d.C. - 150d.C. \\
\hline $80-90 \mathrm{~cm}$ & $\begin{array}{l}\text { Solo arenoso acinzentado com manchas de Terra Preta e grande } \\
\text { fragmentos de cerâmica bem conservados. }\end{array}$ & \\
\hline $90-100 \mathrm{~cm}$ & $\begin{array}{l}\text { Solo arenoso mais claro com manchas de Terra Preta associada à } \\
\text { cerâmica. Há uma grande quantidade de carvão e de cerâmica bem } \\
\text { preservados, praticamente vasilhas completas. Provavelmente é a } \\
\text { base da ocupação. }\end{array}$ & 60 d.C. - 200 d.C. \\
\hline $105 \mathrm{~cm}$ & $\begin{array}{l}\text { Fim dos vestígios arqueológicos. Solo arenoso pouco compactado e } \\
\text { estéril arqueologicamente até os } 150 \mathrm{~cm} \text {. }\end{array}$ & \\
\hline
\end{tabular}

Tabela 23 - Informações estratigráficas da sondagem 1 - 1992 (Hilbert, K., 2007, com. pessoal).

Foi observado, a partir da aplicação da ficha de análise do PAC, um total de 586 fragmentos cerâmicos, dos quais 398 puderam ser com clareza filiados à fase Pocó, que permitiram uma caracterização geral da coleção. Os demais também foram observados e afiliam-se, em sua grande maioria, à fase Konduri. Atenção foi dada, neste momento, aos fragmentos Pocó. Como se pode ver, o nível de ocupação Pocó é bem definido, e ocupa os estratos mais antigos do sítio arqueológico. 


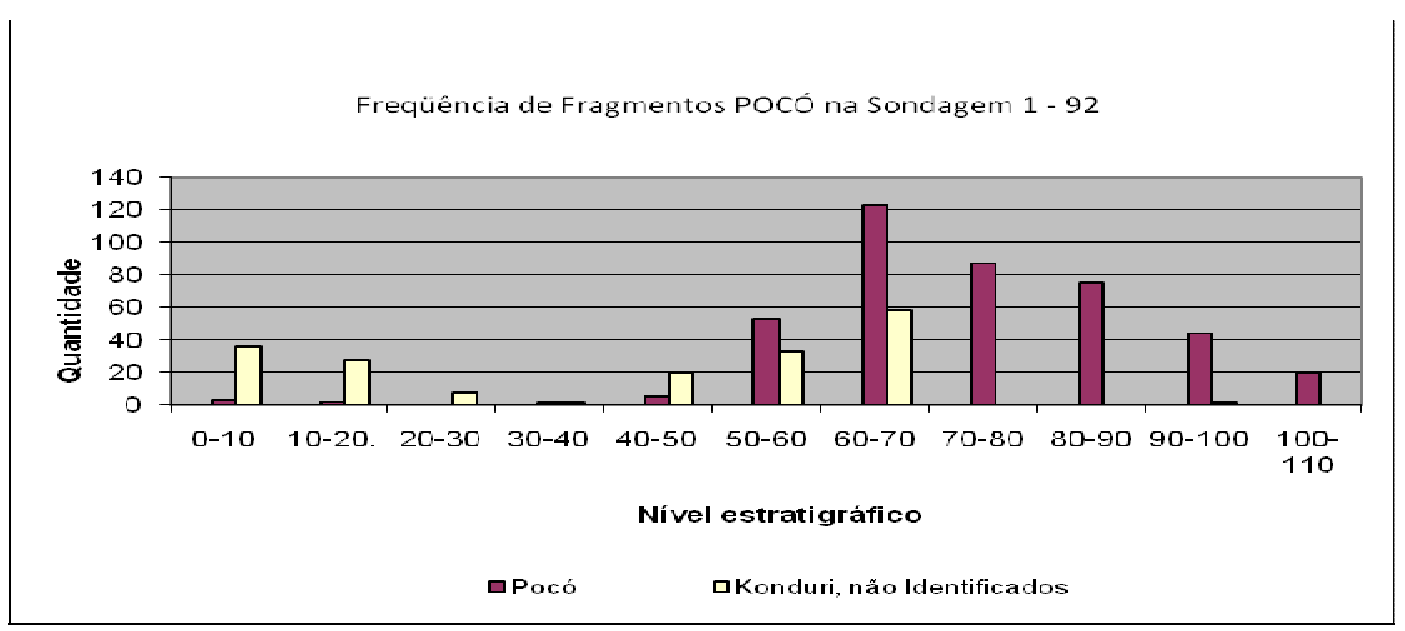

Gráfico 64 - Freqüência de fragmentos Pocó por nível na sondagem 1-92.

Os fragmentos observados apresentaram pastas variadas, mas com certas tendências que diferenciam, inclusive, os níveis Pocó da ocupação Konduri, mais recente. Embora em todos os níveis a coloração mais recorrente seja alaranjada, notar, no gráfico a seguir (gráf. 65), um aumento na incidência de fragmentos de cores escuras nos níveis mais profundos.

O tempero mais utilizado, em todos os casos Konduri e Pocó, é sempre o cauixi. No entanto, a variabilidade da pasta cerâmica é muito maior nos níveis mais profundos. O gráfico abaixo demonstra a freqüência relativa do tempero preponderante nos fragmentos observados nos diferentes níveis estratigráficos (gráf. 66). Significativos, somente nos níveis mais profundos aparecem como elementos preponderantes na pasta cerâmica caco moído, minerais e cariapé. Também nos níveis inferiores, as associações entre os diferentes tipos de temperos são mais freqüentes. O gráfico seguinte demonstra tais associações apenas dentre as cerâmicas Pocó. Notar que, mesmo dentro deste conjunto, o cariapé aparece proporcionalmente mais freqüente nos níveis inferiores (Gráf. $68)$. 


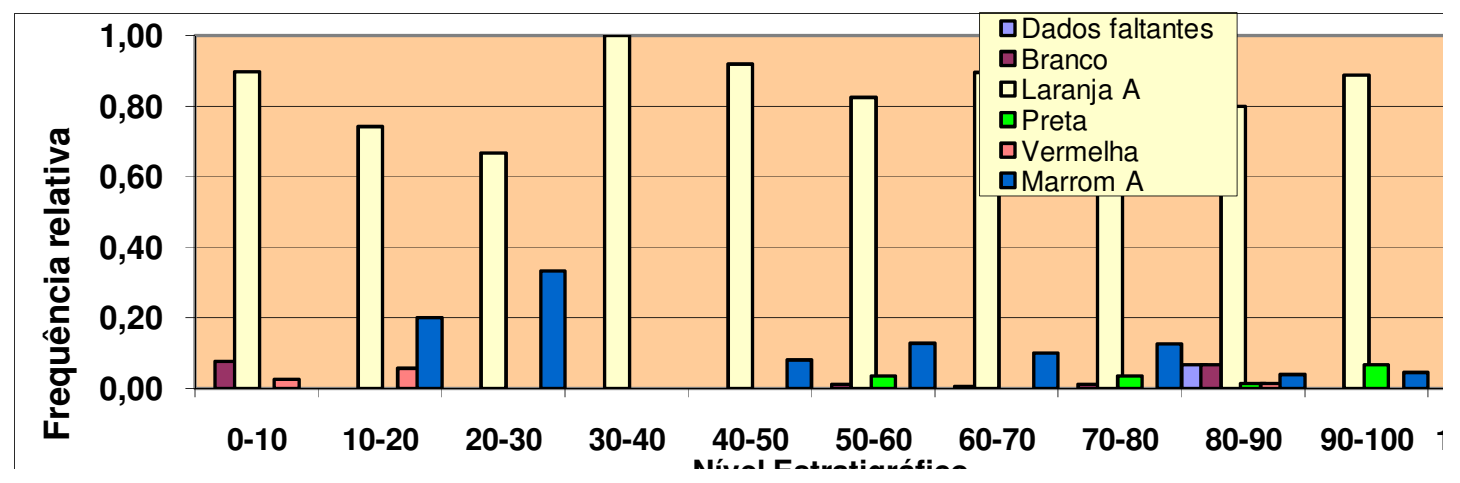

Gráfico 65 - Coloração da superfície da cerâmica, observada em todos os fragmentos da Sondagem 1-92.

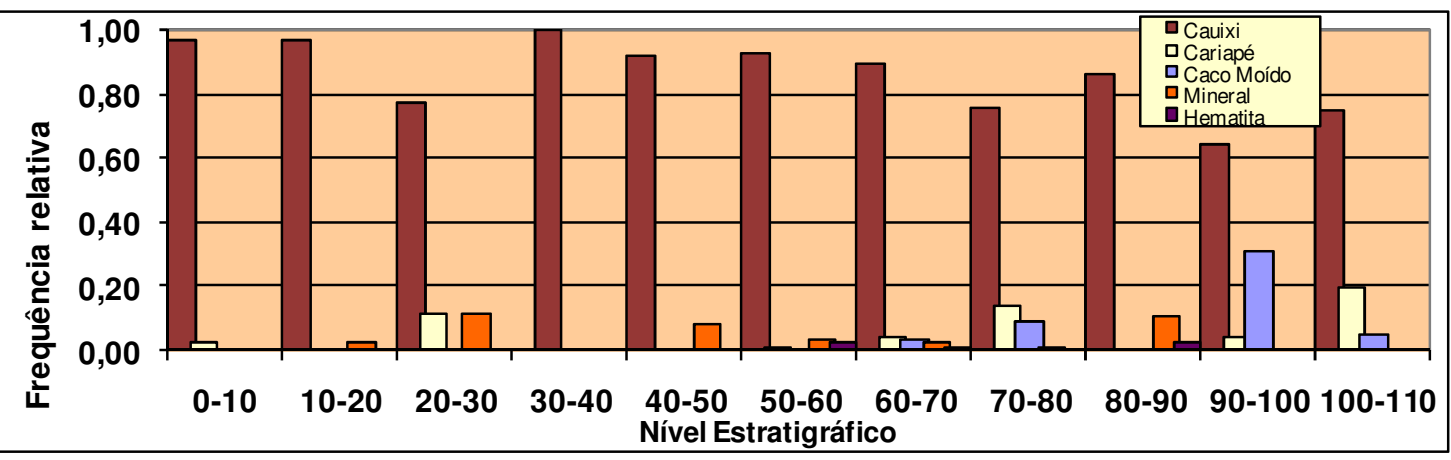

Gáfico 66 - Freqüência relativa do tempero preponderante observado em todos os fragmentos da Sondagem 1-92.

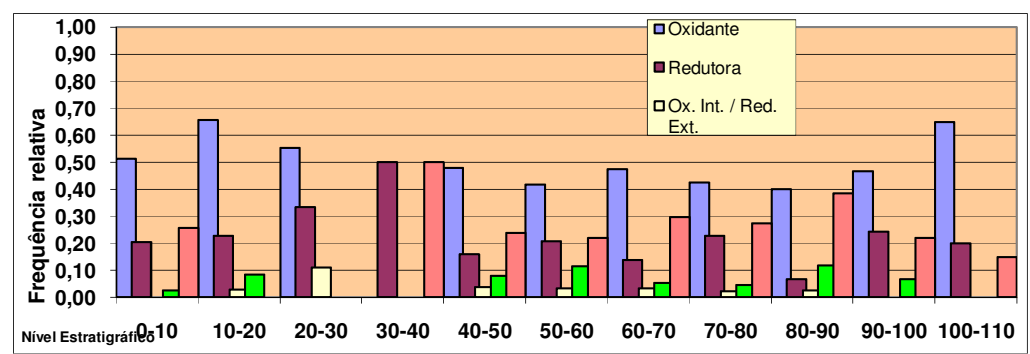

Gráfico 67 - Freqüência relativa dos tipos de queima observados em todos os fragmentos da Sondagem 1-92.

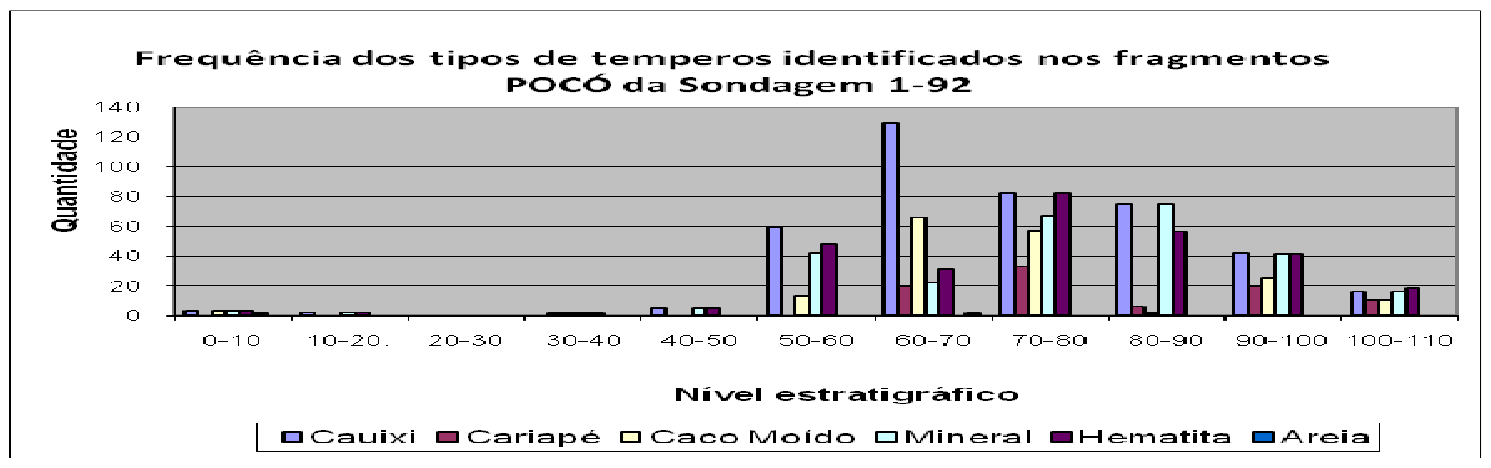

Gráfico 68 - Temperos observados entre os fragmentos Pocó da Sondagem 1-92 
Em relação aos padrões de queima observáveis nas pastas cerâmicas, tem-se predominância do tipo oxidada em relação às redutoras, em todos os níveis. Mas quando se conjuga as associações entre estes dois tipos, (núcleo redutor; oxidante interna / redutora externa; ou o contrário), tem-se certo equilíbrio entre os tipos de queima, não se podendo extrair desta categoria de dados informações diferenciadoras, sejam internas ao conjunto Pocó, seja entre os níveis estratigráficos.

Embora maior freqüência do acabamento de superfície do tipo alisamento seja verificada nas superfícies interna e externa das cerâmicas (gráf. 70), os conjuntos Pocó se diferenciaram dos demais, tanto dos níveis Konduri, assim como daqueles provenientes da Amazônia central. Estes acabamentos Pocó consistem na aplicação de espessas camadas de resina, que dão a elas um aspecto extremamente lustroso. Outro tratamento diferencial é um escovado profundo aplicado à superfície, em geral interna, das vasilhas, dando a elas uma aparência tosca, cujo sentido parece ser proposital.

A triagem dos fragmentos demonstrou, sem causar nenhuma surpresa, uma maior freqüência de paredes em relação às bordas, bases, e outros atributos estruturais. A ausência de tais elementos dificulta uma análise morfológica mais apurada do conjunto. Ainda assim, nota-se uma quantidade significativa de inflexões, o que sugere incidência de formas com contornos compostos e complexos, o que foi, inclusive, corroborado pelas reconstituições e tipologias obtidas para a coleção.

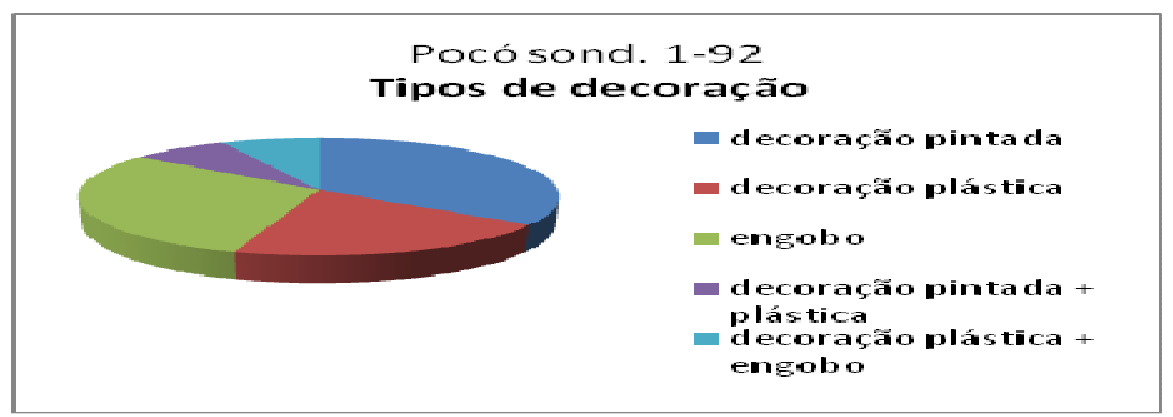

Gráfico 69 - Freqüência dos tipos de decoração dos fragmentos Pocó da Sondagem 1-92 


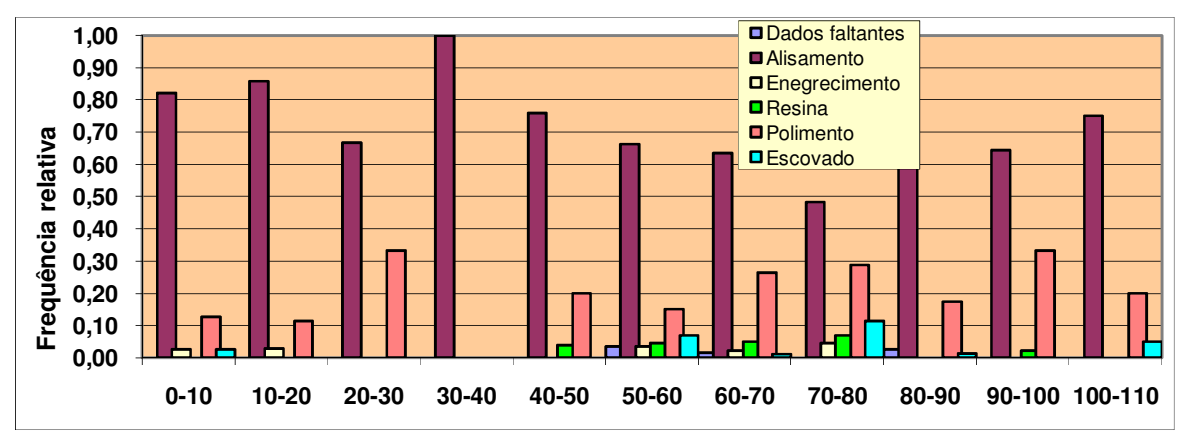

Gráfico 70 - Freqüência relativa dos tipos de tratamentos da superfície das cerâmicas observadas na Sondagem 1-92.

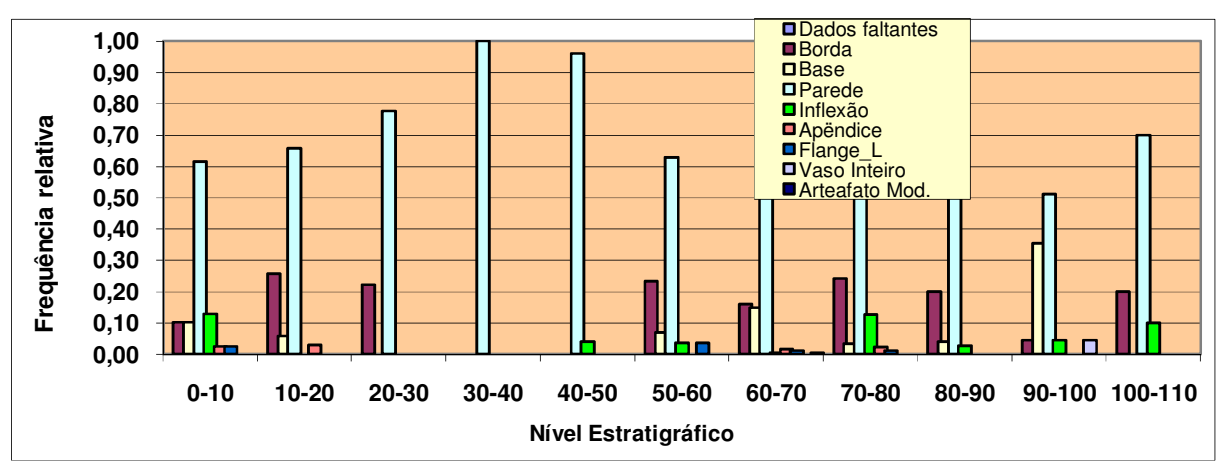

Gráfico 71 - Resultado da triagem dos fragmentos Pocó da Sondagem 1-92

Na tipologia Pocó, apresentada no apêndice dessa tese, encontram-se descritos oito tipos, criados a partir de sete modos distintos de forma (fig. 210). Esclareço, porém, que neste caso a tipologia foi conservadora, considerando como tipo apenas aqueles bem consistentes. Isto porque, diferente das coleções da Amazônia central, que conheço bem, o contato com essas cerâmicas Pocó foi mais efêmero. Observa-se que estas cerâmicas apresentaram formas variadas, em geral complexas e com alta incidência de flanges e inflexões. Tais modificações morfológicas do vaso são comuns aos conjuntos Borda Incisa da Amazônia central, e sempre definem a superfície a ser decorada. Esta parece ser de fato, uma típica característica dos conjuntos amazônicos antigos. No caso das cerâmicas Pocó, ênfase tão grande é dada às decorações pintadas quanto às decorações plásticas, como se vê no gráfico abaixo. 


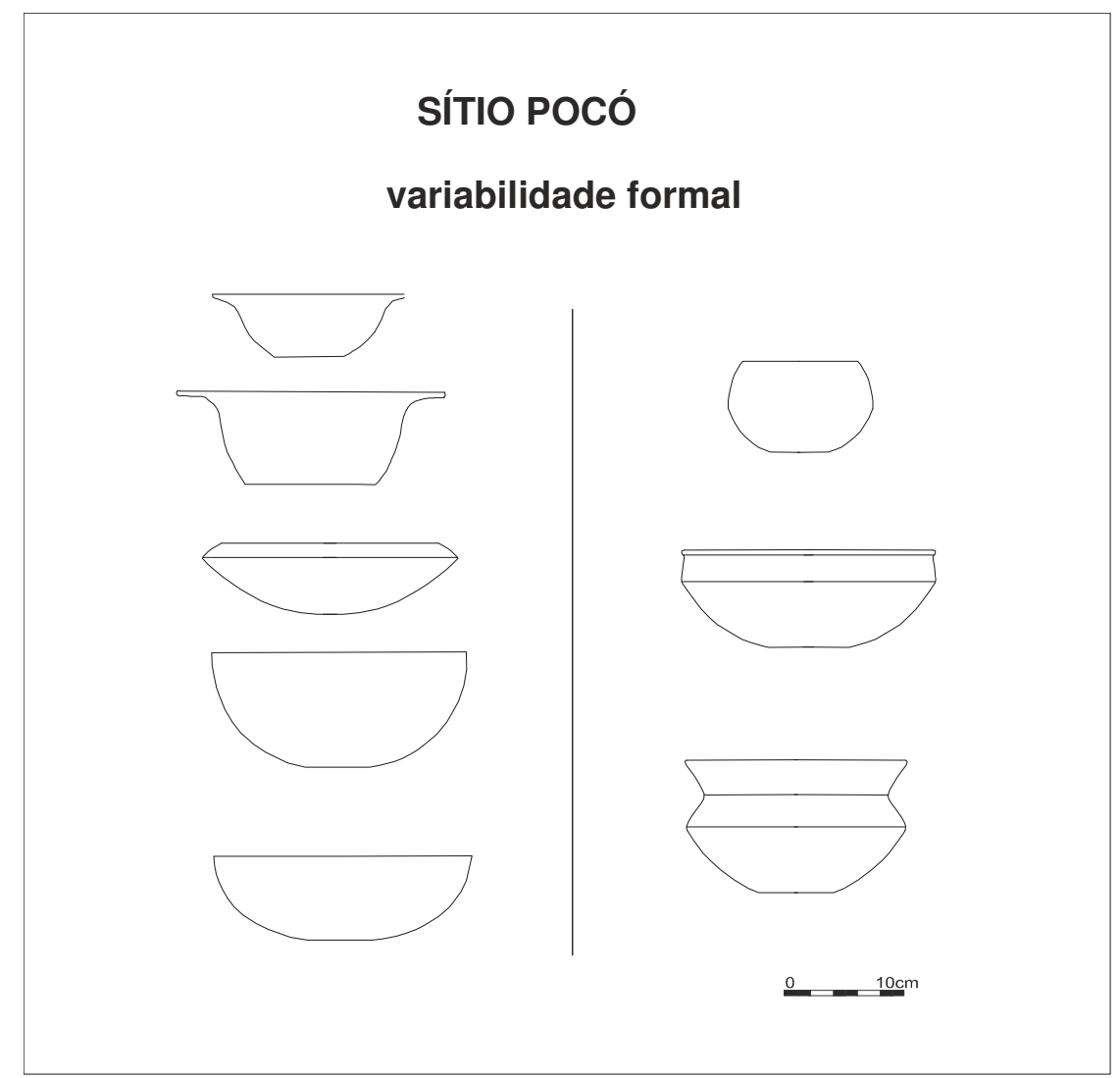

Figura 210 - Reconstituição morfológica a partir de fragmentos Pocó da Sondagem 1-92

As técnicas decorativas são diversas e dividem-se, quase igualmente como se viu, em plásticas e pintadas. Dentre as decorações plásticas encontram-se uma variada gama de incisões, acanalados e excisões, além da modelagem de apliques com representações zoomorfas. Também particular das cerâmicas Pocó é a ocorrência de impressões de corda na superfície da vasilha (fig 211, decoração).
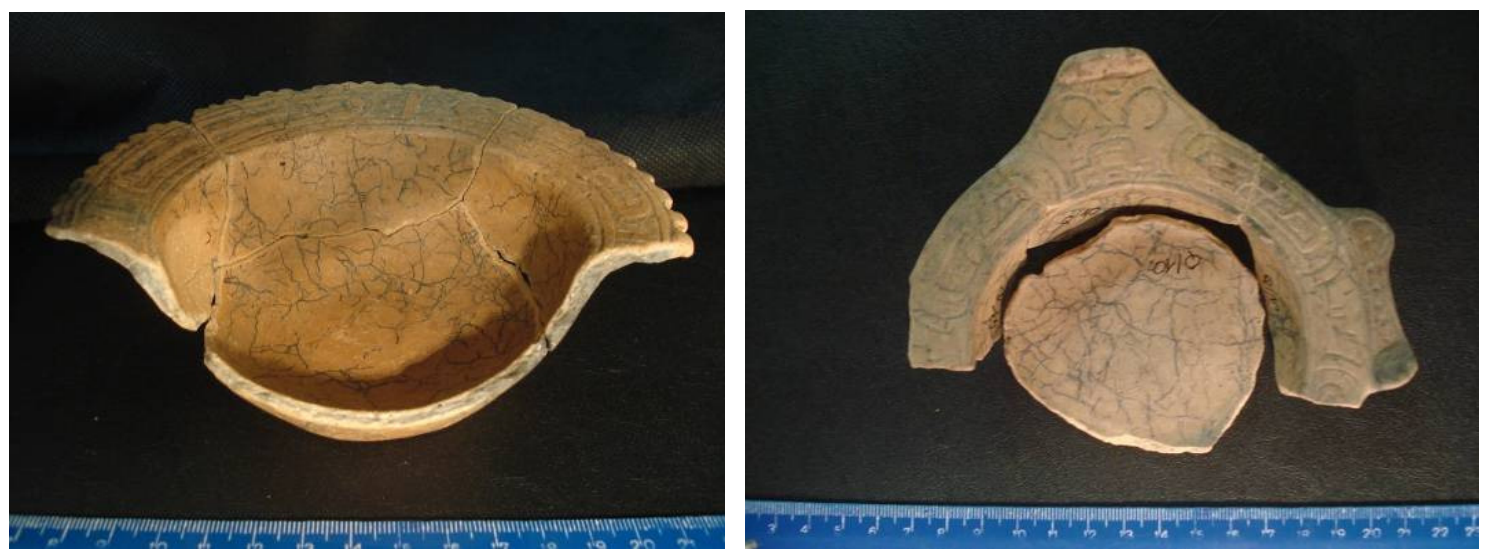

Figura 211 - Cerâmica Pocó: vasilhas com flanges labiais e decoração incisa, uma delas com motivo zoomorfo (fotos: Helena Lima). 

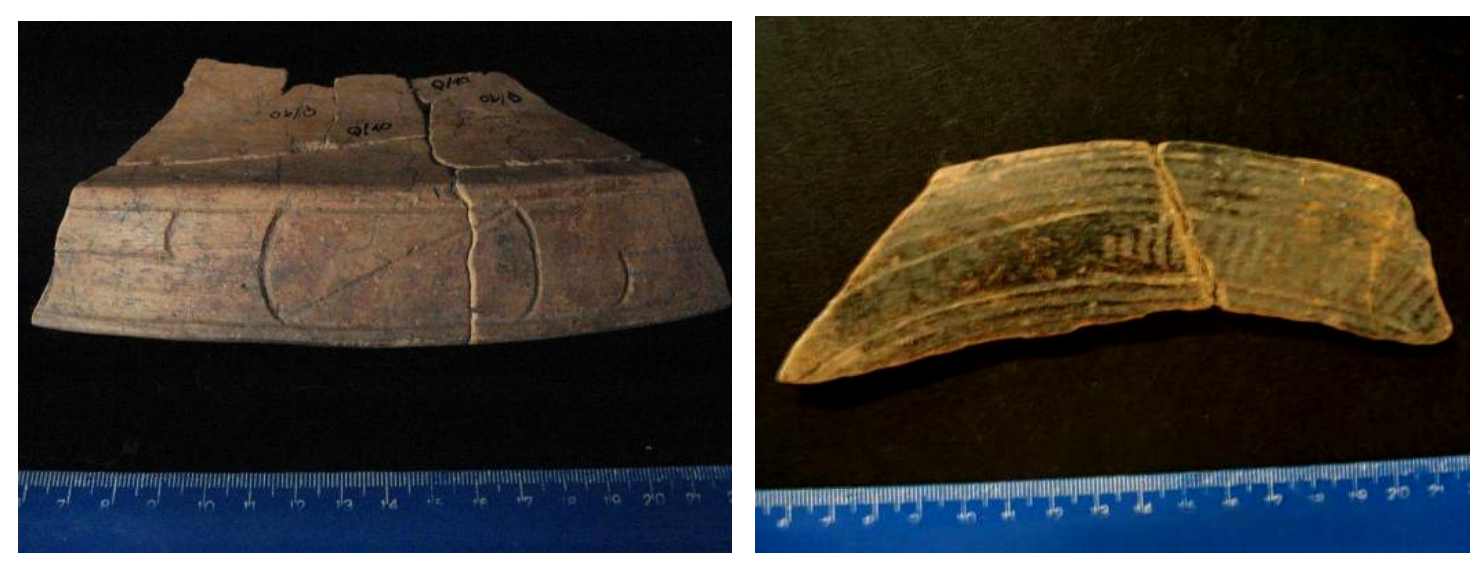

Figura 212 - Cerâmica Pocó: a) vaso com borda incisa, b) fragmento de flange labial com impressão de corda (fotos: Helena Lima)

As decorações pintadas consistem em cores e tons diversos. De fato, a variação crômica é extremamente ampla. Utilizam-se pigmentos pretos, vinho, vermelhos, alaranjados, amarelos e brancos, que extrapolam as considerações de outrora sobre a policromia antiga dos conjuntos venezuelanos e caribenhos. Há também a ocorrência de engobos vermelhos e brancos. Decorações plásticas e pintadas aparecem associadas em diversos fragmentos, compondo, em conjunto, os motivos decorativos finais.

Em contrapartida a essa diversificada gama de técnicas de decoração, as regras definidoras dos motivos decorativos são rígidas. Tanto pintados quanto plásticos, os motivos variam dentro de um arsenal limitado, cujos componentes se combinam de diferentes maneiras.
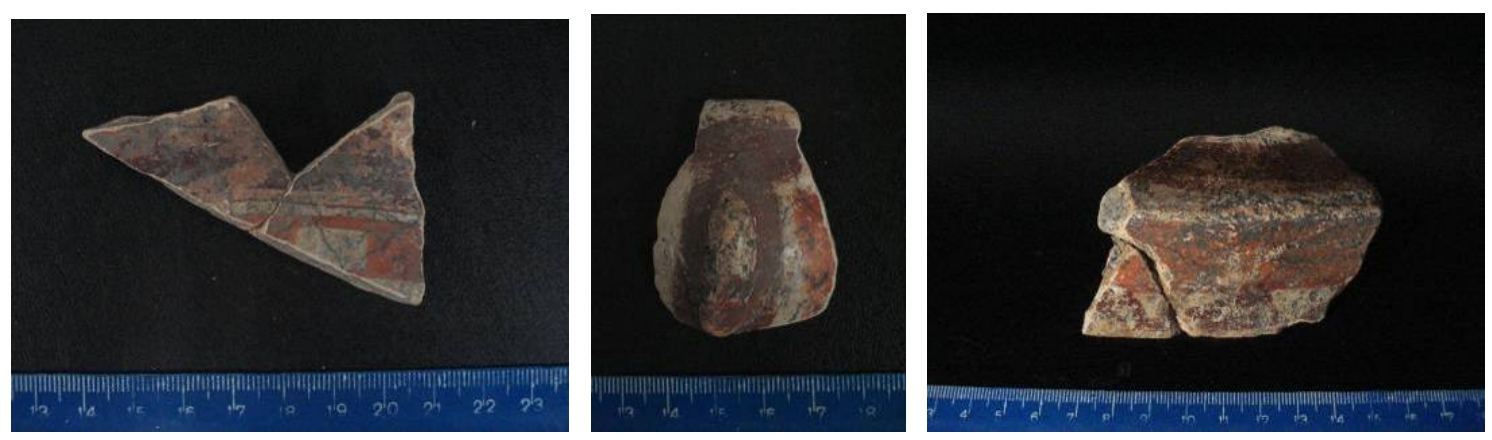

Figura 213 - Cerâmicas Pocó: pintura policroma (fotos: Helena Lima). 
Diferente do que se observou no sítio Açutuba, o bom estado de preservação em que se encontram essas cerâmicas, permitiu que uma série de elementos se conservasse. Os acurados tratamentos de superfície e as pinturas são exemplos disso. Também nesta coleção observou-se, melhor do que em qualquer outra analisada, a ocorrência de determinadas marcas de uso, tais como fuligem e atrito, que podem trazer importantes informações sobre suas funcionalidades. A presença de atrito, por exemplo, não havia sido identificada nas coleções da Amazônia central, justamente por seu grau inferior de preservação.

Como se viu, é grande a quantidade de fragmentos decorados em relação aos não decorados. As técnicas decorativas são, na maior parte, similares àquelas descritas para a fase Açutuba, como a presença de engobo vermelho $\mathrm{e}$ branco, incisões, modelado, acanalados, ponteados, e policromia, entre outras supramencionadas. Estas cerâmicas guardam afinidades também com a fase El Palito, da tradição Barrancóide, que ocorre no litoral caribe-venezuelano (Hilbert \& Hilbert, 1980, p. 8). Estes dados são importantes porque remetem a discussões sobre os contextos que caracterizaram um hipotético início da produção de cerâmica no continente Sul-americano.

A presença da policromia na cerâmica da fase Pocó foi a princípio interpretada como decorrência de relações andinas (idem). Desde o ponto de vista ora apresentado, esta parece representar uma relação com as cerâmicas Saladóides da bacia do Orinoco (Venezuela), assim como ocorre na Amazônia, central nas cerâmicas da fase Açutuba. Da mesma maneira, os materiais cerâmicos representados por estas duas fases, Açutuba e Pocó, compõem um arsenal simbólico comum, caracterizado pela similaridade em vários aspectos do processo de produção dessas cerâmicas, relacionados à série Barrancóide, também do Orinoco. Os contextos de deposição parecem similares. As implicações deste quadro indicariam uma rede de influências que abrangeu parte do norte da América do Sul. Este argumento será posteriormente desenvolvido. 


\section{V. Paralelos materiais}

Feita uma caracterização bem detalhada tanto dos conjuntos artefatuais trabalhados na Amazônia central, vista no capítulo 6, como de uma amostragem do médio Solimões e do Baixo Amazonas, a idéia desta seção é traçar elementos que estes conjuntos têm em comum, assim como mostrar suas diferenças. Tais contextos foram selecionados por apresentarem, a priori, características que os remetem, de diferentes maneiras, à Tradição Borda Incisa, ora estudada. Todos eles apresentam datações da primeira metade do milênio 1 d.C. Portanto, foram selecionados, para uma análise comparativa, os materiais coletados em cinco sítios arqueológicos. Três da área de confluência do Negro com Solimões Açutuba, Nossa Senhora do Perpétuo Socorro e Jacuruxi -, o sítio Nova Esperança, do Solimões e Pocó, do Baixo Amazonas.

Dentre os nove sítios arqueológicos estudados na área de confluência, os três selecionados assim o foram por representarem uma boa amostragem tanto geográfica quanto cronológica da área de pesquisa. O sítio Açutuba, às margens do rio Negro, apresenta os contextos mais antigos, associados à fase homônima; NSP Socorro representa um contexto intermediário entre as fases Açutuba e Manacapuru, onde se tem um início do processo de formação das terras pretas antrópicas, situado no baixo Solimões; e, por fim, o sítio Jacuruxi, com as datações mais recentes entre os três, contando com cerâmicas Manacapuru e situado na área de interflúvio, mediando geograficamente os outros dois sítios.

A esta amostragem se somam os outros dois sítios, Nova Esperança e Pocó, que expandem o universo amostral para além das fronteiras da Amazônia central, permitindo inferências, ainda que parciais, sobre as relações entre ocupações, numa área geográfica mais ampla. Além disso, ao traçar os paralelos entre essas três áreas, a acuidade das interpretações, em termos de continuidades e mudanças dentro da área de pesquisa, torna-se mais apurada. Apesar da irrisória amostragem dentro de uma tão ampla área, resolvi encarar esta tarefa como um exercício comparativo, que acabou por render interessantes informações. Tendo em vista que agora são três as sub-regiões trabalhadas, os problemas de pesquisa passaram a ser testados, ainda que apenas na forma de um ensaio, a partir de comparações concretas entre os sítios arqueológicos e suas coleções. 
Os procedimentos foram os seguintes: feita a análise e caracterização geral de atributos dos fragmentos destes sítios, partiu-se para uma análise estatística comparativa entre esses dados. Mais uma vez, as análises foram realizadas através do Centro de Estatística Aplicada (CEA), do IME-USP (Chiann et al., 2007). O objetivo foi agrupar os dados obtidos para estes sítios a fim de observar a existência ou não de padrões, assim como de registrar as diferenças existentes entre eles. É claro que não se espera que cinco sítios arqueológicos possam dar conta de explicar uma região tão extensa quanto é a Amazônia, da qual estamos tratando. Pelo contrário, este exercício visou, antes de mais nada, pincelar (nada mais do que isso) algumas hipóteses sobre relações entre essas diferentes áreas num mesmo período de tempo, através de sua cultura material. Essas hipóteses, longe de fechadas, abrem portas a novas discussões a serem travadas em estudos de história pré-colonial amazônica.

Como ocorreu com as demais análises comparativas, seja intra-sítios, seja entre os sítios da Amazônia central já discutidos, quantitativamente as amostras foram sempre diferentes, seja na intensidade das intervenções realizadas num determinado sítio, ou na densidade de materiais dentro de um ou de outro sítio. Neste caso, por exemplo, a quantidade de vestígios analisados em cada sítio teve uma grande diferença, ou seja, enquanto alguns sítios tiveram apenas mais do que uma centena de materiais analisados, outros tiveram mais do que dez vezes esta quantidade. É claro que esta diferença foi, sempre, levada em consideração quando feitas as comparações, calculadas em suas devidas proporções. A tabela e o gráfico abaixo mostram a quantidade de observações feitas para cada sítio arqueológico. É importante salientar que o número de peças analisadas não reflete o tamanho ou densidade dos sítios em questão, pois foram apenas amostrados de formas distintas.

\begin{tabular}{|l|l|}
\hline Sítio Arqueológico & frags. Analisados \\
\hline Açutuba & 120 \\
\hline NSP Socorro & 232 \\
\hline Jacuruxi & 1355 \\
\hline Nova Esperança & 637 \\
\hline Pocó & 686 \\
\hline
\end{tabular}

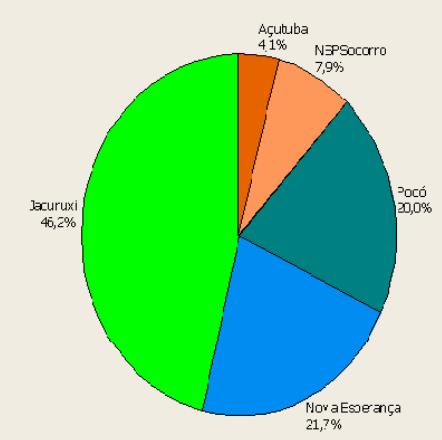

Gráfico 72 e Tabela 24 - Quantidade de vestígios analisados em cada sítio arqueológico. 
Ao que se pôde observar, não houve grande diferenciação entre os sítios no que se refere às variáveis tecnológicas entre as coleções. Como demonstrado na seqüência de gráficos abaixo, existe de fato uma grande padronização em quase todos os aspectos analisados. Sendo assim, grosso modo, todas as coleções teriam pastas caracterizadas por argilas de cores alaranjadas, o uso do cauixi como tempero majoritário e queimas com tendência oxidante. Também em todos os casos as vasilhas foram manufaturadas, em sua maioria, pela técnica de sobreposição de roletes e o tratamento final dado às vasilhas, com a notável exceção dos materiais provenientes do sítio Pocó, é sempre o alisamento.

Dentro dessa generalizante padronização estatística, ocorrem também variações entre estes materiais. Suas peculiaridades se mostram em diferentes aspectos. Em relação à cor, além da predominância das tonalidades alaranjadas na superfície dos fragmentos, são seguidas pelas cores marrom e preta, ainda em todos os sítios e, apenas nos materiais de Jacuruxi, NSP Socorro e Nova Esperança, aparece em menor proporção a cor rosa alaranjado.

A pequena variação observada nas cores não corresponde ao que se vê em relação aos temperos e à queima. A predominância do cauixi como antiplástico preponderante não se mostrou tão marcante nos materiais dos sítios Açutuba e Nova Esperança, nos quais o cariapé atinge, igualmente, grandes proporções. Em Açutuba, por exemplo, a proporção fica em torno de $60 \%$ de cauixi para quase $40 \%$ de cariapé. O sítio Pocó é o que apresenta uma maior variabilidade do tempero principal. É importante deixar claro que se trata apenas do tempero principal, apesar de este poder ser combinado com outros elementos. Como se viu na descrição dos materiais de cada sítio arqueológico, a presença de minerais como o quartzo e hematita é uma constante. Eles, provavelmente, são parte integrante da constituição das próprias argilas.

Embora haja uma maior ocorrência de queimas oxidantes, no sítio NSP Socorro sua concentração é muito mais expressiva, indicando menor variabilidade interna à coleção. Em oposição a isto, as cerâmicas Pocó apresentaram uma maior variabilidade interna. Açutuba e Nova Esperança, mais uma vez, mostraram proporções parecidas.

As técnicas de manufatura foram bastante homogêneas, com uma freqüência maior da roletagem, o que não se mostrou uma surpresa, uma vez que a maioria dos vasos pré-coloniais, amazônicos ou não, eram manufaturados desta 
maneira. As exceções não se constituem em uma diferenciação do modo de produção dos vasos, haja vista que a moldagem geralmente aparece associada à manufatura de apliques, alças, apêndices etc., que por sua vez compõem o próprio vaso roletado. Também a técnica de moldagem, que é comumente utilizada na manufatura das bases desses mesmos vasos, ocorre em associação com a roletagem da vasilha.

Já os tratamentos de superfície mostraram que os sítios Pocó e Açutuba ao mesmo tempo em que apresentam semelhanças entre si, mais uma vez, se distanciaram dos demais. Nestas coleções, a freqüência de fragmentos polidos ou com acabamento escovado é maior do que nos outros sítios. Este peculiar tipo de escovado foi notado anteriormente por Hilbert entre as cerâmicas Pocó, e aparenta ser específico a estas duas coleções antigas, marcado por sulcos mais profundos, podendo, inclusive, manifestar-se como uma decoração. Somente no Pocó aparece o uso de resina. Isto pode ser resultado das boas condições de preservação encontradas neste sítio. Também pode ser por esta razão que, apenas neste sítio, se observou a presença de atrito como marca de uso. Nos demais, a presença de fuligem é constante.

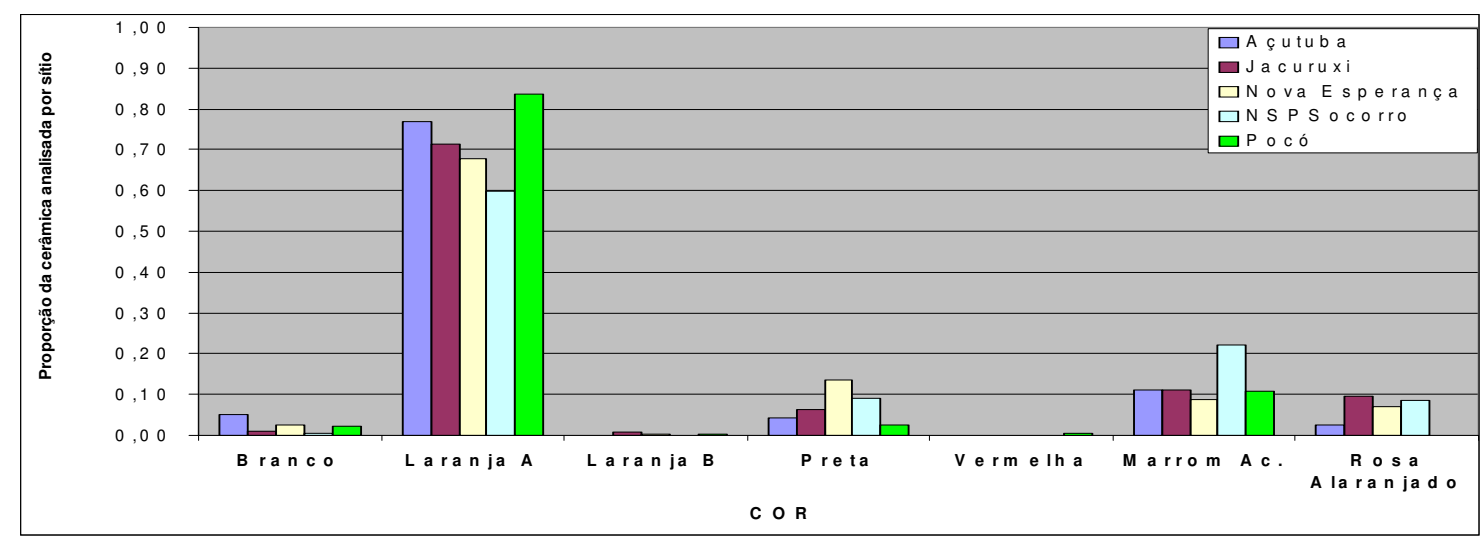

Gráfico 73 - Proporção das cores das argilas observadas nos fragmentos analisados.

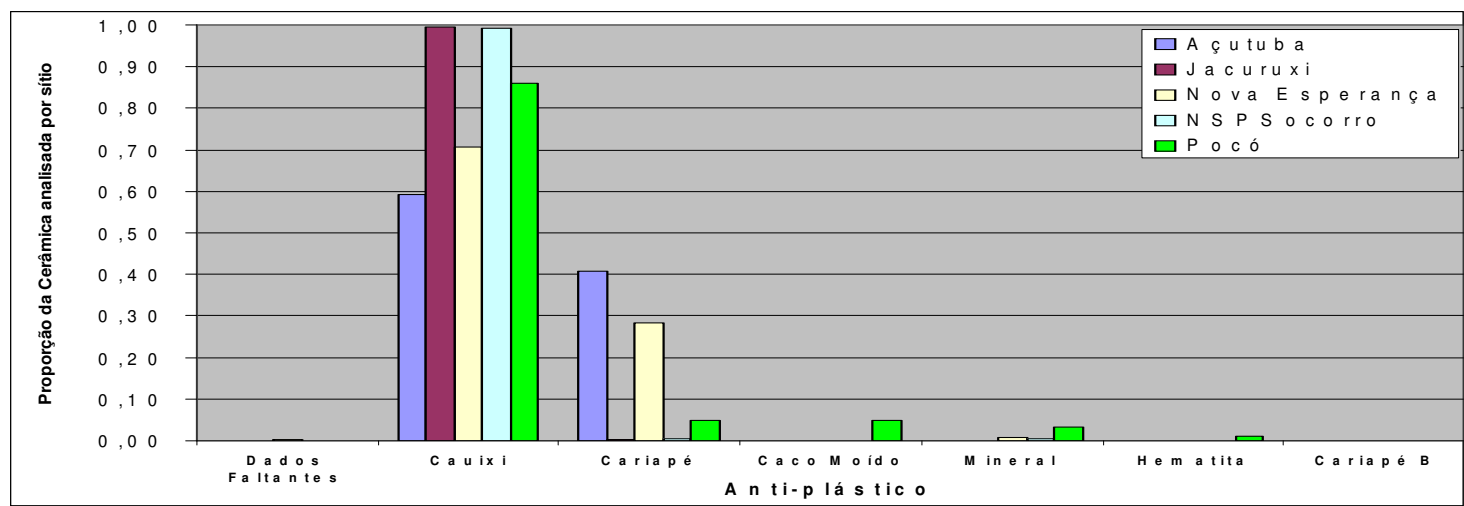

Gráfico 74 - Proporção dos temperos majoritários observados nos fragmentos analisados. 


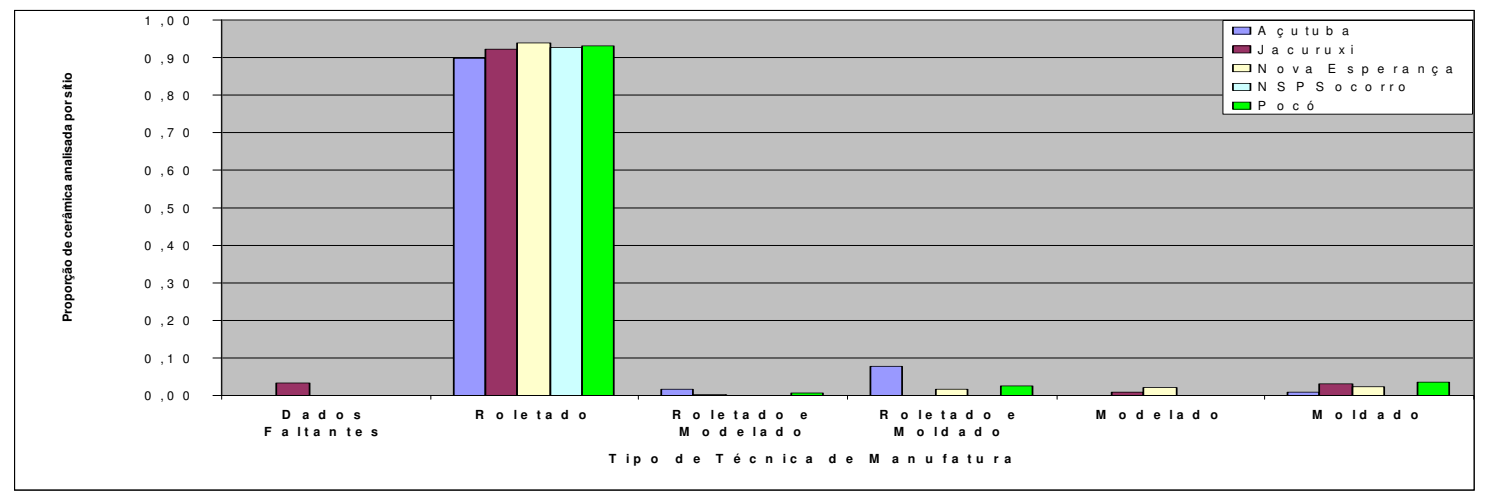

Gráfico 75 - Proporção das técnicas de manufatura observadas nos fragmentos analisados.

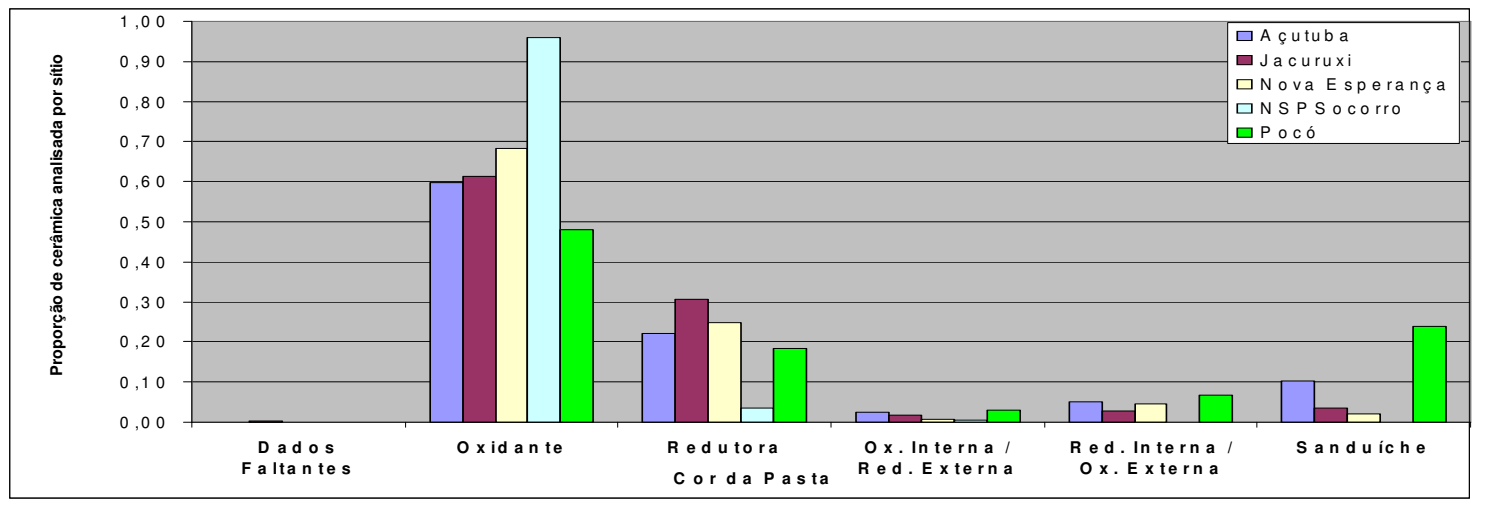

Gráfico 76 - Proporção dos tipos de queima observados nos fragmentos analisados.

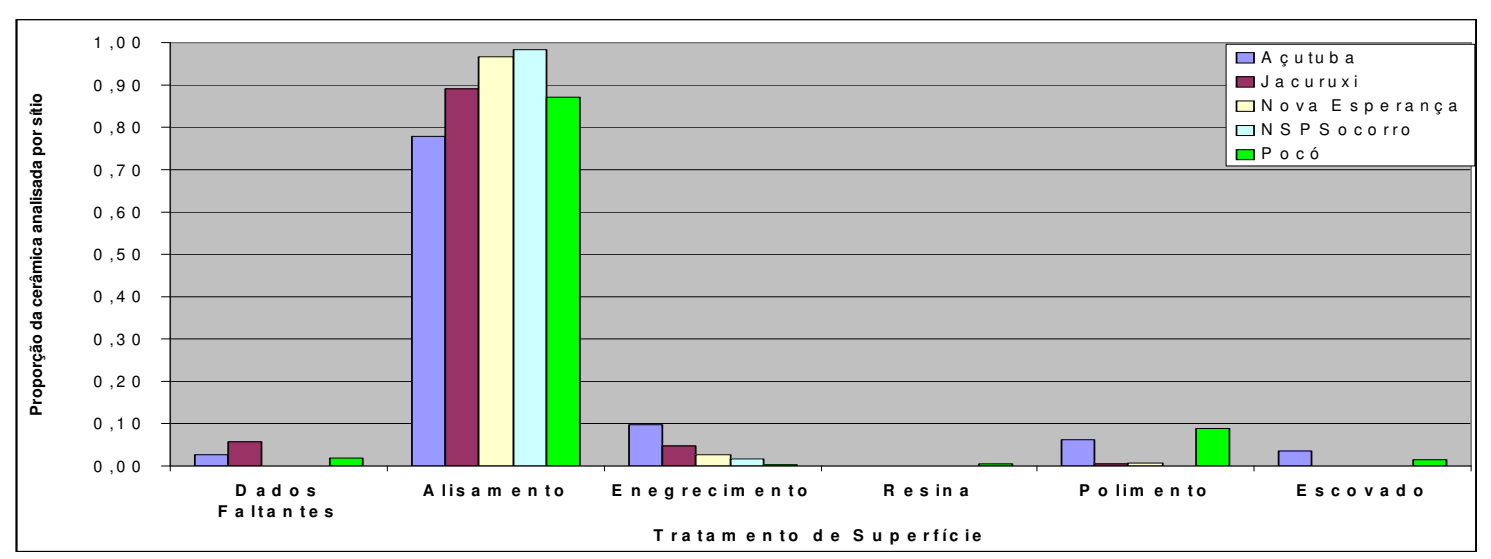

Gráfico 77 - Proporção dos tratamentos de superfície observados nos fragmentos analisados.

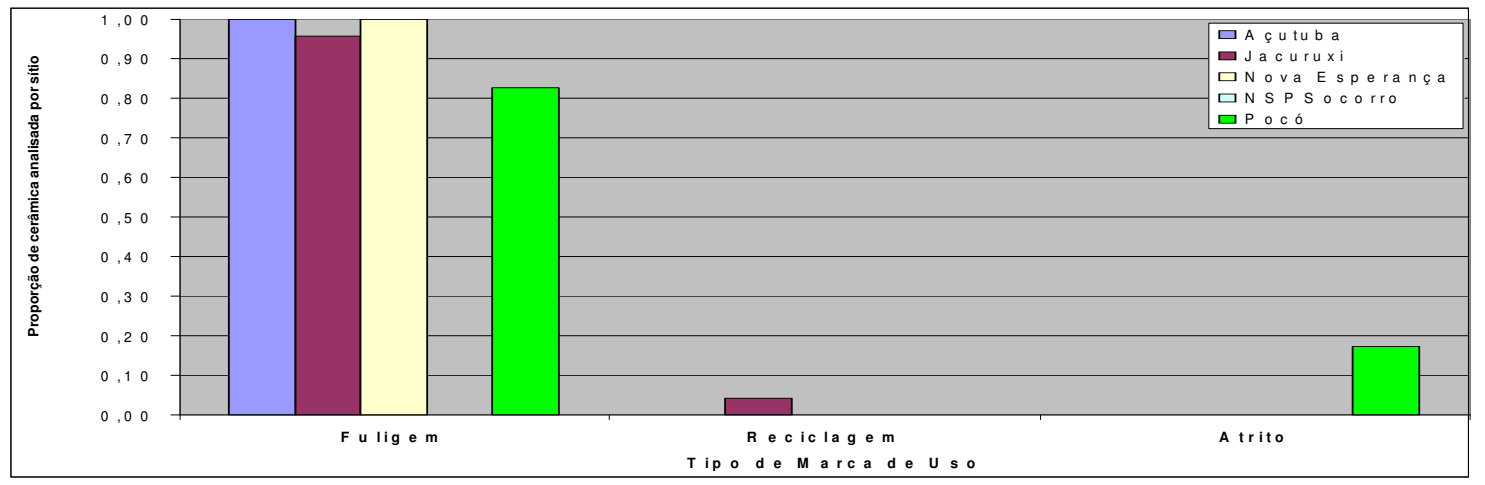

Gráfico 78 - Proporção das marcas de uso observadas nos fragmentos analisados. Característica não registrada no sítio NSP Socorro. 
Finalizando, em relação às formas gerais e espessuras das vasilhas, o conjunto Pocó apresentou tamanhos comparativamente menores, assim como paredes mais finas. Enquanto que, em oposição, as cerâmica de NSP Socorro apresentaram os maiores diâmetros.

As decorações, técnicas e motivos dentro de todas as suas peculiaridades, que serão discutidas no capítulo seguinte, mostram um arsenal comum a todos os conjuntos e, ainda assim, aproxima os contextos mais antigos, Açutuba e Pocó. Era de se esperar, pois, as semelhanças tecnológicas acima discutidas. Afinal, trata-se de materiais que, ao menos por hipótese, mantém relações com a Tradição Borda Incisa e, desta forma, deveriam apresentar afinidades mais do que meramente estilísticas. Lembro que as bases para definição dos antigos horizontes e atuais tradições amazônicas calcaram-se em elementos desta natureza (Meggers e Evans, 1961).

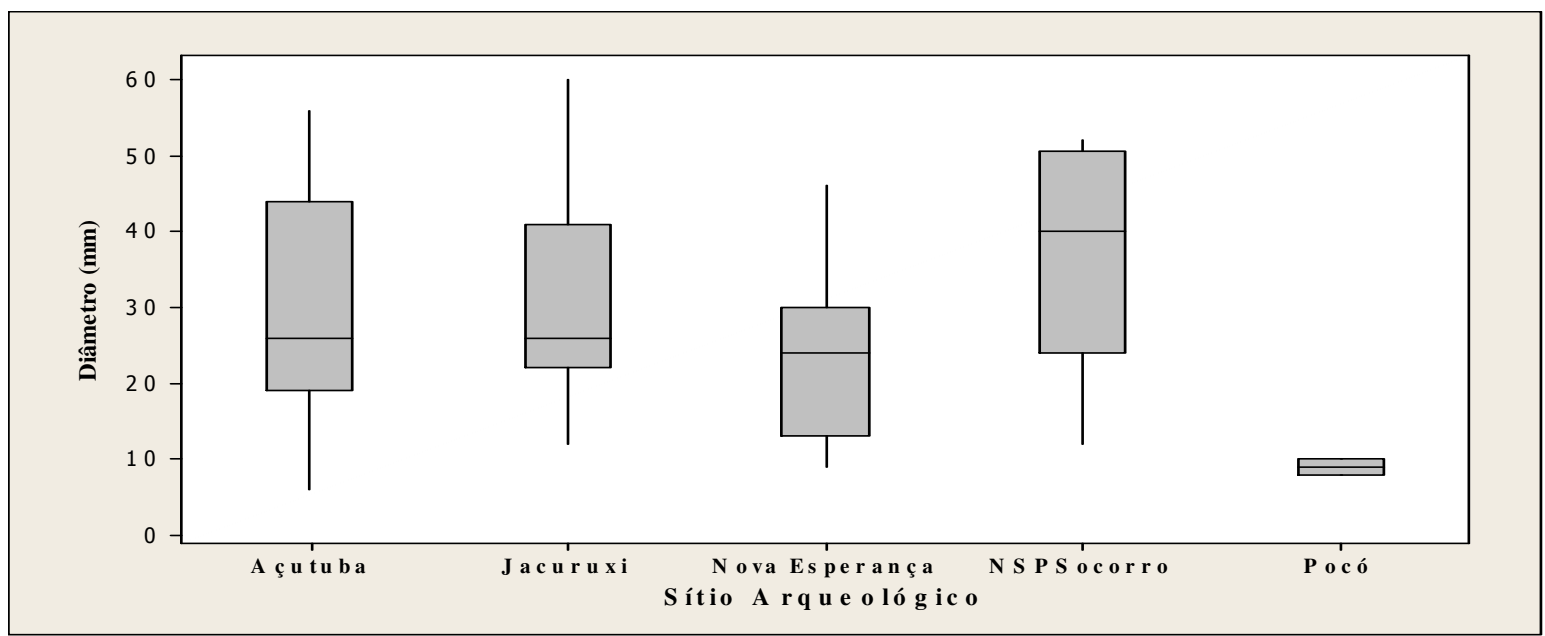

Gráfico 79 - Freqüência de marcas de uso observadas nos fragmentos da Sondagem 1-92.

Neste sentido, as cerâmicas Pocó, quando submetidas às análises estatísticas em conjunto com cerâmicas dos demais sítios arqueológicos, foram as que mais se diferenciaram. Se esta análise procurou visualizar o comportamento das variáveis (os atributos das peças) em escalas temporal e geográfica, isto se deve, provavelmente, a sua maior antigüidade em relação aos conjuntos Borda Incisa conhecidos, bem como à sua localização, com comunicação mais provável com contextos Saladóides e Barrancóides, das 
Guianas e Venezuela. Tal fato explicaria também sua maior proximidade com o contexto Açutuba, em detrimento dos demais.

Assim, pode-se dizer que também os procedimentos tecnológicos, tais como a escolha do tempero, das técnicas de manufatura, além do próprio local da decoração (sempre próximo da borda), técnicas e motivos são semelhantes nos diferentes contextos cronológicos e geográficos associados, em escalas diversas, à Tradição Borda Incisa.

\section{VI. Paralelos regionais}

Os paralelos anteriores traçados em caráter experimental indicaram, como esperado, certas similaridades, não apenas decorativas, mas também tecnológicas, entre os materiais provenientes das três regiões, fato que, sem dúvida, traz contribuições para que se pense nas ligações entre elas. Todavia, nem de longe, estes dados dariam conta de tão complexa tarefa. Para isso é necessário que se conjugue outros elementos que possam auxiliar numa tentativa de compreensão de tão vasto alcance regional. Dessa forma, um trabalho como este deveria ser amparado por dados sólidos dentro de cada uma destas regiões. Esta ainda não é a situação em que se encontra hoje a arqueologia amazônica, cujos registros assumem proporções monumentais, ao passo em que as pesquisas, mesmo crescentes, não conseguem abranger toda a sua extensão.

A idéia aqui promovida é a de que é necessário que se busque dados de diferentes naturezas ao se empreender uma arqueologia, seja de caráter local ou regional. As similitudes entre as três regiões tratadas, com possíveis conexões históricas, estiveram presentes, inclusive, em macro-modelos de ocupações amazônicas (ver, por exemplo, Lathrap, 1970a). No entanto, essa ligação ainda não havia sido testada em bases materiais, como a tentativa empenhada na seção anterior. Afinidades materiais são apenas alguns dos componentes a serem avaliados em uma proposta que abarque uma realidade regional. Em verdade, as próprias semelhanças materiais carregam em si uma multiplicidade de significados que não se pode acessar. Ainda mais sem os tão importantes dados contextuais dentro de cada região.

Mesmo não disponíveis para todas as regiões, dando a esta proposta analítica um caráter ainda especulativo, o que há de se fazer é justamente buscar 
estes dados. $\mathrm{Na}$ área-piloto de minha pesquisa, o almejado controle cronológico, estratigráfico e da própria variabilidade material vem sendo contemplado através de um fluxo de pesquisas de quase quinze anos, que conta com uma série de levantamentos, escavações, análises laboratoriais etc. É isso, portanto, que permite lançar mão do entendimento da relação de cada sítio arqueológico dentro de seus contextos locais e, por conseguinte, dentro da Amazônia central. Conforme salientado, este controle é muito diferente do que se tem para o Solimões e para esta parte específica do baixo Amazonas. Assim, se não se chegou a uma maior compreensão dos locais em questão, não era esse o objetivo. Não houve aqui tamanha ingenuidade de buscar entender complexas regiões arqueológicas através da análise, mesmo que detalhada, de um único sítio. Antes, o que se pretendia era contextualizar a área de confluência - foco direto desta pesquisa - em um quadro pré-colonial mais amplo.

Para tanto, tornou-se necessário conhecer a amplitude da dispersão geográfica dos conjuntos arqueológicos com os quais se está lidando diretamente, neste caso, vinculados à Tradição Borda Incisa e, também, de outros a eles relacionados. Além da anteriormente discutida tecnologia cerâmica, todos estes sítios têm em comum o fato de guardarem preciosas informações sobre $o$ início do processo que deu origem às terras pretas antrópicas e da própria agricultura, assim como de elementos relacionados aos usos e significados sociais dessas cerâmicas, num período em que elas aparecem em seus preâmbulos. Tais fenômenos não se restringem à Amazônia central, razão pela qual a perspectiva regional foi adotada.

Os levantamentos regionais apontaram, neste caso, para relações tecnológicas, cronológicas e espaciais entre as fases e as tradições arqueológicas encontradas na área de confluência dos rios Negro e Solimões, e aquelas de outras áreas da bacia amazônica, como o médio Solimões e o baixo Amazonas. Por conseguinte, surgiram subsídios mais concretos para 0 argumento que desenvolvo ao longo da tese, que versa sobre a natureza das hipotéticas conexões históricas entre os povos dessas regiões, que sugiro terem sido mediadas por uma esfera de interações abrangentes. Assim, a perspectiva macro - regional e temporal - incorporada no trabalho se mostrou útil na explicação dos fenômenos locais tratados na pesquisa.

Projetos que visam o entendimento regional em ambientes de grande extensão territorial, como é o caso da Amazônia, são fundamentais para o 
entendimento do nosso passado pré-colonial (Neves, 2002). Vale lembrar também que as principais fontes de dados arqueológicos disponíveis para a região amazônica, que embasaram diversos modelos de ocupação, bem como nossas hipóteses de trabalho, são provenientes de pesquisas com foco regional, como os levantamentos realizados no âmbito do PRONAPA, que tiveram grande alcance regional (Meggers e Danon, 1988; Simões, 1974).

Além disso, para se fazer arqueologia na Amazônia, as parcerias tornamse fundamentais, pois é através delas que se pode acessar sítios que não estavam dentro da área que se destina às pesquisas do Projeto Amazônia Central, como o próprio Nova Esperança. Estes sítios se colocam além da área de pesquisa do PAC mas, ainda assim, dentro do escopo de problemas conhecidos. A possibilidade de contrapor os dados de fora da área primeiramente colocada como a área de pesquisa se mostrou de grande importância, pois para compreender o registro da Amazônia central é necessário entender como contextos similares se comportam em outras regiões. Estas comparações, mesmo com os sítios dos quais disponho de parcas informações, foram capazes de me fazer pensar em uma área extensa, contextualizando os processos em um caso ou outro.

De fato, apesar da importância destes levantamentos para uma maior compreensão em escala regional, apenas alguns destes sítios vêm sendo trabalhado sistematicamente. Em verdade, a grande maioria dos sítios identificados ainda não foi trabalhada, e nem o será a curto prazo. A quantidade de sítios, caso se pretendesse estudar todos, demandaria uma imensa massa de recursos humanos e financeiros que tornariam a empreitada, no mínimo, inviável. Entretanto, sendo a intenção, desde o princípio, trabalhar estes sítios por meio de amostragens que permitissem obter dados a partir delas, um maior número de sítios possibilitou um recorte mais preciso, de acordo com os problemas de pesquisa tratados. 


\title{
Capítulo VIII \\ O UNIVERSO BORDA INCISA
}

\author{
"o tempo é um constante fluir \\ de continuidades e rupturas (...) \\ e cujos padrões e conteúdos buscamos \\ captar (e construir) com a ação do intelecto"
}

(Tonico Moraes, 2005:, p. 40).

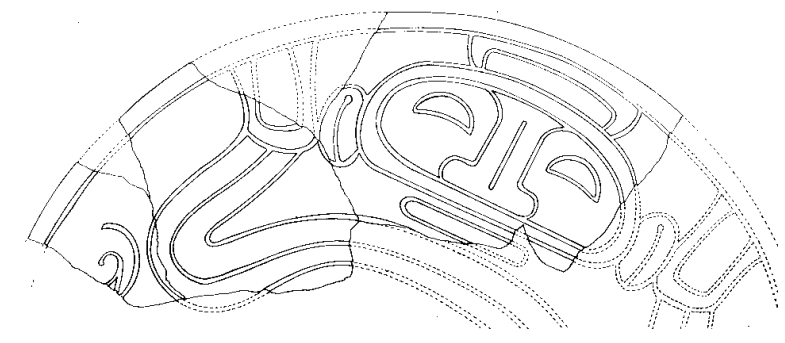

\section{I. Introdução}

Os dados discutidos ao longo do trabalho serão retomados, agora de maneira eminentemente interpretativa, tentando buscar inferências a partir do que foi visto nos sítios da Amazônia central, em uma esfera local, quando então se buscam outros casos que possam contribuir para lançar alguma luz às questões propostas, em uma escala geográfica mais abrangente. A seqüência material correspondente às fases Açutuba, Manacapuru e Paredão vai então ser explorada com vistas a discutir a representatividade dos materiais encontrados, explorando o conceito amplo e genérico de Tradição, que envolve não só sua representação material, mas também sua dimensão cultural e histórica. Para tanto, não acredito ser possível obter uma resposta tão geral a partir de uma amostra tão pequena e contida; por isso foi necessário trazer um olhar sobre os entornos, tanto imediatos quanto mais amplos, de modo que se pudesse explicar tais eventos.

O presente capítulo versa, portanto, sobre como se dão mudanças em certos aspectos da vida humana em sociedade, e como estas interferem em sua cultura material e contexto, objetos, por excelência, da arqueologia. Assim, é 
desenvolvida agora uma discussão sobre as padronizações materiais encontradas nos materiais da Tradição Borda Incisa, indicativas, a meu ver, de uma continuidade cultural colocada em perspectiva a partir de sua inserção em um largo quadro social, econômico e político, de caráter genérico e sistêmico que, por sua materialidade, se torna historicamente datável. Dessa forma, o continuum proposto para a área de confluência dos rios Negro e Solimões é apenas parte de um mosaico cultural integrado como um todo, neste sistema de interações que se pretende explorar.

Ao se lidar com problemas desta natureza, as necessidades de uma perspectiva teórica de longa duração ficam claras. Fica aparente, também, o caráter histórico da abordagem feita na presente pesquisa. Foi não só o desejo de empreender uma revisão da literatura arqueológica produzida na Amazônia, como também o de se chegar a uma hipótese de trabalho que pudesse preencher algumas das lacunas deste conhecimento, o que me levou a um ecletismo teórico e metodológico, aqui colocado em prática. Dessa forma, mais do que um uso de conceitos tão caros ao culturalismo histórico, ao aproximar-me de suas tipologias e de seus modelos, apropriei-me destes para reinterpretá-los à luz de outras áreas do saber, como é o caso das fronteiras culturais, colocadas frente às modernas discussões sobre a noção de território e paisagem dentro da Geografia.

O arcabouço teórico e as bases conceituais da pesquisa foram explicitados, de antemão, logo no primeiro capítulo deste doutoramento. O caminho percorrido na discussão dos dados, fosse na apresentação dos problemas, dos sítios arqueológicos tratados e suas coleções, ou mesmo da exploração simplória de outras áreas adjacentes, criou a necessidade de um reposicionamento teórico que fosse mais flexível e, ao mesmo tempo, mais abrangente. O próprio conceito-chave utilizado na interpretação destes dados, o de esfera de interação, veio a se consolidar como tal tanto com base nos conceitos tradicionais, como na busca por novos substratos teóricos que permitissem uma leitura mais adequada do registro arqueológico com o qual me deparei.

O tratamento interpretativo dedicado aos dados, que aqui apresento, tenta mostrar que as continuidades e transformações vistas no material são os correlatos de uma continuidade cultural mais ampla, que ocorrera na Amazônia central durante o primeiro milênio da era Cristã. Esta continuidade não seria 
possível, a meu ver, caso não houvesse um sistema que abrangeria estas relações em uma escala ainda maior.

Cabe lembrar que entre o conjunto mais antigo e o mais recente, com o qual se está lidando, existe um intervalo temporal de mais de mil anos, e que, ao pleitear uma relativa continuidade desta magnitude, há de se supor que, mesmo apesar de toda a mudança, há reminiscências estruturais. É este o ponto salientado aqui ao pensar em Borda Incisa como uma tradição tecnológica com tamanha duração, sendo, nesta perspectiva, a materialização de todo um processo social-econômico-simbólico que envolve múltiplas relações transmitidas em uma ampla escala temporal, e que tem em seu âmago certo continuum. É assim que a perspectiva de Tradição é pensada nesta pesquisa.

\section{II. Conceituando um Universo}

Como alternativa epistemológica aos já discutidos paradigmas e dicotomias do determinismo ecológico e cultural dos tradicionais modelos de ocupação da Amazônia, propõe-se aqui a exploração de conceitos que podem ter grande validade para dar conta de explicar histórica e culturalmente a distribuição dos vestígios arqueológicos em amplas áreas de floresta tropical, tal como se vê no estudo de caso apresentado. Sob variados rótulos, a idéia de redes de trocas de diferentes naturezas, atuando em matrizes regionais, vem sendo utilizada por arqueólogos que trabalham nas terras baixas sul-americanas (Boomert, 2000; Neves, 1998; Heckenberger, 1999).

Trata-se do conceito de esfera de interação (interaction sphere), tal qual foi apresentado desde uma perspectiva etnoarqueológica por A. Boomert (2000), para as regiões de Trindade, Tobago e Baixo Orinoco. A preferência por este conceito teve como base sua aparente aplicabilidade ao caso Amazônico pesquisado. Através de um estudo das interações sociais levadas a cabo nesses locais, o autor argumenta que "o Baixo Orinoco, com seu denso emaranhado de canais marítimos, lagoas, rios e estuários, deveria ser concebido como um corpo de terra unido e não dividido ou circundado por água" (2000, p. 3). Tais interações envolveriam - no presente e no passado - redes de troca e informações, através das quais, artefatos, com seu status específico, assim como conceitos estilísticos e outras normas, circulariam. 
A partir de uma semelhança dos aspectos de cultura material por ele trabalhados que, no caso, remetem à série Barrancóide ${ }^{15}$, Boomert desenvolve uma pesquisa etnoarqueológica e chega a uma hipótese de como sociedades se estruturam, e de como o registro arqueológico se definiu. A semelhança tanto da empreitada, quanto da natureza dos dados, ainda mais quando vinculamos a possibilidade de uma relação ainda não muito bem compreendida, entre Borda Incisa e Barrancóide, fez com que a utilização deste modelo parecesse plausível e, mais do que isso, possível para lançar luz aos problemas pertinentes a este trabalho.

Sua apreciação teórica, no que concerne à construção de uma narrativa histórica que se pretende enquanto modelo explanatório da configuração do registro arqueológico, tal como o amazônico tratado, é aqui pensada a partir de duas noções geográficas: a de paisagem e a de território. Trata-se, por um lado, de uma abordagem interdisciplinar focada na observação das chamadas paisagens históricas, vistas como entidades físicas que têm características espaciais e temporais modificadas pela atividade humana, de tal maneira que seja possível se inferir, a partir da cultura material, ações e intenções (Balée \& Erickson, 2005).

O objetivo interpretativo se volta, então, a um entendimento mais amplo do registro arqueológico, indo além da simples observação dos conjuntos artefatuais para tentar compreendê-los em seu contexto. Tal noção, que entende paisagem como uma interface cognitiva entre ambiente e sociedade que, em constante interação, constroem-se mutuamente em uma relação dialética, faz com que o olhar analítico se desvie do objeto somente, e volte-se para todo o cenário no qual se encontra inserido. Neste ponto de vista, tanto o fragmento cerâmico quanto a feição do solo, e mesmo a disposição topográfica do lugar onde o sítio se

${ }^{15}$ Materiais associados à série Barrancóide foram identificados pela primeira vez em 1941 por Osgood e Howard, durante a escavação do sítio Los Barrancos, localizado no baixo curso do rio Orinoco, Venezuela. Tais trabalhos forneceram a primeira descrição detalhada dos vestígios arqueológicos da região, com cerâmicas decoradas através de uma combinação de modelagem e incisão (Howard, 1943, p. 96-111). Estes dados foram reavaliados por Cruxent e Rouse (1963), cujas análises acabaram por definir as séries Barrancóide e Saladóide.

O conceito de série empregado por Rouse e seus associados na Venezuela é similar ao conceito de tradição utilizado por Meggers no Brasil, podendo estes ser mutuamente comparáveis (Meggers \& Evans, 1983). 
encontra, fazem parte de um mesmo contexto, e devem ser pensados como tal (Ingold, 2000).

Vale lembrar que paisagem (landscape), enquanto campo da geografia, vem sendo conceituada desde o início do século passado como "uma área composta por distintas associações de formas, tanto físicas como culturais" (Sauer, 1963[1925], p. 316). Certo caráter cientificista desse período é refletido na definição de suas proporções, necessariamente mensuráveis, ao tratar-se de "uma unidade identificável em termos de sua constituição, limites e relações genéricas com outras paisagens, que em conjunto compõem um sistema geral" (idem, p. 321). Nota-se, então, uma apropriação do conceito no intuito de torná-lo um objeto de análise. Mais recentemente, passou-se a dar maior ênfase ao aspecto relacional entre sociedade e meio físico, trazendo à luz uma carga ideológica inerente a este complexo produto cultural que é a paisagem (Cosgrove, 1984).

Comum às diversas interpretações do conceito é a pressuposição da presença de um sujeito como observador $e$ parte inerente a ele. $O$ sujeito tem uma participação ativa no processo inter-relacional de construção do meio enquanto realidade perceptiva, da mesma maneira como este meio também atua sobre a construção do sujeito. Longe de ser uma categoria que supõe uma interação passiva, é justamente nesta idéia de agência que se constrói a noção de paisagem. Portanto, sua análise pressupõe que a agência humana esteja expressa na própria materialidade de tais relações.

No que concerne às discussões aqui propostas, o seguinte paralelismo pode ser estabelecido: o estudo da paisagem poderia ser feito de maneira a se identificar seus aspectos físicos, e ater-se à sua mensuração e descrição como finalidade última, da forma como o faz um topógrafo ou engenheiro agrimensor. Ou, por outro lado, seus aspectos físicos podem ser tomados para a construção de uma análise como a que fora acima pontuada: a compreensão dos aspectos relacionais que levaram à formação do lugar ali observado. Neste sentido, a construção de tipologias pode ir além da simples identificação e classificação dos materiais arqueológicos, mas, da mesma forma, buscar entender as relações subjacentes ao registro arqueológico.

A inserção de uma perspectiva holística e multi-escalar dos fatores temporal e geográfico ao conceito de paisagem se aproxima da idéia de $M$. 
Santos quando coloca que "paisagem é o espaço humano em perspectiva (2002, p. 106)", pois ela "existe através de suas formas, criadas em momentos históricos diferentes, porém coexistindo no momento atual" (idem, p. 104). Assim como em recentes estudos orientados pela ecologia histórica, na presente abordagem disciplinar o fator diacrônico (a contingência histórica) da análise das relações entre povos e meio ambiente é enfatizado. Procura-se entender como fenômenos históricos transformam a cultura material (parte integrante da paisagem), e como tais transformações tornam-se condicionadas e são compreendidas através do conhecimento do local, do comportamento e da cultura, ao longo do tempo (Balée, 2006, p. 45).

Em certa medida, o estudo da paisagem torna-se semelhante ao da arqueologia por seu próprio caráter histórico, de um fenômeno estático participante de uma história viva (idem, p. 107), o que faz dela um interessante instrumento de trabalho para o arqueólogo, que procura reconstruir o contexto sistêmico (o das esferas de interação, neste caso) a partir de um contexto estático, que é o registro arqueológico (Schiffer, 1972).

E este mesmo contexto sistêmico, que remete ao universo das esferas de interações, se deu em um determinado espaço, cujos limites não são facilmente identificáveis e, menos ainda, historicamente datáveis, uma vez que é resultado de um processo histórico, social e cultural. Processo este que envolve múltiplas percepções daquilo que definimos como paisagem, através de um uso contínuo de seu espaço e recursos, onde se dá uma relação socialmente constituída através do entendimento que uma sociedade impõe ao seu ambiente a qualquer tempo - o que convenciono chamar de território. E este, por conseguinte, é definido dentro de um conjunto de relações histórico-sociais e que, por ser sistêmico, faz sentido apenas dentro do universo cultural a que ele remete. Neste sentido, a definição de território assume tanto um sentido funcional, que tem como base os recursos e facilidades que este oferece, assim como uma apropriação simbólica deste meio (Darvill, 1999, p. 108; Haesbaert, 2004, p. 78; Zedeño, 1997, p. 69).

Com tudo o que foi exposto, em relação à dificuldade de se compreender em profundidade e, em certa medida, delimitar a abrangência espaço-temporal e caracterizar pretéritos sistemas sociais em sua inerente complexidade, é que se procurou pensar em modelos teóricos aplicáveis ao caso em questão, e que 
dessem conta de explicar os fenômenos subjacentes à configuração do registro arqueológico, tal como visto nos sítios da Amazônia central. Os conceitos explorados, portanto, tiveram sua utilização como ferramentas analíticas e interpretativas que, neste caso, estabelecem uma difícil tentativa de mensuração de uma materialidade das relações que perfazem esses complexos sistemas.

Da forma como tais conceitos foram estruturados na presente pesquisa, sua aplicação não deixa de ser uma re-interpretação do conceito antropológico de área cultural anteriormente discutido, desde uma perspectiva arqueológica, através da qual se busca entender relações sincrônicas em seqüências diacrônicas. Área cultural, então, se transforma numa tentativa de mensuração e caracterização da territorialidade dessas esferas de interações.

A abordagem regional foi desenvolvida, então, através do uso do conceito de esfera de interações, entendendo assim que as sociedades pré-coloniais amazônicas eram integradas política e economicamente em redes regionais multiétnicas, cujas origens e história só há pouco começaram a ser entendidas (Neves, 2006). Interessante é perceber que tais sistemas ou esferas de interação regional têm sido etnográfica e historicamente reportados em diferentes partes do norte da América do Sul, desde a Amazônia até o Caribe. Relatos descrevem, à época da conquista, a presença de formações políticas regionais, comandadas por chefes supremos, com distintas formas de subordinação entre grupos locais, amplo comércio regional, organização de guerra bem estruturada e especialização na produção de bens materiais (Porro, 1996). Não se trata, obviamente, da aceitação acrítica de desses relatos, assunto este já intensamente debatido e duramente criticado, em alguns casos (Denevan, 1996; Meggers, 1971; Barreto \& Machado, 2001).

Pesquisas etnoarqueológicas voltadas para a construção de uma história indígena têm demonstrado que em muitos casos tais sistemas têm, de fato, uma origem pré-colonial (Neves, 1998; Heckenberger, 2002, 2003). É o que mostra, por exemplo, o trabalho de Neves (1998) no alto rio Negro. Ele utilizou dados etnográficos e fontes históricas secundárias para apresentar o sistema de interdependência regional (system of regional interdependece, ou SRI) do alto rio Negro, como proposta metodológica. Sua argumentação é que “... muitas formações sociais da Amazônia têm caráter regional, de redes que conectam comunidades locais. Tal dimensão, ao menos como é conhecida hoje, inclui a 
circulação de pessoas e bens através de grandes áreas" (1998, p. 67). Faz-se assim necessária uma mudança de abordagem da comunidade local para a região, enquanto unidade de análise (1998, p. 69).

Pesquisas desenvolvidas no alto Xingu, às quais a discussão inevitavelmente há de remeter por diversas vezes, atestam a antigüidade de um sistema regional que remonta ao período pré-colonial e perpassa a história da sociedade nacional. A seqüência cultural da bacia do alto Xingu se estende de cerca de 800 d.C. até ao presente. Dentro desta seqüência, a continuidade cultural pode ser demonstrada pelo conservadorismo de três aspectos fundamentais da cultura xinguana, observados no registro arqueológico: 1) a tecnologia cerâmica; 2) a organização espacial das aldeias; e 3) a localização dos assentamentos dentro da bacia. Argumenta-se ainda que a principal diferença entre as aldeias contemporâneas e os sítios pré-coloniais é em escala: as aldeias pré-coloniais são imensas, até dez vezes maiores dos que as hoje (Heckenberger, 2002, p. 41-42).

Exemplos como estes deixam clara a necessidade de uma avaliação arqueológica, com base em dados lingüísticos e históricos, para a identificação da natureza de tais sistemas. A relação entre dados arqueológicos e lingüísticos nunca foi simples. A velha equação estabelecida por Childe [1929] entre culturas arqueológicas, povos e línguas há muito não é aceita como um dado. Entretanto, a lingüística histórica e a arqueologia podem se complementar ao lidar com processos e eventos que são hoje diretamente observáveis - língua e cultura material - que representam a passagem do tempo. É nesta perspectiva que se insere o chamado modelo de dispersão língua/agricultura (language/farming dispersal model), sugerindo uma solução para o problema da dispersão espacial das línguas numa perspectiva global (Renfrew, 2000, p. 9-10). O modelo objetiva estabelecer certos princípios gerais, relacionando mudanças lingüísticas às mudanças demográficas, sociais e econômicas. Tais princípios atuariam como hipóteses acerca de determinadas regularidades, que devem ser testadas através de observações cautelosas, incluindo o registro arqueológico (idem, p. 11, 25-26).

De acordo com este modelo, há diferenças na natureza da distribuição geográfica das famílias lingüísticas. Numa primeira configuração, denominada zona de dispersão (spread zone), pressupõe-se uma baixa variabilidade genética (apenas um número limitado de unidades lingüísticas não geneticamente 
relacionadas a uma língua ancestral comum). Este tipo de configuração é considerada pelo autor como resultante de um processo de dispersão demográfica, possivelmente de expansão agrícola, e relativamente recente (idem, p. 24-25). Este poderia ser o caso das línguas Arawak, a cujos povos se atribui a dispersão da agricultura e de determinados traços culturais, como o padrão de assentamento em aldeias circulares e a produção de cerâmicas com traços Barrancóides (Heckenberger, 1999, 2002; Lathrap, 1970). A um segundo padrão, denominado "mosaic zone", associa-se maior variedade línguas dentro de uma família, e maior antiguidade dos troncos lingüísticos no local (Renfrew, 2000, p. 24-25).

P. Bellwood, trabalhando inicialmente no Pacífico para depois generalizar ao nível global, chega a conclusões similares na relação entre a dispersão de línguas e da agricultura na gênese das distribuições lingüísticas atuais. Tal estudo mostra como a arqueologia pode ser útil na identificação dos traços materiais deixados pelos representantes de várias línguas, tanto nas regiões onde são faladas, quanto na inferência de sua área de origem. (Bellwood 1996, 1997 apud. Renfrew, 2000, p. 9). E é o que tem sido feito com sucesso na Amazônia para as dispersões Arawak e Tupi (Heckenberger et al, 1998; Noelli, 1996).

A dedução feita por W. Balée, por exemplo, de proximidade lingüística e cultural entre os Ka'apor e os Wajãpi, ambos os grupos falantes de línguas da família tupi-guarani, que hoje estão separados por cerca de $900 \mathrm{~km}$, teve como base um ritual de iniciação feminina no qual se utilizam formigas que recebem 0 mesmo nome nas duas línguas (2006, p. 48). A correlação histórica por ele proposta, neste caso através da língua e simbologia, pode, a meu ver, ter aplicação enquanto ferramenta analítica a outras fácies culturais, tais como cultura material e representações simbólicas. Caso semelhante seria o das tão difundidas figuras zoomórficas dispersas por uma ampla região do norte da América do Sul, interpretadas como um correlato arqueológico de uma determinada esfera de interação, resultado de um processo econômico e demográfico, simbólico e lingüístico, eminentemente inteligível.

A questão da grande extensão da dispersão Arawak é bastante antiga. Desde as viagens dos naturalistas do século XIX, povos de língua Arawak têm sido descritos. Von Den Steinen e Ehreinreich já colocavam em pauta estudos relativos a grupos falantes de línguas deste tronco, sendo Von Den Steinen o 
primeiro a identificar o tronco lingüístico, e nominá-lo nu-Arawak (Cruz \& Christino, 2005). As posteriores pesquisas de Koch-Grünberg (2005 [1907]) e Erland Norenskiöld (1930) deram um fôlego extra para os estudos de língua e cultura material Arawak.

Dentre uma das contribuições importantes sobre a dispersão lingüística deste tronco está o trabalho de Max Schmidt, que em 1917 escreve sua tese de doutorado chamando a atenção para estes povos que apresentam "a mais ampla dispersão dentre os povos da América do Sul' (Schmidt, 1917, p. 5), fato que não torna coincidência que Colombo tenha feito seu primeiro contato com os povos ameríndios deste tronco lingüístico. Neste trabalho, Schmidt trata a dispersão desses grupos como um processo de expansão cultural, focalizando explicações não apenas nos processos migratórios, mas também nos movimentos de imposição cultural a outros povos, através dos quais disseminou-se sua língua, sua cultura material e, principalmente, seus modos de vida - entre eles, a agricultura.

Apesar da perspectiva difusionista, própria da época, este trabalho suscita questões que, reinterpretadas tendo por base o pensamento acadêmico-científico vigente, parecem bastante atuais para esta discussão. Uma delas é a nãovinculação direta entre língua e cultura Arawak, haja vista que a associação das línguas Arawak a outras, em meio ao processo de expansão, geraria uma crescente diversidade lingüística e, conseqüentemente, uma aproximação cultural entre povos de diferentes etnias.

Foram estas as idéias que autores como Lathrap (1970a), Brochado (1984) e Oliver (1989) utilizaram para compor seus trabalhos sobre as dispersões lingüísticas na América do Sul que, direta ou indiretamente, lidaram com associação entre língua e cultura material, utilizando-se de dados etno-históricos, lingüísticos e arqueológicos. Destes trabalhos, o de D. Lathrap é o que tem uma maior relevância para os assuntos aqui tratados, já que ao lidar com a expansão Arawak, propõe um quadro de migrações para os povos por detrás das cerâmicas Barrancóides, que teriam como ponto de partida a Amazônia central.

Mais uma vez, a dispersão dos componentes ligados à Tradição Barrancóide fomenta debates. Conforme já mencionado, autores como Meggers defendem tratar-se de um fenômeno resultante de migrações antigas provenientes dos Andes, "parece claro que as cerâmicas Barrancóides são 
derivadas de um complexo Formativo dos Andes" (1983, p. 305). Por outro lado, a presença de materiais relacionados a esta tradição em grande parte da América do Sul setentrional, desde o norte da Colômbia (tradição Malambo), Venezuela (Barrancas e Los Barrancos), Amazônia brasileira (tradição Borda Incisa), até as Antilhas e Caribe (Palo Seco) (Boomert, 2000; Lathrap, 1970a; Roosevelt, 1997) levou autores como Lathrap (1970a, 1970b), Heckenberger (2002) e Petersen (2003) a defender que se tratava de um fenômeno regional, que abrangeria uma ampla área interligada política e socialmente.

O padrão de dispersão das cerâmicas Barrancóide, bem como das Saladóide, seria, conforme proposto por Lathrap (1970) e posteriormente reavaliado por Heckenberger (2002), o correlato arqueológico de grandes levas de dispersão, ou "diásporas", ocorridas no passado dos povos falantes de línguas do tronco Proto-Arawak. Através desses movimentos migratórios, os supostos portadores dessas cerâmicas teriam difundido também outros elementos como a agricultura e formas de aldeia circulares por todo o norte da América do Sul e Caribe. Junto a essas cerâmicas, outros elementos inerentes à cultura Arawak também teriam se difundido, tais como a espacialidade das aldeias circulares com uma praça central, e toda uma visão de mundo a elas subjacente, e a agricultura (Lathrap 1970a; Heckenberger, 2002).

Duas áreas que ainda funcionariam segundo o modelo pluriétnico e multilíngüe, com origens pré-coloniais, contando com maior ou menor influência dos sistemas Arawak, seriam o alto Xingu e o alto rio Negro. Citados por Schmidt já em 1917, estas e outras questões suscitam a importância daquele trabalho, que caiu em descrédito nas décadas seguintes, sendo recuperado apenas na década de 90 por alguns autores para pensar tanto a diáspora Arawak quanto a similaridade cultural entre povos falantes deste tronco, distintos temporal e geograficamente (Heckenberger, 1996; Neves, 1998).

Mais uma maneira de analisar o surgimento de sistemas sócio-políticos e a emergência de complexidade cultural é oferecida desde uma perspectiva processual de C. Renfrew (1986). Analisando um caso grego e um da cultura Maia, o autor propõe o conceito de peer polity interaction, para "designar toda a variabilidade de relações, incluindo imitação e emulação, competição, guerra, e trocas de bens e informações, entre unidades sócio-políticas autônomas" 
(Renfrew, 1986, p. 114). Mesmo que originalmente proposto para aplicação em sociedades do tipo cacicado ou estados, este tipo de análise evita qualquer ênfase em relações de dominação e subordinação entre sociedades. Esta ferramenta pode ser útil também para o caso das sociedades amazônicas, que experimentam trocas e relações de natureza semelhante.

Pressupõe-se, no caso analisado, que interações de cunho simbólico, social, político e econômico (mas não necessariamente de homogeneização étnica ou lingüística) resultaram em certa padronização da cultura material. $E$ neste sentido, evoca-se uma forte movimentação de idéias, sem excluir a possibilidade de migrações de povos terem também ocorrido ${ }^{16}$. Não proponho aqui que padronização material seja um indicador de homogeneidade étnica ou lingüística.

Ao contrário, o que se vê é a formação e expansão de determinados modos de vida e simbolismos, dentro dos quais as especificidades locais são menores do que a semelhança regional. $E$ tais formações - tão complexas quanto podem ser - não se traduzem necessariamente em cacicados. Neste sentido, a proposta interpretativa incorporada nesta pesquisa, que se calca na idéia de sistema ou esfera de interações, se contrapõe, sem refutar, ao conceito de cacicado. A oposição se coloca nas formas de organização sócio-politicas, mais calcadas na horizontalidade do que na centralidade e hierarquização inerentes a este último conceito. Esta idéia encontra ecos em outras pesquisas. A organização regional xinguana apresenta certos problemas para o modelo tradicional de cacicado: ela não apresenta hierarquia e centralização entre os assentamentos. As diversas aldeias compõem, ao invés disso, uma sociedade regional, compartilhando um mesmo sistema de valores e significados, que regem a reprodução social (Heckenberger, 2002, p. 44). Talvez seja este seu aspecto de

\footnotetext{
${ }^{16} \mathrm{O}$ conceito de migração, assim como o de difusão, foi indiscriminadamente utilizado enquanto paradigma explanatório por antropólogos e arqueólogos dos anos 50 a 70, para explicar a presença de sociedades complexas numa Amazônia pré-Colombiana, cujo ambiente hostil não poderia suportar a emergência autóctone de formações dessa natureza. Expoentes deste pensamento são J. Steward e B. Meggers. No reverso deste movimento, arqueólogos dos anos 80 e 90 criticaram duramente o uso deste conceito. Sob a minha ótica, estes e outros conceitos podem ser válidos, desde que dêem conta de explicar os vestígios de maneira coerente.
} 
rede que permitiu a existência de certas esferas de interação por tanto tempo, até milhares de anos, na Amazônia central.

\section{III. O Universo Material Borda Incisa}

Neste momento, já em vias de conclusão da tese, os dados são tratados mais livremente, sendo os conjuntos cronológicos abordados em suas principais características. Sem gráficos ou tabelas exaustivas, procura-se, ao invés disso, focar na discussão da representatividade das mesmas. A perspectiva, sempre, é de um estudo comparativo, seja nas diferentes escalas temporais ou geográficas. Os elementos tomados para as comparações - as cerâmicas, líticos, distribuição, cronologias, ou seja, elementos contextuais - encontram-se já classificados e, por conseguinte, interpretados nos termos gerais das fases arqueológicas anteriormente caracterizadas: Açutuba, Manacapuru e Paredão. Tais comparações visam, sempre, interpretações que corroborem ou refutem as suposições aventadas ao longo do trabalho, sobre a organização deste complicado sistema de interações, em termos de sua continuidade, que se deu na Amazônia central e em suas adjacências.

A partir das diversas etapas de campo realizadas nos sítios arqueológicos estudados, e de um exaustivo trabalho de laboratório, foi possível obter elementos que permitiram a formulação de uma hipótese mais consistente sobre a história de ocupação da área de confluência dos rios Negro e Solimões. Nas comparações entre os sítios arqueológicos, foram levados em conta os dados internos a cada um deles, (como seu tamanho, forma e duração de ocupação, inserção na paisagem, informações gerais, etc.), compondo, assim, um quadro cronológico e espacial geral para a área de pesquisa.

Para que esta última análise pudesse ser feita, ligada ao uso do espaço e aos aspectos da paisagem, foi necessário que se amostrasse sítios em diferentes ambientes, considerados aqui como relativos às calhas dos rios, de água branca, preta ou àqueles de interflúvio. Além disso, a amostragem levou em conta uma maior diversidade de compartimentos topográficos, como em terraços, várzeas altas, às margens dos grandes rios e lagos, e de pequenos igarapés. Foram trabalhados diretamente neste doutoramento nove sítios arqueológicos da Amazônia central, além de um no médio Solimões e uma coleção cerâmica do 
baixo Amazonas. Este universo amostral é pequeno, considerando o número de sítios já identificados pelo PAC, que somam mais de uma centena. Esta amostragem tentou ser representativa frente à variedade de nichos onde estão os sítios encontrados pelo projeto, tal como se pode ver no mapa, fig. 214.

Uma primeira constatação, e a mais óbvia delas, é a preferência dos assentamentos por locais próximos a cursos d'água. Entretanto, esta ocupação não é uniforme. A variação de tamanho e duração de ocupação parece estar diretamente relacionada aos locais onde se encontram os sítios. De antemão se percebe que os maiores, mais profundos e mais densos, e com uma maior duração das ocupações, são aqueles localizados às margens dos grandes rios, Negro ou Solimões, indistintamente. Os sítios Hatahara, no Solimões, e Açutuba, no Negro, podem ser colocados como exemplos ilustrativos desta situação.

Muito já se discutiu sobre a fertilidade dos ambientes relacionados às águas brancas, em oposição àqueles ligados às águas pretas, principalmente quando se trata de disponibilidade de recursos. Dessas discussões, era de se esperar que as maiores e mais densas ocupações estivessem na margem do Solimões e não do rio Negro, o que de fato não acontece. A semelhança das ocupações entre estas duas áreas pode ser explicada pela localização no baixo curso de ambos os rios, próxima à sua confluência, de modo que o acesso aos nichos de cada um deles é bastante facilitado. Outra possível explicação pode residir na configuração espacial desta área de confluência como um todo, uma vez que alguns cursos d'água interpolam a calha dos rios maiores. Em determinadas épocas do ano, águas e sedimento carreado pelo Solimões são lançados no Negro, tornando-o mais fértil, já bem próximo da confluência, como é o caso do rio Ariaú, que tem a denominação local de "furo" justamente por conectar dois cursos d'água (ver mapa, fig. 214). De fato, o maior sítio encontrado na área de pesquisa do PAC, Açutuba, está na margem do rio Negro.

Ainda sobre estes dois nichos, a diferença entre eles fica por conta de uma inserção dos sítios na paisagem, embora isto se relacione muito mais à própria peculiaridade das características fito-geográficas de cada local, do que à disponibilidade de recursos. Os sítios do Solimões encontram-se implantados sobre os altos terraços, geralmente com topos aplainados e vertentes abruptas, que dão acesso às áreas de várzea, ainda que nesta parte do rio esta seja pouco extensa. Este padrão de uso do espaço remete a discussões importantes em 
arqueologia amazônica, que dizem respeito à velha dicotomia entre várzea e terra firme. Os principais modelos de ocupação da Amazônia consideram a contraposição entre os ambientes de várzea e de terra firme como determinantes dos padrões de assentamento e desenvolvimento cultural. Tais debates versam sobre a preferência dos povos pré-coloniais por estabelecerem-se em ambientes de várzea em detrimento das áreas de terra firme, mas interpretam os sítios ali existentes de maneiras diversas e antagônicas (Lathrap, 1970a; Meggers, 1970, 1990). Tais debates foram tratados nos capítulos iniciais desta tese.

O padrão encontrado na área de pesquisa do PAC, no qual os sítios encontram-se implantados não nas várzeas propriamente ditas, mas nos terraços, corroboram o modelo de uso do espaço proposto por Denevan, o bluff model, que pressupõe interações sociais e ecológicas entre ambientes de várzea e de terra firme, através do estabelecimento dos assentamentos nestes bluffs, permitindo a exploração de ambos (1996, p. 661). Além do Hatahara, outros sítios em situação semelhante são: Lago do Iranduba I e II, Laguinho e o Bela Vista do Iranduba (Figura 214).

Também os grandes sítios do rio Negro, tais como os já citados Açutuba e Paricatuba, encontram-se em situações topográficas semelhantes: sobre terraços com topos aplainados, com vertentes mais ou menos suaves. A diferença destes em relação aos sítios do Solimões reside justamente no fato de que este rio não forma várzea. Mas, ao contrário das discussões, estes sítios são tão grandes e densos quanto os do Solimões. Em suma, de toda a área de pesquisa do PAC, os sítios localizados próximos das calhas dos grandes rios, o Negro e o Solimões indistintamente, além de serem maiores, mais profundos e mais densos, apresentam uma seqüência cronológica mais completa, com datações tão recuadas quanto as que se tem para a fase Açutuba, perpassando por todos os períodos cronológicos vinculados à Tradição Borda Incisa e, mais ainda, ocupados durante o período pré-colonial mais tardio, com materiais relacionadas à fase Guarita. Mesmo que esta longa seqüência cronológica não esteja completamente compreendida, ela não parece ter indícios de longos intervalos entre uma ocupação e outra, sugerindo tratar-se de assentamentos duradouros.

Estas ocupações recentes, com materiais Guarita, são mais concentradas nesses sítios à beira dos maiores cursos d'água. Foi justamente em dois deles, Hatahara e Açutuba, onde se identificou padrões de assentamento em formato 
linear, associados à dispersão dos materiais. Acredita-se que as unidades habitacionais fossem voltadas para os rios, tal como contam alguns relatos de cronistas (Rebellato, 2007), distanciando-se do padrão identificado com os materiais Borda Incisa, em formato circular ou elipsoidal.

Não se pode deixar de dizer que o fato das seqüencias mais longas e contínuas de ocupação estarem aparentemente relacionadas aos sítios nos grandes rios pode ser resultado de um viés amostral, e não que reflitam uma realidade pré-colonial. Sítios como Açutuba e Hatahara têm uma longa história de intervenções e pesquisas dentro do PAC, diferente dos demais sítios que, muitas vezes, foram alvo de trabalhos pontuais ou ainda não foram pesquisados. Mesmo feito este adendo, tem-se fortes subsídios para crer que tal padrão seja de fato verossímil. Alguns sítios de ambientes lagunares e de interflúvio analisados foram alvo de um volume relativamente grande de pesquisas, alguns deles com muitas baterias de datações, e ainda assim não demonstraram um padrão semelhante ao visto nas margens do Negro e do Solimões.

Um segundo padrão de implantação dos sítios na área de pesquisa encontra-se naqueles situados às margens dos lagos de interflúvio. Estes interflúvios são caracterizados por enormes quantidades de lagos, que se conectam por meio de igarapés em uma extensa rede, ligando-se tanto a rios de água branca ou de águas pretas, dependendo da época do ano em questão. Ocupam, em geral, o topo da maioria das penínsulas que se projetam sobre os lagos da região. Estes possuem topos aplainados e suas vertentes podem ser suaves ou abruptas. Como exemplos disso, no Lago Grande foram identificados cinco sítios (Donatti, 2003), dentre os quais o sítio de mesmo nome trabalhado nesta pesquisa e, no Lago do Limão, outros nove sítios (Moraes, 2006). Estes são também sítios grandes e densos, embora menores do que aqueles dos grandes rios.

O Lago do Limão é a formação lacustre arqueologicamente mais bem conhecida na área de atuação do PAC, e vários destes sítios já foram objeto de estudo, permitindo um melhor entendimento da implantação e configuração de sítios nas mesmas condições. Uma destas características observadas a partir destes estudos é a contemporaneidade que boa parte deles compartilham, ao menos ao longo de alguns curtos períodos, como os sítios Osvaldo, Pilão, Lago 
do Limão e Antonio Galo, todos situados às margens do Lago do Limão (Abreu, 2000; Moraes, 2006; Neves, 2007; Portocarrero, 2007).

Nestes sítios situados nos ambientes lacustres de interflúvio também foram identificados os materiais com as datas mais antigas para a fase Açutuba, como em Osvaldo e Lago Grande, apesar de serem pontuais e sem evidências de uma seqüência mais contínua, como se observa nos sítios dos grandes rios. As ocupações do interflúvio parecem mais concentradas, ao menos na maioria dos sítios, aos materiais Borda Incisa: Manacapuru e, em maior escala, Paredão. Costumam ter uma seqüência cronológica menos longa, com ocupações de duração em torno de algumas gerações; alguns deles apresentam grandes intervalos de tempo, de várias centenas de anos, entre uma e outra ocupação relacionadas, respectivamente, aos conjuntos mais antigos, Açutuba, e às ocupações subseqüentes, Manacapuru e Paredão.

Também situado às margens de um lago, muito próximo e diretamente ligado ao Solimões, o sítio Nossa Senhora do Perpétuo Socorro se diferencia do padrão de interflúvio descrito. Está localizado numa planície com áreas periodicamente alagadas pelas águas do Lago Manacapuru, que é a própria desembocadura do rio Manacapuru junto ao curso Solimões, que acaba por formar um extenso lago. Trata-se de uma feição geográfica comumente encontrada nos tributários deste grande rio. As características deste sítio arqueológico são peculiares, diferenciando-se por sua vez dos demais encontrados próximos do Solimões. NSP Socorro tem uma área não muito grande, de apenas 8 ha, distribuídos num pacote arqueológico pouco espesso, com uma média de $20 \mathrm{~cm}$. As duas datações radiocarbônicas obtidas, entre $2 \mathrm{e}$ 220 d. C., perfazem um período de ocupação de duzentos anos, relativamente curto quando comparado aos grandes sítios do Solimões, ou mesmo daqueles encontrados junto aos lagos de interflúvio. Esse sítio parece ter tido funções específicas, dada a quantidade e concentração de estruturas de combustão encontradas em toda sua área, que totalizam quase uma centena. Este dado sugere uma interpretação específica que remete ao início de um processo de formação das terras pretas na Amazônia central, mas que será discutido mais a fundo nas páginas subseqüentes.

Ainda fugindo aos padrões de uso do espaço vinculados aos três macroambientes encontrados na área de pesquisa está o sítio Cachoeira, pois se situa 
às margens de um igarapé, junto à sua desembocadura no rio Negro, e não em sua margem propriamente dita. A área do sítio foi estimada em 1,5 ha. Suas pequenas dimensões, no entanto, não condizem com a espessura do pacote arqueológico, com uma terra preta que chega a $75 \mathrm{~cm}$.

Por fim, no que diz respeito aos sítios de interflúvio não relacionados aos lagos, eles se localizam sempre nas proximidades de igarapés. Suas águas pretas e ambientes são características dos pequenos corpos d'água, cujas nascentes se encontram nos próprios interflúvios, e vão desaguar tanto nos lagos, quanto nos rios maiores. É interessante notar que os sítios estudados nestes ambientes divergem sobremaneira, em muitos aspectos. Por um lado, o Jacuruxi tem suas proporções reduzidas (5,6ha.) e uma densidade baixa de vestígios, dispostos num pacote cultural pouco espesso, com cerca de $20 \mathrm{~cm}$. Ou seja, segue o padrão das típicas ocupações de terra firme, tal como observado por Meggers (1970, 1990) e Lathrap (1970a). As datas obtidas para este sítio, 490 e 570 d.C., apontam a ocupação para um período de oitenta anos. Ainda não se tem claro se tal ocupação é contínua ou não, o que teria grande importância na discussão sobre mobilidade dessas ocupações pré-coloniais. A presença das terras pretas e a própria densidade cerâmica sugere uma ocupação minimamente densa, ou que o local fora revisitado por diversas vezes. Mais datações seriam necessárias para esclarecer tal questão. 


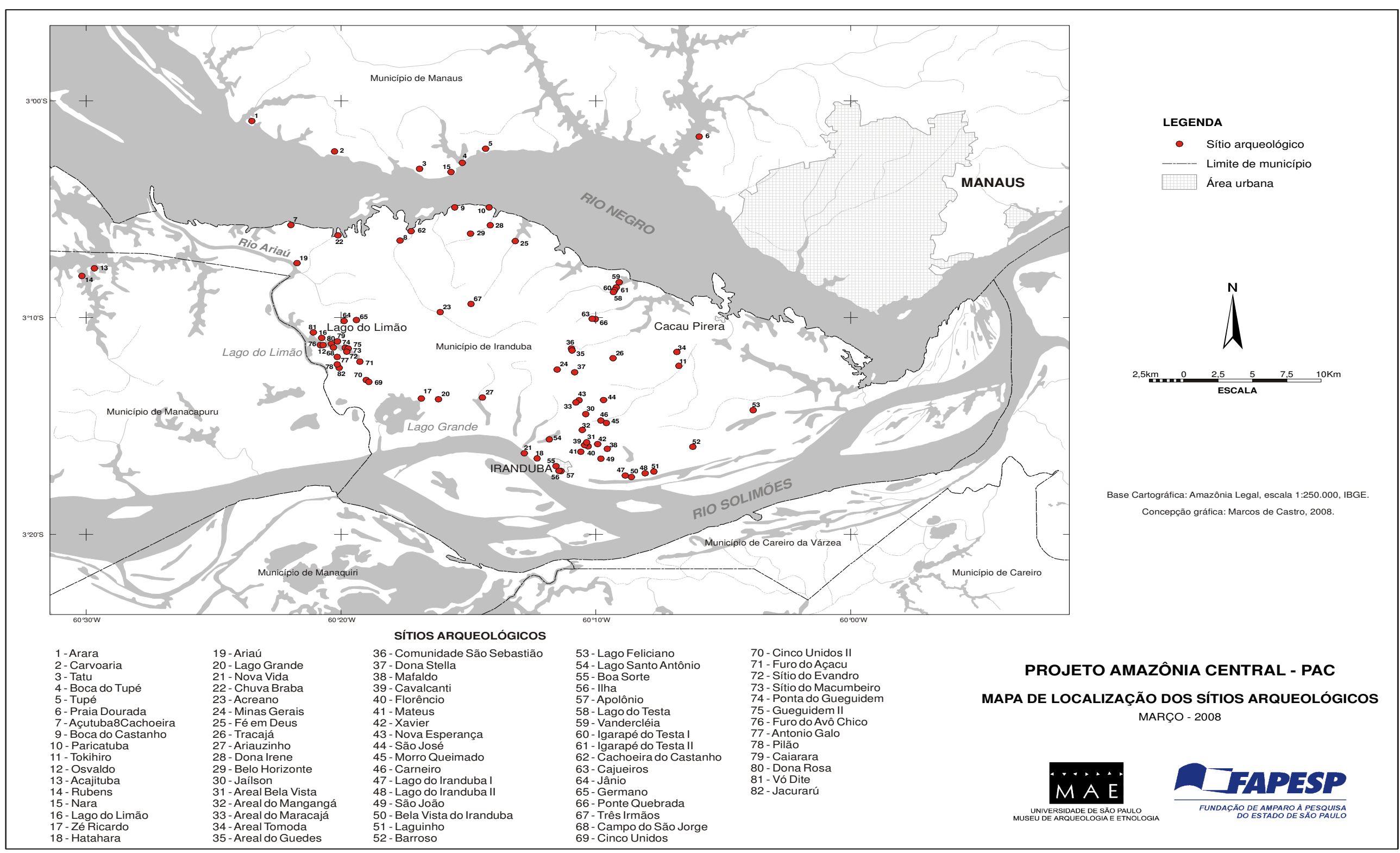

Figura 214 - Mapa dos sítios identificados pelo Projeto Amazônia Central (fonte: Neves, 2008b). 
Já o sítio Nova Cidade, também situado em interflúvio e próximo de igarapés, apresenta-se de maneira bem diferente. É composto por um espesso pacote de solo antrópico e tem em sua cronologia relativas evidências de ocupação por um longo período de tempo, com materiais vinculados às fases Manacapuru, Paredão e Guarita. Dados relativos à sua forma, bem como a própria obtenção de uma seqüência de datações radiocarbônicas, ficaram impossibilitados em função da situação de destruição que se encontrava o sítio quando das pesquisas. Situado na zona urbana de Manaus, este foi bastante impactado pela construção de um conjunto habitacional.

Ainda assim, como mencionado, Nova Cidade mostrou ter uma longa seqüência cronológica, e que durante este tempo teve funções distintas, incluindo a de cemitério. Também suas dimensões puderam ser identificadas, o que encaminhou às discussões mais importantes sobre a relevância deste sítio arqueológico. Tem uma área de aproximadamente 12,4 ha, o que o torna um sítio de grandes proporções. Com uma distância de $15 \mathrm{~km}$ do rio Negro, e maior ainda do Solimões, ou seja, longe de qualquer grande corpo d'água, este sítio foge aos padrões de assentamento de terra firme tal como colocados nas clássicas discussões sobre os padrões de mobilidade e uso do espaço na Amazônia. E este caso não é único: outros sítios ainda não estudados, situados nos interflúvios hoje tomados pela capital amazonense como Japiim, Puraquequara e UDV apresentam também grandes proporções. Parece clara a necessidade de uma profunda reavaliação e atualização de tais debates com base em novos elementos.

Enfim, o que se pode apreender sobre uma análise preliminar dos padrões de uso do espaço e inserção na paisagem dos sítios arqueológicos, na área de confluência dos rios Negro e Solimões, é que existe uma relação positiva entre tamanho do sítio, tempo de ocupação e características ambientais. Os padrões que emergem são os seguintes: sítios implantados junto aos grandes rios, independente de serem estes de águas brancas ou pretas, tendem a ser maiores e a apresentar seqüências de ocupação longas e aparentemente mais contínuas. O segundo padrão são os sítios de interflúvio em lagos, que aparecem em maior profusão e são também de grande porte, embora sua seqüência de ocupação seja mais restrita do que os anteriores. Finalmente, os sítios de interflúvio em igarapés não relacionados a formações lacustres são menos freqüentes, menores 
e menos densos, com seqüências curtas e aparentemente descontínuas, aproximando-se do modelo de ocupação de terra firme. Outra constatação é que tanto os sítios encontrados em lagos como aqueles em igarapés, mas próximos à desembocadura nos grandes rios, não seguirão os padrões identificados.

A partir destes resultados, começa-se a pensar nos fatores que poderiam levar a tal configuração espacial. A área de confluência dos rios Negro e Solimões apresenta uma peculiaridade que se caracteriza por uma grande proximidade de diferentes nichos de recursos, sejam eles ligados aos grandes rios, ou à várzea, sejam eles de interflúvio. Tal proximidade possibilita uma exploração destes diferentes nichos a partir de quaisquer ambientes.

Em relação aos sítios arqueológicos ali implantados, salienta-se certa preferência das populações ligadas aos materiais da Tradição Borda Incisa, em especial Manacapuru e Paredão, pelas regiões de lagos. Duas hipóteses explicativas podem ser aventadas para tentar responder estas questões. Uma delas é a de que isto se deve possivelmente a um processo de adensamento populacional que parece ter ocorrido neste período. O aumento de população teria levado a uma exploração mais sistemática de outros nichos, que não aqueles onde as maiores populações estariam instaladas, uma vez que os sítios dos grandes rios não deixam de ser ocupados, em nenhum momento. A outra se relaciona a uma maior facilidade de comunicação, com o acesso facilitado por meio de canais e furos, viabilizando o estabelecimento de uma rede onde circulariam pessoas, idéias, objetos e, principalmente, informações. Assim, outros elementos que não apenas a disponibilidade imediata de recursos parecem influenciar na configuração espacial dos assentamentos. Tais elementos apontam para a necessidade de reavaliação da clássica dicotomia várzea versus terra firme que, na Amazônia central, não se coloca como único modelo explicativo satisfatório. 


\begin{tabular}{|c|c|c|c|}
\hline \multicolumn{2}{|c|}{ Sítio Arqueológico } & Intervalo Cronológico & Área \\
\hline \multicolumn{4}{|c|}{ Rio Negro } \\
\hline \multicolumn{2}{|c|}{ Açutuba } & 1110 a.C. -1380 d.C. & 90ha \\
\hline \multicolumn{2}{|c|}{ Paricatuba } & $\mathrm{n} / \mathrm{a}$ & 49,4 ha \\
\hline Cachoeira & igarapé & $\mathrm{n} / \mathrm{a}$ & $1,5 \mathrm{ha}$ \\
\hline \multicolumn{4}{|c|}{ Rio Solimões } \\
\hline \multicolumn{2}{|c|}{ Hatahara } & $\begin{array}{l}450 \text { a.C. }-1550 \text { d.C } \\
\text { (checar) }\end{array}$ & $15,4 \mathrm{ha}$ \\
\hline NSP Socorro & lago & 20 - 220 d.C. & 8ha \\
\hline \multicolumn{4}{|c|}{ Interflúvio } \\
\hline Osvaldo & \multirow{2}{*}{ lago } & 20 d.C. - 720 d.C. & $17,5 \mathrm{ha}$ \\
\hline Lago Grande & & 750 d.C. - 1100 d.C. & $5,8 \mathrm{ha}$ \\
\hline Jacuruxi & \multirow{2}{*}{ igarapé } & 490 d.C. -570 d.C. & 5,6 ha \\
\hline Nova Cidade & & $\mathrm{n} / \mathrm{a}$ & $12,7 \mathrm{ha}$ \\
\hline
\end{tabular}

Tabela 25 - Relação entre os ambientes, tamanhos e intervalo cronológico dos sítios arqueológicos pesquisados.

Também os poucos exemplares líticos encontrados nos sítios se mostram como exemplos de tal circulação. A indústria lítica desses grupos ceramistas divide-se em duas categorias principais. Por um lado, verifica-se uma ampla dispersão de lâminas polidas, de diferentes formas e tamanhos, geralmente obtidas através de matérias primas semelhantes, em sua maioria, rochas básicas. Com se viu, em todos os sítios contemplados neste estudo houve a recorrência, sempre em proporções extremamente reduzidas, deste tipo de artefato. As fontes destas matérias primas não se encontram disponíveis nas regiões estudadas, sugerindo um transporte e mesmo uma grande circulação desses materiais.

A segunda categoria de líticos encontrada refere-se aos instrumentos obtidos através da técnica do lascamento. Tanto os artefatos lascados, brutos e os fragmentos produzidos pela ação térmica, são de arenito ou argilito-silicificado, ambos da unidade Manaus, da Formação Altér do Chão. Este tipo litológico encontra-se distribuído nas margens do rio Negro nos arredores de Manaus, bem com em todo médio Amazonas e seus afluentes do baixo curso (Costa, 2003). Já a bacia do rio Solimões apresenta aspectos diferentes. Nas imensas faixas de planície, próximas de onde se situa a maioria dos sítios arqueológicos estudados, encontram-se principalmente aluviões fluviais holocênicos, extremamente férteis. Nos trechos de inteflúvio tabular ocorrem sedimentos da formação Solimões (também Altér do Chão) sob a forma de espessas camadas de latossolo amarelo [Projeto RADAMBRASIL (1978)]. Não se verificam nessas áreas afloramentos 
rochosos passíveis de exploração de matérias primas para o lascamento (Costa, 2003).

Interessante é notar que desta mesma forma se distribuem as indústrias líticas (de ceramistas) na área de pesquisa, independente do período cronológico tratado. De uma centena de sítios identificados, apenas aqueles encontrados às margens do rio Negro apresentaram uma indústria lítica lascada, como é o caso de Açutuba e Paricatuba. Ali, é possível identificar os afloramentos do arenito utilizado como matéria prima numa proximidade de poucos quilômetros da área de habitação. Os habitantes de Açutuba ou Paricatuba devem ter levado em conta o fácil acesso às jazidas de arenito quando escolheram o local para erguer e manter o assentamento por tanto tempo, uma vez que o controle desta área implica também no controle de inesgotáveis jazidas deste arenito. E pode não ser um acaso o fato de Açutuba ser o maior sítio arqueológico da região. Como colocado por Costa (idem), as próprias características tecnológicas das indústrias líticas desta região contribuem para sepultar a idéia da inexistência de artefatos líticos, especialmente lascados, entre os ceramistas amazônicos.

Quanto às cerâmicas, as análises dos materiais e contextos Borda Incisa permitiram um mapeamento mais consistente de elementos indicativos de mudanças ao longo do tempo, bem como das continuidades que marcam esta tradição tecnológica. Sua organização tecnológica (as seqüências de ações e escolhas) indica um longo processo de desenvolvimento cultural: certos elementos presentes e subjacentes ao ciclo de vida dos artefatos não mudam ao longo do tempo. Se tal observação é verdadeira, então quais são as regras que regem o processo de fabricação, uso e descarte da cerâmica da Tradição Borda Incisa? O que muda? O que permanece?

Com relação aos nichos ambientais já mencionados, é importante notar que nem todos eles possuem as mesmas disponibilidades de recursos como, por exemplo, o cauixi. Apesar de ser encontrado apenas nos ecossistemas de águas pretas, há uma permanência do uso do cauixi como tempero preponderante das cerâmicas Borda Incisa nos sítios arqueológicos dispostos em diversos ambientes, ao longo de centenas de anos. A disseminação e conservação de seu uso devem ser interpretadas, portanto, como uma escolha cultural que não resulta unicamente da disponibilidade dessa matéria prima na região. Embora na época da vazante dos rios de águas pretas seja possível coletar centenas destes 
espongiários em uma só manhã, por ter uma ocorrência restrita a certos locais e apenas sazonalmente, sua coleta poderia não ser suficiente para suprir tão larga área sem interrupções, caso não houvesse transporte e/ou armazenagem desta matéria-prima.

Outro indicativo de seu uso indiscriminado - em uma larga área e em tamanho período de tempo - ser fruto de uma escolha cultural é o fato de que o cauixi não é a única matéria-prima passível de ser utilizada como anti-plástico disponível. As cerâmicas Guarita, por exemplo, são amplamente temperadas com cariapé. Também este tipo de fibra vegetal utilizada como tempero é abundante em toda a área de pesquisa. Parte dos grupos indígenas ceramistas atuais não adiciona temperos em suas cerâmicas, usando como anti-plástico apenas os minerais presentes na constituição das argilas e, em outros casos, temperos diversos são aplicados.

Lembro ainda que, como foi detalhado anteriormente, o cauixi nunca aparece sozinho na pasta cerâmica, em nenhum período cronológico identificado. As associações são variadas, havendo certa prevalência de sua associação com o cariapé nas cerâmicas Açutuba, com o caco moído entre os fragmentos Manacapuru e, finalmente, com carvão nos conjuntos Paredão (esta última associação aparece entre os fragmentos provenientes dos sítios do Lago do Limão, estudados por Moraes (2007). Estas misturas foram outrora utilizadas como argumento para refutar as associações entre tipos de anti-plástico a uma ou a outra fase cerâmica (Machado, 2005; Moraes, 2007). A crítica é perfeitamente cabível e não vai contra o argumento que aqui se estabelece. Entretanto, a persistência e prevalência do cauixi é sim uma escolha cultural relacionada aos materiais da Tradição Borda Incisa. Mais uma vez, a simples detecção de sua presença em um determinado fragmento não o associa diretamente a esta tradição numa relação normativa. Mais do que isso, é seu contexto que irá distingui-lo enquanto tal.

Intrigante é a observação de que a prevalência desta escolha não se restringe à Amazônia central, estando disseminada por uma área ainda mais ampla: no baixo Amazonas, no médio Solimões e, principalmente, nas cerâmicas Barrancóides da bacia do Orinoco. Em conjunto com outros vários elementos, a escolha pelo cauixi se coloca como mais um elemento que indica uma semelhança entre diferentes conjuntos, resultante da integração de um sistema 
de interações bastante complexo, que acabaria por gerar como produto algumas padronizações dentro da cultura material de tão distantes regiões.

Tem-se, entre as cerâmicas Borda Incisa, a identificação de um padrão de escolha, transmitido de geração a geração, não necessariamente em um mesmo grupo étnico, no âmbito de uma tradição tecnológica que perdurou por mais de um milênio através da interação de povos e culturas em diferentes lugares. Conclui-se que dentre diversas possibilidades, diferentes grupos optaram por este elemento específico, demonstrando que suas escolhas não se deram ao acaso ou por simples fatores ambientais. Neste sentido, as acirradas críticas sofridas pelo PRONAPA quanto à utilização do tempero como definidor cultural devem ser reavaliadas em diferentes bases, ao menos no caso da Amazônia. Obviamente não proponho aqui uma relação causal ou normativa entre escolha do antiplástico e grupo étnico, mas procuro apontar que as escolhas neste caso têm um caráter cultural, e podem ser consideradas como marcadores cronológicos e culturais desta esfera de interações, que envolve a Tradição Borda Incisa.

Apesar da similaridade da escolha do tempero, são notáveis as diferenças entre as pastas cerâmicas. O uso e tratamento das argilas parecem se modificar com o passar do tempo, na Amazônia central. Materiais associados à fase Açutuba apresentam argilas de colorações claras, entre o bege e o alaranjado que, em conjunto com uma queima oxidante, resultam em uma consistência peculiar: bastante leves e porosas. Já as pastas de materiais da fase Manacapuru são mais acinzentadas, densas e pesadas. Finalmente, as pastas Paredão demonstram extremo controle da matéria-prima desde o seu cuidadoso preparo até a sua manufatura e queima, resultando numa cerâmica extremamente fina e bem acabada, resistente e com alto grau de dureza. Comparação semelhante pode ser feita entre os estilos Barrancas e Los Barrancos, nas cerâmicas Barrancóides ${ }^{17}$. Parece haver, também neste caso, um tratamento mais apurado

\footnotetext{
17 Tais conjuntos foram formados a partir da junção de diversos grupos de estilos (fases?), dispersos no tempo e no espaço. A Tradição Barrancóide é composta por uma seqüência cronoespacial de cinco estilos, três na Venezuela central - La Cabrera, El Palito e Taborda - e outros dois, mais antigos, localizados no Baixo Orinoco - Barrancas e Los Barrancos (Rouse \& Cruxent, 1963, p. 81-83). A cronologia regional proposta por estes autores situa a Tradição Barrancóide entre 900 a.C. e 1000 d.C.
} 
das pastas, que se tornam, no estilo mais recente, mais finas e polidas (Rouse \& Cruxent, 1963, p. 86-87).

A variação formal ao longo do tempo suscita, pois, uma série de novas questões. É observada uma redução da variabilidade formal entre os materiais das fases Açutuba, Manacapuru e Paredão, respectivamente. Enquanto o conjunto mais antigo apresenta, ao mesmo tempo, uma grande quantidade de formas e uma maior variação interna a elas, a fase mais recente mostra-se ao contrário: um número reduzido de formas e uma maior padronização das mesmas, tornando-as características. Este fenômeno vem acompanhado de uma diminuição do rebuscamento das técnicas e motivos decorativos. Neste sentido, a própria forma padronizada pode ter um forte paralelismo com a decoração, na medida em que se mostra um vetor de mensagens, tanto quanto um motivo decorado, veiculando significados.

A variação de temas, das maneiras de apresentá-los e as próprias mudanças das técnicas, em épocas diferentes, configuram uma fonte de dados essencial para identificar a diversidade de códigos de apresentação e, portanto, de comunicação social. Embora tais sistemas não possam ser completamente apreendidos em seu contexto sistêmico, sua capacidade de transmissão de conteúdos simbólicos é evidente. Estas regras sociais de representação gráfica podem estar refletidas nos conjuntos identificados arqueologicamente. Estes conteúdos não podem ser acessados, mas suas marcas impressas na cultura material podem servir para a compreensão de alguns destes sistemas de representações, permitindo que se identifiquem as temáticas valorizadas socialmente, e que refletem as questões que concernem às comunidades.

Quanto às regras que regem a aplicação da decoração, verificam-se elementos estruturais comuns aos diferentes períodos Borda Incisa na Amazônia central, e que têm correlatos com materiais de outras áreas que compartilham da mesma esfera de interações. Como visto, há uma clara preferência pela parte superior das vasilhas para a aplicação de decorações, marcadas pela plasticidade. Embora ocorram mudanças ao longo do tempo em termos das técnicas e motivos, certas regras permanecem, como a estrutura do vaso, que define as áreas a serem decoradas, bem como a composição de alguns dos motivos, discutidos em páginas anteriores. A diminuição da variação de formas e 
motivos decorativos pode ser interpretada, na Amazônia central, como reflexo de mudanças históricas dos modos de vida de tais populações.

Como mudanças históricas entende-se a influência de processos e contingências históricas às quais todas as sociedades estão sujeitas e que, de uma forma ou de outra, são interpretadas e incorporadas à sócio-lógica vigente. Desta forma, alterações nas disponibilidades de recursos e matérias-primas, inovações tecnológicas, modismos relativos a elementos socialmente aceitos e desejáveis, através dos processos de transmissão cultural, geram mudanças que reverberam em toda a sociedade, alterando-a ao longo do tempo.

Ainda que não tenham uma rápida absorção, certas mudanças poderiam gerar, em uma escala de tempo tão longa, profundas transformações em uma sociedade. Fenômenos como estes não implicam em uma ruptura na estrutura social. Ao contrário, a identificação da mudança acaba por ser vista como um indício de continuidade. Assim, a transformação cultural representa um modo de sua reprodução, na qual continuidade e mudança se enquadram em uma relação essencialmente dialética, arbitrária e histórica, sendo que "reavaliações funcionais sempre aparecem como extensões lógicas dos conceitos tradicionais" (Sahlins, 1989, p. 76, p. 174).

Soma-se a isso o fato de estarem estas sociedades conectadas, em diferentes graus, a um intricado sistema de interações que abrangeria uma região tão ampla quanto parte das bacias amazônica e do Orinoco, como propõe este trabalho. Transformações advindas de pontos dessa complexa rede de idéias, objetos e informações teriam influência mútua, também em níveis diferenciados, sobre os demais pontos de conexão. Esta hipotética esfera de interações, em forma de rede, não teria um funcionamento homogêneo nas diferentes regiões, e nem mesmo ao longo de todo o tempo, mas apenas durante certos períodos em que alguns desses pontos teriam mantido uma relação de contemporaneidade. Talvez seja, portanto, este seu aspecto de rede que tenha viabilizado sua existência por tanto tempo, na Amazônia central, por exemplo. Este pode ser também o caso dos sistemas encontrados no Alto Xingu (Heckenberger, 2002, 2003) e no alto rio Negro, que existem até hoje, mas têm suas origens nos tempos pré-coloniais (Neves, 1998, p. 363).

Mudanças na cultura material, tais como aquelas observadas entre as fases da Tradição Borda Incisa da Amazônia central, refletem uma série de 
contingências históricas, tanto locais como regionais, experimentadas por esses povos. Por conseguinte, a mencionada simplificação morfológica, assim como das decorações, entre outras mudanças na tecnologia cerâmica e na configuração do registro arqueológico relacionado a esta tradição, podem ser interpretadas à luz dessas mudanças, como se mostrará nas páginas que seguem.

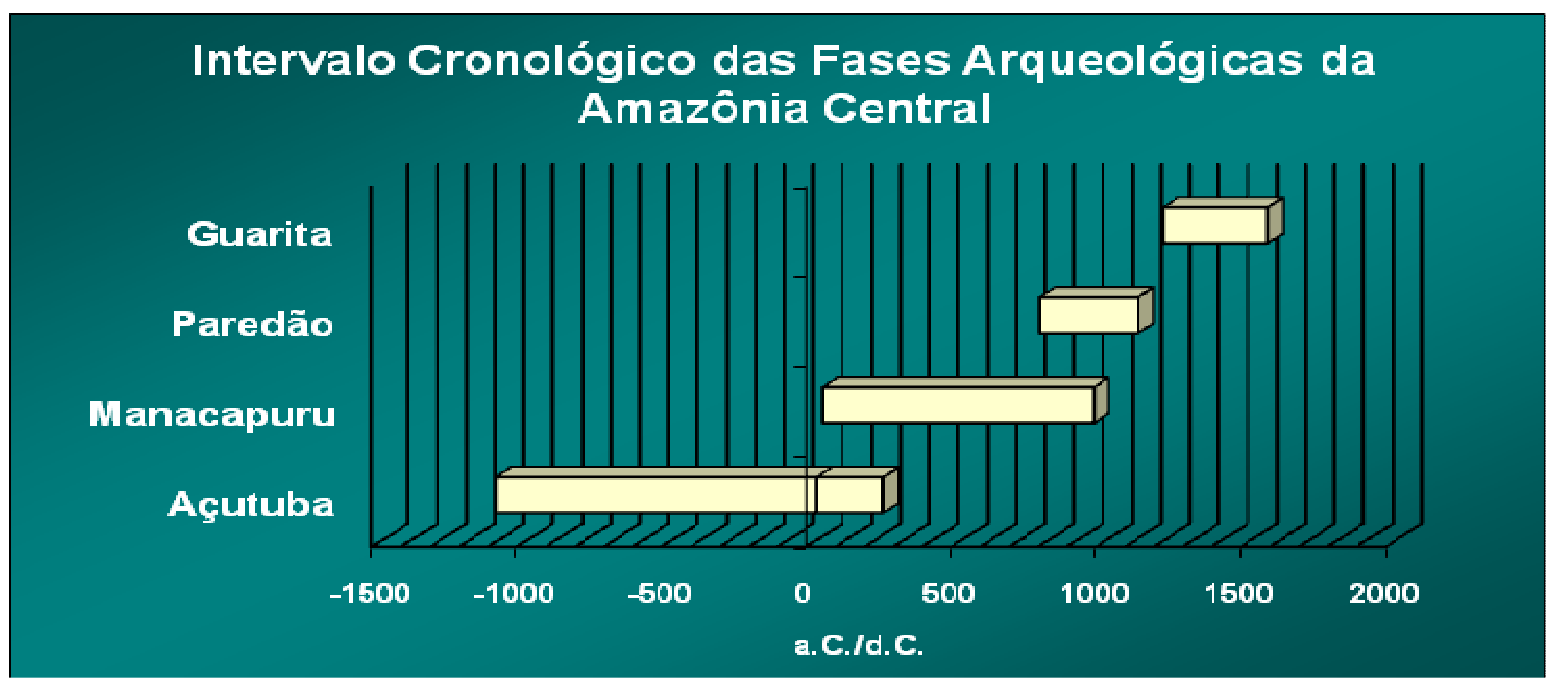

Gráfico 80 - Intervalo cronológico das fases arqueológicas da Amazônia central. Obtido através de datações radiocarbônicas calibradas nos sítios arqueológicos.

As evidências mais antigas de ocupação dessa área por grupos ceramistas e horticultores remontam ao séc. I a.C. Estas aparecem em vários pontos da Amazônia central, em sítios arqueológicos multicomponenciais, com pacotes profundos, geralmente a mais de um metro abaixo da superfície, pequenos e pouco densos. Mostram um uso de solo não intenso e discretas alterações na paisagem ou em suas matrizes de solo relacionadas, que podem ser arenosas (espodossolos) ou argilosas (latossolos). Os sítios Açutuba e Hatahara, próximos de grandes rios, são as evidências mais claras de assentamentos sedentários relacionados a esta fase arqueológica. Além destes, há dois outros pontos, ainda mais discretos, onde se identificou materiais semelhantes. São os sítios Lago Grande e Osvaldo, nas margens de lagos de interflúvio.

A estes materiais, que têm características peculiares, convencionou-se chamar de fase Açutuba, por razões já descritas. A delimitação destas ocupações apontou para uma baixa densidade de fragmentos cerâmicos espalhados por uma área não muito ampla dos sítios, indicando tratar-se de assentamentos de proporções reduzidas. Nos casos onde a densidade de material arqueológico é 
visivelmente maior, estes parecem agrupamentos associados a áreas de atividade dentro do sítio, através de diferentes estruturas e feições. No sítio Açutuba, as datas indicam uma duração aproximada de sete séculos.

As cerâmicas relacionadas são caracterizadas por um alto rebuscamento das decorações e por uma grande variabilidade em termos formais e decorativos. Alguns de seus elementos de cultura material aludem a outros conjuntos antigos. As formas, bem como as sofisticadas decorações plásticas, são comparáveis às cerâmicas Barrancóides encontradas no baixo Orinoco, na Venezuela. Mais especificamente, ao estilo Barrancas, embora este seja mais antigo, com datas que recuam até o séc. X a.C. Algumas formas Barrancóides apresentam características semelhantes a esta cerâmica da Amazônia central, como flanges labiais e apêndices decorados através de incisões, modelagens, e engobo vermelho (Rouse \& Cruxent, 1963, p.84). Mais ainda, as afinidades entre estes dois conjuntos vão além. Alguns fragmentos deste estilo Barrancóide apresentam traços que podem ser atribuídos à influência Saladóide (idem). Trata-se, a rigor, da presença da pintura policrômica, assim como identificado entre as cerâmicas da fase Açutuba. Em ambos os casos, possuem formas específicas, com lábios cortados, e não em flanges labiais.

Não é necessário ir tão longe para se identificar outros conjuntos com características congruentes com esta fase cerâmica. Trata-se dos sítios com ocupações relacionadas à fase Pocó, encontrados na região do baixo Trombetas e Nhamundá, na região da atual fronteira entre os Estados do Amazonas e Pará (Hilbert \& Hilbert, 1980; Guapindaia, 2008). Comparações detalhadas entre estes materiais, Açutuba e Pocó, foram apresentadas no capítulo VII. Estes últimos também são marcados pela presença (em maior proporção) de pinturas policrômicas, executadas nos potes cerâmicos sob um sistema de regras semelhante, que se refere às formas dos vasos, às técnicas, cores, motivos e locais preferenciais da aplicação da pintura. Da mesma maneira, os exemplares com decoração plástica mostram-se semelhantes àqueles da Amazônia central, com o largo uso de incisões, excisões e modelagens, executados em flanges labiais e apêndices. Vale lembrar que, quando inicialmente descritas pelos Hilbert, as semelhanças destas cerâmicas com a Tradição Barrancóide foram notadas (Hilbert \& Hilbert, 1980, p. 8). 
As afinidades ultrapassam o próprio conjunto artefatual. Ambos os conjuntos remontam a uma cronologia semelhante, datadas em torno do anno domini. A fase Açutuba, tal como avaliada agora, situa-se no intervalo cronológico aproximado entre 1000 a.C e 300 d.C. As datas do sítio Pocó situam-se entre 65 e 205 d.C., as do sítio Boa Vista, um pouco mais antigo, acusaram 1330 e 1000 a.C. (Hilbert \& Hilbert, 1980, p. 9). Além disso, ambas apresentam-se nos sítios arqueológicos de maneira semelhante, em pacotes culturais profundos e relativamente discretos, quando comparados com as ocupações mais recentes nestes locais.

Estas similitudes de materiais em regiões tão distantes, com datas e contextos análogos, aliadas às já discutidas características inerentes ao conjunto Açutuba, sempre marcadas pela alta variabilidade e rebuscamento, levam a crer que o estabelecimento dessas ocupações, na Amazônia central, não foi um processo autóctone e independente, mas sim parte, talvez inicial, desta suposta esfera de interações. Se, por um lado, tais semelhanças corroboram a proposição de uma rede de interações, tamanho rebuscamento e variabilidade interna à indústria cerâmica podem remeter, por outro lado, a uma necessidade de afirmação de identidade e status social, próprias de alguns complexos cerâmicos iniciais do norte da América do Sul (Oyuela-Caycedo, 2005).

Ainda dentro desta mesma esfera de interações, que teria sido responsável pela própria introdução destas cerâmicas na Amazônia central, mudanças locais passam a acontecer. Uma dessas mudanças, claramente perceptível no registro arqueológico, é um gradual aumento demográfico, demonstrado pelo tamanho, a densidade e quantidade de sítios. Paralelo a isto, passa-se a uma exploração mais intensiva dos recursos, bem como a uma ampliação de nichos ambientais ocupados, como o povoamento dos ambientes dos lagos de interflúvio e a exploração dos recursos de cabeceiras de igarapés, por exemplo. Os sítios passam a ter usos e funções específicas, para além da categoria de sítiohabitação. É a todo este processo que associo as cerâmicas e contextos da fase Manacapuru.

Este gradual processo de mudanças na Amazônia central parece ter início tão logo estas populações primeiras, ligadas à fase Açutuba, se estabelecem, embora de maneira mais sutil. Ele se intensifica com o passar do tempo, levando a modificações em elementos sociais, que acabam por se manifestar em 
diferentes elementos da paisagem, na cultura material e na própria manufatura das cerâmicas.

O caso do sítio Nossa Senhora do Perpétuo Socorro, que conta quase com uma centena de estruturas de combustão, aparenta ser um local de formação deliberada das terras pretas, como uma das atividades específicas ali desenvolvidas. Esta interpretação foi dada pela altíssima concentração de fornos e estruturas de combustão associadas a um pacote arqueológico discreto, com concentração de matéria orgânica, que não chega a constituir uma terra preta, a não ser no interior dessas feições. Outra evidência de atividade especifica são as estruturas para o cozimento de cerâmicas. Estas cerâmicas, com características Manacapuru, têm datas tão recuadas quanto os primeiros séculos d.C., ou seja, que coincidiriam com a fase Açutuba, numa visão seqüencial e normativa das mesmas.

Assim como NSP Socorro, o sítio Jacuruxi nos coloca no limiar do entendimento das reais significações das fases cerâmicas encontradas na Amazônia central. Sua cultura material, vinculada tanto à fase Açutuba como Manacapuru, em maioria, apresenta uma matriz de solo antrópico, mas que também não caracterizaria uma terra preta propriamente dita. Com datas em torno dos séc. V e VI d.C., antigas para a fase Manacapuru e recentes para a fase Açutuba, as relações entre uma e outra em termos processuais fica mais clara.

Ao contrário do que foi apresentado quando inicialmente se definiu a fase Açutuba, as datações agora disponíveis para as fases Açutuba e Manacapuru se interpolam em algumas centenas de anos em alguns sítios. Naquela ocasião, uma indagação deixada em aberto era, com efeito, sobre o entendimento das relações entre estas duas fases: "Sendo assim, pode-se dizer que há ainda uma imensa lacuna a ser preenchida, de modo que se esclareçam as relações históricas entre as primeiras indústrias cerâmicas da região e as cerâmicas produzidas a partir do século V d.C. (Lima et al., 2006, p. 27-28). Com os dados hoje disponíveis, acredito estar no caminho para tal resposta: as relações entre Açutuba e Manacapuru se deram de um modo muito mais processual e contínuo do que outrora se imaginava.

É também neste limiar entre uma e outra fase que se percebe, em diferentes escalas, elementos que lançam luz ao processo produtivo das terras pretas de índio, que se tornarão um marco das ocupações pré-coloniais 
amazônicas. As datas obtidas para o sítio Osvaldo indicam um rápido processo de formação da terra preta, o que mais uma vez sugere uma mudança de modo de vida de uma ocupação para a outra. Esta mudança implicaria em, pelo menos, uma grande intensificação do uso do solo. É, portanto, com a fase Manacapuru e seus contextos associados que se tem os primeiros assentamentos vinculados a matrizes antrópicas, com a presença das terras pretas propriamente ditas. Estas, agora mais densas e profundas, se formam na mesma intensidade tanto em solos arenosos (sítios Açutuba e Cachoeira), quanto em solos argilosos (Osvaldo). A densidade de material arqueológico é, na maioria dos casos, superior à das ocupações da fase Açutuba e a tecnologia da indústria cerâmica é muito semelhante em todos os sítios estudados.

De um modo geral, as cerâmicas Manacapuru apresentam aspectos tecnológicos semelhantes com a fase que a antecede, embora as mudanças neste processo produtivo sejam visíveis. As pastas (ao menos as diagnósticas) tornam-se mais densas e pesadas, sugerindo alterações no preparo e queima das argilas. O rebuscamento dos motivos incisos e modelados dá lugar a certa estilização, sendo que novos elementos técnicos são introduzidos, como o ponteado e o ungulado, enquanto outros, tais como excisões e a pintura policrômica são paulatinamente abandonados. Verifica-se que o vasilhame tende a uma ligeira redução em sua variabilidade morfológica. Como se vê, um processo de mudança local, aparentemente continuado, mas que resulta no que foi, ao final, denominado como fases Açutuba e Manacapuru.

Mais do que isso, percebe-se que não se tratam de eventos históricos isolados. Mudanças semelhantes, vinculadas não apenas à tecnologia cerâmica, são vistas entre as cerâmicas do baixo Orinoco, sugerindo um processo correlato. As cerâmicas Barrancóides são as evidências mais claras de ocupações relacionadas a pacotes culturais espessos, com registro de terra preta naquela região. Os depósitos Saladóides, mais antigos, são caracterizados por lentes discretas (Boomert, 2000, p.106; Lathrap, 1970a, p. 113). A maior ou menor antigüidade em relação às Tradições Barrancóide e Saladóide é, até hoje, um elemento de discussão entre os pesquisadores (Heckenberger, 2002; Boomert, 2000; Roosevelt, 1997), e as relações cronológicas e culturais entre elas foram interpretadas de diferentes maneiras. Pesquisas recentes, em diferentes regiões 
da Venezuela e Caribe, vêm refinando esse quadro, com os trabalhos de Boomert (2000), Gasson (2002), entre outros.

Num processo de mudanças locais entre os estilos Barrancas e Los Barrancos, observa-se entre as cerâmicas uma crescente estilização das decorações, o uso do aditivo de cauixi e o abandono da policromia, neste caso a Saladóide (Rouse e Cruxent, 1963, p. 86-87). Todos estes elementos são comparáveis ao caso aqui apresentado, principalmente no que concerne à utilização das decorações plásticas e pintadas.

Na Amazônia central, a fase Manacapuru, mais do que todas as outras, se mostra como um processo gradual e contínuo de mudança, englobando sítios discretos, com uma terra preta ainda em formação, e com datas bastante recuadas, e também sítios grandes e densos, com evidências de ocupação de algumas centenas de anos. É nestes sítios maiores e mais densos que se observa uma série de elementos comuns à fase Paredão, mais recente. Dentre esses elementos cabe destacar a identificação dos assentamentos em formato circular ou elipsoidal, que evidenciam uma diferença de usos relativos ao espaço, bem como uma modificação mais intensa da paisagem. É um formato pode denotar a materialização de uma cosmovisão, que distinguiria e beneficiaria espaços públicos-rituais (Fausto, 2005, p. 17), e que, neste sentido, estaria, de certa forma, imprimindo suas marcas na paisagem.

Diferentemente dos contextos Açutuba, sempre encontrados em sítios multicomponenciais, a fase Manacapuru está presente também em sítios unicomponenciais, o que facilitou a identificação da disposição espacial dos assentamentos. Exemplo de tal associação é o sítio Osvaldo, cujo padrão de disposição espacial das cerâmicas, em termos de densidade e variabilidade, sugere tratar-se de unidades habitacionais dispostas circularmente, com uma área próprial identificada como a praça central (central Plaza) (Abreu, 2000; Portocarrero, 2007). Do mesmo modo, o sítio arqueológico Santa Etelvina, situado na área urbana de Manaus, mostrou a presença predominante de cerâmicas Manacapuru associadas a poucos exemplares de cerâmica Paredão, com uma dispersão superficial sugerindo um assentamento de forma elíptica, com pelo menos 900m de comprimento ao longo de seu maior eixo (L. Lima, 2003, p. 25). O sítio encontra-se hoje completamente destruído. 
A proposta de associação entre cerâmicas Barrancóides e aldeias circulares é antiga nos modelos de ocupação da Amazônia. Tem-se observado associação semelhante na Amazônia central com os materiais da fase Manacapuru. Estes dados, de certa forma, vêm confirmar o modelo proposto na década de setenta por $D$. Lathrap, e recentemente reelaborado por $M$. Heckenberger (2002), que associa a dispersão das cerâmicas Borda Incisa/Barrancóides e das aldeias circulares aos grupos indígenas pré-coloniais falantes de línguas do tronco proto-arawak, em uma ampla região do norte da América do Sul.

Numa região adjacente à área de pesquisa, de confluência dos rios Negro e Solimões, percebe-se a ocorrência de eventos semelhantes. Mais uma vez, as evidências arqueológicas mostram-se como correlatos locais de um amplo processo. Neste caso, levado a cabo numa região entre a Amazônia central e o baixo Amazonas, nas proximidades dos municípios de Itacoatiara. Ali se encontra uma fase cerâmica que, embora não tenha sido alvo direto deste estudo, apresenta paralelismos com os processos observados nos materiais da fase Manacapuru, tornando sua menção importante. Trata-se da fase Itacoatiara, que é composta por cerâmicas similares às das fases Açutuba e Manacapuru, apresentando características claramente associadas à Tradição Borda Incisa e, também, às cerâmicas Barrancóides (fig. 215).
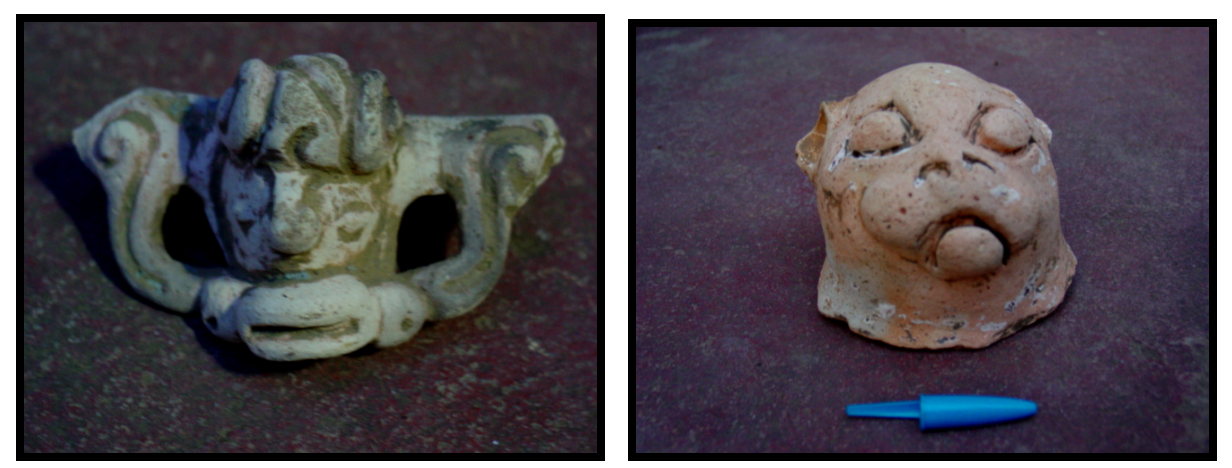

Figura 215 - Cerâmicas associadas à fase Itacoatiara, de coleções particulares, recolhidas por moradores de Itacoatiara. (Fotos: Helena Lima).

Vale lembrar que também esta fase arqueológica foi foco de intensos debates e discussões, em especial no que concerne a sua validade classificatória. Essas cerâmicas foram identificadas por P. Hilbert e afiliadas à Tradição Incisa e 
Ponteada (1968, p. 207-224), cuja cronologia relativa é posterior à Tradição Policroma da Amazônia, ou seja, supostamente muito mais recente do que a Tradição Borda Incisa. Suas premissas foram o tempero e a posição estratigráfica.

Estes materiais foram encontrados em um sítio multicomponencial, sobre materiais relativos às ocupações Guarita. Esta configuração estratigráfica, provavelmente resultado de processos pós-deposicionais - além de diversos outros fatores, levaram Hilbert a classificá-los como parte de um complexo mais recente, pertencente à Tradição Incisa e Ponteada. Isto se deu pela falta de datações de $\mathrm{C}_{14}$ para ancorar a cronologia, pela presença do cauixi numa seriação por gênero, assim como pela influência da classificação das cerâmicas amazônicas em quatro horizontes (Meggers e Evans, 1961). Ou seja, materiais superficiais, temperados com cauixi e sobre cerâmicas Guarita no sítio arqueológico deveriam indicar tratar-se de um conjunto recente.

Ocorre, no entanto, que não há cerâmicas da Tradição Incisa e Ponteada na Amazônia central (Lima et al. 2006). Este fato já havia sido notado - e duramente criticado - por D. Lathrap, que alegou a ocorrência de mistura mecânica entre os dois componentes, e defendeu que também a fase Itacoatiara seria associada à série Barrancóide e, portanto, mais antiga (1970b, p. 500-501). Mas a perturbação estratigráfica no sítio arqueológico não passou despercebida por Hilbert, que observou: "o sítio sofreu perturbações significativas durante $o$ processo de urbanização e devido à erosão do barranco que transformou a topografia da margem do rio Amazonas" (K. Hilbert, comunicação pessoal, jan. 2007).
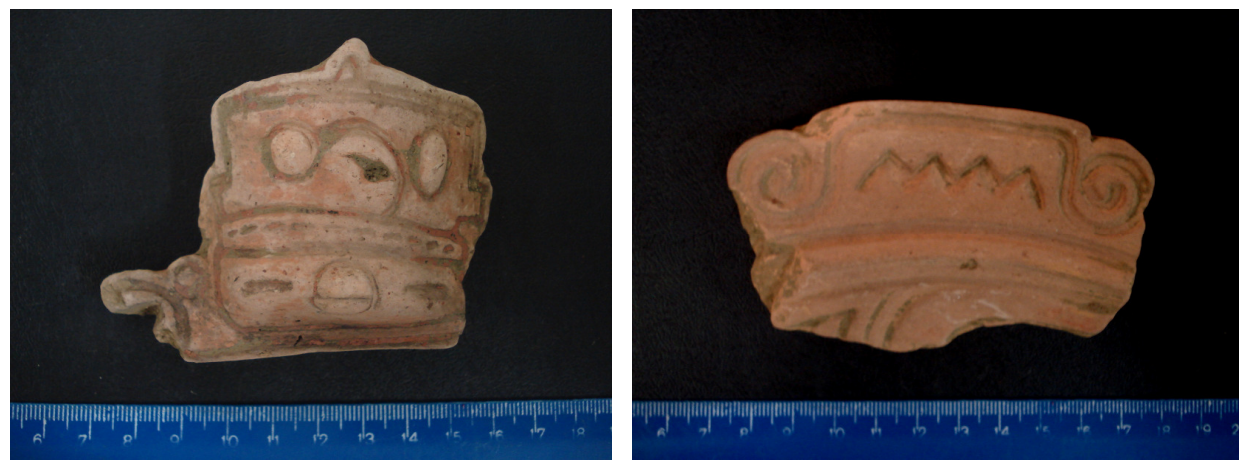

Figura 216 - Cerâmicas associadas à fase Itacoatiara, coletadas por P. Hilbert (Fotos: Helena Lima). 
Mais um dado relevante é a datação radiocarbônica obtida por P. Hilbert para uma cerâmica do sítio Itacoatiara, temperada com cauixi. A antigüidade da datação não condizia com os argumentos acima colocados, o que levou o pesquisador a descartá-la na ocasião. Esta data, em torno de dois mil A.P., coloca-se cronologicamente contígua de nossa recém-definida fase Açutuba, e nunca foi publicada (K. Hilbert, comunicação pessoal, jan. 2007).

Os problemas com a classificação de Hilbert se devem ao estado do conhecimento arqueológico com que se contava na ocasião, certamente muito diferente do que se tem hoje. O sítio Paredão, por exemplo, também demonstra isso. Trata-se de um sítio localizado na área urbana de Manaus, "no topo de uma falésia de 50 metros de altura (...). O sítio deu nome a esta fase arqueológica (Paredão). A terra preta de origem antrópica ocupa uma área elíptica de aproximadamente 160×100 metros de extensão, inclinada em direção ao rio e coberta em sua maioria por uma vegetação secundária (capoeira). Chama atenção a escolha favorável deste local. Paredão não somente oferece uma visão panorâmica sobre a extensa superfície d'água da região da foz do rio Negro. Três cortes estratigráficos foram realizados de 1,50x1,50 metros de extensão e escavados em níveis de $15 \mathrm{~cm}$ por Peter Paul Hilbert e Joseph Fittkau em 1959. Abundante material arqueológico foi recolhido em superfície." (idem).

Das três escavações estratigráficas realizadas no sítio, duas delas se situavam próximo aos seus limites e apresentaram um pacote arqueológico com 45 e $60 \mathrm{~cm}$ de profundidade. Já a sondagem 2 apresentou uma terra preta tão profunda quanto $90 \mathrm{~cm}$. Numa revisão do material arqueológico e dos perfis, pude perceber que esta última se localizava sobre um montículo (pela estratigrafia, materiais e também pela própria profundidade da terra preta). À época, tais estruturas artificiais não eram conhecidas na região, o que levou o autor a classificar cerâmicas antigas, com características semelhantes à fase Açutuba, tais como policromia, modelagem e incisões como pertencentes ao conjunto mais recente, da fase Guarita. As datas antigas obtidas para este sítio foram descartadas. 

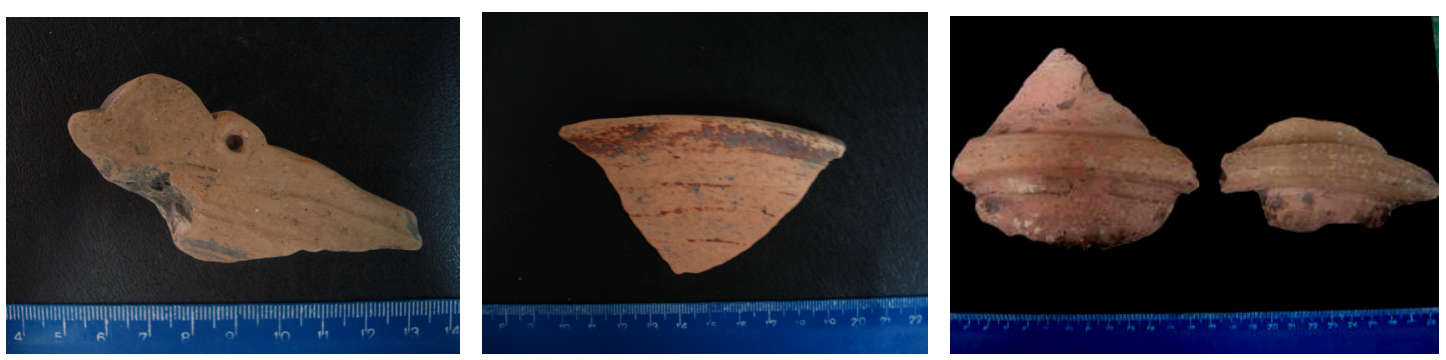

Figura 217 - Cerâmicas Manacapuru, Paredão e Guarita, encontradas no sítio Paredão por P. Hilbert, respectivamente nos níveis $30-45 \mathrm{~cm}, 45-60 \mathrm{~cm}$ e 1-15 cm, da sondagem 1 (fotos: Helena Lima).

Sendo assim, as datas então descartadas por Hilbert, por não se adequarem ao padrão por ele esperado, podem ser agora incorporadas ao quadro hoje disponível, contribuindo para uma melhor caracterização de contextos antigos presentes na Amazônia central.

\begin{tabular}{|l|l|l|l|l|l|}
\hline \multicolumn{1}{|c|}{ Sítio } & Corte & Nível & Data & Laboratório & Obs. \\
\hline AM-IT-14, Itacoatiara & 1 & $30-45 \mathrm{~cm}$ & $2036 \pm 58$ & $\mathrm{P}-372$ & Cauixí \\
\hline AM-MA-18, Paredão & 1 & $45-60 \mathrm{~cm}$ & $2400 \pm 75$ & GrN-4328 & \\
\hline
\end{tabular}

Tabela 26 - Datações radiocarbônicas antigas obtidas por P. Peter Hilbert para os sítios Itacoatiara e Paredão.

É interessante notar ainda a constante correlação entre as cerâmicas das fases Manacapuru e Paredão na área de pesquisa, a partir de certo período cronológico, a saber, dos séculos VII e VIII. Os sítios de ocupação Manacapuru, tais como Açutuba, Osvaldo e Santa Etelvina, apresentam pequenas porcentagens de cerâmica Paredão e, do mesmo modo, todos os sítios com materiais Paredão, como Nova Cidade e Lago Grande, têm uma pequena porcentagem de material Manacapuru em todos os níveis, indicando indubitável associação estratigráfica entre estas duas fases. Uma correlação de tal ordem pode ser entendida em parte pelas datas, que indicam uma contemporaneidade entre ocupações, ditas Manacapuru e Paredão, além da proximidade dos sítios. Contudo, um entendimento mais profundo sobre tais relações pode ser obtido a partir das ferramentas disponibilizadas por uma análise em termos de esferas de 
interações. Desta perspectiva, uma e outra fase seriam materializações de partes de um processo imbricado de relações sociais e mudanças ao longo do tempo.

Outro viés interpretativo dentro do PAC coloca essas duas fases, que são contemporâneas em alguns séculos, como conjuntos específicos de artefatos dentro de uma mesma sociedade ou grupo cultural. Esta hipótese, aventada por J. Petersen (2004, comunicação pessoal), entende as cerâmicas Paredão como aparato funerário pertencente aos mesmos povos produtores das cerâmicas Manacapuru. De fato, os contextos funerários Paredão são recorrentes ao passo em que há uma aparente ausência dos mesmos entre os conjuntos Manacapuru. Esta idéia não é excludente ao que agora é proposto, uma vez que ambas pressupõem interações entre os conjuntos. No entanto, queda por entender a relação cronológica entre eles. Pois, embora sejam concomitantes num dado intervalo de tempo, a fase Manacapuru antecede a Paredão na cronologia regional.

$\mathrm{Na}$ verdade, se há algum aspecto a ser destacado quando se tratam dessas fases cerâmicas, é por certo todo o processo de mudança gradual e contínua que leva ao contexto ao qual se associa a fase Paredão, que seria, sob esta ótica, o ápice da ocupação Borda Incisa na Amazônia central.

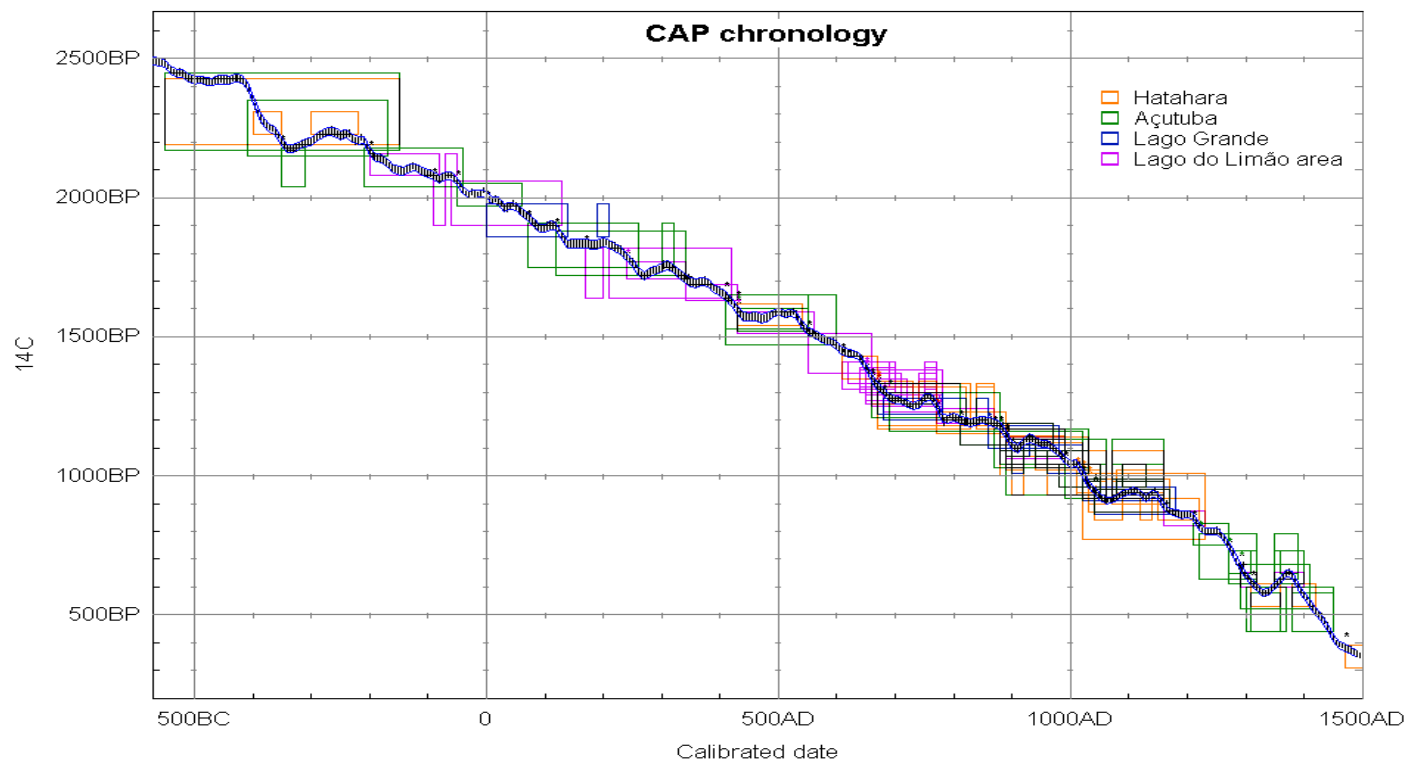

Gráfico 81 - Quadro cronológico contendo datações de $\mathrm{C}_{14}$, obtidas para os sítios Hatahara, Açutuba, Lago Grande e área do Lago do Limão, na Amazônia central 
Já em torno dos sécs. IX, $\mathrm{X}$ e os seguintes, a quantidade de sítios é maior, assim como a densidade dos materiais nos mesmos. A terra preta é mais escura. O quadro cronológico (graf. 81, acima) mostra esta maior quantidade de sítios, em torno dessas datas. É quando se tem evidências mais claras de assentamentos circulares, e os nichos de interflúvio se encontram largamente ocupados. Se observam também sinais de construção dos montículos artificiais, os quais reforçam a idéia de usos específicos a determinados espaços, como os montículos funerários. A própria construção dos montículos, considerando sua artificialidade, é um evento de construção relativamente rápida, como é o caso do Hatahara, onde se pode aventar uma grande mobilização de mão de obra. Tal mobilização, que envolveria uma divisão de trabalho social, está impressa também na construção de grandes valas defensivas, junto aos limites de grandes sítios arqueológicos, como o Lago Grande e Açutuba, servindo para se pensar sobre a convivência conflituosa ou pacífica entre diferentes grupos. Todas estas características mostram um adensamento populacional, verificado no registro arqueológico dos sítios identificados e relacionados a esta fase arqueológica.

Tais mudanças podem também ser percebidas com a análise das coleções cerâmicas dos sítios. Muito já se falou sobre a padronização das cerâmicas Paredão, onde o rebuscamento visto na fase Açutuba dá lugar à sobriedade e estilização. Em análise de alguns contextos cerâmicos na Amazônia central, Moraes sugere que na fase Paredão há uma "diminuição de fragmentos decorados, o que pode representar uma necessidade de produção de mais cerâmica utilitária" (2007, p. 178). De fato, se observarmos o quadro cronológico hoje disponível para as ocupações pré-coloniais amazônicas, verificaremos um pico populacional em torno dos séculos XI e XII, período este que culmina com a diminuição gradual da variabilidade decorativa e formal dos artefatos.

O desenvolvimento destas sociedades arqueológicas está associado a uma intensificação da ocupação dos sítios na área. Há uma maior quantidade de sítios, muitas vezes contíguos e contemporâneos, e eles são maiores e mais densamente povoados, quando comparados a quaisquer outros períodos da história da região, sejam anteriores ou posteriores.

Uma série de contextos unicomponeciais associados à fase Paredão, como é o caso dos sítios Antonio Galo e Pilão, foram recentemente escavados pelo PAC, e renderam algumas hipóteses interessantes sobre os povos que 
produziram essas cerâmicas (Moraes, 2007). Em primeiro lugar, a configuração espacial desses sítios é sempre semelhante. São os montículos artificialmente construídos, cuja composição e disposição espacial sugerem tratar-se de unidades habitacionais. Moraes os interpreta como evidências de aldeias circulares, associadas à fase Paredão, preenchendo uma lacuna entre a arqueologia Caribenha, e da Amazônia, em especial a xinguana (idem).

Apesar da filiação cultural da fase Paredão à Tradição Borda Incisa não ser consensual dentre os pesquisadores do PAC, há uma linha interpretativa, na qual este trabalho se inclui, que considera esta fase arqueológica como uma manifestação de mudanças dentro da fase Manacapuru. Essa correlação é utilizada para definir os produtores de cerâmica da fase Paredão como possíveis falantes de línguas Arawak, e mais importante, participantes de um sistema cultural Arawak. A vinculação dos materiais associados à fase Manacapuru com culturas Arawak não é novidade. Donald Lathrap (1970a) já o fizera antes, hipotetizando sobre a dispersão das cerâmicas Barrancóide. Entretanto, tais considerações não incluíam diretamente a fase Paredão, sendo esta última pensada por ele como parte de uma expansão Carib (idem, p. 168). Na presente pesquisa, e no âmbito do PAC, ao caracterizar um continuum entre as fases Açutuba, Manacapuru e Paredão, e suas características condizentes àquelas Arawak, estas são automaticamente incorporadas a esta discussão (Abreu, 2000; Moraes, 2007; Portocarrero, 2007).

Assim, as sociedades por detrás da fase Paredão teriam na construção dos montículos uma inovação, mas mantendo um mesmo padrão circular identificado para as aldeias mais antigas, com materiais da fase Manacapuru, indo mais uma vez de encontro aos elementos culturais relacionados à chamada Diáspora Arawak (Heckenberger, 2002). Dentre as características que denotam semelhanças entre os grupos Arawak, que também seriam fatores que mostrariam uma retenção de certos elementos de sua gramática cultural, mesmo em uma escala de longa duração, se encontram os seguintes elementos: hierarquia social, espaços públicos político-rituais bem definidos, participação em sistemas multiétnicos e multilíngües, extensas redes pacíficas de troca em escala regional, uma horticultura elaborada e sedentarismo (Fausto, 2005, p. 17-18; Heckenberger, 2002, 2003). 
Curiosamente, muitos dos elementos propostos para entender o registro arqueológico encontrado na Amazônia central são condizentes com tais características. Hierarquia social pode ser inferida através da divisão de trabalho social necessária para a construção, em eventos relativamente rápidos, de modificações significativas na paisagem, tais como os montículos funerários e as valas defensivas (Donatti, 2003; Machado, 2005, Neves, 2008). Espaços públicosrituais bem definidos são evidentes na configuração espacial das aldeias identificadas, em formato elipsoidal e circular (Abreu, 2000; Donatti, 2003; Moraes, 2007; Portocarrero, 2007). A participação em sistemas multiétnicos e multilíngües, bem como as extensas redes de troca em escala regional, são, portanto, as propostas deste trabalho para explicar os contextos identificados, as generalizações e particularidades do material arqueológico observado. O modo de vida sedentário e horticultor é visto desde o começo dos assentamentos, interpretados como um desenvolvimento exógeno à região, que se desenvolve, tornando-se mais intensivo e denso na Amazônia central à medida em que o tempo passa.

Como se vê, a grande dificuldade está em aceitar que estas características viriam de uma gramática cultural hoje identificada com os povos falantes de línguas Arawak. Entretanto, ao pensar em regiões tão díspares quanto o alto Xingu, o baixo Orinoco e a Amazônia central pode-se aventar, sem tanto receio, que "Os padrões distribucionais, a correlação entre língua e cultura, neste caso, é indubitável: onde encontramos falantes de línguas Arawak, também se encontra hierarquia social, sedentarismo e regionalidade" (Heckenberger, 2002, p. 46). $O$ que o autor chama de regionalidade é o que se propõe para o entendimento de uma esfera de interações em seu contexto sistêmico, com vistas ao que outrora se convencionou chamar território.

Desse modo, um território, denotado em lugares pretéritos e com histórias culturais próprias, seria a materialidade espacial e temporal de uma esfera de interações. Esta, por sua vez, estaria refletida arqueologicamente em uma determinada tradição tecnológica: a cultura material, expressa na paisagem. Como decorrência da tese ora exposta, pressupõe-se a existência, no passado, de fronteiras culturais. Fronteiras estas que delimitariam diferentes territórios cuja mobilidade e flexibilidade são variáveis de um binômio espaço-tempo, objetos de investigação. 
De acordo com o quadro cronológico que ora se delineia, este parece ser um ápice, em um determinado território, de uma série de processos: sociais, políticos, econômicos, demográficos e simbólicos, que se desenrolam até os sécs. XII ou XIII, quando há sérios indícios de uma ruptura, em elementos tão diversos como a tecnologia cerâmica, formas de uso de espaço e construção da paisagem. Este momento marca precisamente o início da identificação de elementos associados às ocupações Guarita na estratigrafia destes sítios. Vê-se, então, o início do fim deste sistema de interações.

\section{IV. Formativo na Amazônia Central?}

O início do Formativo no norte da América do Sul alude ao processo de sedentarização das sociedades pré-coloniais. Tal processo está intrinsecamente ligado ao desenvolvimento da horticultura em diversas partes da região e retrata processos de mudanças sociais qualitativas e quantitativas (Sanoja \& Arenas, 1992, p. 355). Trata-se de um longo e heterogêneo processo de mudanças ambientais, adaptativas, culturais e simbólicas que levaram à domesticação de plantas, ao desenvolvimento da horticultura, da vida sedentária e da produção da cerâmica (Reichel-Dolmatoff, 1997, p. 64).

As evidências de produção de cerâmica ocorrem em diferentes pontos das terras baixas tropicais, a partir de aproximadamente 6.000 anos. Estas podem estar associadas a Sambaquis, como a fase Mina, na foz do rio Amazonas. No baixo Madalena, ao norte da Colômbia, cerâmicas sofisticadas começam a ser fabricadas, como aquelas associadas à Tradição Malambo, representada nos sítios Malambo e Los Mangos (Ângulo, 1981, p. 35). Na Colômbia, a tradição Puerto Hormiga foi datada, através do sítio San Jacinto 1, em até 6.000-5.500 A.P. (Boomert, 2000, p. 100). Essas cerâmicas são em geral temperadas com fibra vegetal ou areia, e as formas mais comuns são vasos com gargalo e tigelas restritivas. A decoração inclui incisões em linhas largas e excisões.

Vale começar aludindo ao uso do conceito adotado por diferentes linhas de pesquisa. Existe, de fato, uma polissemia conceitual em torno do termo Formativo (Rouse, 1992; Willey e Phillips, 1958). O conceito foi inicialmente introduzido no Peru e América central em fins da década de quarenta (Ford, 1965), mas adquire significado e relevância para as terras baixas tropicais apenas a partir da década 
de sessenta, com os trabalhos de Angulo (1963) e de Reichel-Dolmatoff (1965) (Herrera et al., 1992, p. 74).

Falar em sedentarismo, e porque os povos se tornam mais sedentários, é pensar como eles partem de uma territorialidade fluida para uma territorialidade mais restrita. De fato, em casos de floresta tropical, a combinação dos conceitos de territorialidade e sazonalidade diz respeito às estratégias que levam à domesticação de plantas e produção de alimentos (Oyuela-Caycedo, 2005, p. 150). Desde uma perspectiva da ecologia histórica, propõe-se que a conexão entre as origens da produção de alimentos e as transformações refletidas em sedentarismo seja pensada em termos de mudança de padrões de territorialidade e distribuição de recursos. Assim, aumentos e reduções do uso de um padrão de assentamento sedentário ocorreriam porque os povos mudam suas estratégias de mobilidade (idem).

No caso colombiano por ele investigado, isso ocorreria em função de mudanças ambientais. Para o autor, a redução da mobilidade é vista como estratégia para lidar com um território no qual a disponibilidade de recursos flutuava em termos de tempo (as estações) e espaço (as mudanças na paisagem). O estabelecimento de acampamentos com propósitos específicos - 0 de obtenção de recursos - é encontrado em tal tipo de mobilidade. Em San Jacinto 1, as evidências de mobilidade logística e de territorialidade restrita incluem: 1) a pequena variabilidade de atividades identificáveis no sítio; 2) a redundância do tipo de vestígios: as feições (fornos); 3) episódios sazonais de alagamento entre as ocupações; 4) o uso de áreas de captação de recursos (catchment areas) muito localizadas (Oyuela-Caycedo, 2005, p. 146-7).

Estudos como este mostram, num processo de mudanças, a fluidez das fronteiras territoriais das esferas de interações. Trata-se, em última instância, de fluxos populacionais verticais e horizontais, com ciclos de convivência e antagonismos de integração e desintegração de sociedades regionais (Sanoja \& Arenas, 1992, p. 355). O caso de maior interesse para este trabalho, de dispersão cultural, envolve o que pode ser chamado Diáspora Lingüística: a "dispersão e influência de um padrão cultural, com um ancestral comum" (Heckenberger, 2002, p. 116).

Estudiosos tendem a dividir o período Formativo em diferentes etapas, tendo seu início considerado em torno de 4.000 e 2.000 a.C em diferentes 
regiões. No sudeste amazônico, por exemplo, o surgimento das Terras Pretas de Índio tem uma origem diversa da Amazônia central. Ali estão as terras pretas mais antigas, com até 4.000 anos. A elas se associam uma baixa densidade de refugos arqueológicos, representados por líticos da Tradição Massangana; cerâmicas seriam ausentes. A este evento cultural Miller denomina primeira etapa do período Formativo. Os primeiros vestígios de uma agricultura incipiente apareceriam neste período, na forma de antropocória intencional (disseminação de plantas, cultivadas ou daninhas, feita pelo homem) (Miller, 1992, p. 331). A introdução da cerâmica marcaria a segunda etapa do Formativo. Esta teria ocorrido na Amazônia em momentos distintos, com cerâmicas que surgiriam já elaboradas, produtos de difusão. E elas teriam se diversificado pouco ao longo do tempo, mas se diferenciado ao longo do espaço geográfico (idem, p. 335).

Também sobre o surgimento e adoção dessa nova tecnologia os arqueólogos se colocam em posições contrastantes. $O$ debate reflete pressupostos diferentes sobre os mecanismos de mudança cultural e os padrões que estes deixam no registro arqueológico (Meggers, 1997, p. 9). A partir de uma perspectiva "criacionista", a ocorrência aparentemente simultânea de diferentes centros de produção antiga espalhados por uma ampla área indicaria que o início da produção cerâmica teria ocorrido de forma independente em diferentes locais (Hoopes, 1994; Raymond et al., 1994). Já outros autores trabalham com uma hipótese alternativa, de que teria havido um único centro de produção antiga, possivelmente localizado na região do baixo rio Magdalena, no norte da Colômbia, a partir da qual as idéias e técnicas relativas à produção cerâmica teriam se difundido para o resto do continente (Meggers, 1997; Williams, 1997). De acordo com esta segunda alternativa, propõe-se que o Formativo no norte da América do Sul teria representado um processo de mudança sócio-histórica autogerado que adotou elementos culturais derivados principalmente da área andina central, criando formas sincréticas originais, que definem objetivamente os diversos modos de vida regionais a partir do começo da era cristã. (Sanoja \& Arenas, 1992).

Como procurei demonstrar ao longo do trabalho, a perspectiva adotada visa entender processos integrados de intensificação do uso do solo, aumento populacional e conseqüente surgimento das terras pretas de índio, assim como a produção de cerâmicas na Amazônia central. Este viés analítico se aproxima da 
visão de alguns autores que defendem que padrões associados a tal modo de vida tenham chegado à região já consolidados. Na Amazônia central, verifica-se um grande hiato temporal entre as ocupações de caçadores-coletores, portadores de uma sofisticada indústria lítica, e as ocupações de grupos cuja atividade econômica se baseava na caça, pesca, coleta e também na agricultura.

Ao contrário do que alguns pesquisadores pensavam, há evidências de ocupações humanas remotas dispersas ao longo da bacia amazônica e regiões adjacentes no decorrer do Pleistoceno tardio e do início do Holoceno (Roosevelt, 1992, p. 58). Estas evidências consistem em artefatos líticos lascados, encontrados em sub-superfície, em abrigos e também em Sambaquis. A julgar pelas evidências disponíveis, trata-se de grupos humanos de tamanho reduzido, com uma economia baseada na caça, pesca e coleta, que viveram na região há aproximadamente onze mil anos, como é o caso da Caverna da Pedra Pintada, em Monte Alegre, Pará. A opinião de que não havia ocupações tão antigas na Amazônia estava associada, em parte, à suposta ausência de fontes de matéria prima lítica (Costa, 2002). Ocorre, no entanto, que durante muito tempo os pesquisadores se voltaram apenas para a prospecção de sítios cerâmicos, perdendo de vista os vestígios arqueológicos menos evidentes na região (Roosevelt, 1992). Trabalhos recentes desenvolvidos pelo PAC têm mostrado a ocorrência sítios líticos antigos em toda a região dos municípios de Iranduba e Manaus, AM. Esses sítios estão localizados em áreas de areal, e datam de até aproximadamente 8000 A.P. (Costa, 2002; L. Lima, 2003; Neves, 2003).

O presente trabalho se constitui como uma tentativa de construção de uma seqüência cronológica sólida para a região, diminuindo tal lacuna temporal em milhares de anos, pois, até recentemente, não havia evidências de ocupações entre estas datas tão recuadas e os primeiros séculos da era Cristã na Amazônia central. Além disso, alguns dados levantados nesta pesquisa podem, ainda que de maneira incipiente, inserir a Amazônia central nas discussões sobre o período Formativo vigentes em diversas regiões das terras baixas, oferecendo uma possibilidade comparativa.

Em primeiro lugar, os dados analisados mostraram a existência de um conjunto cerâmico mais antigo do que se conhecia na região. As ocupações relacionadas à fase Açutuba, em especial o modo como elas se configuram, podem contribuir para uma discussão sobre o tema. Muito já foi dito sobre esta 
fase cerâmica em páginas anteriores. Cabe salientar que apesar da grande porcentagem de cerâmicas decoradas, oferecendo a elas um possível papel de identificador étnico, encontram-se também todo um conjunto de artefatos que remetem ao processamento de cultivares. Trempes, alguidares e os típicos assadores, em geral com marcas de uso, sugerem que algum tipo de cultivo, ainda que incipiente, fosse praticado por estas populações.

Assim sendo, uma questão que se coloca é: houve de fato um período Formativo na Amazônia central? Quais foram os processos que levaram à ocupação da região? Uma hipótese hoje difundida na antropologia das terras baixas da América do Sul correlaciona a expansão Arawak à domesticação e ao cultivo da mandioca. $E$, como já fora discutido, este modelo associa também a difusão de cerâmicas com traços Barrancóides e aldeias circulares ao processo de expansão e ocupação de diferentes regiões por povos falantes de línguas pertencentes a este tronco lingüístico (vide Brochado, 1984; Heckenberger, 2002; Lathrap, 1970a; Neves, 2006; Schmidt, 1917; entre outros). Poderia ter sido este um amálgama do Formativo da Amazônia central? Os dados hoje disponíveis parecem apontar que sim.

A fase Açutuba, em si, é um elemento de relevância nesta discussão. Suas datações, em torno do anno domini, contextos e tecnologia sugerem uma vinculação dessas ocupações à diáspora Arawak. Deste modo, uma origem não autóctone na Amazônia central destas cerâmicas, tal como sugeri anteriormente, poderia encontrar nesta expansão Arawak uma explicação. Ainda, algumas cerâmicas encontradas no sítio Açutuba apresentam características tecnológicas peculiares que as remetem a algumas interpretações sobre a origem destes conjuntos mais antigos. São caracterizadas por uma pasta de coloração acinzentada, queimadas em ambientes redutores e temperadas com grande quantidade de fibras vegetais (cariapé). A decoração é feita principalmente com incisões em linhas largas, que definem zonas que são posteriormente preenchidas por incisões finas, paralelas ou cruzadas (Fig. 218). Este tipo de decoração é característico de materiais associados à Tradição Hachurada Zonada, a mais antiga tradição cerâmica definida para a Amazônia, com datas entre 500 a.C e 500 d.C (Hilbert 1968, p. 272-273). Também seu tempero em fibras tem uma ampla disseminação entre cerâmicas remotas, do período 
Formativo. A datação radiocarbônica obtida diretamente para o tempero (cariapé) de um fragmento oriundo deste contexto acusou uma antiguidade de 590 a.C., ou seja, uma das datas mais antigas obtidas para contextos cerâmicos da Amazônia central.

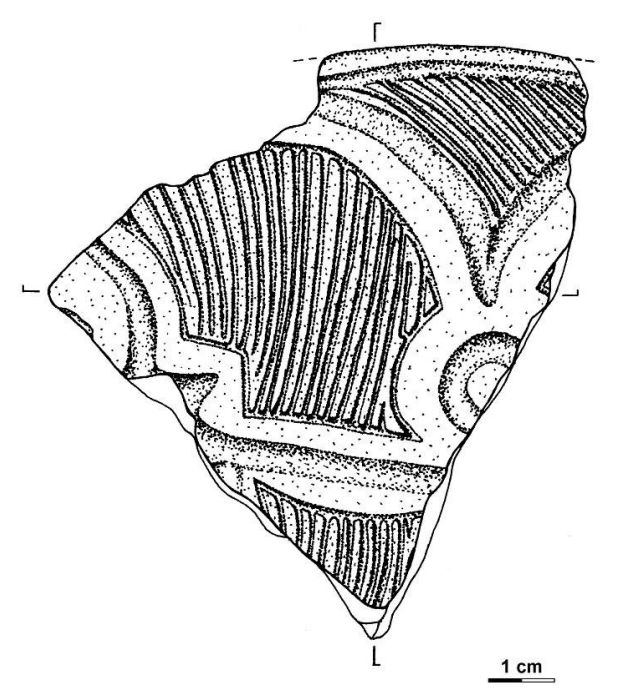

Figura 218 - Fragmento cerâmico associado ao contexto anteriormente descrito, do sítio Açutuba (desenho: Marcos Brito).

Há quase cinqüenta anos, evidências de cerâmicas antigas, encontradas na Amazônia brasileira, foram agrupadas por Meggers na tradição Hachurada Zonada, por ela datada entre 500 a.C. e 500 d. C. (1961, 1983). Algumas das fases cerâmicas identificadas por estes autores são: Jauarí, proveniente de um depósito de conchas próximo de Alenquer (PA), Ananatuba, na llha de Marajó, que tem data terminal de 900 a.C., Yasuní, no Equador oriental, e Tutishcainyo, no Peru Oriental (Hilbert, 1968, p. 272-273). Estes autores pleiteiam uma origem dos materiais associados à Tradição Hachurada Zonada no noroeste da Colômbia, nas cerâmicas de Puerto Hormiga, datadas de 3.090 - 2.552 a. C. (Meggers \& Evans, 1968, p. 88-92).

Na seqüência cronológica da Amazônia central pouco se conhece sobre ocupações ceramistas tão remotas, associadas à Tradição Hachurada Zonada. Além da fase Jauari, os conjuntos mais antigos por nós identificados datam em torno do anno domini, mas são filiados culturalmente à Tradição Borda Incisa. A interpretação que pleiteio é a de que tais conjuntos surgiram na região já formados, e trazendo consigo um arsenal simbólico estruturado. Partindo desta perspectiva, determinados modos de vida teriam atingido a Amazônia central 
dentro de um processo de expansão advinda de outros locais, o que explicaria o hiato cronológico desde a ocupação da região por grupos caçadores-coletores, que perdura até o Holoceno médio, e as primeiras ocupações ceramistas, que só vão acontecer milhares de anos mais tarde.

\section{V. Amazônia central: cronologias e implicações}

Vista como exógena à área pesquisada e como parte de um processo de expansão ligado às populações Arawak, a ocupação da Amazônia central é aqui entendida como parte de um processo que tem ampla dispersão geográfica e temporal que, uma vez instalado na região, terá reverberações sobre a configuração cultural local. Essas mudanças de longa duração dentro de um sistema tecnológico e sócio-econômico resultam no que aqui chamo fases Açutuba, Manacapuru e Paredão, em escala local. Assim, apesar de compartilharem os elementos comuns à Tradição Borda Incisa, o acúmulo de mudanças históricas acaba por resultar em grupos culturais diferenciados, mas compartilhando de uma mesma estrutura. E o entendimento de sua cultura material deve ser pensado como tal. Ressalto novamente que não há aqui nenhuma vinculação entre cultura material e grupo étnico. Conforme apontado ao longo do trabalho, Açutuba, Manacapuru e Paredão apresentam elementos tecnológicos e contextuais que exigem uma abordagem como fases distintas. $\mathrm{E}$ se fases cerâmicas são vistas como entidades independentes, elas podem ser relacionadas de maneira descritiva, distribucional e genética (Rouse, 1955). A correlação argumentada neste trabalho é eminentemente genética, na qual uma daria origem à outra, localmente, e sob influências regionais.

Um desenvolvimento local de uma para outra implicaria sem dúvida numa mudança in loco de modos de vida. Mudanças estas que dariam origem às terras pretas, e acompanhadas de um maior dinamismo nos próprios padrões tecnológicos da cerâmica. Compreender este processo significa ser capaz de pensar mais profundamente na relação entre aqueles por detrás das fases arqueológicas que, na Amazônia central, apresentam-se como um complexo mosaico cultural. Quanto mais se avança no conhecimento sobre este registro material, mais se nota uma profunda fluidez entre as fases ali representadas, onde as ausências de intervalos entre elas e as semelhanças vão se 
multiplicando a cada contexto analisado, ainda que numa escala temporal de mil anos.

Quando se fala em "cronologia" - e este é um trabalho essencialmente cronológico - fala-se em algo seqüencial. Com o uso das fases, logra-se uma seqüência linear de diferentes conjuntos, como algo normativo. Pretendi, com este trabalho, propor uma revisão não apenas dos conjuntos e suas significações históricas, mas também do modo como pensamos e utilizamos tais ferramentas e a colocamos numa "ordem" cronológica.

A cronologia amazônica pode oferecer um bom caminho para pensarmos tais questões. Numa perspectiva normativa de fases cerâmicas, torna-se difícil entender, por exemplo, a co-ocorrência temporal de conjuntos cronologicamente distintos. Mas pelo contrário, o que se observa no registro arqueológico amazônico é a concomitância de todas as fases arqueológicas em uma seqüência cronológica local. No caso da Amazônia central, Açutuba, Manacapuru, Paredão e Guarita co-ocorrem na maioria dos sítios conhecidos.

A esta interpolação temporal somam-se os limites materiais observáveis entre uma e outra fase, que são extremamente fluidos. Como pretendi demonstrar com as análises cerâmicas e discussões dos capítulos anteriores, a fluidez de limites é inerente aos conjuntos artefatuais amazônicos, uma vez que estes são intimamente conectados, histórica e culturalmente. As continuidades culturais e tecnológicas devem assim ser interpretadas junto às mudanças, que por sua vez definem os conjuntos com os quais estamos trabalhando. Sendo assim, seus limites espaço-temporais são necessariamente relacionados.

Já era hora da teoria arqueológica voltar-se para a discussão destes dois conceitos a ela tão caros, como são os de Fase e Tradição. Interpretados enquanto materialidade de relações sociais, com "espaço-temporalidades" definidas, as diferentes escalas inerentes a estes conceitos nos permitem perceber esferas da história e cultura pretéritas, intangíveis aos olhos daqueles que outrora as classificavam como um fim ou daqueles que não classificam a cultura material, sabidamente o objeto de análise do arqueólogo.

A hipótese testada na presente pesquisa é a de que as fases cerâmicas relacionadas à Tradição Borda Incisa representam um desenvolvimento cultural, sócio-político e econômico de sociedades vivendo dentro de um mesmo sistema macro-regional, intimamente conectado. A este sistema, que aqui denomino 
esfera de interações, estão ligados elementos culturais, tais como a padronização de um sistema de comunicação, expresso através da cultura material, e as formas de usar e organizar o espaço. Pelo fato de poderem ser observáveis arqueologicamente na paisagem, estes elementos possibilitam a identificação da territorialidade de tal esfera relacionada à Tradição Borda Incisa, bem como a determinação de seu espaço e tempo.

O instrumental interpretativo é, portanto, de que tais relações possam ser entendidas a partir da presença de sistemas regionais que, embora multiétnicos, eram marcados por intensas redes de troca e comunicação. Tais sistemas marcariam os diferentes territórios do passado. Desta forma, Pocó, Açutuba, Manacapuru, Itacoatiara e Paredão são partes e representações de mudanças dentro deste sistema que não se limita à Amazônia, tendo uma área de abrangência bastante ampla, abarcando grande parte das terras baixas da América do Sul setentrional, com as já mencionadas séries Barrancóide e Saladóide.

Tal continuidade somente teria sido interrompida tardiamente, com o surgimento das cerâmicas policromas, que marcariam, a meu ver, uma forte ruptura cultural. Assim como o continuum cultural relacionado a essas cerâmicas Borda Incisa pode ser arqueologicamente delimitado em tempo e espaço, sua ruptura também o poderá. 


\section{REFERÊNCIAS BIBLIOGRÁFICAS}

ABREU, Maria E. Estudo dos padrões do uso do espaço no sitio Osvaldo (Am-Ir09). Relatório de Iniciação Cientifica encaminhado à FAPESP, (processo $n$. 00/00566-4) - Museu de Arqueologia e Etnologia. São Paulo: Universidade de São Paulo, 2000.

ADAMS, Cristina; MURRIETA, Rui; NEVES, Walter. (Orgs.). Sociedades Caboclas Amazônicas: modernidade e invisibilidade. São Paulo: Annablume, 2006.

ALMEIDA, Fernando. O Complexo Tupi na Amazônia Oriental. Dissertação (Mestrado em Arqueologia) - Museu de Arqueologia e Etnologia. São Paulo: Universidade de São Paulo, 2008.

ANGULO VALDÉS, Carlos. La tradición malambo: un complejo temprano en el Noroeste de Suramérica. Bogotá: Banco de la República, 1981.

ARNOLD, Dean. Ceramic Theory and Cultural Process. Cambridge/New York: Cambridge University, 1985.

ARROYO-KALIN, Manoel. Towards a Historical Ecology of Pre-Columbian Central Amazonia. In: $71^{\text {st }}$ Society for American Archaeology Annual Meeting. San Juan: Puerto Rico, 2006.

ARSUAGA, Juan Luis. O Colar do Neandertal: em busca dos primeiros pensadores. São Paulo: Globo, 2005.

BALÉE, William. Biodiversidade e os Índios Amazônicos. In: CUNHA, Manuela. (Ed.). Amazônia: Etnologia e História Indígena. São Paulo: NHII-USP-FAPESP. 1993. p. 385-393.

. Footprints of the Forest. New York: Columbia University, 1994.

BALÉE, William; ERICKSON, Clark. Time and Complexity in Historical Ecology: Studies in Neotropical Lowlands. New York: Columbia University, 2006.

BANDEIRA, Arkley. O Sambaqui do Bacanga na ilha de São Luís - Maranhão: um estudo sobre a ocorrência cerâmica no registro arqueológico. Dissertação (Mestrado em Arqueologia) - Museu de Arqueologia. São Paulo: Universidade de São Paulo, 2008.

BARRETO, Cristina. A Construção de um Passado pré-colonial: Uma Breve História da Arqueologia no Brasil. In: Revista da USP, n. 44, p. 32-51, 2000.

BARSE, William. Ronquin, AMS Dates, and the Middle Orinoco Sequence. Interciencia, v. 25, n. 7, p. 337-341, 2000. 
BELLWOOD, Peter. Early agriculturalist population diasporas? Farming, languages, and genes. Annual Review of Anthropology, v. 30, p. 181-207, 2001.

Blackwell, 2005.

First Farmers: The Origins of Agricultural Societies. Malden:

BELTRÃO, Otto. Realidade da Amazônia Brasileira. Fundação Biblioteca Nacional: Ministério da cultura. Obra não publicada, s/d.

BIGARELLA, João, et al. Estrutura e Origem das Paisagens Tropicais e Subtropicais. Florianópolis: UFSC, 1996.

BINFORD, Lewis. Organization and Formation Processes: Looking at curated Technologies. In: 1983, p. 269-286. Working at Archaeology. New York: Academic,

BLEED, Peter. Artifice Constrained: What Determines Technological Choice? In: Schiffer, Michael. (Ed.). Anthropological Perspectives on Technology. Albuquerque: University of New Mexico, 2001.

BOAS, Franz. Race, Language and Culture. New York: The Macmillan Company, 1940.

. Primitive Art. New York: Dover Publications, 1955 (1927).

BOOMERT, Arie. Trinidad, Tobago and the Lower Orinoco Integration Sphere: an archaeological/ethnohistorical study. Alkmaar: Cairi Publications, 2000.

BORGES, Wagner.; COELHO, Danilo. Levantamento e estudo dos sítios arqueológicos da margem do Lago Grande, AM e análise dos vestígios cerâmicos do sítio arqueológico Açutuba, Iranduba/AM. Relatório de Análise Estatística sobre o Projeto - Instituto de Matemática e Estatística. São Paulo: Universidade de São Paulo, 2003. (RAE-CEA-03P12)

BROCHADO, José. A expansão dos tupi e da cerâmica da tradição policrômica amazônica. Dédalo, Revista do Museu de Arqueologia e Etnologia, v. 9, n. 17-18, p. 41-47, 1989.

Um Modelo Ecológico da Difusão da Cerâmica e da Agricultura no Leste da América do Sul. In: Anais do $1{ }^{\circ}$ Simpósio de Pré-História do Nordeste. Revista Clio, v. 4, p. 85-88, 1991.

BROCHADO, José; LATHRAP, Donald. Chronologies in the New World: Amazonia. Manuscrito não publicado, 1982.

CALDARELLI, Solange. Resgate Arqueológico da Área de Influência Direta do Poliduto Urucu-Coari-AM. Scientia Consultoria, relatório entregue ao IPHAN, não publicado. 1999. 
CAPOBIANCO, João, et al. (Org.). Biodiversidade na Amazônia Brasileira. São Paulo: Estação Liberdade/Instituto Socioambiental, 2001.

CARNEIRO, Robert. The Cultivation of Manioc among the Kuikuru of the Upper Xingú. In: HAMES, Raymond; VICKERS, William. (Eds.). Adaptative Responses of Native Amazonians. New York: Academic, 1983.

CASTRO, Márcio. Padrões de Assentamento da Fase Paredão na Amazônia Central. Projeto de Mestrado, Programa de Pós-Graduação do Museu de Arqueologia e Etnologia, 2006.

CHIANN, Chang; MAGALHÃES, Marcos; CARVALHO, João; ANDERSSON, Vanessa. Cronologia da Amazônia Central e Implicações para os Trópicos Úmidos Sul-americanos. Relatório de Análise Estatística sobre o Projeto Instituto de Matemática e Estatística. São Paulo: Universidade de São Paulo, 2007. (RAE-CEA-07P09).

CHILDE, Gordon. What Happened in History. New York: Penguin Books, Inc. 1946

CHILTON, Elizabeth. The Cultural Origins of Technical Choice: Unraveling Algonquian and Iroquian Ceramic Traditions in the Northeast. In: Stark, Miriam. (Ed.). The Archaeology of Social Boundaries. Washington, D.C. Smithsonian Institution. 1998.

CHMYZ, Igor. Terminologia Arqueológica Brasileira para a Cerâmica. Manuais de Arqueologia, n. 1. Curitiba: Centro de Ensino e Pesquisas Arqueológicas, Universidade Federal do Paraná, 1966.

COSGROVE, Denis. Social Formation and Symbolic Landscape. New Jersey: Barns and Noble Books, 1985.

COSTA, Fernando. Estudo das Indústrias Líticas da Área de Confluência dos Rios Negro e Solimões. Dissertação (Mestrado em Arqueologia) - Museu de Arqueologia e Etnologia. São Paulo: Universidade de São Paulo, 2003.

COSTA, Fernando; LIMA, Helena. Levantamento Arqueológico do Município de Manaus. Relatório encaminhado ao Ministério Público Federal e IPHAN, $1^{\underline{a}}$ Superintendência Regional - Manaus, 2006.

CRUZ, Aline \& CHRISTINO, Beatriz. O Contato Lingüístico para Martius (17941868), Steinen (1855-1929) e Ehrenreich (1855-1914). PAPIA 15, 2005, P. 102110

DANIEL, Pe. João. Tesouro Descoberto no Máximo Rio Amazonas 1722-1776. 2 vols. Rio de Janeiro/Belém: Contraponto/Prefeitura Municipal de Belém, PA, 2004.

DARVILL, T. The Historic Environment, Historic Landscapes, and Space-TimeAction Models in Landscape Archaeology. In: Peter Ucko \& Robert Layton (Ed.). 
The Archaeology and Anthropology of Landscape: Shaping your Landscape. New York, Routledge. 1999.

DeBOER, Warren \& LATHRAP, Donald. The Making and Breaking of ShipiboConibo Ceramics. In: Ethnoarchaeology: implications of ethnography for archaeology. Kramer, Carol (Ed.), New York: Columbia University Press. p. 102138, 1979.

DeBOER, Warren; KINTIGH, Keith; ROSTOKER, Arthur. Ceramic seriation and site reoccupation in Lowland South America. Latin American Antiquity, v. 7, n.3, p. 263-278, 1996.

DeBOER, Warren. Traces Behind the Esmeraldas Shore, Prehistory of the Santiago-Cayapas Region, Ecuador. Tuscaloosa: University of Alabama, 1996.

DENEVAN, William. A Bluff Model of Riverine Settlement in Prehistoric Amazonia. Annals of the Association of American Geographers, v. 86, n. 4, p. 654-681, 1996.

Comments on Prehistoric Agriculture in Amazonia. Culture \& Agriculture, v. 20, n. 2-3, p. 54-59, 1998.

DUNNELL, Robert C. Methodological Issues in Americanist Artifact Classification. In: Advances in Archaeological Method and Theory. Vol. 9, p. 149-207. Orlando: Academic Press, 1986.

DIAS, Adriana. Sistemas de assentamento e estilo tecnológico: uma proposta interpretativa para a ocupação pré-colonial do Alto Vale do Rio dos Sinos, Rio Grande do Sul. Tese (Doutorado em Arqueologia) - Faculdade de Filosofia, Letras e Ciências Humanas. São Paulo: Universidade de São Paulo, 2003.

Novas perguntas para um velho problema: escolhas tecnológicas. In: Boletim do Museu Paraense Emílio Goeldi. Ciências Humanas, Belém, v.2, n.1, p.59-76, 2007.

DIAS, Adriana Schmidt; SILVA, Fabíola Andrea. Sistema tecnológico e estilo: as implicações desta inter-relação no estudo das indústrias líticas do sul do Brasil. Revista do Museu de Arqueologia e Revista do Museu de Arqueologia e Revista do Museu de Arqueologia e Revista do Museu de Arqueologia e Revista do Museu de Arqueologia e Etnologia, n. 11, p. 95-108, 2001.

DONATTI, Patricia. Levantamento dos Sítios Arqueológicos na Margem Norte do Lago Grande, na Confluência dos Rios Negro e Solimões. $2^{\circ}$ Relatório de atividades apresentado à FAPESP - Museu de Arqueologia e Etnologia. São Paulo: Universidade de São Paulo, 2002.

A ocupação pré-colonial da área do lago Grande, Iranduba, AM. Dissertação (Mestrado em Arqueologia) - Museu de Arqueologia e Etnologia. São Paulo: Universidade de São Paulo, 2003. 
ESCOLAR, Marcelo. Crítica do Discurso Geográfico. São Paulo: Hucitec, 1996.

EVANS, Clifford; MEGGERS, Betty. Formative period cultures in the Guayas basin, coastal Ecuador. American Antiquity, v. 22, n.3, p. 235-247, 1957.

Archaeological Investigations on the Rio Napo, Eastern Ecuador. Smithsonian Contributions to Anthropology, v. 6. Washington, D.C.: Smithsonian Institution, 1968.

FARIA, Dr. João. A Cerâmica da Tribo Uboaí dos Rios Trombetas e Jamundá (contribuição para o estudo da arqueologia pré-histórica do Baixo Amazonas). Publicação da antiga Comissão de Linhas Telegráficas Estratégicas de MatoGrosso ao Amazonas - Comissão Rondon. Rio de Janeiro: Imprensa Nacional, 1946.

FARIAS, Sarah. Análise dos Vestígios Faunísticos do Sítio Hatahara. Iniciação Científica. Relatório encaminhado à FAPESP, 2006.

FAUSTO, Carlos. Entre o Passado e o Presente: mil anos de história indígena no alto Xingu. Revista de Estudos e Pesquisas, FUNAI, Brasília, v.2, n.2, p. 9-51, dez. 2005

FORD, James. On the Concept of Types: The Type concept Revisited. American Anthropologist, New Series, v. 56, n. 1, p. 42-57, 1954.

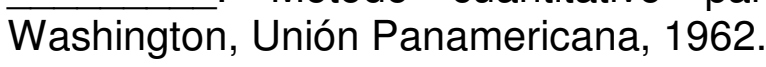

FRANZINELLI, Elena; IGREJA, Hailton. Modern sedimentation in the Lower Negro River, Amazonas State, Brazil. Geomorphology, v. 44, n. 3-4, p. 259-271, 2002.

GALVÃO, Eduardo. Áreas culturais indígenas do Brasil; 1900 - 1959. In: Boletim do Museu Paraense Emílio Goeldi, Antropologia, n. 8, p. 1-41, 1960.

. Encontros de sociedades. Rio de Janeiro: Paz e Terra, 1979.

GASSON, Rafael. Orinoquia: The Archaeology of the Orinoco River Basin. In: Journal of World Prehistory, v. 16, n. 3, p. 237-311, 2002.

Steps to an environmental history of the Western Llanos of Venezuela: a world-system perspective. Paper apresentado na Conferência System History and Global Enviromental Change, Lund University, 2003.

GIBERTONI, Carla. Ações educacionais relativas à Arqueologia Preventiva: uma proposta para a Amazônia. Projeto (Doutorado em Arqueologia) - Museu de Arqueologia e Etnologia. São Paulo: Universidade de São Paulo, 2004.

GLASER, Bruno; WOODS, William. (Eds.). Amazonian dark earths: Explorations in space and time. Berlin: Springer Verlag, 2004. 
GOMES, Denise. Reescavando o Passado: um estudo do vasilhame cerâmico da coleção tapajônica do MAE-USP. Dissertação (Mestrado em Arqueologia) Faculdade de Filosofia, Letras e Ciências Humanas. São Paulo: Universidade de São Paulo, 1999.

McEWAN,

Santarém: Symbolism and Power in the Tropical Forest. In: Colin; BARRETO, Cristina; NEVES, Eduardo. (Eds.). Unknown Amazon: Culture in

Nature in Ancient Brazil. London: British Museum, p. 134-155, 2001.

Tapajônica

Cerâmica Arqueológica da Amazônia: Vasilhas da Coleção

do MAE-USP. São Paulo: EDUSP/FAPESP/Imprensa oficial do Estado, 2002.

Análise Arqueológia dos Padrões de Organização Comunitária no Baixo Tapajós. Tese (Doutorado em Arqueologia) - Museu de Arqueologia. São Paulo: Universidade de São Paulo, 2005.

GOULDING, Michael; CARVALHO, Mirian; FERREIRA, Efren. Rio Negro: Rich Life in Poor Water. The Hague: SPB Academic Publishing, 1988.

GUAPINDAIA, Vera L. Fontes Históricas e Arqueológicas sobre os Tapajó de Santarém - A coleção Frederico Barata do Museu Parense Emílio Goeldi. Dissertação (Mestrado em História) - Centro de Filosofia e Ciências Humanas. Recife: Universidade Federal de Pernambuco, 2001.

Além da margem do rio: as ocupações Konduri e Pocó na região de Porto Trombetas, PA. Tese (Doutorado em Arqueologia) - Museu de Arqueologia e Etnologia. São Paulo: Universidade de São Paulo, 2008.

HAESBAERT, Rogério. O Mito da Desterritorialização: Do Fim dos Territórios à Multiterritorialidade. Rio de Janeiro: Bertrand Brasil, 2004.

HECKENBERGER, Michael. War and peace in the shadow of empire: Sociopolitical change in the upper Xingu of southeastern Amazonia A.D. 14002000. Tese (Doutorado em Arqueologia) - Department of Anthropology, University of Pittsburgh. 1996.

Estrutura, história e transformação: a cultura xinguana da long durée, 1000-2000d.C. In: Heckenberger, Michael; Franchetto, Bruna. (Orgs.). Os povos do alto xingu. Rio de Janeiro: UFRJ, 2001, p. 21-62.

Rethinking the Arawakan Diaspora: Hierarchy, Regionality, and the $\overline{\text { Amazonian }}$ Formative. In: HILL, Jonathan; SANTOS-GRANERO, Fernando. (Eds.). Comparative Arawakan Histories: Rethinking Language Family and Culture Area In Amazonia. Urbana/Chicago: University of Illinois, 2002. p. 99-122. 
. The Enigma of the Great Cities: Body and State in Amazônia. In: Tipití v. 1, n. 1, p. 27-58, SALSA, 2003.

. The Ecology of Power: Culture, Place and Personhood in the Southern Amazon, AD 1000-2000. New York: Routledge, 2005.

HECKENBERGER, M., I, Kuikuro, A., Kuikuru, U.T., Russell, J.C., Schimdt, M., Fausto, C. Franchetto . Amazonia 1492: Pristine Forest or Cultural Parkland? Science, v. 301, n. 5640, p. $1710-1714,2003$.

HECKENBERGER, Michael; NEVES, Eduardo; PETERSEN, James. De onde surgem os modelos? Considerações sobre a origem e expansão dos Tupi. Revista de Antropologia, v. 41, n. 1, p. 69-96, 1998.

. Village permanence in Amazonia: two archaeological examples from Brazil. Latin American Antiquity, v. 10, n. 4, p. 353-376, 1999.

HEGMON, Michelle. Archaeological Research on Style. Annual Review of Anthropology, v. 21, p. 517-36, 1992.

HERRERA, Leonor; BRAY, Warwick; McEWAN, Colin. Datos Sobre la Arqueología de Araracuara. Revista Colombiana de Antropología, v. 23, p. 185251, 1980-1981.

HILBERT, Peter. A Cerâmica Arqueológica da Região de Oriximiná. Belém: Instituto de Antropologia e Etnologia do Pará. Publicação n. 9, 1955.

Archäologische Untersuchungen am Mittlern Amazonas. Berlin: Dietrich Reimer Verlag, 1968.

HILBERT, Peter; HILBERT, Klaus. Resultados Preliminares da Pesquisa Arqueológica nos Rios Nhamundá e Trombetas, Baixo Amazonas. Boletim do Museu Paraense Emilio Goeldi, Antropologia, v. 75, p. 1-11, 1980.

HOOPES, John. Ford revisited: a critical review of the chronology and relationships of the earliest ceramic complexes in the New World, 6000-1500 B.C. Journal of World Prehistory, v. 8, n. 1, p. 1-49, 1994.

HOWARD, George; OSGOOD, Cornelius. An Archaeological Survey of Venezuela. In: Yale University Publications in Anthropology, n. 27, 1943.

INGOLD, Tim. The Perception of the Environment: Essays on Livelihood, Dwelling and Skill. New York, Routledge. 2000.

JOLY, Aylthon. Botânica: Introdução à Taxonomia Vegetal. 12 ed. São Paulo: Companhia Editora Nacional, 1998.

JORDAN, Carl. Soils of the Amazon Rainforest. In: PRANCE, Ghillean; LOVEJOY, Thomas. (Eds.). Amazonia. Oxford: Pergamon, 1985. p. 83-94. 
KOCH-GRÜNBERG, Theodor. Dois anos entre os indígenas. Viagens no noroeste do Brasil (1903-1905). Manaus: Edua, 2005.

KROEBER, Alfred. A Natureza da Cultura. Lisboa: Edições 70, 1952 [1948].

LATHRAP, Donald. The Upper Amazon. London: Thames and Hudson, 1970a.

. Review of Archäologische Untersuchungen am Mittlern Amazonas, by Peter Hilbert. American Antiquity, v. 35, n. 4, p. 499-501, 1970b.

. Our Father the Cayman, Our Mother the Gourd: Spinden Revisited or a Unitary Model for the Emergence of Agriculture in the New World. In: REED, Charles. (Ed.). Origins of Agriculture. The Hague: Mouton, 1977. p. 713-751.

LATHRAP, Donald; OLIVER, José: El complejo policromo más antiguo de America en la confluencia del Apure y el Orinoco (Venezuela). Interciencia, v. 12, n. 6, p. 274-289, 1987.

LATRUBESSE, Edgardo; FRANZINELLI, Elena. The Holocene alluvial plain of the middle Amazon River, Brazil. Geomorphology, v. 44 n. 3-4, p. 241-257, 2002.

LEHMANN, Johannes; KERN, Dirse; GLASER, Bruno; WOODS, William. (Eds.). Amazonian dark earths: Origin, properties, management. Dordrecht: Kluwer Academic Publishers, 2003.

LEMONNIER, Pierre. The Study of Material Culture Today: Towards an Anthropology of Technical Systems. Journal of Anthropological Archaeology, v. 5, p. 147-186, 1986.

Elements for an Anthropology of Technology. University of Michigan, Museum of Anthropology, Anthropological Papers, n. 88. Ann Arbor: Michigan, 1992.

LIMA, Helena. Análises dos Vestígios Cerâmicos do Sítio Arqueológico Açutuba, Iranduba. Relatório de Iniciação Científica encaminhado à FAPESP - Museu de Arqueologia e Etnologia. São Paulo: Universidade de São Paulo, 2003.

Cronologia da Amazônia Central: o significado da variabilidade da fase Manacapuru. Relatório Científico I, MS1, encaminhado à FAPESP - Museu de Arqueologia e Etnologia. São Paulo: Universidade de São Paulo, 2004.

LIMA, Helena; MACHADO, Juliana. Las Tradiciones Alfarreras de la Amazonia Central. In: Revista Unay Runa, v. 7. Lima: Instituto Cultural Runa, 2005.

LIMA, Helena; NEVES, Eduardo; PETERSEN, James. A fase Açutuba: um novo complexo cerâmico na Amazônia central. In: Arqueologia Sul-Americana v. 2, n. 1 , 2006. 
LIMA, Helena; SILVA, Carlos. Levantamento Arqueológico do Médio Amazonas. Relatório encaminhado ao IPHAN, 1르 Superintendência Regional - Manaus, 2005.

LIMA, Luis. Levantamento Arqueológico das Áreas de Interflúvio na Área de Confluência dos Rios Negro e Solimões. Dissertação (Mestrado em Arqueologia) - Museu de Arqueologia e Etnologia. São Paulo: Universidade de São Paulo, 2003.

LONEY, Helen. Society and Technological Control: a Critical Review of Models of Technological Change in Ceramic Studies. American Antiquity, v. 65, n. 4, p. 646668, 2000.

LOWIE, Robert. The tropical forests: an introduction. In: STEWARD, Julian. (Ed.) Handbook of South American Indians. The Tropical Forest Tribes. v. 3. Bulletin n. 143, Bureau of American ethnology. Washington, D.C.: Smithsonian Institution, 1948.

MAUSS, Marcel. As Técnicas do Corpo. In:Sociologia e Antropologia. São Paulo: Cosac Naify, 2003.

MACHADO, Juliana. A formação de montículos artificiais: um estudo de caso no sítio Hatahara, Amazonas. Dissertação (Mestrado em Arqueologia) - Museu de Arqueologia e Etnologia. São Paulo: Universidade de São Paulo, 2005.

. O Potencial interpretativo das análises tecnológicas: um exemplo amazônico. In: Revista do Museu de Arqueologia e Etnologia, São Paulo, 15-16: 87-111, 2005-2006.

MAGALHÃES, Marcos. A Physis da Origem: o sentido da história na Amazônia. Belém: Museu Paraense Emílio Goeldi, 2005.

MEGGERS, Betty. The Archaeology of the Amazon Basin. In: STEWARD, Julian (Ed.) Handbook of South American Indians. The Tropical Forest Tribes. v. 3. Bulletin n. 143, Bureau of American ethnology. Washington, D.C.: Smithsonian Institution, 1948. p. 146-166.

. Environmental Limitations on the Development of Culture. American Anthropologist, v. 56, p. 801-824, 1954.

Archaeological sequence on the Rio Napo, Ecuador and its implications. In: Simpósio sobre a Biota Amazônica, v. 2, Antropologia, 1966. Rio de Janeiro: Conselho Nacional de Pesquisas, 1967.

Amazonia: Man and Culture in a Counterfeit Paradise. Chicago: Aldine/Atherton, 1971.

Reconstrução do comportamento locacional pré-histórico na Amazônia. Boletim do Museu Paraense Emílio Goeldi, Série Antropologia,v. 6, n. 2, p. 183-203, 1990. 
. La cerámica temprana en América del Sur: ¿invención independiente o difusión? Revista de Arqueología Americana, v. 13, p. 7-40, 1997.

MEGGERS, Betty; DANON, Jacques. Identification and Implications of A Hiatus in the Archaeological Sequence on Marajó Island, Brazil. Journal of the Washington Academy of Sciences, v. 78, n. 3, p. 245-253, 1988.

MEGGERS, Betty; EVANS, Clifford. Archaeological Investigations at the Mouth of the Amazon. Bureau of American Ethnology, Bulletin $n^{\circ} 167$, Washington, D.C., 1957.

. An experimental Formulation of Horizon Styles in the Tropical Forest Area of South America. In: LOTHROP, Samuel. (Ed.). Essays in Precolumbian Art and Archaeology. Cambridge: Harvard University, 1961.

A Utilização de seqüências cerâmicas seriadas para inferir comportamento social. In: Boletim Série Ensaios, $\mathrm{n}^{\circ} 3$, Instituto de Arqueologia Brasileira, 1966.

Como Interpretar a Linguagem da Cerâmica: Manual para Arqueólogos. Washington, D.C.: Smithsonian Institution, 1970.

. Lowland South America and the Antilles. In: JENNINGS, Jesse. (Ed.). Ancient South Americans. San Francisco: W. H. Freeman, 1983.

MEGGERS et al. Implications of Archaeological Distributions in Amazonia. In: VANZOLINI, Paulo; HEYER, Ronald. (Eds.). Proceedings of a Workshop on Neotropical Distribution Patterns. Rio de Janeiro: Academia Brasileira de Ciências, 1988.

MILLER, George. A Limitação Ambiental como Barreira à Transposição do Período Formativo no Brasil. In: Ledergerber-Crespo, Paulina. (Ed.). Formativo Sudamericano: Una Revaluación: Ponencias Presentadas En El Simposio Internacional De Arqueologia Sudamericana, Cuenca, Ecuador, 13-17 De Enero De 1992. Homenaje a Alberto Rex Gonzalez Y Betty J. Meggers. Cuenca: Abya Yala, 1992.

MORA, Santiago; HERRERA, Luisa; CAVALIER, Inés; RODRíGUEZ, Camilo. Cultivars, Anthropic Soils and Stability: a preliminary report of archaeological research in Araracuara, Colombian Amazon. University of Pittsburgh Latin American Archaeology Reports, $n^{\circ}$ 2. Pittsburgh: 1991.

MORAES, Antonio. "Historicidade, consciência e construção do espaço: notas para um debate". In: SANTOS, Milton; SOUZA, Maria. A Construção do Espaço. São Paulo: Nobel, 1986.

"Na Trilha do Purgatório: política e modernidade na geografia contemporânea". In: SILVA, José; LIMA, Luiz; DANTAS, Eustógio. (Orgs.). Panorama da Geografia Brasileira II. São Paulo: Annablume, 2006. 
MORAES, Claide de P. Levantamento arqueológico das áreas de entorno do Lago do Limão, município de Iranduba - AM. Dissertação (Mestrado em Arqueologia) Museu de Arqueologia e Etnologia. São Paulo: Universidade de São Paulo, 2007.

MORAES, Camila A. Arqueologia Tupi no nordeste de São Paulo: um estudo de variabilidade artefatual. Dissertação (Mestrado em Arqueologia) - Museu de Arqueologia e Etnologia. São Paulo: Universidade de São Paulo, 2007.

MORAN, Emílio. Adaptabilidade Humana: Uma Introdução à Antropologia Ecológica. São Paulo: EDUSP, 1994. (Coleção Ponta).

MOREIRA, Maurício. Fundamentos do Sensoriamento Remoto e Metodologias de Aplicação. São José dos Campos: Instituto Nacional de Pesquisas Espaciais (INPE), 2001.

NEVES, Eduardo. Village Fissioning in Amazonia: a Critique of Monocausal Determinism. In: Revista do Museu de Arqueologia e Etnologia da Universidade de São Paulo, v. 5, p. 195-209, 1995.

. Paths in Dark Waters: Archaeology as Indigenous History in the Upper Rio Negro Basin, Northwest Amazon. Tese (Doutorado em Arqueologia) Department of Anthropology, Indiana University, 1998.

Levantamento Arqueológico da Área de Confluência dos Rios Negro e Solimões, Estado do Amazonas. Relatório de Atividades apresentado à FAPESP -

Museu de Arqueologia e Etnologia. São Paulo: Universidade de São Paulo, junho 1999 - ago 2000.

. Levantamento arqueológico da área de confluência dos rios Negro e Solimões, Estado do Amazonas: Continuidade das escavações, análise da composição química e montagem de um sistema de informações geográficas. Relatório de Atividades apresentado à FAPESP - Museu de Arqueologia e Etnologia. São Paulo: Universidade de São Paulo, 2003.

- Cronologias Regionais, Hiatos e Continuidades na História PréColonial da Amazônia. Projeto Temático - FAPESP. Museu de Arqueologia e Etnologia. São Paulo: Universidade de São Paulo, 2005.

Tradiçao Oral e Arqueologia na História Indígena do Alto Rio Negro. In: FORLINE, Louis; MURRIETA, Rui; VIEIRA, Ima. (Orgs.). Amazônia, Além dos 500 Anos. Belém: Museu Paraense Emílio Goeldi, 2006. p. 1-37.

Warfare in Pre-Colonial Amazonia: When Carneiro Meets Clastres. In: Axel Nilsen; William Walker. (Org.). Warfare in Cultural Context: Practice Theory and the Archaeology of Violence. Tucson: University of Arizona Press, 2008 , v. , p. -

Cronologias Regionais, Hiatos e Continuidades na História PréColonial da Amazônia. Relatório de Atividades Referente ao Projeto Temático - 
FAPESP. Museu de Arqueologia e Etnologia. São Paulo: Universidade de São Paulo, 2008b.

NEVES, Eduardo; BARRETO, Cristina; McEWAN, Colin. Introduction. In: McEWAN,

Colin; BARRETO, Cristina; NEVES, Eduardo. (Eds.). Unknown Amazon: Culture in Nature in Ancient Brazil. London: British Museum, 2001. p. 14-17.

NEVES, Eduardo; COSTA, Fernando. Resgate Emergencial do Sítio Arqueológico Nova Cidade, Manaus-AM (Parte 1). Relatório encaminhado ao Ministério Público Federal e IPHAN 1ํㅡㄹ Superintendência Regional - Manaus, 2001.

NEVES, Eduardo; PETERSEN, James; BARTONE, Robert; SILVA, Carlos. Historical and Socio-cultural origins of Amazonian dark earths. In: LEHMANN, Johannes, et al. (Eds.). Amazonian Dark Earths: Origin, Properties, Management. Dordrecht: Kluwer Academic, 2003. p. 1-45.

NEVES, Eduardo; COSTA, Fernando. Resgate Emergencial do Sítio Arqueológico Nova Cidade, Manaus-AM (Parte 2). Relatório encaminhado ao Ministério Público Federal e IPHAN 1ํㅡㄹ Superintendência Regional - Manaus, 2004.

NEVES, Eduardo; PETERSEN, James; BARTONE, Robert; HECKENBERGER, Michael. The timing of terra preta formation in the central Amazon: Archaeological data from three sites. In: GLASER, Bruno; Woods, William. (Eds.). Amazonian dark earths: Explorations in space and time. Berlin: Springer Verlag, 2004. p. 125134.

NEVES, Eduardo; PETERSEN, James. The Political Economy of Pre-Columbian Landscape Transformations in Central Amazonia. In: BALÉE, William; ERICKSON, Clark. (Eds.). Time and Complexity in Historical Ecology: Studies in the Neotropical Lowlands. New York: Columbia University, 2005.

NEVES, Eduardo; CASTRO, Márcio; COSTA, Fernando; LIMA, Helena; PYDANIEL, Anne. Cronologias Regionais, Hiatos e Continuidades na História PréColonial da Amazônia. 1ํㅡㄹ Relatório Parcial do Projeto Temático, processo ํㅡㄴ 05/606003-4, apresentado à FAPESP, 2007.

NEWTON, Dolores. Cultura Material e História Cultural. In: Suma Etnológica Brasileira. Vol. 2 - Tecnologia Indígena. Petrópolis: Vozes, 1987.

NICOLESCU, Basarab. O Manifesto da Transdisciplinaridade. São Paulo: Triom, 2005.

NUNES, Kelly P. Estudos arqueométricos do sítio arqueológico Hatahara. Projeto de mestrado, Instituto de Pesquisas Energéticas e Nucleares - IPEN, 2008.

NOELLI, Francisco. The Tupi? Explaining origin and expansions in terms of archaeology and historical linguistics. In: Antiquity, v. 72, n. 277, p. 648-63, 1998. 
OLIVEIRA, Alexandre, et al. Florestas sobre Areia: Campinaranas e Igapós. In: OLIVEIRA, Alexandre; DALY, Douglas. (Eds.). Florestas do Rio Negro. São Paulo: Companhia das Letras/UNIP/The New York Botanical Garden, 2001. p. 181-219.

OLIVER, José. The Archaeological, linguistic and etnohistorical evidence for the expansion of Arawakan into Northwestern Venezuela and Northeastern Colombia. Ph.D. Dissertation, University of Illinois.

OYUELA-CAYCEDO, Augusto. Rock versus Clay: the evolution of pottery technology in the case of San Jacinto 1, Colombia. In: BARNETT, William; HOOPES, John. (Eds.). The emergence of pottery: Technology and innovation in ancient societies. Washington, D.C.: Smithsonian Institution, 1995. p. 133-144.

PEIXOTO, Claudia; OKURA, Roberta. O significado da variabilidade da Fase Manacapuru na Amazônia Central. Relatório de análise estatística sobre o projeto - Instituto de Matemática e Estatística. São Paulo: Universidade de São Paulo, 2003. (RAE - CEA - 03P32)

PELISSIER, Catherine. The Anthropology of Teaching and Learning. Annual Review of Anthropology, v. 20, p. 75-95, 1991.

PEREIRA, Edith. Testimony in Stone: Rock Art in the Amazon. In: McEWAN, Colin; BARRETO, Cristina; NEVES, Eduardo. (Eds.). Unknown Amazon, Culture in Nature in Ancient Brazil. London: British Museum, 2001.

PETERSEN, James; NEVES, Eduardo; HECKENBERGER, Michael. Gift from the past: Terra preta and Prehistoric Amerindian Occupation in Amazonia, In: McEWAN, Colin; BARRETO, Cristina; NEVES, Eduardo. (Eds.). Unknown Amazon, Culture in Nature in Ancient Brazil. London: British Museum, 2001.

A prehistoric ceramic sequence from the central Amazon and its relationship to the Caribbean. In: ALOFS, Luc; DIJKHOFF, Raymundo. (Eds.). Proceedings of the $19^{\text {th }}$ International Congress for Caribbean Archaeology. Aruba: Archaeological Museum of Aruba, 2003. p. 250-259.

PETERSEN, James; NEVES, Eduardo; BARTONE, Robert; ARROYO-KALIN, Manuel. An overview of Amerindian cultural chronology in the central Amazon. In: Annual Meeting of the Society for American Archaeology. Montreal: 2004.

PIRES, João; PRANCE, Ghillean. The Vegetation types of the Brazilian Amazon. In: PRANCE, Ghillean; LOVEJOY, Thomas. (Eds.). Amazonia. Oxford: Pergamon, 1985. p. 109-145.

PORRO, Antonio. O Povo das Águas: Ensaios de Etno-História Amazônica. Petrópolis: Vozes, 1996.

PORTOCARRERO, Ricardo. A variabilidade espacial no sítio Osvaldo: estudo de um assentamento da Tradição Barrancóide na Amazônia Central. Dissertação (Mestrado em Arqueologia) - Museu de Arqueologia e Etnologia. São Paulo: Universidade de São Paulo, 2006. 
PY-DANIEL, Anne. Arqueologia Funerária na Amazônia Central. Projeto de Mestrado, Programa de Pós-Graduação em Arqueologia, Museu de Arqueologia e Etnologia da USP, 2006.

RAYMOND, J. Scott. From potsherds to pots: a first step in constructing cultural context from tropical forest archaeology. In: STAHL, Peter. (Ed.). Archaeologby in the lowland American Tropics: current analytical methods and applications. Cambridge: Cambridge University, 1995. p. 224-242.

RAYMOND, J. Scott; OYUELA-CAYCEDO, Augusto; CARMICHAEL, Patrick. Una comparación de las tecnologías de la cerámica temprana de Ecuador y Colombia. In: SHIMADA, Izumi. (Ed.). Tecnología y organización de la producción cerámica prehispánica en los Andes. Lima: Fondo Editorial, Pontifícia Universidad Católica del Peru, 1994. p. 33-52.

REBELLATO, Lilian. Interpretando a variabilidade cerâmica e as assinaturas químicas e físicas do solo no sítio arqueológico Hatahara. Dissertação (Mestrado em Arqueologia) - Museu de Arqueologia e Etnologia. São Paulo: Universidade de São Paulo, 2007.

REICHEL-DOLMATOFF, Gerardo. Arqueología de Colombia. Bogotá: Biblioteca Familiar Presidencia de la República, 1997.

REIS, José. "Não pensa muito que dói": um palimpsesto sobre teoria na arqueologia brasileira. Tese (Doutorado em História) - Instituto de Filosofia e Ciências Humanas. Campinas: Universidade de Campinas, 2004.

RENFREW, Colin. At the Edge of Knowability: Towards a Prehistory of Languages. In: Cambridge Archaeological Journal, v. 10, n. 1, p. 7-34, 2000.

RENFREW, Colin; CHERRY, John. Peer Polity Interaction and socio-political change. New York: Cambridge University, 1986.

RICE, Prudence. Pottery Analysis: a source book. Chicago: the University of Chicago Press, 1987.

ROOSEVELT, Anna. Parmana: prehistoric maize and manioc subsistence along the Amazon and the Orinoco. New York: Academic Press, 1980.

Resource Management in Amazonia Before the Conquest: Beyond Ethnographic Projection. In: Economic Botany, v. 7, p. 30-62, 1989.

Moundbuilders of the Amazon: Geophysical Archaeology on Marajó Island, Brazil. San Diego: Academic Press, 1991.

Arqueologia Amazônica. In: CUNHA, Manuela (Org.). História dos índios no Brasil. São Paulo: Companhia das Letras, 1992. 
. Early Pottery in the Amazon. Twenty Years of Scholarly Obscurity. In: BARNETT, William; HOOPES, John (Eds.). The Emergence of Pottery. Technology and Innovation in Ancient Societies. Washington, D.C.: Smithsonian Institution, 1995. p. 115-131.

The Excavations at Corozal, Venezuela: Stratigraphy and Ceramic Seriation. In: Yale University Publications in Anthropology, n. 83. London: Yale University, 1997.

The Development of Prehistoric Complex Societies: Amazonia, A Tropical Forest. Archeological Papers of the American Anthropological Association v. 9, n. 1, p. 13-33, 1999.

ROOSEVELT et al. Eighth Millenium Pottery from a Prehistorical Shell Midden in the Brazilian Amazon. Science, v. 254, p. 1621-1624, 1991.

Paleoindian Cave Dwellers in the Amazon: the Peopling of the Americas. Science, v. 272, p. 373-384, 1996.

ROUSE, Irving. The Circum-Caribbean Theory, an Archaeological Test. In: American Anthropologist. New Series, Vol. 55, No. 2, Part 1, p. 188-200, 1953.

. On the Correlation of Phases of Culture. In: American Anthropologist, New Series, Vol. 57, No. 4, p. 713-722, 1955.

. The Classification of Artifacts in Archaeology. American Antiquity, v. 25, n. 3, p. 313-323, 1960.

ROUSE, Irving; CRUXENT, José. Venezuelan Archaelogy. New Haven/London: Yale University, 1963.

RYE, Owen. Pottery technology: principles and reconstruction. Manuals on archaeology, n. 4. Washington, D.C.: Taraxacum, 1981.

SAHLINS, Marshall. Ilhas de História. Tradução Barbara Sette. Rio de Janeiro: Jorge Zahar, 1989.

SALAZAR, Ernesto. Entre Mitos y Fabulas: el Ecuador aborigen. Biblioteca General de Cultura, n. 4. Quito: Corporacion Editora Nacional, 1995.

SANOJA, Mario. Las Culturas Formativas del Oriente de Venezuela: la Tradición Barrancas del Bajo Orinoco. Monografías y Ensayos, 6, Caracas: Academia Nacional de la Historia, 1979.

SANTOS, Milton. A Natureza do Espaço: Técnica e Tempo, Razão e Emoção. São Paulo: Edusp, 2002.

SAUER, Carl. Land and Life. Berkeley: University of California, 1963. 
SCHAAN, Denise. The Camutins Chiefdom: Rise and Development of Social Complexity on Marajó Island, Brazilian Amazon. Tese (Doutorado em Antropologia) - Departamento de Antropologia. Pittsburgh: Universidade de Pittsburgh, 2004.

Uma Janela para a História Pré-colonial da Amazônia: Olhando Além

- e apesar - das Fases e Tradições. Boletim do Museu Paraense Emílio Goeldi, Ciências Humanas, v. 2, n. 1, p. 77-89, 2007.

SCHIFFER, Michael. Archaeological Context and Sistemic Context. American Antiquity, Vol. 37, No. 2, p. 156-165, 1972.

. Formation Processes of the Archaeological Record. Albuquerque: University of Mexico Press, 1987.

- Technology and Society. In: Technological Perspectives on Behavioral Change. Tucson: University of Arizona, 2001.

The Explanation of Long-Term Technological Change. In: Anthropological Perspectives on Technology. Albuquerque: University of New Mexico, 2001.

SCHIFFER, Michael; SKIBO, James. The explanation of Artifact Variability. American Antiquity, v. 62, n. 1, p. 27-50, 1997.

SCHMIDT, Max. The Arawaks. A contribution to the Problem of the Expansion of Culture. Tese (Doutorado em Filosofia) - Faculdade de Filosofia. Leipzig: Universität Leipzig, 1917.

SERRANO, Antonio. Manual de la ceramica indígena. Cordoba: Assandri, 1966.

SHEPARD, Anna. Ceramics for the Archaeologist. Washington, D.C.: Carnegie Institution of Washington (Publication n. 609), 1956.

SHORR, Nicolas. Early Utilization of Flood-Recession Soils as a response to the Intensification of Fishing and Upland Agriculture: Resource-Use Dynamics in a Large Tikuna Community. Human Ecology, v. 28, n. 1, p. 73-107, 2000.

SIEGEL, Peter. An Interview with Irving Rouse. Current Anthropolgy, v. 37, n. 4, p. 671-689, 1996.

SILVA, Fabíola. As tecnologias e seus significados: um estudo da cerâmica Asuriní do Xingu e da cestaria dos Kayapó-Xikrin sob uma perspectiva etnoarqueológica. Tese (Doutorado em Antropologia) - Faculdade de Filosofia, Letras e Ciências Humanas. São Paulo: Universidade de São Paulo, 2000.

SILVEIRA BUENO, Francisco. Vocabulário Tupi Guarani Português. 6 ed. São Paulo: Éfeta, 1998. 
SIMÕES, Mario. The Castanheira site: new evidence on the antiquity and history of the Ananatuba phase (Marajó Island, Brazil). American Antiquity, v. 34, n. 4, p. 402-410, 1969.

. Contribuição à arqueologia dos arredores do baixo Rio Negro. In: Programa Nacional de Pesquisas Arqueológicas 5. Publicações Avulsas do Museu Paraense Emilio Goeldi, v. 26, p. 165-200188. Belém: 1974.

Coletores-pescadores ceramistas do litoral do Salgado (Pará). Boletim do Museu Paraense Emílio Goeldi. Nova Série, n. 78, p. 1-31, 1981.

SIMOES, Mario; KALKMAN, Ana. Pesquisas arqueológicas no Médio Rio Negro (Amazonas). Revista de Arqueologia, v. 4, n. 1, p. 83-116, 1987.

SKIBO, James. Pottery Function: a use alteration perspective. New York: Plenum, 1992.

SKIBO, James; SCHIFFER, Michael. Understanding Artifact Variability and Change: a Behavioral Framework. In: SCHIFFER, Michael. (Ed). Anthropological Perspectives on Technology. Albuquerque: University of New Mexico, 2001.

STALLER, John. Reassessing the Developmental and Chronological Relationships of the Formative of Coastal Ecuador. Journal of World Prehistory, v. 15, n. 2, p. 193-256, 2001.

STERNBERG, Hilgard. A água e o homem na várzea do Careiro. 2 ed. Belém: Museu Paraense Emílio Goeldi, 1998.

STEWARD, Julian. (Ed.). Handbook of South American Indians. The Tropical Forest Tribes. v. 3. Bulletin n. 143, Bureau of American ethnology. Washington, D.C.: Smithsonian Institution, 1940-50.

TAMANAHA, Eduardo. Estudo de um Montículo Artificial no Sítio Hatahara, AM. Projeto de Iniciação Científica encaminhado à FAPESP, 2006.

TAMURA, Anderson. A Ocupação pré-colonial do sítio Lago Grande. Relatório Parcial de Iniciação Científica apresentado à FAPESP - Museu de Arqueologia e Etnologia. São Paulo: Universidade de São Paulo, 2005.

THOMAS, Homer; EHRICH, Robert. Some problems in chronology. World Archaeology, v. 1, p. 143-156, 1969.

TRIGGER, Bruce. A History of Archaeological Thought. Cambridge: Cambridge University, 1989.

VICENTINI, A. As Florestas de Terra Firme. In: OLIVEIRA, Alexandre; DALY, Douglas. (Eds.). Florestas do Rio Negro. São Paulo: Companhia das Letras/UNIP/The New York Botanical Garden, 2001. p. 145-177. 
VIERTLER, Renate. Ecologia Cultural: uma Antropologia da Mudança. São Paulo: Ática, 1988.

VIVEIROS de CASTRO, Eduardo. Images of Nature and Society in Amazonian Ethnology. Annual Review of Anthropology, v. 25, n. 1, p. 179-200, 1996.

WALLACE, Russel. Peixes do Rio Negro. São Paulo: Edusp. 2002.

WILLEY, Gordon; PHILLIPS, Philip. Method and Theory in American Archaeology. Chicago: University of Chicago, 1958.

WILLIAMS, Dennis. Early pottery in the Amazon: a correction. American Antiquity, v. 62, n. 2, p. 342-352, 1997.

WILSON, David. Indigenous South Americans of the Past and Present: An Ecological Perspective, Boulder: Westview, 1999.

WOODS, William; McCANN, Joseph. The Anthropogenic Origin and Persistence of Amazonian Dark Earths. In: Yearbook, Conference of Latin Americanist Geographers, v. 25, n. 7-14, 1999.

ZEDEÑO, Maria. Landscapes, Land Use, and the History of Territory Formation: An Example from Puebloan Southwest. Journal of Archaeological Method and Theory, 4(1): 63-103. 1997. 